
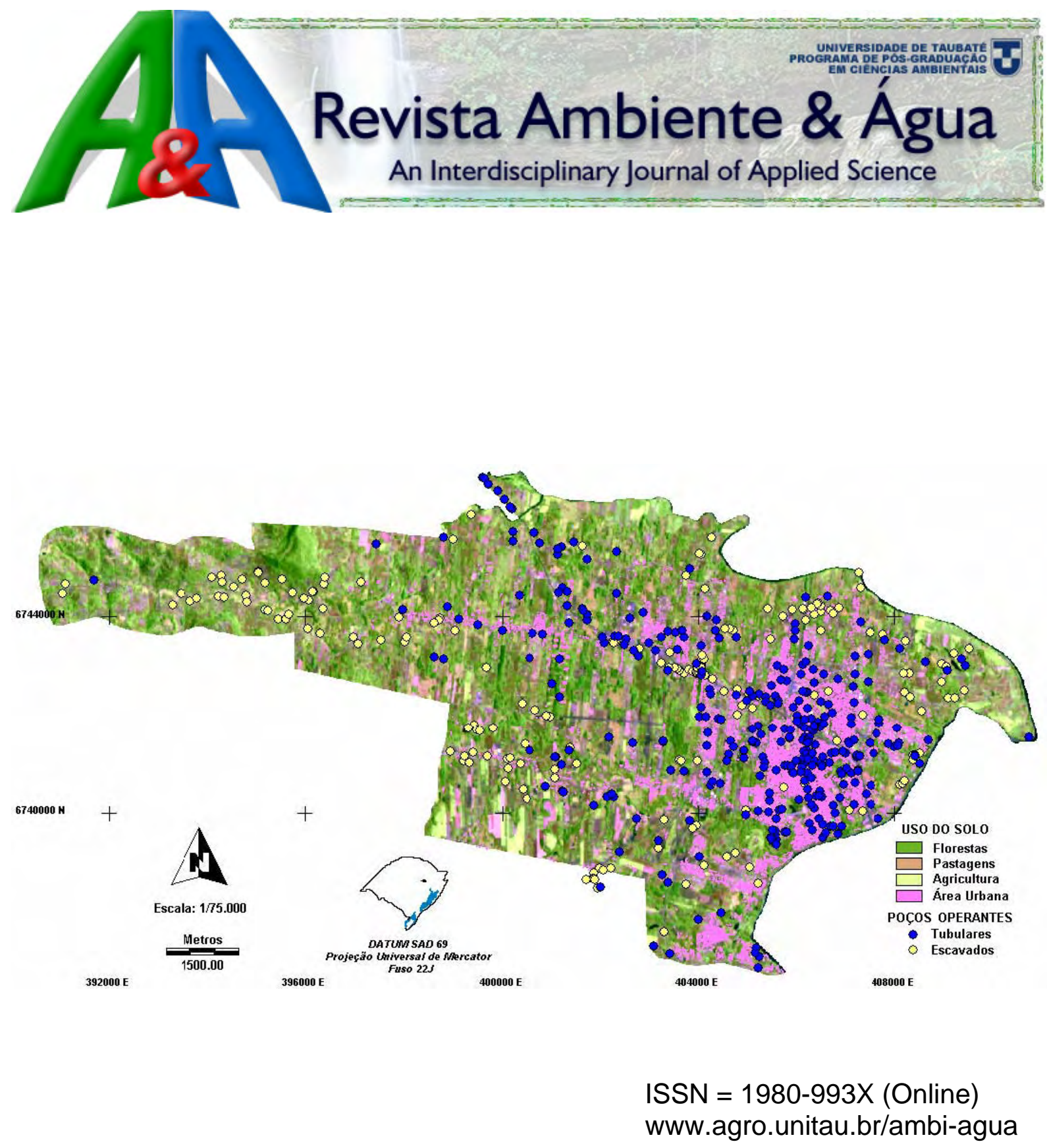

Edição 09 da Revista Ambiente \& Agua - An Interdisciplinary Journal of Applied Science, Taubaté, v. 4, n. 1, p. 1-182, Abril 2009. (doi:10.4136/ambi-agua.v4.n1) 


\section{COMITÊ EDITORIAL}

\section{Editor}

Getulio Teixeira Batista

Instituto de Pesquisas Ambientais em Bacias Hidrográficas (IPABHi), Brasil

\section{Editores Associados}

Amaury Paulo de Souza

Universidade Federal de Viçosa (UFV), Brasil

\section{Antonio Evaldo Klar}

Universidade Estadual Paulista Júlio de Mesquita Filho, UNESP, Brasil

\section{Dar Roberts}

Universidade de Stanford; BA pela Universidade da Califórnia, EUA

Hans Raj Gheyi

Universidade Federal de Campina Grande (UFCG), Brasil

\section{Hélio Nóbile Diniz}

Instituto Geológico, Secretaria do Meio Ambiente do Estado de São Paulo (IG/SMA), Brasil

\section{João Vianei Soares}

Instituto Nacional de Pesquisas Espaciais (INPE), Brasil

Editor da Seção Editorial

Editora de Texto

Editora de Referência
Luis A. Bartolucci

Florida International University (FIU), EUA

Marcelo dos Santos Targa

Universidade de Taubaté (UNITAU), Brasil

Nelson Wellausen Dias

Universidade de Taubaté (UNITAU), Brasil

Paul W. Mausel

Indiana State University (ISU), EUA

Paulo Renato Schneider

Universidade Federal de Santa Maria (UFSM), Brasil

Sebastião do Amaral Machado

Universidade Federal do Paraná (UFPR), Brasil

Silvio Jorge Coelho Simões

Universidade Estadual Paulista Júlio de Mesquita Filho (UNESP), Brasil

Yosio Edemir Shimabukuro

Instituto Nacional de Pesquisas Espaciais (INPE), Brasil

Nelson Wellausen Dias, PPGCA, UNITAU, Brasil

Maria de Jesus Ferreira Aires, GELP, UNITAU, Brasil

Liliane Castro, Biblioteca ECA/Civil, UNITAU, Brasil

Ficha catalográfica elaborada pelo SIBi - Sistema Integrado de Bibliotecas / UNITAU

Revista Ambiente \& Água - An Interdisciplinary Journal of Applied Science / Instituto de Pesquisas Ambientais em Bacias Hidrográficas. Taubaté. v. 4, n. 1 (2006) Taubaté: IPABHi, 2009.

Quadrimestral

ISSN 1980-993X

1. Ciências ambientais. 2. Recursos hídricos. I. Instituto de Pesquisas Ambientais em Bacias Hidrográficas. III. Título. 


\section{ÍNDICE}

\section{CAPA}

Localização dos poços ativos de captação de água subterrânea em Lajeado, RS, Brasil.

Fonte: ECKHARDT, R. R.; DIEDRICH, V. L.; FERREIRA, E. R.; STROHSCHOEN, E.; DEMAMAN, L. C. Mapeamento e avaliação da potabilidade da água subterrânea do município de Lajeado, RS, Brasil. Ambi-Agua, Taubaté, v. 4, n. 1, p. 58-80, 2009. (doi:10.4136/ambi-agua.74)

\section{EDITORIAL}

New accomplishments of Ambiente \& Agua scientific journal (doi:10.4136/ambi-agua.69)

Getulio Teixeira Batista

\section{ARTIGOS}

Accumulation, distribution and toxicological effects induced by chromium on the development of mangrove plant Kandelia candel (L.) Druce (doi:10.4136/ambi-agua.70)

Mohammed M. Rahman; Yan Chongling; Md. Motiur Rahman; Kazi S. Islam

Influence of additives on the retention of metal ions in a soil of Bangalore, India (doi:10.4136/ambi-agua.71)

Syed A. S. Mohammed; Maya Naik; Syed Tanveeruddin

Diversity and abundance of aquatic macroinvertebrates in a lotic environment in Midwestern São Paulo State, Brazil (doi:10.4136/ambi-agua.72)

Fabio L. Silva; Diana C. Moreira; Sonia S. Ruiz; Gabriel L. Bochini

Production and properties of $\alpha$-amylase from Citrobacter species (doi:10.4136/ambi-agua.73)

Justina C. Orji; Christian O. Nweke; Rose N. Nwabueze; Christopher E. Nwanyanwu; Chinwe S. Alisi; Ebuta N. Etim-Osowo

Mapeamento e avaliação da potabilidade da água subterrânea do município de Lajeado, RS, Brasil (doi:10.4136/ambi-agua.74)

Rafael R. Eckhardt; Vianei L. Diedrich; Everaldo R. Ferreira; Eduardo S.; Letícia C. Demaman

Validação do método para a determinação do ácido 3 - indolacético em água de rios por cromatografia líquida de alta eficiência (doi:10.4136/ambi-agua.75)

Sérgio M. Sanches; Renata Martins; Paulo J. M. Cordeiro; Luiz A. A. Vaz; Eny M. Vieira

Vulnerabilidade de sub-bacias hidrográficas por meio da equação universal de perda de solo e da integração de parâmetros morfométricos, topográficos, hidrológicos e de uso/cobertura da terra no estado do Rio de Janeiro, Brasil (doi:10.4136/ambi-agua.76)

Thomaz C. C. da Costa; Elaine C. C. Fidalgo; Uebi J. Naime; Saulo P. Guimarães; Maria J. Zaroni; Mariella C. Uzeda

Desenvolvimento e avaliação de sonda de TDR para o manejo racional da água em substratos utilizados na produção de mudas florestais (doi:10.4136/ambi-agua.77)

Marcelo L. C. Elaiuy; Lucas M. Sato; Antonio C. T. Varallo; Claudinei F. Souza

Estado trófico da água na bacia hidrográfica da Lagoa Mirim, RS, Brasil (doi:10.4136/ambiagua.78)

Ronaldo Fia; Antonio T. Matos; Paulo C. Coradi; Orlando Pereira-Ramirez

Efeito do antigo Lixão do Roger, João Pessoa, Brasil, na qualidade da água subterrânea local (doi:10.4136/ambi-agua.79)

Gilson B. A. Júnior; Claudia C. Nóbrega; Carmem L. M. Gadelha; Irene M. F. Souza; Giulliano S. Fagundes

Diagnóstico hidroambiental da bacia hidrográfica da Cachoeira das Pombas, município de Guanhães, MG, Brasil (doi:10.4136/ambi-agua.80)

Kelly C. T.; Herly C. T. D.; Agostinho L. S.; Carlos A. A. S. R.; Deuseles J. F.; Fernando P. L.

Aplicação da probabilidade condicional e do processo de cadeia de Markov na análise da ocorrência de períodos secos e chuvosos para o município de Garanhuns, PE, Brasil (doi:10.4136/ambi-agua.81)

Antonio R. S. Andrade; Joherlan C. Freitas; José I. B. Brito; Hugo O. C. Guerra; Josilda F. Xavier 


\title{
New accomplishments of Ambiente \& Agua scientific journal
} (doi:10.4136/ambi-agua.69)

\section{Getulio Teixeira Batista}

\begin{abstract}
Professor of the Master Degree Program in Environmental Sciences of the University of Taubaté Estrada Municipal Dr. José Luiz Cembranelli, 5.000, Bairro Itaim, 12.081-010 - Taubaté, SP

E-mail: ambi-agua@agro.unitau.br
\end{abstract}

\begin{abstract}
Ambiente \& Água - An Interdisciplinary Journal of Applied Science (Ambi-Agua) was classified as B2 in the Interdisciplinary Area, the major thematic area of this journal, by CAPES classification system known as "Qualis". Also, the journal was registered in the Digital Object Identifier (DOI ${ }^{\circledR}$ ) System. Three other facts were accomplished: 1) all published articles since April, 2008 have the submitted and accepted dates stamped; 2) longterm preservation will be now secured in association with DOAJ - Lund University Libraries and the e-Depot of the National Library of the Netherlands (KB); and 3) we entered into an electronic licensing relationship with EBSCO Publishing to have full text of our journal in EBSCO Publishing's databases in the near future.
\end{abstract}

Keywords: Ambi-Água; Qualis CAPES; DOI ${ }^{\circledR}$; environment; water.

Recently, the Brazilian Agency from the Ministry of Education concerned with the graduate level education, known as CAPES, published its ranking of major scientific journals that have articles published by graduate school programs (master and doctoral degree students and professors) in Brazil. Ambiente \& Água - An Interdisciplinary Journal of Applied Science (Ambi-Agua) was classified as B2 in the Interdisciplinary Area, the major thematic area of this journal. CAPES classification system known as "Qualis" ranks all journals (national and international) based on bibliometric parameters, in the following categories:

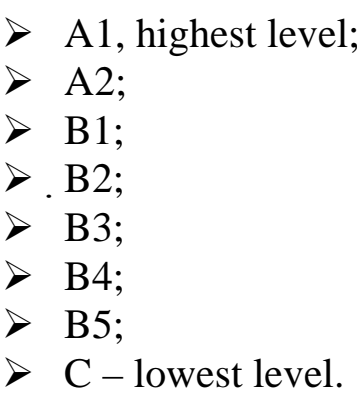

This classification system is the result of a new structure for publication judgment that tried to improve the previous system and establish criteria that consider which "scientific journals" are relevant for each specific knowledge area and only those that met that criterion were classified by CAPES “Qualis”. In addition, only those publications that have renowned editorial board, peer review evaluation by ad hoc reviewers, and a valid ISSN can be considered. Some thematic areas have well established indexing criteria that can be used as reference, such as impact factor indices (H Index, for instance). CAPES considers that the two top strata (A1 and A2) should not be over populated in order to emphasize the unquestionable 
quality of journals classified in these two strata that are left blank in several areas or include only journals that have long term irrefutable quality. Thus, each area indicates their own direction to improve the quality of its community scientific production and not only points out where the production that is being published but also emphasizes the highest classified journals of that area. Another feature of these "Qualis" new criteria is the policy to establish unique criteria for large knowledge areas such as Engineering or Health. Thus, inside a large area the rules should be similar, but a journal can still have different grades in distinct areas with different traditions. Therefore, Qualis continues to be the reference for the intellectual production of graduate "Strictu Sensu" programs evaluated by CAPES. More details on "Qualis" can be seen in Batista (2007) and in http://www.capes.gov.br/servicos/sala-deimprensa/36-noticias/2550-capes-aprova-a-nova-classificacao-do-qualis. In this new classification system, the criteria of each area have to be approved by the Technical Scientific Council of Higher Education (CTC-ES) to secure transparency among the several thematic areas.

The classification of Ambiente \& Água journal by Qualis CAPES opens up new opportunities to improve this journal's infrastructure. From now on the journal can apply to government funds to cover operational expenses. The B2 grade obtained in its first classification was, in fact, an excellent one. This achievement could be compared with other grades received by several more traditional journals that publish in similar scientific areas. It certainly will increase the number of submissions due an increased confidence factor to be perceived by the scientific community. However, Ambi-Agua scientific board will continually strive to improve its quality to deserve a better classification in future CAPES Qualis announcements.

Another important accomplishment is Ambi-Agua registration in the Digital Object Identifier $\left(\mathrm{DOI}^{\circledR}\right)$ System that was conceived for identifying content objects in the digital environment, fulfilling an announcement made in the editorial of volume 3 , number 1 (Batista, 2008). The DOI ${ }^{\circledR}$ System provides a persistent identification of a published article or object, even if it is deposited in a different location. In addition, it helps to secure intellectual content of online published articles, and facilitate the visibility to content suppliers. The system is developed and controlled by the International DOI Foundation (http://dx.doi.org/).

The DOI system was conceived in the late 1990's to fulfill the need to uniquely and unambiguously identify content entities, rather than to refer to them by location addresses (URL). The International DOI Foundation was incorporated in 1998 to develop the system. The first DOI Registration Agency began in 2000; by mid 2008 around 40 million DOI names had been assigned through eight Registration Agencies affiliated with the DOI Foundation. The most widely known application of the DOI system is the CrossRef crosspublisher citation. Its service allows a researcher to link a reference citation directly to the cited content on another publisher's platform. Ambi-Agua is registered with this Agency by its editing institution, the Institute for Environmental Research in Hydrographic Basins (IPABHi). More details on DOI system can be seen in Paskin (2009).

As of this issue Ambi-Agua has the following DOIs registration:

$>$ doi:10.4136/1980-993X for the journal Ambiente \& Água - An Interdisciplinary Journal of Applied Science;

$>$ doi:10.4136/ambi-agua.v1.n1 for the first issue (volume 1, number 1, August 2006);

$>$... up to doi:10.4136/ambi-agua.v4.n1 for the current issue (volume 4, number 1, April 2009);

$>$ doi:10.4136/ambi-agua.1 for the first published article (August 2006);

$>$... up to doi:10.4136/ambi-agua.80 for the last published article of this issue. 
To resolve a DOI one has to link to DOI Foundation (http://dx.doi.org/) and type the DOI of the article or object. No matter where it is currently deposited the DOI should direct to the sought object.

Three other facts are worthy mentioning: First, all published articles since April 2008 have the submission and acceptance dates stamped on them. This is important for potential authors that could verify the throughput of manuscripts throughout the editorial procedure. This is also used in several indexing systems for journal evaluation. Secondly, long-term preservation of Open Access Journals will be now secured in association with The Directory of Open Access Journal (DOAJ) - Lund University Libraries and the e-Depot of the National Library of the Netherlands (KB) that announced the start of cooperation in order to secure long-term preservation of open access journals. The Swedish Library Association is generously acting as sponsor for this. Therefore, all articles published in Ambi-Agua are expected to have this additional storage location. Third, Ambi-Agua has entered into an electronic licensing relationship with EBSCO Publishing, the world's most prolific aggregator of full text journals, magazines, and other sources. The full text of our journal will be found on EBSCO Publishing's databases shortly.

\section{REFERENCES}

BATISTA, G. T. Geographical impact of scientific journals. Ambi-Agua, Taubaté, v. 2, n. 3, p. 12-18, 2007. (doi:10.4136/ambi-agua.29).

BATISTA, G. T. Ambiente e Água - An Interdisciplinary Journal of Applied Science em seu terceiro ano de publicação. Ambi-Agua, Taubaté, v. 3, n. 1, p. 3-4, 2008. (doi:10.4136/ambi-agua.37).

Ministério da Educação - MEC. Coordenação de Aperfeiçoamento de Pessoal de Nível Superior - CAPES. Diretoria de Avaliação - DAV. Reestruturação do QUALIS. <http://www.capes.gov.br/images/stories/download/avaliacao/Restruturacao_ Qualis.pdf>. Acess: April 10, 2009.

PASKIN, N. Digital object identifier (DOI ${ }^{\circledR}$ ) system. Forthcoming publication in the third edition of the Encyclopedia of Library and Information Sciences (Taylor \& Francis Group). Final reviewed and corrected text February 2009. (C) International DOI Foundation 2009. <http://www.doi.org/overview/090225DOI-ELIS-Paskin.pdf>. Access: April 11, 2009. 


\begin{tabular}{ccc|} 
ISSN = 1980-993X - doi:10.4136/1980-993X \\
www.agro.unitau.br/ambi-agua \\
E-mail: ambi-agua@agro.unitau.br \\
Tel.: (12) 3625-4116
\end{tabular}

\title{
Accumulation, distribution and toxicological effects induced by chromium on the development of mangrove plant Kandelia candel (L.) Druce
} (doi:10.4136/ambi-agua.70)

\author{
Mohammed Mahabubur Rahman'; Yan Chongling²; Md. Motiur Rahman³; \\ Kazi Shakila Islam ${ }^{4}$ \\ ${ }^{1}$ Education and Research Center for Subtropical Field Science, Kochi University, Nankoku, Japan, 783-8502 \\ E-mail: t_rahman76@yahoo.com \\ ${ }^{2}$ School of Life Sciences, Xiamen University, Xiamen, Fujian-361005, P.R. China \\ E-mail: ycl@xmu.edu.cn \\ ${ }^{3}$ Slivacom Ltd. Edmonton, Alberta, Canada \\ E-mail: Motiur.Rahman08@gmail.com \\ ${ }^{4}$ The School of Oceanography and Environmental Science, Xiamen University, Xiamen, Fujian-361005, China \\ E-mail: shakila_tanee@yahoo.com
}

\begin{abstract}
A study was performed for investigating accumulation, distribution and toxicological effects induced by chromium (Cr) on the development of the mangrove seedling Kandelia candel (L.) Druce. Seedlings treated with increasing concentrations of $\mathrm{CrCl}_{3}$ solution $(0,0.5$, $1,1.5,2,2.5,3 \mathrm{mg} \mathrm{L}^{-1}$, respectively) were grown in a basic nutrient solution for three months. The five month old seedlings were harvested for the experiment. This study showed that $\mathrm{Cr}$ treatment significantly decreased growth of $K$. candel in terms of seedling height, leaf number and total biomass. At the highest $3 \mathrm{mg} \mathrm{L}^{-1} \mathrm{Cr}$ exposure, there was a 34.47\% decrease in final seedling height, $68.95 \%$ decrease in leaf number and a $60.65 \%$ decrease in total biomass. The present study demonstrates that $\mathrm{Cr}$ accumulation ability of $K$. candel seedlings increased with the increase of treatment strength up to certain level. The concentrations of $\mathrm{Cr}$ in root, hypocotyl, stem and leaf ranged from 22.87 to $1.43 \mathrm{mg} \mathrm{kg}^{-1}, 1.30$ to $0.68 \mathrm{mg} \mathrm{kg}^{-1}$, 2.42 to 0.91 $\mathrm{mg} \mathrm{kg}$, and 1.74 to $0.74 \mathrm{mg} \mathrm{kg}^{-1}$, respectively. When comparing $\mathrm{Cr}$ concentration in different plant parts with respect to their controls, the results showed that treated plant root bioaccumulated high amounts of $\mathrm{Cr}$. Almost $80 \%$ of $\mathrm{Cr}$ was accumulated mainly in roots. The distribution pattern of $\mathrm{Cr}$ in $\mathrm{K}$. candel was Root $>$ Stem $>$ Leaf $>$ Hypocotyl. Our findings indicated that the high concentration of Cr supply may interfere with several metabolic processes of seedlings, causing toxicity to plants as exhibited by chlorosis, necrosis, and finally, plant death.
\end{abstract}

Keywords: Chromium; plant growth; metal accumulation; metal distribution pattern; toxic effect; mangrove.

\section{Acumulação, distribuição e efeitos toxicológicos induzidos por cromo no desenvolvimento da planta de mangue Kandelia candel (L.) Druce}

\section{RESUMO}

Este estudo teve o objetivo de investigar a acumulação, a distribuição e os efeitos toxicológicos induzidos por cromo (Cr) no desenvolvimento de mudas da planta de mangue Kandelia candel (L.) Druce. Mudas tratadas com concentrações crescentes de solução de CrCl3 $\left(0 ; 0,5 ; 1 ; 1.5 ; 2 ; 2,5 ; 3 \mathrm{mg} \mathrm{L}^{-1}\right.$, respectivamente) foram cultivadas em uma solução básica de nutrientes durante três meses. As mudas foram colhidas com cinco meses de idade. Este estudo mostrou que o tratamento com Cr diminuiu significativamente o crescimento da 
RAHMAN, M. M.; CHONGLING, Y.; RAHMAN, M. M.; ISLAM, K. S. Accumulation, distribution and toxicological effects induced by chromium on the development of mangrove plant Kandelia candel (L.) Druce. Ambi-Agua, Taubaté, v. 4, n. 1, p. 6-19, 2009. (doi:10.4136/ambi-agua.70)

K. candel, em termos da altura da muda, número de folhas e biomassa total. No nível mais alto (3 $\mathrm{mg} \mathrm{L}^{-1}$ ) de exposição ao $\mathrm{Cr}$, houve uma diminuição de $34,47 \%$ na altura final da muda, $68,95 \%$ de diminuição no número de folhas e uma diminuição de $60,65 \%$ na biomassa total. $\mathrm{O}$ presente estudo demonstrou que a habilidade de acumulação $\mathrm{Cr}$ das mudas de K.candel aumentou com o aumento da concentração no tratamento até um certo nível. As concentrações de $\mathrm{Cr}$ na raiz, hipocótilo, caule e folha variaram de 22,87 a $1,43 \mathrm{mg} \mathrm{kg}^{-1}$, de 1,30 a $0,68 \mathrm{mg} \mathrm{kg}^{-1}$, de 2,42 a $0,91 \mathrm{mg} \mathrm{kg}^{-1}$, e de 1,74 a $0,74 \mathrm{mg} \mathrm{kg}^{-1}$, respectivamente. Ao comparar a concentração de $\mathrm{Cr}$ em diferentes partes da planta em relação ao controle, os resultados mostraram que a raiz da planta acumulou grande quantidade de Cr. Foram acumulados quase $80 \%$ de $\mathrm{Cr}$, principalmente nas raízes. O padrão de distribuição do $\mathrm{Cr}$ em K. candel foi raiz $>$ caule $>$ folha $>$ hipocótilo. Os resultados indicaram que a alta concentração de $\mathrm{Cr}$ suprida pode interferir em vários processos metabólicos das mudas, causando toxicidade às plantas manifestada por cloroses, necroses e, por fim, morte de planta.

Palavras-chave: Cromo; crescimento de plantas; acumulação de metais; padrão de distribuiçãode metais; efeito tóxico; mangue.

\section{INTRODUCTION}

Mangroves are trees and shrubs that grow in saline coastal habitats in the tropical and subtropical regions of the world. These ecosystems are highly productive but extremely sensitive and fragile (Hogarth, 1999). Due to industrial development and population expansion, heavy metal pollution in mangrove wetland environment is becoming an increasingly serious problem worldwide. Along the southern coast of China, the severity of impact on coastal habitats has increased dramatically, a wide variety of anthropogenic activities have affected the mangrove ecosystem, as reflected by faecal coliform counts, heavy metal and inorganic nitrogen concentrations exceeding national standards (Chua and Gorre, 2000; Alongi et al., 2005). The sources of metal input are industrial effluents and wastes, urban runoff, sewage treatment plants, boating activities, agricultural fungicide runoff, domestic garbage dumps and mining operations (Tam and Wong, 2000; MacFarlane, 2002; Cox and Preda, 2005; Gonzalez-Mendoza et al., 2007). The heavy metals AS, Cd, Pb, Zn and $\mathrm{Cr}$ are of greatest ecotoxicological concern in Chinese estuaries and are often found in high concentrations in polluted sediments (Zhou and Zhu 2006; Li et al., 2007). Mangrove plants can absorb pollutants from the environment and accumulate them in the bodies. Different species have different abilities to absorb and enrich heavy metals (Lin, 1999). Studies performed with mangrove seedlings exposed to heavy metals have demonstrated a relatively low transport of metals from roots to leaves (Chiu et al., 1995). A number of researchers have found high concentrations of accumulated metals in the tissues of numerous mangrove species in the polluted localities including K. candel, Rhizophora spp. and Avicennia spp. (MacFarlane and Burchett, 2000). Heavy metal contamination is one of the major environmental stresses that affect plant metabolism. Due to its widespread industrial use, $\mathrm{Cr}$ has become a serious pollutant of soil and aquatic bodies (Zayed and Terry, 2003). Cr can be transferred and concentrated into plant tissues from soil, and pose significant damaging effect on the plant. Many studies have appeared in the literature investigating the effects of toxic metals on growth of plants and the distribution of metals (Wong et al., 1988; Moral et al., 1994, and Yim and Tam, 1999), but very little is known about the specific effects and accumulation of heavy metals such as $\mathrm{Cr}$ in mangroves. Thus, the present pot experiment aims to: (1) investigate the effects of $\mathrm{Cr}$ on growth of young $K$. candel seedlings, (2) determine the distribution and accumulation patterns of $\mathrm{Cr}$ in the various organs of young $\mathrm{K}$. candel seedlings, and (3) assess the $\mathrm{Cr}$ toxicity effect on young $\mathrm{K}$. candel seedlings. 
RAHMAN, M. M.; CHONGLING, Y.; RAHMAN, M. M.; ISLAM, K. S. Accumulation, distribution and toxicological effects induced by chromium on the development of mangrove plant Kandelia candel (L.) Druce. Ambi-Agua, Taubaté, v. 4, n. 1, p. 6-19, 2009. (doi:10.4136/ambi-agua.70)

\section{MATERIALS AND METHODS}

\subsection{Experimental setup}

For each with 3 replicates in a complete randomized design were set up to examine $\mathrm{Cr}$ ( 7 treatments) accumulation, distribution and their effects on growth of $K$. candel mangrove seedlings.

\subsection{Field collection and germination}

The propagules of $K$. candel were collected from plants grown at the Jiulongjiang mangrove forest stand $\left(24^{\circ} 24^{\prime} \mathrm{N}, 117^{\circ} 23^{\prime} \mathrm{E}\right)$, Xiamen, Fujian, China. The region is subtropical with most of the annual rainfall $(1284 \mathrm{~mm})$ derived from summer typhoons. The average annual temperature range of estuarine waters is from 14.8 to $27.8^{\circ} \mathrm{C}$, with salinities adjacent to the mangroves ranging from 12 to 26 psu. After removal of the bracts, only complete, undamaged propagules with testa intact and no emergent hypocotyls or radicles were selected for planting. Propagules chosen for germination were those collected in the most abundant weight class, 18.0-19.55 g fresh weights. Propagules were planted in plastic pots filled with washed sand. Three plastic pots were placed inside a plastic container $(30 \mathrm{~cm}$ long $\times 40 \mathrm{~cm}$ wide $\times 30 \mathrm{~cm}$ high). Four propagules were randomly planted in each plastic pot for germination and growth $(3 \times 4, n=12)$. All the pots were placed in the green house. The propagules were kept in a greenhouse under natural lighting with a temperature of $28 \pm 5^{\circ} \mathrm{C}$. A quantity of 2 liters tap water was irrigated to each pot 2 times each week. The water level of each container was adjusted daily with tap water (free- $\mathrm{NaCl}$ ) to compensate for the amount of water lost by evaporation. Propagules started to germinate within one month. After 3 weeks, the young seedlings were adapted to Hoagland's nutrient solution (Table 1). The solutions were changed every 7 days to prevent depletion of metals, nutrients and oxygen.

Table 1. Basal nutrient solution used for sand culture of Kandelia candel (L.) Druce seedlings.

\begin{tabular}{ccc}
\hline Solution & Chemical composition & Value (g/L) \\
\hline $\mathrm{A}$ & $\mathrm{KNO}_{3}$ & 70.77 \\
& $\mathrm{NH}_{4} \mathrm{H}_{2} \mathrm{PO}_{4}$ & 23.00 \\
& $\mathrm{MgSO}_{4} \cdot 7 \mathrm{H}_{2} \mathrm{O}$ & 49.29 \\
$\mathrm{~B}$ & $\mathrm{H}_{3} \mathrm{BO}_{3}$ & 2.86 \\
$\mathrm{CuSO}_{4} \cdot 7 \mathrm{H}_{2} \mathrm{O}$ & 0.08 \\
& $\mathrm{ZnSO}_{4} \cdot \mathrm{H}_{2} \mathrm{O}$ & 0.22 \\
& $\mathrm{MnSO}_{4}$ & 1.55 \\
& $\left(\mathrm{NH}_{4}\right)_{6} \mathrm{MO}_{7} \mathrm{O}_{24} \cdot 4 \mathrm{H}_{2} \mathrm{O}$ & 0.61 \\
& $\mathrm{FeSO}_{4} \cdot 7 \mathrm{H}_{2} \mathrm{O}$ & 5.57 \\
$\mathrm{C}$ & $\mathrm{EDTA}^{\mathrm{N} \mathrm{Na}_{2}}$ & 7.45 \\
& $\mathrm{Ca}\left(\mathrm{NO}_{3}\right)_{2}$ & 118.07 \\
\hline
\end{tabular}

Note: 1 L Hoagland's solution $=10 \mathrm{ml}$ solution $\mathrm{A}+1 \mathrm{ml}$ solution $\mathrm{B}+1 \mathrm{ml}$ solution $\mathrm{C}+10 \mathrm{ml}$ solution $\mathrm{D}$ with rest of water.

\subsection{Preparation of chromium solution}

$\mathrm{Cr}$ solutions were prepared by dissolving $5.124 \mathrm{~g}$ of chromium chloride salts ( $\mathrm{CrCl}_{3} .6 \mathrm{H}_{2} \mathrm{O}$, Xilong chemical factory, Guangdong, China.) in $1000 \mathrm{ml}$ of distilled water. From this stock solution, various concentrations $\left(1,1.5,2,2.5\right.$ and $\left.3 \mathrm{mg} \mathrm{L}^{-1}\right)$ of $\mathrm{Cr}$ solution were prepared.

\subsection{Chromium exposure}

Two-months old $K$. candel seedlings were put in individual plastic containers holding $1000 \mathrm{ml}$ of Hoagland's solution prepared with the addition of $\mathrm{Cr}\left(\mathrm{as} \mathrm{CrCl}_{3}\right)$ treatment in seven 
RAHMAN, M. M.; CHONGLING, Y.; RAHMAN, M. M.; ISLAM, K. S. Accumulation, distribution and toxicological effects induced by chromium on the development of mangrove plant Kandelia candel (L.) Druce. Ambi-Agua, Taubaté, v. 4, n. 1, p. 6-19, 2009. (doi:10.4136/ambi-agua.70)

levels: $0,0.5,1,1.5,2,2.5$, and $3 \mathrm{mg} \mathrm{L}^{-1}$. The concentration of the metal ion was maintained by adding tap water up to the mark in the plastic container in order to correct the evaporation loss. Plants were exposed to $\mathrm{Cr}$ for 12 weeks under greenhouse conditions. Control (CK) plants were irrigated with $1000 \mathrm{ml}$ of Hoagland's solution without $\mathrm{CrCl}_{3}$. These exposures were performed in triplicates. After 90 days of cultivation under $\mathrm{Cr}$ stress, the symptoms of heavy metal toxicity appeared in the seedling. On the base of the symptoms of the seedlings after three months, we assessed the effects of Cr toxicity.

\subsection{Analyses of samples}

The propagules were allowed to germinate and grow for five months under glasshouse conditions in sand culture before the experiment started. At the end of 90 days of cultivation of seedlings with heavy metals, the plants were uprooted from the plastic pots, washed thoroughly with tap water and rinsed again in distilled water. The samples were then divided into root, hypocotyl, stem, and leaf portions and the fresh weights (FW) of individual parts were recorded. The samples were oven-dried at $70^{\circ} \mathrm{C}$ to constant weight before taking dry weights (DW). Furthermore, the oven-dried samples were ground with an agate grinder (FW100, China) to pass through a 60 mesh sieve. Heavy metals contents were determined after incinerating the samples in a muffle oven at $550^{\circ} \mathrm{C}$ for $6 \mathrm{~h}$. Samples (about $0.2 \mathrm{~g}$ ) were digested for heavy metal analysis with a mixture of concentrated nitric acid and hydrogen peroxide at $90^{\circ} \mathrm{C}$, adapting the methods of MacFarlane et al. (2003) and Defew et al. (2005). The digested samples were made in to $50 \mathrm{ml}$ volume for root, hypocotyl, stem and leaf tissue and were stored in labeled acid-washed glass vials. Samples were analyzed by inductively coupled plasma-mass spectroscopy ICP-MS (PerkinElmer, America). To ensure precision of ICP-MS results, three replicates of each sample were measured for absorbencies. Metal concentrations were calculated from each replicate absorbance value, which was then used to calculate an average sample metal concentration. All concentrations were expressed in $\mathrm{mg} \mathrm{kg}$ ${ }^{1}$ on a dry-weight (DW) basis using weights obtained from oven-dried specimens.

\subsection{Statistical analysis}

Two statistical programs (Microsoft Excel 2003 package; SSPS 13.0, Chicago, IL, USA) were used to analyze the data. The descriptive statistics (mean, standard deviation) of the heavy metal concentrations were calculated by using the Microsoft Excel 2003 package. A one way analysis of variance (ANOVA) followed by Duncan's post-hoc test was employed to examine any statistical differences between different treatments in terms of changes in biomass, plant growth parameters, bioaccumulation rate, and distribution of heavy metal concentration. The differences were considered statistically significant when the $p$-value was equal to or less than 0.05 .

\section{RESULTS AND DISCUSSION}

\subsection{Plant growth}

At the end of the three month experiment on five month old seedlings, stem height, and leaf numbers of the Cr-treated $K$. candel seedlings were found to be significantly less than that of the control (Figure. 1 and 2). As Cr concentration was increased, seedling height at harvest decreased (Table 2). Cr treatments of $1 \mathrm{mg} \mathrm{L}^{-1}$ and above reduced seedling height significantly. The $3 \mathrm{mg} \mathrm{L}^{-1} \mathrm{Cr}$ exposure resulted in a 34.47\% decrease in final height and with the same Cr stress; the leaf number was decreased 68.95\% (Table 2). At the end of three month experimental period the mean stem height and number of leaves ranged from $19.06 \pm$ $0.66 \mathrm{~cm}$ to $12.43 \pm 0.11 \mathrm{~cm}$ and $7.73 \pm 0.20$ to $2.40 \pm 0.60$ and treatment had significant effect on these parameters (Table 2). The high concentration of $\mathrm{Cr}$ inhibits the growth of plants, 
RAHMAN, M. M.; CHONGLING, Y.; RAHMAN, M. M.; ISLAM, K. S. Accumulation, distribution and toxicological effects induced by chromium on the development of mangrove plant Kandelia candel (L.) Druce. Ambi-Agua, Taubaté, v. 4, n. 1, p. 6-19, 2009. (doi:10.4136/ambi-agua.70)

causing chlorosis, and necrosis. It was observed that the older leaves on the lower portion of the plant started to turn yellow and fall off. These findings are supported by other similar studies. For example, it has been reported that high concentration of excessive Cr supply may interfere with several metabolic processes of seedlings, causing toxicity to plants as exhibited by chlorosis, photosynthetic decline and, finally, plant death (Panda and Choudhury, 2005; Shanker et al., 2005). Cr causes reduction of leaf area and biochemical changes responsible for the inhibition of chlorophyll synthesis (Vajpayee et al., 1999), and disorganization of the chloroplast ultrastructure (Panda and Choudhury, 2005).

Table 2. Growth parameter under Cr supply after cultivation of 3 months

\begin{tabular}{ccc}
\hline $\begin{array}{c}\text { Treatment } \\
\left(\mathbf{m g ~ L}^{-\mathbf{1}}\right)\end{array}$ & $\begin{array}{c}\text { Stem height } \\
(\mathbf{c m})\end{array}$ & $\begin{array}{c}\text { Leaf number } \\
\mathbf{( n )}\end{array}$ \\
\hline CK & $19.06 \pm 0.66(\mathrm{a})$ & $7.73 \pm 0.20(\mathrm{a})$ \\
0.5 & $18.00 \pm 0.34(\mathrm{~b})$ & $6.40 \pm 0.20(\mathrm{~b})$ \\
1.0 & $17.26 \pm 0.58(\mathrm{c})$ & $5.60 \pm 0.10(\mathrm{c})$ \\
1.5 & $16.80 \pm 0.26(\mathrm{c})$ & $4.70 \pm 0.10(\mathrm{~d})$ \\
2.0 & $14.80 \pm 0.10(\mathrm{~d})$ & $3.80 \pm 0.10(\mathrm{e})$ \\
2.5 & $12.86 \pm 0.05(\mathrm{e})$ & $3.03 \pm 0.15(\mathrm{f})$ \\
3.0 & $12.43 \pm 0.11(\mathrm{e})$ & $2.40 \pm 0.60(\mathrm{~g})$ \\
\hline
\end{tabular}

Note: Mean values in the same column with different letters are significantly different at $\mathrm{p} \leq 0.05$ level. The values were the means and SD of 3 replicates.

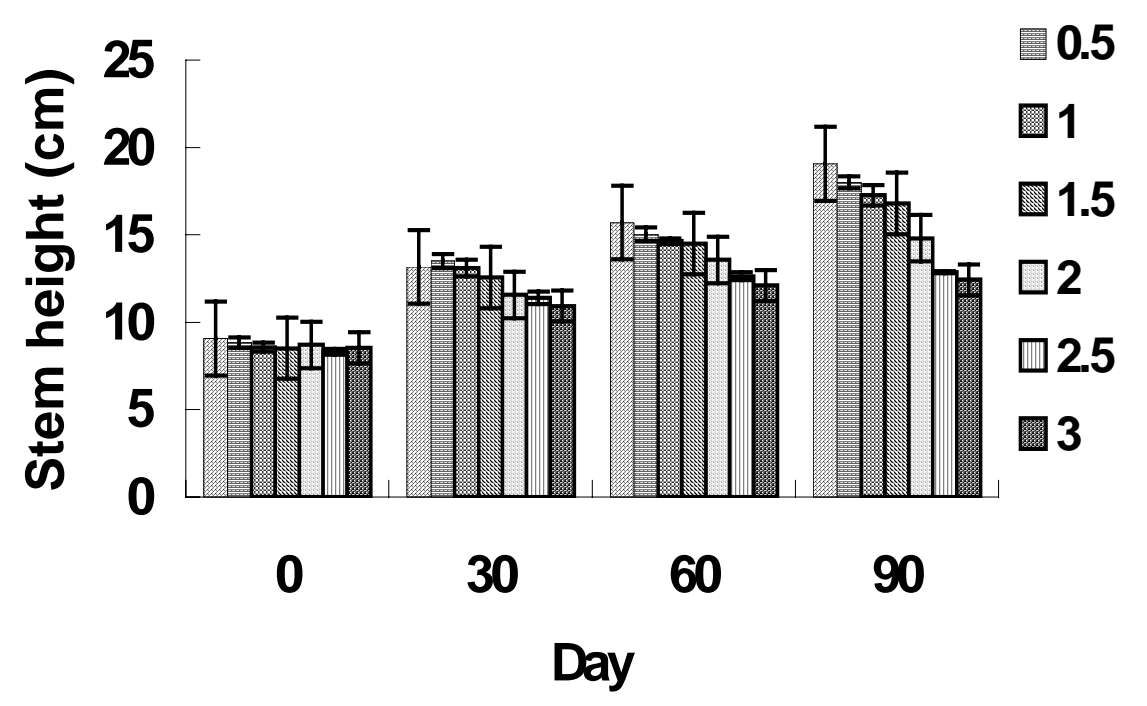

Figure 1. Stem heights of $K$. candel seedlings under different $\mathrm{Cr}$ treatments at different times (mean and standard deviation values of 3 replicates are shown, vertical bars represent SD). 


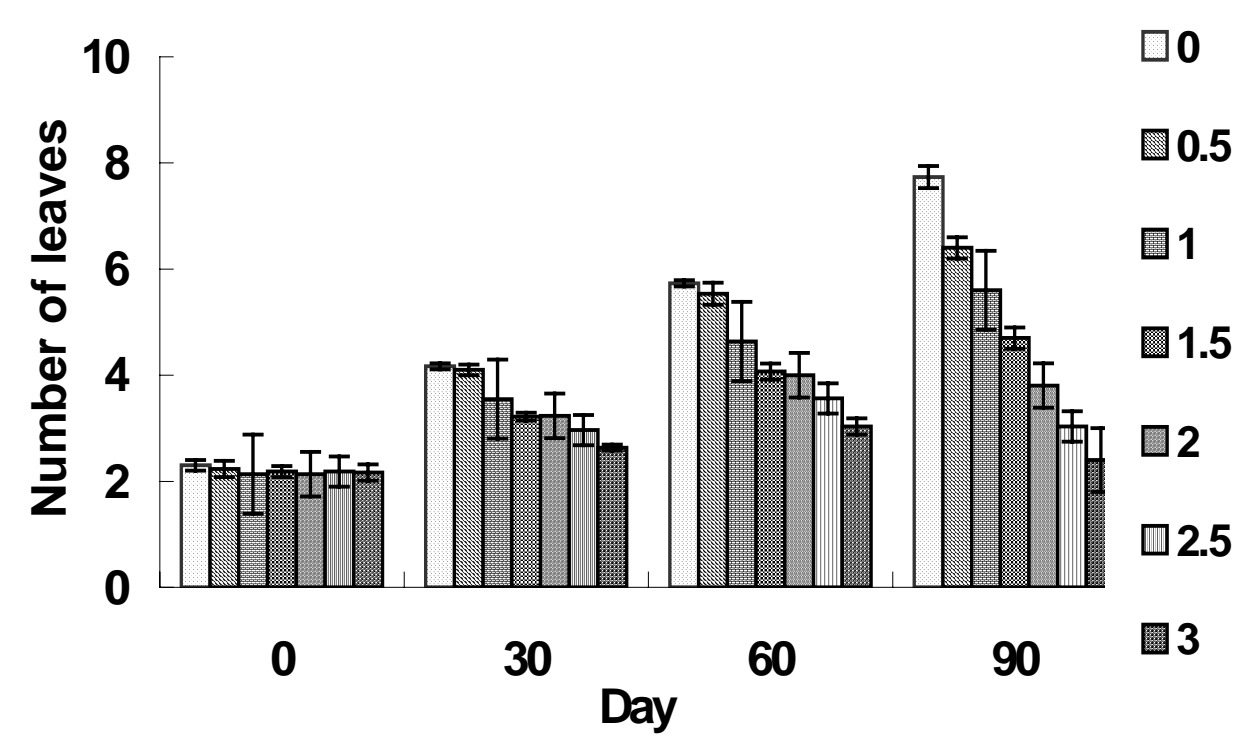

Figure 2. Number of leaves found on $K$. candel under different $\mathrm{Cr}$ treatments at different times (mean and standard deviation of 3 replicates are shown, vertical bars represent SD).

\subsection{Plant biomass}

Increasing the concentrations of $\mathrm{Cr}^{+3}$ ions in the nutrient solution produced a significant growth inhibition of $K$. candel seedlings, measured as dry and fresh weight of root, hypocotyl, stem and leaf. At the highest Cr concentration ( $3 \mathrm{mg} \mathrm{L}^{-1}$ ), total biomass (dry weight DW) was decreased by $60.65 \%$ and the root biomass was decreased by $45.19 \%$ compared to the CK (Table 3). The production of root biomass was reduced due to high Cr concentration in the sand culture. The heavy metal was found to inhibit root production. The stem biomass decreased significantly with the increase of $\mathrm{Cr}$ concentration in certain levels of the nutrient solutions (Table 3). For example, there was a significant difference between the highest $\mathrm{Cr}$ (3 $\mathrm{mg} \mathrm{L}^{-1}$ ) concentration and the CK samples. However, from 0.5 to $1.5 \mathrm{mg} \mathrm{L}^{-1}$ concentration there were no significant differences. The reduction in leaf biomass due to the Cr treatment was more obvious than that of stem biomass (Table 3), suggesting that growth parameters related to leaves were more sensitive than those associated with stems. These findings are consistent with Zhang et al. (2007) who also have found similar results in the Leersia hexandra plants. The differences between $\mathrm{CK}$ and $\mathrm{Cr}$ on growth inhibition were significant in the present study. Cr stress resulted in a significant decrease in plant biomass at the highest concentration in comparison to CK. The decrease in dry weight might be due to accumulation of certain nutrients and $\mathrm{Cr}$ in different parts of $\mathrm{K}$. candel grown with excess $\mathrm{Cr}$. The decrease in dry weight might also be due to a reduction in photosynthesis and chlorophyll ' $a$ ' synthesis under excess Cr conditions (Dube et al., 2003). It has been reported that Cr readily forms complexes with - $\mathrm{COOH}$ groups, which inhibits the translocation of metal from roots to shoots (Rai et al., 2002). As a consequence, the final dry matter values of roots ranged from $4.52 \pm$ 0.50 to $1.25 \pm 0.57 \mathrm{~g}$ and leaves ranged from $1.73 \pm 0.15$ to $0.4 \pm 0.26 \mathrm{~g}$ when harvested from the Cr-treated plants. Due to its structural similarity with some essential elements, Cr can affect the mineral nutrition of plants in a complex way (Shanker et al., 2005). Once accumulated and distributed within the plant, it can interact with other essential elements and significantly affect the concentration and distribution of nutrients in the plant, as well as modify morphology and some physiological processes (Barbosa et al., 2007). Formation of complexes of $\mathrm{Cr}$ with organic acids can play an important role in the inhibitory and stimulatory effects of $\mathrm{Cr}$ in the translocation of different mineral nutrients (Panda and Choudhury, 2005). An excess of $\mathrm{Cr}$ interferes in the absorption of $\mathrm{Na}, \mathrm{Fe}, \mathrm{Mn}, \mathrm{Cu}, \mathrm{N}, \mathrm{P}, \mathrm{K}$ 
RAHMAN, M. M.; CHONGLING, Y.; RAHMAN, M. M.; ISLAM, K. S. Accumulation, distribution and toxicological effects induced by chromium on the development of mangrove plant Kandelia candel (L.) Druce. Ambi-Agua, Taubaté, v. 4, n. 1, p. 6-19, 2009. (doi:10.4136/ambi-agua.70)

and Mg (Barbosa et al., 2007). One of the reasons for the decrease in the absorption of some nutrients in Cr-stressed plants is the inhibition of the plasma membrane $\mathrm{H}^{+}$ATPase activity (Shanker, 2003). Cr strongly inhibits the incorporation of P, K, Ca, Mg, Fe, Mn, Zn and Cu in different cellular constituents in Cocos nucifera. The inhibitory effects of $\mathrm{Cr}$ on plant growth are the result of specific interactions between $\mathrm{Cr}$ and $\mathrm{P}, \mathrm{Cr}$ and $\mathrm{Fe}$ or $\mathrm{Cr}$ and $\mathrm{Cu}$ (Barbosa et al., 2007). Such interactions could be associated with the chemical properties of these metals, for example the charge $\left(\mathrm{Cr}^{3+}\right.$ and $\left.\mathrm{Fe}^{3+}\right)$ and the effective ionic radius $(\mathrm{Cr}$ and $\mathrm{Cu})$. Thus, $\mathrm{Cr}$ can reduce the uptake and translocation of mineral nutrients and can induce deficiencies and imbalances of essential nutrients thereby resulting in poor growth and reduced biomass production.

Table 3. Biomass (DW) of different parts of $K$. candel seedlings under Cr supply after cultivation of 3 months.

\begin{tabular}{clllll}
\hline $\begin{array}{c}\text { Treatment } \\
\mathbf{~ m ~ L ~}^{-1}\end{array}$ & \multicolumn{1}{c}{$\begin{array}{c}\text { Root } \\
\text { DW(g) }\end{array}$} & $\begin{array}{c}\text { Hypocotyl } \\
\text { DW(g) }\end{array}$ & $\begin{array}{c}\text { Stem } \\
\text { DW(g) }\end{array}$ & $\begin{array}{c}\text { Leaf } \\
\text { DW(g) }\end{array}$ & $\begin{array}{c}\text { Total } \\
\text { DW(g/pot) }\end{array}$ \\
\hline CK & $4.52 \pm 0.50(\mathrm{a})$ & $11.90 \pm 0.89(\mathrm{a})$ & $1.4 \pm 0.16(\mathrm{a})$ & $1.73 \pm 0.15(\mathrm{a})$ & $19.56 \pm 1.70$ \\
0.5 & $3.39 \pm 0.43(\mathrm{a})$ & $11.13 \pm 0.62(\mathrm{ab})$ & $1.11 \pm 0.16(\mathrm{~b})$ & $1.4 \pm 0.44(\mathrm{ab})$ & $17.04 \pm 1.67$ \\
1.0 & $2.79 \pm 0.42(\mathrm{bc})$ & $10.06 \pm 0.84(\mathrm{bc})$ & $0.96 \pm 0.22(\mathrm{bc})$ & $1.16 \pm 0.71(\mathrm{bc})$ & $14.99 \pm 2.0$ \\
1.5 & $2.51 \pm 1.42(\mathrm{bc})$ & $9.4 \pm 1.26(\mathrm{~cd})$ & $0.78 \pm 0.54(\mathrm{bcd})$ & $1.00 \pm 0.40(\mathrm{bcd})$ & $13.7 \pm 3.63$ \\
2.0 & $1.91 \pm 0.98(\mathrm{c})$ & $8.56 \pm 0.20(\mathrm{~d})$ & $0.61 \pm 0.33(\mathrm{~cd})$ & $0.6 \pm 0.36(\mathrm{~cd})$ & $11.69 \pm 1.87$ \\
2.5 & $1.50 \pm 0.66(\mathrm{~cd})$ & $7.12 \pm 0.42(\mathrm{e})$ & $0.46 \pm 0.19(\mathrm{de})$ & $0.53 \pm 0.10(\mathrm{de})$ & $9.62 \pm 1.38$ \\
3.0 & $1.25 \pm 0.57(\mathrm{~d})$ & $5.76 \pm 0.42(\mathrm{f})$ & $0.36 \pm 0.16(\mathrm{e})$ & $0.4 \pm 0.26(\mathrm{e})$ & $7.78 \pm 1.43$ \\
\hline
\end{tabular}

Note: Mean values in the same column with different letters are significantly different at $\mathrm{p} \leq 0.05$ level. The values were the means and SD of 3 replicates.

\subsection{Accumulation of $\mathrm{Cr}$ in different parts of $\mathrm{K}$. candel seedlings}

Under the different $\mathrm{Cr}$ treatments in sand culture condition, the $\mathrm{Cr}$ concentrations in roots, hypocotyls, stems, and leaves of $K$. candel seedlings are shown in Figure 3 . The $\mathrm{Cr}$ concentration in roots ranged from 22.87 to $1.43 \mathrm{mg} \mathrm{kg}^{-1}$. The maximum Cr concentration in the dry root matter was $22.87 \mathrm{mg} \mathrm{kg}^{-1}$, which was significantly higher than the CK. The concentration in hypocotyls ranged from 1.22 to $0.68 \mathrm{mg} \mathrm{kg}^{-1}$. The Cr concentration in stems ranged from 2.42 to $1.30 \mathrm{mg} \mathrm{kg}^{-1}$. The $\mathrm{Cr}$ concentration in the leaves ranged from $1.98 \mathrm{t} 00.98$ $\mathrm{mg} \mathrm{kg}^{-1}$. Ninety days after $\mathrm{Cr}$ treatment, lower $\mathrm{Cr}$ concentration was detected in leaves. On the other hand, when comparing the heavy metal concentration in different tissues, we observed that the $\mathrm{Cr}$ concentrations were $22.87 \mathrm{mg} \mathrm{kg}^{-1}$ in the roots (Figure 3A), $1.30 \mathrm{mg} \mathrm{kg}^{-}$ ${ }^{1}$ in the hypocotyls ( Figure 3B), $2.42 \mathrm{mg} \mathrm{kg}^{-1}$ in the stems (Figure 3C) and $1.74 \mathrm{mg} \mathrm{kg}^{-1}$ in the leaves (Figure 3D). When comparing Cr concentrations in different plant parts with respect to their CK, the results showed that treated plant root bioaccumulated high amounts of this metal. The reason of the high accumulation in roots of the plants could be because $\mathrm{Cr}$ is immobilized in the vacuoles of the root cells, thus rendering it less toxic, which may be a natural toxicity response of the plant (Shanker et al., 2004). The results showed that after $22.87 \mathrm{mg} \mathrm{kg}^{-1} \mathrm{Cr}$ concentration, the seedling could not accumulate more $\mathrm{Cr}$ from the restricted environment. Under the treatments of 2.5 and $3 \mathrm{mg} \mathrm{L}^{-1}$, the seedlings showed significant amount of decrease in $\mathrm{Cr}$ accumulation. It may be the cause for seedlings cell malfunction, cell damaging, and the depletion in chlorophyll. It has been reported that high concentration of excessive Cr supply may interfere with several metabolic processes of seedlings, causing toxicity to plants (Panda and Choudhury, 2005; Shanker et al., 2005). 


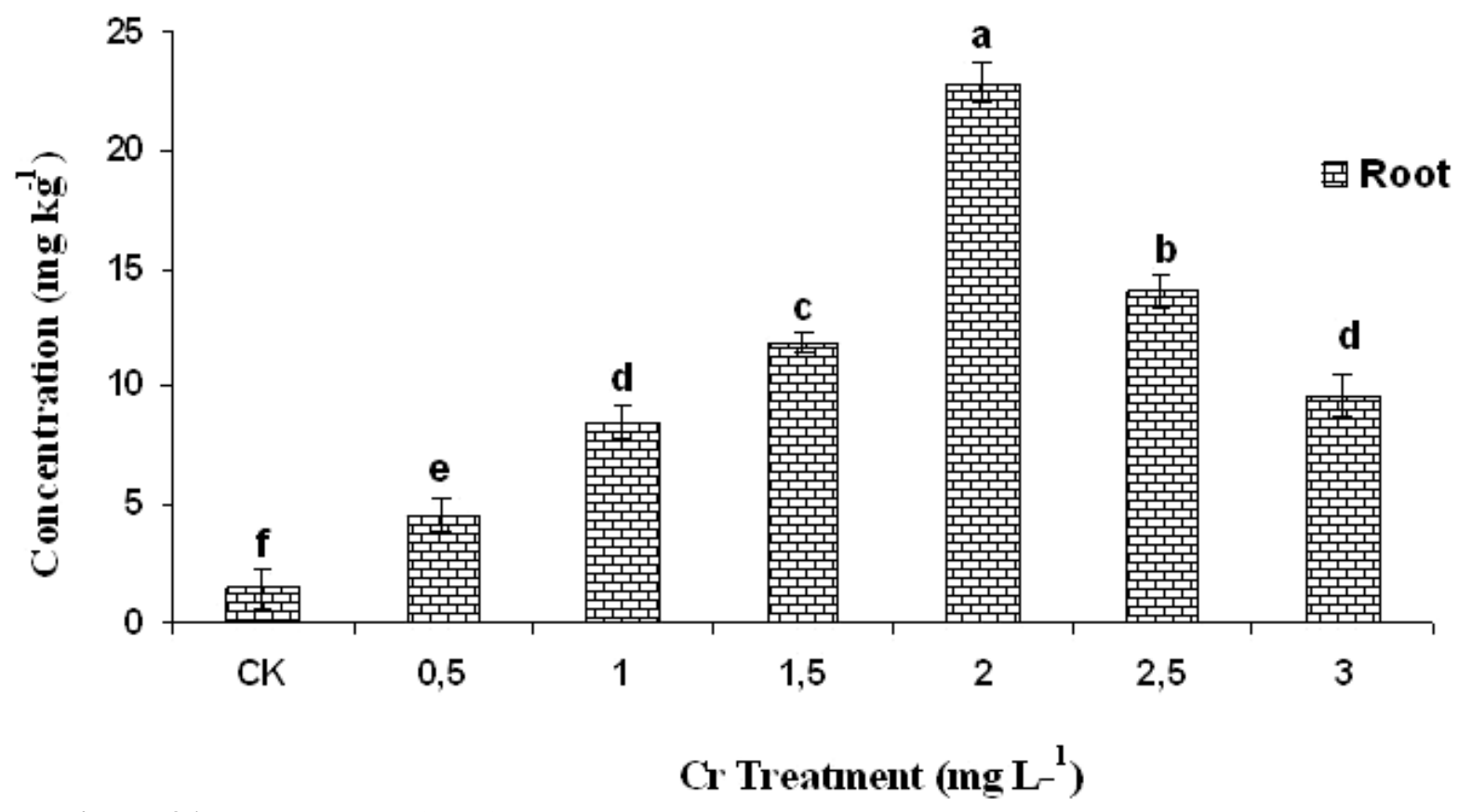

Figure 3A. Cr concentrations in roots.

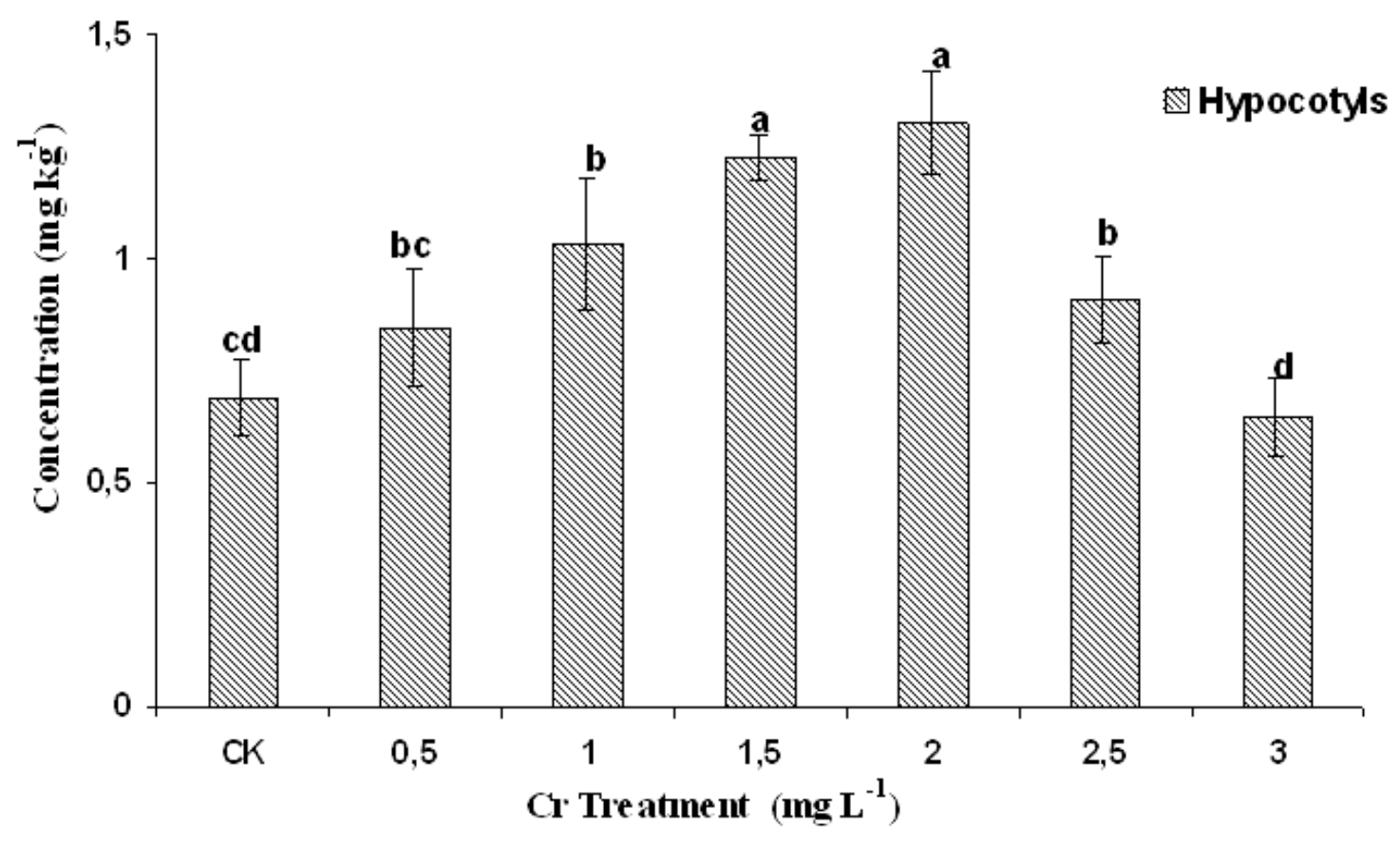

Figure 3B. Cr concentrations in hypocotyls. 


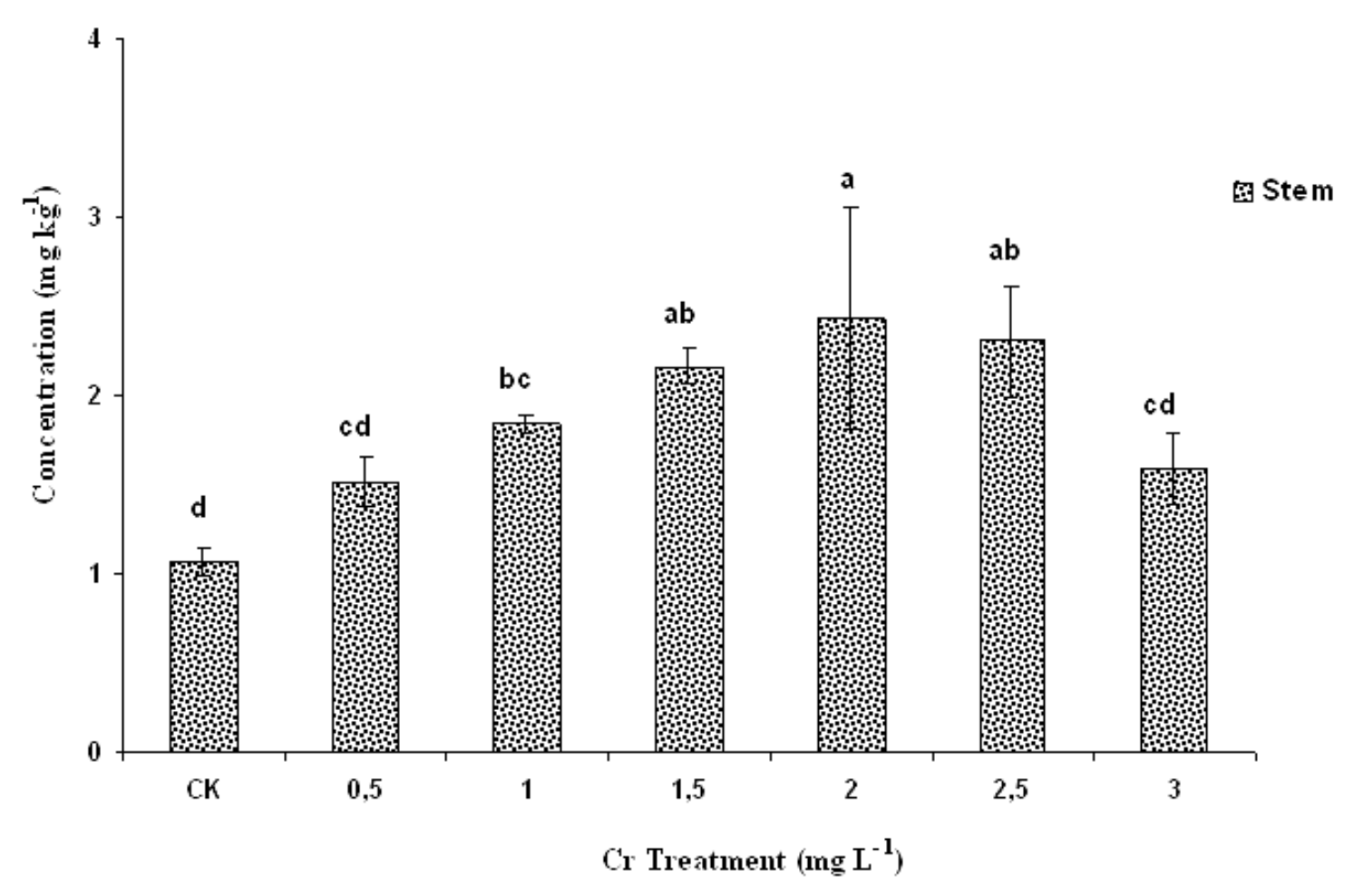

Figure 3C. Cr concentrations in stems.

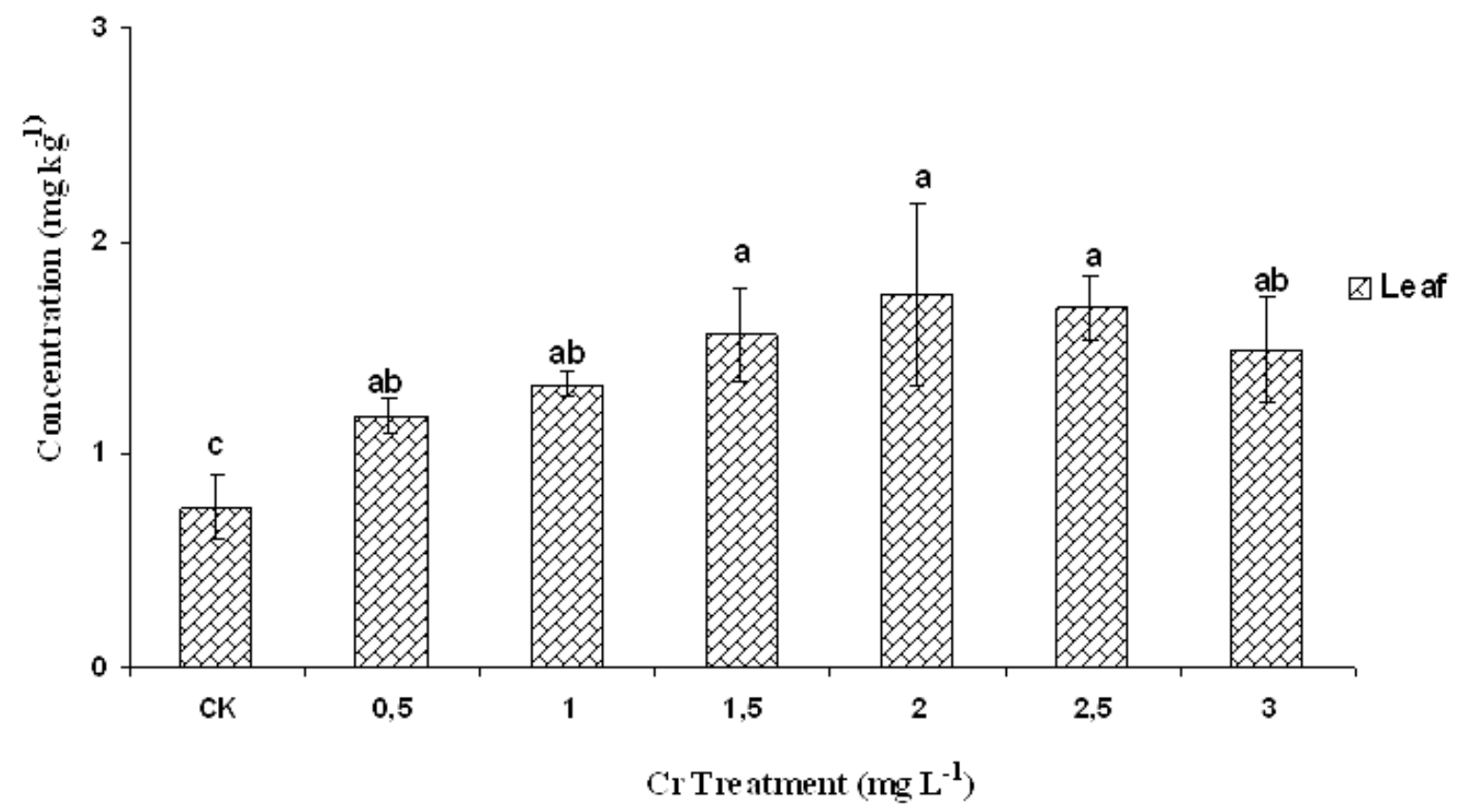

Figure 3D. Cr concentrations in leaves.

Figure 3 (A, B, C, D). Cr concentrations in different parts of $K$. candel seedlings under different $\mathrm{Cr}$ stresses (Mean \pm S.D). Different letters on the vertical bars indicate statistical significance $(p \leq 0.05)$ of difference between the means according to Duncan's test.

\subsection{Distribution pattern of $\mathrm{Cr}$ in different parts of $K$. candel seedlings}

Increased levels of heavy metals such as $\mathrm{Cr}$ in $\mathrm{K}$. candel seedlings generally resulted in higher heavy metal concentrations in mangrove plants, but the degree of increase in different plant parts were varied (Figure 4). The heavy metal concentrations in roots were significantly higher than those found in the other plant parts. At low to medium heavy metal inputs (the 0 
RAHMAN, M. M.; CHONGLING, Y.; RAHMAN, M. M.; ISLAM, K. S. Accumulation, distribution and toxicological effects induced by chromium on the development of mangrove plant Kandelia candel (L.) Druce. Ambi-Agua, Taubaté, v. 4, n. 1, p. 6-19, 2009. (doi:10.4136/ambi-agua.70)

and $2 \mathrm{mg} \mathrm{L}^{-1}$ treatments), most added heavy metals were accumulated in roots, with little transportation to the leaf and stem portions. The roots have been known as an absorptive sponge to heavy metals in soil and water. Metals absorbed or adsorbed by roots are often bound with the cell wall material or other macromolecules to prevent them from translocation to the sensitive plant parts (Chen et al., 1995). When the Cr concentration increased, the defensive mechanism of roots (as a barrier) might have been exhausted and more metals were found in either leaves or stems. In addition, it is known that $\mathrm{Cr}$ is passively taken up and retained by cation exchange sites of the cell wall (Shanker et al., 2005). Therefore, such a non-specific absorption to cell walls could be another way to immobilize the metal at the root level. The distribution pattern of $\mathrm{Cr}$ in $\mathrm{K}$. candel was Root $>$ Stem $>$ Leaf $>$ Hypocotyl. From our investigation we found that the root accumulated the greatest amount of heavy metal at almost $80 \%$ (Figure 4).

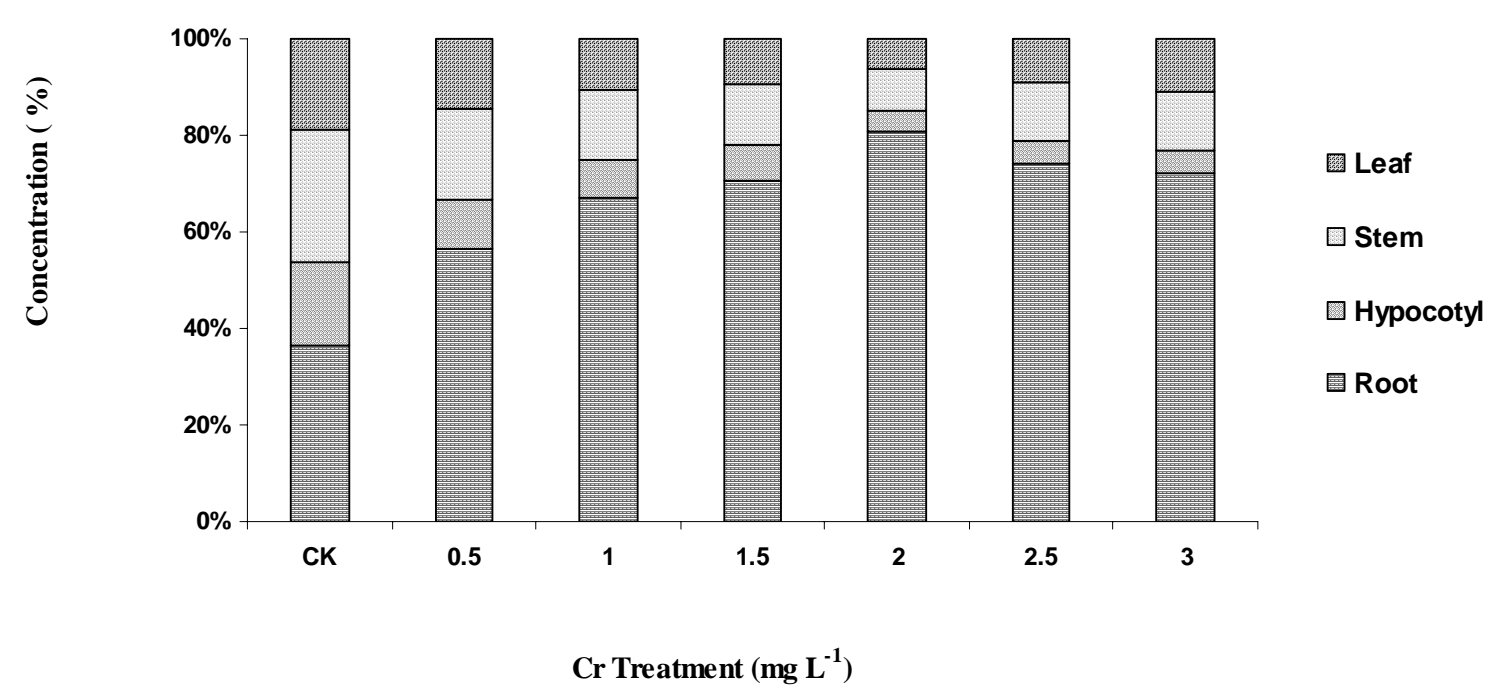

Figure 4. Distribution pattern of $\mathrm{Cr}$ in different parts of $\mathrm{K}$. candel seedlings.

\subsection{Bioaccumulation factor of $\mathrm{Cr}$ in $\mathrm{K}$. candel}

The $\mathrm{Cr}$ uptake in different parts of the plants was calculated using the bioaccumulation factor (BAF). The $B A F$ provides an index of the ability of the plant to accumulate a particular metal with respect to its concentration in the medium (Tam and Wong, 1997; Zayed et al., 1998; Ghosh and Singh, 2005), which is calculated as follows:

$$
B A F=\frac{\text { Trace element conc. in plant tissue }\left(\mathrm{mg} \mathrm{kg}^{-1}\right) \text { at harvest }}{\text { Conc. of the element is the external nutrient solution added }\left(\mathrm{mg} \mathrm{kg}^{-1}\right)} \times 100
$$

The bioaccumulation coefficient of roots, hypocotyls, stems, and leaves ranged from 1143.75 to $143.60,169.56$ to $21.64,303.10$ to 52.99 and 251.46 to 60.75 , respectively. When the plants were exposed to $2 \mathrm{mg} \mathrm{L}^{-1} \mathrm{Cr}$ treatment, the bioaccumulation coefficient reached a maximum in roots (1143.75) and significantly higher than those of other treatments (Table 4). The $\mathrm{Cr}$ bioaccumulation rate in roots ranged from 1143.75 to 143.60 . The maximum $\mathrm{Cr}$ bioaccumulation rate in the root was 1143.75, which was significantly higher than the CK.

\subsection{Assessment of effects of $\mathrm{Cr}$ toxicity on $\mathrm{K}$. candel seedlings}

In three months cultivation under $\mathrm{Cr}$ stress, the symptoms of heavy metal toxicity appeared in the seedlings. The initial symptom of $\mathrm{Cr}$ toxicity appeared to cause chlorosis in $K$. candel seedlings. Chlorosis appeared in the upper leaves of seedlings as an effect of $\mathrm{Cr}$, 
RAHMAN, M. M.; CHONGLING, Y.; RAHMAN, M. M.; ISLAM, K. S. Accumulation, distribution and toxicological effects induced by chromium on the development of mangrove plant Kandelia candel (L.) Druce. Ambi-Agua, Taubaté, v. 4, n. 1, p. 6-19, 2009. (doi:10.4136/ambi-agua.70)

Table 4. Bioaccumulation factors for $\mathrm{Cr}$ in K. candel (an average of three replicates).

\begin{tabular}{crcrr}
\hline Treatment & Root & Hypocotyls & Stem & Leaf \\
\hline CK & 143.60 & 68.90 & 106.91 & 74.9 \\
0.5 & 911.39 & 169.56 & 303.10 & 235.4 \\
1.0 & 850.37 & 103.27 & 183.54 & 132.9 \\
1.5 & 791.59 & 81.64 & 144.28 & 104.0 \\
2.0 & 1143.75 & 65.21 & 121.35 & 87.3 \\
2.5 & 561.118 & 36.36 & 92.16 & 67.5 \\
3.0 & 321.13 & 21.64 & 52.99 & 49.7 \\
\hline
\end{tabular}

probably due to the retardation of Fe and Zn translocation. The primary toxic effect seemed to be membrane damage due to the high oxidative potential of Cr. Severe necrosis was observed in the lower leaves of $K$. candel seedling with increased $\mathrm{Cr}$ concentrations. The statistical analysis showed that the toxic effects on the seedling stem height, leaf number and biomass were significantly $(p \leq 0.05)$ different with increasing $\mathrm{Cr}$ concentrations at $3 \mathrm{mg} \mathrm{L}^{-1}$. Metal sensitivity and toxicity is influenced by the concentration range of the toxicant the length of the exposure period, and the life-stage or biological process (germination, seedling survival, vegetative growth) examined and hence are important considerations in toxicity assessment (Ernst and Nelissen, 2000). Moreover, very little information exists on the relative sensitivities of semi-aquatic angiosperms to heavy metals (Mohan and Hosetti, 1999), or the combined effects of metals to plants, as exposure to mixtures are more reflective of environmental situations and may alter biological responses in quantitative ways relative to that of single toxicants (MacFarlane and Burchett, 2002). Cr treatment had toxicity effect on the roots and leaves suggesting that metal toxicity induces stress, at least for the duration of exposure considered in the present study. Table 5 shows the visible toxicity symptoms on $K$. candel seedlings under different $\mathrm{Cr}$ stresses. Cr stress can induce metabolic modifications in plants, such as alterations in photosynthesis (Barbosa et al., 2007), degradation of photosynthetic pigments and induction of oxidative stress (Panda and Choudhury, 2005).

Table 5. Visible symptoms on seedlings of $K$. candel with increasing Cr concentrations.

\begin{tabular}{|c|c|c|}
\hline $\begin{array}{l}\text { Cr treatments } \\
\quad\left(\mathrm{mg} \mathrm{L}^{-1}\right)\end{array}$ & Visible symptoms & $\begin{array}{l}\text { Stem growth } \\
\text { Reduction (\%) }\end{array}$ \\
\hline $\begin{array}{l}\text { CK } \\
0.5\end{array}$ & $\begin{array}{l}\text { No symptoms } \\
\text { No obvious symptoms }\end{array}$ & $\begin{array}{l}0.00 \\
5.59\end{array}$ \\
\hline 1 & Chlorosis & 9.44 \\
\hline 1.5 & $\begin{array}{l}\text { Chlorosis, reddish-brown discoloration of the leaf } \\
\text { blades }\end{array}$ & 11.88 \\
\hline 2 & Chlorosis $(+)$, necrosis & 22.36 \\
\hline 2.5 & $\begin{array}{l}\text { Chlorosis }(++) \text {, necrosis }(+) \text {, root worsened with less } \\
\text { root hair }\end{array}$ & 32.51 \\
\hline 3 & $\begin{array}{l}\text { Chlorosis }(+++) \text {, necrosis }(++) \text {, senescence, root } \\
\text { becomes shorter and thicker, root hairs sparser and } \\
\text { color is black and brown, and stem deep brown in } \\
\text { color, plant stared to die. }\end{array}$ & 34.79 \\
\hline
\end{tabular}

Note: Relative symptom intensity is given in brackets. Percent of growth reduction is given to the $0 \mathrm{mg} \mathrm{L}^{-1} \mathrm{Cr}$ treatment. 


\section{CONCLUSIONS}

The present study clearly shows that $\mathrm{Cr}$ has significant effects on the $K$. candel seedlings growth parameters. This heavy metal decreased the $K$. candel seedlings stem height, leaf number and total biomass with increased concentrations. At the end of the three months experiment, stem height, leaf number and biomass of the Cr-treated $K$. candel seedlings were significantly less than those of the control. At the highest $\mathrm{Cr}\left(3 \mathrm{mg} \mathrm{L}^{-1}\right)$ exposure, a $34.47 \%$ decrease in final seedling height, 68.95\% decrease in leaf number and $60.65 \%$ decrease in total biomass were noted. The $\mathrm{Cr}$ absorption abilities for different parts of the plant also varied. Roots can accumulate the highest percentage of heavy metal. The heavy metal concentrations in various plant parts increased with the increase concentration of heavy metal in the treatment. K. candel can be affected by very low concentrations of Cr. With a continuous supply of a Cr solution at a concentration of $3 \mathrm{mg} \mathrm{L}^{-1}$, the poisoned root system turned to black-brown and 90 days later the seedlings began to die.

\section{REFERENCES}

ALONGI, D. M.; PFITZNER, J.; TROTT, L. A.; TIRENDI, F.; DIXON, P.; KLUMPP, D.W. Rapid sediment accumulation and microbial mineralization in forests of the mangrove Kandelia candel in the Jiulongjiang Estuary, China. Estuarine, Coastal and Shelf Science, v. 63, p. 605-618, 2005.

BARBOSA, R. M. T.; ALMEIDA, A-A F.; MIELKE, M. S.; LOGUERCIO, L. L.; MANGABEIRA, P. A. O.; GOMES, F. P. A physiological analysis of Genipa americana L.: A potential phytoremediator tree for chromium polluted watersheds. Environmental and Experimental Botany, v. 61, p. 264-271, 2007.

CHEN, G. Z.; MIAO, S. Y.; TAM, N. F. Y.; WONG, Y.S.; LI, S. H.; LAN, C. Y. Effect of synthetic wastewater on young Kandelia candel plants growing under greenhouse conditions. Hydrobiologia, v. 295, p. 263-274, 1995.

CHIU, C. Y.; HSIU, F. S.; CHEN, S. S.; CHOU, C. H. Reduced toxicity of Cu and Zn to mangrove seedlings in saline environments. Botany Bulletin of Academia Sinica, v. 36, p. 19-24, 1995.

CHUA, T. E.; GORRE, I. R. Xiamen region, China. In: SHEPPARD, C. (Ed.), 2000. Seas at the millennium: an environmental evaluation. Amsterdam: Elsevier Science 2000. p. 513-533.

COX, M.; PREDA, M. Trace metal distribution within marine and estuarine sediments of western moreton bay, Queensland, Australia: relation to land use and setting. Geographical Research, v. 43, p. 173-193, 2005.

DEFEW, L. H.; MAIR, J. M.; GUZMAN, H. M. An assessment of metal contamination in mangrove sediments and leaves from Punta Mala Bay, Pacific Panama. Marine Pollution Bulletin, v. 50, p. 547-552, 2005.

DUBE, B. K.; TEWARI, K.; CHATTERJEE, J.; CHATTERJEE, C. Excess chromium alters uptake and translocation of certain nutrients in citrullus. Chemosphere, v. 53, p. 11471153, 2003. 
ERNST, W. H. O.; NELISSEN, H. J. M. Life-cycle phases of a zinc- and cadmium-resistant ecotype of Silene vulgaris in risk assessment of polymetallic mine soils. Environmental Pollution, v. 97, p. 229-338, 2000.

GHOSH, M.; SINGH, S. P. A comparative study of cadmium phytoextraction by accumulator and weed species. Environmental Pollution, v. 133, p. 365-371, 2005.

GONZALEZ-MENDOZA, D.; GOLD-BOUCHOT, G.; ESCOBEDO-GRACI, R. M. et al. Coordinated responses of phytochelatin synthase and metallothionein genes in black mangrove, Avicennia germinans, exposed to cadmium and copper. Aquatic Toxicology, v. 83, p. 306-314, 2007.

HOGARTH, P. J. The biology of mangroves. Oxford: Oxford University Press, 1999. p. 1525p.

LI, G.; CAO, Z. ; LAN, D. et al. Spatial variations in grain size distribution and selected metal contents in the Xiamen Bay, China. Environmental Geology, v. 52, p. 15591567, 2007.

LIN, P. Mangrove ecosystem in China. Beijing: Science Press, 1999. 232p.

MACFARLANE, G. R.; BURCHETT, M. D. Cellular distribution of copper, lead and zinc in the grey mangrove, Avicennia marina (Forsk.) Vierh. Aquatic Botany, v. 68, p. 45-59, 2000.

MACFARLANE, G. R. Leaf biochemical parameters in Avicennia marina (Forsk.) Vierh. as potential biomarkers of heavy metal stress in estuarine ecosystems. Marine Pollution Bulletin, v. 44, p. 244-256, 2002.

MACFARLANE, G. R.; BURCHETT, M. D. Toxicity, growth and accumulation relationships of copper, lead and zinc in the grey mangrove Avicennia marina (Forsk.) Vierh. Marine Environmental Research, v. 54, p. 65-84, 2002.

MACFARLANE, G. R.; PULKOWNIKB, A.; BURCHETT, M. D. Accumulation and distribution of heavy metals in the grey mangrove, Avicennia marina (Forks.) Vierh.: biological indication potential. Environmental Pollution, v. 123, p. 129-151, 2003.

MOHAN, B. S.; HOSETTI, B. B. Aquatic plants for toxicity assessment. Environmental Research, v. 81, p. 259-274, 1999.

MORAL, R.; GOMEZ, I.; NAVARRO, P. J.; MATAIX, J.; Effects of cadmium on nutrient distribution, yield, and growth of tomato grown in soilless culture Journal of Plant Nutrition, v. 17, p. 953-962, 1994.

PANDA, S. K.; CHOUDHAURY, S. Chromium stress in plants. Brazilian Journal of Plant Physiology, v. 17, p. 95-102, 2005.

RAI, R. D.; TRIPATHI, P.; VAJPAYEE, V. N.; JHA, V.; ALI, M. B. Bioaccumula-tion of toxic metals ( $\mathrm{Cr}, \mathrm{Cd}, \mathrm{Pb}$, and $\mathrm{Cu}$ ) by seeds of Euryale ferox Salisb. (Makhana). Chemosphere, v. 46, p. 267-272, 2002.

SHANKER, A. K.; CERVANTES, C.; LOZA, T. H.; AVUDAINAYAGAM. Chromium toxicity in plants. Environment International, v. 31, p. 739- 753, 2005. 
SHANKER, A. K.; DJANAGUIRAMAN, M.; SUDHAGAR, R.; CHANDRASHEK- AR, C. N.; PATHMANABHAN, G. Differential antioxidative response of ascorbate glutathione pathway enzymes and metabolites to chromium speciation stress in green gram (Vigna radiate (L) R. Wilczek, cv CO4) roots . Plant Science, v. 166, p. 10351043, 2004.

SHANKER, A. K. Physiological, biochemical and molecular aspects of chromium toxicity and tolerance in selected crops and tree species. 2003, Dissertation (Ph.D in plant physiology) - Tamil Nadu Agricultural University, Coimbatore, 2003.

TAM, N. F. Y.; WONG, W. S. Spatial variation of heavy metals in surface sediments of Hong Kong mangrove swamps. Environmental Pollution, v. 110, p. 195-205, 2000.

TAM, N. F. Y.; WONG. Y. Accumulation and distribution of heavy metals in a simulated mangrove system treated with sewage. Hydrobiologia, v. 352, p. 67-75, 1997.

VAJPAYEE, V. N.; SHARMA, S. C.; RAI, U. N.; YUNUS, M. Bioaccumulation of chromium and toxicity to photosynthetic pigment, nitrate reductase and protein content of Nelumbo nucifera Gaetrn. Chemosphere, v. 39, p. 2159-2169, 1999.

WONG, Y. S.; LAM, H. M.; DHILLON, E. Physiological effects and uptakes of cadmium in Pisum sativum. Environmental International, v. 14, p. 535-543, 1988.

YIM, M. W.; TAM, N. F. Y. Effects of wastewater-borne heavy metals on mangrove plants and soil microbial activities. Marine Pollution Bulletin, v. 39, p. 179-186, 1999.

ZAYED, A.; LYTLE, M. C.; JIN-HONG, Q.; TERRY, N. Chromium accumulation, translocation and chemical speciation in vegetable crop. Planta, v. 206, p. 293-299, 1998.

ZAYED, A.; TERRY, N. Chromium in the environment: factors affecting biological Remediation. Plant Soil, v. 249, p. 139-156, 2003.

ZHANG, X. H.; JIE, L.; HAI, T. H.; JUN, C.; YI, N. Z.; DUN, Q. W. Chromium accumulation by the hyperaccumulator plant Leersia hexandra Swartz. Chemosphere, v. 60, p. 1138-1143, 2007.

ZHOU, M.; ZHU, M. Progress of the project, ecology and oceanography of harmful algal blooms in China. Advanced Earth Science, v. 21, p. 673-679, 2006. 


ISSN = 1980-993X - doi:10.4136/1980-993X
www.agro.unitau.br/ambi-agua
E-mail: ambi-agua@agro.unitau.br
Tel.: (12) 3625-4116

\title{
Influence of additives on the retention of metal ions in a soil of Bangalore, India (doi:10.4136/ambi-agua.71)
}

\author{
Syed Abu Sayeed Mohammed ${ }^{1}$; Maya Naik²; Syed Tanveeruddin ${ }^{3}$ \\ ${ }^{1}$ Faculty of Civil Engineering, HKBK College of Engineering, \#22/1, Nagawara, \\ Bangalore 560045, India \\ E-mail: abubms@rediffmail.com \\ ${ }^{2}$ Faculty of Civil Engineering, BMS College of Engineering, \\ Bull Temple Road, Bangalore 560019, India \\ E-mail: snmcvbms@gmail.com \\ ${ }^{3}$ Alumni, Department of Medical Electronics, HKBK College of Engineering, \#22/1, Nagawara, \\ Bangalore 560045, India \\ E-mail: sy_tanveeruddin@yahoo.com
}

\begin{abstract}
Liners play an important role in minimizing migration of contaminants and are frequently constructed with natural materials serving as the primary barrier to contain chemicals and potentially harmful pollutants from municipal toxic waste leachates. To improve the performance of liners, additives like lime and cement at low percentages were added to Red Soil of Bangalore. Heavy metals like hexavalent chromium, copper and zinc and alkali metals like sodium and potassium were taken as contaminants. Batch leaching tests on 50 samples were performed according to ASTM D 3987 - 85 for soil and soil mixtures with contaminants. The heavy metals were potentiometrically monitored using ion selective mercury and platinum electrodes. The alkali metals were determined using a Flame Photometry. It has been observed that the retention of heavy metals elements followed the order copper $>$ zinc $>$ chromium over a period of 7 to 28 days. Chromium, zinc and copper attained equilibrium in this period as confirmed based on conductivity and $\mathrm{pH}$ data. Cement and lime had significant effect on copper and zinc. Specific adsorption of $\mathrm{Cu}$ onto $\mathrm{CaCO}_{3}$ surfaces may control $\mathrm{Cu}$ concentration in solution. Zn adsorption increases with $\mathrm{pH}$; Zinc hydrolysed at $\mathrm{pH}>7.7$ and these hydrolyzed species are strongly adsorbed to soil surfaces. $\mathrm{Cr}$ was retained only by $50 \%$ and additives did not have much effect as it is subjected to nonspecific adsorption (temporary). Cr was found to be highly mobile in alkaline soils. It was observed that the retention of alkali metals follows the order: $\mathrm{K}>\mathrm{Na}$. Cement and lime had positive effect on the retention of $\mathrm{Na}$ and $\mathrm{K}$. Sodium ion retarded immediately due to the removal of exchangeable cations, whereas potassium retarded more than sodium due to the lower hydrated radius of potassium. Scanning Electron Microscopy (SEM) characterization tests were performed to understand the soil mineral structure. Regular porous, sponge like, particles were detected in virgin soil containing crystals possibly of alumino sicilicate. Energy Dispersive Spectroscope (EDS) analysis indicated the presence of $\mathrm{Si}, \mathrm{Al}, \mathrm{Ca}, \mathrm{Ti}, \mathrm{Fe}, \mathrm{K}$, and $\mathrm{Na}$. These results indicate the possibility of using Red Soil as an adsorbent.
\end{abstract}

Keywords: Adsorption; liners; precipitation; leaching; electrodes; cation; ion exchange; landfill pollution. 


\section{Influência de aditivos na retenção de íons metálicos em um solo de Bangalore, Índia}

\section{RESUMO}

Camadas protetoras exercem um papel importante para minimizar a migração de contaminantes e, frequentemente, são construídas com materiais naturais que servem como barreira primária para contenção de substâncias químicas potencialmente poluentes e prejudiciais, resultantes da lixiviação de dejetos municipais tóxicos. Para melhorar o desempenho da camada protetora, calcário e cimento foram adicionados em baixas porcentagens em Solo Vermelho de Bangalore. Foram considerados contaminantes os metais pesados como cromo hexavalente, cobre e zinco, e também, metais alcalinos como sódio e potássio. Realizou-se uma bateria de testes de lixiviação em 50 amostras de acordo com o procedimento ASTM D 3987 - 85 recomendado para solos e misturas de solo com contaminantes. Os metais pesados foram potenciometricamente monitorados usando íons seletivos de mercúrio e eletrodos de platina. Os metais alcalinos foram analisados, usando-se um fotômetro de chamas. Foi observado que a retenção de metais pesados seguiu a ordem: cobre $>$ zinco $>$ cromo no período de 7 a 28 dias. O cromo, zinco e cobre atingiram equilíbrio nesse período, verificado com base nos dados de condutividade e $\mathrm{pH}$. Cimento e calcário tiveram efeito significativo para o cobre e zinco. Adsorção de $\mathrm{Cu}$ em superfícies de $\mathrm{CaCO}_{3}$ pode controlar a concentração de $\mathrm{Cu}$ em solução. Adsorção de $\mathrm{Zn}$ aumenta com o pH. O zinco foi hidrolisado em $\mathrm{pH}>7,7$ e esses elementos hidrolisados são fortemente adsorvidos nas superfícies dos solos. Só 50\% do Cr foi retido, uma vez que o aditivo não teve muito efeito devido à adsorção não-específica (temporária). Verificou-se que o Cr é altamente móvel em solos alcalinos. Foi observado que a retenção de metais alcalinos seguiu a ordem $\mathrm{K}>\mathrm{Na}$. $\mathrm{O}$ cimento e o calcário tiveram efeito positivo na retenção de $\mathrm{Na}$ e K. Íons de sódio foram retardados imediatamente devido à remoção de cátions trocáveis enquanto que os de potássio foram mais retardados do que os de sódio devido ao menor raio de hidratação do potássio. Foram realizadas análises com o microscópio de varredura eletrônica (SEM, sigla em inglês) para a caracterização da estrutura mineral dos solos. Partículas regulares e porosas, como esponjas, foram verificadas em solos virgens que continham cristais possivelmente de alumino-sicilicatos. Análises com espectroscópio de energia dispersiva (EDS, sigla em inglês) indicaram a presença de $\mathrm{Si}, \mathrm{Al}, \mathrm{Ca}, \mathrm{Ti}, \mathrm{Fe}, \mathrm{K}$, e $\mathrm{Na}$. Esses resultados indicam a possibilidade de se usar o Solo Vermelho como um adsorvente.

Palavras-chave: Adsorção; camadas de proteção; precipitação; lixiviação; eletrodos; cátion; troca iônica; poluição de aterros sanitários.

\section{INTRODUCTION}

Many cities in the developing countries are facing serious problem of disposing solid, liquid and hazardous waste generated by various sources. The large quantities of waste generated, which are disposed off on to the land, often pose a threat to ground water quality and has resulted in many incidents of ground water contamination.

Landfills have been the most economical and environmentally acceptable method for disposal of solid waste. However, the Leachate generated in landfills migrate downwards and poses threat to ground water, unless properly contained by a barrier system. Percolating fluid will tend to migrate downward through the landfill as Leachate. Unless properly regulated, leachate generated by precipitation and other liquids with in the waste flows from the landfill into underlying ground water. And thus, potentially, contaminate the drinking water aquifer. 
Liners play an important role in minimizing migration of contaminants. Liners are frequently constructed with natural materials serving as the primary barrier to contain chemicals and potentially harmful pollutants from municipal and toxic waste leachates. Geo technical liners are widely used for the control and containment of pollution. Hence the objective of any barrier system is to minimize the potential dangers associated with the migration of leachate generated, depending on the environmental requirements and the nature of the leachate itself. Liners may be designed for permanent containment, or temporary storage to allow for slow controlled migration of non-toxic leachate.

By comparing the literature, it has been found that Geosynthetic Clay Liners have more advantages (which give a hydraulic conductivity $\leq 1 \times 10^{-9} \mathrm{~cm} / \mathrm{s}$ ) than compacted clay liners (CCL), but their availability is limited. Soil liners possess many limitations but are widely used because of their universal availability, low cost, large attenuation capacity and their resistance to puncture and damage. In developing countries CCL's are more popular because of cheap labour and availability of good quality clays. Land fill engineering is sufficient to ensure a leachate retention time of 50 years (Mohammed, et al., 2006).

\subsection{Indian Scenario}

India has more than 285 million city dwellers even though the rate of urbanization is among the lowest in the world. The percentage of urban dwellers in India has been increasing from $10.8 \%$ in 1901, to $17.3 \%$ in 1951 and to $25.7 \%$ in 1991 . Rural urban migration and high demographic natural increase in cities will further increase the proportion to more than 50 percent of the total population by 2020. A major concern is the safe disposal of solid waste generated by growing Indian cities. With advancements of new types of wastes added, particularly urban areas are affected the most as the volume of waste starts increasing, municipalities face severe problems in managing the wastes. Table 1 gives an indication of the waste generated by Indian cities per day (Naik and Mohammed, 2008).

Table 1. Solid Waste generation in major Indian cities in a day.

\begin{tabular}{clc}
\hline $\begin{array}{c}\text { Sample } \\
\mathbf{N}^{\mathbf{0}}\end{array}$ & \multicolumn{1}{c}{ City } & $\begin{array}{c}\text { Solid waste generated } \\
\text { per day in tonnes }\end{array}$ \\
\hline 1. & Delhi & 5922 \\
2. & Greater Mumbai & 5320 \\
3. & Chennai & 3036 \\
4. & Kolkatta & 2653 \\
5. & Hyderabad & 2187 \\
6. & Bangalore & 1669 \\
7. & Ahmedabad & 1302 \\
\hline
\end{tabular}

Scientifically designed sanitary land fills are a solution but for Indian conditions locally available soils can be used as liner materials but they have advantages and disadvantages, a number of studies on liners have already been done but emphasis was on determining strength and stability and also on chemical compatibility. The behaviour of CCL's to diffusion and transport phenomenon for major ions of leachates have been studied for Brown and Red Earth of Bangalore. Mathematical models have been used to model the migration of contaminants through soil liners. Different ions migrate through soil liners at different velocities depending on their diffusion coefficients (Naik and Sivapullaiah, 2003).

The behaviour of combination of materials has also been enumerated. Materials like Fly ash, Illite, Red Earth and mixture of fly ash and Bentonite, Illite and Bentonite by mixing lime has also been studied. 
It has been found that fly ash has high hydraulic conductivity, Illite possess reasonably high cation exchange capacity and specific surface area, the hydraulic conductivity is lower in chemical solutions than in water. Addition of $20 \%$ bentonite to Illite greatly enhances its quality as liner material. The compressibility of mixture is decreased and hydraulic conductivity lowered. The fly ash bentonite mixture is least compressible, possess good strength but its chemical compatibility is poor. It can be used to contain leachates containing heavy metal ions. Red Earth Bentonite mixture possesses many desirable properties for its potential use as a liner. Inclusion of bentonite has helped to increase the cation exchange capacity, it possess reasonably low compression index.

Non-plastic fly ash bentonite mixture becomes plastic on addition of lime. It slightly increases the compression index but lowers the hydraulic conductivity. Stabilization of Illite with Lime has improved its plasticity but slightly increased its hydraulic conductivity (Kantha and Sivapullaiah, 2000).

From the above work it can be concluded that the selection of barrier system should be site specific considering local hydrogeology, nature of waste, size of the landfill, climatic conditions, availability of suitable materials and economy. The phenomena of leaching (desorption) have not been given much thought on the soil of Bangalore. Transport parameters that can be used to predict transport of heavy metals are rarely reported in literature. Particularly hazardous waste might leach out from these liners and finally enter the ground water (Tanit et al., 2009).

\subsection{Behaviour of metals in soils}

Metals added to soil will normally be retained at the soil surface. Movement of metals into other environmental compartments, i.e., ground water, surface water, or the atmosphere, should be minimal as long as the retention capacity of the soil is not exceeded. The extent of movement of a metal in the soil system is intimately related to the solution and surface chemistry of the soil and to the specific properties of the metal and associated waste matrix. The retention mechanisms for metals added to soil include adsorption of the metal by the soil solid surfaces and precipitation. The retention of cationic metals by soil has been correlated with such soil properties as $\mathrm{pH}$, redox potential, surface area, cation exchange capacity, organic mater content, clay content, iron and manganese oxide content, and carbonate content. Anion retention has been correlated with $\mathrm{pH}$, iron and manganese oxide content, and redox potential.

In addition to soil properties, consideration must be given to the type of metal and its concentration and to the presence of competing ions, complexing ligands, and the $\mathrm{pH}$ and redox potential of the soil-waste matrix. Transport of metals associated with various wastes may be enhanced due to:

1) Facilitated transport caused by metal association with mobile colloidal size particles;

2) Formation of metal organic and inorganic complexes that do not sorb to soil solid surfaces;

3) Competition with other constituents of waste, both organic and inorganic, for sorption sites, and;

4) Decreased availability of surface sites caused by the presence of a complex waste matrix.

Because of the wide range of soil characteristics and various forms by which metals can be added to soil, evaluating the extent of metal retention by a soil is site/soil/waste specific. Changes in the soil environment over time, such as the degradation of the organic waste matrix, changes in $\mathrm{pH}$, redox potential, or soil solution composition, due to various 
remediation schemes or to natural weathering processes also may enhance metal mobility. The extent of vertical contamination is intimately related to the soil solution and surface chemistry of soil matrix with reference to the metal and waste matrix. It has been found that the relative mobility of nine metals through Montmorillinite and Kaolinite to be $\mathrm{Cr}(\mathrm{VI})>\mathrm{Se}$ $>\mathrm{As}(\mathrm{III})>\mathrm{As}(\mathrm{V})>\mathrm{Cd}>\mathrm{Zn}>\mathrm{Pb}>\mathrm{Cu}>\mathrm{Cr}(\mathrm{III})$ (Mc Lean and Bert, 1992).

The main aim of this work is to study the leaching behaviour of soil and soil mixtures to different chemical contaminants by conducting leaching tests. Scanning Electron Microscopy (SEM) characterization tests were performed for through understanding of soil mineral structure.

\section{MATERIALS AND METHODS}

Red Soil of Bangalore drawn from the Campus of Indian Institute of Science (IISc), Bangalore is taken as the main soil; IISc was selected as it is a big campus with minimal contamination. Additives to enhance its properties selected were Lime and Cement. A known percentage by weight of an inorganic contaminant is mixed with soil or soil mixture and allowed to dry naturally for 7 days and also extended to cure for 28 days. Some of the contaminants introduced are sodium, potassium, copper, zinc, and chromium. The standard procedures followed were the ASTM (American Standard Testing Methods) D3987 - 85 (Reapproved 2004). A load ratio of $100 \mathrm{mg} / \mathrm{kg}$ and $50 \mathrm{mg} / \mathrm{kg}$ was maintained (1000 ml of 100 ppm contaminant solution was added to $1 \mathrm{~kg}$ of soil to give a load ratio of $100 \mathrm{mg} / \mathrm{kg}$ ).

Batch leaching test was done by taking a known weight of dried mixture and mixing it in a known volume of distilled water maintaining a solid to liquid (S/L) ratio of 1:20, and subjecting it to shaking for a period of 18 hours in a sample shaker at a speed of 30 RPM. The leached solution is taken and after centrifuging and filtering, the sample was sent for chemical analysis, the amount of contaminant leached was determined (ASTM, 2004).

A cost effective method has been used to determine concentrations of copper, zinc and chromium by Potentiometry. For the determination of copper and zinc, mercury electrode with Calomel as reference electrode was used. First standardization of this method was done using standard samples of $10,20,50,100 \mathrm{mg} / \mathrm{l}$ of contaminants prepared and determined potentiometrically and standard graphs were obtained (Jeffery et al., 1997).

\subsection{Apparatus: Mercury Electrode}

The electrode is a $U$ tube easily constructed with pyrex tubing. The platinum wire dipping into the mercury welded to a copper wire. The mercury must be pure and clean, in case of doubt, the mercury should be washed with dilute nitric acid and then thoroughly rinsed with distilled water. The electrode is filled with mercury so that the wide portion is half full. It is most important that no mercury is spilled into the titration vessel during the titration. After each titration the electrode is repeatedly washed with distilled water as shown in Figures 1, 2 and 3.

\subsection{Titration Assembly}

The electrode system consists of a mercury electrode and a saturated Calomel reference electrode, both supported in a $250 \mathrm{ml}$ pyrex beaker. Provision is made for magnetic stirring and the potential is followed by means of an electronic milli voltmeter.

\subsection{Reagents required}

Standard EDTA solution of 0.05 M, Mercury EDTA Solution (Mixequal volumes of 0.05 M Mercury Nitrate and 0.05 M EDTA, neutralize the liberated acid by addition of a few drops of $3 \mathrm{M}$ ammonia solution, dilute $10 \mathrm{ml}$ of this solution to $100 \mathrm{ml}$ with distilled water). 
Acetate buffer solution: - mix equal volumes of $0.5 \mathrm{M}$ sodium acetate solution and $0.5 \mathrm{M}$ acetic acid solution. The resulting solution has a pH of about 4.7.

\subsection{Procedure}

The general procedure is as follows: place $25 \mathrm{ml}$ of the metal ion solution in a $250 \mathrm{ml}$ pyrex beaker, add $25 \mathrm{ml}$ of the acetate buffer solution and one drop of Mercury EDTA solution. Use the titration assembly described above, stir magnetically. Titrate potentiometrically with a standard $0.05 \mathrm{M}$ EDTA solution added to $0.1 \mathrm{ml}$ or less as soon as the potential begins to rise, wait for a steady potential to be established after each addition. Soon after the end point the change of potential with each addition of EDTA becomes smaller and only a few large additions need be made.

Plot the titration curve (potentiometrically in millivolts against volume of standard EDTA solution) and evaluate the end point. In general, results accurate to better than 0.1 percent are obtained (Jeffery et al., 1997).

\subsection{Determination of chromium}

The chromium in the substance is converted into chromate or dichromate by any of the usual methods. A platinum indicator electrode and a saturated Calomel electrode are used. Place a known volume of the dichromate solution in the titration beaker and add $10 \mathrm{ml}$ of 10 percent sulphuric or hydrochloric acid per $100 \mathrm{ml}$ of final volume of the solution and also 2.5 $\mathrm{ml}$ of phosphorus acid. Insert electrodes stir and after adding $1 \mathrm{ml}$ of a standard ammonium iron sulphate solution the emf is measured continue to add the iron solution reading the emf after each addition then plot the titration curve and determine the end point (Jeffery et al., 1997).

\subsection{Flame photometric estimation of sodium and potassium}

Transfer 2, 4, 6, 8 and $10 \mathrm{~cm}^{3}$ of standard $\mathrm{NaCl}$ or $\mathrm{KCl}$ solution into different $50 \mathrm{~cm}^{3}$ volumetric flasks. Make up all the solutions upto the mark with distilled water and shake well for uniform concentration. Switch on the flame photometer and light the gas at the burner. Regulate the flow of gas and air supply. Now dip the capillary tube into the beaker containing distilled water and adjust the reading to zero. Now feed the $100 \mathrm{ppm} \mathrm{NaCl} / \mathrm{KCl}$ solution and adjust the reading to hundred. Feed the $\mathrm{NaCl} / \mathrm{KCl}$ solutions prepared through the capillary tube one by one including the solution of unknown volume, and note down the intensity (flame photometer reading) for each. Plot a graph of intensity against the volume of $\mathrm{NaCl} /$ $\mathrm{KCl}$ and find the unknown volume and calculate amount of sodium / potassium in it (Jeffery et al., 1997).

\subsection{Preparation of leached samples for SEM analysis}

A L/s ratio of 20 was maintained and samples of mixtures spiked with contaminants were taken and subjected to leaching tests according to ASTM D3987- 85 for 18 hours, with a buffer period of another 8 hours. The extraction time was kept at about 24 hours. The extract was filtered through Whatman $n^{0} .45$ filter paper to separate soil from fluid. The filter paper was rinsed with distilled water and the resulting soil solution was transferred into a porcelain dish and covered to avoid contamination and allowed to dry naturally. The dried soil extract was sent for SEM and EDS analysis. One sample of virgin soil was also sent to develop a comparison (Ali Baig and Sivapullaiah, 2008). 


\subsection{Preparation of moulds for Scattering Electron Microscopy (SEM) and Energy Dispersive Spectroscope (EDS)}

The specimen is mounted in this fashion: first there is a metal stub on top of which double sided carbon tape is used and sample is stuck on this carbon tape; later this entire stub is placed in the coating machine for the metal coating process. For an electrically conductive specimen, observation of the specimen without metal coating is the best method. For a nonconductive specimen, however, metal coating is usually applied to give the specimen electrical conductivity. This decreases the specimen's capacity to acquire an electrostatic charge and increases the yield of secondary electrons. The important thing to remember when applying a metal coating is that the coat of metal film must be as thin as possible so that the specimen surface morphology is not completely covered by coating.

The resultant images reveal remarkable structural resolution down to a few nanometers with great accuracy because the film provides a continuous coating over all the sample contours. In our case platinum was used with coating time of 120 seconds and vacuum less than 5 Pascal, as soil is a non magnetic material.

The mould or stub is kept in the vacuum chamber and SEM imaging and EDS is done, SEM and EDS was taken through JEOL JSM 6360 - A Model with a magnification capacity of X500, X1000, X2000 and accelerating voltage of $20 \mathrm{KV}$ with working distance (WD) 10 $\mathrm{mm}$ with a Spot size 58. First area of image is chosen and focused then via software EDS. Analysis is done on the same image by either selecting spot analysis or line analysis or area analysis. In our case area analysis was done and after the x-ray scan is complete the EDS result is also obtained simultaneously both qualitative and quantitatively (Jeol, 2008).

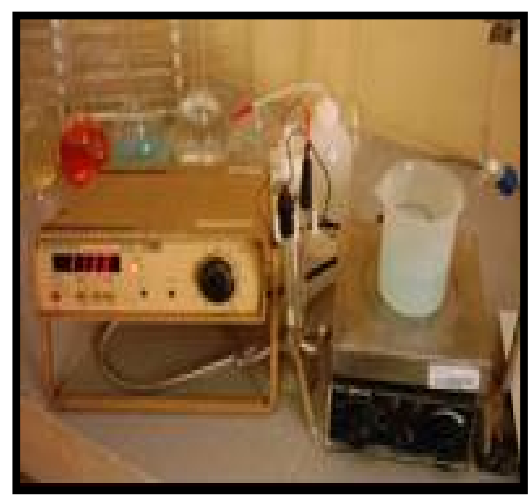

Figure 1. A set up for the potentiometric determination of copper using mercury electrode.

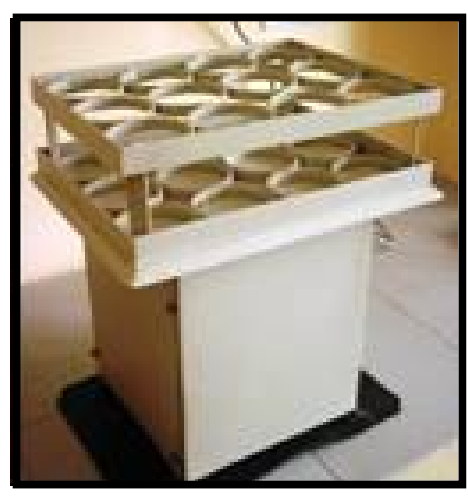

Figure 2. Sample shaker fabricated by the authors.

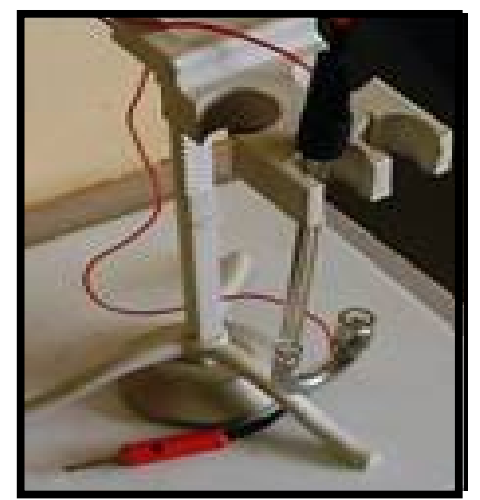

Figure 3. Close up of mercury electrode specially fabricated for this work.

\section{RESULTS AND DISCUSSION}

The results of all the tests conducted on samples have been shown in Tables 2, 3, 4, 5 and also graphs have been plotted as shown in Figures 9 and 10.

\subsection{Chromium}

In the present study the initial results obtained with different materials are not encouraging, only soil with 6\% lime showed some adsorption but over 28 days period it has been desorbed suggesting nonspecific (temporary) adsorption. As observed from the graph, the leachability of $\mathrm{Cr}^{6+}$ is highest in almost all the combinations studied; indicating $\mathrm{Cr}$ is not sorbed by the given soil.

The present study highlights that only soil with $6 \%$ lime showed some adsorption but over 28 days period it has been desorbed suggesting nonspecific adsorption. 
Hexavalent chromium was found to be highly mobile in alkaline soils, and hence other properties such as Cation Exchange Capacity, surface area and percent clay content have no significant influence on the mobility of $\mathrm{Cr}$ (VI). And hence $\mathrm{Cr}$ (VI) is not retained in Red soil treated with lime and cement. The reduction reaction in the presence of organic matter proceeds at a slow rate at environmental $\mathrm{pH}$ and temperatures.

It may be due to redox reactions that occur at extremely slow rate requiring more time which is $\mathrm{pH}$ dependent. Irrespective of adsorbent chromium (VI) adsorption increases with decrease in $\mathrm{pH}$. Cations like $\mathrm{K}^{+}, \mathrm{Ca}^{2+}, \mathrm{Mg}^{2+}$ can compete with hexavalent chromium and slightly influence the $\mathrm{Cr}$ (VI) adsorption.

Conductivity data suggests that it varies from 0.7 to1.50 millisiemens after seven days and after reaching 28 days it varied from 1.90 to 3.20 because hexavalent chromium is highly mobile in soils due to addition of excess lime.

Chromium exists in two possible oxidation states in soils: the trivalent chromium, $\mathrm{Cr}$ (III) and the hexavalent chromium, $\mathrm{Cr}(\mathrm{VI})$. Forms of $\mathrm{Cr}(\mathrm{VI})$ in soils are as chromate ion, $\mathrm{HCrO}^{4}$ predominant at $\mathrm{pH}<6.5$, or $\mathrm{CrO}_{4}{ }^{2-}$ predominant at $\mathrm{pH} 6.5$, and as dichromate, $\mathrm{Cr}_{2} \mathrm{O}_{7}{ }^{2-}$ predominant at higher concentrations $(>10 \mathrm{mM})$ and at $\mathrm{pH} 2-6$. The dichromate ions pose a greater health hazard than chromate ions. Both $\mathrm{Cr}(\mathrm{VI})$ ions are more toxic than $\mathrm{Cr}(\mathrm{III})$ ions.

Because of the anionic nature of $\mathrm{Cr}(\mathrm{VI})$, its association with soil surfaces is limited to positively charged exchange sites, the number of which decreases with increasing soil $\mathrm{pH}$. Iron and aluminum oxide surfaces will adsorb $\mathrm{CrO}_{4}{ }^{2-}$ at acidic and neutral $\mathrm{pH}$. It was concluded that the adsorption of $\mathrm{Cr}(\mathrm{VI})$ by ground-water alluvium was due to the iron oxides and hydroxides coating the alluvial particles. The adsorbed $\mathrm{Cr}(\mathrm{VI})$ was, however, easily desorbed with the input of uncontaminated ground water, indicating nonspecific adsorption of $\mathrm{Cr}(\mathrm{VI})$. The presence of chloride and nitrate had little effect on $\mathrm{Cr}(\mathrm{VI})$ adsorption, whereas sulfate and phosphate inhibited adsorption. It has been found that $\mathrm{SO}_{4}{ }^{2-}$ and dissolved inorganic carbon inhibited $\mathrm{Cr}(\mathrm{VI})$ adsorption by amorphous iron oxyhydroxide and subsurface soils (Grove and Ellis, 1980).

The presence of sulfate, however, enhanced $\mathrm{Cr}(\mathrm{VI})$ adsorption to kaolinite and $\mathrm{BaCrO}_{4}$ may form in soils at chromium contaminated waste sites. No other precipitates of hexavalent compounds of chromium have been observed in a $\mathrm{pH}$ range of 1.0 to 9.0. Hexavalent chromium is highly mobile in soils. In a study of the relative mobilities of 11 different trace metals for a wide range of soils. It was found that clay soil, containing free iron and manganese oxides, significantly retarded $\mathrm{Cr}(\mathrm{VI})$ migration.

Hexavalent chromium was found to be the only metal studied that was highly mobile in alkaline soils. The parameters that correlated with $\mathrm{Cr}(\mathrm{VI})$ immobilization in the soils were free iron oxides, total manganese, and soil $\mathrm{pH}$, whereas the soil properties, cation exchange capacity, surface area, and percent clay had no significant influence on $\mathrm{Cr}(\mathrm{VI})$ mobility. It has been reported that $\mathrm{Cr}(\mathrm{III})$ forms hydroxy complexes in natural water, including $\mathrm{Cr}(\mathrm{OH})_{2}{ }^{+}$, $\mathrm{Cr}(\mathrm{OH})^{2+}, \mathrm{Cr}(\mathrm{OH})_{3}{ }^{0}$ and $\mathrm{Cr}(\mathrm{OH})_{4}{ }^{-}$. Trivalent chromium is readily adsorbed by soils. In a study of the relative mobility of metals in soils at $\mathrm{pH} 5, \mathrm{Cr}$ (III) was found to be the least mobile. Hydroxy species of $\mathrm{Cr}$ (III) precipitate at $\mathrm{pH} 4.5$ and complete precipitation of the hydroxy species occurs at $\mathrm{pH}$ 5.5. Hexavalent chromium can be reduced to $\mathrm{Cr}$ (III) under normal soil $\mathrm{pH}$ and redox conditions. Soil organic matter has been identified as the electron donor in this reaction. The reduction reaction in the presence of organic matter proceeds at a slow rate at environmental $\mathrm{pH}$ and temperatures. It has been reported that in natural soils the reduction reaction may be extremely slow, requiring years. The rate of this reduction reaction, however, increases with decreasing soil $\mathrm{pH}$. Soil organic matter is probably the principal reducing agent in surface soils. In subsurface soils, where organic matter occurs in low concentration, $\mathrm{Fe}(\mathrm{II})$ containing minerals reduce $\mathrm{Cr}(\mathrm{VI})$ however it was observed that this reaction only occurred in the subsurface soil with a $\mathrm{pH}<5$. The reduction of $\mathrm{Cr}(\mathrm{VI})$ occurred 
in all four subsurface soils tested by decreasing the $\mathrm{pH}$ to 2.5. However, it has been demonstrated that under conditions prevalent in some soils, $\mathrm{Cr}$ (III) can be oxidized. In the presence of oxidized $\mathrm{Mn}$, which serves as an electron acceptor, was determined as an important factor in this reaction. Industrial use of chromium also includes organic complexed Cr(III). Chromium (III) complexed with soluble organic ligands will remain in the soil solution. In addition to decreased $\mathrm{Cr}$ (III) adsorption, added organic matter also may facilitate oxidation of Cr(III) to Cr(VI) (Mc Lean and Bert, 1992).

Even $\mathrm{pH}$ and conductivity data suggest that there is lot of activity taking place which suggests that it is one of the metal ion with the highest mobility.There has been adsorption of over $50 \%$ compared to zinc and copper, and this being the lowest in agreement with Mc Lean and Bert. (1992).

\subsection{Copper}

It has been found that copper reaches equilibrium in a short period and there is not much change with time. It is observed from the graph that copper leachability is about $10-12 \%$, lime has been found to have good attenuation effect on copper. However, copper has high affinity for soluble organic ligands and the formation of complexes may greatly increase its mobility in soils. The present study supports the fact that copper is retained in soils through exchange and specific adsorption mechanisms. Particularly in alkaline mixtures specific adsorption of copper onto $\mathrm{CaCO}_{3}$ is likely to take place and cement has moderate effect probably due to very low concentration of cement used. Variation of $\mathrm{pH}$ with time for different combinations of soil mixures with copper. It is observed that $\mathrm{pH}$ varies from 4.86 to 8.12 with the addition of lime which contributes hydroxyl ions (Lo and Lin, 2009).

At concentrations typically found in native soils, $\mathrm{Cu}$ precipitates are unstable. This may not be the case in waste-soil systems and precipitation may be an important mechanism of retention. It has been suggested that a clay mineral exchange phase may serve as a sink for $\mathrm{Cu}$ in noncalcareous soils. It has been found that copper reaches equilibrium in a short period; there is not much change over time (McBride and Bouldin, 1984).

\subsection{Zinc}

Zinc is readily adsorbed by clay minerals, carbonates, or hydrous oxides. It has been found that the greatest percent of the total $\mathrm{Zn}$ in polluted soils and sediments was associated with $\mathrm{Fe}$ and $\mathrm{Mn}$ oxides. Precipitation may become a more important mechanism of $\mathrm{Zn}$ retention in soil-waste systems. As with all cationic metals, Zn adsorption increases with $\mathrm{pH}$. Zinc hydrolysed at $\mathrm{pH}>7.7$ and these hydrolyzed species are strongly adsorbed to soil surfaces. Zinc forms complexes with inorganic and organic ligands that will affect its adsorption reactions with the soil surface. It has been found that Zinc reaches equilibrium over a period of 144 hours there is not much change over time. Lime and cement have been found to retain zinc more than only soil (Kurdi and Doner, 1983).

It has been found that zinc reaches equilibrium within 28 days and there is not much change with time. Lime and cement have been found to retain zinc more than any soil.

As observed from the graph, zinc is readily adsorbed by the present Red Soil and precipitation may become a more important mechanism of $\mathrm{Zn}$ retention in soil-waste systems. It is observed that conductivity varies from 0.90 to 2.2 millisiemens which is mainly due to addition of lime which contributes many ions to soil solution.(Lo and Lin, 2009).

In soil lime system the $\mathrm{pH}$ of the system increases immediately. Due to this, there is a possibility of formation of $\mathrm{ZnOH}^{+}$species and also to some extent precipitation of zinc onto the surface of the soil. The $\mathrm{ZnOH}^{+}$species gets adsorbed onto the soil surface along with zinc 
ions, in addition to zinc retention through ion exchange and adsorption mechanism. This leads to an increase in the total capacity of soil to retain more zinc (Rajasekhar et al., 1995).

The $\mathrm{pH}$ at the surface of the particle is 0.5 to 1 unit higher than the ambient $\mathrm{pH}$. Hence the precipitation of the metal ions can still occur onto the surfaces of the material at $\mathrm{pH}$ values 0.5 to 1.0 unit lower than the $\mathrm{pH}$ at which solution precipitation occurs. For only soil, since Red Soil is acidic with a $\mathrm{pH}$ of 4 at low $\mathrm{pH}$ conditions the concentration of the $\mathrm{H}^{+}$ions is high, hence these $\mathrm{H}^{+}$ions are also competing with zinc ions for the available exchangeable positions as well as adsorption sites leading to low retention of zinc ions at low $\mathrm{pH}$ conditions (Kantha et al., 2003). It is observed that $\mathrm{Zn}$ adsorption increases with $\mathrm{pH}$ in soil-lime system and reaches equilibrium condition. There is a possibility of formation of $\mathrm{ZnOH}^{+}$and the hydrolysed species are strongly adsorbed to soil surfaces.

\subsection{Sodium and potassium}

By comparing the experimental data it has been found that potassium is being adsorbed more than sodium. Over a period of time the sorption of potassium is getting stronger where as desorption of sodium has occurred. Lime and cement as additives to soil have proved to enhance its retention capacity. The $\mathrm{pH}$ for sodium varied between 7.75 to 12.83 and conductivity between 0.7 to 2.8 after 7 days and after 28 days it varied from 7.83 to 8.96 and conductivity from 1 to 1.0 millisiemens. The $\mathrm{pH}$ for Potassium varied between 7.2 to 13.03 and conductivity from 0.6 to 2 after 7 days and after 28 days $\mathrm{pH}$ varied from 7.2 to 8.3 and conductivity from 0.7 to 1.4 millisiemens.

The surface of an individual clay particle or organic colloid is negatively charged. As a consequence their surfaces attract and adsorb positively charged ions called cations. When water is added to soil, cations can move into solution; however they are still attracted to the clay particle or surface and as a result swarm around them. The mechanism of adsorption and desorption is important even though less than $1 \%$ of cations will do this at any one time. This is because detached cations become available to plants. Positively charged ions capable of being readily substituted from soil solution and onto the surface of a negatively charged soil particle and vice a versa are termed as exchangeable cations. The exchangeable cations of most importance are $\mathrm{Ca}^{2+}, \mathrm{Mg}^{2+}, \mathrm{K}^{+}, \mathrm{Na}^{+}, \mathrm{H}^{+}, \mathrm{Al}^{3+}$. In order to become available to a plant, a cation adsorbed on a soil particle must be replaced by a cation present in the soil solution. Plant roots facilitate this process by excreting a hydrogen ion into soil solution in order to exchange this for a cation (e.g. potassium).

The process of substitution is known as cation exchange and occurs when a cation in the soil solution moves into the hemisphere of a cation located on the surface of a negatively charged particle. Cation exchange is therefore defined as the interchange between a cation on the surface of any negatively charged particle and the soil solution. Whilst the cation themselves are still attracted to the clay particle the force of attraction on the cations diminishes rapidly with increasing distance from the negatively charged surface. This phenomenon of attracted cations and negatively charged particles is known as diffuse double layer. Literally it is a double layer because there are two layers of charge (i.e. negative and positive) and diffuser because the outer layer of cations is not well defined. The force of attraction between the negatively charged particles and the cations reduces quickly with increasing distance.

The more strongly attracted a cation is to their exchange surface the greater is the chance of adsorption. This is known as energy of adsorption. The energy of adsorption of a cation is a function of the valence. This is the reason why trivalent cations such as aluminium and divalent cations such as calcium and magnesium have energy of adsorption almost three and two times that of monovalent cations such as potassium and sodium. As a consequence exchangeable cations of aluminium, calcium or magnesium stay close to the soil particle and 
do not interfere with the cohesion between aggregated particles. In fact, these cations initiate the process of particle aggregation in soil.

The valence of an exchangeable cation therefore determines the double layer thickness. Higher the valence of the dominant exchangeable cation, the thinner is the double layer. However, differences in the thickness of the double layer can still occur even when the cations are of equivalent charge or valency.

When the valence of the cation is equal the cation with the smallest hydrated radius is more strongly adsorbed. In case of the monovalent cations of potassium and sodium, the potassium ion is more strongly adsorbed since it has a smaller hydrated radius, hence is more strongly adsorbed to the site of negative charge in comparison to sodium ion, is loosely held and so ready to hydrate and sodium rich soil will disperse. (The hydrated radius of potassium is 0.330 nanometer and for sodium it is 0.360 nanometer).

This phenomenon was observed while mixing sodium into soil; it turned into slurry where as the same quantity of potassium made the soil hard and workability started reducing.

The charge of the cation and the size of the hydrated cation essentially govern the preferences of cation exchange equilibria. In summary, highly charged cations tend to be held more tightly than cations with less charge and secondly cations with a small hydrated radius are bound more tightly and are less likely to be removed from the exchange complex. The combined influence of these can be summarized by the lysotropic series $\mathrm{Al}^{3+}>\mathrm{Ca}^{2+}>\mathrm{Mg}^{2+}>$ $\mathrm{K}^{+}>\mathrm{Na}^{+}>\mathrm{H}^{+}$. (University of New South Wales, 2007).

\subsection{SEM and EDS analysis}

Scattering Electron Microscopy (SEM) characterization tests were performed for thorough understanding of soil mineral structure, the observations reveal at higher size range regular porous sponge like large particles were detected from virgin soil sample.

In the regular porous sponge like particles crystals seem to be of alumino silicate can be seen. This is widely used as an adsorbent for removal of metals. The main crystalline material of zeolite is alumino silicate indicating possibility of using Red Soil as an adsorbent for removing metal ions (Figures 4, 5, 6, 7 and 8).

SEM observations of samples spiked with sodium, potassium, zinc and copper show aggregation and formation of homogenous mass from regular sponge like particles of virgin soil, which shows sorption has taken place. Energy Dispersive Spectroscope (EDS) analysis indicates presence of elements like $\mathrm{Si}, \mathrm{Al}, \mathrm{Ca}, \mathrm{Ti}, \mathrm{Fe}, \mathrm{k}, \mathrm{Na}$. This is in accordance with the conductivity data obtained experimentally (Young and Young, 2003).

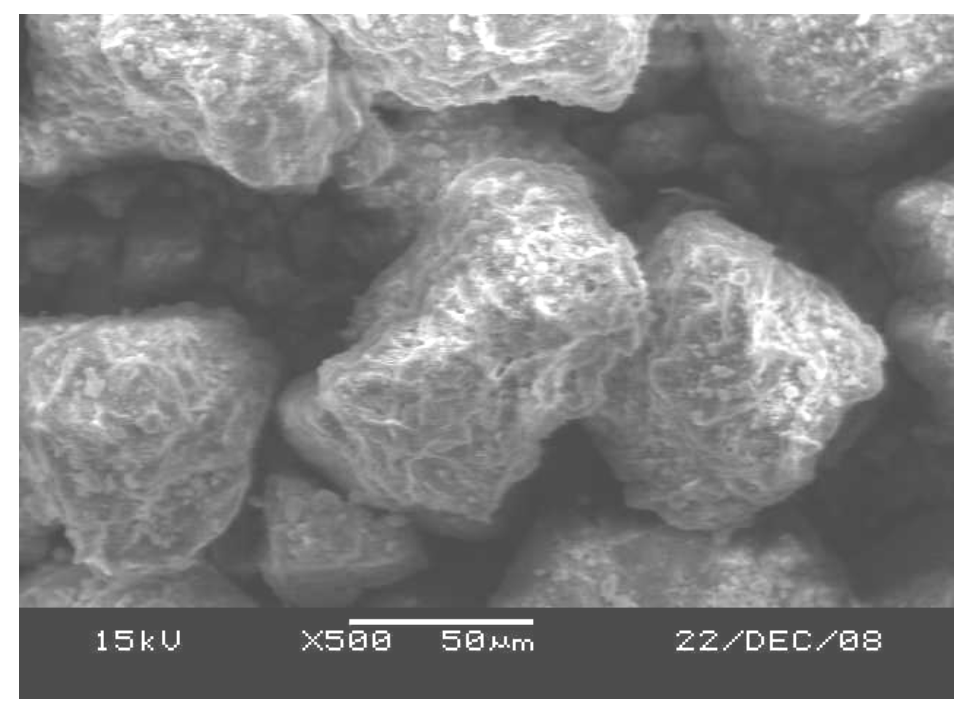

Figure 4. Virgin Soil. 
MOHAMMED, S. A. S.; NAIK, M.; TANVEERUDDIN, S. Influence of additives on the retention of metal ions in a soil of Bangalore, India. Ambi-Agua, Taubaté, v. 4, n. 1, p. 20-36, 2009. (doi:10.4136/ambi-agua.71)

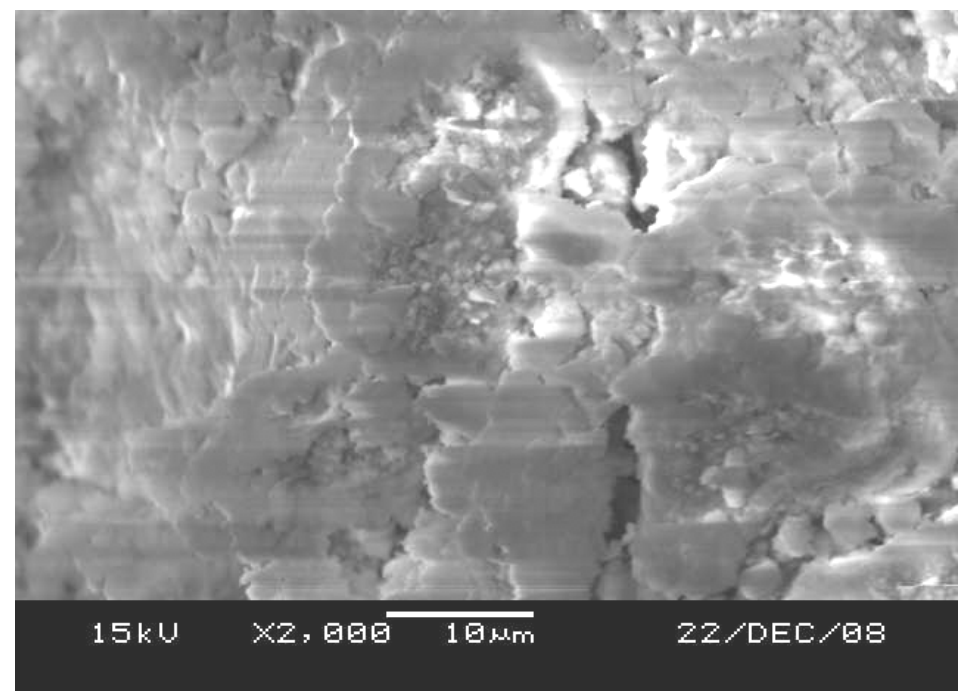

Figure 5. Soil + 6\% Lime $+100 \mathrm{mg} / \mathrm{kg} \mathrm{K}$.

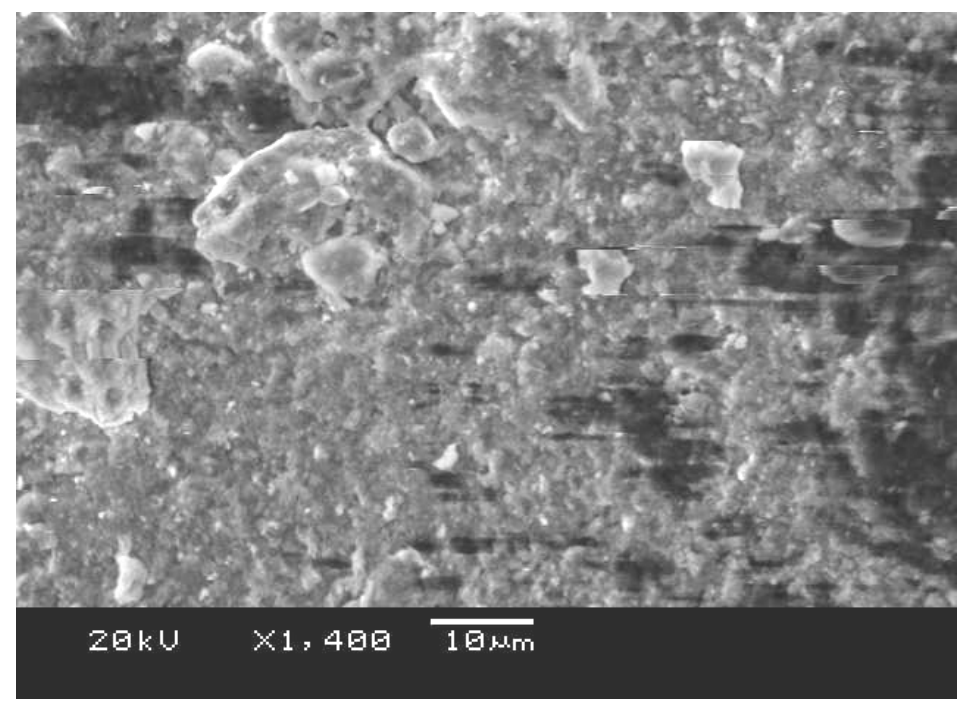

Figure 6. Soil + 1\% Cement +100 mg/kg Na.

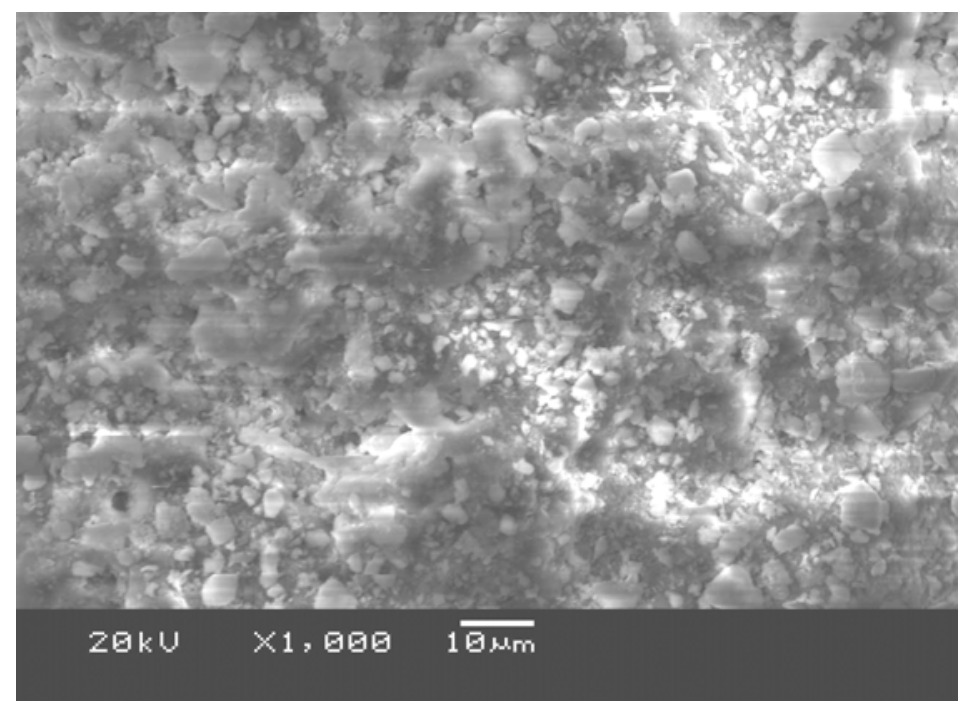

Figure 7. Soil $+3 \%$ Lime +100 mg/kg Zn . 


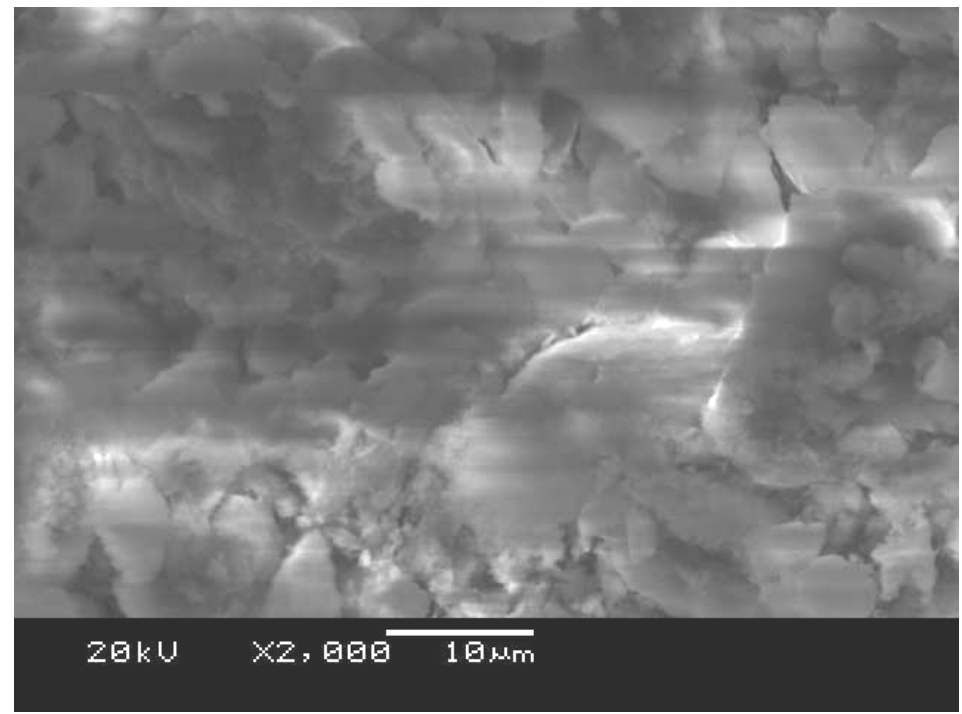

Figure 8. Soil +1\% Cement $+100 \mathrm{mg} / \mathrm{kg} \mathrm{Cu}$.

Table 2. Physico- chemical properties of Red Soil.

\begin{tabular}{lc}
\hline Property & Red Earth \\
\hline Specific Gravity & 2.64 \\
Liquid Limit (\%) & 38.0 \\
Plastic Limit (\%) & 21.0 \\
Shrinkage Limit (\%) & 18.0 \\
Max Dry Density (KN/m ${ }^{3}$ ) & 16.8 \\
Optimum Moisture Content (\%) & 19.2 \\
Cation Exchange Capacity (Meq/100g) & 18.5 \\
Specific Surface Area (m $\left.{ }^{2} / g\right)$ & 44.0 \\
Fine Sand \% & 31.8 \\
Silt \% & 30.2 \\
Clay \% & 38.0 \\
Unified Soil Classification Symbol & $\mathrm{CL}$ \\
\hline
\end{tabular}

Table 3. Variation of chromium for different mixtures.

\begin{tabular}{|c|c|c|c|c|c|c|c|c|c|}
\hline \multirow{2}{*}{\multicolumn{4}{|c|}{ Combination of Parameters }} & \multicolumn{6}{|c|}{ Chromium } \\
\hline & & & & \multicolumn{3}{|c|}{ After 7 Days } & \multicolumn{2}{|c|}{ After 28 Days } & \multirow[b]{2}{*}{$\begin{array}{c}\% \\
\text { Leached }\end{array}$} \\
\hline $\begin{array}{l}\text { Sample } \\
\mathrm{N}^{\mathrm{o}}\end{array}$ & $\begin{array}{l}\text { Sample } \\
\text { Code }\end{array}$ & $\begin{array}{l}\text { Load } \\
\text { Ratio in } \\
\text { mg/kg }\end{array}$ & Sample Composition & $\mathrm{pH}$ & $\begin{array}{l}\text { Conductivity } \\
\text { in ms }\end{array}$ & $\begin{array}{c}\% \\
\text { Leached }\end{array}$ & $\mathrm{pH}$ & Conductivity & \\
\hline 1 & $\mathrm{C} 1$ & 100 & Red Soil & 5.08 & 0.9 & 47.8 & 5.08 & 0.9 & 47.8 \\
\hline 2 & $\mathrm{C} 2$ & 100 & RedSoil + 3\% lime & 9.38 & 1.3 & 50.1 & 8.33 & 1.7 & 45.6 \\
\hline 3 & $\mathrm{C} 3$ & 100 & Red Soil + 6\% Lime & 11.67 & 1.5 & 45.6 & 8.74 & 1.6 & 42.8 \\
\hline 4 & $\mathrm{C} 4$ & 100 & Red Soil + 1\% Cement & 7.00 & 1.2 & 48.4 & 7.52 & 1.6 & 48.6 \\
\hline 5 & $\mathrm{C} 5$ & 100 & Red Soil + 3\% Cement & 8.50 & 1.3 & 44.5 & 8.22 & 1.7 & 16.2 \\
\hline 6 & C6 & 50 & Red Soil & 6.23 & 0.7 & 44.6 & 6.95 & 0.5 & 48.2 \\
\hline 7 & $\mathrm{C} 7$ & 50 & RedSoil + 3\% lime & 8.65 & 0.8 & 55.6 & 8.41 & 1.1 & 43.4 \\
\hline 8 & C8 & 50 & Red Soil + 6\% Lime & 11.93 & 1.0 & 28.4 & 9.22 & 1 & 41.4 \\
\hline 9 & C9 & 50 & Red Soil + 1\% Cement & 7.70 & 0.7 & 38.8 & 7.84 & 1.2 & 50.0 \\
\hline 10 & C10 & 50 & Red Soil + 3\% Cement & 8.70 & 0.9 & 47.8 & 8.36 & 1.1 & 43.2 \\
\hline
\end{tabular}


MOHAMMED, S. A. S.; NAIK, M.; TANVEERUDDIN, S. Influence of additives on the retention of metal ions in a soil of Bangalore, India. Ambi-Agua, Taubaté, v. 4, n. 1, p. 20-36, 2009. (doi:10.4136/ambi-agua.71)

Table 4. Variation of copper and zinc for different mixtures.

\begin{tabular}{|c|c|c|c|c|c|c|c|c|c|}
\hline \multirow{2}{*}{\multicolumn{4}{|c|}{ Combination of Parameters }} & \multirow{2}{*}{\multicolumn{3}{|c|}{$\begin{array}{c}\text { Copper } \\
\text { After } 28 \text { Days }\end{array}$}} & \multicolumn{3}{|c|}{ Zinc } \\
\hline & & & & & & & & After 28 Day: & \\
\hline $\begin{array}{l}\text { Sample } \\
\mathrm{N}^{\mathrm{o}}\end{array}$ & $\begin{array}{l}\text { Sample } \\
\text { Code }\end{array}$ & $\begin{array}{l}\text { Load } \\
\text { Ratio in } \\
\mathrm{mg} / \mathrm{kg}\end{array}$ & Sample Composition & $\mathrm{pH}$ & $\begin{array}{l}\text { Conductivity } \\
\text { in ms }\end{array}$ & $\begin{array}{c}\% \\
\text { Leached }\end{array}$ & $\mathrm{pH}$ & Conductivity & $\begin{array}{c}\% \\
\text { Leached }\end{array}$ \\
\hline 1 & $\mathrm{C} 1$ & 100 & Red Soil & 4.86 & 1.2 & 18.5 & 5.08 & 1.2 & 43.2 \\
\hline 2 & $\mathrm{C} 2$ & 100 & RedSoil + 3\% lime & 7.34 & 1.4 & 12.6 & 6.74 & 1.1 & 13.3 \\
\hline 3 & C3 & 100 & Red Soil + 6\% Lime & 8.12 & 1.9 & 6.5 & 7.72 & 1 & 10.6 \\
\hline 4 & $\mathrm{C} 4$ & 100 & Red Soil + 1\% Cement & 6.64 & 1.5 & 12.5 & 6.54 & 1.4 & 16.7 \\
\hline 5 & C5 & 100 & Red Soil + 3\% Cement & 6.91 & 1.4 & 12.1 & 7.42 & 1.5 & 16.3 \\
\hline 6 & C6 & 50 & Red Soil & 6.52 & 0.9 & 17.8 & 6.20 & 0.9 & 34.1 \\
\hline 7 & C7 & 50 & RedSoil + 3\% lime & 7.74 & 1.0 & 10.8 & 9.95 & 0.9 & 12.6 \\
\hline 8 & C8 & 50 & Red Soil + 6\% Lime & 8.10 & 2.1 & 8.9 & 10.74 & 2.2 & 12.6 \\
\hline 9 & C9 & 50 & Red Soil + 1\% Cement & 6.93 & 0.9 & 7.6 & 7.83 & 1.4 & 13.1 \\
\hline 10 & C10 & 50 & Red Soil + 3\% Cement & 7.27 & 1.2 & 10.1 & 10.63 & 1.8 & 12.3 \\
\hline
\end{tabular}

Table 5. Variation of potassium for different mixtures.

\begin{tabular}{|c|c|c|c|c|c|c|c|c|c|}
\hline \multirow{2}{*}{\multicolumn{4}{|c|}{ Combination of Parameters }} & \multicolumn{6}{|c|}{ Potassium } \\
\hline & & & & \multicolumn{3}{|c|}{ After 7 Days } & \multicolumn{3}{|c|}{ After 28 Days } \\
\hline $\begin{array}{c}\text { Sample } \\
\mathrm{N}^{\mathrm{o}}\end{array}$ & $\begin{array}{l}\text { Sample } \\
\text { Code }\end{array}$ & $\begin{array}{c}\text { Load } \\
\text { Ratio in } \\
\text { mg/kg }\end{array}$ & Sample Composition & $\mathrm{pH}$ & $\begin{array}{l}\text { Conductivity } \\
\text { in ms }\end{array}$ & $\begin{array}{c}\% \\
\text { Leached }\end{array}$ & $\mathrm{pH}$ & Conductivity & $\begin{array}{c}\% \\
\text { Leached }\end{array}$ \\
\hline 1 & $\mathrm{C} 1$ & 100 & Red Soil & 7.20 & 1.4 & 52.8 & 7.20 & 1.4 & 46.0 \\
\hline 2 & C2 & 100 & RedSoil + 3\% lime & 11.03 & 1.4 & 62.0 & 7.84 & 1.2 & 18.4 \\
\hline 3 & C3 & 100 & Red Soil + 6\% Lime & 13.03 & 2.0 & 55.6 & 7.90 & 1.2 & 18.4 \\
\hline 4 & $\mathrm{C} 4$ & 100 & Red Soil + 1\% Cement & 9.33 & 0.9 & 32.0 & 7.82 & 1.3 & 20.0 \\
\hline 5 & C5 & 100 & Red Soil + 3\% Cement & 10.06 & 1.3 & 56.4 & 8.30 & 1.2 & 16.8 \\
\hline 6 & C6 & 50 & Red Soil & 8.40 & 0.6 & 61.2 & 6.38 & 0.8 & 20.8 \\
\hline 7 & C7 & 50 & RedSoil + 3\% lime & 11.21 & 0.7 & 24.0 & 7.45 & 0.8 & 14.4 \\
\hline 8 & C8 & 50 & Red Soil + 6\% Lime & 12.70 & 1.3 & 35.2 & 8.45 & 0.7 & 14.4 \\
\hline 9 & C9 & 50 & Red Soil + 1\% Cement & 9.71 & 0.9 & 64.0 & 7.70 & 0.8 & 25.6 \\
\hline 10 & C10 & 50 & Red Soil + 3\% Cement & 11.30 & 0.6 & 32.0 & 8.50 & 0.8 & 20.8 \\
\hline
\end{tabular}

Table 6. Variation of Sodium for different mixtures.

\begin{tabular}{|c|c|c|c|c|c|c|c|c|c|}
\hline \multirow{2}{*}{\multicolumn{4}{|c|}{ Combination of Parameters }} & \multicolumn{6}{|c|}{ Sodium } \\
\hline & & & & \multicolumn{3}{|c|}{ After 7 Days } & \multicolumn{3}{|c|}{ After 28 Days } \\
\hline $\begin{array}{c}\text { Sample } \\
\mathrm{N}^{\mathrm{o}}\end{array}$ & $\begin{array}{l}\text { Sample } \\
\text { Code }\end{array}$ & $\begin{array}{l}\text { Load } \\
\text { Ratio in } \\
\text { mg/kg }\end{array}$ & Sample Composition & $\mathrm{pH}$ & Conductivity & $\begin{array}{c}\% \\
\text { Leached }\end{array}$ & $\mathrm{pH}$ & Conductivity & $\begin{array}{c}\% \\
\text { Leached }\end{array}$ \\
\hline 1 & $\mathrm{C} 1$ & 100 & Red Soil & 7.83 & 1.8 & 46.0 & 7.83 & 1.8 & 52.0 \\
\hline 2 & $\mathrm{C} 2$ & 100 & RedSoil + 3\% lime & 10.89 & 1.9 & 18.4 & 8.4 & 1.8 & 21.3 \\
\hline 3 & C3 & 100 & Red Soil + 6\% Lime & 12.83 & 2.8 & 20.0 & 8.32 & 1.7 & 30.4 \\
\hline 4 & $\mathrm{C} 4$ & 100 & Red Soil + 1\% Cement & 8.72 & 1.7 & 18.4 & 8.96 & 1.9 & 25.6 \\
\hline 5 & C5 & 100 & Red Soil + 3\% Cement & 10.98 & 1.8 & 16.8 & 8.9 & 1.8 & 19.2 \\
\hline 6 & C6 & 50 & Red Soil & 7.75 & 0.7 & 20.0 & 8.5 & 1.2 & 28.8 \\
\hline 7 & C7 & 50 & RedSoil + 3\% lime & 10.67 & 1.2 & 19.2 & 8.36 & 1.0 & 19.2 \\
\hline 8 & $\mathrm{C} 8$ & 50 & Red Soil + 6\% Lime & 12.8 & 1.8 & 20.0 & 8.54 & 1.0 & 19.2 \\
\hline 9 & C9 & 50 & Red Soil + 1\% Cement & 8.63 & 0.9 & 20.0 & 8.53 & 1.2 & 30.4 \\
\hline 10 & C10 & 50 & Red Soil + 3\% Cement & 10.47 & 1.3 & 19.2 & 9.12 & 1.1 & 27.2 \\
\hline
\end{tabular}




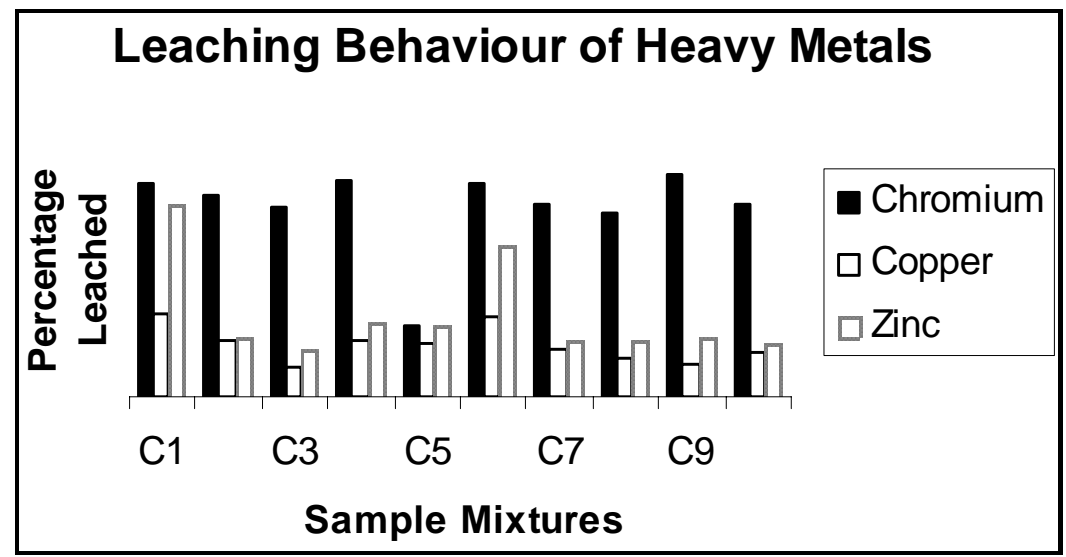

Figure 9. Percentage leaching of heavy metals.

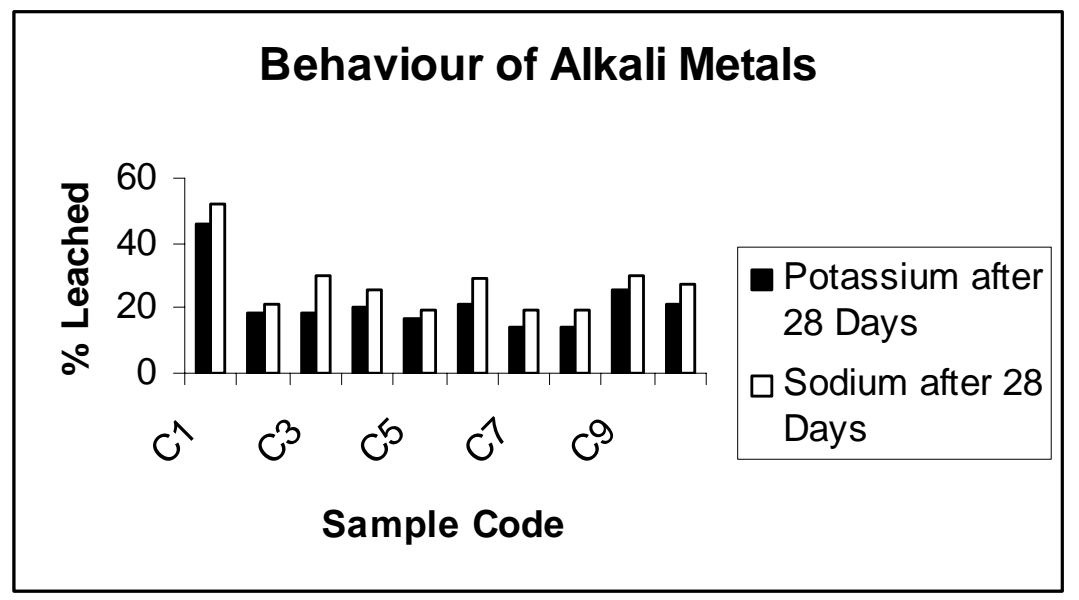

Figure 10. Percentage leaching of potassium and sodium.

\section{CONCLUSIONS}

From the present study the following general conclusions can be drawn.

Enhanced retention capacity for contaminants has been obtained with Red Soil of Bangalore with additives like cement and lime. Copper is sorbed immediately due to formation of organic ligands and complexes, specific adsorption of $\mathrm{Cu}$ onto $\mathrm{CaCO}_{3}$ surfaces has taken place. Zinc has been sorbed mostly due to precipitation of zinc into zinc hydroxide. Chromium is the least sorbed and is subjected to nonspecific adsorption. The sorption sequence for the heavy metals considered are $\mathrm{Cu}>\mathrm{Zn}>\mathrm{Cr}$.

Maximum sorption of copper and zinc was observed at relatively higher $\mathrm{pH}$ due to various geochemical reactions. Potassium and sodium are mostly sorbed by cation exchange and formation of diffuse double layer. Potassium is subjected to specific adsorption due to lower hydrated radius of its ions and sodium is subjected to non specific adsorption, it is dispersive in nature. The sorption sequence is $\mathrm{K}>\mathrm{Na}$.

SEM observations reveal at higher size range regular porous like large particles were detected from virgin soil. In the regular porous sponge like particles, crystals seem to be of alumino silicate which is widely used as an adsorbent for removal of metals, indicating possibility of using Red Soil as an adsorbent for removing metal ions. SEM observations of samples spiked with sodium, potassium, zinc and copper show aggregation and formation of homogenous mass from regular sponge like particles of virgin soil, which demonstrate that sorption has taken place. 
Energy Dispersive Spectroscope (EDS) analysis indicates the presence of elements like $\mathrm{Si}, \mathrm{Al}, \mathrm{Ca}, \mathrm{Ti}, \mathrm{Fe}, \mathrm{k}, \mathrm{Na}$. This is in accordance with the conductivity data obtained experimentally.

\section{ACKNOWLEDGEMENTS}

Sincere thanks to the encouragement of Honourable Administrator Mr. Abdul Hameed S. A., Respected Principal Dr. Chaitanya Kumar M. V., Head of Engineering Chemistry, Prof. Sanaulla P. F. of HKBK College of Engineering, Bangalore 5600 45. Appreciation is expressed to Mr. M. N. Zulfiqar Ahmed, Senior Lecturer Dept. of Eng. Chemistry HKBKCE for helping in setting up the experiments.

We are highly indebted for the scholastic help rendered by Prof. Dr. P. V. Sivapullaiah, Prof of Civil Engineering and Mr. Mughal Arif Ali Baig, Research Scholar, Indian Institute of Science (IISc), Bangalore 560012.

\section{REFERENCES}

ALI BAIG, AARIF; SIVAPULLAIAH, P. V.; Heavy metal leachability of low lime flyashes., In: Indian Geotechnical Conference - 2008: Advances in Geotechnical Enginnering GEOAGE Bangalore .Proceedings Vol II, p. 470 - 473, 2008.

ASTM INTERNATIONAL - AMERICAN STANDARD TESTING METHOD . D3987 - 85 (reapproved 2004), Standard test mMethod for shake extraction of solid waste with water. West Conshohocken: ASTMUSA, 2004. p. $1-5$.

BAR-YOSEF, P. H. Dependent zinc adsorption of soils. Soil Sci.Am Journal, v. 43, p. 1095 - 1099, 1979.

GROVE, J. H.; ELLIS, B. G. Extractable chromium as related to soil $\mathrm{pH}$ and applied chromium. Soil Sci. Soc. Am. J., v. 44, p. 238-242, 1980.

JEFFERY, G. H.; BASSETT, S.; MENDHAM, J. Vogel's text book of quantitative chemical analysis. 5.ed. New York: John Wiley \& Sons, 1997. p. 953.

JEOL ANALYTICAL SUPPLIERS. SEM Tutorials 2008. Available: $<$ http://www.jeol.com>. Access: January 2009.

KANTHA, H. LAKSHMI; SIVAPULLAIAH, P. V. Clay minerals as liner material for waste containment facilities. 2000. Thesis (Doctoral degree in Civil Engineering) Indian Institute of Science, (IISc), Bangalore, 2000.

KANTHA, H. LAKSHMI; SIVAPULLAIAH, P. V.; MADHU, KIRAN. Geotechnical properties of stabilised Indian red earth. Geotechnical and Geological Engineering, v. 21, p. 399-413, 2003.

KURDI, F.; DONER, H. E. Zinc and copper sorption an interaction in soils. Soil Sci. Soc. Am. J., v. 47, p. 873-876, 1983.

LO, H. M.; LIN, K. C. Solubility of heavy metals added to MSW. Journal of Hazardous Materials, v. 161, p. 294 - 299, 2009.

MCBRIDE, M. B.; BOULDIN, D. R. Long-term reactions of copper(II) in a contaminated calcareous soil. Soil Sci. Soc. Am. J., v. 48, p. 56-59, 1984. 
MC LEAN, JOAN E.; BERT, E. Behaviour of metals in soils. Environmental Protection Agency Report n ${ }^{\circ} .540$ S- 92-018. Ada: EPA, 1992.

MOHAMMED, S. A. S.; NAIK, MAYA. Innovative materials as liners for waste containment facilities., In: TECHNOMILLENIUM 2006 - INTERNATIONAL TECHNICAL SYMPOSIUM, Aurangabad, 2006. Proceedings p. 170 - 176, 2006.

NAIK, MAYA; MOHAMMED, S. A. S. Influence of additives on the retention of heavy metal ions in local Red Soil of Bangalore City, RETBE 08. In: INTERNATIONAL CONFERENCE, 7., 2008. Procedings... Egypt: Alexandria University, 2008. 1 CDROM.

NAIK, MAYA; SIVAPULLAIAH, P. V. Influence of diffusion coefficient and retardation factor in contaminant transport through soil liners. 2003. Thesis (Doctoral degree in Civil Engineering) - Indian Institute of Science, Bangalore, 2003.

RAJASEKHAR, C.; SRIDHARAN, A.; PANDIAN, N. S. Effect of lime on the heavy metals ions retention characteristics of Fly Ash. In: SYMPOSIUM ON NATURAL HAZARDS AND ENVIRONMENTAL GEOTECHNIQUES, Bangkok, 1995. Proceedings p. 1-9, 1995.

TANIT, C.; SURAPON, A.; NANTHANIT, C. Potential use of lateritic and marine clay soils as landfill liners to retain heavy metals. Journal of Waste Management, v. 29, p. 117 - 127, 2009.

UNIVERSITY OF NEW SOUTH WALES. Terra GIS Soil, 2007. Available: $<$ http://www.terraGIS Soil.org>. Access June 18, 2008.

YOUNG, SOOK SHIM; YOUNG, KEUM KIM. The adsorption characteristics of heavy metals by various particle sizes of MSWI bottom ash. Journal of Waste Management, v. 23, p. $851-857,2003$. 


\begin{tabular}{ccc|} 
ISSN = 1980-993X - doi:10.4136/1980-993X \\
www.agro.unitau.br/ambi-agua \\
E-mail: ambi-agua@agro.unitau.br \\
Tel.: (12) 3625-4116
\end{tabular}

\title{
Diversity and abundance of aquatic macroinvertebrates in a lotic environment in Midwestern São Paulo State, Brazil (doi:10.4136/ambi-agua.72)
}

\author{
Fabio Laurindo da Silva1; Diana Calcidoni Moreira²; Sonia Silveira Ruiz ${ }^{3}$; Gabriel \\ Lucas Bochini ${ }^{2}$ \\ ${ }^{1}$ Programa de Pós-graduação em Ecologia e Recursos Naturais PPGERN/CCBS - UFSCar, Laboratório de \\ Entomologia Aquática, Departamento de Hidrobiologia, Universidade Federal de São Carlos, UFSCar \\ E-mail: fabelha@hotmail.com \\ ${ }^{2}$ Departamento de Ciências Biológicas, Universidade Estadual Paulista, UNESP \\ E-mail: dicalcidoni@hotmail.com; bochini@fc.unesp.br \\ ${ }^{3}$ Universidade Paulista, UNIP \\ E-mail: ssruiz@fc.unesp.br
}

\begin{abstract}
This study analyzed the diversity and abundance of aquatic macroinvertebrates community in the Vargem Limpa stream located in Bauru, Midwestern São Paulo State, and characterized the water quality based on biological parameters. The sampling was carried out during the rain season (December, 2004). It was analyzed and identified 3,068 organisms belonging to 9 macroinvertebrate families. The system showed low richness and diversity of organisms in response to water quality.
\end{abstract}

Keywords: Diversity; richness; bioindicators; ecology.

\section{Diversidade e abundância de macroinvertebrados aquáticos em um ambiente lótico da região centro-oeste do Estado de São Paulo, Brasil}

\section{RESUMO}

Este estudo analisou a diversidade e abundância da comunidade de macroinvertebrados aquáticos presente no córrego Vargem Limpa, região centro-oeste do Estado de São Paulo, e caracterizou a qualidade das águas, baseado em parâmetros biológicos. As coletas foram realizadas na estação chuvosa (dezembro - 2004). 3.068 organismos pertencentes a 9 famílias de macroinvertebrados foram analisados e identificados. O sistema apresentou baixa riqueza e diversidade de organismos em resposta à qualidade da água do sistema aquático.

Palavras-chave: Diversidade; riqueza; bioindicadores; ecologia.

\section{INTRODUCTION}

Anthropogenic activities in water bodies (e.g., mining, dam construction, artificial eutrophication, river canalization, and recreation) have caused a number of environmental impacts with negative consequences to water quality. These factors can affect the communities of aquatic organisms leading to loss of diversity and species extinction (Primack and Rodrigues, 2001). The detection of these impacts on streams depends on studies on biological communities, associated to the evaluation of habitat diversity and measurements of abiotic parameters (Pompeu et al., 2005; Casatti et al., 2006). 
Biological indicators have the advantage of monitoring water quality over a period of time, providing a more exact measure of anthropogenic effects on aquatic ecosystems, where physical and chemical data provide only momentary evidence (Camargo et al., 2004; Callisto et al., 2001). Freshwater macroinvertebrates have frequently been used in water quality studies as bioindicators. These animals, used in such investigations, offer several benefits including easy identification of high taxonomic levels (such as family) by non-specialists, high sensitivity of a great number of species to environmental stress, a wide distribution in various freshwater habitats, and a relatively sedentary behavior and short life cycle, in comparison to fish, which facilitates the detection of changes over time (Johnson et al., 1993).

The benthic community in lotic environments is represented by various phyla, such as Artropoda (insects, mites and crustaceans), Mollusca (gastropods and bivalves), Anellida (oligochaetes), Nematoda, and Platyhelminthes (Hauer and Resh, 1996). Among benthic macroinvertebrates, insects are noteworthy in terms of diversity and abundance (Lake, 1990). The distribution of these organisms is directly related to water current, quality and availability of food, type of substratum (sandy, stone, wood or aquatic macrophytes), water temperature, and concentrations of dissolved oxygen and hydrogen sulfide (Pamplin et al., 2006).

The present study aims to characterize the water quality of a lotic environment, located in the Midwestern region of São Paulo State (SP), based on biological parameters, including the analysis of the diversity and abundance of aquatic macroinvertebrates.

\section{MATERIAL AND METHODS}

This study was carried out in the córrego Vargem Limpa, municipality of Bauru $\left(22^{\circ}\right.$ $19^{\prime} 18^{\prime \prime}$ S and $49^{\circ} 04^{\prime} 13^{\prime \prime}$ ), located in the Midwest of São Paulo State (Figure 1). This water body runs through a protected area and receives discharges of domestic and industrial effluents in different points along its course (Figure 2). Sediment samples were collected during the month of December 2004 (rainy season) in 4 sample sites: Point 1 (P1) located inside the perimeter of the city's botanical garden (JBMB), is a spring system and present many sedimentation areas; Point 2 (P2) is a stretch of lentic character connected to a reservoir within the city's zoo (PZMB); Point 3 (P3), beside industrial accumulators, shows various sediment deposits due to silting processes;and Point 4 (P4), located in the industrial district of Bauru, receives input domestic sewage and industrial effluents.

A total of 84 samples (3 replicates in each site) were collected during seven days using an Ekman-Birge grab (area of $0.0225 \mathrm{~m}^{2}$ ) and immediately fixed in a $10 \%$ formalin solution. In the laboratory, the samples were washed using $0.250 \mathrm{~mm}$ sieves, sorted and preserved in $70 \%$ ethanol. The organisms were subsequently identified, under stereomicroscope, using appropriate literature (Brinkhurst and Marchese, 1989; Merrit and Cummins 1996; Fernandez and Dominguez, 2001) and counted.

The relative participation of each taxon was calculated separately for the four sampling sites. The ecosystem diversity was evaluated through species richness (S), Shannon diversity index (H'), Pielou evenness index (equitability) (J), and Simpson dominance index (D), according to Pinto-Coelho (2002). Pearson's correlation analyses (Zar, 1974) were performed between association descriptions and the water variables. It was utilized significance level of $5 \%(\mathrm{p}<0.05)$.

The temperature, $\mathrm{pH}$, and electrical conductivity values were determined in situ by mercury thermometer, a Corning - pH 30 meter and a Corning - CD-55 meter, respectively. The oxygen concentration was determined in laboratory by Winkler method (Golterman et al. (1978). 
SILVA, F. L.; MOREIRA, D. C.; RUIZ, S. S.; BOCHINI, G. L. Diversity and abundance of aquatic macroinvertebrates in a lotic environment in Midwestern São Paulo State, Brazil. Ambi-Agua, Taubaté, v. 4, n. 1, p. 37-44, 2009. (doi:10.4136/ambi-agua.72)

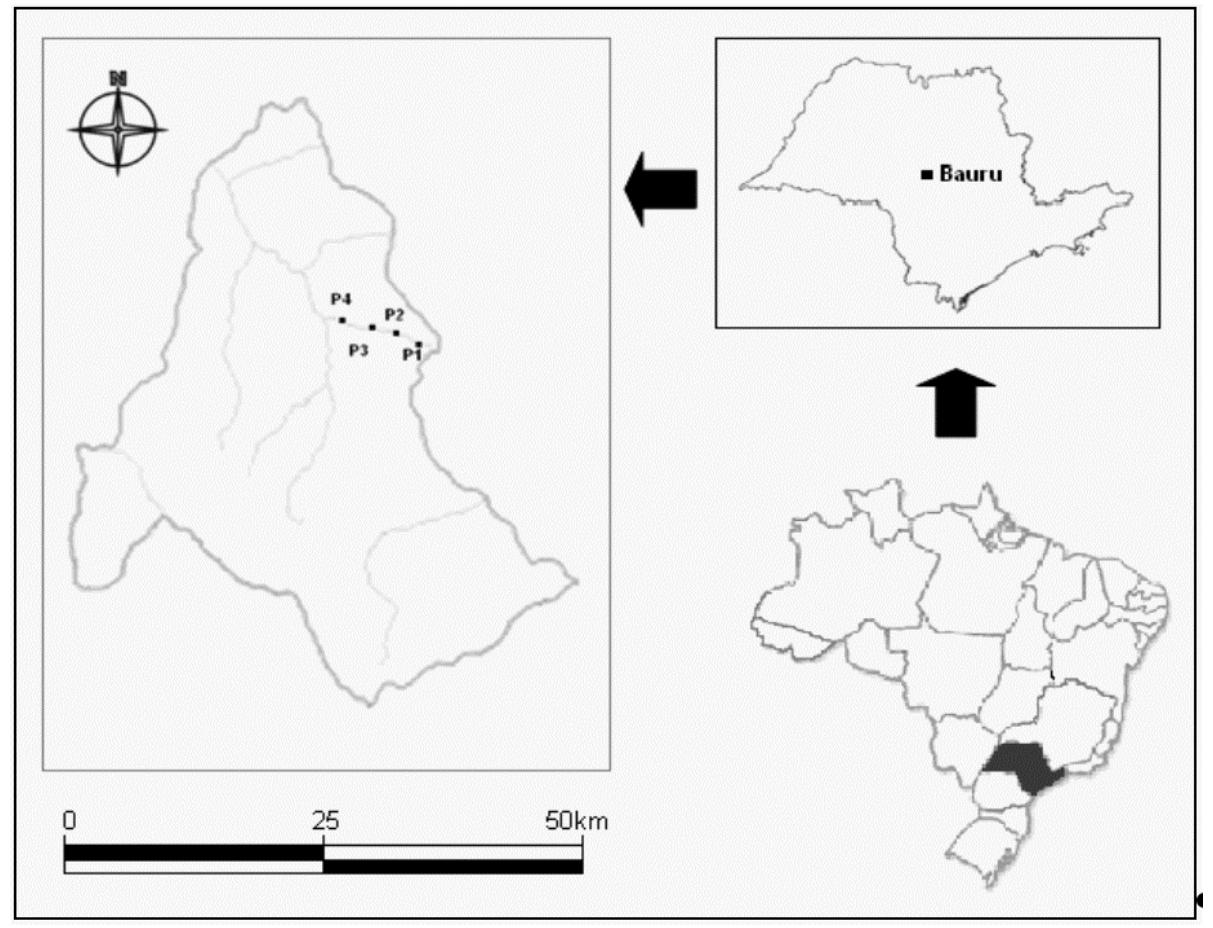

Figure 1. Map of the municipality of Bauru (SP), showing the location of sample sites in the córrego Vargem Limpa area.
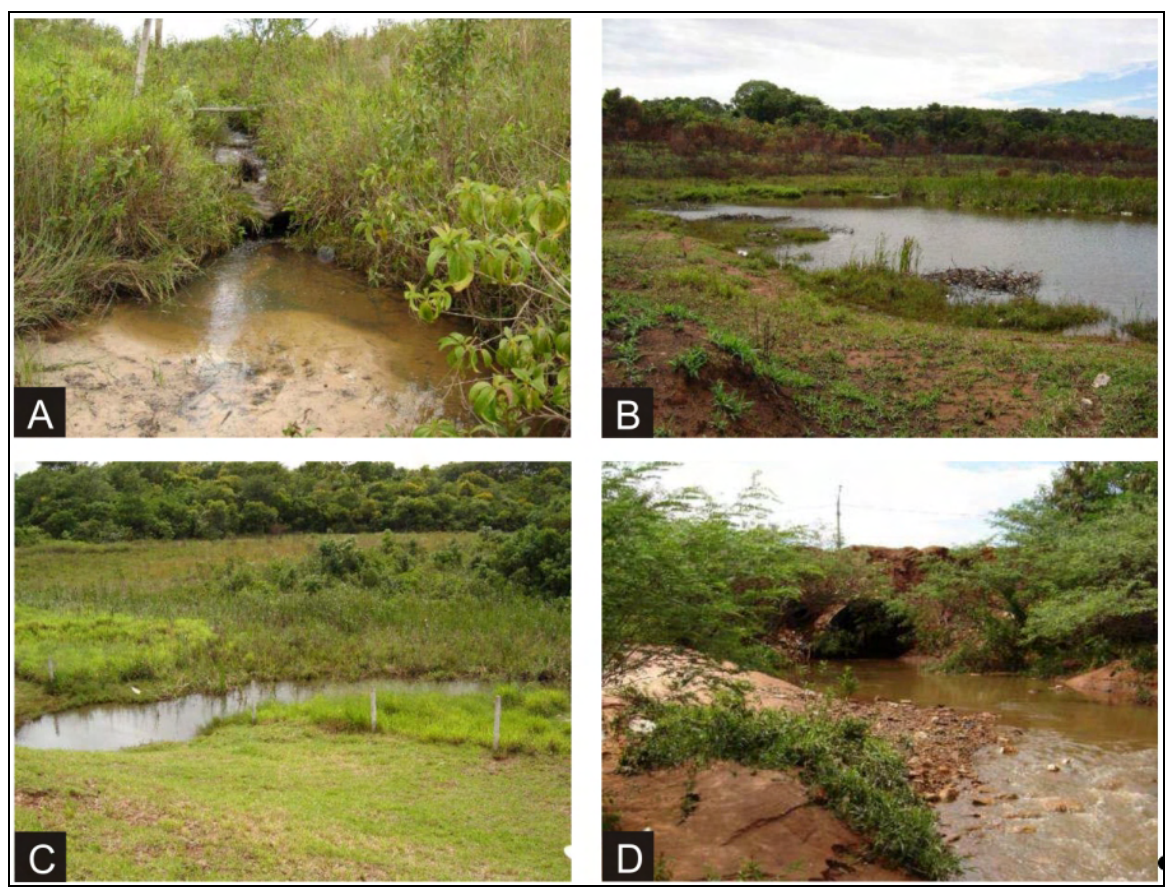

Figure 2. Sampling points of Córrego Vargem Limpa, Bauru (SP): A) Point 1, B) Point 2, C) Point 3, D) Point 4.

\section{RESULTS AND DISCUSSION}

In this study, 3,068 specimens belonging to 25 macroinvertebrate taxa and 9 families were collected (Table 1). The results indicate a predominance of organisms pertaining to the families Chironomidae and Tubificidae, as well as significant values of Naididae and Glossiphoniidae, in all sampling points. The high densities of these families may indicate an 
input of organic matter in the system, since they have a distinguished high tolerance to organic enrichment, compared to other organisms (Fusari and Fonseca-Gessner, 2006). In P1, the constant input of allochthonous material from riparian vegetation might be responsible for these values. P2 and P3 receive organic matter from the Zoo's reservoir, derived from the cleaning of the animals' cages. The situation in $\mathrm{P} 4$ is probably a consequence of the increase of organic matter due to discharges of domestic sewage.

Within Chironomidae, Polypedilum was the dominant genus in P1 and P2 (Table 1). This genus is composed of grazer-collectors (Coffman and Ferrington, 1996) and belongs to a group of psammophilic Chironomidae (Barton and Smith, 1984), generally associated with sandy bottoms. The silting process and formation of sediment deposits in P2 may have contributed to the predominance of this genus. In P3, where the bottom shows similar characteristics as P2, the most abundant genus within the family was Cladopelma (10.6\%), which is also composed of grazer-collectors, associated with sandy substratum.

Table 1. Absolute abundance $(\mathrm{N})$ and relative abundance (ni) of benthic macroinvertebrates in the four sampling sites along Vargem Limpa stream, in December 2004.

\begin{tabular}{|c|c|c|c|c|c|c|c|c|}
\hline \multirow{2}{*}{ Taxa } & \multicolumn{2}{|r|}{ P1 } & \multicolumn{2}{|r|}{ P2 } & \multicolumn{2}{|r|}{ P3 } & \multicolumn{2}{|c|}{ P4 } \\
\hline & $\mathbf{N}$ & ni & $\mathbf{N}$ & ni & $\mathbf{N}$ & ni & $\mathbf{N}$ & ni \\
\hline \multicolumn{9}{|l|}{ Diptera } \\
\hline \multicolumn{9}{|l|}{ Chironomidae } \\
\hline Ablabesmyia & 19 & 4.83 & 11 & 0.98 & 2 & 0.47 & 1 & 0.09 \\
\hline Beardius & 1 & 0.25 & 1 & 0.09 & 1 & 0.24 & & \\
\hline Caladomyia & 3 & 0.76 & 10 & 0.89 & & & & \\
\hline Chironomus & 2 & 0.51 & 1 & 0.09 & & & 437 & 38.81 \\
\hline Cladopelma & & & & & 45 & 10.64 & & \\
\hline Clinotanypus & & & & & 1 & 0.24 & & \\
\hline Corynoneura & 1 & 0.25 & & & & & & \\
\hline Cricotopus & 4 & 1.02 & 1 & 0.09 & & & & \\
\hline Cryptochironomus & 1 & 0.25 & & & 6 & 1.42 & & \\
\hline Dicrotendipes & & & 7 & 0.62 & & & & \\
\hline Endotribelos & & & & & 1 & 0.24 & & \\
\hline Fissimentum & 2 & 0.51 & 12 & 1.07 & 9 & 2.13 & 1 & 0.09 \\
\hline $\begin{array}{l}\text { Harnischia } \\
\text { complex }\end{array}$ & 47 & 11.96 & 5 & 0.44 & & & & \\
\hline Lopescladius & 1 & 0.25 & & & & & & \\
\hline Polypedilum & 109 & 27.74 & 13 & 1.15 & 20 & 4.73 & 2 & 0.18 \\
\hline Tanypus & & & 1 & 0.09 & & & & \\
\hline Tanytarsus & 24 & 6.11 & 1 & 0.09 & & & & \\
\hline Ceratopogonidae & 1 & 0.25 & & 0.00 & & & & \\
\hline Tabanidae & & & 1 & 0.09 & & & & \\
\hline Tipulidae & 2 & 0.51 & 1 & 0.09 & & & & \\
\hline \multicolumn{9}{|l|}{ Hirudinea } \\
\hline Glossiphoniidae & 6 & 1.53 & 40 & 3.55 & 7 & 1.65 & & \\
\hline Psicolidae & & & 1 & 0.09 & & & & \\
\hline \multicolumn{9}{|l|}{ Oligochaeta } \\
\hline Tubificidae & 158 & 40.20 & 912 & 80.99 & 302 & 71.39 & 601 & 53.37 \\
\hline Naididae & 11 & 2.80 & 108 & 9.59 & 29 & 6.86 & 84 & 7.46 \\
\hline \multicolumn{9}{|l|}{ Trichoptera } \\
\hline Limnephilidae & 1 & 0.25 & & & & & & \\
\hline
\end{tabular}


Chironomus was the dominant genus in P4 with $38.8 \%$ of relative abundance (Table 1). According to Marques et al. (1999), Chironomus exhibits high tolerance to eutrophic conditions, showing significant increase in abundance in response to anthropogenic organic enrichment and consequent water quality deterioration, being considered a reliable environmental indicator. The predominance of this genus in P4 may be associated with discharges of domestic sewage, which causes the increase of organic matter and reduction of dissolved oxygen levels, making the environment more adequate for these organisms.

Shannon diversity index values indicated little variation between sampling points (Table 2) displaying an increase only in $\mathrm{P} 1$, which can be explained by the relation between richness and relative abundance of macroinvertebrates in this site. In P4, however, the predominance of Tubificidae and Chironomus resulted in a smaller diversity and richness.

Table 2. Values of richness (S), number of individuals $(\mathrm{N})$ diversity $\left(\mathrm{H}^{\prime}\right)$, equitability $(\mathrm{J})$ and dominance (D) of benthic macroinvertebrates registered along Vargem Limpa stream, in December 2004.

\begin{tabular}{crrrcc}
\hline & S & N & H' & J & D \\
\hline P1 & 18 & 393 & 1.71 & 0.59 & 0.26 \\
P2 & 17 & 1,126 & 0.81 & 0.28 & 0.67 \\
P3 & 11 & 423 & 1.09 & 0.45 & 0.53 \\
P4 & 7 & 1,126 & 0.92 & 0.47 & 0.44 \\
\hline Total & 25 & 3,068 & & & \\
\hline
\end{tabular}

Pielou evenness values produced a similar pattern, with the highest values in P1 and the smallest in P4 (Table 2). The high value in P1 can be attributed to the homogenous distribution of individuals among the taxa collected. Simpson's dominance (D) index was highest in P2 ( $\mathrm{D}=0.67)$ and lowest in P1 (0.26). The large number of individuals (highest among all four points), mainly belonging to the family Tubificidae, and the low richness, explain these results in $\mathrm{P} 2$.

According to Esteves (1998), most aquatic ecosystems exhibit $\mathrm{pH}$ values varying from 6 to 8. The $\mathrm{pH}$ measured in Vargem Limpa stream ranged from 5.7 to 6.9 (Table 3), characterizing the water system as acidic. This variable is influenced, amongst others, by concentrations of carbon dioxide and organic acids dissolved in the water, which reduce $\mathrm{pH}$.

Table 3. Values of $\mathrm{pH}$, electrical conductivity (CE), water temperature (T) and dissolved oxygen (OD) registered along Vargem Limpa stream, in December 2004.

\begin{tabular}{ccccc}
\hline & $\mathbf{p H}$ & $\mathbf{C E}(\boldsymbol{\mu s} / \mathbf{c m})$ & $\mathbf{T}\left({ }^{\mathbf{0}} \mathbf{C}\right)$ & OD $(\mathbf{m g} / \mathbf{L})$ \\
\hline P1 & 6.0 & 35.14 & 21.64 & 6.41 \\
P2 & 5.7 & 51.57 & 24.79 & 2.86 \\
P3 & 6.3 & 44.14 & 23.86 & 4.88 \\
P4 & 6.9 & 312.86 & 25.07 & 1.29 \\
\hline
\end{tabular}

The lowest electrical conductivity values were registered in P1 and the highest in P4: $35.14 \mu \mathrm{s} / \mathrm{cm}$ and $312.86 \mu \mathrm{s} / \mathrm{cm}$, respectively. Electrical conductivity is more influenced by physical (climate, hydrology) and chemical (geology, minerals solubility) factors, as well as 
anthropogenic impacts (deforestation, silting process), than by biologic factors (Pedrosa and Rezende, 1999). However, high concentrations of decomposing organic matter increase the quantity of ions dissociated in the water, which results in an elevated electrical conductivity such as the values registered in P4, where a large quantity of allochthonous material may have played a significant role (see Table 3). P2 and P3 presented intermediate values, $51.57 \mu \mathrm{s} / \mathrm{cm}$ and $44.14 \mu \mathrm{s} / \mathrm{cm}$ respectively, since they have a more restricted access than P4, yet still suffer anthropogenic impact. In addition, P2 is also an area of more intense draught, enhancing the transport of materials from this site to others, resulting in a smaller local conductivity.

Pearson's correlation $(\mathrm{p}<0.05)$ indicates only positive (significant) correlations between descriptors and physical and chemical parameters (Table 4). Such results suggest that the environmental variables are favoring the fauna in regards to density and composition. Considering the high tolerance of organisms collected in this study to organic matter and the alterations evidenced by physical and chemical variables, Pearson's correlation analysis serves as additional evidence.

Table 4. Significant Pearson correlations (r) between descriptors of benthic macroinvertebrates and environmental variables in Vargem Limpa stream, in December 2004.

\begin{tabular}{|c|c|c|c|c|}
\hline \multirow{2}{*}{ Descriptors } & \multicolumn{4}{|c|}{ Environmental variables } \\
\hline & $\mathrm{pH}$ & $\mathrm{CE}$ & $\mathrm{T}^{\circ} \mathrm{C}$ & OD \\
\hline Chironomus & 0.60 & 0.60 & 0.60 & 0.60 \\
\hline Polypedilum & 0.60 & & & \\
\hline \multicolumn{5}{|l|}{ Harnischia } \\
\hline Cladopelma & 0.74 & 0.74 & 0.74 & 0.74 \\
\hline \multicolumn{5}{|l|}{ Ablabesmyia } \\
\hline \multicolumn{5}{|l|}{ Tanytarsus } \\
\hline Fissimentum & & 0.80 & 0.80 & 0.80 \\
\hline Caladomyia & & 0.79 & 0.79 & 0,79 \\
\hline Cryptochironomus & 0.89 & & & \\
\hline Dicrotendipes & & 0.74 & 0.74 & 0.74 \\
\hline \multicolumn{5}{|l|}{ Cricotopus } \\
\hline \multicolumn{5}{|l|}{ Beardius } \\
\hline Clinotanypus & 0.74 & 0.74 & 0.74 & 0.74 \\
\hline Corynoneura & 0.74 & & & \\
\hline Endotribelos & 0.74 & 0.74 & 0.74 & 0.74 \\
\hline Lopescladius & 0.74 & & & \\
\hline Tanypus & & 0.74 & 0.74 & 0.74 \\
\hline Ceratopogonidae & 0.74 & & & \\
\hline Tabanidae & & 0.74 & 0.74 & 0.74 \\
\hline \multicolumn{5}{|l|}{ Tipulidae } \\
\hline Glossiphoniidae & & 0.80 & 0.80 & 0.80 \\
\hline Psicolidae & & 0.74 & 0.74 & 0.74 \\
\hline Tubificidae & 0.80 & & & \\
\hline Naididae & 0.80 & & & \\
\hline Limnephilidae & 0.74 & & & \\
\hline \multicolumn{5}{|l|}{ Richness } \\
\hline Diversity & 0.80 & & & \\
\hline Equitability & 0.60 & 0.60 & 0.60 & 0.60 \\
\hline Dominance & 0.60 & 0.60 & 0.60 & 0.60 \\
\hline
\end{tabular}


Dissolved oxygen concentrations (OD) depend on two main factors: water temperature and atmospheric pressure. As temperature and pressure decrease, the water oxygenation increases. OD levels diminish mainly due to consumption by organic matter decomposition, losses to the atmosphere, breathing of aquatic organisms, and metallic ion (iron and manganese) oxidation (Esteves, 1998). The lowest values for this parameter were registered in P4, located in an urban zone, with great alterations in the water's physical and chemical characteristics (Table 3). In contrast, the highest values were registered in P1, where restricted access to the spring, within JBMB, reduces the possibility of human influence.

\section{CONCLUSIONS}

An overall analysis of the results (physical, chemical, and biological) indicates the predominance of organisms tolerant to organic matter, associated with environmental alterations in the aquatic system, which allow attributing a low quality status for Vargem Limpa stream water. This data reaffirms the importance of using aquatic macroinvertebrates as bioindicators in environmental diagnoses.

\section{ACKNOWLEDGEMENTS}

The authors extend their thanks to Jardim Botânico Municipal de Bauru, to Prof. Dr. Jandira Liria Biscalquini Talamoni and to Anderson Lucindo for their great help in the field work. Special thanks to Amanda Andrade and Carolina Cunha Andrade for their suggestions and comments.

\section{REFERENCES}

BARTON, D. R.; SMITH, S. M. Insects of extremely small and extremely large aquatic habits. In: The ecology of aquatic insects. New York: Preager, 1984. p. 457-483.

BRINKHURST, R. O.; MARCHESE, M. R. Guia para la identification de Oligoquetos aquaticos continentales de Sud y Centroamerica. Santa Fé: Clímax, 1989. 207 p.

CALLISTO, M.; MORETTI, M.; GOULART, M. Macroinvertebrados bentônicos como ferramenta para avaliar a saúde de riachos. Revista Brasileira de Recursos Hídricos, Porto Alegre, v. 6, n. 1, p. 71-82, 2001.

CAMARGO, J. A.; ALONSO, A.; DE LA PUENTE, M. Multimetric assessment of nutrient enrichment in impounded rivers based on benthic macroinvertebrates. Environmental Monitoring and Assessment, Dordrecht, v. 96, p. 233-249, 2004.

CASATTI, L.; LANGEANI, F.; SILVA, A. M.; CASTRO, R. M. C. Stream fish, water and habitat quality in a pasture dominated basin, Southeastern Brazil. Brazilian Journal of Biology, v. 66, n. 2B, p. 681- 696, 2006.

COFFMAN, W. P.; FERRINGTON, L. C. Chironomidae. In: An introduction to the aquatic insects of North America. Dubuque: Kendall Hunt, 1996. p. 635-754.

ESTEVES, F. A. Fundamentos de Limnologia. Rio de Janeiro: Interciência, 1998. 602 p.

FERNANDEZ, H. R.; DOMINGUEZ, E. Guía para la determinación de los artrópodos bentónicos sudamericanos. Tucumán: Universidad Nacional de Tucumán, Faculdade de Ciencias Naturales e Instituto Miguel Lillo, 2001. 282p. 
FUSARI, L. M.; FONSECA-GESSNER, A. A. Environmental assessment of two small reservoirs in southeastern Brazil, using macroinvertebrate community metrics. Acta Limnologica Brasiliense, Botucatu, v. 18, n. 1, p. 89-99, 2006.

GOLTERMAN, H. L.; CLYMO, R. S.; OHNSTAD, M. A. M. Methods for physical and chemical analysis of freshwater. Oxford: Blackwell Scientific Publications, 1978. 213 p.

HAUER, F. R.; RESH, V. H. Benthic macroinvertebrates. In: Stream ecology. San Diego: Academic Press, 1996. p. 339-369.

JOHNSON, R. K.; WIEDERHOLM, T.; ROSENBERG, D. M. Freshwater biomonitoring using individual organisms, populations, and species assemblages of benthic macroinvertebrates. In: Freshwater biomonitoring and benthics macroinvertebrates. New York: Chapman \& Hall, 1993. p. 40-158.

LAKE, P. S. Disturbing hard and soft bottom communities: a comparison of marine and freshwater environments. Australian Journal of Ecology, Carlton, v. 15, p. 477-488, 1990.

MARQUES, M. M. G. S. M.; BARBOSA, F. A. R.; CALLISTO, M. Distribution and abundance of Chironomidae (Diptera, Insecta) in an impacted watershed in south-east Brazil. Revista Brasileira de Biologia, São Carlos, v. 59, n. 4, p.553-561, 1999.

MERRIT, R.; CUMMINS, K. An introduction to the aquatic insects of North America. Dubuque: Kendall Hunt, 1996. 722 p.

PAMPLIN, P. A. Z.; ALMEIDA, T. C. M.; ROCHA. O. Composition and distribution of benthic macroinvertebrates in Americana Reservoir (SP, Brazil). Acta Limnologica Brasiliensia, v. 18, n. 2, p. 121-132, 2006.

PEDROSA, P.; REZENDE, C. E. As muitas faces de uma lagoa. Ciência Hoje, São Paulo, v. 69, n. 153, p. 40-47, 1999.

PINTO-COELHO, R. M. Fundamentos em Ecologia. Porto Alegre: Artmed, 2002. 252 p.

POMPEU, P. S.; ALVES, C. B. M.; CALLISTO, M. The effects of urbanization on biodiversity and water quality in the Rio das Velhas basin, Brasil. American Fisheries Society Symposium, v. 47, p. 11-22, 2005.

PRIMACK, R. B.; RODRIGUES, E. Biologia da Conservação. Londrina: Editora Viva, 2001. 328 p.

ZAR, J. H. Biostatistical analysis. Englewood Cliffs: Prentice-Hall, 1974. 620 p. 


\begin{tabular}{ccc|} 
ISSN = 1980-993X - doi:10.4136/1980-993X \\
www.agro.unitau.br/ambi-agua \\
E-mail: ambi-agua@agro.unitau.br \\
Tel.: (12) 3625-4116
\end{tabular}

\title{
Production and properties of $\alpha$-amylase from Citrobacter species
} (doi:10.4136/ambi-agua.73)

\section{Justina Chibuogwu Orji ${ }^{1}$; Christian O. Nweke ${ }^{2}$; Rose N. Nwabueze ${ }^{3}$; Christopher E. Nwanyanwu $^{4}$; Chinwe S. Alisi ${ }^{5}$; Ebuta N. Etim-Osowo ${ }^{1}$}

\author{
Federal University of Technology, Owerri, Imo State, Nigéria \\ ${ }^{1}$ E-mail: chiookolo@yahoo.com \\ ${ }^{2}$ E-mail: xrisokey@yahoo.com \\ ${ }^{3}$ E-mail: r_n_nwabueze@yahoo.com \\ ${ }^{4}$ E-mail: cnwanyanwu2000@yahoo.com \\ ${ }^{5}$ E-mail: silverpresh@yahoo.com
}

\begin{abstract}
Amylase production by Citrobacter sp. isolated from potato was optimized in batch culture studies under shake flask conditions. Effects and interactions of best sources and levels of carbon and nitrogen estimated by $4 \times 5$ and $4 \times 4$ factorial experimental arrangements were significant $(\mathrm{P}<0.01)$ on amylase production. Optimal $\alpha$-amylase yield was obtained in a medium containing sorghum flour $(2.0 \% \mathrm{w} / \mathrm{v})$ and a mixture of $\left(\mathrm{NH}_{4}\right)_{2} \mathrm{SO}_{4}$ + soybean meal $(1.5 \% \mathrm{w} / \mathrm{v})$ with an initial medium $\mathrm{pH}$ of 8.0 . Under optimum conditions, amylase yield was maximal $(0.499 \mathrm{U} / \mathrm{ml})$ after $60 \mathrm{~h}$ incubation at room temperature $\left(28^{\circ} \mathrm{C} \pm\right.$ $2^{\circ} \mathrm{C}$ ). Characterization studies showed that the enzyme had maximum activity at $60^{\circ} \mathrm{C}$, retained $100 \%$ of its original activities at $60^{\circ} \mathrm{C}$ for $2 \mathrm{~h}$, was maximally active at $\mathrm{pH} 7.0$ and retained $100 \%$ of original activities at $\mathrm{pH} 9.0$ for $2 \mathrm{~h}$. Enzyme activity was stimulated by urea, $\mathrm{Mg}^{2+}, \mathrm{Ca}^{2+}$ and $\mathrm{Zn}^{2+}$ but inhibited by $\mathrm{Hg}^{2+}$.
\end{abstract}

Keywords: Citrobacter sp.; mixture of $\left(\mathrm{NH}_{4}\right)_{2} \mathrm{SO}_{4}$, soybean meal; sorghum flour.

\section{Produção de alfa-amilase a partir de Citrobacter spp}

\section{RESUMO}

A produção de amilase por Citrobacter sp. isolada a partir de batata foi otimizada pelo estudo de cultura em incubadoras com frascos rotativos. Efeitos e interações das melhores fontes e níveis de carbono e nitrogênio calculadas em desenhos experimentais fatoriais 4 x 5 e $4 \times 4$ foram significantes $(\mathrm{P}<0,01)$ para a produção de amilase. A produção ótima de alfaamilase foi obtida em um meio contendo farinha de sorgo $(2,0 \% \mathrm{~m} / \mathrm{v})$ e uma mistura de $\left(\mathrm{NH}_{4}\right)_{2} \mathrm{SO}_{4}$ + torta de soja $(1,5 \% \mathrm{~m} / \mathrm{v})$ com um pH médio inicial de 8,0. Em condições ótimas, a produção de amilase foi máxima $(0.499 \mathrm{U} / \mathrm{ml})$ após $60 \mathrm{~h}$ de incubação à temperatura ambiente $\left(28^{\circ} \mathrm{C} \pm 2^{\circ} \mathrm{C}\right)$. Estudos de caracterização mostraram que a enzima teve atividade máxima a $60^{\circ} \mathrm{C}$, quando reteve $100 \%$ de suas atividades originais por $2 \mathrm{~h}$, com $\mathrm{pH} 7,0$ e reteve $100 \%$ das atividades originais com $\mathrm{pH} 9,0$ por $2 \mathrm{~h}$. A atividade da enzima foi estimulada pela urea, por $\mathrm{Mg}^{2+}, \mathrm{Ca}^{2+}$ e $\mathrm{Zn}^{2+}$ mas, foi inibida por $\mathrm{Hg}^{2+}$.

Palavras-chave: Citrobacter sp.; $\left(\mathrm{NH}_{4}\right)_{2} \mathrm{SO}_{4}$, torta de soja; farinha de sorgo. 


\section{INTRODUCTION}

The fundamental idea in sustainable development is the provision of a framework for integration of economic, environmental and social development. In the industries, sustainability principles involve continuous innovation, improvement and use of clean technology to reduce pollution levels and consumption of resources (Lau and Jaworski, 2003). Bio-based industrial processes especially enzyme based technologies have been found to meet these demands through the elimination of the use of hazardous raw materials, reduction in energy consumption, production of emissions and by-products as well as in ensuring complete biodegradability of effluents (OECD, 2001). Due to their metabolic diversity, microorganisms and their products are a major resource in a bio-based economy.

The $\alpha$-amylase (1, 4- $\alpha$-D-glucan glucanohydrolase, EC 3.2.1.1) hydrolyses internal $\alpha-1,4$ glycosidic linkages in starch and related substrates (Bolton et al., 1997). Microbial amylases have found use in desizing of fabric to enhance good finishing in textile industry (Yoon, 2005), clean-up of drilling fluids during oil drilling, manufacture of cleaner biofuels from agricultural wastes, lowering toxic byproducts from pulp processing in paper industry, production of syrup, laundry and dish washing detergents (OECD, 2001). The enzyme has been demonstrated extracellularly in a wide variety of microorganisms such as members of the genera Lactobacillus (Ilori et al., 1996), Aspergillus (Obineme et al., 2003), and Bacillus (Uguru et al., 1997). However, Gram-positive bacteria and particularly the genus Bacillus are prolific amylase producers (Pandey et al., 2000). Despite their diverse applications, it is often difficult to find all the desirable attributes in an amylase produced by a naturally occurring microorganism. Special amylolytic attributes could be engineered into a microorganism, however, a necessary first step is the study of the production and characterization of amylases from naturally occurring amylolytic organisms to provide a pool for the selection. This is pertinent since the production requirements and characteristics of microbial amylases isolated from different sources vary (Pandey et al., 2000). This study was therefore designed to evaluate the amylolytic productivity of a Citrobacter sp. under different conditions, and characterize the enzyme produced under optimal conditions.

\section{MATERIAL AND METHODS}

\subsection{Isolation and screening of $\alpha$-amylase-producing microorganisms}

The organisms were isolated from rotten potato. Five gram of the rotten potato was weighed into $45 \mathrm{ml}$ sterile distilled water in a $250 \mathrm{ml}$ Erlenmeyer flask and shaken vigorously to suspend the organisms. The resultant suspension was serially diluted and $0.1 \mathrm{ml}$ of the $10^{-3}$ dilution was spread onto nutrient agar plates containing $1 \%(\mathrm{w} / \mathrm{v})$ soluble starch. The plates were incubated at room temperature $\left(28 \pm 2^{\circ} \mathrm{C}\right)$ for $48 \mathrm{~h}$. Thereafter the colonies were purified by sub culturing onto fresh nutrient agar plates. The purified bacterial cultures were transferred into nutrient agar slants, incubated at room temperature for $48 \mathrm{~h}$ and thereafter stored in the refrigerator prior to screening.

Screening was done by point-inoculating the isolates on a medium which consisted of 2 $\mathrm{g} / \mathrm{l}\left(\mathrm{NH}_{4}\right)_{2} \mathrm{SO}_{4} ; 0.5 \mathrm{~g} / \mathrm{l} \mathrm{MgSO}_{4} .7 \mathrm{H}_{2} \mathrm{O} ; 0.01 \mathrm{~g} / \mathrm{l} \mathrm{FeSO}{ }_{4} .7 \mathrm{H}_{2} \mathrm{O} ; 0.07 \mathrm{~g} / \mathrm{l} \mathrm{K} \mathrm{HPO}_{4} ; 10 \mathrm{~g} / \mathrm{l}$ Soluble starch and $17 \mathrm{~g} / \mathrm{l}$ agar in distilled water (Shaw et al.,1995). The medium was incubated at room temperature $\left(28 \pm 2^{\circ} \mathrm{C}\right)$ for $48 \mathrm{~h}$. Thereafter the plates were flooded with Gram's iodine solution $\left(0.1 \%\left({ }^{\mathrm{w}} / \mathrm{v}\right)\right.$ Iodine crystals and $1 \%(\mathrm{w} / \mathrm{v})$ Potassium Iodide). Formation of clear zones around the colonies was suggestive of amylase production. The diameter of the zone of clearing was measured and the organisms with zones of clearing up to $1.0 \mathrm{~mm}$ were selected. 
One of the chosen organisms was identified as Citrobacter sp. using standard microbiological methods and scheme of Holt et al. (1994). This organism was used for further studies.

\subsection{Optimization of media for amylase production}

Optimization studies were done sequentially. Firstly, the effect of different carbon and nitrogen sources were studied together using a 4 x 4 factorial experimental layout. Thereafter, the effects of different concentrations of carbon and nitrogen combination that gave the highest amylase production were studied using a 4 x 5 factorial. Finally the effect of initial $\mathrm{pH}$ of medium on amylase production was studied.

The mineral salt medium hereafter referred to as basal salt medium (BSM) was adapted

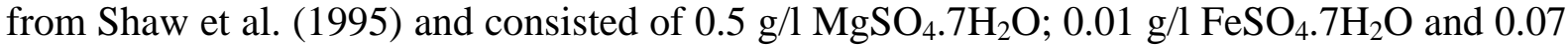
$\mathrm{g} / \mathrm{l} \mathrm{K}_{2} \mathrm{HPO}_{4}$. For each study, the BSM was dispensed in $30 \mathrm{ml}$ volume into $100 \mathrm{ml}$ Erlenmeyer flasks while the carbon, nitrogen and $\mathrm{pH}$ were varied.

The carbon sources included crude carbon (sorghum and sweet potato flours) and purified carbon (soluble starch (Sigma)). The nitrogen sources included organic nitrogen (groundnut cake and soybean meal) and the inorganic nitrogen (ammonium sulphate (BDH)). The nitrogen sources were used alone or as a mixture in a 1:1 ratio.

The inoculum consisted of pure cultures of the organism grown on nutrient agar plates for 24 hours. The cells were introduced into sterile normal saline tubes and washed twice by centrifugation (3000 rpm). Washed cells were resuspended in normal saline and standardized to obtain a cell suspension of approximately $600 \times 10^{6} \mathrm{cfu} / \mathrm{ml}$ using the McFarland standard of the nephelometry method (Campbell et al., 1970). One milliliter of this suspension was used as the inoculum in each flask.

For each study, fermentation lasted for $48 \mathrm{~h}$ at room temperature $\left(28 \pm 2^{\circ} \mathrm{C}\right)$ on a rotary incubator $(150 \mathrm{rpm})$. After fermentation, the supernatant recovered after centrifugation at $3000 \mathrm{rpm}$ and $4^{\circ} \mathrm{C}$ for 15 min was used as the enzyme source.

\subsection{Enzyme assay}

Amylase activity was estimated by the dinitrosalicyclic acid (DNS) method of Bernfeld (1955), using $0.5 \%(\mathrm{w} / \mathrm{v})$ soluble starch in $0.05 \mathrm{M}$ phosphate buffer (pH 6.0). One unit (U) of $\alpha$-amylase activity was defined as the amount of enzyme required to release one micromole of reducing sugar expressed as glucose per minute under the assay conditions.

\subsection{Time course for amylase production}

Time course for the production of $\alpha$-amylase was studied at room temperature $\left(28 \pm 2{ }^{\circ} \mathrm{C}\right.$ ) on a rotary incubator $(150 \mathrm{rpm})$ for $96 \mathrm{~h}$ using the most productive fermentation medium which consisted of BSM supplemented with sorghum flour $(2.0 \% \mathrm{w} / \mathrm{v})$, ammonium sulphate $\left.\left(\mathrm{NH}_{4}\right)_{2} \mathrm{SO}_{4}\right)+$ soybean meal $(1: 1)(1.5 \% \mathrm{w} / \mathrm{v})$ at an initial $\mathrm{pH}$ of 6.0 . Enzyme assays were done at intervals of $12 \mathrm{~h}$ after centrifugation as previously described.

\subsection{Characterization of enzyme}

The organism was grown for $60 \mathrm{~h}$ on the most productive fermentation medium whose composition was given above. Thereafter, the enzyme was harvested after centrifugation as previously described and then characterized. 


\subsection{Temperature activity and stability profiles}

The effect of temperature on enzyme activity was studied by measuring the amount of reducing sugar released during the reaction at different temperatures $\left(30-90^{\circ} \mathrm{C}\right)$. The reaction mixture consisted of $0.5 \mathrm{ml}$ each of the enzyme solution and $0.5 \%\left({ }^{\mathrm{w}} / \mathrm{v}\right)$ soluble starch in $0.05 \mathrm{M}$ phosphate buffer ( $\mathrm{pH}$ 6.0) incubated at the different temperatures for $30 \mathrm{~min}$. Thereafter, the reaction was stopped by the addition of $1 \mathrm{ml}$ of DNS reagent and enzyme activity determined as previously described Bernfeld (1955).

Thermal stabilities at $50^{\circ} \mathrm{C}, 60^{\circ} \mathrm{C}$ and $70^{\circ} \mathrm{C}$ were studied by incubating $0.5 \mathrm{ml}$ of the enzyme in thin walled test tubes at the various temperatures in a water bath incubator for $3 \mathrm{~h}$. At 30 min interval, one test tube from each temperature was withdrawn and cooled promptly on ice. At the end of $3 \mathrm{~h}$ the residual enzyme activity in the tubes were determined by the addition of $0.05 \mathrm{ml}$ of $0.5 \%\left({ }^{\mathrm{w}} / \mathrm{v}\right)$ soluble starch in $0.05 \mathrm{M}$ phosphate buffer, $\mathrm{pH} 6.0$ and incubating at $50^{\circ} \mathrm{C}$ for $30 \mathrm{~min}$. Reactions were stopped by the addition of 3,5-DNS reagent and enzyme activity determined.

\section{7. $\mathrm{pH}$ activity and stability profiles}

The effects of $\mathrm{pH}$ on amylase activity were studied using the following buffers: $(0.2 \mathrm{M})$ citrate phosphate buffer ( $\mathrm{pH} 3$ - 5), sodium phosphate buffer ( $\mathrm{pH} 6$ - 8) and sodium hydrogen carbonate- sodium hydroxide buffer ( $\mathrm{pH} 9$ - 11).

The $\mathrm{pH}$ activity profile was determined in a reaction mixture consisting of $0.5 \mathrm{ml}$ each of the enzyme solution and $0.5 \%(\mathrm{w} / \mathrm{v})$ soluble starch prepared in buffers of the different $\mathrm{pH}$ values. The tubes were incubated at $50^{\circ} \mathrm{C}$ for $30 \mathrm{~min}$. The reaction was terminated by the addition of 3, 5-DNS reagent and enzyme activities determined as described.

For the $\mathrm{pH}$ stability profile, test tubes containing $0.5 \mathrm{ml}$ enzyme and $0.5 \mathrm{ml}$ of the respective buffers of different $\mathrm{pH}$ values were incubated at room temperature $\left(28 \pm 2^{\circ} \mathrm{C}\right)$ for 2 h. Thereafter, enzyme activities were analyzed by the addition of $0.5 \mathrm{ml}$ of starch in $0.05 \mathrm{M}$ phosphate buffer ( $\mathrm{pH} \mathrm{6.0)}$ to each tube and incubated at $50^{\circ} \mathrm{C}$ for $30 \mathrm{~min}$. The reaction was terminated by the addition of 3,5-DNS reagent and enzyme activities determined as previously described.

\subsection{Effects of metal ions and enzyme modulators}

Metal ions which included $\mathrm{Ca}^{2+}, \mathrm{Ba}^{2+}, \mathrm{Co}^{2+}, \mathrm{Cu}^{2+}, \mathrm{K}^{+}, \mathrm{Fe}^{2+}, \mathrm{Ni}^{2+}, \mathrm{Zn}^{2+}, \mathrm{Na}^{+}$, at concentrations of $1 \mathrm{mM}$ each, and modulators, namely EDTA (50 mM), Urea (2 $\mathrm{mM})$ and $\mathrm{HgCl}_{2}(1 \mathrm{mM})$, were tested for their effects on enzyme activity. The reaction mixture consisted of $0.5 \mathrm{ml}$ of enzyme and $0.5 \mathrm{ml}$ of the respective enzyme modulators or metal solutions in $0.05 \mathrm{M}$ phosphate buffer, $\mathrm{pH}$ 6.0. The reaction mixtures were left for $30 \mathrm{~min}$ at room temperature $\left(28 \pm 2{ }^{\circ} \mathrm{C}\right)$. Thereafter, $0.5 \mathrm{ml}$ of $0.05 \%(\mathrm{w} / \mathrm{v})$ soluble starch in $0.05 \mathrm{M}$ phosphate buffer, $\mathrm{pH} 6.0$, was added, and the mixture incubated at $50^{\circ} \mathrm{C}$ for $30 \mathrm{~min}$. The reaction was terminated by the addition of 3, 5-DNS reagent and enzyme activities determined as previously described. Results were compared with a control treated in the same manner as the test but which contained the buffer in place of the solution of the metals or enzyme modulators.

\subsection{Analysis of findings}

Each experiment was carried out in triplicates. Data collected were subjected to analysis of variance (ANOVA) and the means separated using GenStat for Windows (GenStat, 2005). 
ORJI, J. C.; NWEKE, C. O.; NWABUEZE, R. N.; NWANYANWU, C. E.; ALISI, C. S.; ETIM-OSOWO, E. N. Production and properties of $\alpha$-amylase from Citrobacter species. Ambi-Agua, Taubaté, v. 4, n. 1, p. 45-57, 2009. (doi:10.4136/ambi-agua.73)

\section{RESULTS AND DISCUSSION}

The amylolytic organism identified as Citrobacter sp is a motile, Gram negative, citrate utilizing, indole negative and urease negative rod that ferments glucose and sucrose. The organism showed a zone of clearing of $1.2 \mathrm{~mm}$ in diameter on the screening medium. Amylolytic ability is widely distributed among several mesophilic microbial genera. However, only a few extracellular enzymes produced from Gram-negative mesophiles have been reported (Pandey et al., 2000). Members of the genus Citrobacter have not been reported to be prolifically amylolytic. Being a predominantly non-pathogenic soil resident, this organism lends itself amenable for use in the industrial production of amylases.

The effects of carbon source, nitrogen source and the interactions were significant $(\mathrm{P}<$ 0.01) on amylase production (Table 1). Within carbon sources, using soluble starch (pure) as the carbon source, significantly $(\mathrm{P}<0.01)$ lowest amylase yield $(0.071 \mathrm{U} / \mathrm{ml})$ was obtained when the purified inorganic $\left(\mathrm{NH}_{4}\right)_{2} \mathrm{SO}_{4}$ was used as the nitrogen source, compared with other sources of nitrogen. With cassava starch, there were no significant $(\mathrm{P}>0.01)$ differences between amylase yields $(0.285 \mathrm{U} / \mathrm{ml})$ due to a combination of $\left(\mathrm{NH}_{4}\right)_{2} \mathrm{SO}_{4}+$ groundnut cake or $\left(\mathrm{NH}_{4}\right)_{2} \mathrm{SO}_{4}+$ soybean meal as the nitrogen source, but the yields were significantly $(\mathrm{P}<0.01)$ greater than those obtained when either $\left(\mathrm{NH}_{4}\right)_{2} \mathrm{SO}_{4}$ or groundnut cake or soybean meal were used as the nitrogen source. Also, using sorghum flour, a combination of organic and inorganic nitrogen source was preferred to either organic or inorganic nitrogen as the nitrogen source.

Table1. Effects of different carbon and nitrogen sources on amylase production.

\begin{tabular}{|c|c|c|c|c|c|}
\hline \multirow{3}{*}{$\begin{array}{l}\text { Nitrogen sources } \\
(1 \% \mathrm{w} / \mathrm{v})\end{array}$} & \multicolumn{5}{|c|}{ Amylase activity (U/ml) } \\
\hline & \multicolumn{4}{|c|}{ Carbon sources (1\% w/v) } & \multirow[b]{2}{*}{ Mean } \\
\hline & $\begin{array}{l}\text { Soluble } \\
\text { starch } \\
\text { (pure) }\end{array}$ & $\begin{array}{c}\text { Cassava } \\
\text { starch } \\
\text { (crude) }\end{array}$ & $\begin{array}{c}\text { Sorghum } \\
\text { flour (crude) }\end{array}$ & $\begin{array}{l}\text { Sweet potato } \\
\text { flour (crude) }\end{array}$ & \\
\hline $\begin{array}{l}\left(\mathrm{NH}_{4}\right)_{2} \mathrm{SO}_{4} \\
\text { (Inorganic) }\end{array}$ & $0.071(5.31)$ & 0.107 (5.55) & 0.142 (4.69) & 0.214 (5.13) & $0.134(5.17)$ \\
\hline $\begin{array}{l}\text { Groundnut cake } \\
\text { (Organic) }\end{array}$ & $0.249(4.78)$ & $0.071(5.61)$ & $0.249(4.73)$ & $0.178(4.84)$ & $0.187(4.99)$ \\
\hline $\begin{array}{l}\text { Soy bean meal } \\
\text { (Organic) }\end{array}$ & $0.107(4.61)$ & $0.178(4.46)$ & $0.214(4.35)$ & $0.249(4.64)$ & $0.187(4.52)$ \\
\hline $\begin{array}{l}\left(\mathrm{NH}_{4}\right)_{2} \mathrm{SO}_{4}+ \\
\text { groundnut cake }\end{array}$ & $0.142(4.92)$ & $0.285(4.75)$ & $0.285(4.62)$ & $0.285(4.59)$ & $0.249(4.72)$ \\
\hline $\begin{array}{l}\left(\mathrm{NH}_{4}\right)_{2} \mathrm{SO}_{4}+\text { soy bean } \\
\text { meal }\end{array}$ & $0.214(4.51)$ & $0.285(4.39)$ & $0.321(4.32)$ & $0.178(4.48)$ & $0.250(4.43)$ \\
\hline Mean & $0.157(4.83)$ & $0.185(4.95)$ & $0.242(4.54)$ & $0.221(4.74)$ & $0.201(4.77)$ \\
\hline
\end{tabular}

Basal medium contains the different combinations of the carbon and nitrogen sources. Initial media $p H=6.0$

Figures in parenthesis are final media $\mathrm{pH}$

$L S D_{0.01}$ for nitrogen source $=0.0092$

$L S D_{0.01}$ for carbon source $=0.0082$

$L S D_{0.01}$ for means of different nitrogen source at the same or different carbon source $=0.018$

Within nitrogen sources, using $\left(\mathrm{NH}_{4}\right)_{2} \mathrm{SO}_{4}$, lowest yield was obtained with soluble starch as the carbon source. With a combination of $\left(\mathrm{NH}_{4}\right)_{2} \mathrm{SO}_{4}+$ groundnut cake, there were no 
significant $(\mathrm{P}>0.01)$ differences in amylase yields $(0.285 \mathrm{U} / \mathrm{ml})$ obtained with either cassava starch, sorghum flour or sweet potato flour as the carbon source. However, these yields were significantly higher than the yield obtained with soluble starch as the carbon source. It thus appears that there is a preference for a combination of both organic and inorganic nutrient sources for optimal production of amylase by the organism. The requirement for the inclusion of crude nutrient sources could be attributed to the provision by the crude nutrients of other growth factors and ancillary substances which interacted significantly to influence enzyme production positively or negatively. The most significant negative interaction gave the lowest amylase yield of $0.071 \mathrm{U} / \mathrm{ml}$ observed in the treatment containing groundnut cake as the nitrogen source and cassava starch as the carbon source, while the most significant positive interaction gave the highest amylase yield of $0.321 \mathrm{U} / \mathrm{ml}$ obtained in the treatment containing a combination of $\left(\mathrm{NH}_{4}\right)_{2} \mathrm{SO}_{4}+$ soybean meal as the nitrogen source and sorghum flour as the carbon source. These nutrient sources were therefore considered optimal for enzyme production. Haq et al. (2002) also reported that both organic and inorganic nitrogen sources were essential for amylase production by Saccharomyces cerevisiae. The significant interaction between the carbon and nitrogen sources implies that the effects of one factor depended on the level of the other factor.

The final $\mathrm{pH}$ of the fermentation media varied (Table 1). However, in all the treatments, there were significant reductions in final media $\mathrm{pH}$ from the initial $\mathrm{pH}$ of 6.0. The final media $\mathrm{pH}$ of the treatment $\left(\left(\mathrm{NH}_{4}\right)_{2} \mathrm{SO}_{4}+\right.$ soybean meal $)+$ sorghum flour $)$ that gave the highest reduction in $\mathrm{pH}$ was 4.32 . Incidentally, this treatment also gave the highest enzyme yield. Likewise, the least reduction in $\mathrm{pH}$ (5.6) was also obtained in the treatment (groundnut cake + cassava starch) that gave the lowest enzyme yield. Further analysis of the amylase yield and final media $\mathrm{pH}$ of the various treatments showed that a negative correlation $(\mathrm{r}=-0.66)$ existed between the two parameters. It is therefore possible that $\mathrm{pH}$ plays a vital role in the interaction of the various carbon and nitrogen sources.

Further studies were done to determine the effects of levels of the optimal nutrients. Results presented in Table 2 shows that the effects of the different concentrations of sorghum flour as the carbon source, and a mixture of $\left(\mathrm{NH}_{4}\right)_{2} \mathrm{SO}_{4}+$ soybean meal as the nitrogen source, and their interactions were significant $(\mathrm{P}<0.01)$ on amylase production. At all the concentrations of sorghum flour, enzyme production increased with increasing concentration of the mixture of $\left(\mathrm{NH}_{4}\right)_{2} \mathrm{SO}_{4}+$ soybean meal, until a peak was reached, beyond which further increase in the concentration of the mixture of $\left(\mathrm{NH}_{4}\right)_{2} \mathrm{SO}_{4}+$ soybean meal led to a decrease in enzyme production. At the lower concentrations of sorghum flour $(0.5-1.0 \% \mathrm{w} / \mathrm{v})$, the peaks were obtained with $1 \% \mathrm{w} / \mathrm{v}\left(\mathrm{NH}_{4}\right)_{2} \mathrm{SO}_{4}+$ soybean meal while at the higher concentrations $(2.0-3.0 \% \mathrm{w} / \mathrm{v})$, the peaks were obtained with $1.5 \% \mathrm{w} / \mathrm{v}\left(\mathrm{NH}_{4}\right)_{2} \mathrm{SO}_{4}+$ soybean meal. These results suggest that amylase production respond to variations in the carbon: nitrogen ratios of the medium. The highest amylase yield of $0.427 \mathrm{U} / \mathrm{ml}$ was obtained at the respective concentrations of $1.5 \% \mathrm{w} / \mathrm{w}$ for the mixture of $\left(\mathrm{NH}_{4}\right)_{2} \mathrm{SO}_{4}+$ soy bean meal, and $2.0 \% \mathrm{w} / \mathrm{w}$ for sorghum flour. A negative correlation, though weak $(\mathrm{r}=-0.23)$ also existed between amylase yield and final media $\mathrm{pH}$. This also suggests that $\mathrm{pH}$ might have played a vital role in the significant $(\mathrm{P}<0.01)$ interaction of the different concentrations of sorghum flour and a mixture of $\left(\mathrm{NH}_{4}\right)_{2} \mathrm{SO}_{4}+$ soybean meal on amylase production.

The production of $\alpha$-amylase is very sensitive to initial $\mathrm{pH}$ of the fermentation medium. Enzyme production increased as the initial medium $\mathrm{pH}$ increased from $3-5$ (Figure 1). Between pH 5 - 7, there were no differences in enzyme yields, however, a sharp increase was observed at $\mathrm{pH}$ 8, beyond which amylase production dropped. The amylase yield at this optimal $\mathrm{pH}$ was $0.463 \mathrm{U} / \mathrm{ml}$ and the final media $\mathrm{pH}$ was 5.27 . This yield was however not 
ORJI, J. C.; NWEKE, C. O.; NWABUEZE, R. N.; NWANYANWU, C. E.; ALISI, C. S.; ETIM-OSOWO, E. N. Production and properties of $\alpha$-amylase from Citrobacter species. Ambi-Agua, Taubaté, v. 4, n. 1, p. 45-57, 2009. (doi:10.4136/ambi-agua.73)

significantly different $(\mathrm{P}>0.01)$ from $0.392 \mathrm{U} / \mathrm{ml}$ obtained at $\mathrm{pH} 9.0$. Hence the organism required a slightly alkaline environment for optimal amylase production. Also in line with the previous observations (Tables 1 and 2), as the amylase yield started declining, the final media $\mathrm{pH}$ started rising. Reports on the optimal $\mathrm{pH}$ for amylase production by microbes are varied. UI Qader et al. (2006) reported optimal amylase production by Bacillus sp AS-1 at pH 7.0 while Kiran et al. ( 2005) observed that in Bacillus licheniformis TCRDC-B13, amylase synthesis drastically dropped as $\mathrm{pH}$ was increased to 8.5 .

Table 2. Effects of different concentrations of sorghum flour and $\left(\mathrm{NH}_{4}\right)_{2} \mathrm{SO}_{4}+$ soybean meal on amylase production.

\begin{tabular}{cccccc}
\hline \multirow{2}{*}{$\begin{array}{c}\text { Sorghum } \\
\text { flour } \\
\text { (\% w/v) }\end{array}$} & $\mathbf{5 . 5}$ & $\mathbf{1 . 0}$ & $\mathbf{1 . 5}$ & $\mathbf{2 . 0}$ & \multirow{2}{*}{ Mean } \\
\cline { 2 - 5 } & $0.107(4.54)$ & $0.160(5.08)$ & $0.107(4.92)$ & $0.071(4.93)$ & $0.111(4.87)$ \\
\hline 0.5 & $0.053(4.83)$ & $0.294(4.79)$ & $0.214(4.63)$ & $0.178(4.87)$ & $0.185(4.78)$ \\
1.0 & $0.249(4.51)$ & $0.285(4.59)$ & $0.427(4.68)$ & $0.321(4.74)$ & $0.321(4.63)$ \\
2.0 & $0.071(4.57)$ & $0.107(4.65)$ & $0.249(4.64)$ & $0.214(4.86)$ & $0.160(4.68)$ \\
3.0 & $0.120(4.61)$ & $0.212(4.65)$ & $0.250(4.64)$ & $0.178(4.86)$ & $0.190(4.74)$ \\
Mean & &
\end{tabular}

Basal medium contains Sorghum flour and $\left(\mathrm{NH}_{4}\right)_{2} \mathrm{SO}_{4}+$ Soy bean meal at the stated concentrations. Initial media $\mathrm{pH}=6.0$; Figures in parenthesis are final media $\mathrm{pH}$

$L S D_{0.01}$ for Sorghum flour concentration $=0.014$

$L S D_{0.01}$ for $\left(\mathrm{NH}_{4}\right)_{2} \mathrm{SO}_{4}+$ Soybean meal $=0.014$

$L S D_{0.01}$ for means of different concentrations of Sorghum flour at the same or different concentrations of $\left(\mathrm{NH}_{4}\right)_{2} \mathrm{SO}_{4}+$ Soybean meal $=0.027$

Time course for amylase production shows that the highest yield of enzyme $(0.499 \mathrm{U} / \mathrm{ml})$ was obtained after $60 \mathrm{~h}$ of incubation. (Figure 2). Beyond $60 \mathrm{~h}$, drastic reduction in yield was obtained probably due to the production of secondary metabolites that are inhibitory to enzyme synthesis. Although biomass was not monitored in this study, this view is accentuated by previous reports on microbial amylase production which showed enzyme production accompanying exponential growth and continuing into the stationary phase where the production of other metabolites inhibited enzyme production (Obineme et al., 2003; Fossi et al., 2005). Kiran et al., 2005 also reported maximum enzyme production by a thermophilic Bacillus sp. K12 after $60 \mathrm{~h}$ incubation using starch as the carbon source.

Characterization of the crude enzyme showed that the enzyme was maximally active at $60^{\circ} \mathrm{C}$, retaining $100 \%$ of its original activity at $60^{\circ} \mathrm{C}$ for $2 \mathrm{~h}$ and over $65 \%$ at $70^{\circ} \mathrm{C}$ for $3 \mathrm{~h}$ (Figures 3 and 4). High thermostability is a desirable attribute for amylases suitable for use in high temperature fermentations such as the gelatinization of starch. High processing temperatures also limit the growth of mesophilic contaminants in fermentation processes and ensure the generation of effluents with more uniform characteristics, which would be easier to dispose. The crude $\alpha$-amylase of the Citrobacter sp. has a comparable temperature activity range with that of Bacillus sp reported by Teodoro and Martins (2000) but was however less stable. 


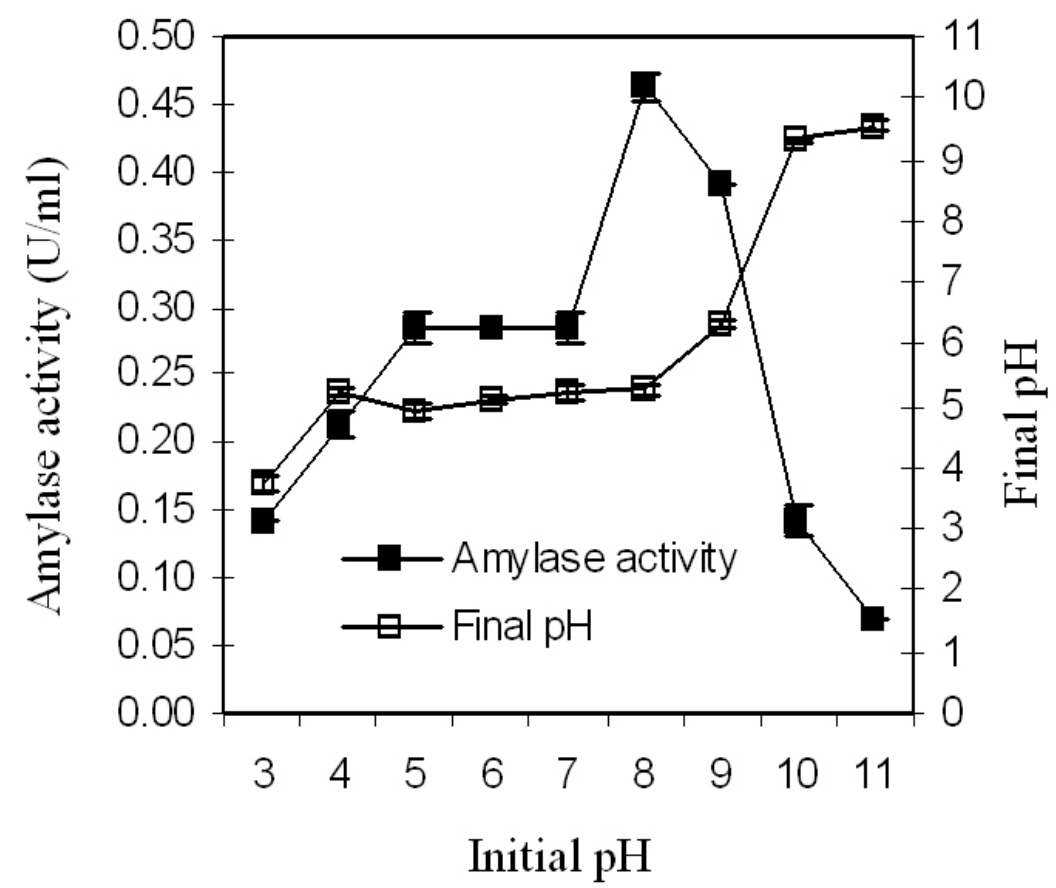

Figure 1. Effects of initial $\mathrm{pH}$ of medium on amylase production by Citrobacter species. (Basal medium contains sorghum flour $(2.0 \% \mathrm{w} / \mathrm{v})$ and a mixture of $\left(\mathrm{NH}_{4}\right)_{2} \mathrm{SO}_{4}+$ soybean meal $(1.5 \%$ $\mathrm{w} / \mathrm{v})$.

The $\mathrm{pH}$ activity and stability profiles of the organism showed that at a $\mathrm{pH}$ range of $3-6$, there was no appreciable difference in amylase activity. However, at $\mathrm{pH} 7$ a sharp increase in amylase activity was observed and this declined thereafter. Also, the enzyme maintained $100 \%$ of its original activity at $\mathrm{pH} 9-10$ for 2 hours at room temperature $\left(28+2^{\circ} \mathrm{C}\right)$ (Figure 5). Since the amylase was optimally produced at an initial medium $\mathrm{pH}$ of $8-9$, had optimal activity at $\mathrm{pH} 7.0$ and retained maximum activity at $\mathrm{pH} 9-10$, this strain of Citrobacter sp would survive under neutral to slightly alkaline environments. Pandey et al. (2000) noted that the fundamental characteristics of extracellular amylases reflect the $\mathrm{pH}$ of the environment in which the organisms are grown. The enzyme resembles that of a strain of alkaliphilic Bacillus sp. which grew best at $\mathrm{pH} 8.5$ and produced an $\alpha$-amylase which had a $\mathrm{pH}$ optimum of 9.0 (Lin et al., 1998). Also for Bacillus sp AS-1, optimal amylase production was at pH 7.0, and optimal activity was obtained at pH 7.5 (UI Qader et al., 2006).

Significant $(\mathrm{P}<0.01)$ stimulatory effects on amylase activity were observed with various cations $\left(\mathrm{Mg}^{2+}, \mathrm{Ca}^{2+}, \mathrm{Zn}^{2+}, \mathrm{Co}^{2+}, \mathrm{Ba}^{2+}, \mathrm{K}^{+}, \mathrm{Na}^{+}, \mathrm{Fe}^{2+}, \mathrm{Ni}^{2+}\right)$ (Table 3). This suggests that metal ions are essential for the activity of the $\alpha$-amylase from Citrobacter sp. The cations protect the enzyme from heat denaturation and contribute to thermostability (Forgaty and Kelly, 1980). The effect of enzyme modulators showed that urea was stimulatory, $\mathrm{HgCl}_{2}$ inhibitory while EDTA had no effect (Table 3). The inactivation of the enzyme by $\mathrm{HgCl}$ suggests that the enzyme require reduced thiol groups for activity since $\mathrm{Hg}^{2+}$ has been reported to have a very high affinity for thiol groups (Nies, 1999). With respect to the effects of the divalent cations $\mathrm{Mg}^{2+}, \mathrm{Ca}^{2+}, \mathrm{Co}^{2+}, \mathrm{K}^{+}$and $\mathrm{Fe}^{2+}$, and responses to the modulators, $\mathrm{HgCl}$ and EDTA, the extracellular amylase from Citrobacter sp differs from that of Thermus sp (Shaw et al., 1995). 
ORJI, J. C.; NWEKE, C. O.; NWABUEZE, R. N.; NWANYANWU, C. E.; ALISI, C. S.; ETIM-OSOWO, E. N. Production and properties of $\alpha$-amylase from Citrobacter species. Ambi-Agua, Taubaté, v. 4, n. 1, p. 45-57, 2009. (doi:10.4136/ambi-agua.73)

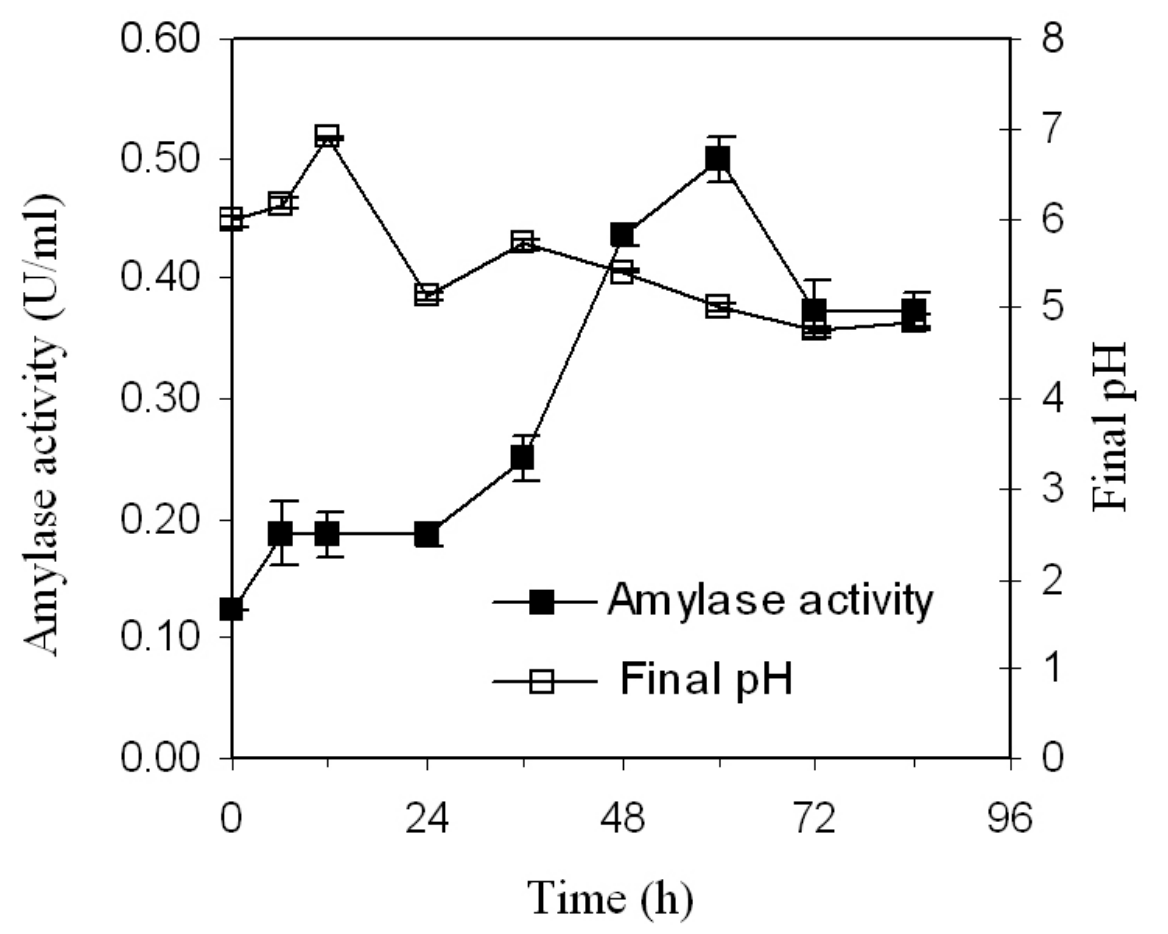

Figure 2. Time course for amylase production by Citrobacter species (Basal medium contains sorghum flour $(2.0 \% \mathrm{w} / \mathrm{v})$ and a mixture of $\left(\mathrm{NH}_{4}\right)_{2} \mathrm{SO}_{4}+$ soybean meal $(1.5 \% \mathrm{w} / \mathrm{v})$, Initial $\mathrm{pH}$ 8.0).

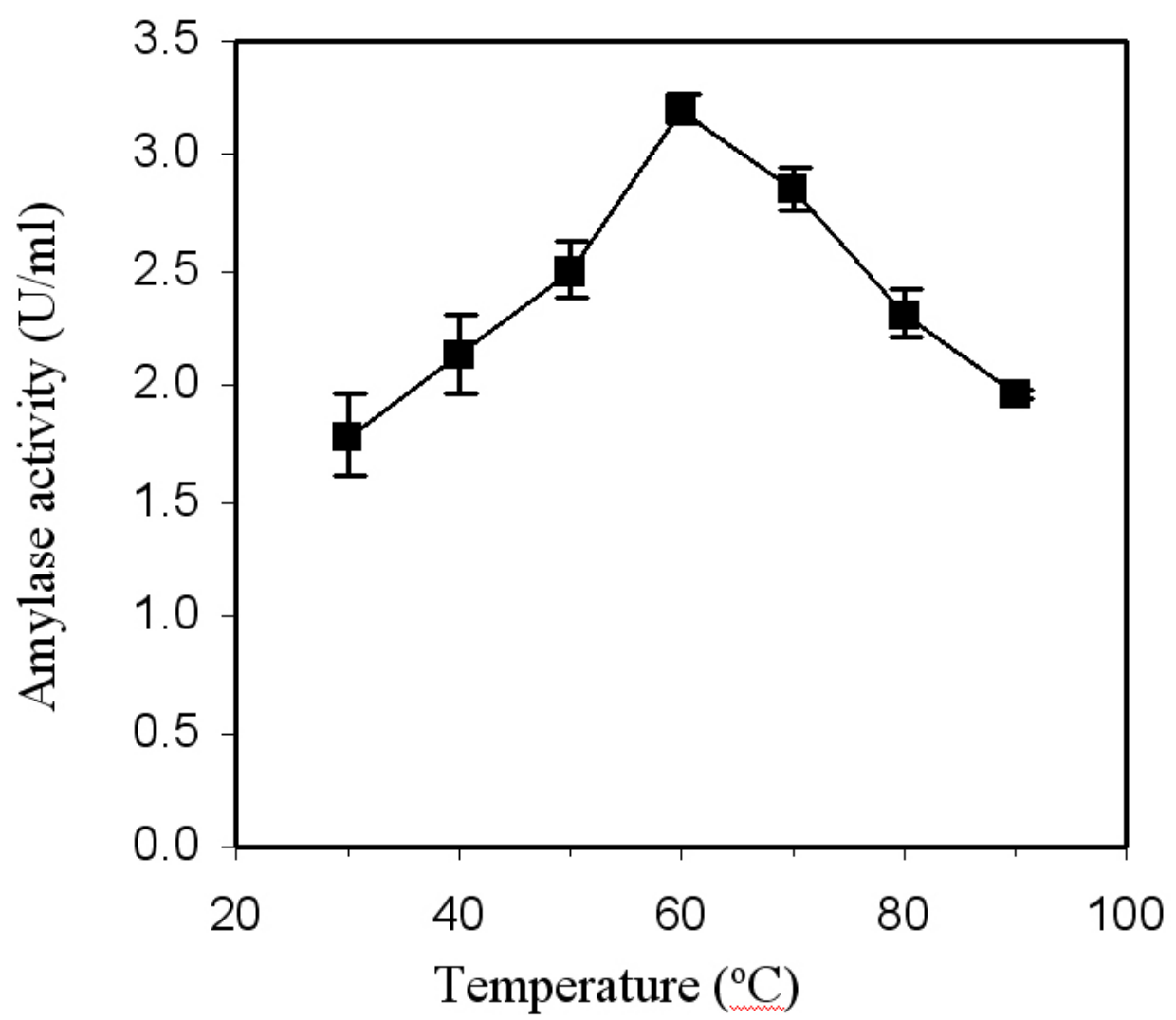

Figure 3. Effects of temperature on amylase activity. 
ORJI, J. C.; NWEKE, C. O.; NWABUEZE, R. N.; NWANYANWU, C. E.; ALISI, C. S.; ETIM-OSOWO, E. N. Production and properties of $\alpha$-amylase from Citrobacter species. Ambi-Agua, Taubaté, v. 4, n. 1, p. 45-57, 2009. (doi:10.4136/ambi-agua.73)

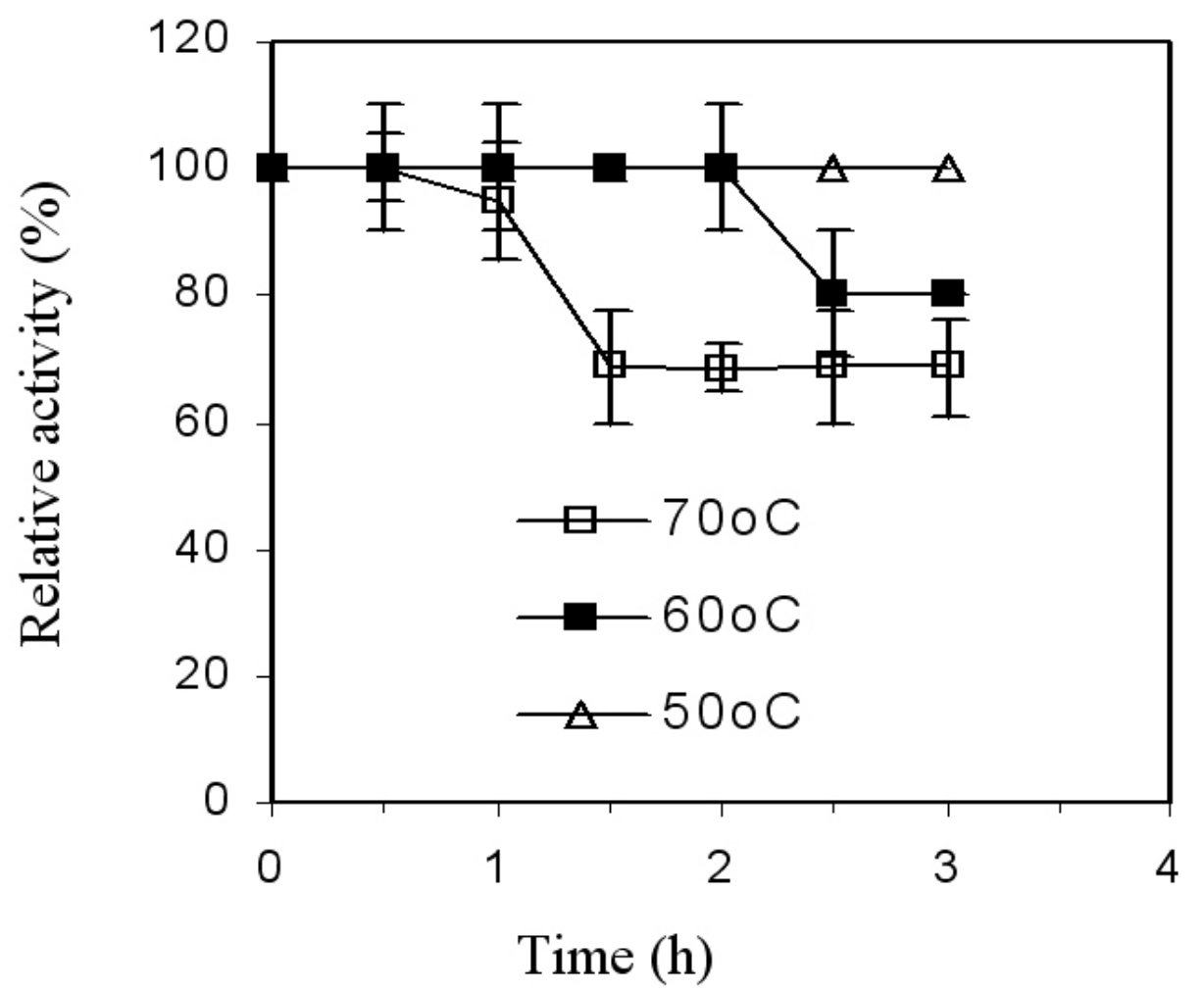

Figure 4. Thermal stabilities of the amylase enzyme at 50, 60 and $70^{\circ} \mathrm{C}$.

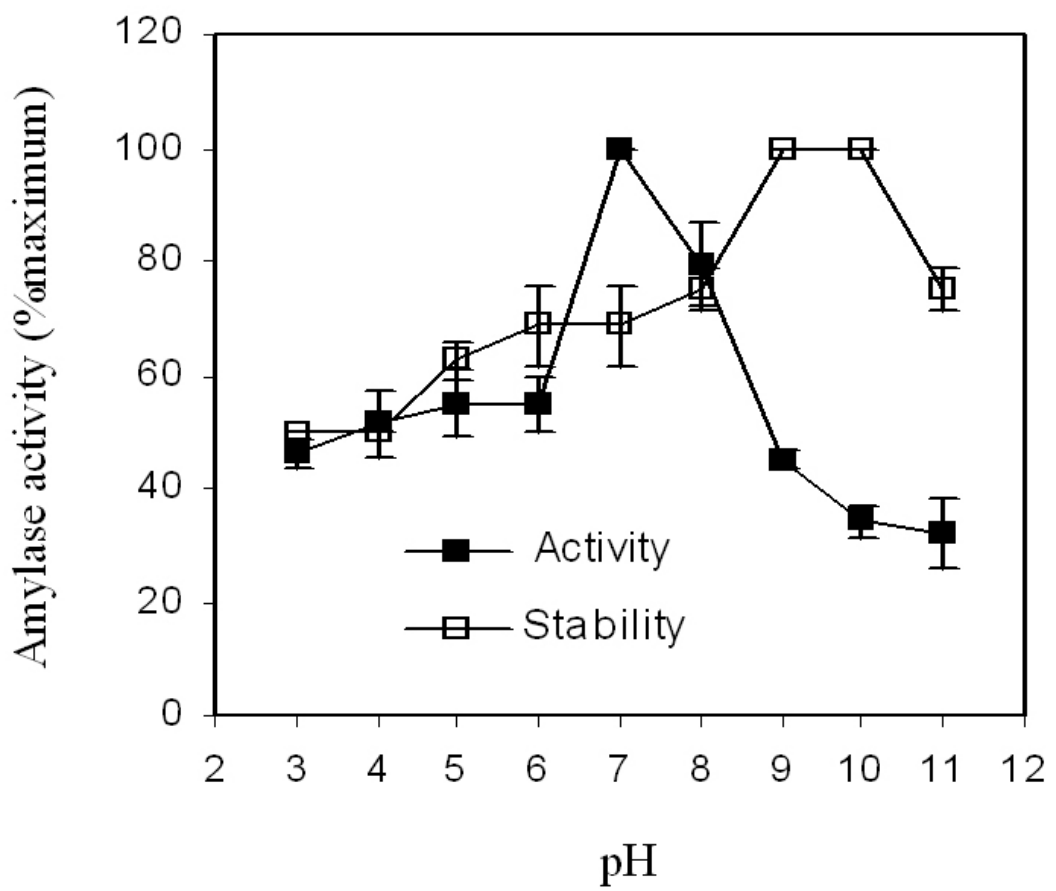

Figure 5. Effects of pH on amylase activity and stability. 
ORJI, J. C.; NWEKE, C. O.; NWABUEZE, R. N.; NWANYANWU, C. E.; ALISI, C. S.; ETIM-OSOWO, E. N. Production and properties of $\alpha$-amylase from Citrobacter species. Ambi-Agua, Taubaté, v. 4, n. 1, p. 45-57, 2009. (doi:10.4136/ambi-agua.73)

Table 3. Effects of metal ions and enzyme modulators on amylase activity.

\begin{tabular}{cc}
\hline $\begin{array}{c}\text { Metal ions/ } \\
\text { Enzyme modulators }\end{array}$ & $\begin{array}{c}\text { Relative } \\
\text { Activity (\%) }\end{array}$ \\
\hline $\mathrm{Control}$ & $100.00 \pm(0.00)$ \\
$\mathrm{Mg}^{2+}$ & $123.45 \pm(3.65)$ \\
$\mathrm{Ca}^{2+}$ & $163.25 \pm(28.25)$ \\
$\mathrm{Zn}^{2+}$ & $125.92 \pm(9.24)$ \\
$\mathrm{Co}^{2+}$ & $163.40 \pm(32.88)$ \\
$\mathrm{Ba}^{2+}$ & $125.92 \pm(29.24)$ \\
$\mathrm{K}^{+}$ & $138.68 \pm(23.64)$ \\
$\mathrm{Na}^{+}$ & $120.14 \pm(11.38)$ \\
$\mathrm{Fe}^{2+}$ & $133.92 \pm(17.44)$ \\
$\mathrm{Urea}^{2+}$ & $123.15 \pm(13.18)$ \\
$\mathrm{Ni}^{2+}$ & $146.48 \pm(29.78)$ \\
$\mathrm{EDTA}$ & $100.17 \pm(21.73)$ \\
$\mathrm{Hg}^{2+}$ & $58.10 \pm(15.23)$ \\
\hline
\end{tabular}

Note: Figures in parenthesis are standard deviations from the means).

\section{CONCLUSION}

The ability to produce a thermostable $\alpha$-amylase at mesophylic temperature would lower production cost and lend the organism, Citrobacter sp. economical for industrial exploitation. Its use will eliminate mesophylic contaminants in the production process and ensure generation of effluents, which would be easier to dispose. Furthermore, the non-inhibitory effect of the enzyme by various inorganic chemicals implies that the Citrobacter sp. amylase would find use in industries where these metals pose problems either in the production process or in waste treatment facilities. All these are desirable attributes, which could equally be engineered into another organism to improve amylase activity and engender industrial sustainability.

\section{ACKNOWLEDGEMENT}

The authors express their heartfelt gratitude to Dr Ogoke of the Department of Crop Science and Technology, Federal University of Technology, Owerri for the statistical analysis.

\section{REFERENCES}

BERNFELD, P. Amylases $\alpha$ and $\beta$. Methods Enzymol, v. 1, p.149-158, 1955.

BOLTON, D. J.; KELLY, C. T.; FOGARTY, W. M. Purification and characterization of the a-amylase of Bacillus flavothermus. Enz. Microbial Technol, v. 20, p. 340-343, 1997.

CAMPBELL, D. H.; GARVY, S. J.; CREMER, N. E.; SUSSDERF, D. H. Methods in immunology. A laboratory test for instruction and research . 2. ed. New York: W. A. Benjamin, 1970. , p. 475.

FORGATY, W. M.; KELLY, C. T. Microbial enzymes and bioconversions: amylases. New York: Academic Press, 1980. p.115-170. 
FOSSI, B. T.; TAVEA, F.; NDJOUENKEU, R. Production and partial characterization of a thermostable amylase from Ascomycetes yeast strain. Afr. J. Biotechnol, v. 4, p. 14-18, 2005.

GENSTAT. GenStat for Windows Release 4.24DE Discovery edition. Hemel Hempstead: VSN International, 2005.

HAQ, I.; ABDULLAH, R.; ASHRAF, H.; SHAH, A. Isolation and screening of fungi for the biosynthesis of alpha amylase. Biotechnol., v. 1, p. 61-66, 2002.

HOLT, J. G.; KRIEG, N. R.; SNEATH, P. H. A.; STALEY, J. T.; WILliAMS, S. T. Bergey's Manual of Determinative Bacteriology. 9. ed. Baltimore: Williams, Wilkins, 1994.

ILORI, M. O.; AMUND, O. O.; OMIDIJI, O. Effect of carbon and nitrogens sources on glucoamylase production in Lactobacillus brevis. Folia Microbiol., v. 41, p. 339-340, 1996.

KIRAN, O. I.; COMLEKCIOGLU, U. I.; ARIKAN, B. Effects of carbon sources and various chemicals on the production of a novel amylase from a thermophilic Bacillus sp. K-12. Turk. J. Biol., v. 29, p. 99-103, 2005.

LAU, P. C. K.; JAWORSKI, J. F. Industrial sustainability through biotechnology. Biotechnology Industry Organization. ASM News 69 (3):111, 2003.

LIN, L. L.; CHYAU, C. C.; HSU, W. H. Production and properties of a raw-starch-degrading amylase from thermophilic and alkaliphilic Bacillus sp. TS-23. Biotech. Appl. Biochem., v. 28, p. 61-68, 1998.

NIES, D. H. Microbial heavy-metal resistance. Appl. Microbiol. Biotechnol., v. 51, p. 730750, 1999.

OBINEME, O. J.; EZEONU, I. M.; MUONEKE, A. N.; OBI, S. K. C. Production and characterization of an $\alpha$-amylase from an Aspergilus oryzae isolated from soil. Nig. J. Microbiol., v. 17, p.71-79, 2003.

ORGANISATION FOR ECONOMIC CO-OPERATION AND DEVELOPMENT - OECD . The application of biotechnology for industrial sustainability. 2001. Available: <http://www1.oecd.org/publications/e-book/9301061e.pdf>. Access: 20 February, 2009.

PANDEY, A.; NIGAM, P.; SOCCOL, C. R.; SOCCOL, V. T.; SINGH, D.; MOHAN, R. . Advances in microbial amylases. Biotechnol. Appl. Biochem., v. 31, p. 135-152, 2000.

SHAW, J. F.; LIN, F. P.; CHEN, C. H. Purification and properties of an extracellular alphaamylase from Thermus sp. Bot. Bull. Acad. Sin., v. 36, p.1, 1995.

TEODORO, C. E. S.; MARTINS M. L. L. Culture conditions for the production of thermostable amylases by Bacillus sp. Braz J. Microbiol., v. 31, p. 1-9, 2000.

UGURU, G. C.; ROBB, D.; AKINYANJU, J. A.; SAM, A. Purification, characterization and mutagenic enhancement of a thermoactive a-amylase from Bacillus subtilis. J. Ind. Microbiol. Biotechnol., v.19, p. 273-279, 1997. 
ORJI, J. C.; NWEKE, C. O.; NWABUEZE, R. N.; NWANYANWU, C. E.; ALISI, C. S.; ETIM-OSOWO, E. N. Production and properties of $\alpha$-amylase from Citrobacter species. Ambi-Agua, Taubaté, v. 4, n. 1, p. 45-57, 2009. (doi:10.4136/ambi-agua.73)

UI QADER, S.; BANO, S.; AMAN, A.; SYED, N.; AZHAR, A. Enhanced production and extracellular activity of commercially important amylolytic enzyme by a newly isolated strain of Bacillus. sp. AS-1. Turk J Biochem., v. 31, n. 3, p. 135-140, 2006.

YOON, M. Y. Denim finishing with enzymes. 2005. Dyer International, v. 11: 16-19, 2005. 


ISSN = 1980-993X - doi:10.4136/1980-993X
www.agro.unitau.br/ambi-agua
E-mail: ambi-agua@agro.unitau.br
Tel.: (12) 3625-4116

\title{
Mapeamento e avaliação da potabilidade da água subterrânea do município de Lajeado, RS, Brasil \\ (doi:10.4136/ambi-agua.74)
}

\author{
Rafael Rodrigo Eckhardt'; Vianei Luís Diedrich²; Everaldo Rigelo Ferreira ${ }^{3}$; Eduardo \\ Strohschoen $^{4}$; Letícia Craide Demaman ${ }^{5}$

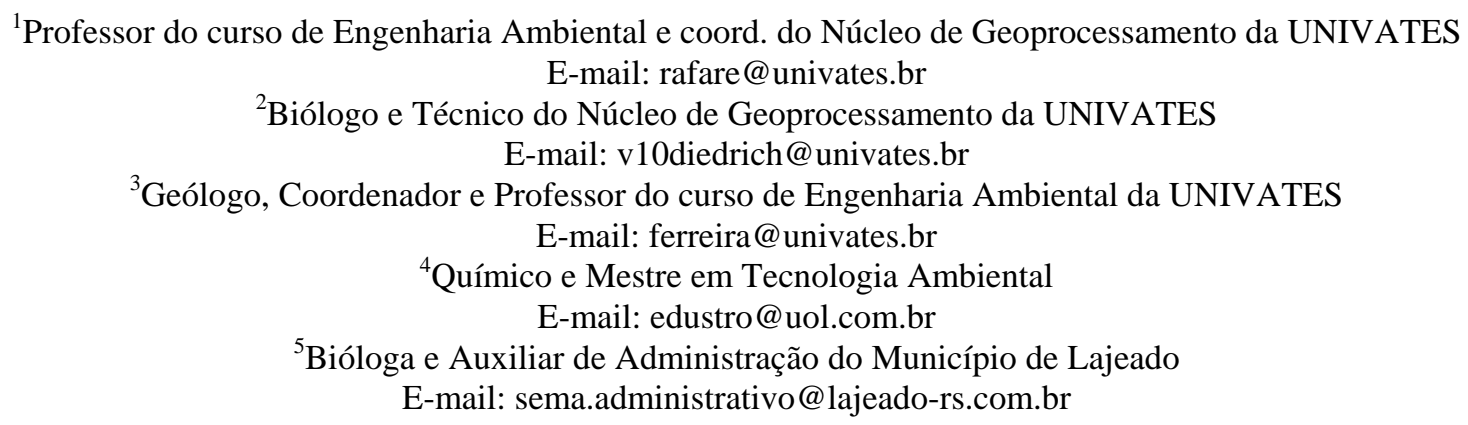

\section{RESUMO}

Os mananciais subterrâneos ocorrem de forma extensiva e estão relativamente protegidos dos agentes de poluição em comparação aos rios e reservatórios artificiais. Essas condições, aliadas aos baixos custos de captação, favoreceram um crescimento vertiginoso no consumo de água subterrânea nas últimas décadas. Águas subterrâneas se tornaram uma alternativa importante para o abastecimento público no Brasil. Este estudo apresenta o levantamento georreferenciado dos pontos de captação de água subterrânea no município de Lajeado, RS e o diagnóstico da potabilidade dessas águas. A captação da água subterrânea na área de estudo é realizada no Aquífero Serra Geral e no Aquífero Guarani. Os pontos de captação de água subterrânea foram identificados no campo, com uso de um receptor GPS e espacializados, utilizando técnicas de geoprocessamento e sensoriamento remoto. A potabilidade da água subterrânea foi averiguada a partir da realização de análises microbiológicas e físico-químicas em 100 poços de captação de água, sendo 78 em poços tubulares e 22 em poços escavados. Para os parâmetros analisados nos poços tubulares foram gerados os mapas de isoteores e isovalores, utilizando recursos de geoestatística. No estudo foram levantados 362 poços tubulares e 253 poços escavados. Os resultados mostram que os poços escavados localizam-se predominantemente nas áreas rurais e, dos poços escavados analisados, 77,27\% apresentam níveis de contaminação além dos limites de potabilidade, não sendo adequados para o consumo. Os poços tubulares concentram-se em áreas urbanas e, pelas análises realizadas, 76,92\% apresentam água com qualidade adequada para o consumo humano.

Palavras-chave: água subterrânea; análises microbiológicas e físico-químicas; padrões de potabilidade; geoprocessamento; geoestatística.

\section{Mapping and analysis of the groundwater potability in the Lajeado municipality, Rio Grande do Sul State, Brazil}

\section{ABSTRACT}

The groundwater sources spread in extensive areas and are relatively protected from pollution agents when compared to rivers and artificial reservoirs. These aspects, combined with low exploitation costs, provided a considerable growth in the groundwater use in the last 
decades. Groundwater became an important alternative source for public water supply in Brazil. This paper shows the georeferenced location of the groundwater exploitation points in the Lajeado, RS municipality and the potability analyses of this water. The groundwater exploitation in the study area is accomplished in the Serra Geral and Guarani aquifers and the exploitation points were identified in field campaigns using a GPS receiver and plotted over satellite imagery using remote sensing and geoprocessing techniques. The groundwater potability assessment was based on 100 samples for microbiological and physico-chemical analyses that included 78 samples of tubular wells and 22 of dug wells. Contour maps were generated for the analyzed parameters in the tubular wells, using geostatistics procedures. In this study, 362 tubular wells and 253 dug wells were studied. The results show that the dug wells are located mainly in rural areas and $77.27 \%$ of them aren't suitable for human consumption due to high levels of contamination. The tubular wells are concentrated in urban areas and results revealed that $76.92 \%$ of them have water with suitable quality for the human consumption.

Keywords: groundwater; microbiological and physico-chemical analysis; potability standards; geoprocessing; geostatistics.

\section{INTRODUÇÃO}

De acordo com Capucci et al. (2001), devido à degradação de sua qualidade, a água doce líquida que circula em muitas regiões do mundo perdeu a característica de recurso renovável, em particular nos países ditos em desenvolvimento, na medida em que os efluentes e os resíduos domésticos e industriais são dispostos no ambiente sem tratamento ou de forma inadequada. Além disso, desequilíbrios na oferta de água à população e conflitos pelo seu uso também apresentam aspectos preocupantes.

Diante desse cenário turbulento, a água subterrânea vem assumindo uma importância cada vez mais relevante como fonte de abastecimento. Devido a uma série de fatores que restringem a utilização das águas superficiais, bem como ao crescente aumento dos custos da sua captação, adução e tratamento, a água subterrânea está sendo reconhecida como alternativa viável aos usuários e tem apresentado uso crescente nos últimos anos, obtidas em poços bem locados e construídos. Além dos problemas relacionados à facilidade de contaminação das águas superficiais, o maior interesse pelo uso da água subterrânea vem sendo despertado pela maior oferta desse recurso e em decorrência do desenvolvimento tecnológico, que promoveu uma melhoria na produtividade dos poços e um aumento de sua vida útil (Capucci et al., 2001).

Segundo Rebouças et al. (2006), a partir da década de 1960 o termo águas subterrâneas é utilizado apropriadamente para designar a totalidade das águas do subsolo. A partir desse período, a abordagem evoluiu da tradicional determinação das reservas de água disponíveis no subsolo, das vazões de produção das obras de captação ou dos poços tubulares, para uma análise mais abrangente das suas condições de uso e proteção. Assim, tornou-se necessário considerar os principais tipos de água que ocorrem abaixo da superfície da Terra, como as águas do solo, da camada não saturada do subsolo e da sua zona saturada.

As águas que atingem a superfície do solo a partir das precipitações, retidas nas depressões do terreno, ou escoando superficialmente ao longo dos talvegues, podem infiltrarse por efeito das forças devido à atração molecular, aos efeitos de capilaridade e à atração gravitacional. Abaixo da superfície do solo, em função das ações dessas forças e da natureza do terreno, a água pode se encontrar na zona de aeração ou na zona saturada. Na primeira, os interstícios do solo ou rochas são parcialmente ocupados pela água, enquanto o ar preenche os 
ECKHARDT, R. R.; DIEDRICH, V. L.; FERREIRA, E. R.; STROHSCHOEN, E.; DEMAMAN, L. C. Mapeamento e avaliação da potabilidade da água subterrânea do município de Lajeado, RS, Brasil. Ambi-Agua, Taubaté, v. 4, n. 1, p. 58-80, 2009. (doi:10.4136/ambi-agua.74)

demais espaços livres e, na segunda, a água ocupa todos os vazios e se encontra sob pressão hidrostática (Pinto et al., 2008).

A percolação da água no solo varia de intensidade em função do tipo de terreno encontrado em seu caminho. Algumas formações apresentam vazios relativamente importantes e contínuos facilitando o fluxo descendente. Entretanto, se encontrar camadas menos permeáveis, a água será retardada e, eventualmente, preencherá todos os interstícios da região sobrejacente, formando as zonas saturadas (Pinto et al., 2008). Uma parcela desses fluxos deságua na superfície dos terrenos, formando fontes, olhos de água, abastece os poços e outras obras de captação. Outra parcela dos fluxos de água subterrânea da zona saturada deságua nos rios, tornando-os perenes durante períodos em que as precipitações atmosféricas são relativamente escassas ou descarregam diretamente nos lagos e oceanos (Rebouças et al., 2006).

A rocha que tem porosidade e permeabilidade é chamada de aquífera, independentemente de estar ou não saturada. Quando a camada aquífera em apreço apresenta grande espessura saturada, a sua função principal poderá ser de produção de água, a qual poderá ser extraída por meio de poços tubulares perfurados, túneis ou qualquer outra obra de captação. A água subterrânea da zona saturada constitui o manancial subterrâneo propriamente dito (Rebouças et al., 2006). De acordo com Capucci et al. (2001), há três tipos básicos de aquíferos, classificados de acordo com a formação rochosa na qual está contido:

- Aquíferos granulares ou porosos: a água está armazenada e flui nos poros dos solos e das rochas sedimentares de estrutura granular. Exemplo: arenitos e aluviões;

- Aquíferos fissurais: a água circula pelas fraturas, fendas e falhas nas rochas cristalinas. Exemplo: granitos, gnaisses e diabásios;

- Aquíferos cársticos ou cavernosos: a água se faz presente e circula pelas aberturas ou cavidades causadas pela dissolução das rochas. Exemplo: calcários e mármores.

As formações geológicas portadoras de água superpostas por camadas impermeáveis são denominadas de aquíferos confinados. A sua recarga, por meio das chuvas, dá-se somente nos locais onde a formação aflora à superfície. Neles o nível hidrostático encontra-se sob pressão, causando artesianismo nos poços que captam suas águas. Já os aquíferos livres são aqueles constituídos por formações geológicas superficiais, totalmente aflorantes, portanto com a recarga no próprio local, em toda a extensão da formação. Os aquíferos livres têm a chamada recarga direta e os aquíferos confinados, a recarga indireta (Capucci et al., 2001).

Dois são os fatores fundamentais determinantes na ocorrência de águas subterrâneas em determinada área. Os fatores geológicos, que regulam as condições de ocorrência - aquífero livre, confinado ou intermediário - as características hidrodinâmicas das rochas aquíferas da área em questão - porosidade intergranular e fissuras - a extensão, espessuras e profundidades das camadas aquíferas, entre outros aspectos. Por sua vez, a quantidade e o regime de ocorrência das precipitações determinam as taxas e os processos de recarga (Rebouças et al., 2006).

A disponibilidade hídrica subterrânea e a produtividade dos poços geralmente são os principais fatores determinantes na explotação dos aquíferos. Em função do crescimento descontrolado da perfuração de poços tubulares e das atividades antrópicas, que acabam contaminando os aquíferos, a questão da qualidade da água subterrânea vem se tornando cada vez mais importante para o gerenciamento dos recursos hídricos no país (Zoby e Oliveira, 2005). Tendo em vista que a captação de mananciais superficiais muito distantes, assim como o tratamento de águas de qualidade excessivamente degradada, ou o reuso, apresentam limitações técnicas e econômicas, a utilização das águas subterrâneas constitui alternativa 
ECKHARDT, R. R.; DIEDRICH, V. L.; FERREIRA, E. R.; STROHSCHOEN, E.; DEMAMAN, L. C. Mapeamento e avaliação da potabilidade da água subterrânea do município de Lajeado, RS, Brasil. Ambi-Agua, Taubaté, v. 4, n. 1, p. 58-80, 2009. (doi:10.4136/ambi-agua.74)

promissora (Rebouças, 1992), por se tratar de uma fonte mais segura e menos onerosa (Pimentel, 1999). Por sua vez, a sua extração desordenada poderá produzir sérios impactos nas descargas dos rios, nos níveis mínimos dos reservatórios e recalques nos terrenos (Rebouças, 2004).

Segundo Rebouças (2004), as águas subterrâneas no Brasil continuam sendo extraídas livremente por meio de poços de qualidade técnica duvidosa, para o abastecimento de hotéis, hospitais, indústrias, condomínios privados e, de forma geral, todos aqueles que dispõem de recursos financeiros para abrir um poço de captação de água subterrânea. Devido à falta de controle na captação, recarga e monitoramento da água subterrânea não se tem uma avaliação segura do número de poços já perfurados, tanto no mundo quanto no Brasil. A UNESCO estima que cerca de 250 milhões de poços estão em operação no mundo. No Brasil, a água subterrânea também é explotada intensamente. Zoby e Matos (2002) estimam que existam no país pelo menos 400.000 poços. Os estados com maior número de poços perfurados, segundo Leal (1999) são: São Paulo, Bahia, Rio Grande do Sul, Ceará e Piauí.

No que diz respeito ao consumo de água no Brasil, o Instituto Brasileiro de Geografia e Estatística - IBGE (2002) aponta que 15,6 \% dos domicílios utilizam exclusivamente água subterrânea, 77,8 \% usam rede de abastecimento de água e 6,6 \% usam outras formas de abastecimento. O mesmo estudo ainda indica que, entre os domicílios que possuem rede de abastecimento de água, uma parte significativa utiliza água subterrânea. Embora o uso do manancial subterrâneo seja complementar ao superficial em muitas regiões, em outras áreas do país, a água subterrânea representa o principal manancial hídrico. Ela desempenha importante papel no desenvolvimento socioeconômico do país.

Enquanto a contaminação de um manancial de superfície constitui, em geral, um problema agudo e visível, identificável pela mudança da cor da água, presença de espuma, aparecimento de peixe morto, etc., a contaminação dos aquíferos é invisível e pode transformar-se em um problema crônico, na medida em que só venha a ser identificado por meio dos seus efeitos na saúde pública (Rebouças, 1992).

Segundo Rebouças (1992), as alterações na qualidade das águas subterrâneas são ditas diretas quando engendradas por substâncias naturais ou artificiais introduzidas pelo homem no ciclo geoquímico da Terra. Influências indiretas podem ser consideradas como sendo aquelas alterações da qualidade, as quais ocorrem sem adição de substâncias geradas pelo homem ou são produzidas pela interferência nos processos químicos, biológicos, físicos e hidrológicos. Quando essa degradação física, química ou bacteriológica ultrapassa os limites de potabilidade, isto é, tornando-a imprópria para o consumo, diz-se que houve contaminação. Quando a degradação fica abaixo desses limites, diz-se que há poluição (Zaporozec, 1981). De acordo com Matthess (1982), quando a água, em condições naturais, apresenta constituintes excedendo os limites de potabilidade, a contaminação será caracterizada pelo aumento nas concentrações desses elementos específicos.

De acordo com Zaporozec e Miller (2000), a contaminação das águas subterrâneas pode originar-se da superfície do solo, do solo da zona não saturada, ou do solo da zona saturada. Há pelo menos três maneiras pela qual pode ocorrer a contaminação das águas subterrâneas: infiltração, migração direta e troca entre aquíferos. A contaminação por infiltração é, provavelmente, o mecanismo mais comum de contaminação da água subterrânea. Um poluente liberado na superfície infiltra através dos poros da matriz do solo e move-se abaixo através da zona não saturada pela força da gravidade até que o topo da zona saturada seja alcançado. Depois que o poluente entra na zona saturada, ele se movimenta na direção do fluxo da água subterrânea.

Rebouças (1992) considera que todo processo antropogênico capaz de poluir ou contaminar as águas subterrâneas tem origem na superfície do solo, de modo que o papel da 
zona não saturada assume especial importância, em virtude de nesta zona se realizarem as interações do meio aquífero com o contexto ambiental natural e as formas de uso e ocupação do meio físico. O local em que um poluente se origina é um fator que pode afetar seu impacto na qualidade da água subterrânea. Se um poluente é liberado na superfície do solo, precisa se mover por numerosas camadas de solo e outros materiais na zona não saturada antes de alcançar a água subterrânea. Como o poluente se move através dessas camadas, processos físicos, químicos e biológicos em atividade reduzem o impacto eventual da substância poluente ao atingir a água subterrânea. A efetividade deste processo de atenuação aumenta com a ampliação da distância, com o aumento do tempo de concentração e a condição de permeabilidade do solo ou rocha até que a substância poluente atinja a água subterrânea (Zaporozec e Miller, 2000).

As fontes de poluição da água subterrânea são muito diversas, como resultado do uso do solo urbano, industrial e agrícola. As substâncias poluentes resultantes dessas atividades incluem, principalmente, substâncias químicas orgânicas, pesticidas, metais pesados, nitratos, bactérias e vírus (Zaporozec e Miller, 2000). Frente a esse cenário e, em virtude das zonas de águas subterrâneas degradadas serem difíceis de detectar (Freeze e Cherry, 1979), as análises microbiológicas e fisico-químicas das águas subterrâneas são importantes e requeridas (Celligoi, 1999) para a avaliação da potabilidade da água.

A indicação da potabilidade da água subterrânea para o consumo é feita a partir da análise de um conjunto de parâmetros microbiológicos e físico-químicos, de acordo com as normas vigentes no País e eventualmente as internacionais (Celligoi, 1999). No Brasil, a avaliação da potabilidade da água subterrânea é realizada considerando os limites máximos apresentados pela Portaria nº. 518, de 2004, do Ministério da Saúde (Brasil, 2004).

\subsection{Objetivos}

O objetivo principal deste trabalho foi traçar um panorama geral da situação de uso e diagnosticar a condição de potabilidade das águas subterrâneas captadas e utilizadas no município de Lajeado, RS. Em termos específicos, o presente estudo procurou atingir 4 grandes metas:

- Realizar o levantamento georreferenciado de todos os poços de captação de água subterrânea e subsuperficial existentes na área urbana e rural do município;

- Organizar um cadastro dos usuários de água subterrânea do município de Lajeado, contando com dados da localização geográfica dos poços, dados construtivos dos poços, dados sobre a vazão e a finalidade de uso da água;

- Realizar análises microbiológicas e físico-químicas para avaliar a condição de potabilidade das águas subterrâneas para o consumo humano;

- Organizar mapas de isoteores e isovalores dos parâmetros analisados para os poços tubulares profundos.

\subsection{Enquadramento geológico da área de estudo}

O município de Lajeado está localizado a nordeste do estado do Rio Grande do Sul, apresenta área territorial de 90,42 km² (IBGE, 2004) e população de 67.474 habitantes (IBGE, 2007), o que confere uma densidade demográfica de 746 habitantes por $\mathrm{km}^{2}$. O abastecimento de água em Lajeado é realizado pela Companhia Riograndense de Saneamento - CORSAN, que capta a água desse rio, realiza a adução, o tratamento e a distribuição da água no município. Ao mesmo tempo, existem diversas organizações, como as Sociedades de Água, particulares e indústrias que dispõem de poços de captação de água subterrânea no município.

O município de Lajeado localiza-se na Bacia Hidrográfica do Rio Taquari-Antas, que deságua na Bacia Hidrográfica do Guaíba. Geograficamente, localiza-se no Fuso 22J, sendo 
delimitado pelas seguintes coordenadas UTM SAD69: 390000 - 412000 E e 6736000 6748000 N. Em termos geológicos, de acordo com Wildner et al. (2008), as litologias aflorantes na área de estudo pertencem ao intervalo Jurássico Cretáceo da Bacia do Paraná, representadas pelos derrames basálticos (Fácies Gramado) da Formação Serra Geral e arenitos intertrápicos da Formação Botucatu. Depósitos aluviais quaternários se estendem às margens do Rio Taquari e Rio Forqueta, correspondendo aos ambientes de sedimentação provocados por inundações. A Figura 1 apresenta a localização e a geologia do município de Lajeado.
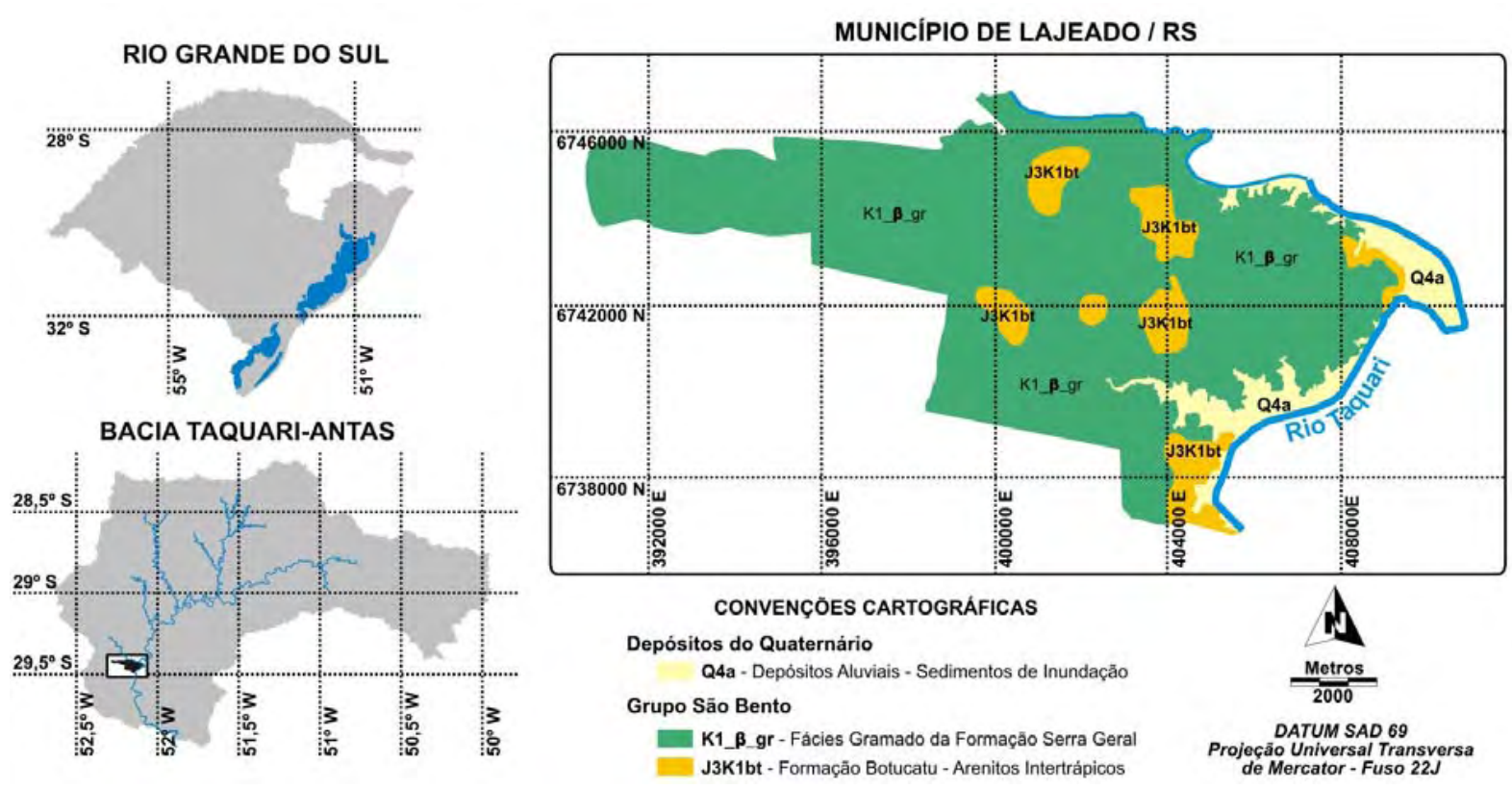

Figura 1. Mapa geológico do município de Lajeado, adaptado do Mapa Geológico do Estado do Rio Grande do Sul em escala 1:750.000 (Wildner et al., 2008).

Em termos hidrogeológicos, a área de estudo está localizada na borda sul do Aquífero Guarani, próximo às áreas de recarga regional. O aquífero possui características de confinado, com locais onde os parâmetros hidrodinâmicos evidenciam um comportamento semiconfinado, provavelmente relacionada a pouca espessura dos basaltos e acompanhado com um intenso fraturamento destes. Por essas características, as águas subterrâneas da região de Lajeado apresentam, em geral, uma ótima qualidade, não apresentando restrições para o consumo humano (Souza et al., 2002).

A Formação Serra Geral apresenta derrames de basaltos, andesitos, riodacitos e riolitos, de filiação toleítica, onde se intercalam arenitos intertrápicos Botucatu na base e litarenitos e sedimentos vulcanogênicos da porção mediana ao topo da sequência. Na área de estudo ocorre a Fácies Gramado (K1_ $\left.\beta \_g r\right)$, que consiste de derrames basálticos granulares finos a médio, melanocráticos cinza, com horizontes vesiculares preenchidos por zeolitas, carbonatos, apofilitas e saponita, estruturas de fluxo, pahoehoe comuns e intercalações com os arenitos Botucatu (Wildner et al., 2008), com espessuras de até $40 \mathrm{~m}$ (Souza et al., 2002). De acordo com um amplo estudo realizado pelo Conselho de Recursos Hídricos do Rio Grande do Sul - CRH (1997), o conjunto de rochas vulcânicas da Bacia Taquari-Antas é representado por uma sequência de até 10 derrames cuja espessura média é de $70 \mathrm{~m}$. No município de Lajeado a espessura dessa Formação varia de 10 até 500 m.

Falhamentos ocorrem na área de estudo, separados em falhamentos regionais com direções preferenciais NE e NW de até $20 \mathrm{~km}$, e falhamentos de menor expressão com 
ECKHARDT, R. R.; DIEDRICH, V. L.; FERREIRA, E. R.; STROHSCHOEN, E.; DEMAMAN, L. C. Mapeamento e avaliação da potabilidade da água subterrânea do município de Lajeado, RS, Brasil. Ambi-Agua, Taubaté, v. 4, n. 1, p. 58-80, 2009. (doi:10.4136/ambi-agua.74)

direções preferenciais E e NE de 500 m a 4 km. Zonas de disjunção horizontal estão presentes em toda a área da porção vulcânica da Formação Serra Geral (Souza et al., 2002).

Em termos hidrogeológicos, os basaltos da Formação Serra Geral se comportam como um aquífero fraturado, onde a circulação da água se dá através das superfícies de descontinuidades geradas pelas fraturas e falhas existentes. A maior ou menor quantidade de água circulante está condicionada ao não preenchimento das fraturas por mineralizações secundárias e à largura destas. Essa Formação apresenta vazão potencial de 1 a 3 m³/h (CRH, 1997).

A Formação Botucatu (J3K1bt), na Bacia Hidrográfica do Rio Taquari-Antas, encontrase depositada sobre as Formações Rosário do Sul e Rio do Rasto, ocorrendo, em grande parte, recoberta pelos derrames basálticos da Formação Serra Geral. Essa Formação pode ocorrer na forma de arenitos intertrápicos entre derrames basálticos, podendo atingir espessuras da ordem de 10 m, enquanto que a espessura total da Formação Botucatu pode atingir 200 m. É constituída por arenitos de sedimentação eólica com marcante estratificação cruzada (CRH, 1997). De acordo com Souza et al. (2002), no município de Lajeado, as espessuras dessa Formação podem variar de 20 a 120 m.

A presença dos arenitos intertrápicos individualizados ou como parte integrante de rochas mistas representa um acréscimo de potencial aquífero, em função de resultar em uma incidência maior de porosidade e permeabilidade intergranular no contexto das rochas vulcânicas, cujas porosidades e permeabilidades decorrem da maior ou menor densidade de fraturas e também do maior ou menor desenvolvimento de zonas vesiculares. A vazão potencial ou provável nessa Formação é de até $30 \mathrm{~m} 3 / \mathrm{h}$ (CRH, 1997), mas poços localizados sobre os falhamentos regionais podem apresentar vazões de até $120 \mathrm{~m}^{3} / \mathrm{h}$ (Souza et al., 2002).

Os depósitos aluviais (Q4a) correspondem aos sedimentos fluviais recentes, constituídos por cascalhos, areias, siltes e argilas depositadas nas calhas dos rios e nas planícies de inundação (CRH, 1997; Wildner et al., 2008). De acordo com Souza et al. (2002), os depósitos aluviais podem alcançar espessuras de até $20 \mathrm{~m}$ e gerar vazões de até $2 \mathrm{~m} 3 / \mathrm{h}$.

\section{MATERIAL E MÉTODOS}

Os procedimentos metodológicos para o desenvolvimento do presente estudo foram divididos em três etapas: a) levantamento georreferenciado dos poços de captação de água subterrânea; b) análises microbiológicas e fisico-químicas; c) avaliação da potabilidade das águas subterrâneas.

\subsection{Levantamento georreferenciado dos poços de captação de água subterrânea}

Esta etapa do estudo consistiu na realização de atividades exploratórias de campo para localizar os poços que realizam captação de água subterrânea no município de Lajeado, uma vez que somente alguns poucos poços apresentavam registros cadastrais na Secretaria Municipal de Meio Ambiente de Lajeado. A localização geográfica dos poços foi aferida com GPS de navegação. O sistema de coordenadas utilizado no levantamento foi o Universal Transverso de Mercator (UTM), referenciado ao South American Datum, de 1969 - SAD69.

Foram levantados os poços tubulares operantes, os poços tubulares desativados, os poços escavados operantes e os poços escavados desativados. Para cada poço localizado foi preenchida uma ficha cadastral, com os dados da situação do poço, que incluíram dados construtivos, profundidade, vazão, finalidade de uso da água e características ambientais do entorno dos poços.

Mapas temáticos da distribuição espacial dos poços de captação de água subterrânea no município de Lajeado foram organizados no Sistema de Informação Geográfica (SIG) Idrisi. 
ECKHARDT, R. R.; DIEDRICH, V. L.; FERREIRA, E. R.; STROHSCHOEN, E.; DEMAMAN, L. C. Mapeamento e avaliação da potabilidade da água subterrânea do município de Lajeado, RS, Brasil. Ambi-Agua, Taubaté, v. 4, n. 1, p. 58-80, 2009. (doi:10.4136/ambi-agua.74)

Os dados cadastrais dos poços mapeados foram utilizados para quantificar os usuários de águas subterrâneas em Lajeado e aferir a finalidade de uso dessas águas. Além disso, esta etapa do estudo permitiu que a Secretaria Municipal de Meio Ambiente organizasse medidas administrativas para a regularização dos poços em operação e medidas de controle sobre a potabilidade das águas subterrâneas consumidas.

\subsection{Análises microbiológicas e físico-químicas}

Dos poços de captação de água subterrânea operantes no município de Lajeado foram realizadas coletas para análise da água em 100 poços. Desses poços analisados, 78 coletas foram realizadas em poços tubulares e 22 coletas ocorreram em poços escavados. A definição dos poços analisados foi realizada atendendo a uma distribuição espacial aleatória, mas procurando abranger todos os quadrantes da área de estudo.

A coleta da água subterrânea foi realizada diretamente na saída de água dos poços, a qual foi desinfetada para manter as características naturais da água subterrânea. As análises microbiológicas e físico-químicas foram realizadas pelo Laboratório de Prestação de Serviços Analíticos da UNIVATES. Foram analisados os seguintes parâmetros microbiológicos: coliformes fecais, coliformes totais e contagem total de bactérias; e físico-químicos: $\mathrm{pH}$, fósforo total, dureza total, nitrogênio, nitratos, sulfatos, chumbo, cromo e matéria orgânica.

Os parâmetros acima relacionados foram selecionados em função da complexidade das atividades humanas na área urbana, em função do uso agropecuário do solo nas áreas rurais e considerando a interação rocha-água na área de estudo. Segundo Foster e Hirata (1993), dos parâmetros analisados, os nitratos, chumbo, cromo, coliformes fecais, coliformes totais, contagem total de bactérias e matéria orgânica tem importância para a saúde, enquanto os sulfatos apresentam importância organoléptica. Além disso, os parâmetros microbiológicos, o pH e a matéria orgânica são parâmetros básicos para a caracterização da água.

\subsection{Avaliação da potabilidade das águas subterrâneas}

Ao término das etapas 2.1 e 2.2 foram identificados os poços de captação de água subterrânea que apresentavam parâmetros que ultrapassavam os limites máximos de potabilidade estabelecidos pela Portaria $n^{\circ}$. 518, de 2004, do Ministério da Saúde (Brasil, 2004). Essa portaria é utilizada atualmente como norma para indicar a potabilidade da água subterrânea para fins de consumo humano no Brasil. Os poços de captação contaminados foram espacializados sobre a imagem $\mathrm{ETM}^{+}$do satélite Landsat VII (2002), órbita/ponto 222/080, composição colorida RGB543, de 04/02/2002.

As análises microbiológicas e físico-químicas realizadas nos poços amostrados permitiram a geração das curvas de isoteores ou de isovalores dos parâmetros analisados. Esses mapas de isoteores foram gerados pelo método da Krigagem ordinária pontual, com interpolador a partir de semivariogramas, utilizando-se o aplicativo Surfer 8. O processo de Krigagem estima o valor de uma variável, em uma posição $\mathrm{Z}(\chi \mathrm{i})$ não amostrada, a partir de uma pré-análise espacial do conjunto de amostras utilizando-se semivariogramas experimentais. O valor estimado no processo de Krigagem é dado por:

$$
\mathrm{Z}\left(\chi_{\mathrm{O}}\right)=\sum_{\mathrm{I}=1}^{\mathrm{N}} \lambda_{\mathrm{I}} \mathrm{Z}\left(\chi_{\mathrm{I}}\right)
$$

em que: $\mathrm{N}$ é o número de vizinhos medidos, $\mathrm{Z}(\chi \mathrm{i})$ utilizados na estimativa da variável e $\lambda \mathrm{i}$ são os ponderadores aplicados a cada $\mathrm{Z}(\chi \mathrm{i})$, os quais são selecionados de forma que a estimativa obtida seja não tendenciosa. Assim, tem-se o estimador não tendencioso da Krigagem ordinária pontual dado pela fórmula: E[Z0 - Z*] (Guerra, 1988). 


\section{RESULTADOS E DISCUSSÃO}

As atividades exploratórias de campo permitiram identificar, basicamente, dois sistemas de captação de água subterrânea no município de Lajeado. Um sistema mais simples, que capta a água do freático a pouca profundidade. Esses poços são conhecidos como poços escavados, rasos ou cacimbas. O outro sistema, composto por poços tubulares, profundos ou artesianos, é mais complexo. Esse sistema capta a água em grandes profundidades, do Aquífero Serra Geral e do Aquífero Guarani.

Foram localizados 615 pontos de captação de água subterrânea no município de Lajeado. Desses poços levantados, 362 consistem de poços tubulares e 253 poços são poços escavados (Figura 2). A análise dos resultados permite constatar que dos poços de captação de água subterrânea levantados em Lajeado, $14 \%$ dos poços tubulares e $27 \%$ dos poços escavados estão desativados. Em termos totais, $84 \%$ dos poços levantados continuam em operação, fornecendo água para diversas finalidades, incluindo o consumo humano.

A Figura 3 apresenta a distribuição dos poços levantados em Lajeado em função da característica de uso do solo urbano e rural. Ao analisar a Figura 3, percebe-se que $70 \%$ dos poços levantados estão localizados na área urbana, onde também ocorrem $83 \%$ dos poços tubulares. Na área rural do município, 66\% dos poços consistem de poços escavados e somente $17 \%$ dos poços tubulares estão localizados na área rural.

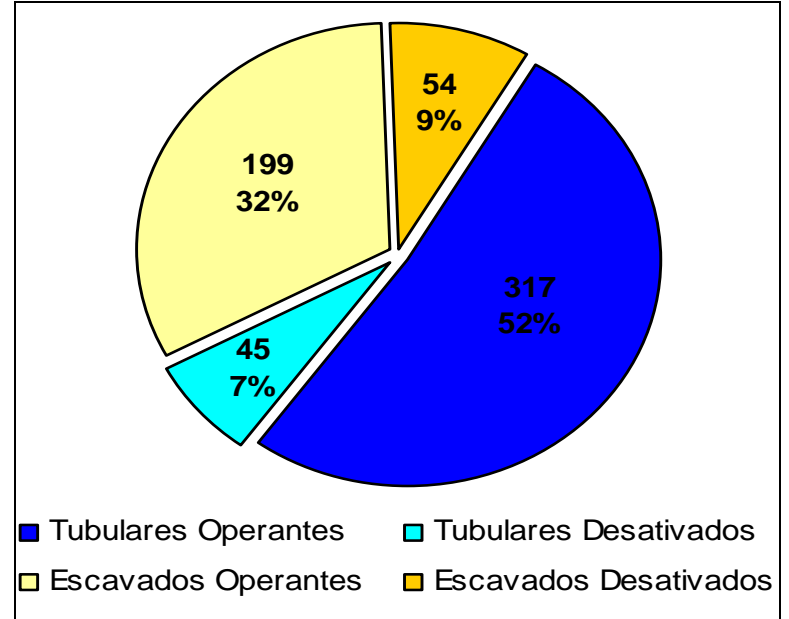

Figura 2. Tipologia e situação de uso dos poço: mapeados em Lajeado.

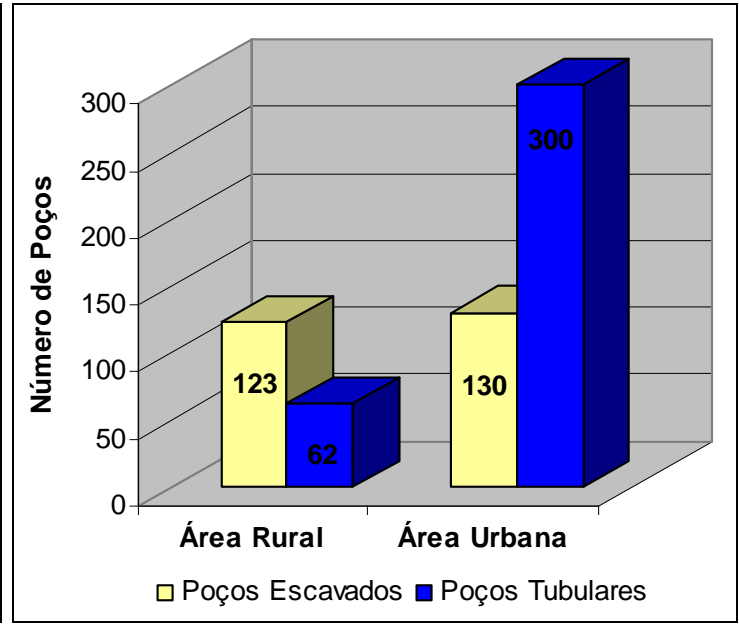

Figura 3. Distribuição dos poços levantados na área rural e urbana de Lajeado.

A Figura 4 apresenta a distribuição espacial dos poços tubulares e dos poços escavados operantes no município de Lajeado. A análise dessa figura permite constatar que os poços tubulares são utilizados prioritariamente na área urbana, enquanto os poços escavados ainda são utilizados intensamente nas áreas rurais. 
ECKHARDT, R. R.; DIEDRICH, V. L.; FERREIRA, E. R.; STROHSCHOEN, E.; DEMAMAN, L. C. Mapeamento e avaliação da potabilidade da água subterrânea do município de Lajeado, RS, Brasil. Ambi-Agua, Taubaté, v. 4, n. 1, p. 58-80, 2009. (doi:10.4136/ambi-agua.74)

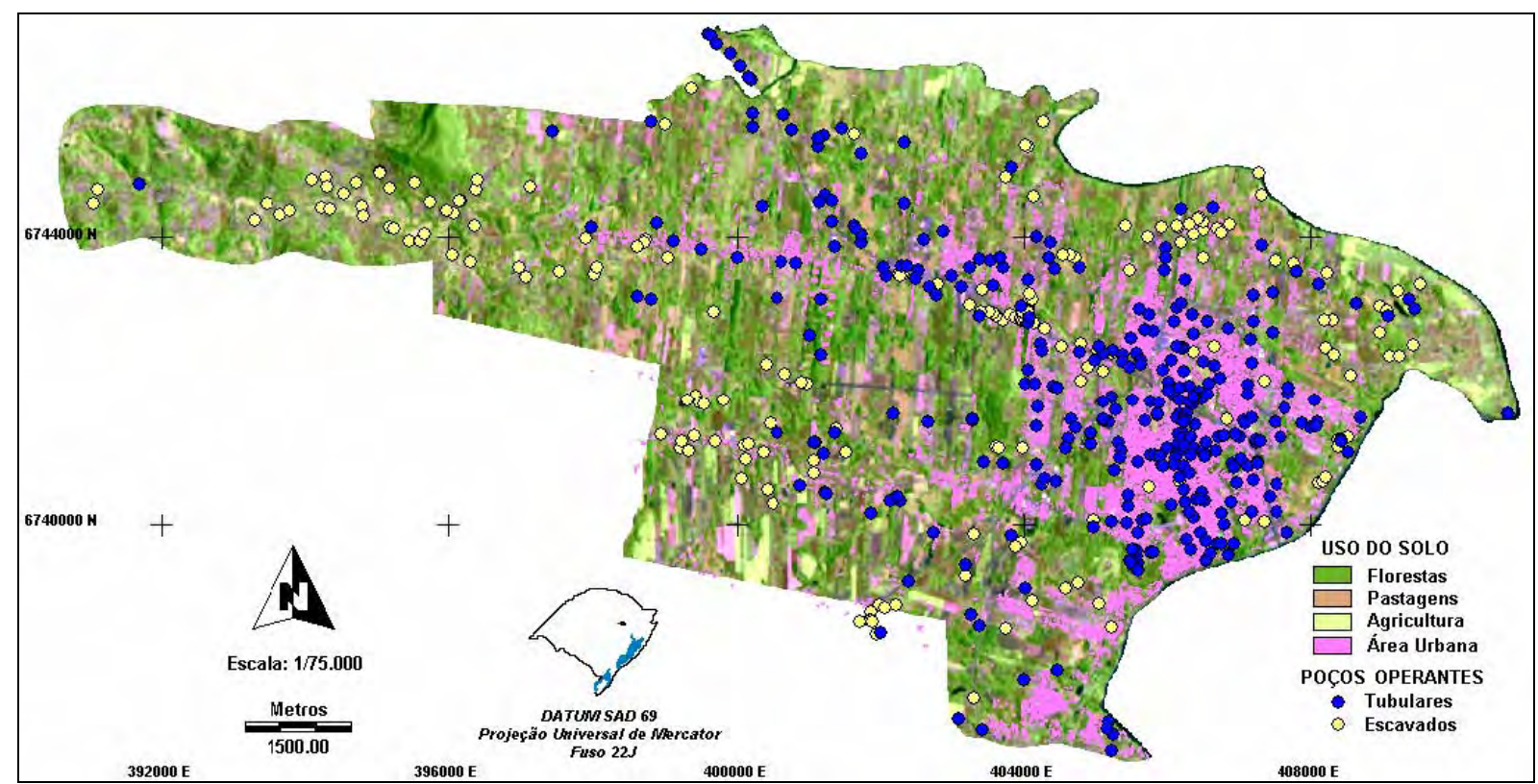

Figura 4. Localização dos poços ativos de captação de água subterrânea em Lajeado.

Em termos de consumo humano, de acordo com os dados informados pelos proprietários dos poços durante as atividades exploratórias de campo, os poços tubulares abastecem 25.797 habitantes, enquanto os poços escavados são utilizados por 670 habitantes. Em relação à população total do município de Lajeado, $29 \%$ da população correspondem aos consumidores de água subterrânea. Os 71\% restantes da população são abastecidos pela rede de distribuição de água tratada da CORSAN. A Figura 5 apresenta a finalidade de uso dos 516 poços ativos levantados no município de Lajeado, de acordo com os dados cadastrais informados pelos proprietários dos poços.

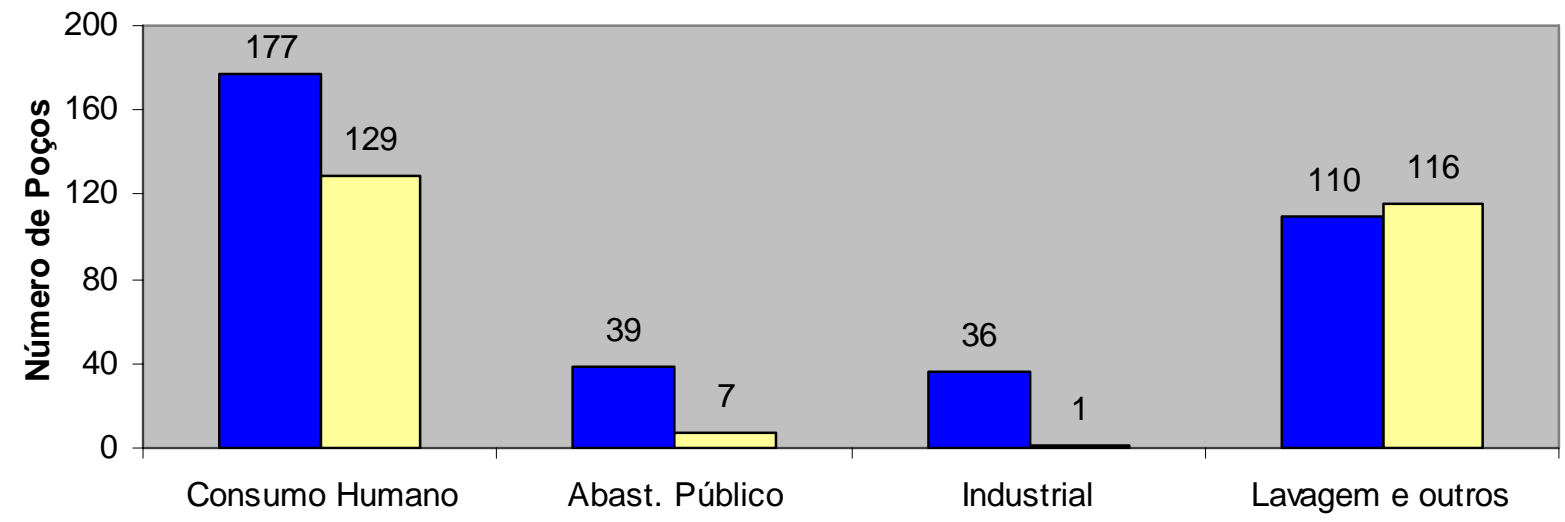

Finalidade de Uso

Poços Tubulares $\square$ Poços Escavados

Figura 5. Finalidade de uso da água subterrânea captada em Lajeado.

A análise da Figura 5 permite aferir que 59,30\% dos poços são utilizados para o consumo humano, 43,80\% são utilizados para usos diversos, como, por exemplo, lavagem de veículos, limpeza, dessedentação de animais, irrigação e piscicultura. Para abastecimento público são utilizados 8,91\% dos poços e 7,17\% ainda são utilizados em atividades industriais. Em virtude de alguns poços apresentarem mais de uma finalidade de uso, os percentuais de uso da água não totalizam 100\%. 
ECKHARDT, R. R.; DIEDRICH, V. L.; FERREIRA, E. R.; STROHSCHOEN, E.; DEMAMAN, L. C. Mapeamento e avaliação da potabilidade da água subterrânea do município de Lajeado, RS, Brasil. Ambi-Agua, Taubaté, v. 4, n. 1, p. 58-80, 2009. (doi:10.4136/ambi-agua.74)

\subsection{Avaliação físico-química e microbiológica}

Conforme descrito no capítulo dos materiais e métodos, foram amostrados 100 poços de captação de água subterrânea, sendo realizadas 78 coletas em poços tubulares e 22 coletas em poços escavados. A localização dos poços analisados está apresentada na Figura 6.

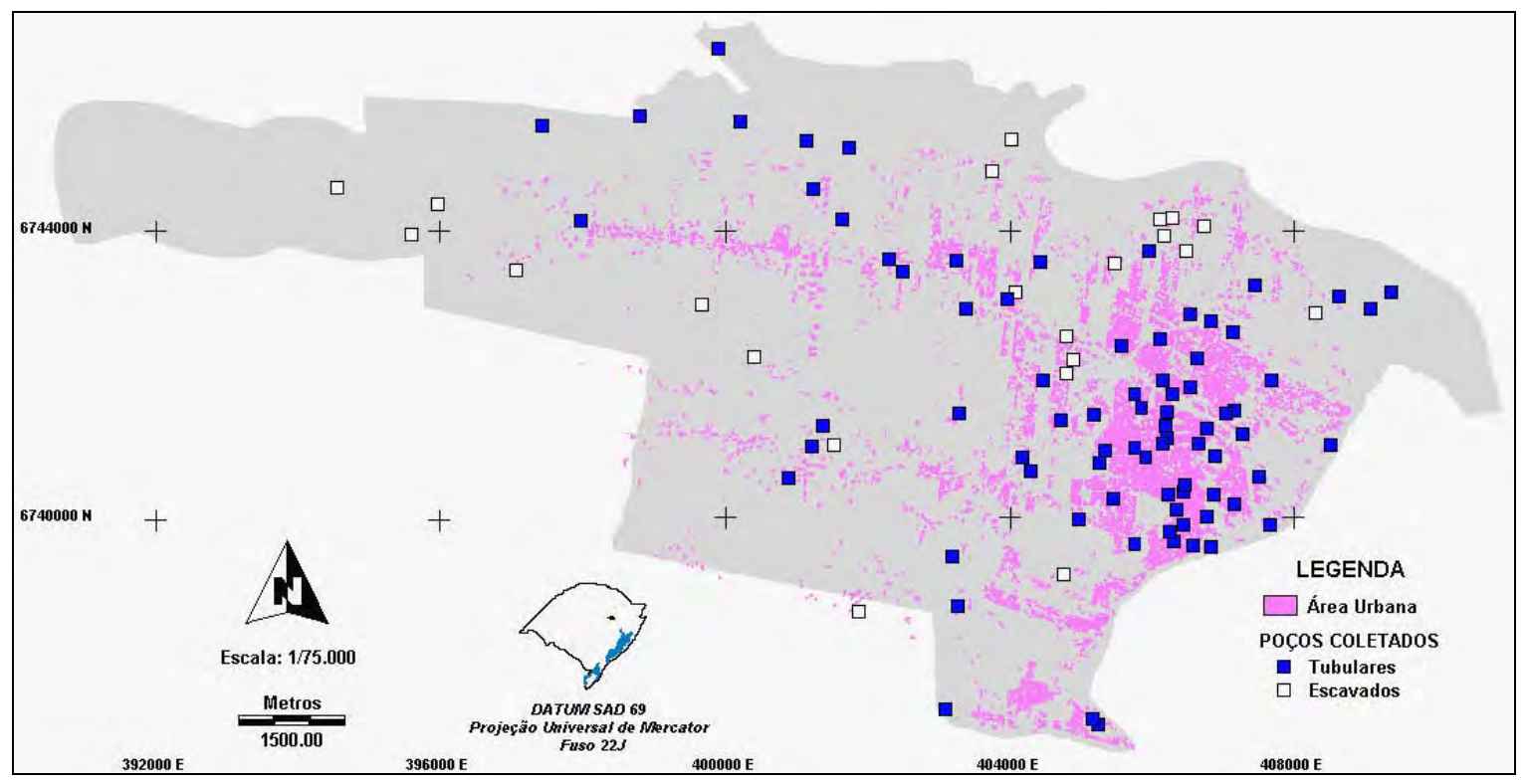

Figura 6. Poços amostrados para a realização das análises microbiológicas e físico-químicas.

A Tabela 1 apresenta o limite máximo permitido pela Portaria ${ }^{\circ} .518$ (Brasil, 2004) para os parâmetros analisados. Os poços que apresentam parâmetros dentro do limite estabelecido pela portaria apresentam água adequada ao consumo humano, sendo consideradas potáveis. Poços que apresentam água com parâmetros microbiológicos e físico-químicos além do limite máximo são considerados contaminados, não sendo adequados ao consumo humano.

Tabela 1. Valor máximo permitido pela Portaria nº 518 para os parâmetros analisados.

\begin{tabular}{ll}
\hline \multicolumn{1}{c}{ Parâmetro } & Valor Máximo Permitido \\
\hline Coliformes Fecais & Ausência em $100 \mathrm{ml}$ \\
Coliformes Totais & Ausência em 100ml \\
Contagem Total de Bactérias Heterotróficas* & $500 \mathrm{UFC} / \mathrm{ml}$ \\
pH & 6,0 a 9,5 \\
Fósforo Total & Sem valor definido \\
Dureza Total & $500 \mathrm{mg} / \mathrm{L}$ \\
Nitrogênio & Sem valor definido \\
Nitratos & $10 \mathrm{mg} / \mathrm{L}$ \\
Sulfatos & $250 \mathrm{mg} / \mathrm{L}$ \\
Teor de Chumbo & $0,01 \mathrm{mg} / \mathrm{L}$ \\
Teor de Cromo & $0,05 \mathrm{mg} / \mathrm{L}$ \\
Matéria Orgânica & Sem valor definido \\
\hline
\end{tabular}

* UFC - Unidade Formadora de Colônia.

Fonte: Brasil, 2004.

A Tabela 2 apresenta os parâmetros microbiológicos e físico-químicos analisados dos 78 poços tubulares. Os teores de chumbo e cromo não constam nessa tabela, pois nenhum poço apresentou concentração acima do limite de potabilidade. 
ECKHARDT, R. R.; DIEDRICH, V. L.; FERREIRA, E. R.; STROHSCHOEN, E.; DEMAMAN, L. C. Mapeamento e avaliação da potabilidade da água subterrânea do município de Lajeado, RS, Brasil. Ambi-Agua, Taubaté, v. 4, n. 1, p. 58-80, 2009. (doi:10.4136/ambi-agua.74)

Tabela 2. Resultados das análises microbiológicas e físico-químicas realizadas nos poços tubulares.

\begin{tabular}{|c|c|c|c|c|c|c|c|c|c|c|c|c|c|}
\hline Amostra & Leste & Norte & Prof. & pH & $\begin{array}{l}\text { Fosf. } \\
\text { Total }\end{array}$ & $\begin{array}{c}\text { Dureza } \\
\text { Total }\end{array}$ & $\mathbf{N}$ & Nitratos & $s$ Sulfatos & $\begin{array}{l}\text { Mat. } \\
\text { Org. }\end{array}$ & $\begin{array}{l}\text { Col. } \\
\text { Fecais }\end{array}$ & $\begin{array}{l}\text { Col. } \\
\text { Totais }\end{array}$ & $\begin{array}{l}\text { Cont. de } \\
\text { Bactérias }\end{array}$ \\
\hline 1 & 406642 & 6742217 & 157 & 6,20 & 0,23 & 96,8 & $<0,02$ & 0,052 & 0,99 & 0,2 & 0 & 0 & 0 \\
\hline 2 & 406536 & 6741815 & 65 & 6,50 & 0,34 & 111,8 & 0,82 & 0,039 & 0,99 & 0,6 & 0 & 0 & 70 \\
\hline 3 & 407041 & 6741440 & 122 & 7,10 & 0,35 & 101 & $<0,02$ & 0,039 & 0,99 & 0,3 & 0 & 0 & 0 \\
\hline 4 & 407277 & 6741153 & 134 & 6,40 & 0,41 & 90,3 & $<0,02$ & 0,039 & 0,99 & 0,3 & 0 & 0 & 0 \\
\hline 5 & 407154 & 6741476 & 118 & 8,80 & 0,41 & 66,7 & 0,25 & 0,046 & 0,99 & 0,4 & 0 & 0 & 0 \\
\hline 6 & 409356 & 6743131 & 82 & 7,00 & 0,57 & 73,1 & 0,96 & 0,061 & 1,18 & 0,9 & 0 & 0 & 180 \\
\hline 7 & 406291 & 6741716 & 42 & 6,80 & 0,74 & 70,95 & 1,32 & 0,039 & 0,99 & 1,02 & 0 & 0 & 220 \\
\hline 8 & 406540 & 6742831 & 50 & 7,00 & 0,23 & 25,8 & 0,82 & 0,039 & 0,99 & 0,6 & 0 & 0 & 80 \\
\hline 9 & 406123 & 6742477 & 26 & 6,60 & 0,52 & 60,2 & 0,9 & 0,048 & 0,99 & 0,3 & 0 & 0 & 90 \\
\hline 10 & 406153 & 6741912 & 60 & 7,40 & 0,42 & 55,9 & 1,49 & 0,092 & 0,99 & 1,43 & 0 & 0 & 350 \\
\hline 11 & 406826 & 6742741 & 9 & 6,30 & 0,28 & 53,75 & 0,9 & 0,042 & 0,99 & 0,8 & 0 & 0 & 200 \\
\hline 13 & 402493 & 6743429 & 128 & 6,30 & 0,48 & 25,8 & $<0,02$ & 0,508 & 0,99 & 0 & 0 & 0 & 0 \\
\hline $14^{*}$ & 402294 & 6743602 & 120 & 5,60 & 0,27 & 6,45 & $<0,02$ & 3,07 & 0,99 & 0 & 0 & 0 & 0 \\
\hline 15 & 400228 & 6745523 & - & 7,00 & 0,44 & 90,3 & $<0,02$ & 0,316 & 0,99 & 0 & 0 & 0 & 0 \\
\hline 16 & 397446 & 6745478 & 160 & 9,30 & 0,22 & 19,35 & 1,6 & 0,039 & 88,6 & 2,9 & 0 & 0 & 0 \\
\hline 17 & 397985 & 6744147 & 114 & 7,60 & 0,32 & 43 & $<0,02$ & 0,039 & 75,41 & 0,08 & 0 & 0 & 0 \\
\hline 18 & 408520 & 6741010 & 80 & 6,30 & 0,71 & 38,7 & $<0,02$ & 0,658 & 0,99 & 0 & 0 & 0 & 0 \\
\hline 19 & 409068 & 6742906 & 100 & 6,50 & 0,37 & 94,6 & 1,6 & 2,42 & 3,79 & 4,3 & 0 & 0 & 80 \\
\hline 20 & 407677 & 6741904 & - & 6,60 & 0,38 & 64,5 & 0,84 & 0,242 & 0,99 & 0,3 & 0 & 0 & 0 \\
\hline 21 & 408635 & 6743083 & 99 & 7,30 & 0,685 & 77,5 & 0,41 & 0,882 & 16,3 & 0,3 & 0 & 0 & 0 \\
\hline 22 & 406768 & 6740006 & 98 & 7,40 & 0,63 & 56,5 & 0,28 & 0,723 & 3 & 1,4 & 0 & 0 & 0 \\
\hline 23 & 406868 & 6740306 & 78 & 6,10 & 0,49 & 96 & 0,28 & 0,974 & 1,57 & 1,6 & 0 & 0 & 0 \\
\hline 24 & 407444 & 6743228 & - & 6,80 & 0,55 & 52,3 & 0,41 & 0,907 & 6,54 & 1,4 & 0 & 0 & 0 \\
\hline 25 & 400903 & 6740545 & 115 & 6,70 & 0,6 & 77,5 & 0,41 & 0,836 & 0,99 & 1,6 & 0 & 0 & 40 \\
\hline 26 & 401372 & 6741274 & 76 & 6,70 & 0,99 & 62,8 & 0,41 & 0,786 & 0,99 & 0,3 & 0 & 0 & 0 \\
\hline 27 & 401216 & 6740990 & - & 6,90 & 0,74 & 90 & 0,41 & 0,685 & 0,99 & 7,4 & 0 & 0 & 0 \\
\hline 28 & 403279 & 6741453 & - & 7,10 & 0,51 & 27,2 & 0,41 & 0,874 & 0,99 & 1,4 & 0 & 0 & 0 \\
\hline 39 & 405899 & 6740820 & 30 & 7,10 & 0,66 & 107 & 0,07 & 0,468 & 6,27 & 2 & 0 & 0 & 0 \\
\hline 40 & 406897 & 6740844 & 160 & 7,00 & 0,32 & 94,2 & 0,17 & 0,619 & 16,72 & 1,4 & 0 & 0 & 320 \\
\hline 41 & 407164 & 6740180 & 119 & 6,80 & 0,4 & 124 & 0,044 & 0,886 & 12,28 & 1,4 & 0 & 0 & 0 \\
\hline 42 & 406259 & 6739795 & 75 & 7,10 & 0,34 & 117 & 0,13 & 0,401 & 11,9 & 0,78 & 0 & 0 & 210 \\
\hline 43 & 406450 & 6740345 & 66 & 7,40 & 0,98 & 211 & 0,14 & 0,389 & 8,36 & 2 & 0 & 0 & 90 \\
\hline 44 & 406242 & 6740302 & 90 & 6,90 & 0,48 & 179,4 & 0,16 & 1,15 & 13,07 & 0,15 & 0 & 0 & 0 \\
\hline 45 & 406307 & 6739658 & 88 & 7,00 & 0,87 & 125,4 & 0,2 & 1,45 & 19,47 & 0 & 0 & 0 & 0 \\
\hline 46 & 406449 & 6739876 & - & 7,30 & 0,69 & 114,6 & 0,39 & 0,69 & 2,74 & 0 & 0 & 0 & 0 \\
\hline 47 & 406475 & 6740444 & 35 & 7,30 & 0,42 & 140,5 & 0,23 & 2,03 & 7,71 & 0,3 & 0 & 0 & 0 \\
\hline 48 & 406345 & 6740096 & 54 & 7,20 & 0,65 & 179,4 & 0,22 & 0,886 & 8,1 & 0 & 0 & 0 & 0 \\
\hline 49 & 407146 & 6742575 & - & 6,6 & 0,59 & 71,3 & 0,21 & 0,685 & 2,87 & 0 & 0 & 0 & 0 \\
\hline 50 & 406590 & 6739590 & 80 & 7,3 & 0,55 & 153,5 & 0,26 & 0,807 & 10,85 & 0 & 0 & 0 & 0 \\
\hline 51 & 405756 & 6741717 & 106 & 6,95 & 0,101 & 53,56 & 1,84 & 1,17 & 0,57 & 1,5 & 0 & 0 & 0 \\
\hline 52 & 405762 & 6740963 & 130 & 6,55 & 0,05 & 41,2 & 0,86 & 0,58 & 1,39 & 1,1 & 0 & 0 & 1,3 \\
\hline 53 & 406212 & 6741092 & 120 & 6,59 & 0,07 & 93,73 & 7,12 & 6,16 & 3,27 & 1,3 & 0 & 0 & 3,2 \\
\hline $54 *$ & 406195 & 6741266 & 32 & 6,10 & 0,09 & 72,1 & 9,4 & 8,12 & 27,9 & 1,1 & 23 & 23 & 1.400 \\
\hline 55 & 404968 & 6739969 & 100 & 6,58 & 0,12 & 97,85 & 5,68 & 4,66 & 12,75 & 1,1 & 0 & 0 & 2 \\
\hline 56 & 404164 & 6740819 & 122 & 6,51 & 0,06 & 72,1 & 3,24 & 2,22 & 0,72 & 0,91 & 0 & 0 & 2,3 \\
\hline 57 & 405169 & 6741417 & 110 & 6,4 & 0,21 & 86,52 & 5,68 & 4,82 & 2,9 & 0,9 & 0 & 0 & 2,1 \\
\hline
\end{tabular}


ECKHARDT, R. R.; DIEDRICH, V. L.; FERREIRA, E. R.; STROHSCHOEN, E.; DEMAMAN, L. C. Mapeamento e avaliação da potabilidade da água subterrânea do município de Lajeado, RS, Brasil. Ambi-Agua, Taubaté, v. 4, n. 1, p. 58-80, 2009. (doi:10.4136/ambi-agua.74)

Tabela 2. Resultados das análises microbiológicas e físico-químicas realizadas nos poços tubulares (Conclusão).

\begin{tabular}{|c|c|c|c|c|c|c|c|c|c|c|c|c|c|}
\hline Amostra & Leste & Norte & Prof. & pH & $\begin{array}{l}\text { Fosf. } \\
\text { Total }\end{array}$ & $\begin{array}{c}\text { Dureza } \\
\text { Total }\end{array}$ & $\mathbf{N}$ & Nitratos & Sulfatos & $\begin{array}{l}\text { Mat. } \\
\text { Org. }\end{array}$ & $\begin{array}{l}\text { Col. } \\
\text { Fecais }\end{array}$ & $\begin{array}{l}\text { Col. } \\
\text { Totais }\end{array}$ & $\begin{array}{l}\text { Cont. de } \\
\text { Bactérias }\end{array}$ \\
\hline 59 & 405971 & 6743717 & 59 & 6,01 & 0,02 & 60,77 & 2,24 & 1,00 & 0,76 & 1,1 & 0 & 0 & 8 \\
\hline $62 *$ & 405846 & 6741527 & 116 & 7,33 & 0,1 & 132,87 & 4,48 & 2,36 & 6,24 & 0,91 & 23 & 43 & 1,4 \\
\hline 63 & 405324 & 6740927 & 91 & 6,98 & 0,08 & 35,02 & 2,24 & 0,25 & 0,78 & 0,94 & 0 & 0 & 2 \\
\hline $64 *$ & 407667 & 6739881 & 120 & 7,05 & 0,12 & 143,17 & 1,68 & 3,15 & 81,6 & 0,81 & 0 & 0 & 880 \\
\hline 66 & 405564 & 6742380 & - & 6,63 & 0,08 & 51,84 & 5,08 & 4,92 & 0,23 & 1,1 & 0 & 0 & 9 \\
\hline $67 *$ & 404415 & 6743559 & 70 & 5,45 & 0,08 & 61,44 & 15,56 & 14,7 & 0,86 & 1,1 & 0 & 0 & 0 \\
\hline $68^{*}$ & 401743 & 6745155 & 120 & 5,84 & 0,08 & 44,16 & 1,12 & 8,7 & 1,48 & 1,1 & 0 & 0 & 380 \\
\hline 69 & 398816 & 6745597 & 80 & 6,87 & 0,1 & 75,8 & 6,28 & 5,2 & 3,38 & 1,2 & 0 & 0 & 270 \\
\hline $70^{*}$ & 399904 & 6746544 & 46 & 6,76 & 0,15 & 72 & 0,96 & 0,75 & 6,03 & 1,1 & 0 & 0 & 2.100 \\
\hline 72 & 405757 & 6739615 & 72 & 6,8 & 0,12 & 91,2 & 4,4 & 3,76 & 11,2 & 1,5 & 0 & 0 & 0 \\
\hline 73 & 403387 & 6742915 & 37 & 7,04 & 0,01 & 75,84 & 3,12 & 2,68 & 0,725 & 1,3 & 0 & 0 & 6 \\
\hline 74 & 403255 & 6743580 & 77 & 6,59 & 0,09 & 53,76 & 1,28 & 0,275 & 1,07 & 1,2 & 0 & 0 & 1 \\
\hline $75 *$ & 403183 & 6739440 & - & 9,73 & 0,012 & 19,2 & 0,28 & 0,168 & 43,6 & 1,1 & 0 & 0 & 8.400 \\
\hline 76 & 403259 & 6738751 & 107 & 6,75 & 0,01 & 93,12 & 0,56 & 4,39 & 3,13 & 1,05 & 0 & 0 & 2,2 \\
\hline 77 & 403963 & 6743044 & 50 & 6,03 & 0,02 & 20 & 3,92 & 0,438 & 0,824 & 1,3 & 0 & 0 & 2,1 \\
\hline $78 *$ & 405448 & 6740253 & 130 & 8,06 & 0,06 & 39,07 & 4,76 & 0,576 & 1,25 & 1,8 & 3,6 & 9,1 & 1,7 \\
\hline 79 & 406150 & 6741024 & 100 & 6,78 & 0,07 & 168,7 & 4,48 & 3,00 & 2,82 & 1,3 & 0 & 0 & 1 \\
\hline $82 *$ & 406656 & 6741016 & 125 & 7,05 & 0,08 & 125,7 & 2,24 & 1,50 & 17,58 & 1,5 & 23 & 23 & 1.400 \\
\hline $85^{*}$ & 401238 & 6744585 & 80 & 6,67 & 0,06 & 100 & 7,28 & 11,20 & 1,7 & 1,2 & 0 & 0 & 3 \\
\hline $86^{*}$ & 401141 & 6745263 & 90 & 6,32 & 0,12 & 70 & 5,6 & 1,03 & 2,11 & 1,1 & 240 & 2400 & 13.000 \\
\hline 87 & 401643 & 6744158 & 80 & 6,44 & 0,06 & 61,8 & 4,48 & 7,17 & 1,47 & 1,12 & 0 & 0 & 7 \\
\hline 88 & 404721 & 6741339 & 108 & 6,67 & 0,06 & 52,5 & 4,48 & 4,21 & 1,7 & 1,15 & 0 & 0 & 2 \\
\hline 89* & 406210 & 6741457 & 40 & 6,86 & 0,08 & 125 & 6,72 & 11,90 & 2,72 & 1,16 & 0 & 0 & 5.500 \\
\hline 90 & 404458 & 6741910 & 103 & 6,72 & 0,06 & 67 & 5,04 & 6,24 & 1,3 & 1,1 & 0 & 0 & 3,6 \\
\hline 91 & 406837 & 6739579 & 100 & 6,57 & 0,12 & 198 & 3,92 & 8,09 & 6,19 & 1,18 & 0 & 0 & 4,1 \\
\hline $92 *$ & 404294 & 6740642 & 62 & 6,61 & 0,06 & 76 & 4,48 & 13,70 & 1,68 & 1,17 & 0 & 0 & 0 \\
\hline 93 & 403084 & 6737292 & 80 & 6,78 & 0,1 & 217 & 5,04 & 8,47 & 8,1 & 1,13 & 0 & 0 & 6,1 \\
\hline $94 *$ & 407503 & 6740564 & 160 & 7,13 & 0,08 & 108 & 3,36 & 10,00 & 2,88 & 1,12 & 0 & 0 & 820 \\
\hline $95^{*}$ & 406774 & 6741240 & 120 & 7,43 & 0,12 & 49,4 & 4,2 & 2,50 & 24,4 & 1,2 & 0 & 0 & 500 \\
\hline 96 & 405226 & 6737096 & 26 & 6,91 & 0,16 & 51 & 3,64 & 9,50 & 6,42 & 1,2 & 0 & 0 & 7 \\
\hline 97 & 405246 & 6740743 & 100 & 6,53 & 0,08 & 60,8 & 1,12 & 0,53 & 3,27 & 1,1 & 0 & 0 & 0 \\
\hline $99 *$ & 405155 & 6737170 & 60 & 6,61 & 0,06 & 150 & 2,8 & 8,47 & 30,2 & 1,1 & 0 & 3,6 & 980 \\
\hline Média & - & - & 89,25 & 6,86 & 0,30 & 84,79 & 2,53 & 2,74 & 8,50 & 1,07 & 4,01 & 32,23 & 482,54 \\
\hline $\begin{array}{l}\text { Desvio } \\
\text { Padrão }\end{array}$ & - & - & 35,31 & 0,66 & 0,26 & 45,26 & 2,77 & 3,58 & 16,72 & 1,00 & 27,43 & 271,65 & $1.849,11$ \\
\hline
\end{tabular}

* Poços que apresentam parâmetros além do limite máximo permitido pela Portaria nº 518 (Brasil, 2004).

Dos 78 poços tubulares analisados, 4 poços apresentaram $\mathrm{pH}$ fora do limite de potabilidade e 5 poços apresentaram quantidade de nitratos superior ao limite máximo permitido pela Portaria $\mathrm{n}^{\circ}$. 518, de 2004. Porém, quando considerados os parâmetros microbiológicos, 12 poços, que correspondem a 15,38\% dos poços tubulares analisados, apresentaram coliformes fecais, coliformes totais ou contagem total de bactérias heterotróficas acima do limite tolerável. Considerando os parâmetros físico-químicos e microbiológicos, 23,08\% dos poços tubulares analisados não atendem aos padrões de potabilidade, não sendo adequadas ao consumo humano. 
Dos 78 poços tubulares amostrados para a realização das análises microbiológicas e físico-químicas, 76,92\% apresentam água potável, isto é, em condições adequadas ao consumo humano para os parâmetros analisados. A Tabela 3 apresenta os parâmetros microbiológicos e físico-químicos analisados dos 22 poços escavados.

Tabela 3. Resultados das análises microbiológicas e físico-químicas realizadas nos poços escavados.

\begin{tabular}{|c|c|c|c|c|c|c|c|c|c|c|c|c|c|}
\hline Amostra & $\mathbf{E}$ & $\mathbf{N}$ & Prof. & $\mathbf{p H}$ & $\begin{array}{l}\text { Fosf. } \\
\text { Total }\end{array}$ & $\begin{array}{c}\text { Dureza } \\
\text { Total }\end{array}$ & $\mathbf{N}$ & Nitratos & Sulfatos & $\begin{array}{l}\text { Mat. } \\
\text { Org. }\end{array}$ & $\begin{array}{c}\text { Col. } \\
\text { Fecais }\end{array}$ & $\begin{array}{c}\text { Col. } \\
\text { Totais }\end{array}$ & $\begin{array}{l}\text { Cont. de } \\
\text { Bactérias }\end{array}$ \\
\hline 12 & 406481 & 6743722 & 0,5 & 6,10 & 0,24 & 40,85 & 0,66 & 0,082 & 0,99 & 0,9 & 0 & 0 & 150 \\
\hline 29 & 406742 & 6744069 & 6,0 & 6,00 & 0,49 & 16,8 & 5,1 & 0,723 & 10,5 & 0,15 & 0 & 0 & 130 \\
\hline $30 *$ & 406179 & 6743934 & 2,0 & 6,00 & 0,73 & 16,8 & 0,38 & 0,343 & 0,99 & 0,62 & 0 & 16 & 1.100 \\
\hline $31 *$ & 406285 & 6744173 & 1,5 & 6,00 & 1,61 & 52,4 & 0,026 & & 3,14 & 0,78 & 2,2 & 16 & 1.250 \\
\hline $32 *$ & 408309 & 6742841 & 2,0 & 5,80 & 0,58 & 25,1 & 0,1 & 0,727 & 16,1 & 0 & 5,1 & 16 & 1.300 \\
\hline $33 *$ & 399679 & 6742960 & 2,5 & 6,30 & 2,82 & 35,6 & 0,17 & 0,89 & 10,2 & 0,31 & 16 & 16 & 1.750 \\
\hline $34^{*}$ & 395978 & 6744381 & 1,0 & 6,50 & 0,51 & 43,9 & 1,15 & 0,648 & 7,18 & 0,31 & 16 & 16 & 1.600 \\
\hline 35 & 395609 & 6743947 & 1,5 & 6,80 & 1,18 & 119 & 0,45 & 0,347 & 15,7 & 0,31 & 0 & 0 & 30 \\
\hline $36 *$ & 397082 & 6743452 & 2,0 & 6,70 & 0,37 & 52,4 & 0,51 & 0,464 & 12,9 & 0,78 & 5,1 & 16 & 1.450 \\
\hline 37 & 401528 & 6740997 & 5,0 & 6,30 & 2,1 & 41,9 & 0,29 & 0,894 & 00 & 0,31 & 0 & 0 & 0 \\
\hline $38 *$ & 400421 & 6742236 & 10,0 & 5,80 & 0,91 & 29,3 & 0,56 & 0,84 & 18,4 & 0,31 & 0 & 0 & 40 \\
\hline $58 *$ & 405456 & 6743547 & 8,0 & 4,01 & 0,01 & 15,45 & 3,36 & 2,25 & 0,33 & 1,1 & 93 & 240 & 1.600 \\
\hline $60 *$ & 404067 & 6743143 & 6,0 & 5,00 & 0,04 & 34 & 7,4 & 6,86 & 4,51 & 1,04 & 43 & 240 & 3.300 \\
\hline $61 *$ & & 6739191 & 3,0 & & 0,1 & 48,41 & 1,96 & & 0,884 & 0,604 & 240 & 240 & 880 \\
\hline $65^{*}$ & 406112 & 6744166 & 7,4 & 6,59 & 0,1 & 88,32 & 5,28 & & 1,05 & 1,3 & 240 & 240 & 7.900 \\
\hline $71 *$ & 404894 & 6742192 & 4,0 & 6,18 & 0,08 & 65,3 & 5,12 & 4,88 & 1,59 & 1,1 & 1.100 & 2.400 & 1.500 \\
\hline $80 *$ & 404016 & 6745278 & 2,5 & 7,47 & 0,04 & 72,4 & 2,8 & 0,794 & 3,1 & 1,6 & 9,5 & 2.400 & 1.300 \\
\hline $81 *$ & 40374 & 6744827 & 3,0 & 6,47 & 0,03 & 95,3 & 3,36 & 2,68 & 3,51 & 1,5 & 3,6 & 43 & 1.100 \\
\hline $83 *$ & 404787 & 6742006 & 7,0 & 5,71 & 0,06 & 88,7 & 3,08 & 1,6 & 2,8 & 1,6 & 93 & 460 & 1.600 \\
\hline $84 *$ & 404786 & 6742530 & 4,5 & 6,00 & 0,08 & 60 & 2,28 & 1,35 & 1,02 & 1,3 & 43 & 460 & 1.900 \\
\hline $98 *$ & 401870 & 6738674 & 1,0 & 5,70 & 0,04 & 86,5 & 2,52 & 5,35 & 3,16 & 1,12 & 0 & 23 & 2.300 \\
\hline $100 *$ & 394550 & 6744596 & 2,0 & 7,10 & 0,05 & 65,9 & 0,28 & 4,78 & 3,34 & 1,15 & 1.100 & 1.100 & 3.700 \\
\hline Média & - & - & 3,75 & 6,12 & 0,55 & 54,29 & 2,13 & 1,92 & 5,96 & 0,83 & 136,80 & 361,00 & $1.630,91$ \\
\hline $\begin{array}{c}\text { Desvio } \\
\text { Padrão }\end{array}$ & - & - & 2,63 & 0,71 & 0,76 & 28,37 & 2,11 & 2,00 & b,69 & 0,49 & 319,61 & 707,80 & $1.699,39$ \\
\hline
\end{tabular}

* Poços que apresentam parâmetros além do limite máximo permitido pela Portaria nº. 518 (Brasil, 2004).

Em relação aos 22 poços escavados analisados, 6 poços apresentaram $\mathrm{pH}$ inferior ao limite de potabilidade estabelecido pela Portaria $n^{\circ}$. 518, de 2004, No que se refere aos parâmetros microbiológicos, 17 poços $(77,27 \%)$ apresentaram coliformes fecais, coliformes totais ou contagem total de bactérias heterotróficas superiores aos limites permitidos, não sendo adequados ao consumo humano. A Figura 7 apresenta a localização dos poços tubulares e escavados contaminados em Lajeado para os parâmetros analisados.

As profundidades dos poços tubulares em Lajeado mostraram-se bastante heterogêneas. Essa característica tem como motivos as limitações econômicas do contratante da obra, maior ou menor necessidade de água e as características litológicas e tectônicas do local de perfuração. Os resultados indicaram que a profundidade média dos poços é de 89,17 m, valor semelhante à profundidade média dos poços tubulares analisados. O poço mais profundo no município apresenta 207 m e capta água do Aquífero Guarani. Porém existem poços tubulares que estão localizados próximos à superfície, com profundidade da ordem de $10 \mathrm{~m}$ e que captam água de fraturas do Aqüífero Serra Geral. 
ECKHARDT, R. R.; DIEDRICH, V. L.; FERREIRA, E. R.; STROHSCHOEN, E.; DEMAMAN, L. C. Mapeamento e avaliação da potabilidade da água subterrânea do município de Lajeado, RS, Brasil. Ambi-Agua, Taubaté, v. 4, n. 1, p. 58-80, 2009. (doi:10.4136/ambi-agua.74)

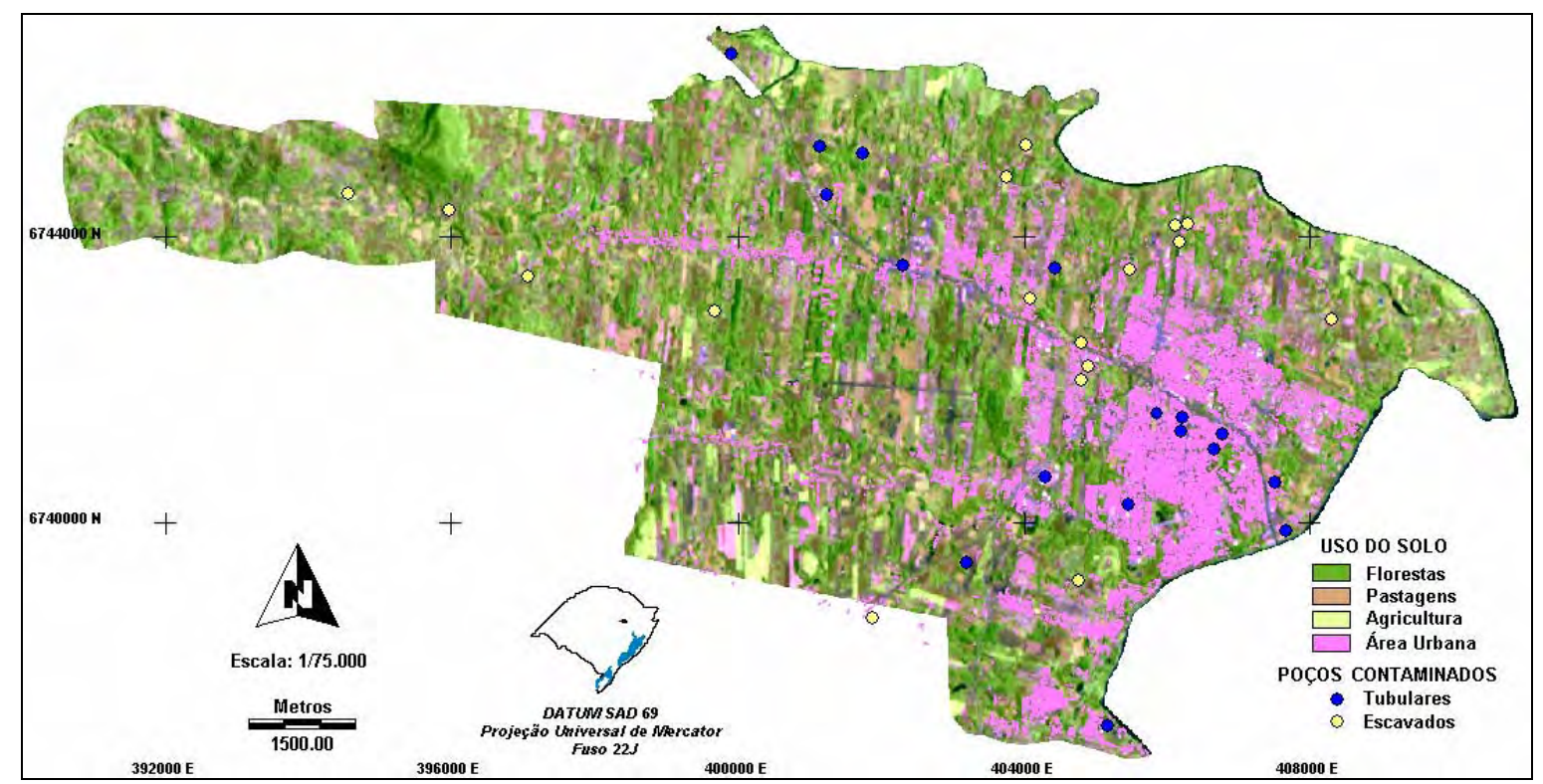

Figura 7. Localização dos poços escavados e tubulares analisados e contaminados em Lajeado.

A vazão dos poços tubulares de Lajeado também apresentou valores heterogêneos. A maior vazão informada pelos proprietários dos poços foi de $80 \mathrm{~m}^{3} / \mathrm{h}$ em um poço com $103 \mathrm{~m}$ de profundidade. Os resultados obtidos pelas atividades exploratórias de campo indicaram que $14,53 \%$ dos poços tubulares operantes apresentam vazão de até $1 \mathrm{~m}^{3} / \mathrm{h}, 35,90 \%$ apresentam vazão de 1 a $10 \mathrm{~m}^{3} / \mathrm{h}$ e 35,04\% apresentam vazão superior a $10 \mathrm{~m}^{3} / \mathrm{h}$ (Figura 8). A vazão média dos poços tubulares do município foi de $10,12 \mathrm{~m}^{3} / \mathrm{h}$ e desvio padrão de 10,81 $\mathrm{m}^{3} / \mathrm{h}$, confirmando que a região de Lajeado tem um bom potencial de produção de água subterrânea.

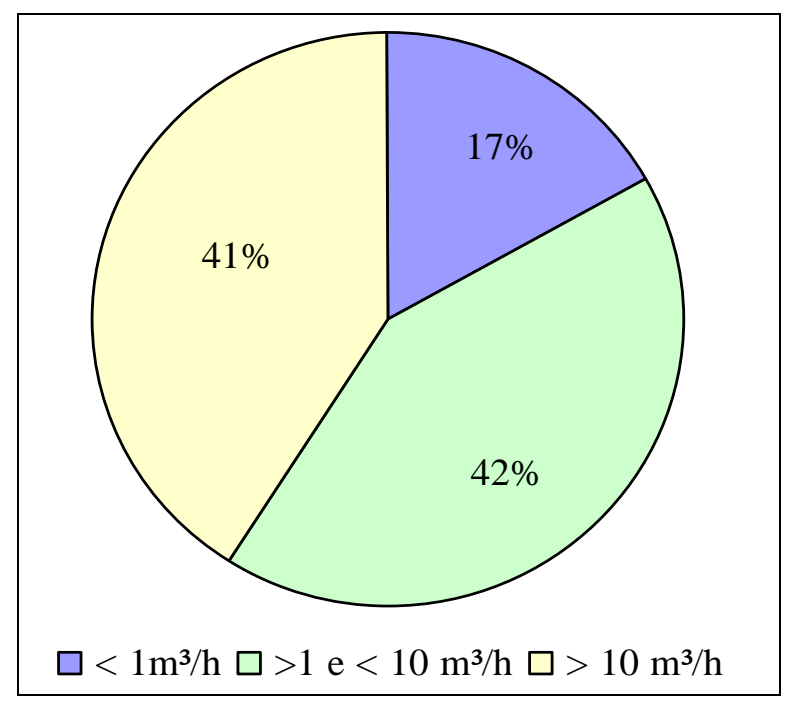

Figura 8. Vazão dos poços tubulares de Lajeado. 
ECKHARDT, R. R.; DIEDRICH, V. L.; FERREIRA, E. R.; STROHSCHOEN, E.; DEMAMAN, L. C. Mapeamento e avaliação da potabilidade da água subterrânea do município de Lajeado, RS, Brasil. Ambi-Agua, Taubaté, v. 4, n. 1, p. 58-80, 2009. (doi:10.4136/ambi-agua.74)

\subsection{Tratamento estatístico dos parâmetros analisados}

Em virtude de terem sido analisados somente 22 poços escavados, amostragem estatisticamente não significativa em relação ao total de poços escavados operantes, optou-se por não realizar nenhum tipo de tratamento estatístico com os resultados das análises microbiológicas e físico-químicas desses poços. Além disso, em virtude de captarem água dos aquíferos em profundidades e condições diferentes os tratamentos estatísticos teriam que ser realizados de forma individualizada para cada sistema de captação. Por esses motivos serão tratados estatisticamente somente os parâmetros analisados nos poços tubulares. Na sequência são apresentados os mapas com as curvas de isoteores de $\mathrm{pH}$, dureza total, nitratos, sulfatos, coliformes fecais, coliformes totais e contagem total de bactérias dos poços tubulares.

\subsection{1. pH}

$\mathrm{O}$ pH dos poços tubulares variou de 5,45 a 9,73, sendo que as amostras 14, 67, 68 e 75 apresentaram valores além do limite máximo recomendado pela Portaria $n^{\circ}$. 518 . Os valores mais baixos de $\mathrm{pH}$ estão localizados no entorno do Rio Forqueta e do Rio Taquari, provavelmente devido a maior proximidade das áreas de recarga e menor tempo de residência no aquífero, enquanto os maiores valores de $\mathrm{pH}$ são distribuídos de forma irregular no município (Figura 9). O pH dos poços escavados varia de 4,01 a 7,47, apresentando valores ligeiramente inferiores em comparação aos poços tubulares.

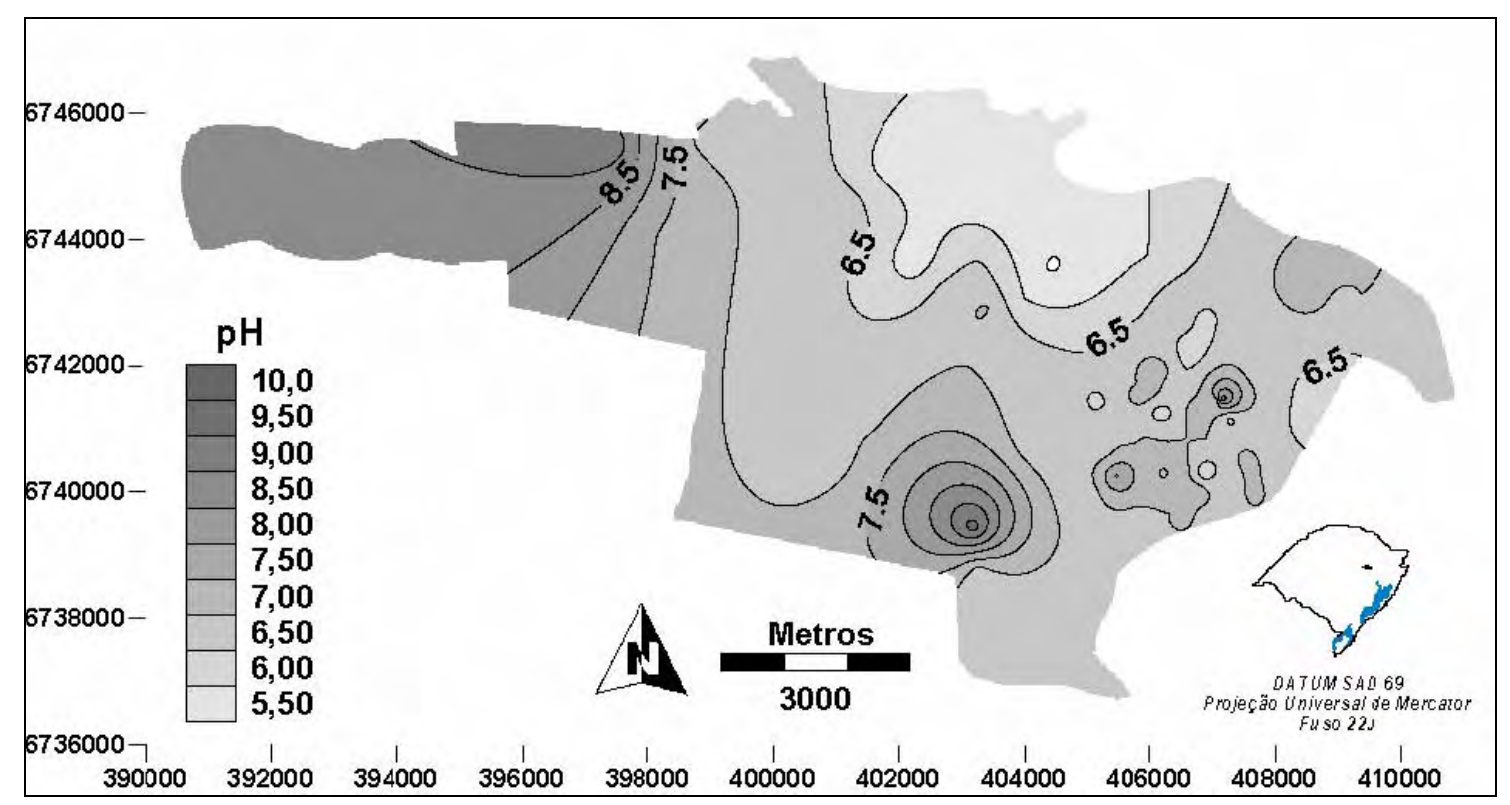

Figura 9. Curvas de isovalores de $\mathrm{pH}$ dos poços tubulares.

\subsubsection{Dureza Total}

Os teores de dureza total dos poços tubulares analisados variaram de 6,45 a $217 \mathrm{mg} / \mathrm{L} \mathrm{em}$ Lajeado, sendo semelhantes aos valores medidos por Souza et al. (2002). Esse intervalo de valores não excede o limite máximo permitido pela Portaria $n^{\circ}$. 518. Os maiores valores de dureza são encontrados no centro da cidade de Lajeado a ao sul do município, onde afloram os arenitos intertrápicos da Formação Botucatu (Figura 10). De acordo com Souza et al. (2002), os maiores valores de dureza total, encontrados no centro da cidade de Lajeado, podem ser considerados anômalos, estando relacionados com mineralizações secundárias nos falhamentos da Formação Serra Geral. Os poços escavados apresentaram valores de dureza de 15,45 a $119 \mathrm{mg} / \mathrm{L}$, também dentro do limite de potabilidade. 
ECKHARDT, R. R.; DIEDRICH, V. L.; FERREIRA, E. R.; STROHSCHOEN, E.; DEMAMAN, L. C. Mapeamento e avaliação da potabilidade da água subterrânea do município de Lajeado, RS, Brasil. Ambi-Agua, Taubaté, v. 4, n. 1, p. 58-80, 2009. (doi:10.4136/ambi-agua.74)

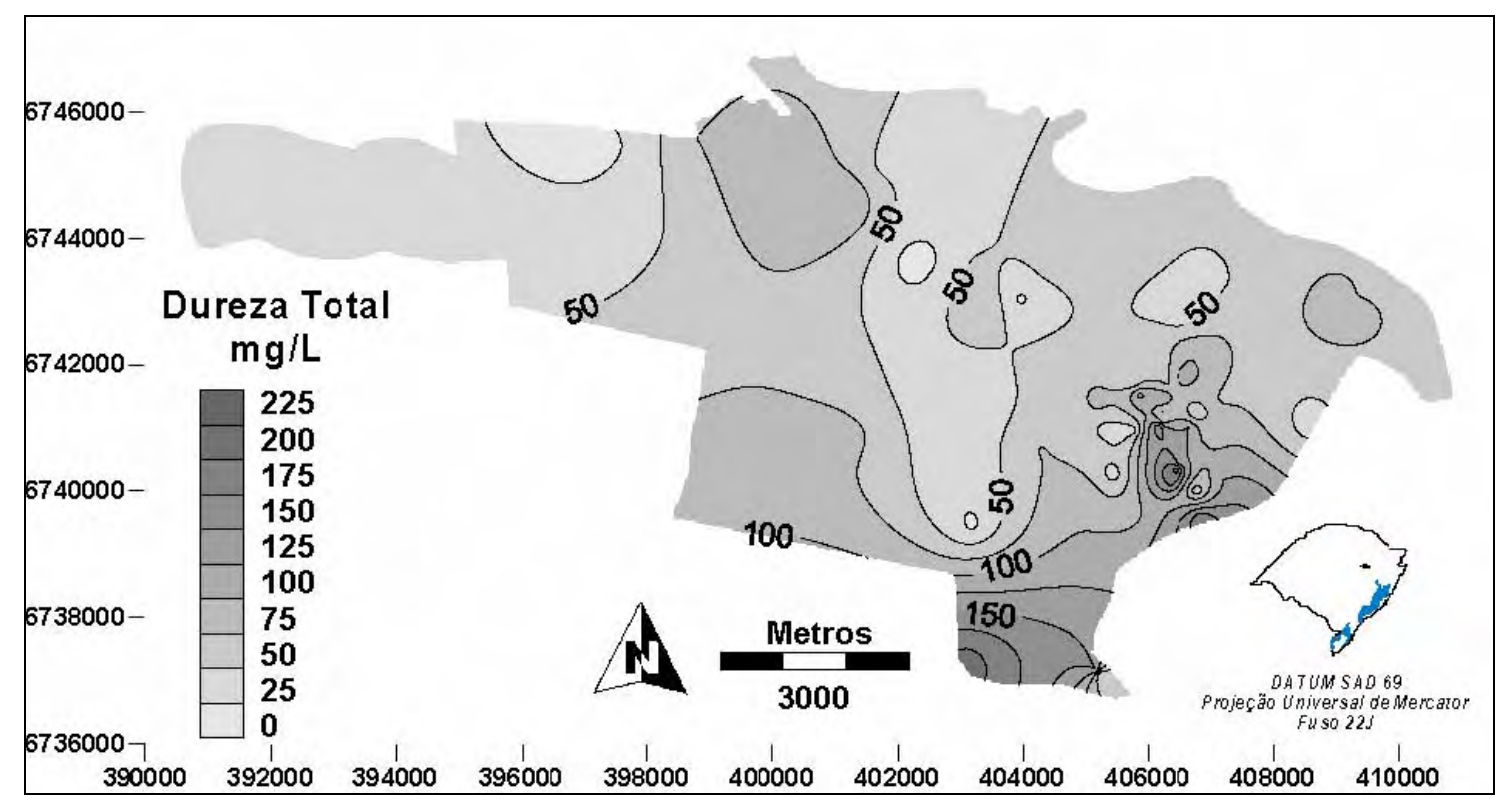

Figura 10. Curvas de isoteores de dureza total dos poços tubulares.

\subsubsection{Nitratos}

As concentrações de nitratos dos poços tubulares apresentaram valores de 0,039 a 14,7 $\mathrm{mg} / \mathrm{L}$, sendo que concentrações acima de $10 \mathrm{mg} / \mathrm{L}$ estão acima do limite de potabilidade. De acordo com Foster e Hirata (1993), o nitrato é o constituinte inorgânico mais problemático, devido a sua ampla distribuição, grande mobilidade em sub-superfície, estabilidade em sistemas aeróbios de águas subterrâneas e risco à saúde humana, principalmente em crianças e em idosos. As áreas que apresentam as maiores concentrações de nitratos estão localizadas ao norte do município, em áreas ainda caracteristicamente rurais (Figura 11). No que se refere aos poços escavados, estes apresentam valores de nitratos dentro dos limites aceitáveis de potabilidade, variando de 0,082 a 6,86 mg/L.

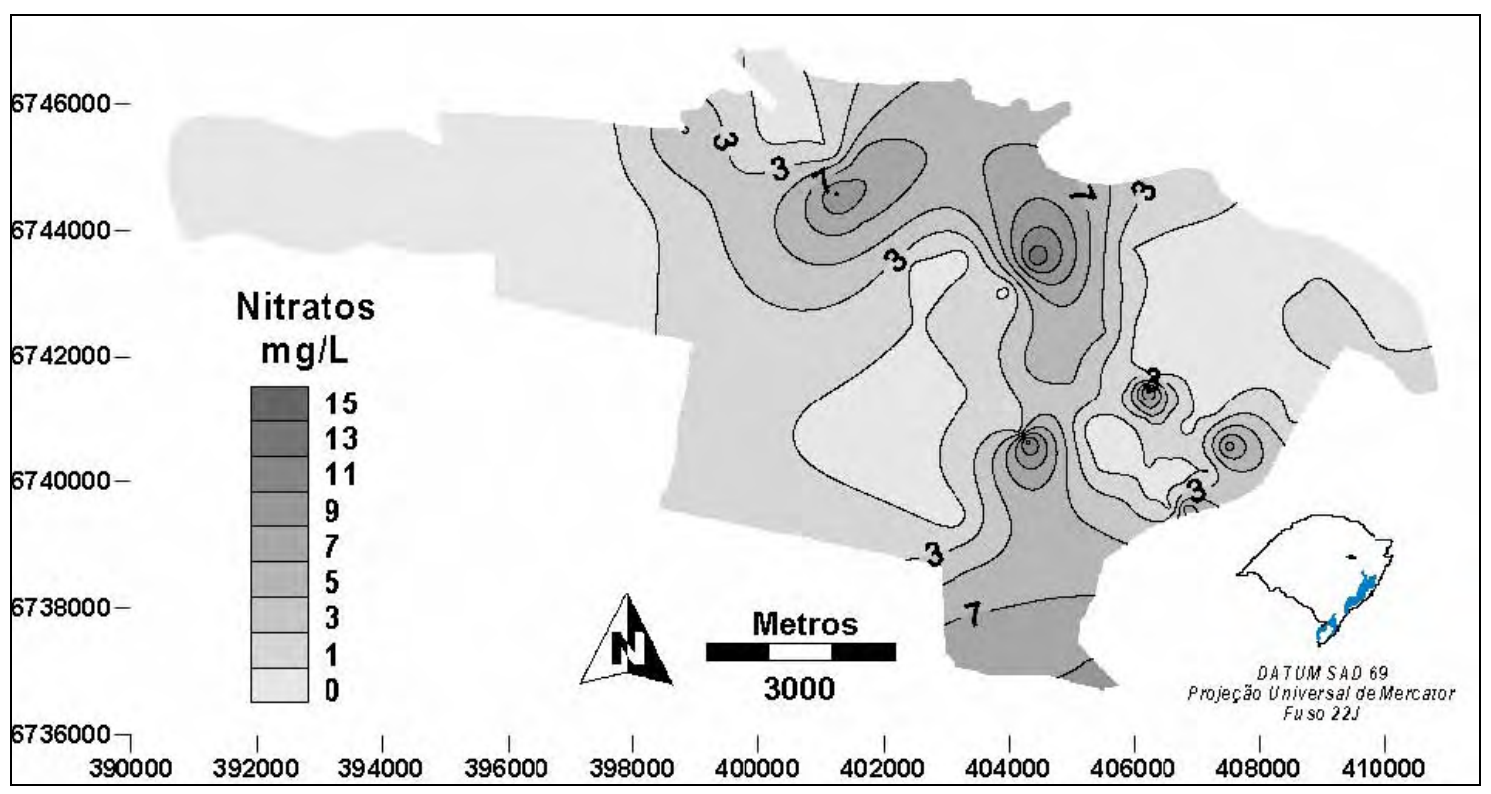

Figura 11. Curvas de isoteores de nitratos dos poços tubulares. 


\subsubsection{Sulfatos}

Os níveis de sulfatos em todos os poços tubulares e escavados analisados estão dentro dos limites de potabilidade. Nos poços tubulares variaram de 0,23 a 88,6 mg/L e nos poços escavados variaram de 0,33 a 18,4 $\mathrm{mg} / \mathrm{L}$. As maiores concentrações de sulfatos estão localizados no oeste do município (Figura 12), em áreas agropecuárias e sua origem está relacionada com causas naturais, como a interação rocha-água.

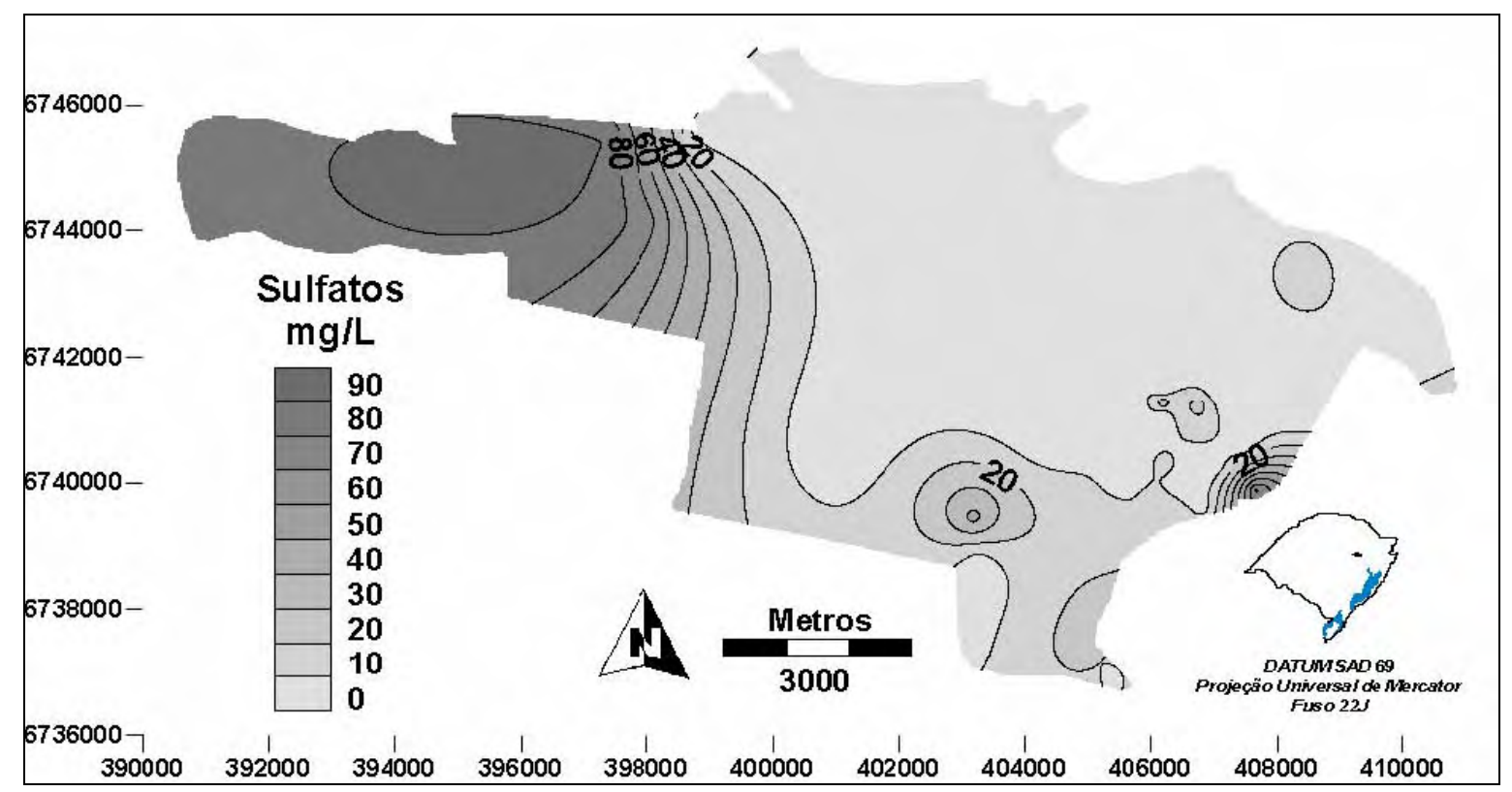

Figura 12. Curvas de isoteores de sulfatos dos poços tubulares.

Além dos parâmetros físico-químicos acima abordados, ainda foram analisados o teor de chumbo, o teor de cromo e a matéria orgânica. Tanto nos poços tubulares como nos poços escavados não foram detectados teores de chumbo e cromo acima do limite de potabilidade. Para a matéria orgânica também não se registraram valores anômalos, de modo que esses três parâmetros estão dentro dos limites de potabilidade.

\subsubsection{Coliformes fecais, coliformes totais e contagem total de bactérias heterotróficas}

As Figuras 13, 14 e 15 apresentam os mapas com as curvas de isovalores dos coliformes fecais, dos coliformes totais e contagem total de bactérias heterotróficas organizados com base nos resultados das análises microbiológicas dos poços tubulares de Lajeado. Como era esperado, esses três parâmetros apresentaram estreita associação espacial. Valores acima do limite de potabilidade foram medidos em 12 poços tubulares (de 78 analisados), localizados no centro da cidade de Lajeado e na confluência entre o Arroio Forquetinha e o Rio Forqueta. Níveis elevados de bactérias heterotróficas ainda ocorrem ao sul do município, próximo ao acesso do município de Cruzeiro do Sul. 
ECKHARDT, R. R.; DIEDRICH, V. L.; FERREIRA, E. R.; STROHSCHOEN, E.; DEMAMAN, L. C. Mapeamento e avaliação da potabilidade da água subterrânea do município de Lajeado, RS, Brasil. Ambi-Agua, Taubaté, v. 4, n. 1, p. 58-80, 2009. (doi:10.4136/ambi-agua.74)

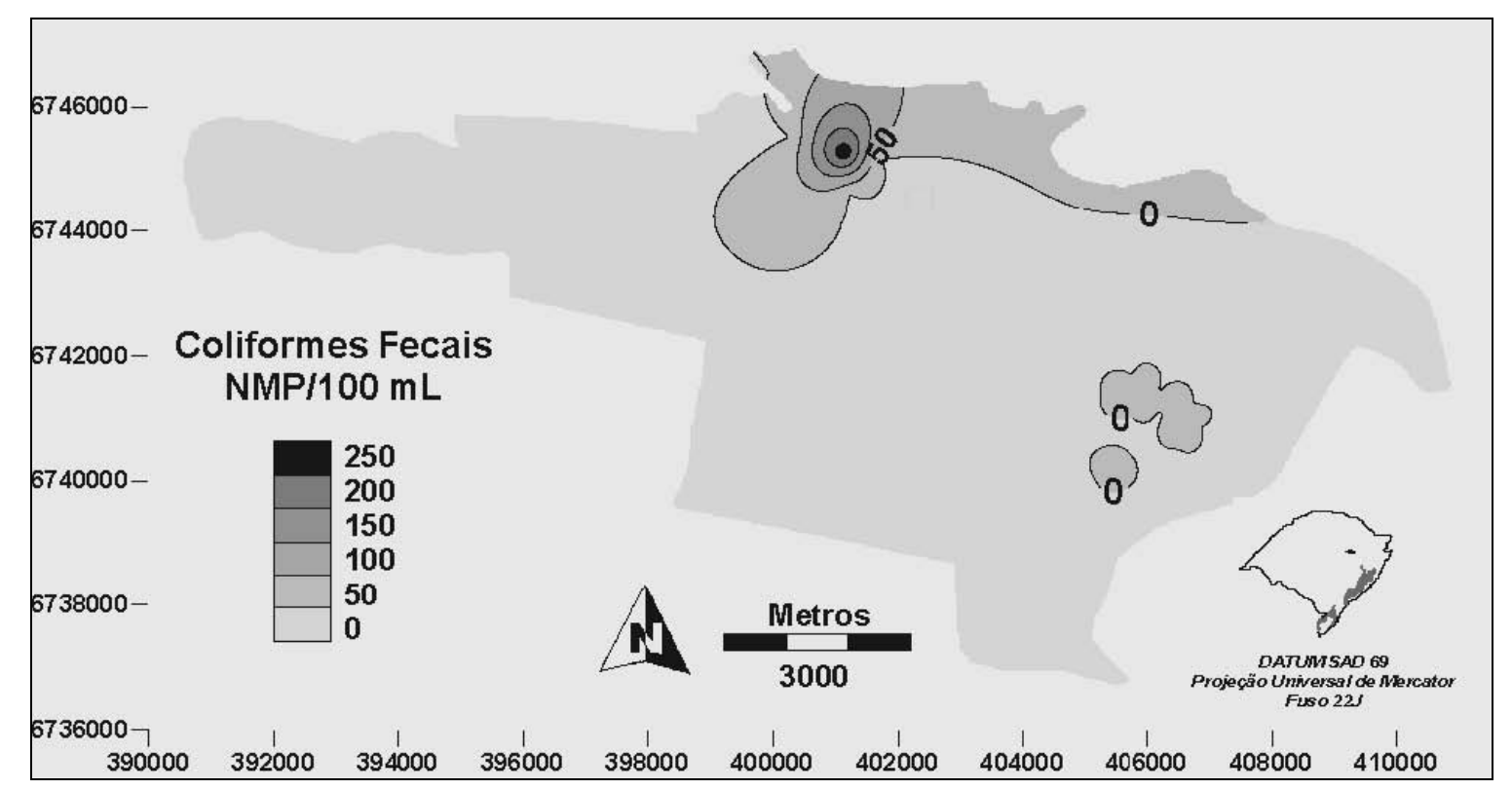

Figura 13. Curvas de isovalores de coliformes fecais dos poços tubulares.

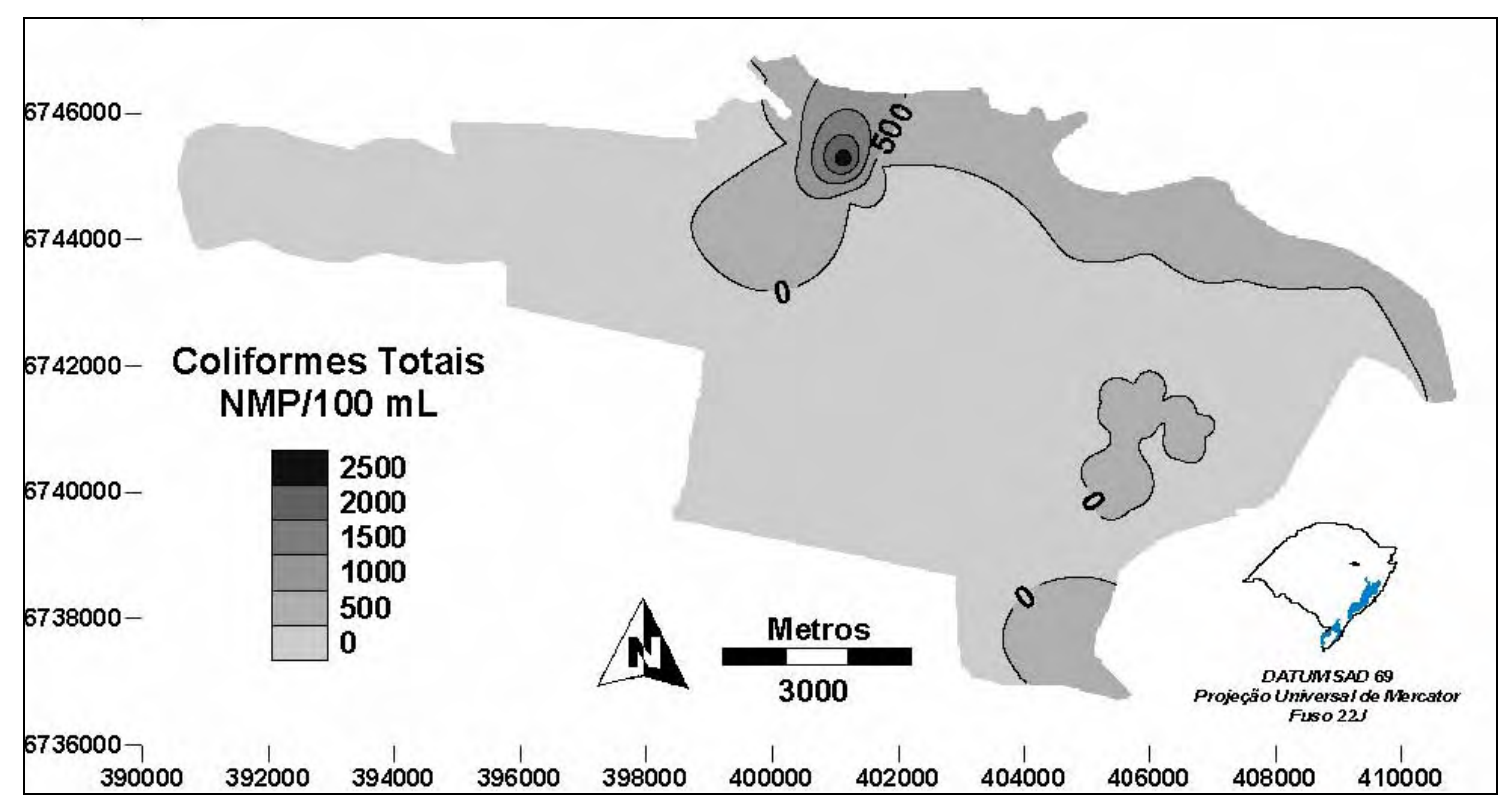

Figura 14. Curvas de isovalores de coliformes totais dos poços tubulares. 
ECKHARDT, R. R.; DIEDRICH, V. L.; FERREIRA, E. R.; STROHSCHOEN, E.; DEMAMAN, L. C. Mapeamento e avaliação da potabilidade da água subterrânea do município de Lajeado, RS, Brasil. Ambi-Agua, Taubaté, v. 4, n. 1, p. 58-80, 2009. (doi:10.4136/ambi-agua.74)

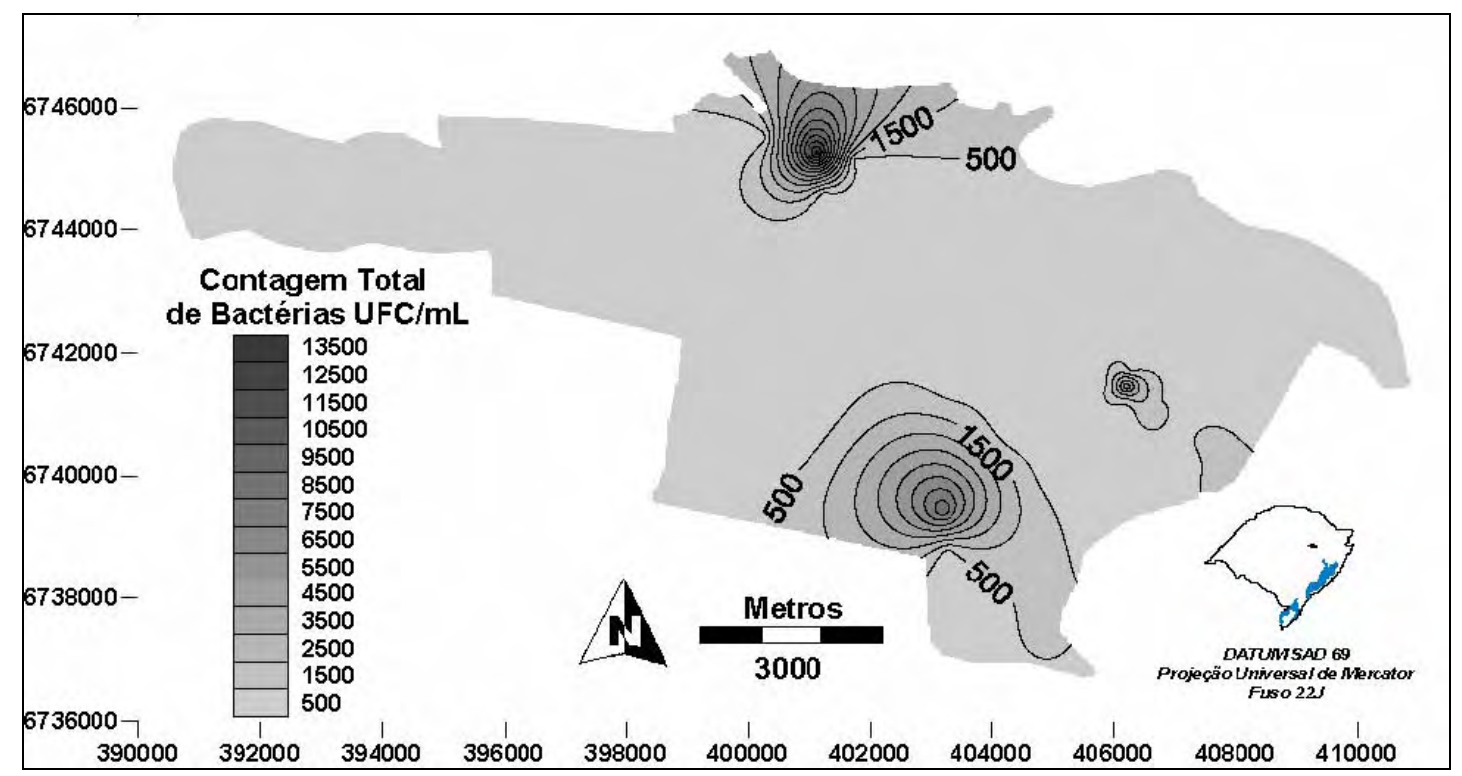

Figura 15. Curvas de isovalores de contagem total de bactérias heterotróficas dos poços tubulares.

Não foram identificadas razões suficientes para explicar a presença desses três parâmetros nos poços contaminados. As evidências indicam que existe forte contribuição dos usos antrópicos no entorno dos poços, expressos pelas áreas agrícolas e áreas urbanas, mas a contaminação microbiológica da água desses poços é potencializada por problemas construtivos. Inclusive, diversos poços tubulares operantes estão localizados em áreas de acúmulo de dejetos de suínos e bovinos, em áreas agrícolas em que ocorre fertilização com dejetos animais ou com adubação química, em áreas de enchentes e ainda em áreas sem saneamento ambiental. Qualquer problema construtivo que determinado poço tubular possa ter potencializa a contaminação da água subterrânea.

Com relação aos poços escavados, dos 22 analisados, 17 poços apresentam níveis de coliformes fecais, coliformes totais ou contagem total de bactérias heterotróficas acima do permitido para o consumo humano, estando contaminadas. A ausência de medidas sanitárias de vedação e de proteção dos poços escavados facilita a contaminação dessas águas, principalmente pelos materiais orgânicos e agentes microbiológicos. Estima-se que a grande maioria dos poços escavados, ainda em operação, não apresentam água adequado ao consumo humano.

\section{CONCLUSÕES}

Os resultados apresentados neste artigo visaram caracterizar a dimensão do consumo de água subterrânea no município de Lajeado e mensurar o estado de potabilidade dessas águas. Ressalta-se que o mapeamento dos pontos de captação de água subterrânea, a caracterização ambiental de entorno e a realização de análises microbiológicas e físico-químicas permitiram traçar um panorama geral das águas subterrâneas no município de Lajeado.

Por estar situado na borda do Aquífero Guarani e sob espessuras relativamente pequenas dos basaltos da Formação Serra Geral, as águas subterrâneas do município de Lajeado apresentam, em geral, ótima qualidade natural, não apresentando restrições de uso. Esta característica foi comprovada pelas análises físico-químicas realizadas. Além disso, os dados de vazão dos poços atualmente em operação indicam que o município apresenta alto potencial de explotação de água subterrânea. 
Ao mesmo tempo, os 15,38\% dos poços tubulares que apresentam parâmetros microbiológicos acima do limite de potabilidade indicam que existem ameaças antrópicas reais que podem afetar a qualidade das águas subterrâneas. Os usos antrópicos elevam o potencial de contaminação da água subterrânea na medida em que novos poços de captação de água subterrânea forem perfurados e sem que métodos adequados de controle sejam estabelecidos.

Quando essa análise é feita para os poços escavados, as preocupações são ainda maiores. Os resultados apontaram que $77,27 \%$ dos poços escavados analisados apresentam coliformes fecais, coliformes totais ou contagem de bactérias heterotróficas com valores muito acima do limite de potabilidade. A situação é agravada quando a água desses poços é utilizada como única fonte de água para o consumo humano, circunstância que ainda persiste na área rural do município.

Os resultados obtidos neste estudo permitiram a criação de um cadastro georreferenciado de usuários de água subterrânea no município de Lajeado. Este cadastro é mantido e atualizado pela Secretaria Municipal de Meio Ambiente de Lajeado. A partir deste cadastro, foram abertos protocolos no Departamento de Recursos Hídricos (DRH) para a obtenção da outorga pelo uso da água. Além disso, periodicamente, são solicitadas análises para mensurar a potabilidade da água subterrânea.

Salienta-se que estudos que buscam compreender a inter-relação entre os constituintes geológicos, antrópicos - como o uso do solo - e os parâmetros microbiológicos e físicoquímicos para a definição de áreas vulneráveis e críticas para a captação de águas subterrâneas no município de Lajeado são de grande relevância.

\section{AGRADECIMENTOS}

Os resultados apresentados neste artigo foram obtidos a partir de um projeto de pesquisa financiado com recursos do Centro Universitário UNIVATES, que custeou a equipe executora da pesquisa. Também o trabalho recebeu recursos do Fundo Municipal do Meio Ambiente do município de Lajeado, oriundos da aplicação de penalidades por parte do Ministério Público e teve apoio do Conselho Municipal de Defesa do Meio Ambiente, para a realização das análises microbiológicas e físico-químicas da água subterrânea. Assim sendo, os autores do artigo destinam especial agradecimento ao Centro Universitário UNIVATES e à Secretaria Municipal de Meio Ambiente de Lajeado.

\section{REFERÊNCIAS}

BRASIL. Ministério da Saúde. Portaria nº 518 de 25 de março de 2004. Estabelece normas e o padrão de potabilidade da água destinada ao consumo humano. Diário Oficial da União, Brasília, v. 59, p. 266-270, 26 mar. 2004, Seção1.

CAPUCCI, E.; MARTINS, A. M.; MANSUR, K. L.; MONSORES, A. L. M. Poços tubulares e outras captações de águas subterrâneas: orientação aos usuários. Rio de Janeiro: SEMADS, 2001. 70 p.

CELLIGOI, A. Considerações sobre análises químicas de águas subterrâneas. Geografia, Londrina, v. 8, n. 1, p. 91-97, 1999.

CONSELHO DE RECUROS HÍDRICOS DO RIO GRANDE DO SUL. Avaliação qualiquantitativa das disponibilidades e demandas de água na Bacia Hidrográfica do Sistema Taquari-Antas. V. 1 - memorial descritivo, Tomo 1. Porto Alegre: Magna Engenharia, 1997. 301 p. 
FOSTER, S.; HIRATA, R. Determinação do risco de contaminação das águas subterrâneas: um método baseado em dados existentes. São Paulo: Instituto Geológico, 1993. 92 p. (Boletim n. 10)

FREEZE, R. A.; CHERRY, J. A. Groundwater. New Jersey: Prentice-Hall , 1979. 604 p.

GUERRA, P. A. G. Geoestatística operacional. Brasília: Departamento Nacional de Produção Mineral - DNPM, 1988. 145 p.

INSTITUTO BRASILEIRO DE GEOGRAFIA E ESTATÍSTICA. Pesquisa nacional de saneamento básico - 2000. Rio de Janeiro: IBGE, 2002. 1 CDROM.

INSTITUTO BRASILEIRO DE GEOGRAFIA E ESTATÍSTICA. Malha municipal digital do Brasil: situação em 2001. Rio de Janeiro: IBGE, 2004. Disponível em: <http://www.ibge.gov.br/>. Acesso em: 25 jan. 2008.

INSTITUTO BRASILEIRO DE GEOGRAFIA E ESTATÍSTICA. Contagem da população de 2007. Rio de Janeiro: IBGE, 2007. Disponível em: <http://www.ibge.gov.br/cidadesat>. Acesso em: 25 jan. 2008.

LANDSAT ETM+ VII: imagem de satélite. Órbita/ponto 222/080, de 04/02/02. Composição colorida RGB543. GeoTiff. São José dos Campos: INPE, 2002. 1 CD-ROM.

LEAL, A. S. As águas subterrâneas no Brasil: ocorrências, disponibilidades e usos. O Estado das Águas no Brasil. Brasília: ANEEL, 1999. 1 CD-ROM. (Série Estudos e Informações Hidrológicas e Energéticas).

MATTHESS, G. The properties of groundwater. New York: Wiley-Interscience, 1982. 406 p.

PIMENTEL, R. Reserva de Água no Planeta. Bahia Análise \& Dados, Salvador, v. 9, n. 3, p.118-122, 1999.

PINTO, N. L. S.; HOLTZ, A. C. T.; MARTINS, J. A.; GOMIDE, F. L. S. Hidrologia básica. 11. Reipr. São Paulo: Edgar Blücher, 2008. 278 p.

REBOUÇAS, A. C. Impactos ambientais nas águas subterrâneas. In: CONGRESSO BRASILEIRO DE ÁGUAS SUBTERRÂNEAS, 7., 1992, Belo Horizonte. Anais... Belo Horizonte: ABAS, 1992. p.11-17.

REBOUÇAS, A. C. Uso inteligente da água. São Paulo: Escrituras, 2004. 207 p.

REBOUÇAS, A. C.; BRAGA, B.; TUNDISI, J. G. (Orgs.) Águas doces no Brasil: capital ecológico, uso e conservação. 3. ed. São Paulo: Escrituras, 2006. 749 p.

SOUZA, E. R.; SOUSA, R. J. P.; HALLMANN, J. R. Avaliação preliminar dos recursos hídricos subterrâneos da região de Lajeado - RS - Brasil. In: CONGRESSO BRASILEIRO DE ÁGUAS SUBTERRÂNEAS, 12., 2002, Florianópolis. Anais... Florianópolis: ABAS, 2002. p.1-10.

ZAPOROZEC, A. Ground-Water pollution and its sources. GeoJournal, Springer Netherlands, v. 5, n. 5, p. 457-471, 1981.

ZAPOROZEC, A.; MILLER, J. C. Ground-Water Pollution. Paris: UNESCO, 2000. p. 27. Disponível em: <http://unesdoc.unesco.org/>. Acesso em: 25 ago. 2008. 
ECKHARDT, R. R.; DIEDRICH, V. L.; FERREIRA, E. R.; STROHSCHOEN, E.; DEMAMAN, L. C. Mapeamento e avaliação da potabilidade da água subterrânea do município de Lajeado, RS, Brasil. Ambi-Agua, Taubaté, v. 4, n. 1, p. 58-80, 2009. (doi:10.4136/ambi-agua.74)

ZOBY, J. L. G.; MATOS, B. Águas subterrâneas no Brasil e sua inserção na Política Nacional de Recursos Hídricos. In: CONGRESSO BRASILEIRO DE ÁGUAS SUBTERRÂNEAS, 12., 2002, Florianópolis. Anais... Florianópolis: ABAS, 2002. 1 CD-ROM.

ZOBY, J. L. G.; OLIVEIRA, F. R. de. Panorama da qualidade das águas subterrâneas no Brasil. Brasília: ANA, 2005. 80 p. (Cadernos de Recursos Hídricos).

WILDNER, W.; RAMGRAB, G. E.; LOPES, R. C.; IGLESIAS, C. M. F. Mapa geológico do Estado do Rio Grande do Sul.. Porto Alegre: CPRM, 2008. $\quad$ Escala 1:750.000. 1 DVD. 


\begin{tabular}{ccc|} 
ISSN = 1980-993X - doi:10.4136/1980-993X \\
www.agro.unitau.br/ambi-agua \\
E-mail: ambi-agua@agro.unitau.br \\
Tel.: (12) 3625-4116
\end{tabular}

\title{
Validação do método para a determinação do ácido 3 - indolacético em água de rios por cromatografia líquida de alta eficiência
}

(doi:10.4136/ambi-agua.75)

\author{
Sérgio Marcos Sanches; Renata Martins²; Paulo Jorge Marques Cordeiro² ${ }^{2}$ Luiz \\ Augusto Artemonte Vaz ${ }^{3}$; Eny Maria Vieira ${ }^{2}$ \\ ${ }^{1}$ Escola de Enfermagem de Ribeirão Preto/USP \\ E-mail: sesanches@hotmail.com \\ ${ }^{2}$ Instituto de Química de São Carlos/USP \\ E-mail: rennata_m@yahoo.com.br; \{cordeiro, eny\}@iqsc.usp.br \\ ${ }^{3}$ Empresa Agrolatino, Matão \\ E-mail: sellyap@hotmail.com
}

\section{RESUMO}

O ácido 3 - indolacético (AIA) é um importante fitormônio natural encontrado em plantas em baixas concentrações. O AIA está envolvido na regulação dos processos de crescimento e desenvolvimento de plantas. Neste estudo foi desenvolvido e validado o método analítico para a determinação e quantificação do ácido 3 - indolacético em amostras de água. A cromatografia líquida de alta eficiência com detector de arranjo de diodos foi empregada como técnica analítica para a determinação do ácido 3 - indolacético. Os parâmetros selecionados para a validação do método foram: limite de detecção e quantificação, linearidade, curva analítica, precisão, sensibilidade e ensaios de recuperação. A curva analítica foi construída com cinco pontos, empregando-se solução padrão. O método apresentou limite de detecção e de quantificação respectivamente 0,05 e $0,5 \mathrm{mg} \mathrm{L}^{-1}$, linearidade no intervalo de 0,5 a $10 \mathrm{mg} \mathrm{L}^{-1}$, o coeficiente de correlação foi superior a 0,99. Com base nesses resultados, conclui-se que o método é eficiente e pode ser empregado em análise para o monitoramento do ácido 3 - indolacético presente em águas naturais.

Palavras-chave: água; validação; ácido 3 - indolacético.

\section{Validation of the method for determining the 3 - indolacetic acid in water from rivers by high performance liquid chromatography}

\section{ABSTRACT}

The 3 - indolyacetic acid is an important natural phytohormone in plants in low concentrations. The 3 - indolyacetic acid is involved in the regulation of many processes of growth and plants development. This study developed and validated an analytical method to quantify 3- indolyacetic acid using the Hight-Performance Liquid Chromatography with DAD detector. The following parameters were chosen: detection and quantification limits, linearity, calibration curve, precision, sensibility and assays of recovery. The calibration curve was obtained with five points based on standard solution. The method presented detection and quantification limits of 0.05 and $0.5 \mathrm{mg} \mathrm{L}^{-1}$, respectively. It showed linearity in the interval of 0.5 to $10 \mu \mathrm{g} \mathrm{\textrm {L } ^ { - 1 }}$ and correlation coefficients higher than 0.99 . These results allow the conclusion that the method can be considered efficient and that it could be used to monitor 3 indolyacetic acid in natural water.

Keywords: water; validation; 3 - indolyacetic acid. 


\section{INTRODUÇÃO}

Os vegetais, assim como os animais, têm grande parte de seu metabolismo controlado por hormônios. O desenvolvimento e crescimento das plantas são afetados pela luz, gravidade, temperatura, fotoperíodo, por meio da influência dos hormônios vegetais (Rolcik et al., 2005). Os fitormônios correspondem a uma série de compostos que agem em muitos fenômenos vegetais tais como, crescimento, floração, divisão celular, amadurecimento de frutos, dormência de gemas. Os principais fitormônios são: auxinas, giberelinas, ácido abscísico e etileno (Rolcik et al., 2005). Desses, os mais importantes são as auxinas e neste caso o ácido 3 - indolacético (AIA).

O AIA é uma substância de crescimento pertencente ao grupo das auxinas. Ele é encontrado em plantas e microrganismos em baixas concentrações, e foi à primeira auxina isolada responsável por numerosos processos biológicos em vegetais. É responsável pela regulação de processos de crescimento e desenvolvimento de plantas como, dominância apical, crescimento de brotos, divisão e elongação celular (Wurst et al., 1984).

Existem várias rotas para a biossíntese do AIA, sendo o aminoácido triptofano o seu provável precursor. Suspeita-se da existência de uma outra via independente do triptofano para a biossíntese desse hormônio vegetal (Arteca, 1995). Apesar de ambas as vias coexistirem nas plantas, a importância relativa de cada uma para o conteúdo de AIA nos tecidos vegetais, ainda não foi esclarecida. Esse hormônio é sintetizado principalmente no meristema apical em folhas jovens e é transportado em sentido polarizado (do ápice para a base), a partir do meristema apical até as extremidades das raízes (Arteca, 1995; Wachowicz e Carvalho, 2002).

As auxinas podem ser encontradas naturalmente nos vegetais sob a forma livre ou conjugada. O AIA, na forma livre, é a forma biologicamente ativa do hormônio, mas a grande maioria é encontrada na forma conjugada. As plantas regulam o nível de AIA livre através de uma complexa rede de vias que além da síntese incluem o transporte, a degradação, a conjugação com aminoácidos, as proteínas, a glicose e o inositol e a hidrólise destes conjugados. A conjugação do AIA é um processo que ocorre em praticamente todos os vegetais superiores e os conjugados de AIA formam-se rapidamente quando a homeostase do hormônio é perturbada como, por exemplo, na aplicação externa de AIA no tecido vegetal (Artega, 1995). Quando conjugado com glicosídeos, o AIA serve basicamente como reserva e quando a conjugação ocorre com aminoácidos ou proteínas é utilizado para desintoxicação (Wachowicz e Carvalho, 2002).

O AIA pode ser degradado na planta por meio da foto-oxidação e pela oxidação enzimática realizada pelo sistema AIA-oxidase (Alvarenga e Carvalho, 1983) pois a ruptura da molécula do AIA garante o seu nível, portanto a nova síntese depende desse processo para regular a taxa hormonal na planta. Inicialmente, o AIA era utilizado somente para o enraizamento de plantas, posteriormente, para promover a floração em amendoim, evitar a abscisão e promover a partenocarpia de frutos como, maçã, abóbora e berinjela (Castro et al., 1993).

O principal objetivo deste estudo foi o desenvolvimento e validação do método analítico para a determinação do ácido 3 - indolacético em amostras de água. Não existe legislação (Brasil, 2004) que mencione o AIA como sendo uma substância que deve ter seu limite máximo na água. 


\section{MATERIAL E MÉTODOS}

\subsection{Preparo da solução padrão do ácido 3 - indolacético}

Preparou-se uma solução padrão do ácido 3 - indolacético de concentração de 100 mg L 1 em metanol.

\subsection{Seleção do comprimento de onda utilizado em HPLC - UV}

Foi obtido um espectro de absorção do padrão ácido 3 - indolacético que compreendeu uma varredura de 200 a $800 \mathrm{~nm}$. Utilizou-se um Espectrofotômetro de UV/Visível da marca Hitachi, modelo U3501.

\subsection{Condições cromatográficas ideais para a determinação do ácido 3 - indolacético em água de rios}

As determinações analíticas do ácido 3 - indolacético foram feitas na Central de Análises Químicas do Instituto de Química de São Carlos-USP empregando um cromatógrafo com detector de arranjo de diodos, da marca SHIMADZU CBM-10A. Foi utilizada uma coluna de fase reversa $\left(\mathrm{C}_{18}\right)$, da marca Zorbax ODS, de $15 \mathrm{~cm}$ de comprimento, diâmetro interno de 4,6 mm e o tamanho de partícula de $5 \mu \mathrm{m}$. As condições cromatográficas para a análise do AIA foram: detector de arranjo de diodos; fluxo de $1,0 \mathrm{~mL} \min ^{-1}$; volume injetado de 20,0 $\mu \mathrm{L}$; comprimento de onda a $280 \mathrm{~nm}$; temperatura ambiente, fase móvel metanol/TFA 0,05\% $(40: 60 \mathrm{v} / \mathrm{v})$, método isocrático.

\subsection{Preparo da curva analítica e linearidade}

Após determinar as condições cromatográficas ideais para a análise do AIA, construiu-se a curva analítica. Esta foi preparada a partir de um padrão da marca Supelco na concentração de $100 \mathrm{mg} \mathrm{L}^{-1}$ com cinco pontos, em que cada ponto foi feito em triplicada, com as respectivas concentrações 0,$5 ; 1,0 ; 2,5 ; 5,0$ e $10 \mathrm{mg} \mathrm{L}^{-1}$. Todos os pontos da curva analítica foram preparados utilizando-se o solvente metanol. Essas soluções foram analisadas em ordem crescente de concentração.

\subsection{Limite de deteç̧ão}

Para a determinação do limite de detecção do método foram preparadas soluções de AIA nas seguintes concentrações: 0,05; 0,1; 0,25 $\mathrm{mg} \mathrm{L}^{-1}$ em metanol.

\subsection{Ensaio de precisão}

Para a determinação da precisão, cada ponto foi feito em quintuplicata em três níveis de concentração: 0,$75 ; 2,0$ e $8 \mathrm{mg} \mathrm{L} \mathrm{L}^{-1}$. Essas concentrações foram empregadas por estarem na faixa linear utilizada, porém as concentrações foram diferentes das utilizadas na curva analítica Todas as soluções foram analisadas por HPLC nas condições descritas no item condições cromatográficas para a determinação do AIA em água.

\subsection{Ensaio de recuperação}

Uma amostra de água natural, coletada na nascente do rio Santa Maria do Leme, no município de São Carlos - SP, foi fortificada com a solução padrão do AIA para preparar duas soluções de concentrações 1,0 e $100 \mu \mathrm{L} \mathrm{L}^{-1}$ e, as soluções foram acidificadas com $2 \%$ de ácido fórmico $(\mathrm{v} / \mathrm{v})$. Foram feitas cinco repetições para cada concentração, e também se fez um branco. As amostras foram então pré-concentradas, utilizando-se o método de extração em fase sólida (SPE). Os cartuchos utilizados foram do tipo ODS-C18, os quais foram ativados 
com $10 \mathrm{~mL}$ de metanol acidificado com $1 \%$ de ácido fórmico (v/v), seguido de $10 \mathrm{~mL}$ de água livre de orgânicos. Transferiram-se as amostras para os cartuchos a uma vazão de aproximadamente $1 \mathrm{~mL} / \mathrm{min}^{-1}$. Secou-se o adsorvente contendo o analito no vácuo por duas horas e eluiu-se com $10 \mathrm{~mL}$ de metanol. As amostras foram secas em corrente de nitrogênio e retomadas com $1 \mathrm{~mL}$ de metanol. Os extratos resultantes foram então analisados em HPLC, empregando-se as mesmas condições descritas no item condições cromatográficas para a determinação do AIA em água. A amostra de concentração de $1,0 \mu \mathrm{g} \mathrm{\textrm {L } ^ { - 1 }}$ foi pré-concentrada 250 vezes e a de concentração $100 \mu \mathrm{g} \mathrm{L}^{-1}$ foi pré-concentrada 25 vezes.( estou em dúvida quanto a este símbolo de medida, não sei a que elemento ele se refere, é litro?).

\section{RESULTADOS E DISCUSSÃO}

\subsection{Espectro de UV e cromatograma do padrão do ácido 3- indolacético}

A Figura 1 apresenta o espectro de UV do padrão do AIA, obtido com o intuito de verificar a região de absorção da substância em estudo e o formato do pico. O pico com comprimento de onda de $217 \mathrm{~nm}$ é referente ao grupo ácido carboxílico e o pico em $280 \mathrm{~nm}$ refere-se ao grupo indol. O comprimento de onda correspondente à absorção máxima do analito em estudo, que foi selecionado para a determinação analítica empregando-se um cromatógrafo em fase líquida com detector de UV-Vis, foi de $280 \mathrm{~nm}$.

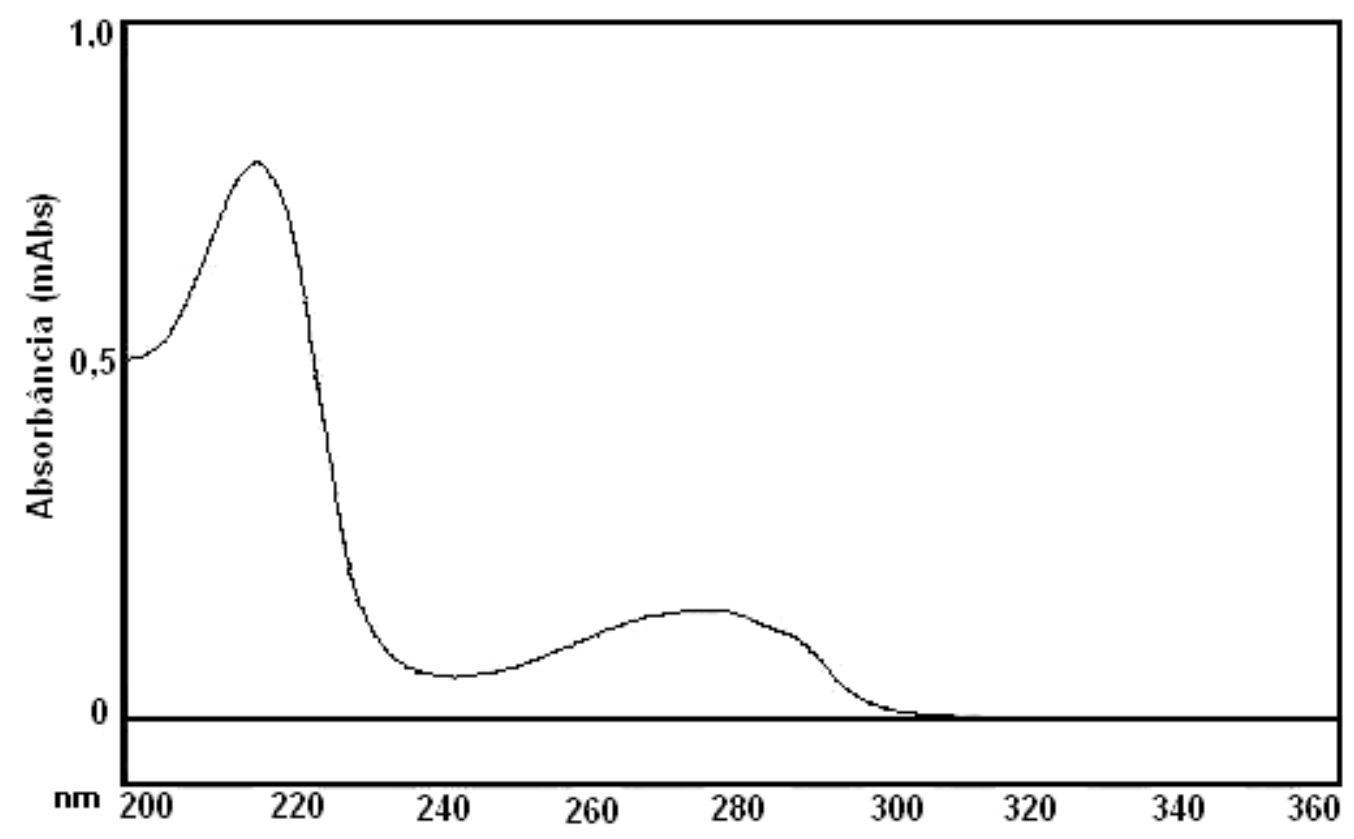

Figura 1. Espectro de UV-Vis do padrão do ácido 3- indolacético.

A Figura 2 apresenta o cromatograma do padrão do AIA na concentração de $100 \mathrm{mg} \mathrm{L}^{-1}$. Utilizou-se a fase móvel metanol/TFA (0,05\%). (40:60 v/v). 


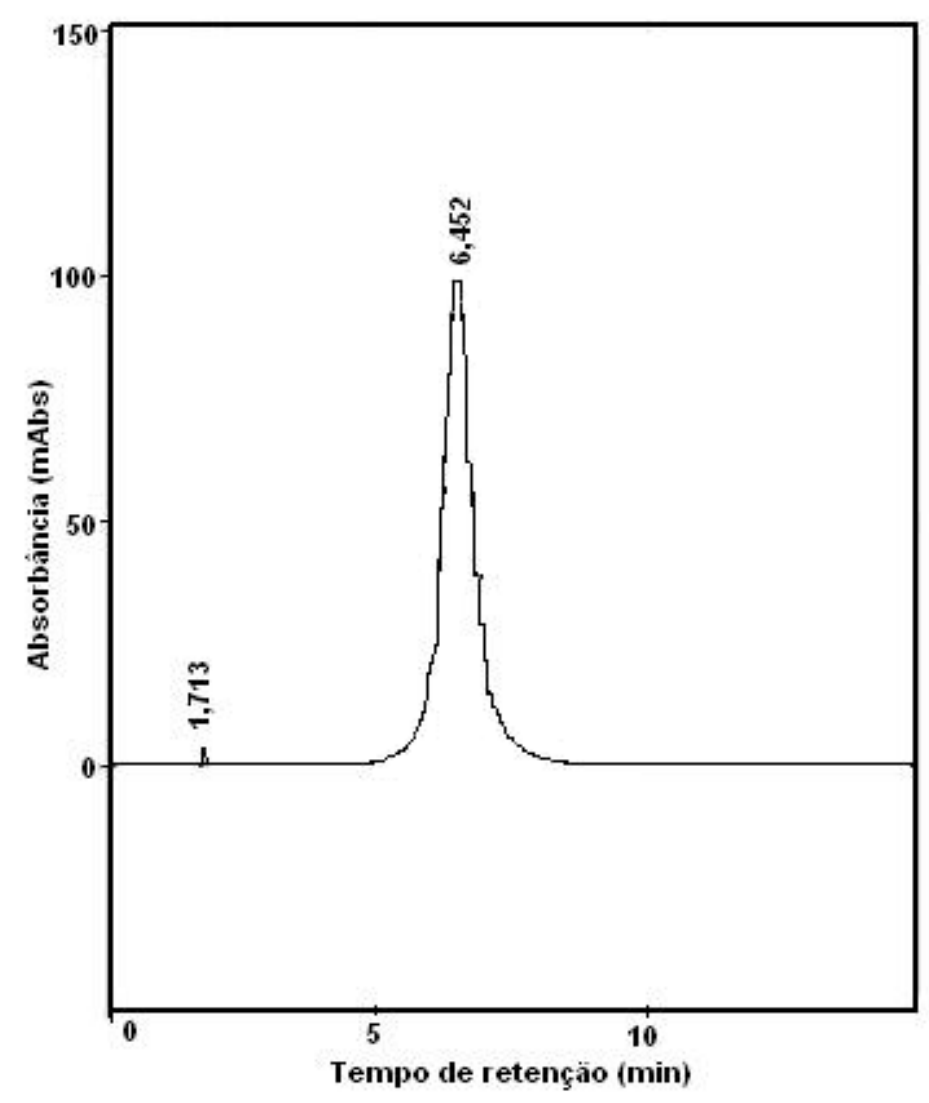

Figura 2. Cromatograma do padrão do ácido 3 indolacético (100 mg L-1).

Verifica-se pelo cromatograma que o pico cromatográfico referente ao AIA está bem definido. Os tempos de retenção do solvente (metanol) e do ácido 3 - indolacético foram, respectivamente, de 1,713 e 6,452 min.

\subsection{Linearidade da curva analítica a ser usada para a determinação do ácido 3 - indolacético em água}

A curva analítica apresentada na Figura 3 foi construída com cinco pontos, em um intervalo de concentração de 0,5 a $10 \mathrm{mg} \mathrm{L}^{-1}$.

A curva analítica obtida para o AIA foi linear, apresentando coeficiente de correlação (R) superior a 0,99. A Agência Nacional de Vigilância Sanitária (Brasil, 2003) recomenda um coeficiente de correlação igual a 0,99 e o Instituto Nacional de Metrologia, Normalização e Qualidade Industrial (Brasil ,2003) acima de 0,90. Esse coeficiente de correlação foi satisfatório, o que demonstra que a resposta do detector foi linear nos intervalos de concentração empregados nesse estudo (Ribani et al., 2004). 
SANCHES, S.M.; MARTINS, R.; CORDEIRO, P.J.M.; VAZ, L.A.A.; VIEIRA, E.M. Validação do método para a determinação do ácido 3 - indolacético em água de rios por cromatografia líquida de alta eficiência. Ambi-Agua, Taubaté, v. 4, n. 1, p. 81-92, 2009. (doi:10.4136/ambi-agua.75)

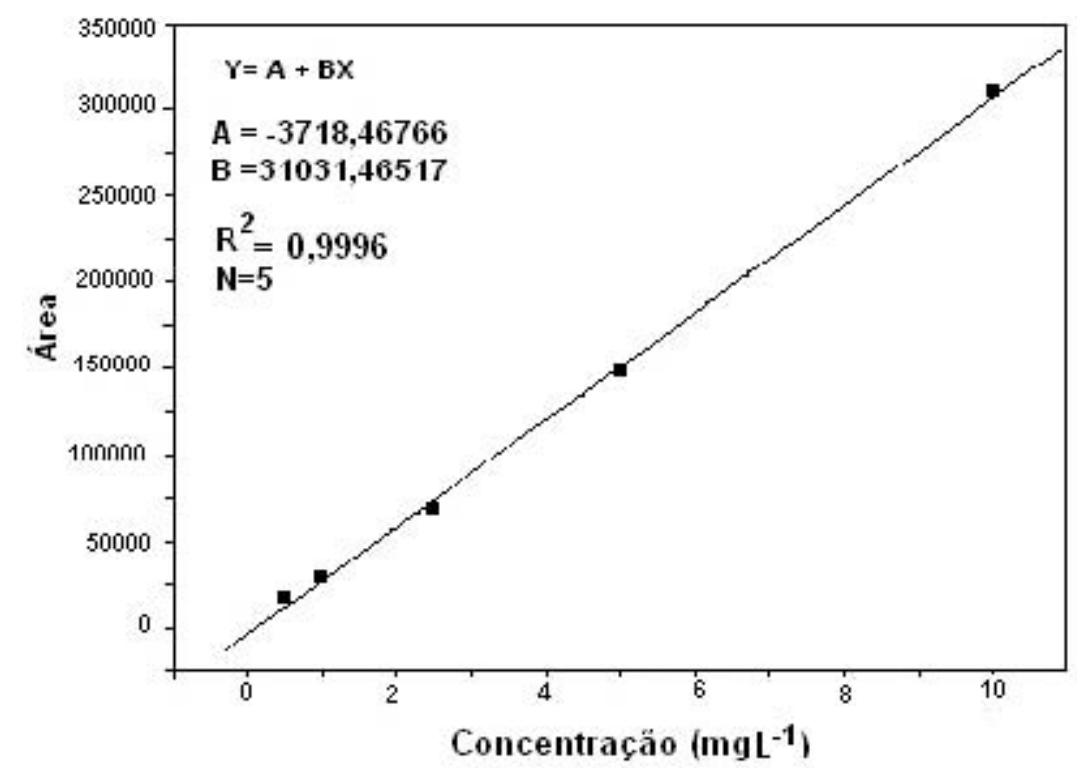

Figura 3. Curva analítica do ácido 3 - indolacético.

\subsection{Limites de deteç̧ão e de quantificação}

Nas Figuras 4 e 5, apresentam-se, respectivamente, os cromatogramas, evidenciando o limite de detecção do método, e também a região do pico expandida para verificar a relação entre a altura do pico e a altura do ruído da linha de base.

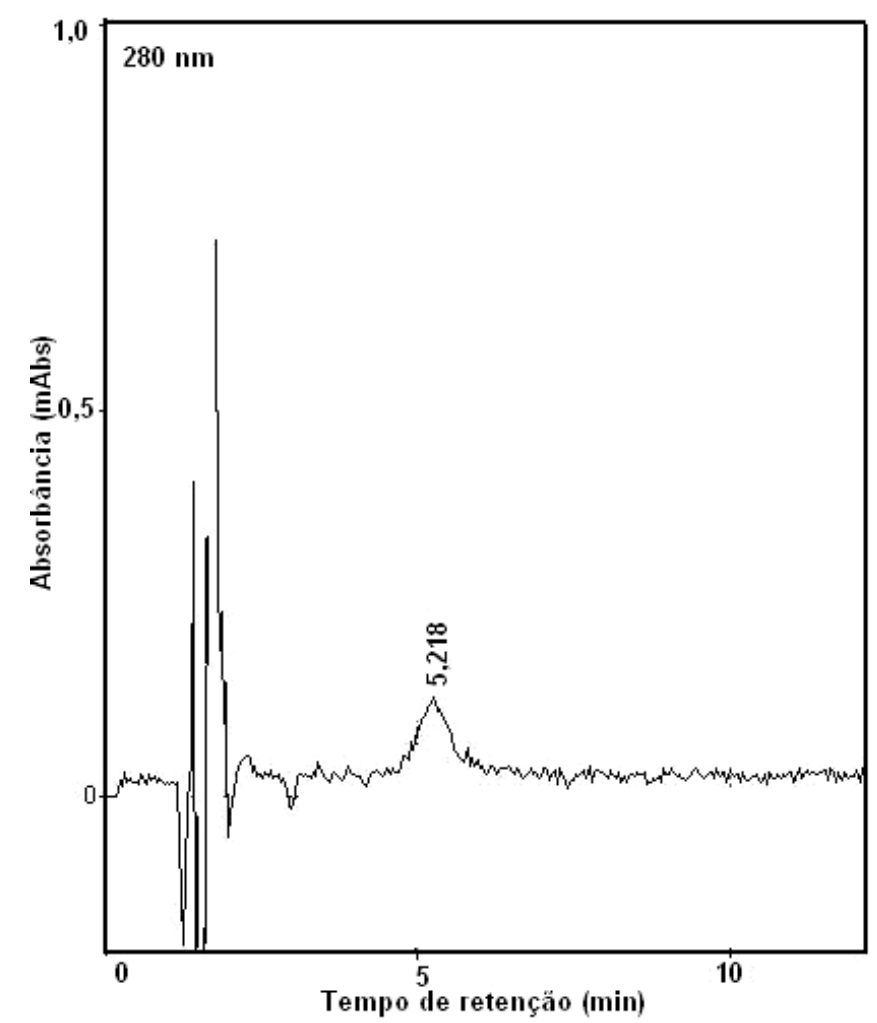

Figura 4. Cromatograma do limite de detecção do método. 


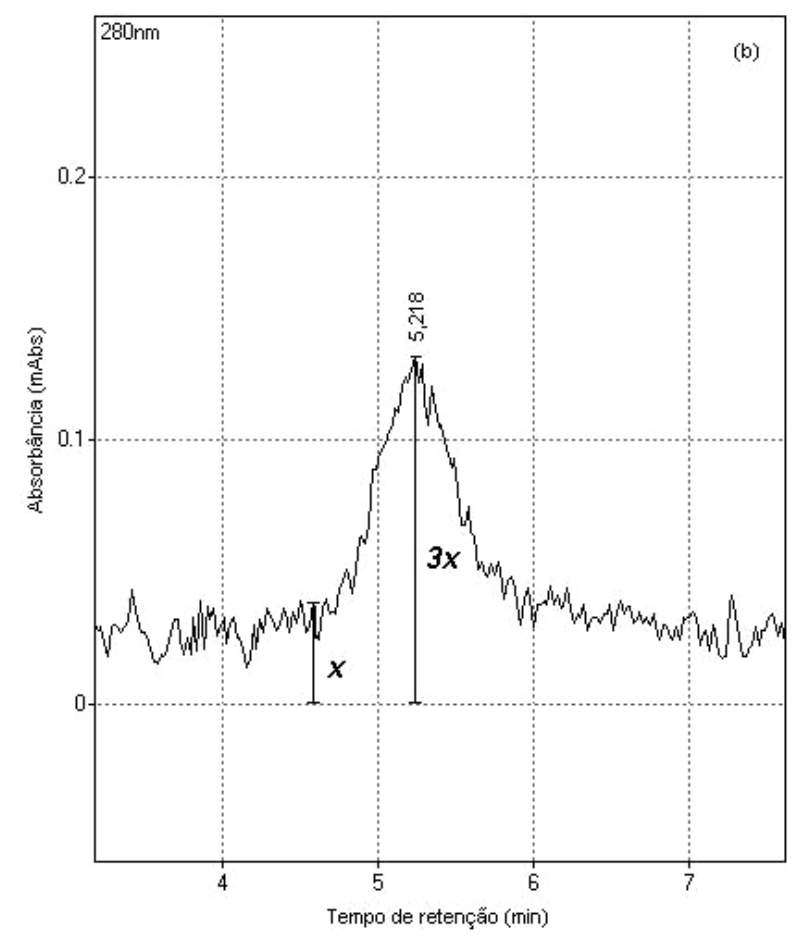

Figura 5. Cromatograma do limite de detecção do método, região do pico aumentada.

O limite de detecção do método foi de $0,05 \mathrm{mg} \mathrm{L}^{-1}$, cuja estimativa foi feita com base na relação: a altura do pico do analito deve ser em torno de 3 vezes a altura do ruído da linha de base, na região aproximada do tempo de retenção do AIA. Já o limite de quantificação é dado pela equação $L Q=10 \times(\mathrm{s} / \mathrm{S})$, em que: $\mathrm{s}=$ desvio-padrão da resposta e $\mathrm{S}=$ coeficiente angular do gráfico de calibração. O limite de quantificação foi de $0,5 \mathrm{mg} \mathrm{L}^{-1}$.

\subsection{Sensibilidade da técnica analítica para a determinação do AIA}

Da equação da reta pode-se estimar a sensibilidade da técnica que é definida como dy/dx, a qual foi de 31031,46517, que é considerado como de sensibilidade alta (Ribani et al., 2004).

\subsection{Ensaio de precisão}

Segundo regulamentação da (Brasil, 2003), a precisão pode ser calculada por meio do coeficiente de variação pela equação:

$$
C V=\frac{D P}{C M D} \times 100
$$

em que, DP é o desvio padrão e CMD, a concentração média determinada.

O valor máximo aceitável deve ser definido de acordo com a metodologia empregada, com a concentração do analito na amostra, com o tipo de matriz e com a finalidade do método, não se admitindo valores superiores a 5\%. A estimativa do desvio padrão pode ser calculada pela equação:

$$
D P=\sqrt{\frac{\sum\left(X_{i}-\bar{X}\right)^{2}}{N-1}}
$$


em que $\mathrm{X}_{\mathrm{i}}$ é a concentração obtida por meio da análise cromatográfica, $\bar{X}$ é a média e $\mathrm{N}$ é o número de medidas.

Neste estudo, a precisão do método foi avaliada referente ao nível de repetibilidade. A repetibilidade apresenta a concordância entre os resultados de medidas sucessivas de um mesmo método, efetuadas sob as mesmas condições que são chamadas condições de repetibilidade: mesmo procedimento; mesmo analista; mesmo instrumento usado sob as mesmas condições; mesmo local; repetições em curto intervalo de tempo (Ribani et al., 2004). A precisão foi avaliada por meio do coeficiente de variação (CV) dos resultados obtidos $(n=5)$, ao nível de repetibilidade, sendo portanto feita em um curto intervalo de tempo. Na Tabela 1, encontram-se os resultados da precisão do método usado neste estudo.

Tabela 1. Dados obtidos para o ensaio de precisão.

\begin{tabular}{|c|c|c|c|c|}
\hline $\begin{array}{l}\text { Concentração } \\
\left(\mathrm{mg} \mathrm{L}^{-1}\right)\end{array}$ & $\begin{array}{c}\text { Concentração obtida } \\
\left(\mathrm{mg} \mathrm{L}^{-1}\right)\end{array}$ & Média & Desvio padrão & CV (\%) \\
\hline 0,75 & $\begin{array}{l}0,7532 \\
0,7683 \\
0,7706 \\
0,7741 \\
0,7835\end{array}$ & 0,7699 & 0,01 & 1,3 \\
\hline 2,0 & $\begin{array}{l}2,1403 \\
2,1307 \\
2,0598 \\
2,1253 \\
2,0951\end{array}$ & 2,1102 & 0,03 & 1,5 \\
\hline 8,0 & $\begin{array}{l}8,1521 \\
8,2932 \\
8,1147 \\
8,1345 \\
8,2369\end{array}$ & 8,1863 & 0,07 & 0,9 \\
\hline
\end{tabular}

Como pode ser observado na Tabela 1 , os coeficientes de variação variaram de 0,9 a 1,5 \% , sendo esses valores menores do que os estipulados pela Agência Nacional de Vigilância Sanitária que é de $5 \%$, sendo portanto, o método considerado preciso e dentro da faixa aceitável para a validação de métodos analíticos (Ribani et al., 2004).

\subsection{Ensaios de recuperação}

Optou-se por acidificar a amostra com $2 \%$ de ácido fórmico, podendo-se obter uma melhor recuperação do analito estudado. A Tabela 2 apresenta a porcentagem de recuperação do AIA em água para os dois níveis de fortificação estudados 0,1 e $0,001 \mathrm{mg} \mathrm{L}^{-1}$. Os ensaios de recuperação foram feitos em quintuplicata.

Tabela 2. Porcentagens de recuperação do ácido 3-indolacético em água.

\begin{tabular}{c|c|c}
\hline Nível de fortificação $\left(\mathbf{m g ~ L}^{\mathbf{- 1}}\right)$ & Recuperação (\%) & CV (\%) \\
\hline 0,1 & $120(113-127)$ & 4,9 \\
0,001 & $80(74-82)$ & 4,8 \\
\hline
\end{tabular}


Analisando-se os dados contidos na Tabela 2, observa-se que houve uma boa recuperação, o que indica que o método empregado é apropriado para a análise de AIA em água, pois o valor está dentro dos limites aceitáveis de recuperação que é de 70 a $120 \%$ (ICH, 1995).

As porcentagens de recuperação obtidas deixam evidente que o método pode ser considerado preciso. A precisão foi avaliada por meio do coeficiente de variação (CV) dos resultados obtidos ( $\mathrm{N}=5$ ), cujos valores são inferiores a 5\% para este método.

Nas Figuras 5 e 6 encontram-se apresentados os cromatogramas obtidos para o ensaio de recuperação do AIA em água, nos níveis de fortificação estudados, 0,1 e 1,0 $\mathrm{mg} \mathrm{L}^{-1}$.

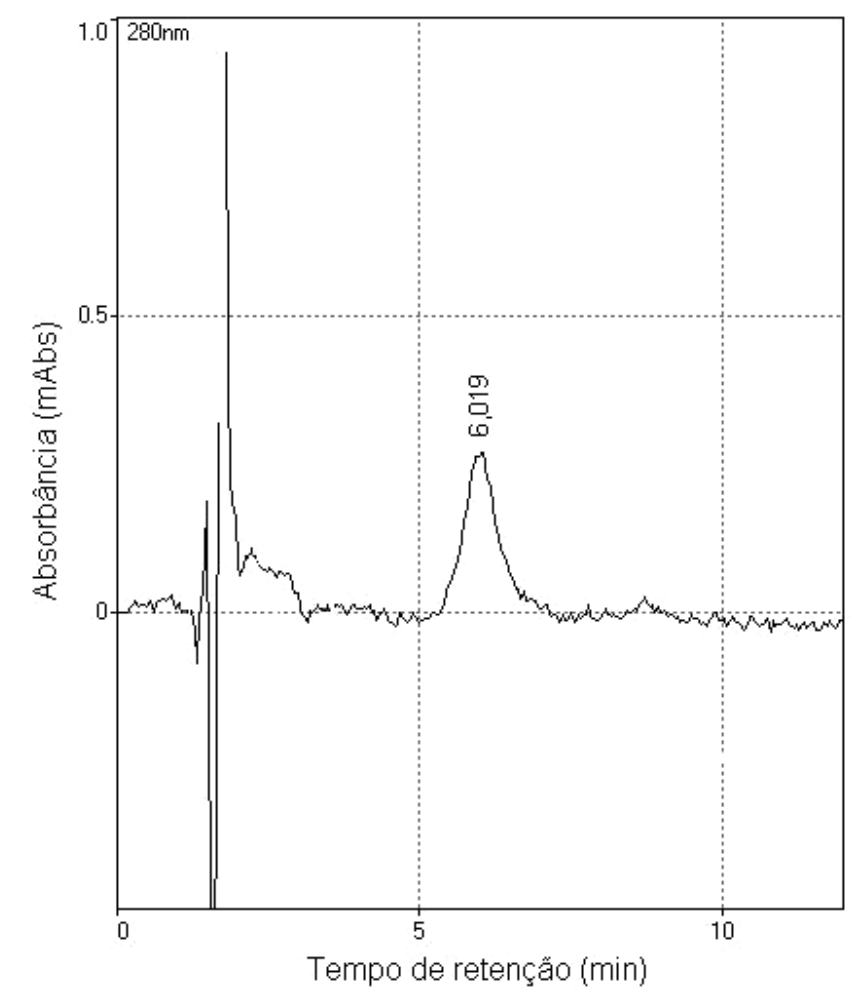

Figura 5. Cromatograma obtido para o ensaio de recuperação do AIA em água no nível de fortificação $0,1 \mathrm{mg} \mathrm{L}^{-1}$.

As amostras fortificadas com AIA foram pré-concentradas 2,5 vezes e as áreas dos picos obtidos foram de 10781 para $0,1 \mathrm{mg} \mathrm{L}^{-1}$ e de 73415 para $1,0 \mathrm{mg} \mathrm{L}^{-1}$. Na Figura 7, está apresentado o cromatograma obtido para o branco. Como pode ser observado, o pico referente ao AIA (tempo de retenção de aproximadamente $6 \mathrm{~min}$ ) não está presente, indicando a ausência desse fitormônio na água coletada na nascente do rio Santa Maria do Leme. A amostra de água foi pré-concentrada 250 vezes, para se garantir que o ácido 3 - indolacético não estaria presente. 
SANCHES, S.M.; MARTINS, R.; CORDEIRO, P.J.M.; VAZ, L.A.A.; VIEIRA, E.M. Validação do método para a determinação do ácido 3 - indolacético em água de rios por cromatografia líquida de alta eficiência. Ambi-Agua, Taubaté, v. 4, n. 1, p. 81-92, 2009. (doi:10.4136/ambi-agua.75)

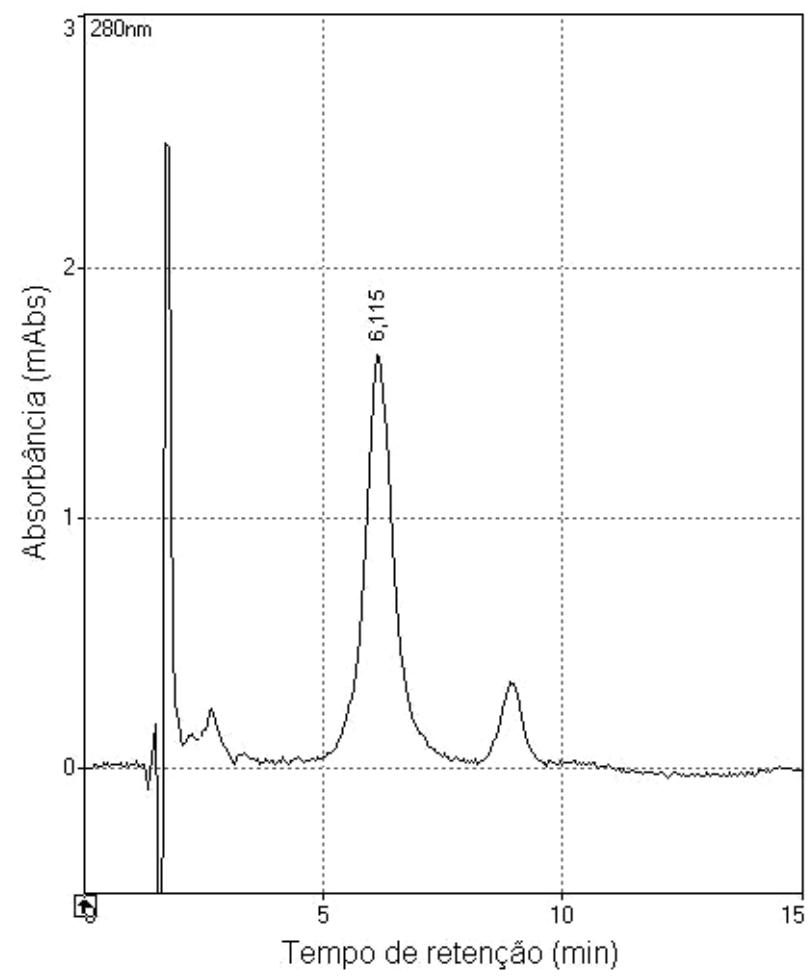

Figura 6. Cromatograma obtido para o ensaio de recuperação do AIA em água no nível de fortificação $1 \mathrm{mg} \mathrm{L}^{-1}$.

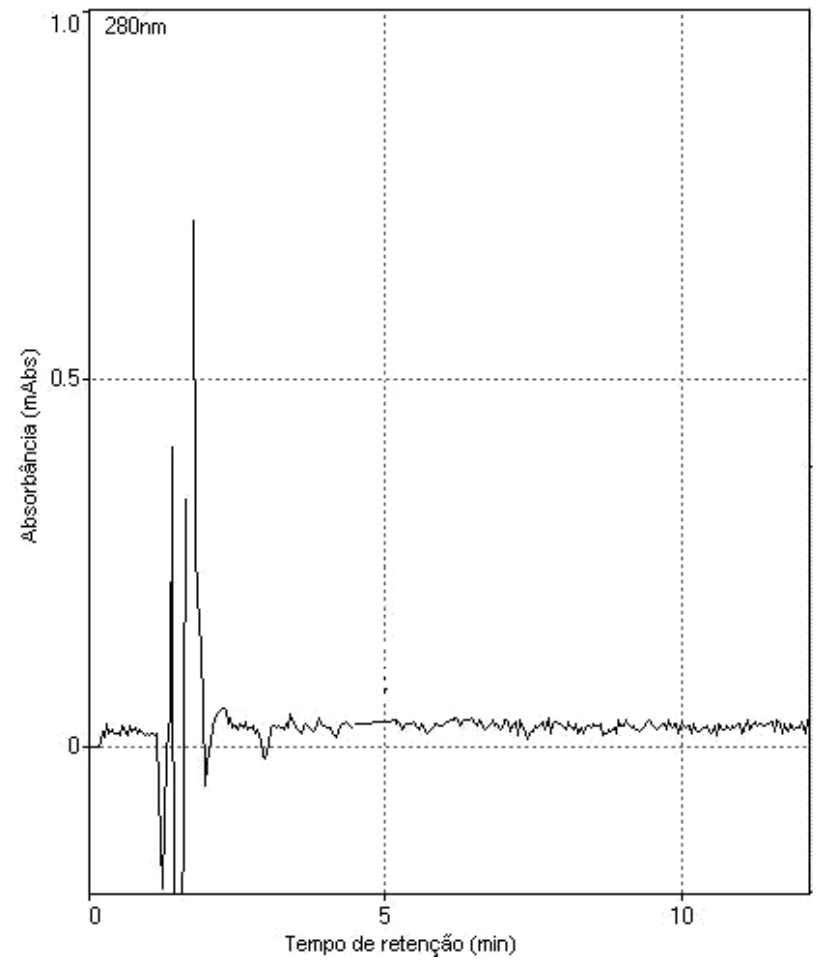

Figura 7. Cromatograma do branco. 


\section{CONCLUSÃO}

Atualmente vem crescendo a preocupação com respeito à poluição, sobretudo à da água. Como as práticas agrícolas contribuem para a poluição da água é, portanto, necessário o desenvolvimento e validação de métodos para a determinação do ácido 3 - indolacético, o qual é um fitormônio amplamente utilizado na agricultura. O método desenvolvido mostrouse eficiente para tal determinação, estando de acordo com as normas estabelecidas pelos órgãos fiscalizadores, ANVISA, INMETRO e ICH. Vale ressaltar que durante o desenvolvimento e validação de um método, os procedimentos analíticos devem ser submetidos à validação estatística, com o objetivo de conhecer suas limitações e confiabilidade dos resultados obtidos, para a aplicação do método para amostras que se deseja analisar.

\section{AGRADECIMENTOS}

À Fundação de Amparo à pesquisa do Estado de São Paulo - FAPESP, pela apoio concedido para a execução deste trabalho.

\section{REFERÊNCIAS}

ALVARENGA, L. R.; CARVALHO, V. D. Uso de substâncias promotoras de enraizamento de estacas frutíferas. Informe Agropecuário, Belo Horizonte, v. 9, n.101, p. 47-55, 1983.

ARTECA, R. N. Plant Growth Substances: principles and application. New York: Chapman and Hall, 1995. 332p.

BRASIL. Ministério da Saúde. Agência Nacional de Vigilância Sanitária - ANVISA. Resolução RE n. 899 de 29 de maio de 2003. Disponível em: <http://www.anvisa.gov.br/legis/resol/2003/re/899_03re.htm>. Acesso em: 20 de Dezembro de 2008.

BRASIL. Ministério da Saúde. Secretaria de Vigilância em Saúde. Coordenação-Geral de Vigilância em Saúde Ambiental. Portaria n 518/2004, de 25 de Março de 2004: estabelece os procedimentos e responsabilidades relativas ao controle de vigilância da qualidade da água para o consumo humano e seu padrão de potabilidade, e dá outras providências. Disponível em: <http://portal.saude.gov.br/portal/arquivos/pdf/portaria _518_2004.pdf>. Acesso em: 30 de Dezembro de 2008.

CASTRO, P. R. C.; APPEZZATO-DA-GLÓRIA, B. Efeitos de reguladores vegetais no desenvolvimento e na produtividade do amendoinzeiro (Arachis hypogaea L.), Scientia Agrícola, Piracicaba, v. 50, n. 2, p. 176 - 184, 1993.

INSTITUTO NACIONAL DE METROLOGIA, NORMALIZAÇÃO E QUALIDADE INDUSTRIAL -INMETRO. Orientações sobre validação de métodos de ensaios, DOQ-CGCRE-008. Disponível em: <http://www.inmetro.gov.br/Sidoq/ Arquivos/CGCRE/DOQ/DOQ-CGCRE-8_02.pdf>. Acesso em: 10 de Janeiro de 2009.

Internacional Conference on Harmonization - ICH, Q2A: validation of analytical procedures: definitions and terminology, Q2A (CPMP/ICH/381/95), 1995. Disponível em: $<$ http://www.tga.gov.au/meds/eucons/ich038195enrrev1.pdf $>$. Acesso em: 15 de Dezembro de 2008. 
RIBANI, M.; BOTTOLI, C. B. G.; COLLINS, C. H. \& JARDIM, I. C. S. F. Validação em métodos cromatográficos e eletroforéticos. Química Nova, v. 27, n. 5, p. 771 - 780, 2004.

ROLCIK, J.; RECINSKA, J.; BARTAK, P.; STRNAD. M.; PRINSEN, E. Purification of 3indolylacetic acid by solid phase extraction. Journal of Separation Science, v. 28, p. 1370-1374, 2005.

WACHOWICZ, C. M.; CARVALHO, R. I. N. Fisiologia Vegetal: produção e pós-colheita. Curitiba: Editora Universitária Champagnat, 2002, 424p.

WURST, M.; PRIKRYL, Z.; VOKOUN, J. High-performance liquid chromatography of plants hormones: II. Determination of plant hormones of the indole type. In: Journal of Chromatography, v. 286, p.237-245, 1984. 


ISSN = 1980-993X - doi:10.4136/1980-993X
www.agro.unitau.br/ambi-agua
E-mail: ambi-agua@agro.unitau.br
Tel.: (12) 3625-4116

\title{
Vulnerabilidade de sub-bacias hidrográficas por meio da equação universal de perda de solo e da integração de parâmetros morfométricos, topográficos, hidrológicos e de uso/cobertura da terra no estado do Rio de Janeiro, Brasil
} (doi:10.4136/ambi-agua.76)

\author{
Thomaz Correa e Castro da Costa ${ }^{1}$; Elaine Cristina Cardoso Fidalgo ${ }^{1}$; Uebi Jorge \\ Naime $^{1}$; Saulo Pedrinha Guimarães ${ }^{2}$; Maria José Zaroni ${ }^{1}$; Mariella Camardelli Uzeda ${ }^{3}$ \\ ${ }^{1}$ Embrapa Solos, Rua Jardim Botânico, 1024 - 22460-000 - Rio de Janeiro - RJ \\ E-mail: thomaz@cnpms.embrapa.br; \{efidalgo, naime, zaroni\}@cnps.embrapa.br \\ ${ }^{2}$ Geólogo. Petróleo Brasileiro S.A. - Petrobras. Av. Chile 65 - 20035-900 - Rio de Janeiro - RJ \\ E-mail: saulo.pedrinha@petrobras.com.br \\ ${ }^{3}$ Embrapa Agrobiologia, Rodovia BR 465, km 7 - 23890-000 - Seropédica - RJ \\ E-mail: mariella@cnpab.embrapa.br
}

\section{RESUMO}

Sub-bacias delimitadas para o estado do Rio de Janeiro foram parametrizadas por meio de duas metodologias que indicam vulnerabilidade, a equação universal de perda de solo que estima a perda de solo em toneladas por hectare/ano; e a integração temática de parâmetros morfométricos, topográficos, hidrológicos e de uso/cobertura da terra, que resulta em um índice de vulnerabilidade adimensional. Os parâmetros de cada método e os resultados foram analisados e comparados para verificação do grau de associação entre as metodologias, concluindo-se que os métodos são complementares para indicar vulnerabilidade de sub-bacia.

Palavras-chave: perda de solo; vulnerabilidade ambiental; sub-bacia.

\section{Vulnerability of the watersheds by universal equation of soil loss and thematic integration of morphometric, topographical, hydrological an land use/land cover parameters in Rio de Janeiro State, Brazil}

\begin{abstract}
Watersheds delimited in the Rio de Janeiro State were parameterized by means of two methods indicate that a measure of environmental vulnerability, the universal equation of soil loss, which estimates the loss of soil in tones per hectare per year, and thematic integration of morphometric, topographical, hydrological an land use/land cover parameters, that result at vulnerability index. The parameters involved and the results were compared to verify the degree of association between methodologies, concluding that these methods are complementary to indicate the vulnerability of watersheds.
\end{abstract}

Keywords: soil loss; environment vulnerability; watershed. 
COSTA, T. C. C.; FIDALGO, E. C. C.; NAIME, U. J.; GUIMARÃES, S. P.; ZARONI, M. J.; UZEDA, M. C. Vulnerabilidade de sub-bacias hidrográficas por meio da equação universal de perda de solo e da integração de parâmetros morfométricos, topográficos, hidrológicos e de uso/cobertura da terra no estado do Rio de Janeiro, Brasil. Ambi-Agua, Taubaté, v. 4, n. 1, p. 93-116, 2009. (doi:10.4136/ambi-agua.76)

\section{INTRODUÇÃO}

Sub-bacias são compartimentos indicados para o gerenciamento ambiental, possibilitando o monitoramento hidrológico, a conservação do solo e a disciplina do uso da terra para produção de água em qualidade e quantidade, proteção da biodiversidade e produção sustentável.

A vulnerabilidade do solo à erosão pode ser indicada por parâmetros físicos e químicos, processos biológicos e antropogênicos. Os parâmetros antropogênicos, como a conversão da cobertura vegetal em outros usos, são responsáveis por expressivas alterações do ambiente natural e mudanças na paisagem, provocadas pela erosão do solo, o assoreamento e a contaminação dos recursos - água e solo, a redução na biodiversidade, dentre outros.

Para quantificar a perda de solo por erosão laminar, modelos, como a equação empírica USLE (Universal Soil Loss Equation) (Wischmeier e Smith, 1978), e o WEPP (Water Erosion Prediction Project), estimam perda de solo, sendo o WEPP mais completo, estimando também a deposição e taxa de arraste de sedimentos em sulcos (Flanagan e Nearing, 1995), mas exigindo um grande número de parâmetros de entrada (Bacchi et al., 2000).

A especificidade desses modelos, desenvolvidos experimentalmente, mostra que são apropriados para aplicação em escalas maiores, como uma gleba de terra ou uma microbacia, não em larga escala, quando existe conectividade entre feições, como bacias a montante e a jusante, ou quando a erosão de uma área pode contribuir com o assoreamento de outras áreas. A bacia hidrográfica com seus parâmetros morfométricos e de fluxo hídrico, pode ser então um método complementar na indicação da vulnerabilidade de terras (Costa et al., 2007).

Para os parâmetros obtidos por bacias hidrográficas, com pertinência à vulnerabilidade das terras, ainda não existem modelos empíricos comprovados, não sendo possível estabelecer relações estatísticas e funções, mesmo porque o índice de vulnerabilidade não é uma variável de mensuração definida, como a perda de solo em uma parcela. Uma forma é recorrer à integração temática por meio de um modelo de suporte à decisão. Um modelo usual e simples é a analise multicriterial (AMC), que executa a agregação de critérios, com a combinação linear de pesos, WLC (Eastman et al., 1995), para gerar variáveis objetivos, como índices de vulnerabilidade (Mendes e Motizuki, 2001; Fuller et al., 2002; Costa et al., 2003).

Essa técnica permite integrar uma complexidade de fatores de diferentes naturezas e escalas, atendendo a um ou múltiplos objetivos, embora forneça resultados com menor consistência e de difícil validação, comparado a um modelo empírico. Sua estratégia é o equilíbrio entre máxima descompensação entre fatores e o máximo risco (Eastman et al., 1995).

A USLE correlaciona a perda de solo com a capacidade erosiva de chuvas intensas, com a erodibilidade do solo, com a declividade contínua do terreno (rampa), com o grau de proteção da cobertura/uso da terra e com o nível de conservação do solo, exigindo o levantamento do perfil de solos, análise mineralógica e de infiltração para o cálculo da erodibilidade. As práticas de conservação de solo devem ser levantadas para cada gleba, e o grau de proteção da classe de uso/cobertura da terra tem que ser obtido, motivo pelo qual torna geralmente inviável sua aplicação em grandes extensões, para avaliar o grau de vulnerabilidade das terras. Por outro lado, parâmetros de bacias hidrográficas são relativamente fáceis de obter por meio de dados de sensoriamento remoto e técnicas de geoprocessamento, devendo-se investigar relações de pertinência entre a vulnerabilidade e parâmetros de bacias.

Parâmetros morfométricos, topográficos, hidrológicos e de uso/cobertura da terra, extraídos por bacias, tem alguma similaridade com os parâmetros da USLE, sendo alguns 
COSTA, T. C. C.; FIDALGO, E. C. C.; NAIME, U. J.; GUIMARÃES, S. P.; ZARONI, M. J.; UZEDA, M. C. Vulnerabilidade de sub-bacias hidrográficas por meio da equação universal de perda de solo e da integração de parâmetros morfométricos, topográficos, hidrológicos e de uso/cobertura da terra no estado do Rio de Janeiro, Brasil. Ambi-Agua, Taubaté, v. 4, n. 1, p. 93-116, 2009. (doi:10.4136/ambi-agua.76)

complementares. A forma da bacia e o escoamento superficial (runoff), por exemplo, não são considerados na equação universal, devido à sua abordagem pontual. Por outro lado, a fragilidade do solo não é considerada na parametrização de sub-bacias, que exigiria os mesmos levantamentos requeridos pela USLE.

O objetivo deste trabalho foi comparar a equação universal de perda de solo com uma metodologia que estabelece uma medida adimensional de vulnerabilidade em sub-bacias, por meio da integração temática de parâmetros morfométricos, topográficos, hidrológicos e de uso/cobertura da terra.

\section{MATERIAL E MÉTODOS}

A área experimental utilizada foi o estado do Rio de Janeiro, com ampla variação do meio físico, representado por sete unidades geomorfológicas (IBGE, 1983), que vão das planícies costeiras, entremeadas por colinas e maciços costeiros, e tabuleiros costeiros. Em direção ao interior, estão a Serra do Mar, o vale do rio Paraíba do Sul e pequenas porções da Serra da Mantiqueira. Fenômenos orográficos e de continentalidade conferem grandes amplitudes pluviométricas, assim como as variações edáficas e topográficas definem regiões distintas em uma pequena porção do território, garantindo variabilidade para o estudo proposto.

Para a delimitação das sub-bacias e a extração de variáveis morfométricas e topográficas, foi utilizado o modelo digital de elevação (MDE) da Missão de Lançamento de Radar Topográfico (SRTM) pela NASA (2005), resolução 90 x 90m, compatível com a escala 1:100.000 (Santos et al. 2005). Para corrigir o modelo, foram realizadas operações de interpolação de falhas, atenuação de ruídos e ajuste de depressões. As pequenas falhas foram interpoladas pela média de pixels vizinhos. As regiões com grandes falhas foram interpoladas separadamente, usando o método de kriging, por meio do software de modelagem geoestatística - GSTAT (Pebesma, 1998).

A atenuação de ruídos foi realizada com a transformação de Fourier, reconstituindo-se uma imagem corrigida ou melhorada, com um procedimento de filtragem no domínio das freqüências (Jensen, 1996, Figueiredo, 1977, Eastman, 2003). A finalidade dessa transformação foi suavizar feições para aumentar a eficiência e precisão na detecção automática, testando-se a aderência com sub-bacias delimitadas manualmente. O ajuste de depressões, que impedem a continuidade do fluxo hídrico, foi executado identificando pixels com cotas mais baixas, que têm variação de cota maior que o limiar estabelecido em relação a sua vizinhança, para serem uniformizados para a cota mais baixa da vizinhança, permitindo a continuidade do fluxo.

A delimitação de sub-bacias foi gerada automaticamente pelo método proposto por Janson e Domingue (1988), com o modelo MDE/SRTM corrigido, e foi editada com o apoio de 100 Cartas Topográficas da Divisão do Serviço Geográfico do Exército (DSG) e do IBGE na escala 1:50.000 que recobrem o Estado.

Baseando-se em uma revisão sobre variáveis morfométricas (Collares, 2000; Teixeira e Cruz, 2005; Ribeiro e Salomão, 2003; Milani e Canali, 2000; Rocha, 1991), foram selecionados parâmetros morfométricos e topográficos das sub-bacias, adequados para a escala de trabalho.

O parâmetro morfométrico densidade de drenagem é dado pela fórmula $D D=\frac{C D}{A}$, sendo $\mathrm{CD}=$ comprimento de drenagem, dado por $C D=\sum R+\sum C+\sum T$, sendo $\mathrm{R}=$ ravinas; $\mathrm{C}=$ canais; e $\mathrm{T}=$ tributários, em km; e A = área da sub-bacia, em hectare (ha). 
COSTA, T. C. C.; FIDALGO, E. C. C.; NAIME, U. J.; GUIMARÃES, S. P.; ZARONI, M. J.; UZEDA, M. C. Vulnerabilidade de sub-bacias hidrográficas por meio da equação universal de perda de solo e da integração de parâmetros morfométricos, topográficos, hidrológicos e de uso/cobertura da terra no estado do Rio de Janeiro, Brasil. Ambi-Agua, Taubaté, v. 4, n. 1, p. 93-116, 2009. (doi:10.4136/ambi-agua.76)

Para a detecção da drenagem a partir do modelo digital de elevação, o escoamento superficial foi reclassificado a partir de testes com limiares, verificando-se a superposição da drenagem gerada com composições coloridas Landsat e o layer de drenagem das cartas topográficas. As linhas de drenagem obtidas dessa forma representam ravinas, canais e tributários não restituídos nas cartas topográficas do levantamento sistemático do DSG e do IBGE.

Para estimar o comprimento da drenagem na estrutura raster, formada por segmentos contínuos de pixels de 90 x 90 m, executou-se o seguinte procedimento: um segmento é um conjunto de direções vertical, horizontal, ou diagonal, em que cada pixel participa com um comprimento de 90 metros (se a direção for vertical ou horizontal), ou com um comprimento de 127,279 metros, se a direção for diagonal. Dessa forma, estima-se o comprimento de drenagem como: $C D=n$ pixels $(2 \times 90 \mathrm{~m}+1 \times 127,279 \mathrm{~m}) / 3=n$ pixels $\times 102,426 \mathrm{~m}$.

Para validação da densidade de drenagem estimada, os valores foram comparados com os de 13 microbacias da sub-bacia do rio Soturno, obtidos em levantamento de campo por Rocha (1991).

O parâmetro morfométrico índice de circularidade, é calculado pela expressão IC=A/AC, sendo $\mathrm{A}=$ área da bacia (ha) e $\mathrm{AC}=$ área do círculo de perímetro igual ao da bacia considerada $\left(\mathrm{AC}=\mathrm{P}^{2} / 4 \pi\right)$.

O parâmetro declividade percentual média da bacia (DECL) foi calculado do modelo digital de elevação pelo gradiente médio entre células vizinhas, pelo módulo Slope do Idrisi (Eastman, 2003), usando a fórmula:

$$
D E C L=\sqrt{\left(\frac{A l t_{\text {dir }}-A l t_{\text {esq }}}{180}\right)^{2}+\left(\frac{A l t_{\text {sup }}-A l t_{\text {inf }}}{180}\right)^{2}} * 100
$$

O desvio padrão da altitude (DPALT) é um parâmetro complementar à declividade média, mensurando a dispersão da altitude. Bacias com maior dispersão em altitude apresentam maior velocidade hídrica, devido às maiores amplitudes topográficas e, portanto, maior capacidade de arraste do solo, sendo mais vulneráveis.

O parâmetro hidrológico, escoamento superficial (RUNOFF), indica a situação de cada pixel em relação à captação pluvial e recepção de água de áreas vizinhas, incluindo a de bacias a montante, na direção do fluxo hídrico. O parâmetro indicador da magnitude do escoamento superficial para uma sub-bacia é o seu valor máximo, conforme o exemplo dado na Figura 1.

Na comparação entre a média, total e valor máximo, a média atenua a intensidade real de escoamento na bacia, enquanto o parâmetro total o superestima, porque acumula o escoamento. O parâmetro que informa o escoamento superficial total da chuva na bacia é ovalor máximo do pixel que se encontra na foz. Por causa da conexão entre bacias a montante e a jusante, esse valor não é somente a quantidade de chuva precipitada na bacia, mas indica bacias com maior recepção na drenagem, considerando bacias a montante. Esse parâmetro foi calculado pelo módulo RUNOFF do Idrisi, utilizando-se a precipitação anual em mm, 
COSTA, T. C. C.; FIDALGO, E. C. C.; NAIME, U. J.; GUIMARÃES, S. P.; ZARONI, M. J.; UZEDA, M. C. Vulnerabilidade de sub-bacias hidrográficas por meio da equação universal de perda de solo e da integração de parâmetros morfométricos, topográficos, hidrológicos e de uso/cobertura da terra no estado do Rio de Janeiro, Brasil. Ambi-Agua, Taubaté, v. 4, n. 1, p. 93-116, 2009. (doi:10.4136/ambi-agua.76)

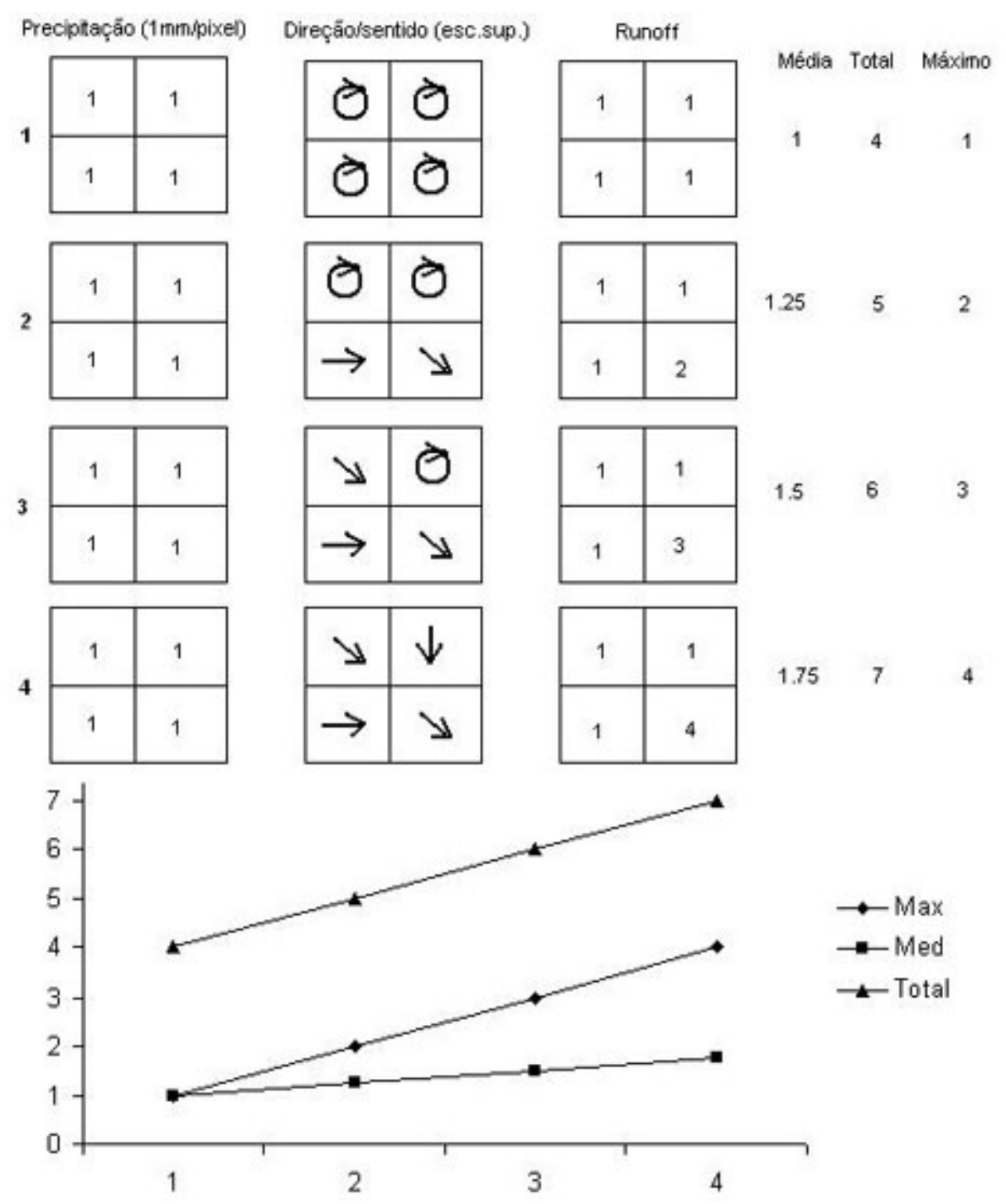

Figura 1. Escoamento superficial para uma área de captação de quatro pixels, variando da condição completamente plana para o máximo escoamento superficial, com recepção de $1 \mathrm{~mm}$ de chuva por pixel.

espacializada pela interpolação por kriging, no software de modelagem geoestatística-GSTAT (Pebesma, 1998), com os dados da série histórica de 1973 a 2000, de 18 estações pertencentes ao Instituto Nacional de Meteorologia (INMET) e 59 estações pluviométricas da Agência Nacional de Águas (2005) (Alfonsi et al., 2003). Parâmetros de infiltração de água no solo não foram considerados, significando que toda a água precipitada irá escorrer.

Os parâmetros de uso/cobertura da terra referem-se às classes de maior ocorrência no mapeamento e correspondem às proporções de área na sub-bacia. Foram consideradas: área relativa da cobertura florestal dada pela área de fragmentos/área da sub-bacia (COBVEG) do mapeamento de remanescentes da Mata Atlântica (Fundação SOS Mata Atlântica, 2002), na escala 1:50.000; e áreas relativas de agricultura (AGRIC), pastagem (PAST) e área urbana (URBAN), extraídas do mapeamento do uso/cobertura da terra (Fundação Centro de Informações e Dados do Rio de Janeiro, 2000).

A correlação entre os parâmetros foi avaliada, tendo como critério a agregação de parâmetros com alto grau de correlação. 
COSTA, T. C. C.; FIDALGO, E. C. C.; NAIME, U. J.; GUIMARÃES, S. P.; ZARONI, M. J.; UZEDA, M. C. Vulnerabilidade de sub-bacias hidrográficas por meio da equação universal de perda de solo e da integração de parâmetros morfométricos, topográficos, hidrológicos e de uso/cobertura da terra no estado do Rio de Janeiro, Brasil. Ambi-Agua, Taubaté, v. 4, n. 1, p. 93-116, 2009. (doi:10.4136/ambi-agua.76)

\subsection{Vulnerabilidade de sub-bacia hidrográfica}

O índice de vulnerabilidade de sub-bacias foi calculado por meio da agregação entre $n$ parâmetros ( $\mathrm{x}_{\mathrm{i}}$ ), pela média aritmética, em que a variável objetivo (S) é o índice de vulnerabilidade: $\mathrm{S}=\Sigma \mathrm{x}_{\mathrm{i}} / \mathrm{n}$. Esse critério foi adotado pelo desconhecimento especialista para arbitrar diferentes graus de importância entre os fatores, não sendo necessário aplicar a AHP (Analytical Hierarchy Process), técnica de atribuição de pesos extrínsecos $\left(\mathrm{w}_{\mathrm{i}}\right)$ aos fatores (Eastman, 2003).

Por causa das diferentes escalas em que cada fator é mensurado, esses foram normalizados para uma escala continua (1byte) que se estende do valor de menor vulnerabilidade (0) para o valor de maior vulnerabilidade (255). A transformação de valores foi linear, que segue a relação de pertinência de cada fator, sendo a proporção de cobertura vegetal, o único fator com relação inversa à vulnerabilidade de bacias.

\subsection{Equação Universal de Perda de Solo}

A USLE é uma equação empírica não linear que estima perda de solo (A), em $\mathrm{Mg} / \mathrm{ha}$. ano, por meio dos fatores $\mathrm{R}=$ erosividade da chuva (MJ.mm/ha.h.ano), $\mathrm{K}=$ erodibilidade do solo (Mg.h/MJ.mm), L = comprimento de rampa (m), $\mathrm{S}=$ declividade (classes em graus), $\mathrm{C}=$ uso e manejo (magnitude da contribuição), e $\mathrm{P}=$ práticas conservacionistas (magnitude da mitigação): A = R x K x L x S x C x P.

$\mathrm{O}$ fator R, uma medida da intensidade da energia cinética da chuva, foi estimado pela soma dos valores mensais do índice de erosividade, em MJ.mm/ha.h.mês obtidos pela equação $\mathrm{Rm} \approx \mathrm{EI}_{30} \approx 89,823\left(\mathrm{r}^{2} / \mathrm{P}\right)^{0,759}$, recomendada por Lombardi para as condições do Estado do Rio de Janeiro, em Carvalho Júnior (1985). Essa equação é uma aproximação do produto da energia cinética da chuva (E) pela sua intensidade máxima em 30 min $\left(\mathrm{I}_{30}\right)$. Foram utilizados os dados de precipitação mensal (r) e anual (P), em mm, da série histórica de 1973 a 2000, e a espacialização da erosividade foi gerada pela interpolação por kriging no software GSTAT.

A erodibilidade é determinada pelas características físicas, químicas e morfológicas do solo. Para estimar o fator K, tomou-se como base o mapa de solo do estado do Rio de Janeiro publicado em Carvalho Filho et al. (2003a; 2003b), na escala 1:250.000. A definição do fator $\mathrm{K}$ para as 161 unidades de mapeamento de solo para o estado do Rio de Janeiro, sendo 458 classes distribuídas em quatro níveis categóricos, foi realizada por meio de levantamento bibliográfico de valores de $\mathrm{K}$ para classes ocorrentes ou similares às presentes no estado do Rio de Janeiro (Bertoni e Lombardi Neto 1985; Galdino et al., 2003; Longhi e Meneses, 2005; Moreira Sá et al., 2004; Pimenta 2005a; Silva, 2004; Vasquez-Fernandez et al., 1996). Esses valores foram sistematizados e outlyers foram eliminados.

A etapa seguinte foi o enquadramento em graus de erodibilidade das classes de solo, com sua posterior conversão para valores de $\mathrm{K}$ padronizados (Tabela 1). Como exemplo, pesquisados os valores de $\mathrm{K}=0,008,0,028$ e 0,033 para a classe Argissolo Vermelho Eutrófico, o valor 0,008 foi eliminado e a classe obteve o grau de moderado a forte, recebendo o K padronizado de 0,030 .

A próxima etapa correspondeu ao cálculo do fator $\mathrm{K}$ para as 161 unidades de mapeamento pedológico, considerando as diferentes proporções de ocorrência das classes de solo, identificadas até o $4^{\circ}$ nível categórico, ou seja, para cada unidade podem existir até quatro classes de solos, de forma que as proporções de ocorrências dessas classes estão discriminadas. Assim, em cada unidade de mapeamento, executa-se uma ponderação entre os fatores K de cada classe de solo por sua proporção na unidade, obtendo-se a média ponderada para cada unidade de mapeamento (Tabela 2). 
COSTA, T. C. C.; FIDALGO, E. C. C.; NAIME, U. J.; GUIMARÃES, S. P.; ZARONI, M. J.; UZEDA, M. C. Vulnerabilidade de sub-bacias hidrográficas por meio da equação universal de perda de solo e da integração de parâmetros morfométricos, topográficos, hidrológicos e de uso/cobertura da terra no estado do Rio de Janeiro, Brasil. Ambi-Agua, Taubaté, v. 4, n. 1, p. 93-116, 2009. (doi:10.4136/ambi-agua.76)

Tabela 1. Graus de Limitação devidos à erodibilidade.

\begin{tabular}{cc}
\hline Graus de Limitação & Fator K: erodibilidade (Mg.h/MJ.mm) \\
\hline 0: nulo & $\mathrm{K}<=0,010$ \\
1: ligeiro & $0,010<=\mathrm{K}<0,020$ \\
2: moderado & $0,020<=\mathrm{K}<0,030$ \\
3: forte & $0,030<=\mathrm{K}<0,040$ \\
4: muito forte & $\mathrm{K}>=0,040$ \\
\hline
\end{tabular}

Fonte: Adaptado de Giboshi (1999).

A próxima etapa correspondeu ao cálculo do fator $\mathrm{K}$ para as 161 unidades de mapeamento pedológico, considerando as diferentes proporções de ocorrência das classes de solo, identificadas até o $4^{\circ}$ nível categórico, ou seja, para cada unidade podem existir até quatro classes de solos, de forma que as proporções de ocorrências dessas classes estão discriminadas. Assim, em cada unidade de mapeamento, executa-se uma ponderação entre os fatores $\mathrm{K}$ de cada classe de solo por sua proporção na unidade, obtendo-se a média ponderada para cada unidade de mapeamento (Tabela 2).

Tabela 2. Média ponderada de K para a unidade de mapeamento PAx3.

\begin{tabular}{l|lcc}
\hline Unidade & \multicolumn{1}{|c}{ Classes de solo } & Proporção (\%) & Fator K \\
\hline \multirow{4}{*}{ PAx3 } & Argissolo Amarelo coeso & 40 & 0,030 \\
& Argissolo Amarelo distrófico & 30 & 0,025 \\
& Argissolo Vermelho-Amarelo distrófico & 30 & 0,025 \\
& & & \\
\cline { 2 - 4 } & Total & $\mathbf{1 0 0}$ & $\mathbf{0 , 0 2 7}$ \\
\hline
\end{tabular}

O fator LS foi obtido pelo módulo da equação de perda de solo revisada (RUSLE) do Idrisi Kilimanjaro, utilizando-se o MDE/SRTM. O valor do comprimento de rampa é dado por: $L=(\lambda / 22,13)^{\mathrm{m}}$, sendo 22,13, o comprimento da parcela experimental em metros (Wishmeier e Smith, 1978); $\lambda$ = projeção horizontal do comprimento de rampa; e $\mathrm{m}=$ variável comprimento-declividade, definido pela expressão (Renard et al., 1997): $m=\beta$ / (1+ $\beta$ ), onde $\beta$ é a razão da erosão em sulcos, causada pelo fluxo da água, pela erosão na região entre sulcos, causada principalmente pelo impacto da chuva.

Em solos onde a susceptibilidade à erosão em sulcos e entre sucos é moderada, $\beta$ é dado pela fórmula (McCool et al., 1989, in: Eastman, 2003): $\beta=(\operatorname{sen} \theta / 0,0896) /[3 \times(\operatorname{sen} \theta) 0,8+$ $0,56]$, sendo $\theta$ a declividade.

Um fator de ajuste para $\beta$ é aplicado conforme limiares estabelecidos para o fator $\mathrm{C}$, do uso e cobertura do solo: se o solo for exposto $(\mathrm{C}=1), \beta$ será multiplicado por 2 ; se a cobertura no solo for do tipo $(\mathrm{C})<=0,004$, $\beta$ será dividido por 2 .

O cálculo do fator S (steepness, classes de declive, ou declividade máxima na direção da rampa), é dado pelas expressões (McCool et al., 1987, in: Eastman, 2003) conforme o limiar de declividade: $S=10,8 \times$ sen $\theta+0,03$ para $\theta<9 \%$; ou $S=16,8 \times$ sen $\theta-0,50$ para $\theta>=9 \%$.

O fator C, parâmetro de proteção do solo para cada classe de uso da terra, foi definido por meio de pesquisa bibliográfica (Bertoni e Lombardi Neto, 1985; Brito et al., 1998; Paranhas Filho et al., 2003; Bueno e Stein, 2004; Santos et al., 2005; Galdino, 2003; Moreira Sá et al., 2004; Pimenta, 2005b), considerando valores médios de classes similares ou iguais 
COSTA, T. C. C.; FIDALGO, E. C. C.; NAIME, U. J.; GUIMARÃES, S. P.; ZARONI, M. J.; UZEDA, M. C. Vulnerabilidade de sub-bacias hidrográficas por meio da equação universal de perda de solo e da integração de parâmetros morfométricos, topográficos, hidrológicos e de uso/cobertura da terra no estado do Rio de Janeiro, Brasil. Ambi-Agua, Taubaté, v. 4, n. 1, p. 93-116, 2009. (doi:10.4136/ambi-agua.76)

às ocorrentes no estado do Rio de Janeiro, do Mapa de Uso e Cobertura do Solo (Fundação Centro de Informações e Dados do Rio de Janeiro, 2000).

$\mathrm{O}$ fator $\mathrm{P}$ foi uniformemente definido como 1 (valor máximo), que indica a não existência de práticas conservacionistas, ou seja, a condição crítica no processo de erosão.

A perda de solo obtida por pixel foi convertida para a perda de solo média por sub-bacia hidrográfica, possibilitando a comparação entre os dois métodos pelo coeficiente de correlação de postos de Spearman (Siegel, 1956), devido à natureza não paramétrica de alguns dados.

\section{RESULTADOS E DISCUSSÃO}

\subsection{Vulnerabilidade de sub-bacia hidrográfica}

Os resultados de densidade de drenagem por sub-bacias em $\mathrm{km} / \mathrm{ha}$ (DD) foram comparados com os levantamentos detalhados em microbacias, em que os pontos em vermelho correspondem a DD e DECL de 13 microbacias da sub-bacia do Rio Soturno (Rocha, 1991) (Figura 2). Os dados de densidade de drenagem processados do MDE apresentam variação com amplitude similar aos dados de campo, sendo uma prova de consistência do método utilizado.

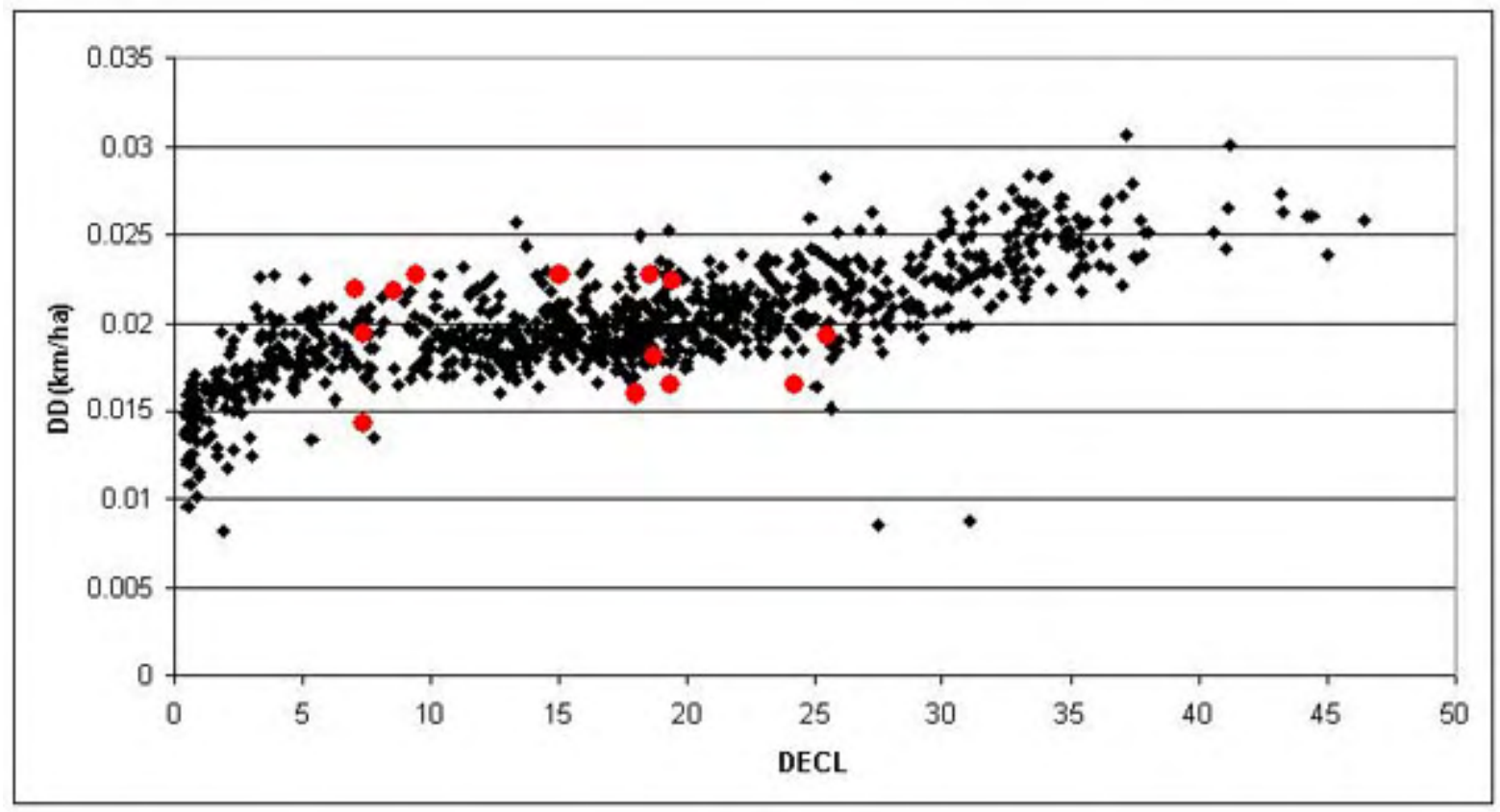

Figura 2. Dispersão da Densidade de Drenagem (DD em km/ha) em função da declividade média percentual de sub-bacias hidrográficas (DECL). Pontos em vermelho, Fonte: DD e DECL de 13 microbacias da sub-bacia do Rio Soturno (Rocha, 1991).

A densidade de drenagem é um indicador da eficiência natural ao escoamento superficial de água e se relaciona com o risco de ocorrência de cheias, processos erosivos e permeabilidade (transmissibilidade) do terreno. Bacias hidrográficas com altas densidades de drenagem apresentam baixas transmissibilidades (impermeáveis), ao contrário de bacias com baixas densidades de drenagem (permeáveis).

Foi constatada uma densidade de drenagem alta, entre 0,025 e 0,031 km/ha, nas Unidades dos Maciços Costeiros, Escarpas Serranas (Serra do Mar - Planalto da Bocaína e Serra dos Órgãos) e Mantiqueira Meridional - Planalto de Itatiaia (Figura 3). 
COSTA, T. C. C.; FIDALGO, E. C. C.; NAIME, U. J.; GUIMARÃES, S. P.; ZARONI, M. J.; UZEDA, M. C. Vulnerabilidade de sub-bacias hidrográficas por meio da equação universal de perda de solo e da integração de parâmetros morfométricos, topográficos, hidrológicos e de uso/cobertura da terra no estado do Rio de Janeiro, Brasil. Ambi-Agua, Taubaté, v. 4, n. 1, p. 93-116, 2009. (doi:10.4136/ambi-agua.76)

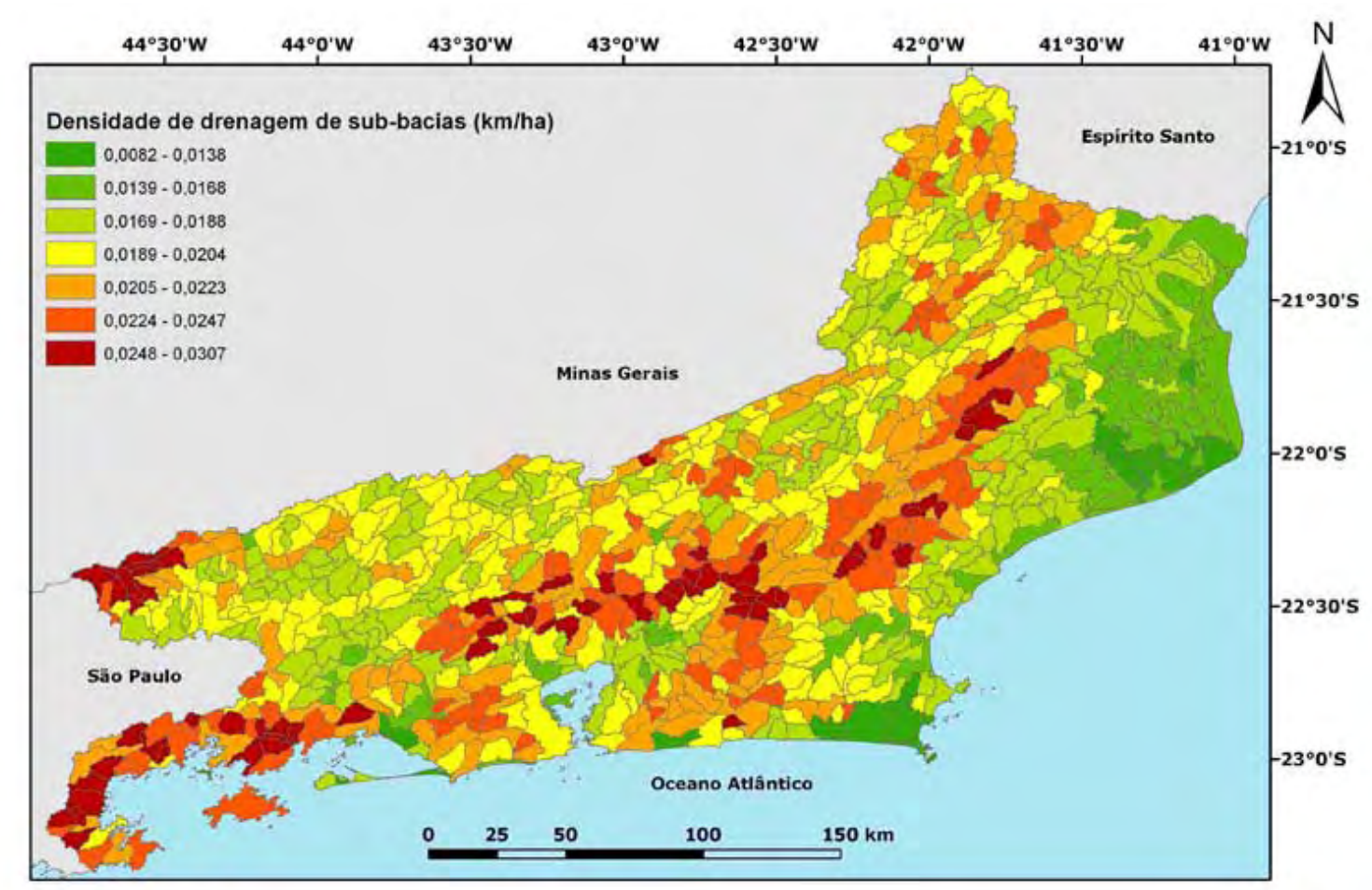

Figura 3. Densidade de drenagem (km/ha) para sub-bacias do estado do Rio de Janeiro.

Densidades intermediárias ocorrem nas depressões e nos alinhamentos de cristas do Paraíba do Sul, incluindo compartimentos planálticos do Leste de Minas, no Noroeste Fluminense e nas Colinas e Maciços Costeiros próximos ao litoral. Regiões com densidade de drenagem baixa são encontradas na baixada litorânea ao leste do Estado, nas Unidades Planícies Costeiras e Tabuleiros de Bacias Sedimentares, onde ocorre predominância de terrenos sedimentares, em que raramente aflora o substrato rochoso. Isso faz com que a transmissibilidade do terreno seja alta, diminuindo a densidade de drenagem nessas regiões. Essas unidades apresentam um baixo potencial de vulnerabilidade aos processos erosivos e movimentos de massa devido à baixa declividade.

Sub-bacias com maior desvio padrão da altitude na bacia (Figura 4) encontram-se protegidas por Unidades de Conservação (UC), como o Parque Nacional de Itatitaia e a APA da Serra da Mantiqueira, Parque Nacional dos Três Picos, Parque Nacional da Serra dos Órgãos, Reserva Biológica do Tinguá, Parque Nacional da Serra da Bocaina e Parque Estadual do Desengano. Essas áreas mantiveram os grandes remanescentes da Mata Atlântica, posteriormente protegidos pelo poder público.

O parâmetro de forma, índice de circularidade, mede a proximidade da forma da bacia ao círculo. Quanto mais próxima da forma circular $(\approx 1)$, maiores os riscos de erosão, assoreamento e enchente na bacia. Esse risco está relacionado com a velocidade e sincronia de tempo entre os escoamentos da água de chuva provenientes das cabeceiras dos rios.

Numa bacia de forma próxima da circular, os escoamentos convergem em instantes similares para pontos próximos, aumentando rapidamente o deflúvio acumulado para o canal principal da bacia, potencializando a carga hídrica, os processos erosivos, o assoreamento e com maior risco de enchentes. Em uma bacia alongada, o deflúvio ocorre em pontos distantes e com um tempo diferente para esses escoamentos chegarem ao mesmo ponto do canal principal, resultando em menor vazão.

O índice de circularidade (Figura 5) indicou uma fraca associação entre o formato da bacia e a geomorfologia e com a densidade de drenagem, declividade e variação da altitude na 
COSTA, T. C. C.; FIDALGO, E. C. C.; NAIME, U. J.; GUIMARÃES, S. P.; ZARONI, M. J.; UZEDA, M. C. Vulnerabilidade de sub-bacias hidrográficas por meio da equação universal de perda de solo e da integração de parâmetros morfométricos, topográficos, hidrológicos e de uso/cobertura da terra no estado do Rio de Janeiro, Brasil. Ambi-Agua, Taubaté, v. 4, n. 1, p. 93-116, 2009. (doi:10.4136/ambi-agua.76)

bacia (Tabela 3). A distribuição heterogênea do formato de bacias é observada em quase todas as formações, com exceção do norte fluminense, com depósitos sedimentares (planícies e tabuleiros), onde predomina a forma alongada.

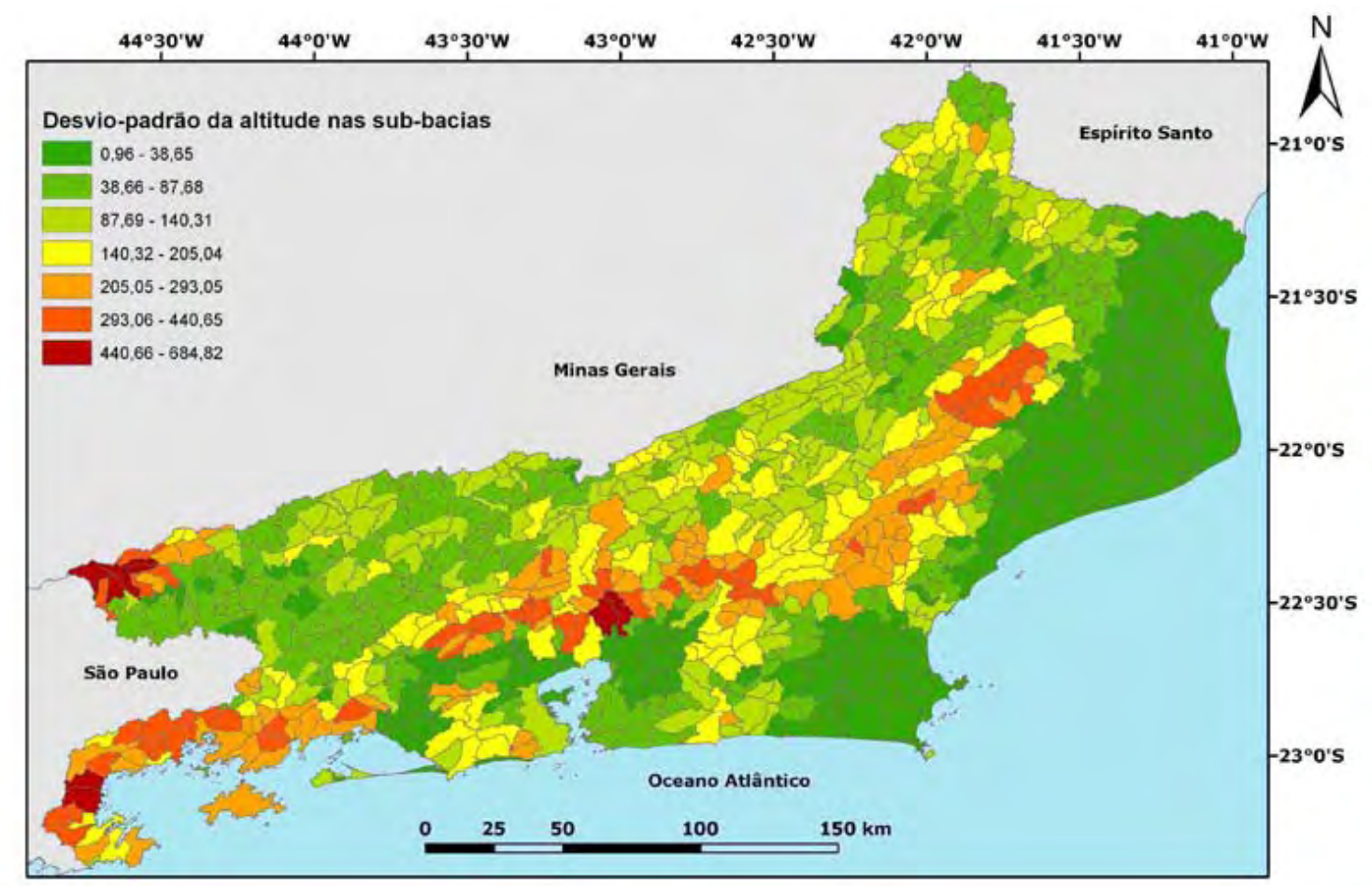

Figura 4. Desvio-padrão da altitude para sub-bacias do estado do Rio de Janeiro.

Tabela 3. Correlação de Spearman $>30(p<0,000000, n=883)$ entre parâmetros indicadores de vulnerabilidade de bacias hidrográficas.

\begin{tabular}{lccc}
\hline & Spearma & $\mathbf{t}(\mathbf{N}-2)$ & $\mathbf{p}$ \\
\hline DD e IC & 0,346115 & 10,9501 & 0,000000 \\
DD e DECL & 0,753299 & 33,9971 & 0,000000 \\
DD e DPALT & 0,831386 & 44,4072 & 0,000000 \\
DD e COBVEG & 0,485925 & 16,5023 & 0,000000 \\
IC e DECL & 0,313745 & 9,8077 & 0,000000 \\
DECL e DPALT & 0,902276 & 62,1142 & 0,000000 \\
DECL e COBVEG & 0,611666 & 22,9489 & 0,000000 \\
DECL e AGRIC & $-0,408066$ & $-13,2669$ & 0,000000 \\
DPALT e COBVEG & 0,673887 & 27,0724 & 0,000000 \\
DPALT e AGRIC & $-0,348089$ & $-11,0211$ & 0,000000 \\
COBVEG e PAST & $-0,351752$ & $-11,1533$ & 0,000000 \\
AGRIC e PAST & $-0,325082$ & $-10,2031$ & 0,000000 \\
\hline
\end{tabular}


COSTA, T. C. C.; FIDALGO, E. C. C.; NAIME, U. J.; GUIMARÃES, S. P.; ZARONI, M. J.; UZEDA, M. C. Vulnerabilidade de sub-bacias hidrográficas por meio da equação universal de perda de solo e da integração de parâmetros morfométricos, topográficos, hidrológicos e de uso/cobertura da terra no estado do Rio de Janeiro, Brasil. Ambi-Agua, Taubaté, v. 4, n. 1, p. 93-116, 2009. (doi:10.4136/ambi-agua.76)

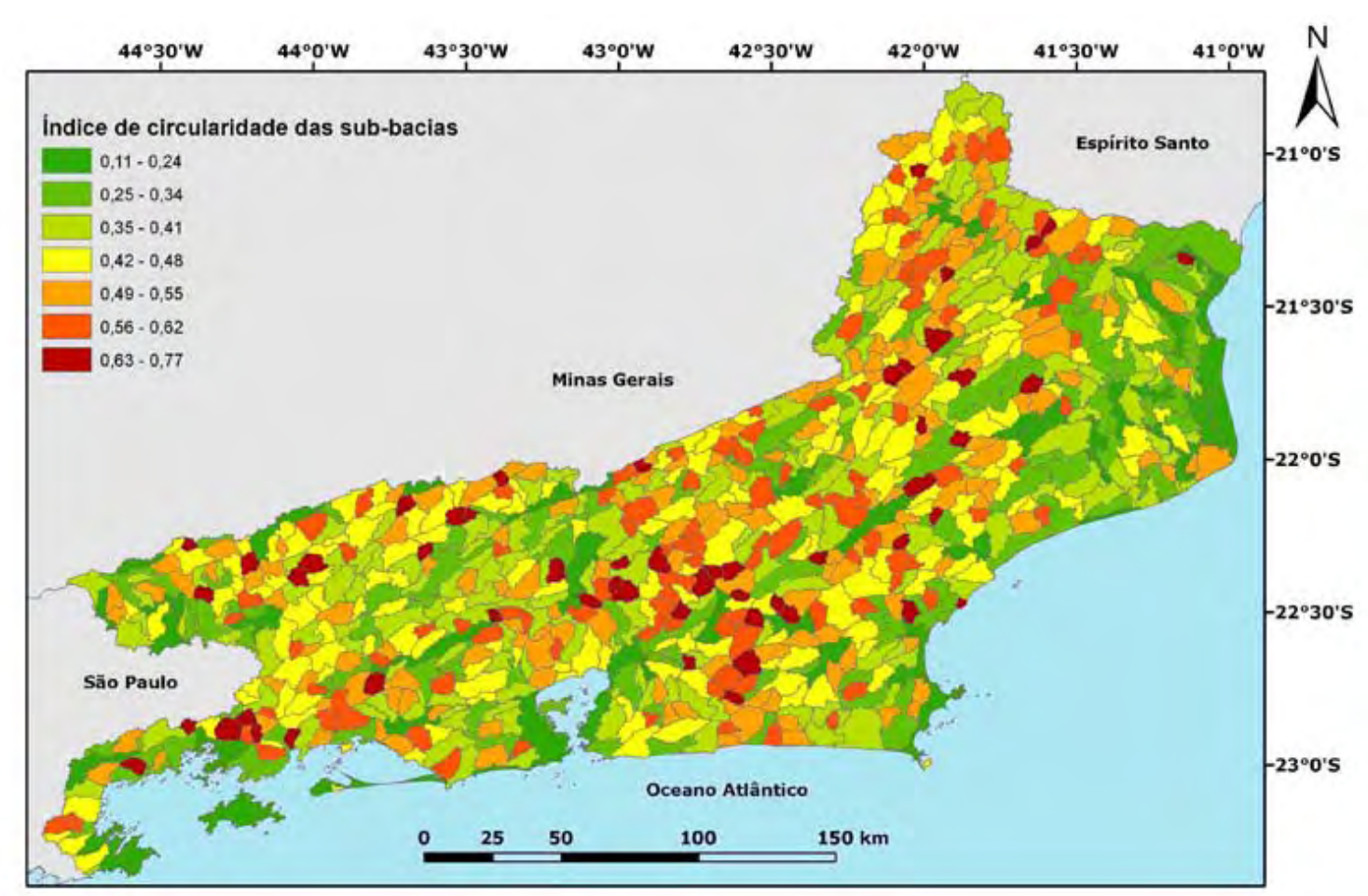

Figura 5. Índice de Circularidade para sub-bacias do estado do Rio de Janeiro.

O parâmetro RUNOFF é não correlacionado com outros parâmetros. A maior magnitude de escoamento superficial ocorre na região dos grandes rios, na lagoa de Araruama, no Norte Fluminense, em direção à Lagoa Feia, e para o oceano, na bacia de Campos (Figura 6). Nessa mesma região, ocorre uma concentração de sedimentos na faixa litorânea em direção ao alto mar, identificada em imagens de satélite Landsat. A moderada magnitude de escoamento superficial ocorre nos cordões arenosos, no delta do Paraíba do Sul, na saída para o manguezal de Guapimirim, que serve como um dissipador de energia, depositando sedimentos antes de atingir a baía de Guanabara. Outra região é a da baía de Sepetiba, onde se observam alguns sedimentos.

Verifica-se que o escoamento superficial é complementar às variáveis topográficas em processos erosivos, pois indica as regiões de maior deflúvio e potencial de arraste pela carga hídrica. Na Tabela 3 acima, são apresentadas as principais correlações significativas entre os parâmetros analisados. Densidade de drenagem, declividade percentual e desvio padrão da altitude na bacia são parâmetros com alta correlação entre si. A dispersão entre DECL e DPALT, que obteve a maior correlação $(>0,90)$ é visualizada na Figura 7.

Em análise de regressão, variáveis explicativas correlacionadas entre si causam instabilidades nos estimadores, devido à correlação serial. Em técnicas de agregação de dados temáticos, variáveis correlacionadas repetem a contribuição de atributos similares para o objetivo. Dessa forma, optou-se pelo produto entre as três variáveis, resultando na variável conjunta DDxDECLxDPALT.

Verificou-se que sub-bacias com maior densidade de drenagem ( $>\mathrm{DD})$, geralmente têm maior declividade média (>DECL) e variação de altitude (>DPALT). Essas condições compensam a maior propensão a processos erosivos, pelo acesso difícil às atividades antrópicas (<AGRIC, <PAST), favorecendo a manutenção da vegetação (>COBVEG). A ausência da cobertura vegetal é um fator de grande peso na vulnerabilidade de sub-bacias, principalmente em áreas críticas, como as de preservação permanente, definidas pelo Código Florestal (Brasil, 1965). 
COSTA, T. C. C.; FIDALGO, E. C. C.; NAIME, U. J.; GUIMARÃES, S. P.; ZARONI, M. J.; UZEDA, M. C. Vulnerabilidade de sub-bacias hidrográficas por meio da equação universal de perda de solo e da integração de parâmetros morfométricos, topográficos, hidrológicos e de uso/cobertura da terra no estado do Rio de Janeiro, Brasil. Ambi-Agua, Taubaté, v. 4, n. 1, p. 93-116, 2009. (doi:10.4136/ambi-agua.76)

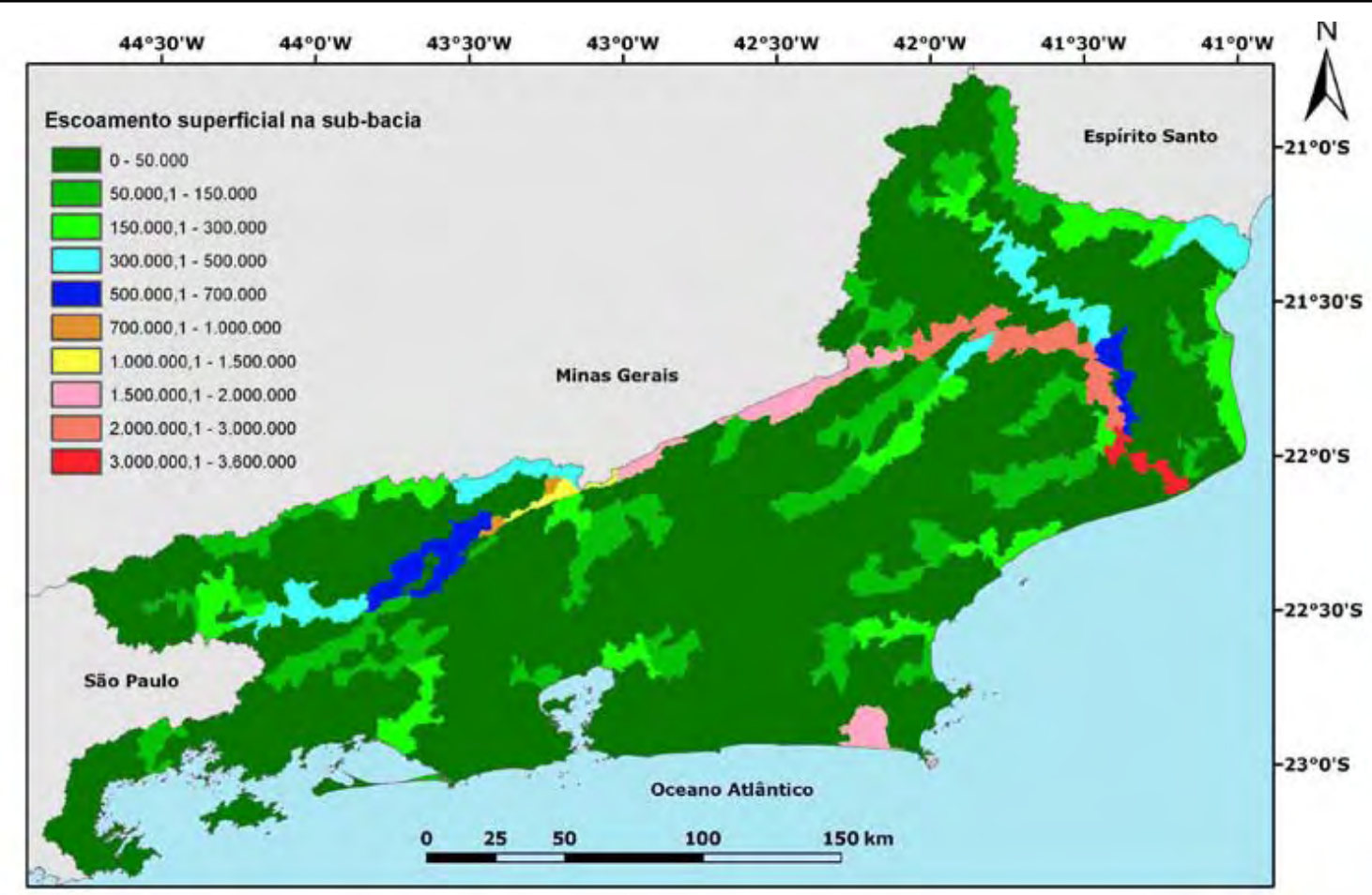

Figura 6. Escoamento superficial (mm/pixel) na foz de sub-bacias do estado do Rio de Janeiro.

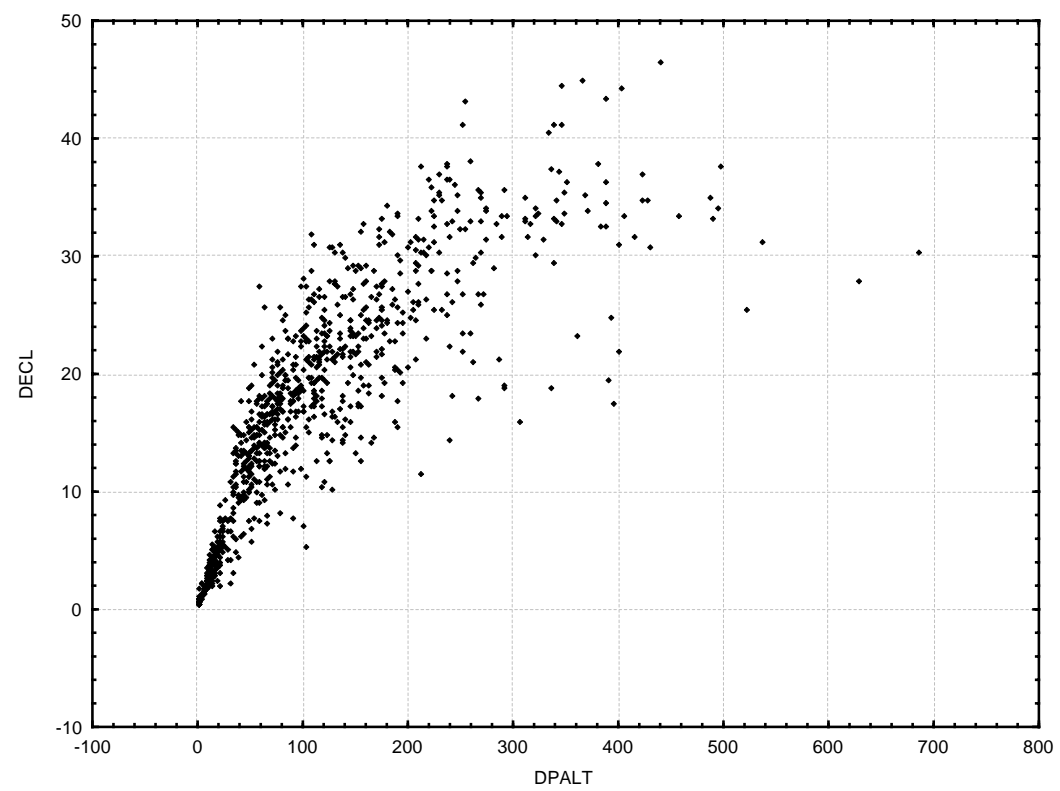

Figura 7. Dispersão da Declividade média percentual de sub-bacias hidrográficas (DECL), em função do desvio padrão da altitude (DPALT).

A agricultura (AGRIC) é um dos principais fatores de degradação, devido ao manejo inadequado que expõe o solo à erosão hídrica, afeta a estrutura e reduz a matéria orgânica. E as pastagens (PAST) constituem outro fator de vulnerabilidade, pois em manejos inadequados e em áreas inaptas são causas de compactação e perda da fertilidade do solo, resultando em processos erosivos, como ravinamentos, erosão laminar e voçorocamentos. E as áreas urbanas (URBAN) têm impactos potenciais em sub-bacias hidrográficas, exigindo ações corretivas 
pontuais, com gestão ambiental distinta do escopo rural. A impermeabilização do solo (aumentando o risco de enchentes), a ocupação em áreas com risco de deslizamento e a disposição de resíduos urbanos e industriais são alguns dos problemas relacionados com a vulnerabilidade em bacias hidrográficas urbanas.

Na Figura 8, é apresentado o índice de vulnerabilidade de bacias hidrográficas pela integração dos parâmetros: DDxDECLxDPALT, IC, RUNOFF, COBVEG, AGRIC, PAST, URBAN. Verifica-se uma concentração de sub-bacias mais vulneráveis no noroeste, com histórico da degradação de pastagens, no oeste do vale do Paraíba, e na região norte.

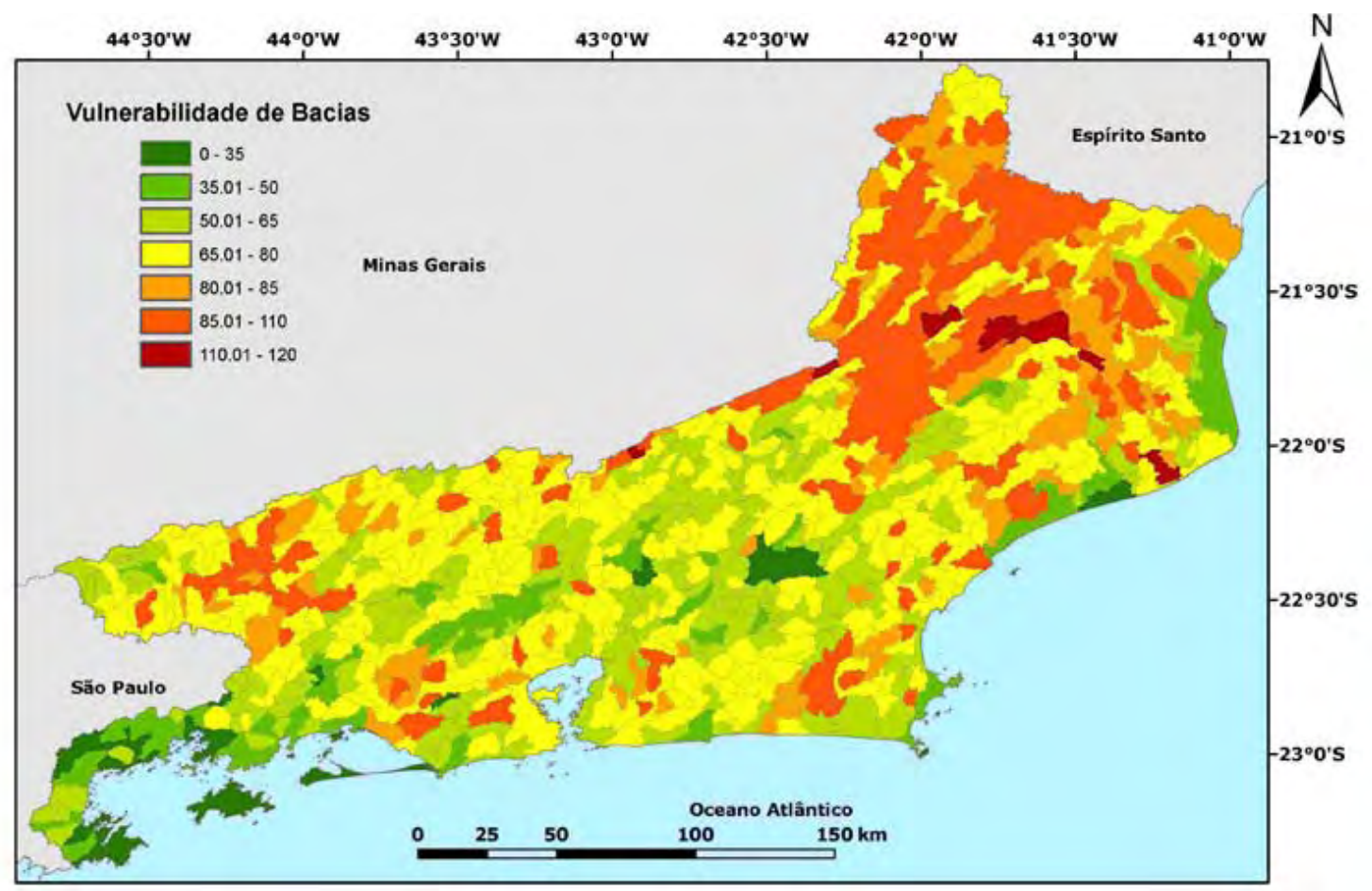

Figura 8. Índice de Vulnerabilidade de sub-bacias do estado do Rio de Janeiro.

\subsection{Equação Universal de Perda de Solo}

Considerando os parâmetros da USLE, o índice de erosividade (R) ficou entre 4000 e $11000 \mathrm{MJ} . \mathrm{mm} /$ ha.h.ano, com os maiores valores, acima de $10.000 \mathrm{MJ} . \mathrm{mm} /$ ha.h.ano, nas Serras do Mar e da Mantiqueira, e os menores valores no litoral norte fluminense, região dos Lagos e na parte leste da baía de Sepetiba (Figura 9).

As regiões com solos menos erodíveis (fator $\mathrm{K}$ ) concentram-se no norte fluminense, regiões alagadiças na baía de Sepetiba e manguezal de Guapimirim na baía de Guanabara, e as com solos mais erodíveis concentram-se na Serra do Mar, na região noroeste do estado do Rio de Janeiro e no leito do rio Paraíba do Sul na porção sul e centro do estado (Figura 10). 
COSTA, T. C. C.; FIDALGO, E. C. C.; NAIME, U. J.; GUIMARÃES, S. P.; ZARONI, M. J.; UZEDA, M. C. Vulnerabilidade de sub-bacias hidrográficas por meio da equação universal de perda de solo e da integração de parâmetros morfométricos, topográficos, hidrológicos e de uso/cobertura da terra no estado do Rio de Janeiro, Brasil. Ambi-Agua, Taubaté, v. 4, n. 1, p. 93-116, 2009. (doi:10.4136/ambi-agua.76)

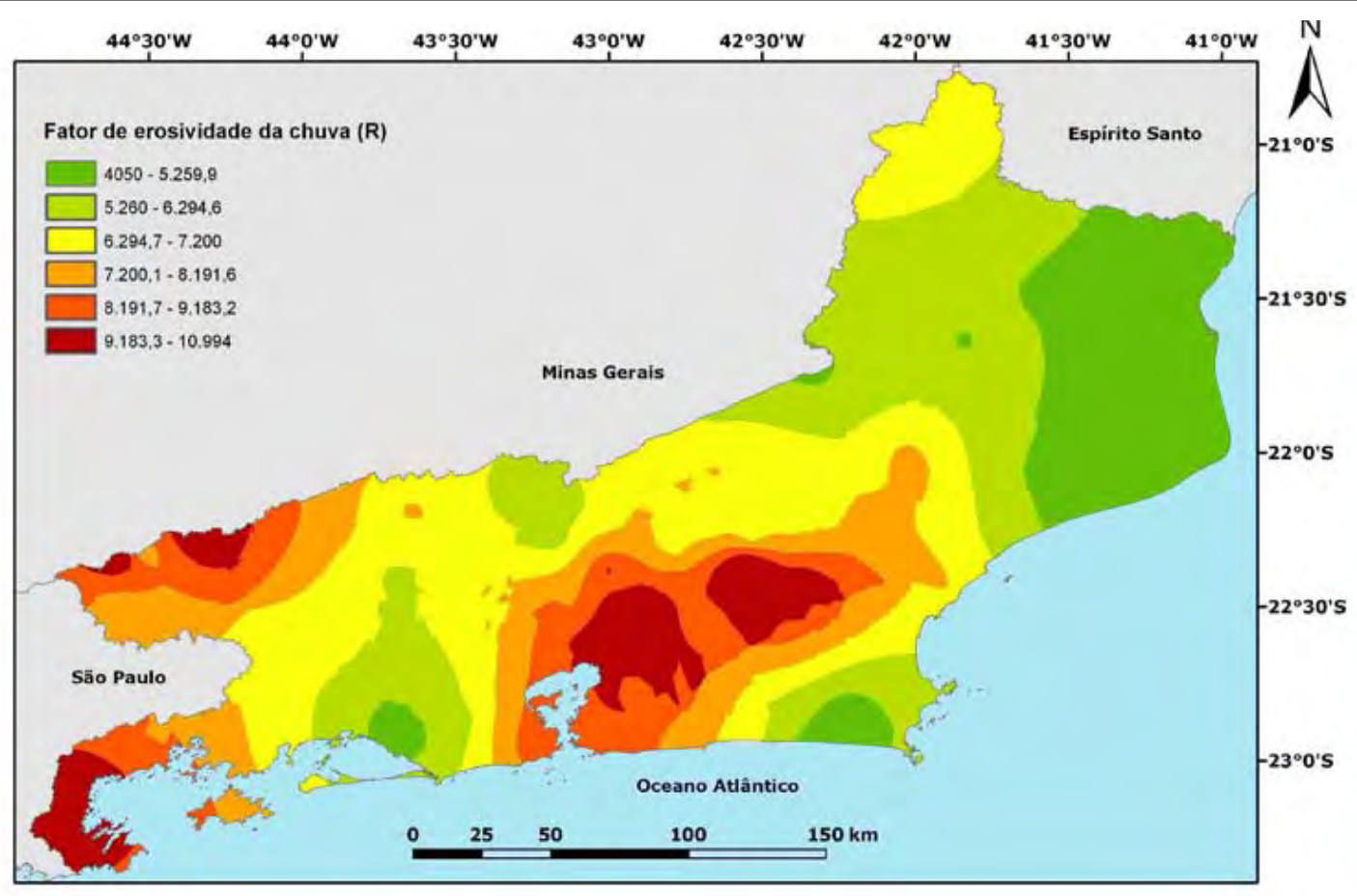

Figura 9. Índice de erosividade anual (R), EI em MJ.mm/ha.h.ano, para o estado do Rio de Janeiro.

Para o fator LS, observa-se alta correlação com o relevo, expressando seu maior valor nas feições escarpadas da Serra do Mar, da Mantiqueira e em maciços costeiros (Figura 11).

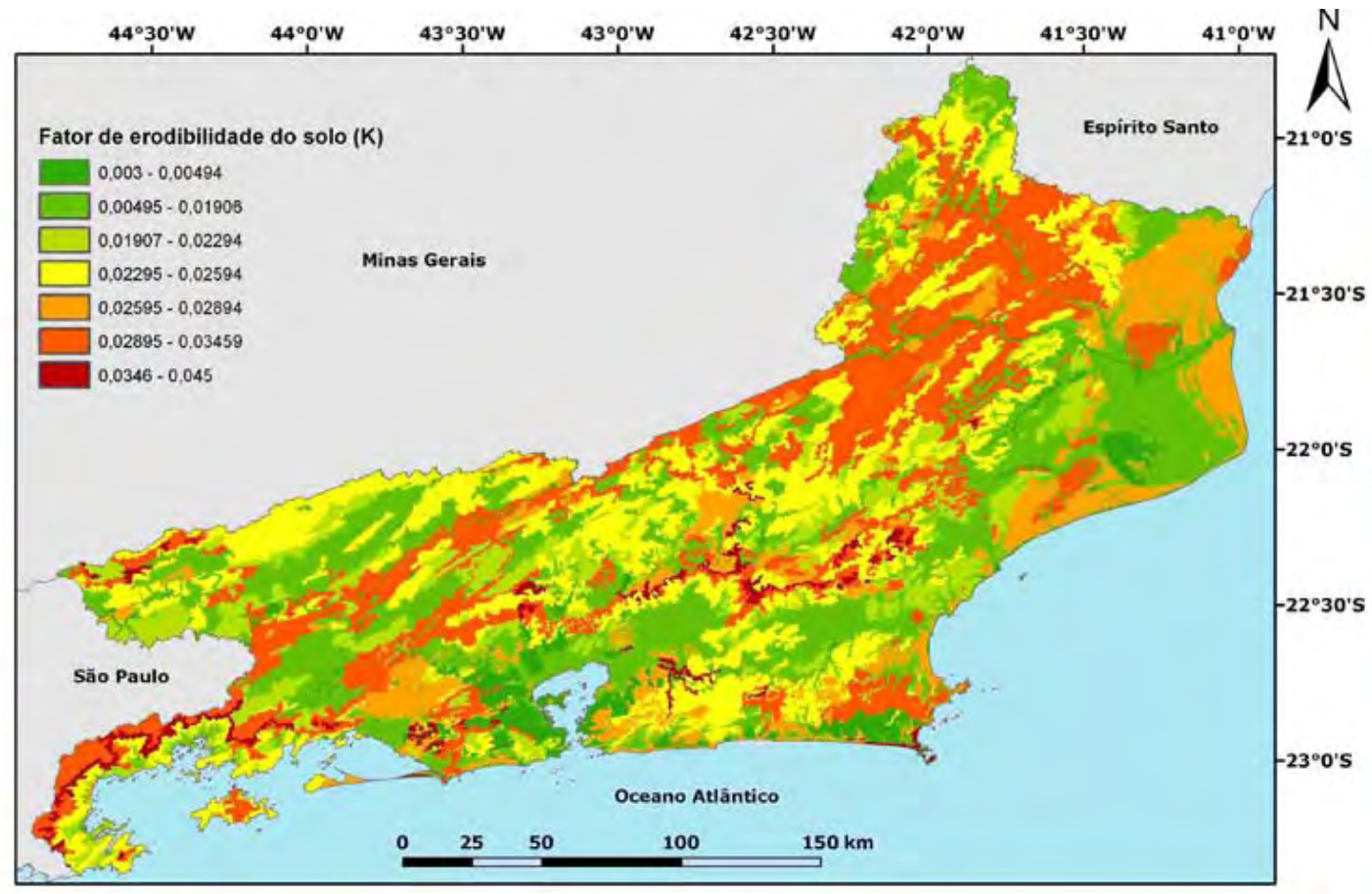

Figura 10. Erodibilidade do solo (fator K), em Mg.h/MJ.mm, para o estado do Rio de Janeiro. 
COSTA, T. C. C.; FIDALGO, E. C. C.; NAIME, U. J.; GUIMARÃES, S. P.; ZARONI, M. J.; UZEDA, M. C. Vulnerabilidade de sub-bacias hidrográficas por meio da equação universal de perda de solo e da integração de parâmetros morfométricos, topográficos, hidrológicos e de uso/cobertura da terra no estado do Rio de Janeiro, Brasil. Ambi-Agua, Taubaté, v. 4, n. 1, p. 93-116, 2009. (doi:10.4136/ambi-agua.76)

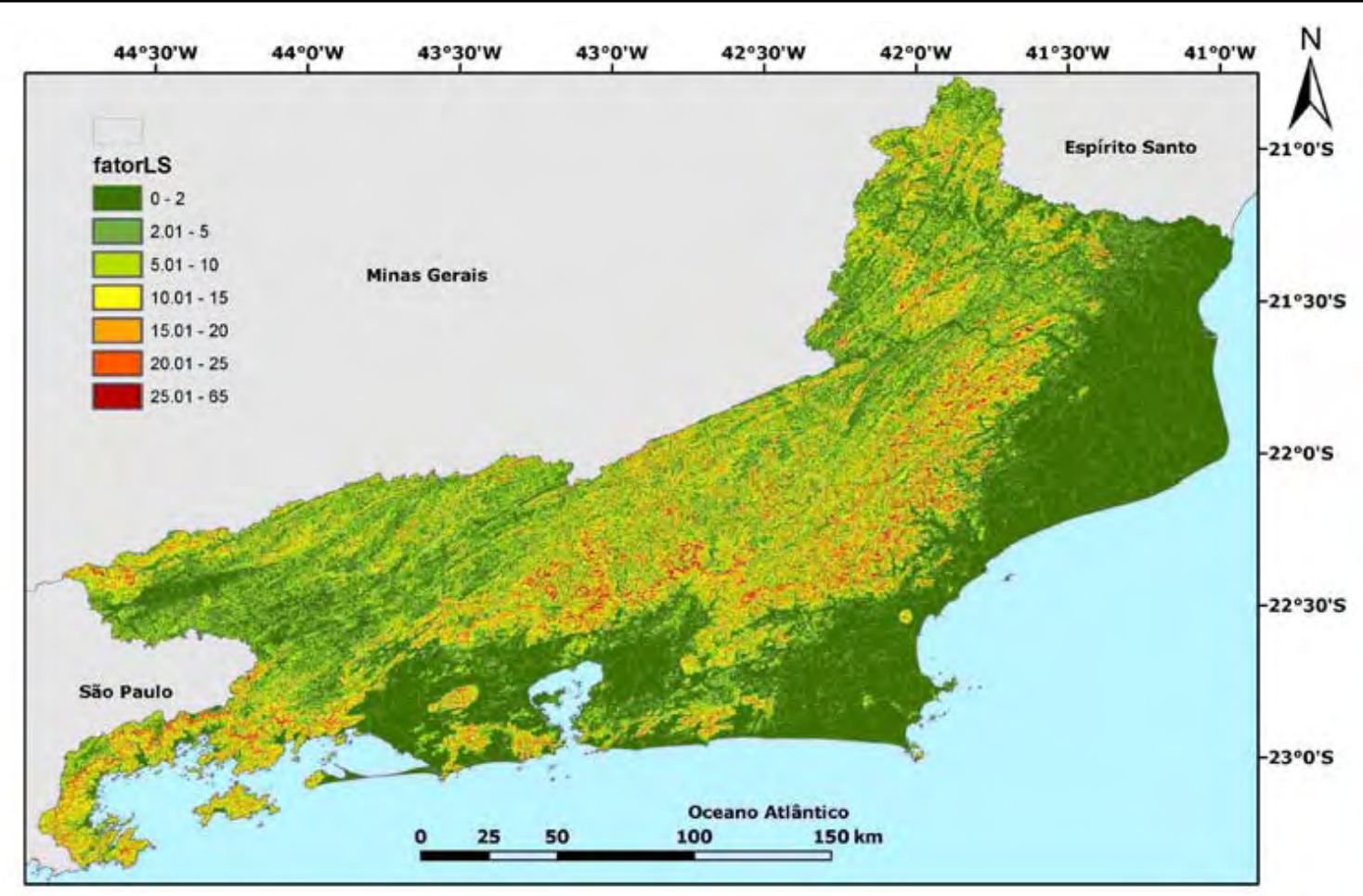

Figura 11. Fator LS para o estado do Rio de Janeiro.

O fator C foi atribuído para as classes do mapeamento de uso/cobertura da terra realizado pela Fundação CIDE, conforme apresentado na Tabela 4.

Na Figura 12 é apresentado o resultado da equação universal de perda de solo, obtendose a perda média de solo por sub-bacia (Mg/ha.ano). Paranhas Filho et al. (2003), com uma análise temporal de perdas de solo por erosão laminar para a bacia do rio Taquarizinho, no estado de Mato Grosso do Sul, obtiveram valores de perdas de 4,44 Mg/ha.ano em 1966; 5,53 Mg/ha.ano em 1985 e 8,65 Mg/ha.ano em 1996, estando a média abaixo de 15 Mg/ha.ano, e raras ocorrências acima de $200 \mathrm{Mg} / \mathrm{ha}$.ano. Na bacia do Alto Taquari, no estado do Mato Grosso, ocorreram perdas médias da ordem de $70 \mathrm{Mg} / \mathrm{ha}$.ano, com 7,79\% da área com perdas acima de $200 \mathrm{Mg} / \mathrm{ha}$.ano (Galdino et al. 2003).

Observa-se que as sub-bacias com maiores estimativas de perdas de solo ocorrem no médio vale do rio Paraíba do Sul, no noroeste, na parte ocidental do norte fluminense e em contrafortes da Serra do Mar. Embora as regiões das Serras da Bocaína-Litoral Sul, Serra dos Órgãos e Serra da Mantiqueira apresentem solos de elevada erodibilidade e relevo muito acidentado, a perda de solos é atenuada devido à proteção aos processos erosivos pela elevada incidência de remanescentes florestais. A grande divergência entre os resultados da USLE e o índice de vulnerabilidade ocorre em regiões planas e de convergência de fluxos hídricos.

\subsection{Comparação entre os métodos}

Na Tabela 5, são apresentadas associações entre os parâmetros de cada método. Os parâmetros R e K são complementares ao método da vulnerabilidade de sub-bacias, pois o parâmetro erodibilidade do solo não é considerado, e a pluviosidade, acessória no cálculo do Runoff, não tem relação com capacidade erosiva, contribuindo apenas para a lâmina de água superficial. 
COSTA, T. C. C.; FIDALGO, E. C. C.; NAIME, U. J.; GUIMARÃES, S. P.; ZARONI, M. J.; UZEDA, M. C. Vulnerabilidade de sub-bacias hidrográficas por meio da equação universal de perda de solo e da integração de parâmetros morfométricos, topográficos, hidrológicos e de uso/cobertura da terra no estado do Rio de Janeiro, Brasil. Ambi-Agua, Taubaté, v. 4, n. 1, p. 93-116, 2009. (doi:10.4136/ambi-agua.76)

Tabela 4. Valores para o fator $C$ das classes de uso e cobertura do solo do mapeamento realizado pela Fundação Centro de Informações e Dados do Rio de Janeiro (2000).

\begin{tabular}{|c|c|c|}
\hline Código da Classe & Uso e Cobertura solo & Fator C \\
\hline 1 & Afloramento Rochoso & 0,0100000 \\
\hline 2 & Área agrícola & 0,2558821 \\
\hline 3 & Área inundável & 0,0050000 \\
\hline 4 & Área não classificada & 0,0578286 \\
\hline 5 & Área urbana (alta densidade) & 0,0050000 \\
\hline 6 & Área urbana (baixa densidade) & 0,0100000 \\
\hline 7 & Área urbana (média densidade) & 0,0075000 \\
\hline 8 & Área urbanizada & 0,0053333 \\
\hline 9 & Campo de altitude & 0,0194000 \\
\hline 10 & Campo-pastagem & 0,0288000 \\
\hline 11 & Encosta degradada & 0,0480000 \\
\hline 12 & Estepe arbórea & 0,0007000 \\
\hline 13 & Floresta estacional semidecidual & 0,0007000 \\
\hline 14 & Floresta ombrófila densa & 0,0001000 \\
\hline 15 & Grandes construções & 0,0100000 \\
\hline 16 & Mangue & 0,0050000 \\
\hline 17 & Mangue Degradado & 0,0050000 \\
\hline 20 & Praia & 0,0050000 \\
\hline 21 & Reflorestamento & 0,0085000 \\
\hline 22 & Rios, lagos e lagoas & 0,0000000 \\
\hline 23 & Salinas & 0,0050000 \\
\hline 24 & Solo exposto & 1,0000000 \\
\hline 25 & Vegetação de restinga & 0,0007000 \\
\hline 26 & Vegetação de várzea & 0,0100000 \\
\hline 27 & Vegetação secundária & 0,0001000 \\
\hline
\end{tabular}

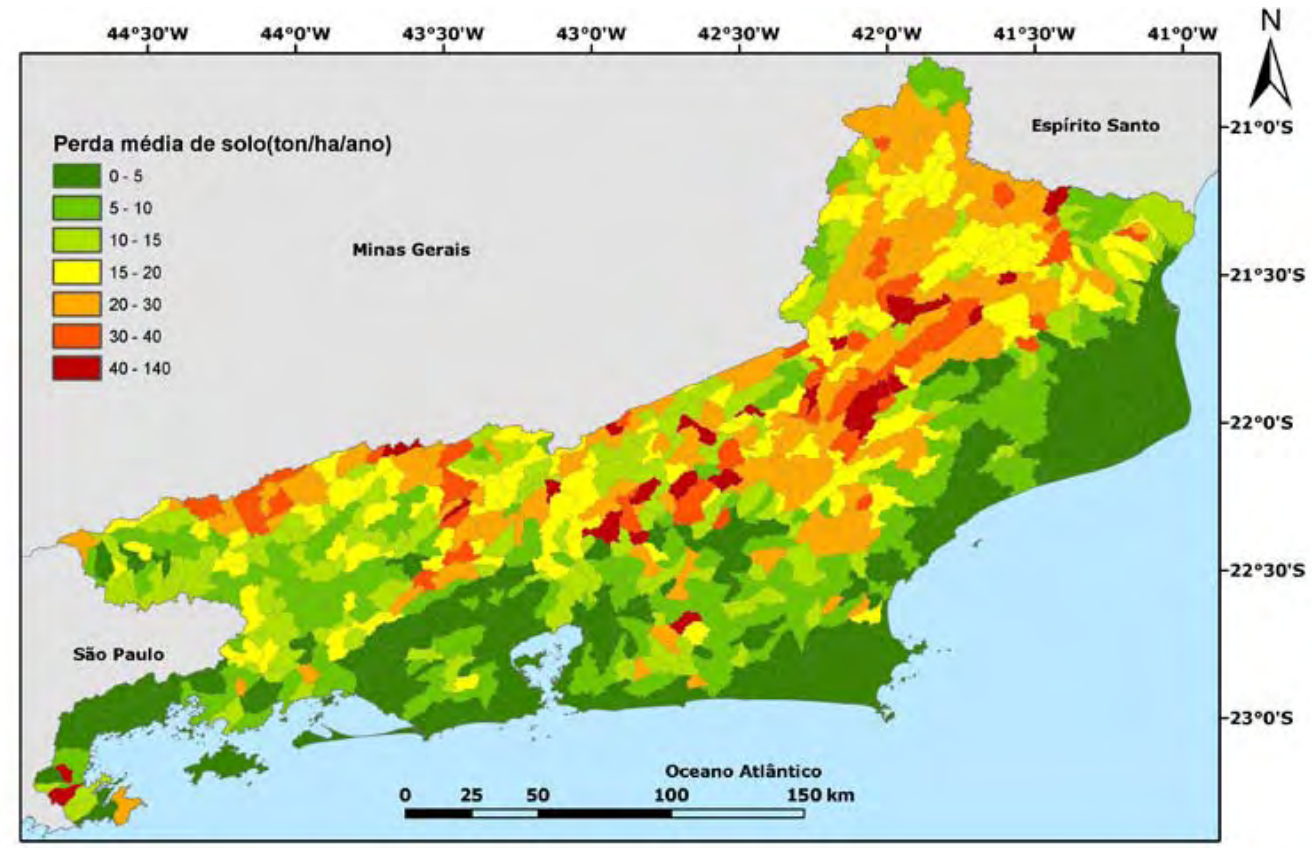

Figura 12. Perda média de solo para as sub-bacias do estado do Rio de Janeiro, em $\mathrm{Mg} / \mathrm{ha}$. ano. 
COSTA, T. C. C.; FIDALGO, E. C. C.; NAIME, U. J.; GUIMARÃES, S. P.; ZARONI, M. J.; UZEDA, M. C. Vulnerabilidade de sub-bacias hidrográficas por meio da equação universal de perda de solo e da integração de parâmetros morfométricos, topográficos, hidrológicos e de uso/cobertura da terra no estado do Rio de Janeiro, Brasil. Ambi-Agua, Taubaté, v. 4, n. 1, p. 93-116, 2009. (doi:10.4136/ambi-agua.76)

Tabela 5. Grau de associação entre os parâmetros da equação universal de perda de solo e da vulnerabilidade de sub-bacias.

\begin{tabular}{clc}
\hline Parâmetros USLE & Parâmetros Vulnerabilidade Sub-bacia & Correlação Sperman \\
\hline R & - & \\
K & - & 0,99 \\
LS & DECL & 0,90 \\
LS & DPALT & $-0,64$ \\
C & COBVEG & 0,61 \\
C & AGRIC & 0,26 \\
C & PAST & $-0,09$ \\
C & URBAN & \\
- & DD & \\
- & IC & \\
- & RUNOFF & \\
\hline
\end{tabular}

Já o parâmetro topográfico LS médio da sub-bacia, tem alta correlação com a declividade percentual média (Figura 13), diferente do desvio padrão da altitude, que apresenta maior dispersão (Figura 14), significando que o fator LS pode ser substituído por uma variável de fácil obtenção quando o objetivo for um indicador topográfico para a sub-bacia.

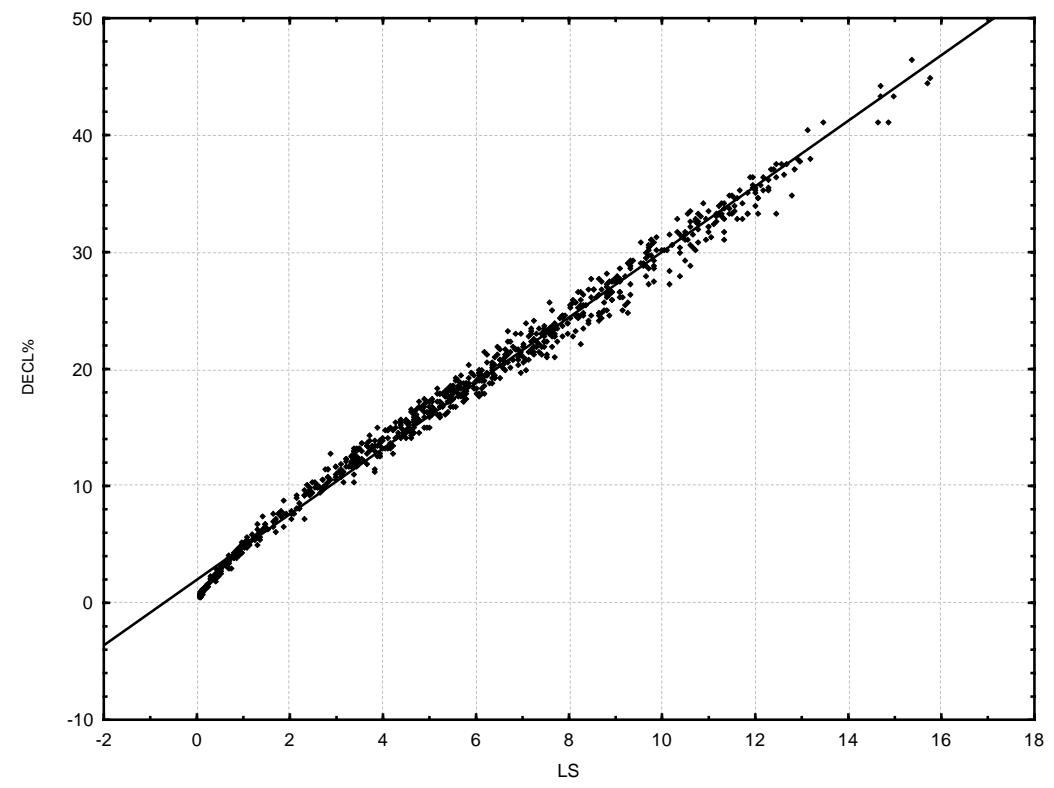

Figura 13. Dispersão entre o fator LS médio por sub-bacia e a declividade percentual média (DECL).

O parâmetro C é uma inferência do grau de proteção do solo de acordo com a classe de uso/cobertura de forma que, quanto menor, maior a proteção. Para o índice de vulnerabilidade, as classes têm pesos iguais, sendo o grau de proteção do solo dado pela proporção da classe na bacia. Existe uma correlação da proporção de classes de uso/cobertura da terra com o fator $C$ médio por sub-bacia, expressa por linhas de tendência que representam bacias com aumento gradativo do uso por pastagens em substituição a cobertura, do aumento gradativo da área agrícola, e uma zona intermediária com bacias que não seguem esse padrão (Figura 15). 

Vulnerabilidade de sub-bacias hidrográficas por meio da equação universal de perda de solo e da integração de parâmetros morfométricos, topográficos, hidrológicos e de uso/cobertura da terra no estado do Rio de Janeiro, Brasil. Ambi-Agua, Taubaté, v. 4, n. 1, p. 93-116, 2009. (doi:10.4136/ambi-agua.76)

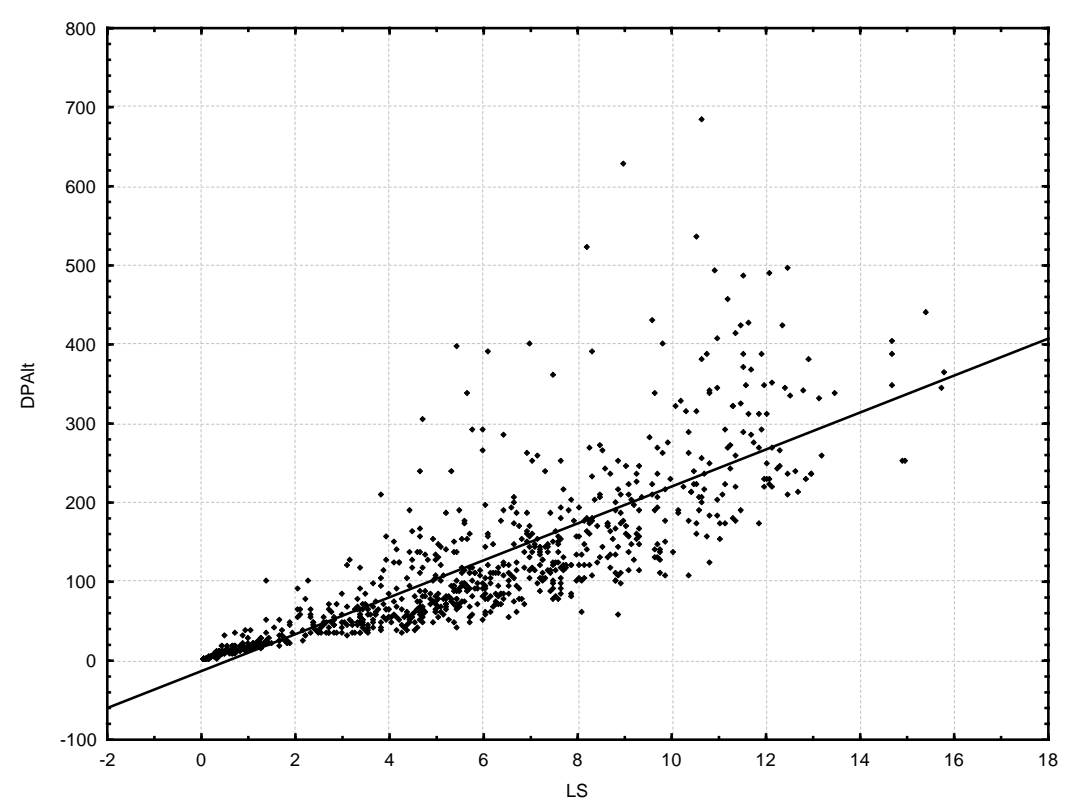

Figura 14. Dispersão entre o fator LS médio por sub-bacia e o desvio-padrão da altitude (DPALT).

Com relação à cobertura vegetal, a linha de tendência mostra um grande número de bacias com gradação da redução da cobertura substituída pela pastagem, e um número relativamente pequeno de bacias que apresentam esse comportamento para áreas agrícolas (Figura 16).

Verifica-se assim a associação do parâmetro da USLE com o critério de proporção da classe de uso/cobertura da terra, podendo-se ainda integrá-los na aplicação por sub-bacia, multiplicando a proporção da classe pelo fator C.

Os demais parâmetros, morfométricos (densidade de drenagem, índice de circularidade), e hidrológico (runoff) são exclusivos ao método de vulnerabilidade de sub-bacias.

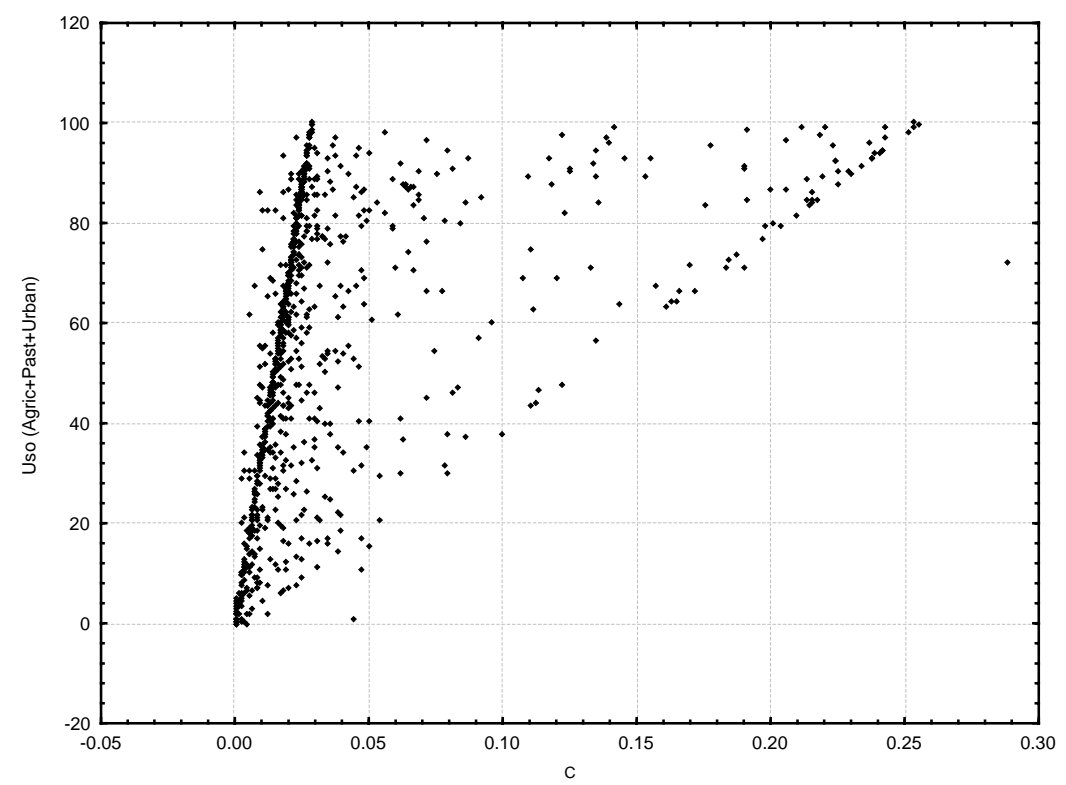

Figura 15. Dispersão do Uso da Terra (soma das proporções de áreas agrícolas, urbanas e pastagens na sub-bacia) em função da média de fatores $\mathrm{C}$ na sub-bacia. 


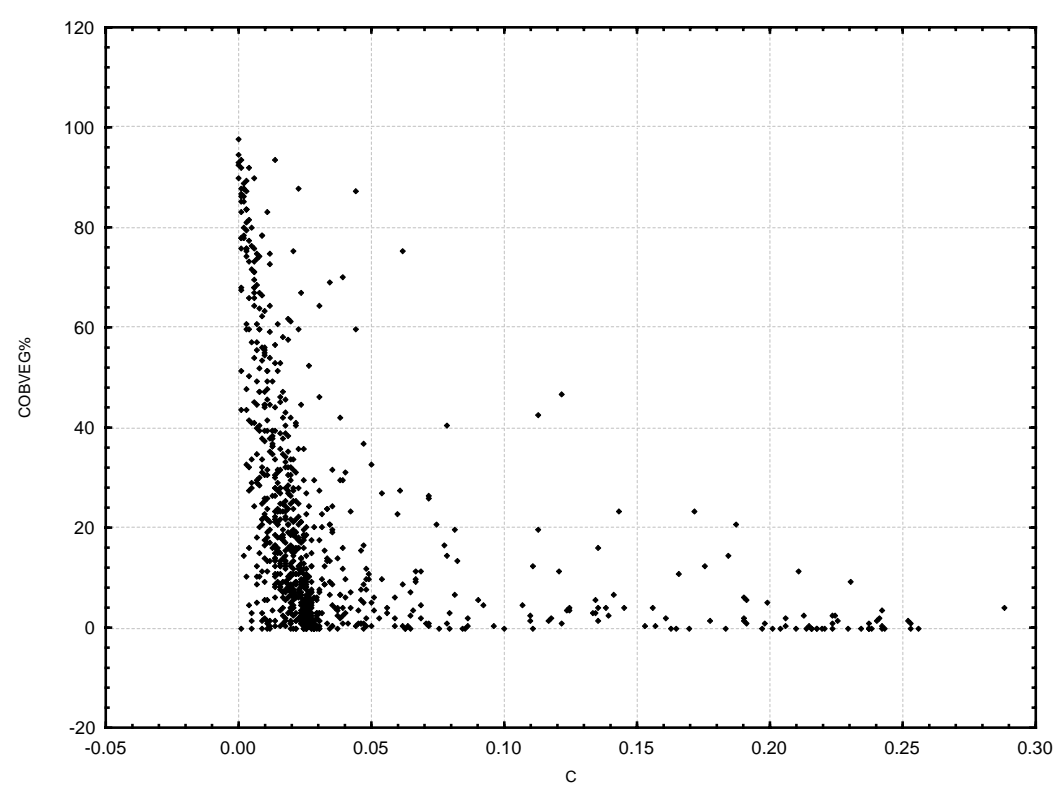

Figura 16. Dispersão da proporção da cobertura vegetal em função da média de fatores $C$ na sub-bacia.

Ao comparar os resultados de ambos os métodos (Figura 17), constata-se fraca associação, embora significativa, devido aos parâmetros exclusivos de cada método, por não apresentarem parâmetros completamente compatíveis, e originarem de resoluções diferentes (pixel e sub-bacia), sendo esse um resultado favorável ao desenvolvimento de uma metodologia integrada de inferência sobre a vulnerabilidade em sub-bacias.

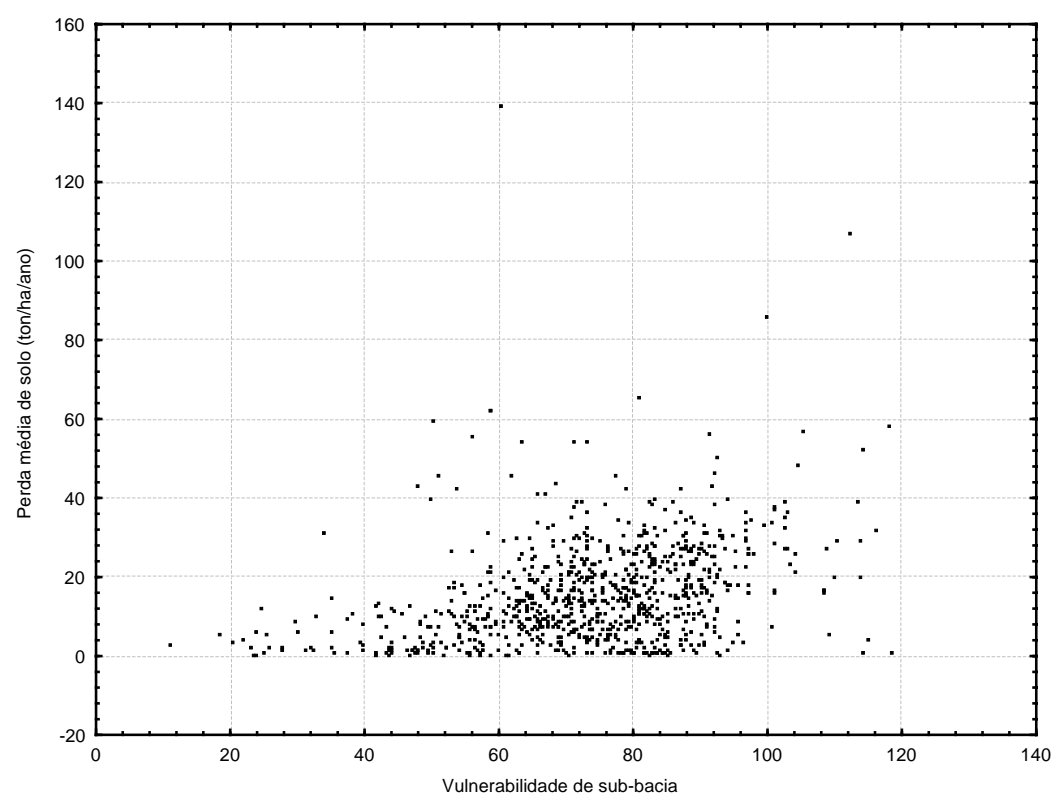

Figura 17. Dispersão da perda média de solo por sub-bacia (Mg/ha.ano) em função do índice de vulnerabilidade de sub-bacia ( $\mathrm{n}=883$, Correlação de Spearman=0,367, $\mathrm{p}<0,0000001$ ).

Ambos os métodos indicaram no noroeste, sub-bacias críticas nos municípios de São Fidelis, Cambuci e São Sebastião do Alto. Na região norte, apenas o método de vulnerabilidade indicou o centro leste de Campos dos Goytacazes e o norte de São Francisco 
de Itabapoana, devido ao relevo suave e ao efeito da variável de fluxo hídrico. O mesmo ocorreu para a bacia da baía de Guanabara, com sub-bacias críticas nos municípios de Itaboraí, São Gonçalo, porção leste de Duque de Caxias, São João de Meriti, Nova Iguaçu, Seropédica, Itaguaí, Queimados e Rio de Janeiro, que, embora, não sujeitas às perdas de solo de grande magnitude, têm o efeito dos fatores de uso da terra, principalmente áreas urbanas.

No vale do Paraíba, as sub-bacias mais vulneráveis estão em Resende, Barra Mansa, Volta Redonda e Quatis, ao norte do município de Cantagalo, e ao noroeste de Sapucaia. Um estudo do risco de erosão do solo para Volta Redonda foi obtido por Dias et al. (2001), concluindo que fatores antrópicos induziram a proliferação de áreas com instabilidade ambiental. Os resultados não serão sempre concernentes com as evidências de degradação na sub-bacia, pela complexidade de fatores extrínsecos aos modelos, como históricos de exploração da terra, podendo-se citar, por exemplo, a cultura do café no vale do Paraíba no período do Brasil Império, que levou a exaustão das terras. Os modelos indicam o potencial de degradação da sub-bacia.

A região dos lagos, também por pressão urbana, foi indicada pelo índice de vulnerabilidade com sub-bacias mais vulneráveis ao sudeste de Saquarema, oeste de Maricá, região central de Araruama e ao norte de Cabo Frio.

Visando à mitigação da degradação e à recuperação ambiental em sub-bacias com predominância da atividade agropecuária, sistemas de produção sustentável podem ser implementados, como os agroflorestais, plantio direto, sistema integração lavoura-pecuária para a recuperação de pastagens degradadas, dentre outros. Sub-bacias em áreas de grande importância biológica e próximas de Unidades de Conservação podem ser integradas às estratégias de serviços ambientais e corredores de biodiversidade. E sub-bacias muito vulneráveis e com inadequação frente à legislação ambiental, devem ser prioritárias para os órgãos de fiscalização ambiental e para programas de recuperação florestal.

\section{CONCLUSÕES}

Parâmetros topográficos e de uso/cobertura da terra da equação universal de perda de solo se correlacionam com os da metodologia de vulnerabilidade de sub-bacias. Parâmetros edáficos, climáticos, hidrológicos e morfométricos são complementares entre os métodos. Conclui-se que a USLE e o índice de vulnerabilidade podem integrar uma metodologia para analisar vulnerabilidade de sub-bacias.

\section{AGRADECIMENTOS}

Agradecemos à Fundação CIDE, ao Instituto Biomas, à Fundação SOS Mata Atlântica, à SERLA, pelo fornecimento de dados e sugestões, também ao pesquisador José Francisco Lumbreras, e ao Critical Ecosystem Partership Fund (CEPF), Conservação Internacional (CI) e Rede para Conservação da Mata Atlântica, pelo apoio financeiro ao Projeto "Estratégias e Ações para Conservação da Mata Atlântica do Estado do Rio de Janeiro”, de onde se originou este trabalho. 


\section{REFERÊNCIAS}

AGÊNCIA NACIONAL DE ÁGUAS - ANA. Disponível em: $<$ http://www.hidroweb.ana.gov.br>. Acesso em: 14 abril de 2005.

ALFONSI, R. R.; PINTO, H. S.; ZULLO JÚNIOR, J.; CORAL, G.; ASSAD, E. D.; EVANGELISTA, B. A. et al.. Zoneamento climático da cultura do café (Coffea Arabica) no Estado do Rio de Janeiro. 2003. Disponível em: http://www.cpa.unicamp.br/cafe/RJ_menu.html. Acesso em: 14 abril de 2005.

BACCHI, O. O. S.; REICHARD, K.; SPAROVEK, G.; RANIERI, S. B. L. Soil erosion e valuation in a small watershed in Brazil through 137Cs fallout redistribution analysis and conventional models. Acta Geologica Hispanica, Barcelona, v. 35, n. 3-4, p. 251259, 2000.

BERTONI, J.; LOMBARDI NETO, F. Conservação do solo. Piracicaba: Ícone, 1985. 392p.

BRASIL. Lei $n^{0}$ 4771, de 15 de setembro de 1965. Institui o Novo Código Florestal. Disponível em < http://www.cetesb.sp.gov.br>. Acesso em: 12 fevereiro de 2009.

BRITO, J. L. S.; LIMA, S. C.; SHIKI, S.; MOREIRA, M. R. Uso do Geoprocessamento na estimativa da perda de solos por erosão laminar em Irai de Minas-MG. In: SIMPÓSIO BRASILEIRO DE SENSORIAMENTO REMOTO (SBSR), 9., 1998, Santos. Anais... São José dos Campos: INPE, 1998. p. 501-512. 1 CD-ROM.

BUENO, C. R. P.; STEIN, D. P. Potencial natural e antrópico de erosão na região de Brotas, Estado de São Paulo. Acta Scientiarum. Agronomy, Maringá, v. 26, n. 1, p. 1-5, 2004.

CARVALHO FILHO, A. dE; LUMBRERAS, J. F.; WITTERN, K. P.; LEMOS, A. L.; SANTOS, R. D. dos; CALDERANO FILHO, B. et al.. Levantamento de reconhecimento de baixa intensidade dos solos do estado do Rio de Janeiro. Rio de Janeiro: Embrapa Solos, 2003a. Contém texto e mapa color. Escala 1:250.000. (Embrapa Solos. Boletim de Pesquisa e Desenvolvimento, 32). No prelo.

CARVALHO FILHO, A. E; LUMBRERAS, J. F.; WITTERN, K. P.; LEMOS, A. L.; SANTOS, R. D. dos; CALDERANO FILHO, B. et al. Mapa de reconhecimento de baixa intensidade dos solos do estado do Rio de Janeiro. Rio de Janeiro: Embrapa Solos, 2003b. 1 mapa, color. Escala 1:250.000. Disponível em: <http://www.cnps.embrapa.br/solosbr/sigweb.html>. Acesso em: 14 de abril de 2005.

CARVALHO JÚNIOR, W. Modelos de planejamento agrícola conservacionista com suporte de geoprocessamento: estudo de caso, municípios de Paty de Alferes e Miguel Pereira - RJ. 1985. 104f. Dissertação (Mestrado em Geoprocessamento) - Universidade Federal do Rio de Janeiro, Rio de Janeiro, 1985.

COLLARES, E. G. Avaliação de alterações em redes de drenagem de sub-bacias como subsídio ao zoneamento geoambiental de bacias hidrográficas: Aplicação na bacia hidrográfica do Rio Capivari-SP. 2000. 211f. Tese (Doutorado em ) - Universidade de São Carlos, Campinas, 2000. 
COSTA, T. C. C.; SOUZA NETO, N. C.; OLIVEIRA, M. A. J.; ACCIOLY, L. J. O. Estimativa da diversidade florística da caatinga por meio da análise multicriterial. In: SIMPÓSIO BRASILEIRO DE SENSORIAMENTO REMOTO (SBSR), 11., 2003, Belo Horizonte. Anais... São José dos Campos: INPE, 2003. p. 2689-2696. 1 CD-ROM.

COSTA, T. C. C.; UZEDA, M. C.; FIDALGO, E. C. C.; LUMBRERAS, J. F.; ZARONI, M. J.; NAIME, U. J. et al. Vulnerabilidade ambiental em sub-bacias hidrográficas do Estado do Rio de Janeiro por meio de integração temática da perda de solo (USLE), variáveis morfométricas e o uso/cobertura da terra. In: SIMPÓSIO BRASILEIRO DE SENSORIAMENTO REMOTO (SBSR), 13., 21-26 abril 2007, Florianópolis. Anais... São José dos Campos: INPE, 2007. p. 2493-2500. 1 CD-ROM.

DIAS, J. E.; GOMES, O. V. O.; GOES, M. H. B. Áreas de riscos de erosão do solo: uma aplicação por geoprocessamento. Floresta e Ambiente, Seropédica, v. 8, n. 1, p. 1-10, 2001.

EASTMAN, J. R. IDRISI Source Code 1987-2003. Worcester: Clark University, 2003. 1 v.

EASTMAN, J. R.; JIN, W.; KYEM, P. A. K.; TOLEDANO, J. Raster procedures for multicriteria, multi-objetive decisions. Photogrammetric Engineering and Remote Sensing, Bethesda, v. 61, n. 5, p. 539-547, 1995.

FIGUEIREDO, D. G. Análise de Fourier e equações diferenciais parciais. Rio de Janeiro: Instituto de Matemática Pura e Aplicada, CNPq, 1977. 274p. (Projeto Euclides).

FLANAGAN, D. C.; NEAREING, M. A. USDA - Water erosion prediction project: hillslope profile and watershed model documentation. West Lafayette: NSERL, 1995. Report n.10.

FULLER, D.; JEFFE, M.; WILLIAMSON, R. A.; JAMES, D. Satellite remote sensing and transportation lifelines: safety and risk analysis along rural Southwest roads. 2002. Disponível em: <http://www.isprs.org/commission1/proceedings/paper/00089.pdf>. Acesso em: 06 maio de 2005.

FUNDAÇÃO CENTRO DE INFORMAÇÕES E DADOS DO RIO DE JANEIRO (CIDE). Índice de qualidade dos municípios - verde (IQM - Verde). Rio de Janeiro: CIDE, 2000. 1 CD-ROM.

FUNDAÇÃO SOS MATA ATLÂNTICA E INSTITUTO NACIONAL DE PESQUISAS ESPACIAIS - INPE. Atlas dos remanescentes florestais da Mata Atlântica: período 1995-2000. Relatório Final. Disponível em: <HTTP://www.rma.org.br>. Acesso em: 12 de fevereiro de 2009.

GALDINO, S.; RISSO, A.; SORIANO, B. M. A.; VIEIRA, L. M.; PADOVANI, C. R.; POTT, A. et al. Perdas de solo na Bacia do Alto Taquari - Corumbá: Embrapa Pantanal. Boletim de Pesquisa e Desenvolvimento, n. 44, p. 40, 2003.

GIBOSHI, M. L. Desenvolvimento de um sistema especialista para determinar a capacidade de uso da terra. 1999. 77f. Dissertação (Mestrado em Planejamento e Produção Agropecuária) - Faculdade de Engenharia Agrícola, Universidade Estadual de Campinas, Campinas, 1999. 
COSTA, T. C. C.; FIDALGO, E. C. C.; NAIME, U. J.; GUIMARÃES, S. P.; ZARONI, M. J.; UZEDA, M. C. Vulnerabilidade de sub-bacias hidrográficas por meio da equação universal de perda de solo e da integração de parâmetros morfométricos, topográficos, hidrológicos e de uso/cobertura da terra no estado do Rio de Janeiro, Brasil. Ambi-Agua, Taubaté, v. 4, n. 1, p. 93-116, 2009. (doi:10.4136/ambi-agua.76)

INSTITUTO BRASILEIRO DE GEOGRAFIA E ESTATÍSTICA - IBGE. Folhas SF 23/24 Rio de Janeiro / Vitória: geologia, geomorfologia, pedologia, vegetação, uso potencial da terra. Rio de Janeiro: IBGE, 1983. 775 p. (Levantamento de Recursos Naturais, 32).

JANSON, S.; DOMINGUE, J. Extracting topographic structure from digital elevation data for geographic information system analysis. Photogrammetric Engineering and Remote Sensing, Bethesda, v. 54, n. 11, p. 1593-1600, 1988.

JENSEN, J. R. Introductory digital image processing: a remote sensing perspective. 2 ed. Englewood-Cliffs: Prentice Hall, 1996. 1996. 316p. (Prentice Hall series in geographic information science).

LONGHI, A. L. B.; MENESES, P. R. O uso de técnicas de geoprocessamento e sensoriamento remoto para o zoneamento de Florestas Nacionais. In: SIMPÓSIO BRASILEIRO DE SENSORIAMENTO REMOTO (SBSR), 12., 16-21 abril 2005, Goiânia. Anais... São José dos Campos: INPE, 2005. p. 2245-2250 1 CD-ROM.

MENDES, J. F. G.; MOTIZUKI, W. S. Urban quality of life evaluation scenarios: the case of São Carlos in Brazil. CTBUH Review, v. 1, n. 2, p. 13-23, 2001.

MILANI, J. R.; CANALI, N. E. O sistema hidrográfico do rio Matinhos: uma análise morfométrica. R. RA'EGA, Curitiba, n. 4, p. 139-152, 2000.

MOREIRA SÁ, A.; LIMA, J. M.; CURI, N.; MASSAROTO, J. A. J. J.; MARQUES, G. S. M. Estimativa da erodibilidade pela desagregação por ultra-som e atributos de solos com horizonte B textural. Pesquisa Agropecuária Brasileira, Brasília, v. 39, n. 7, p. 691699, jul. 2004.

NATIONAL AERONAUTICS AND SPACE ADMINISTRATION - NASA. Homepage. Disponível em: <https://zulu.ssc.nasa.gov/mrsid/mrsid.pl>. Acesso em: 01 de março de 2005.

PARANHAS FILHO, A. C.; FIORI, A. P.; DISPERATI, L.; LUCCHESI, C.; CIALI A.; LASTORIA G. Avaliação multitemporal das perdas de solos na bacia do rio Taquarizinho-MS. Boletim Paranaense de Geociências, Curitiba, n. 52, p. 49-59, 2003.

PEBESMA, E. J. Gstat, a program for geostatistical modelling, prediction and simulation. 1998. Disponível em: <http://www.gstat.org>. Acesso em: 22 de fevereiro de 2009.

PIMENTA M. T. Caracterização da Erodibilidade dos Solos a Sul do Rio Tejo. Disponível em: <http://snirh.inag.pt/snirh/estudos_proj/portugues/docs/ desertificacaofichas.html>. Acesso em: 19 set. 2005a.

PIMENTA M. T. Directrizes para a Aplicação da Equação Universal de Perda dos Solos em SIG. Disponível em: <http://snirh.inag.pt/snirh/estudos_proj/portugues/docs/ desertificacaofichas.html>. Acesso em: 19 set. 2005b.

RENARD, K. G.; FOSTER, G. R.; WEESIES, G. A.; McCOOL, D. K.; YODER, D. C. Predicting soil erosion by water: a guide to conservation planning with the revised universal soil loss equation (RUSLE) - Agricultural handbook, 703. Washington: USDA-ARS, 1997. 384p. 
RIBEIRO, J. C.; SALOMÃO, F. X. T. Abordagem morfopedológica aplicada ao diagnóstico e prevenção de processos erosivos na bacia hidrográfica do alto rio da casca, MT São Paulo, UNESP. Geociências, Rio Claro, v. 22, n. 1, p. 83-95, 2003.

ROCHA, J. S. M. Manual de manejo integrado de bacias hidrográficas. Santa Maria: UFSM, 1991. 181p.

SANTOS, P. R. A.; GABOARDI, C.; OLIVEIRA, L. C. Avaliação da precisão vertical dos modelos SRTM para a Amazônia. In: SIMPÓSIO BRASILEIRO DE SENSORIAMENTO REMOTO (SBSR), 12., 16-21 abril 2005, Goiânia. Anais... São José dos Campos: INPE, 2005. p. 4473-4480. 1 CD-ROM

SIEGEL, S. Nonparametric statistics for the behavioral sciences. New York: McGrawHill, 1956. 350 p.

SILVA, V. C. Estimativa da erosão atual da bacia do Rio Paracatu (MG / GO / DF). Pesquisa Agropecuária Tropical, Goiânia, v. 34, n. 3, p. 147-159, 2004.

TEIXEIRA A. J. A; CRUZ C. B. M. Classificação de bacias de drenagem com o suporte do sensoriamento remoto e geoprocessamento- o caso da Baía de Guanabara. In: SIMPÓSIO BRASILEIRO DE SENSORIAMENTO REMOTO (SBSR), 12., 16-21 abril 2005, Goiânia. Anais... São José dos Campos: INPE,2005. p. 2779-2786. 1 CDROM.

VASQUEZ-FERNANDES, G. A; FORMAGGIO, A. R.; EPIPHANIO, J. C. N.; GLERIANI, J. M. Determinação de sequências culturais em microbacia hidrográfica para caracterização do fator c da EUPS, utilizando fotografia aérea. In: SIMPÓSIO BRASILEIRO DE SENSORIAMENTO REMOTO (SBSR), 8., 14-19 abril 1996, Goiânia. Anais... São José dos Campos: INPE, 1996. p. 63-67 1 CD-ROM

WISCHMEIER, W. H.; SMITH, D. D. Predicting rainfall erosion losses: a guide to conservation planning. Washington: USDA, 1978. 57 p. (Agricultural Handbook, 537). 


ISSN = 1980-993X - doi:10.4136/1980-993X
www.agro.unitau.br/ambi-agua
E-mail: ambi-agua@agro.unitau.br
Tel.: (12) 3625-4116

\title{
Desenvolvimento e avaliação de sonda de TDR para o manejo racional da água em substratos utilizados na produção de mudas florestais (doi:10.4136/ambi-agua.77)
}

\section{Marcelo Leite Conde Elaiuy ${ }^{1}$; Lucas Massayuki Sato; Antonio Claudio Tesla Varallo²; Claudinei Fonseca Souza ${ }^{3}$}

\author{
${ }^{1}$ Estudantes de graduação, Departamento de Engenharia Civil - UNITAU \\ E-mail: trangokauk@gmail.com \\ ${ }^{2}$ Professor Mestre, Departamento de Engenharia Civil - UNITAU. E-mail: antonio.varallo@yahoo.com.br \\ ${ }^{3}$ Professor Adjunto, Departamento de Recursos Naturais e Proteção Ambiental - CCA/UFSCar \\ E-mail: cfsouza@cca.ufscar.br
}

\section{RESUMO}

A Reflectometria no Domínio do Tempo (TDR) é uma técnica confiável para determinar a umidade in situ em diferentes tipos de materiais por meio da utilização de sondas. A produção de mudas florestais implica um exaustivo e empírico processo de manejo da água aplicada ao substrato utilizado para o plantio em tubetes. Esse meio de cultivo requer uma análise quanto ao comportamento físico em relação à retenção de água e nutrientes. $\mathrm{O}$ objetivo deste trabalho foi desenvolver e avaliar uma sonda de TDR do tipo coaxial de maneira a permitir o manejo racional da água na produção de mudas florestais. Inicialmente, uma validação física da sonda foi realizada em função dos seguintes parâmetros: coeficiente de reflexão, impedância característica e sensibilidade espacial. Avaliou-se, também, o desempenho da sonda para estimar a umidade volumétrica em condições de laboratório e obteve-se uma curva de calibração para cada tipo de material poroso utilizado. Os resultados demonstraram a viabilidade no uso da sonda de TDR proposta na estimativa da umidade volumétrica no solo e no substrato.

Palavras-chave: TDR; irrigação; manejo da água.

\section{Development and evaluation of TDR probe for water rational management on substrates used in forest seedlings production}

\begin{abstract}
Time Domain Reflectometry (TDR) is a reliable technique to estimate in situ moisture content in different types of materials using probes. The forest seedlings production implies in a comprehensive and empirical process of water management applied to the substrate used for cultivation in dibble-tube. This type of cultivation requires analysis of the physical characteristics of water and nutrients retention of the substrate. The main goal of this research was to develop and evaluate a TDR coaxial probe for rational management of water in the forest seedlings production. Initially, a physical validation of the probe was performed considering the following parameters: reflection coefficient, characteristic impedance and spatial sensitivity. Also, the performance of the probe was evaluated to estimate water content in laboratory conditions and we obtained a calibration curve for each type of porous material used. The results demonstrated the viability of TDR probes to estimate water content in soil and substrates.
\end{abstract}

Keywords: TDR; irrigation; water management. 


\section{INTRODUÇÃO}

Existem no mundo cerca de 3,4 bilhões de hectares de florestas naturais. No início da década, as florestas plantadas totalizavam aproximadamente 130 milhões de hectares, sendo que, aproximadamente, seis milhões correspondiam a plantações de eucalipto. No Brasil, estima-se que as plantações de pinus e eucalipto são de 4,8 milhões de ha, sendo 2.965.880 ha são cultivados com o gênero Eucalyptus (Mora e Garcia, 2000). Pela importância do cenário, que indica expectativas de grandes investimentos, o aumento da produtividade dos maciços florestais torna-se necessário e requer esforços de pesquisas nas mais diversas áreas. Em relação à produção das mudas, a quantificação da necessidade hídrica na sua formação é extremamente importante, pois a falta ou excesso pode limitar o desenvolvimento destas. A falta de água leva ao estresse hídrico (desejável somente na rustificação), além da diminuição na absorção de nutrientes. O excesso pode favorecer a lixiviação dos nutrientes e também proporcionar um micro-clima favorável ao desenvolvimento de doenças, além das questões sócio-ambientais relativas à economia de água e ao acúmulo de lixiviados no solo.

A necessidade do uso racional dos recursos hídricos aliados ao avanço da eletrônica tem contribuído para a intensificação dos estudos do monitoramento da água no solo. $\mathrm{O}$ conhecimento do conteúdo de água no solo é importante na dinâmica de solutos, calor, gases e da própria água no solo. Em escala global, sua avaliação está relacionada com o significante sistema solo- água- planta - atmosfera. A otimização do uso da irrigação baseado na melhoria de informações sobre o conteúdo de água no solo evitará o desperdício desse recurso, observado em diversas situações. Para isso, a determinação in situ do conteúdo de água do solo é de grande interesse. O uso da instrumentação voltada para a obtenção de informações sobre o sistema água-solo é muito importante. Um método de quantificação ideal da água do solo deve basear-se numa propriedade física, dependente apenas do seu conteúdo e produzir uma resposta direta, rápida e confiável.

Diversos são os métodos para a determinação da umidade do solo. O gravimétrico é considerado o método direto padrão.

Os métodos indiretos estimam a umidade a partir de outras propriedades do solo, tais como, termalização de nêutrons, resistência elétrica e técnicas eletromagnéticas. O método gravimétrico apresenta resultados precisos a um custo relativamente baixo quando usado como técnica laboratorial, mas para medidas no campo, o acondicionamento e transporte das amostras podem reduzir a precisão dos resultados e, ainda, para amostragens repetidas em uma pequena área, podem causar interferência no local em estudo. O uso da sonda de nêutrons exige um treinamento especial para seu manuseio, principalmente pela presença de fontes radioativas. O bloco de gesso é um instrumento simples e de baixo custo, mas o elemento sensor sofre deterioração com o tempo devido à interação com os compostos físicoquímicos do solo (Selker et al. 1993; Coelho e Or, 1996). Para medidas de umidade do solo em laboratório e em campo, a utilização de técnicas eletromagnéticas possui algumas vantagens quanto ao uso, principalmente pela precisão, possibilidade de multiplicação de leituras, repetição sem destruição da amostra de solo e pela segurança (Topp et al., 1980; Coelho e Or, 1996). Entretanto, a principal desvantagem tem sido o custo ainda alto para os padrões nacionais. No caso dos substratos orgânicos, há uma susceptibilidade à decomposição biológica que modifica suas características físicas e químicas ao longo do tempo, exigindo assim uma análise periódica dessas propriedades. Várias são as proposições para determinação da umidade nos substratos, porém nenhuma consegue satisfazer todas as necessidades e apresentar requisitos básicos para que se torne um método ideal. Dos vários 
métodos existentes, a técnica da TDR vem despertando muito interesse devido à possibilidade de leituras em tempo real de forma automatizada (Souza e Matsura, 2003; Souza et al., 2004).

As técnicas eletromagnéticas baseiam-se no efeito da umidade do solo sobre a velocidade de propagação de pulsos de micro-ondas em cabos condutores envoltos por solo. Esse fenômeno se deve à diferença entre as constantes dielétricas, (Ka [adimensional]), da água, do ar e do material sólido do solo. Na matriz do solo, as constantes dielétricas variam entre 1 e 81 . O ar possui valor mínimo igual a 1, as partículas sólidas variam entre 3 e 5, e a água possui o valor máximo de 81 (Noborio, 2001). A constante K medida nesse sistema (arsolo-água-atmosfera) é denominada constante dielétrica aparente, assim, conhecendo-se essa variável, pode-se determinar a umidade volumétrica do solo por meio de calibrações obtidas a partir de dados de campo ou de laboratório (Conciani et al., 1996).

Neste trabalho, a correlação entre os parâmetros citados, para a determinação de uma equação de calibração representativa para o solo e os substratos estudados, foi importante no desenvolvimento da sonda coaxial. Para obtenção desses valores há uma equação genérica proposta pelo fabricante do reflectômetro utilizado $\theta$ Topp (Topp et al., 1980). A correlação estatística entre as técnicas gravimétrica e volumétrica também forneceu resultados pertinentes para validação da metodologia utilizada nos ensaios realizados em laboratório.

\section{MATERIAL E MÉTODOS}

A idealização da construção de uma sonda do tipo coaxial proposta neste trabalho foi baseada no conceito de plantio de mudas em tubetes plásticos, amplamente utilizado no mercado, o qual visa à formação de um sistema radicular perfeito, boas condições para transporte, facilidade para o plantio, etc. A sonda coaxial foi projetada para estimar a umidade do solo e do substrato, e suas dimensões são baseadas em uma célula de transmissão coaxial.

O desenvolvimento da sonda levou em conta os critérios observados na literatura: um mínimo de sinal eletromagnético captado, impedância característica inferior a $200 \Omega$ (Souza et al., 2006), uniformidade na distribuição de energia conduzida pela sonda no meio amostrado e mínimo custo (Souza e Matsura, 2002; Hemiovaara, 1993).

\subsection{Sonda coaxial de TDR}

Na construção da sonda coaxial, foi torneada uma rosca na base de um cilindro de ferro galvanizado com $0,23 \mathrm{~m}$ de extensão e $0,04 \mathrm{~m}$ de diâmetro, onde se rosqueou um "cap" (tampa de PVC) com $1 \frac{1}{4}$ " de diâmetro. Por um orifício desse "cap” passou-se um cabo coaxial RG-58 de $50 \Omega$, cujo condutor interno foi soldado na extremidade inferior de uma haste em aço inox de 0,23 $\mathrm{m}$ de extensão e 0,0045 $\mathrm{m}$ de diâmetro. A malha externa do cabo foi seccionada em duas partes e soldadas em dois pontos paralelos da parede interna do cilindro. Na outra extremidade do cabo foi colocado um conector BNC, ligando a sonda ao reflectômetro. Com o "cap” devidamente rosqueado e a haste já centrada no eixo axial do cilindro, a sonda foi presa num suporte vertical e sua extremidade inferior foi preenchida com resina epóxi até que se atingisse uma altura de 0,05m (Offset), fixando sua haste.

O detalhamento da construção da sonda e suas dimensões seguem na Figura 1. 


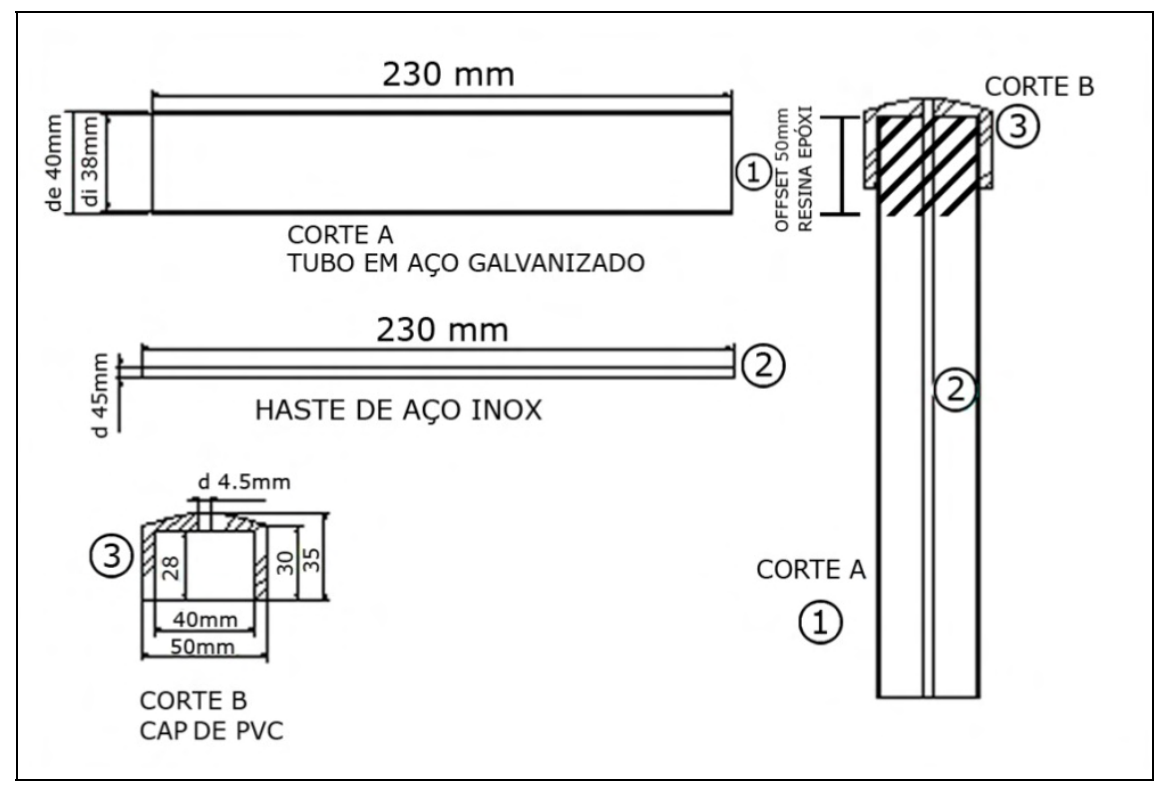

Figura 1. Detalhamento de construção da sonda e suas dimensões.

A sonda coaxial conforme apresentada na Figura 2 foi avaliada fisicamente pelo coeficiente de reflexão, da impedância característica e da sensibilidade espacial.

O coeficiente de reflexão em função da distância percorrida pela onda eletromagnética apontou informações importantes sobre o desempenho das características utilizadas no dimensionamento da sonda, facilitando a interpretação do sinal eletromagnético gerado pelo reflectômetro.

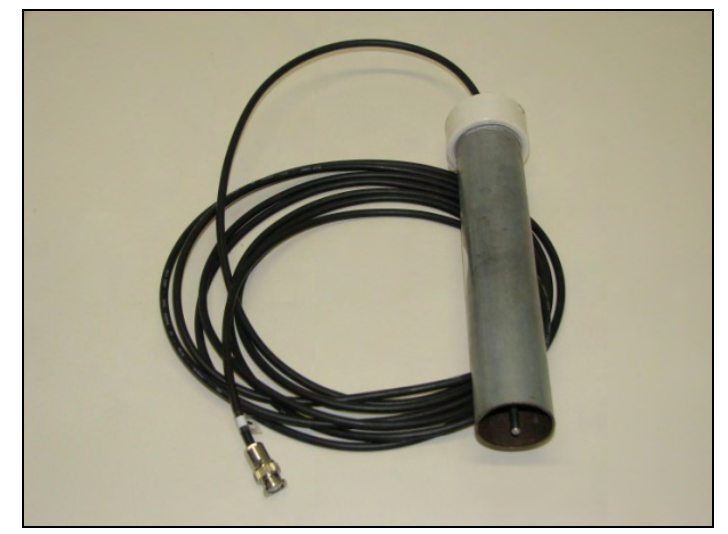

Figura 2. Sonda coaxial de TDR.

A impedância característica $\left(Z_{0}, \Omega\right)$ é o modo de expressar a lei que relaciona a variação de voltagem e corrente com a distância ao longo de uma linha de transmissão uniforme, sendo geralmente utilizada para avaliar o desempenho de sondas de TDR. Em geral, as sondas com $\mathrm{Z}_{0}$ superior a $200 \Omega$ são limitantes para a determinação da umidade do solo, pois, a impedância característica pode causar um aumento na atenuação do sinal da onda eletromagnética a ser analisado durante a distância percorrida, prejudicando a interpretação desse sinal e dificultando que a resina epóxi empregada na confecção do cabeçote da sonda seja utilizada como o marcador do início desta. Entretanto, alguns autores descrevem bons resultados utilizando sondas com valores de $Z_{0}$ superiores ao recomendado. Nesses casos, é comum o uso de componentes eletrônicos para facilitar a interpretação do sinal eletromagnético. 
Segundo Zegelin et al. (1989) e Heimovaara (1993), pode-se medir Z $Z_{0}$ por determinação do coeficiente de reflexão da sonda (p), isso quando ela está envolta por um material dielétrico uniforme.

$$
Z_{0}=Z_{u} \cdot K^{0,5} \cdot \frac{(1+p)}{(1-p)}
$$

sendo,

$$
p=\left(\frac{V_{1}}{V_{0}}\right)-1
$$

$\mathrm{V}_{0}=$ Amplitude do sinal eletromagnético gerado pela TDR, (m);

$\mathrm{V}_{1}=$ Amplitude do sinal eletromagnético depois da reflexão do início da sonda, (m);

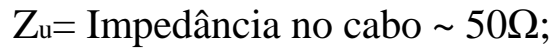

$\mathrm{K}$ = Constante dielétrica, obtida em água destilada (Souza et. al., 2004).

Para a determinação dos parâmetros mencionados, utilizou-se um Reflectômetro (TDR 100 - Campbell Scientific, Figura 3) equipado com uma interface RS 232, em que foi analisado o sinal eletromagnético automaticamente pelo programa WinTDR 6.0 (Utah State University, Logan-Utah).

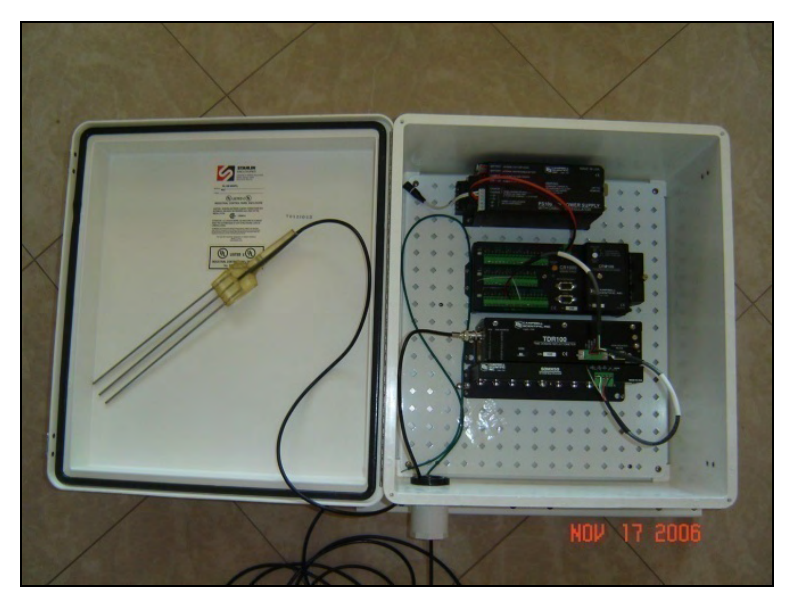

Figura 3. Reflectômetro TDR 100.

A sensibilidade espacial é um conceito introduzido por Knight (1992), o qual descreve a uniformidade de distribuição de energia emitida pela onda eletromagnética em função da água distribuída entre os condutores interno e externo da sonda de TDR. Assim, quanto maior a uniformidade de distribuição melhor será a representatividade da umidade volumétrica espacialmente medida. Knight (1992) sugere uma relação prática para auxiliar na avaliação de sondas de TDR:

$$
\frac{a}{b} \geq 0,1
$$

sendo,

$\mathrm{a}=$ diâmetro do condutor interno;

$\mathrm{b}=$ diâmetro do condutor externo. 


\subsection{Caracterização do solo e do substrato utilizado}

O solo utilizado para avaliação da sonda coaxial pertence ao grupo Latossolo VermelhoAmarelo, coletado no campo do Departamento das Ciências Agrárias da Universidade de Taubaté-SP, da camada de 0 - 0,20 m, com uma textura média do tipo areno-argiloso com as características físico-hídricas apresentadas na Tabela 1.

Tabela 1. Características físico-hídricas do solo.

\begin{tabular}{ccccccccc}
\hline CC & PMP & P & DS & DP & VIB & Areia & Silte & Argila \\
\hline \multicolumn{7}{c}{$\left(\mathrm{m}^{3} / \mathrm{m}^{3}\right)$} \\
0,34 & 0,22 & 0,56 & 1,4 & 2,7 & 7,2 & 59 & 13 & 28 \\
\hline
\end{tabular}

Os substratos submetidos aos estudos foram:

a) Plantmax ${ }^{\circledR}$ : substrato comercial tendo como principais componentes a casca de pinus carbonizada e vermiculita, sendo bastante difundido entre os produtores de mudas de hortaliças.

b) Fibra de coco: substrato comercial Golden Mix tipo 80, sem aditivação, granulado da empresa Amafifra, localizada em Anamindeua - PA. Substrato elaborado a partir do mesocarpo do coco, possuindo textura fina, indicado para formação de mudas em bandejas e tubetes.

Foi utilizado um arranjo para a determinação da densidade úmida dos substratos (Figura 4) empregando-se o método descrito por (Hoffman, 1970), utilizado pela Federação dos Institutos para a Pesquisa e Análises Agrícolas da Alemanha (VDLUFA) para análise de substratos hortícolas (Röber e Schaller, 1985). Nessa metodologia, seis amostras de cada substrato no estado fresco são colocadas em proveta de plástico transparente e graduada de $500 \mathrm{ml}$ de capacidade, a qual deixa-se cair por 10 vezes consecutivas sob ação de seu próprio peso de uma altura de $10 \mathrm{~cm}$. Com ajuda de uma espátula nivelou-se o volume obtido (ml). Em seguida, pesou-se o material fresco (g) e colocou-se em estufa a $65^{\circ} \mathrm{C}$, por 48 horas ou até peso constante. Os valores das densidades de volume (média de três amostras) foram obtidos aplicando-se a seguinte fórmula:

DensidadeÚmida $\left(\mathrm{Kg} \cdot \mathrm{m}^{-3}\right)=\frac{\operatorname{MassaÚmida}(\mathrm{g})}{\operatorname{Volume}\left(\mathrm{cm}^{3}\right)} \times 1000$

\subsection{Determinações da constante dielétrica aparente e da umidade volumétrica}

Para efetuar as determinações da constante dielétrica aparente (Ka) e da umidade volumétrica ( $\theta$ Topp) com a sonda coaxial, seguiu-se o procedimento descrito por Tommaselli e Bacchi (2001). Nessa metodologia, as etapas de umedecimento com adição de $50 \mathrm{~mL}$ de água por etapa foram continuamente repetidas até atingir as umidades próximas à da saturação conforme a seguinte descrição: metade da amostra de solo coletada, cerca de $2 \mathrm{~L}$, foi esparramada em uma mesa formando uma fina camada. Através de um pulverizador adicionou-se cerca de metade da água desejada $(25 \mathrm{~mL})$. A seguir, a outra metade de solo foi esparramada sobre a metade anterior pulverizando-se com água até completar os $50 \mathrm{~mL}$. 


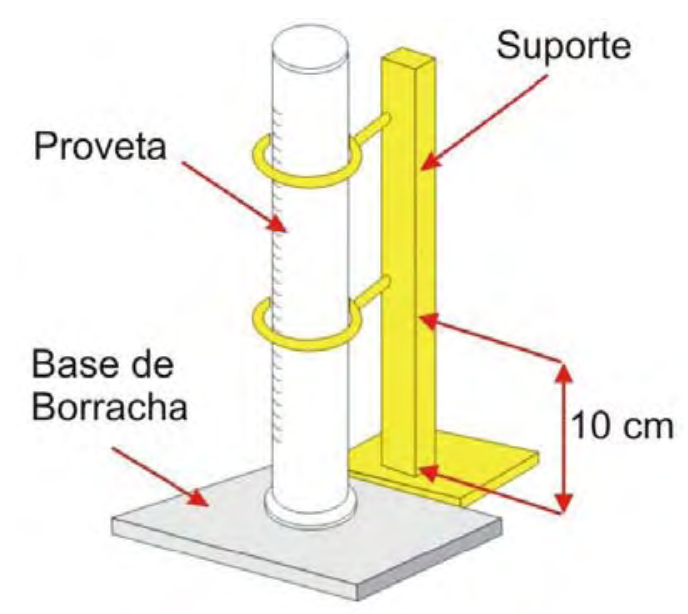

Figura 4. Arranjo para determinação da densidade dos substratos.

O solo foi bem misturado e peneirado de três a quatro vezes, em peneira de malha de $2 \mathrm{~mm}$, obtendo-se sua homogeneização. Após o umedecimento e homogeneização, o solo foi colocado em uma sonda coaxial com cerca de 0,225 L de volume, compactando-se de modo a manter a sua densidade o mais uniforme possível. A sonda foi conectada ao reflectômetro e foram lidos os parâmetros da umidade volumétrica ( $\theta$ Topp) e da constante dielétrica aparente (Ka) para cada umedecimento. Em seguida, uma amostra deste mesmo solo foi colocada em uma cápsula e pesada para depois ser mantida em estufa à $105^{\circ} \mathrm{C}$ por 48 horas, para obtenção da umidade gravimétrica. Para cada determinação de umidade volumétrica foi obtido um parâmetro de umidade gravimétrica. Os substratos foram submetidos aos mesmos procedimentos para obtenção das umidades e da constante dielétrica aparente.

As estimativas determinadas pela sonda proposta foram confrontadas com o método padrão (Gravimetria), utilizando-se um diagrama de dispersão e um coeficiente de correlação.

\section{RESULTADOS E DISCUSSÃO}

\subsection{Coeficiente de reflexão}

A Figura 5 descreve o coeficiente de reflexão em função da distância percorrida para a sonda proposta. Observa-se a interpretação da onda eletromagnética sendo, $\mathrm{X}_{1}$ a distância no início da sonda, $\mathrm{X}_{2}$ a distância no final da sonda, $\mathrm{V}_{0}$ a amplitude do sinal eletromagnético gerado pela TDR e $\mathrm{V}_{1}$ a amplitude do sinal depois da reflexão do início da sonda. Por meio desses parâmetros, pode-se determinar a impedância (Equação 1) e a constante dielétrica pela equação abaixo (Hook e Livingston, 1995). A constante dielétrica é dada por:

$$
K a=\left(\frac{\Delta x}{V p . L}\right)^{2}
$$

sendo,

$\Delta \mathrm{x}=$ Distância percorrida pela onda eletromagnética, (m);

$\mathrm{Vp}=$ Velocidade de propagação, 0,99 (99\% de c);

$\mathrm{c}=$ Velocidade da luz, $3 \times 10^{8} \mathrm{~m} \cdot \mathrm{s}^{-1}$;

$\mathrm{L}=$ Comprimento da haste, $(\mathrm{m})$. 


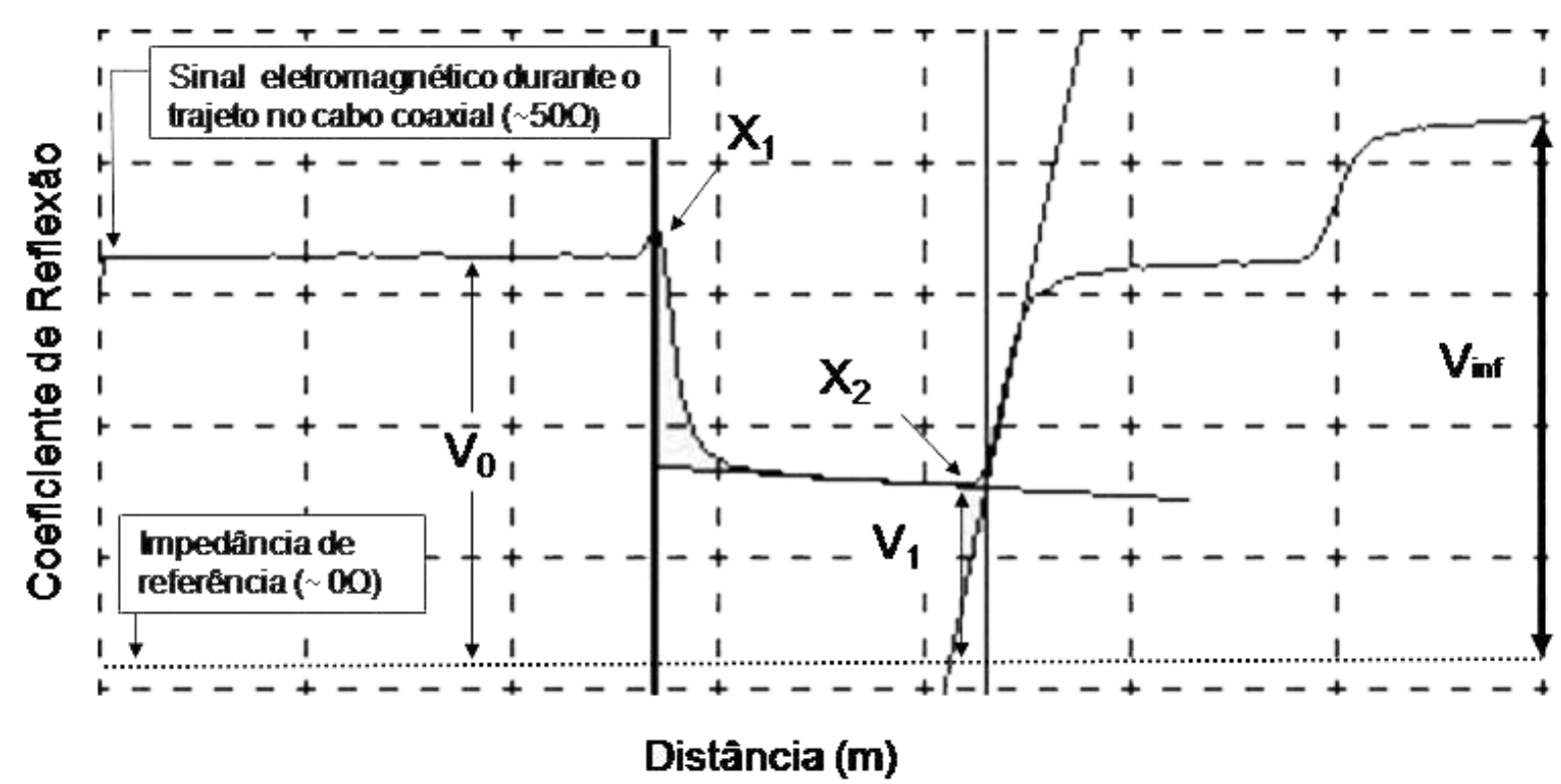

Figura 5. Coeficiente de reflexão em função da distância do sinal eletromagnético percorrido na sonda.

\subsection{Impedância característica e sensibilidade espacial}

A Tabela 2 analisa as dimensões geométricas utilizadas e apresenta os valores de impedância tanto medida como calculada inferior ao recomendado $200 \Omega$ (Zegelin et al., 1989) e com sensibilidade espacial $\geq 0,1$ (Knight, 1992). Os resultados observados demonstram que a sonda proposta possui características dimensionais apropriadas para atender às atribuições físicas desejadas em uma sonda de TDR, quando comparada com outros modelos de sondas (Souza et al., 2006).

Tabela 2. Dimensões geométricas, impedância medida e calculada para diferentes configurações de sondas de TDR.

\begin{tabular}{|c|c|c|c|c|c|c|}
\hline & $\begin{array}{r}\text { Diâm } \\
(m)\end{array}$ & & $\begin{array}{c}\text { Sensibilidade } \\
\text { Espacial }\end{array}$ & \multirow{2}{*}{$\begin{array}{c}\text { Volume } \\
\left(\mathrm{m}^{3}\right)\end{array}$} & \multirow{2}{*}{$\begin{array}{c}\text { Impedância } \\
\text { Calculada } \\
\text { Zo }(\Omega)\end{array}$} & \multirow{2}{*}{$\begin{array}{c}\text { Impedância } \\
\operatorname{Medida} \\
\operatorname{Zo}(\Omega)\end{array}$} \\
\hline & \multicolumn{2}{|c|}{ Interno, Externo, } & $a / b$ & & & \\
\hline Sonda coaxial & 0,0045 & 0,04 & 0,11 & 0,0002 & 131,08 & 172,67 \\
\hline Sonda contínua & 0,003 & 0,027 & 0,11 & 0,0001 & 131,83 & 197,00 \\
\hline Sonda muti-haste & 0,006 & 0,058 & 0,11 & 0,0005 & 132,43 & 168,00 \\
\hline
\end{tabular}

\subsection{Cálculo do erro padrão da estimativa}

A Tabela 3 mostra a avaliação estatística do erro padrão da estimativa na determinação da umidade (Spiegel, 1985):

$S= \pm \sqrt{\frac{\sum\left(Y-Y_{e s t}\right)^{2}}{n}}$

em que, Y é o valor medido e $\mathrm{Y}_{\text {est }}$ o estimado pela equação utilizada (Topp), e $n$ o número de amostras utilizadas. Os dados mostram que o erro padrão é relativamente pequeno para todos 
os materiais analisados, não interferindo dessa forma nos resultados de determinação da umidade, podendo ser facilmente ajustados com uma calibração específica.

Tabela 3. Erro padrão da estimativa na determinação da umidade.

\begin{tabular}{|c|c|}
\hline Amostra & S: Erro padrão da estimativa $\left(\mathrm{m}^{3} \mathrm{~m}^{-3}\right)$ \\
\hline Solo & $\pm 0,039$ \\
\hline Plantmax ${ }^{\circledR}$ & $\pm 0,109$ \\
\hline Fibra de coco & $\pm 0,087$ \\
\hline
\end{tabular}

\subsection{Determinação da densidade úmida}

Os valores das densidades úmidas obtidos em laboratório pelo método descrito por Hoffman (1970) estão apresentados na Tabela 4. Esses valores foram utilizados na determinação da umidade gravimétrica dos substratos. No caso do solo, para a obtenção desse mesmo parâmetro, a densidade utilizada está apresentada na Tabela 1.

Tabela 4. Valores das densidades úmidas obtidos em laboratório.

\begin{tabular}{lc}
\hline Amostra & Densidade úmida $\left(\mathbf{K g} \cdot \mathbf{m}^{-3}\right)$ \\
\hline Plantmax ${ }^{\circledR}$ & 586 \\
Fibra de coco & 131 \\
\hline
\end{tabular}

\subsection{Estimativa da umidade e da constante dielétrica em condições de laboratório}

Com os resultados numéricos das umidades apresentados nas Tabelas de 5 a 7, foi feita a correlação entre os valores obtidos pelas duas técnicas para cada material, a fim de comparar o método gravimétrico com a técnica da TDR. A partir dos resultados de Ka e $\theta$, pôde-se determinar as equações representativas para as condições em estudo.

Tabela 5. Resultados do Latossolo vermelho-amarelo obtidos em condições de laboratório.

\begin{tabular}{cccc}
\hline Leitura & $\begin{array}{c}\text { Constante } \\
\text { Dielétrica, } \boldsymbol{K a}\end{array}$ & \multicolumn{2}{c}{ Umidade $\left(\mathbf{m}^{\mathbf{3}} \cdot \mathbf{m}^{-\mathbf{3}}\right)$} \\
\cline { 2 - 4 } & 4,393 & $\mathbf{0 T o p p}$ & Gravimétrica \\
\hline $1^{\mathrm{a}}$ & 5,061 & 0,067 & 0,023 \\
$2^{\mathrm{a}}$ & 5,602 & 0,081 & 0,032 \\
$3^{\mathrm{a}}$ & 6,085 & 0,093 & 0,079 \\
$4^{\mathrm{a}}$ & 6,446 & 0,103 & 0,078 \\
$5^{\mathrm{a}}$ & 8,030 & 0,115 & 0,091 \\
$6^{\mathrm{a}}$ & 9,182 & 0,148 & 0,119 \\
$7^{\mathrm{a}}$ & 11,388 & 0,176 & 0,138 \\
$8^{\mathrm{a}}$ & 12,833 & 0,214 & 0,154 \\
$9^{\mathrm{a}}$ & 14,900 & 0,241 & 0,186 \\
$10^{\mathrm{a}}$ & 18,201 & 0,277 & 0,226 \\
$11^{\mathrm{a}}$ & & 0,323 & 0,306 \\
\hline
\end{tabular}

\subsection{Correlação e equação de calibração}

As Figuras de 6 a 8 mostram a correlação entre os valores da umidade volumétrica ( $\theta$ Topp) e os da umidade gravimétrica. Observa-se que o desempenho entre as técnicas é praticamente o mesmo. Há um desalinhamento entre os pontos correlacionados dessas figuras, o que demonstra que a água foi retida pelas partículas do solo/substrato e não permanece ou não se encontra mais livre nesse meio. Isso implica uma discrepância entre os valores da umidade obtidos pela técnica da TDR e os valores obtidos pelo método gravimétrico. De acordo com Valero (2006), a afirmativa de TOPP et al. (1980) de que a constante dielétrica aparente dos meios porosos depende apenas do seu conteúdo de água, seria de se esperar que o seu modelo tivesse o mesmo tipo de comportamento em cada um dos 
substratos estudados. Contudo, observa-se que o comportamento do modelo é distinto para cada um dos substratos, demonstrando que a constante dielétrica (Ka) dos substratos depende de suas propriedades intrínsecas.

Tabela 6. Resultados do substrato Plantmax ${ }^{\circledR}$ obtidos em condições de laboratório.

\begin{tabular}{cccc}
\hline Leitura & $\begin{array}{c}\text { Constante } \\
\text { Dielétrica, Ka }\end{array}$ & \multicolumn{2}{c}{ Umidade $\left.\mathbf{( m}^{3} \cdot \mathbf{m}^{-3}\right)$} \\
\cline { 3 - 4 } & 5,597 & 0,096 & Gravimétrica \\
\hline $1^{\text {a }}$ & 6,345 & 0,112 & 0,059 \\
$2^{\text {a }}$ & 7,178 & 0,130 & 0,084 \\
$3^{\text {a }}$ & 8,372 & 0,156 & 0,124 \\
$4^{\text {a }}$ & 9,760 & 0,182 & 0,128 \\
$5^{\text {a }}$ & 14,900 & 0,271 & 0,163 \\
$6^{\text {a }}$ & 16,800 & 0,307 & 0,177 \\
$7^{\text {a }}$ & 20,144 & 0,340 & 0,194 \\
$8^{\text {a }}$ & 21,458 & 0,368 & 0,219 \\
$9^{\text {a }}$ & 27,507 & 0,457 & 0,240 \\
$10^{\text {a }}$ & 32,319 & 0,481 & 0,259 \\
$11^{\text {a }}$ & & & 0,287 \\
\hline
\end{tabular}

Tabela 7. Resultados do substrato Fibra de coco obtidos em condições de laboratório.

\begin{tabular}{cccc}
\hline Leitura & $\begin{array}{c}\text { Constante } \\
\text { Dielétrica, Ka }\end{array}$ & \multicolumn{2}{c}{ Umidade $\left.\mathbf{~ ( ~}^{3} \cdot \mathbf{~ m}^{-3}\right)$} \\
\cline { 3 - 4 } & 2,538 & 0,017 & Gravimétrica \\
\hline $1^{\text {a }}$ & 3,216 & 0,038 & 0,021 \\
$2^{\text {a }}$ & 4,287 & 0,063 & 0,042 \\
$3^{\text {a }}$ & 4,638 & 0,073 & 0,062 \\
$4^{\text {a }}$ & 5,992 & 0,104 & 0,066 \\
$5^{\text {a }}$ & 6,786 & 0,123 & 0,088 \\
$6^{\text {a }}$ & 7,936 & 0,149 & 0,097 \\
$7^{\text {a }}$ & 9,764 & 0,186 & 0,111 \\
$8^{\text {a }}$ & 10,946 & 0,209 & 0,140 \\
$9^{\text {a }}$ & 11,425 & 0,220 & 0,170 \\
$10^{\text {a }}$ & 14,652 & 0,270 & 0,173 \\
$11^{\text {a }}$ & 16,702 & 0,302 & 0,201 \\
$12^{\text {a }}$ & 19,099 & 0,332 & 0,228 \\
$13^{\text {a }}$ & 23,035 & 0,382 & 0,235 \\
$14^{\text {a }}$ & 25,216 & 0,401 & 0,268 \\
$15^{\text {a }}$ & 29,298 & 0,439 & 0,274 \\
$16^{\text {a }}$ & 32,952 & 0,466 & 0,294 \\
$17^{\text {a }}$ & 39,090 & 0,505 & 0,331 \\
$18^{\text {a }}$ & 41,215 & 0,515 & 0,342 \\
$19^{\text {a }}$ & & & 0,363 \\
\hline
\end{tabular}

Os resultados deste trabalho dão evidências de que, além da água, a distribuição e o tamanho de partículas e a superfície específica são características que podem influenciar no valor da constante dielétrica do material, como no caso dos substratos orgânicos em estudo. 


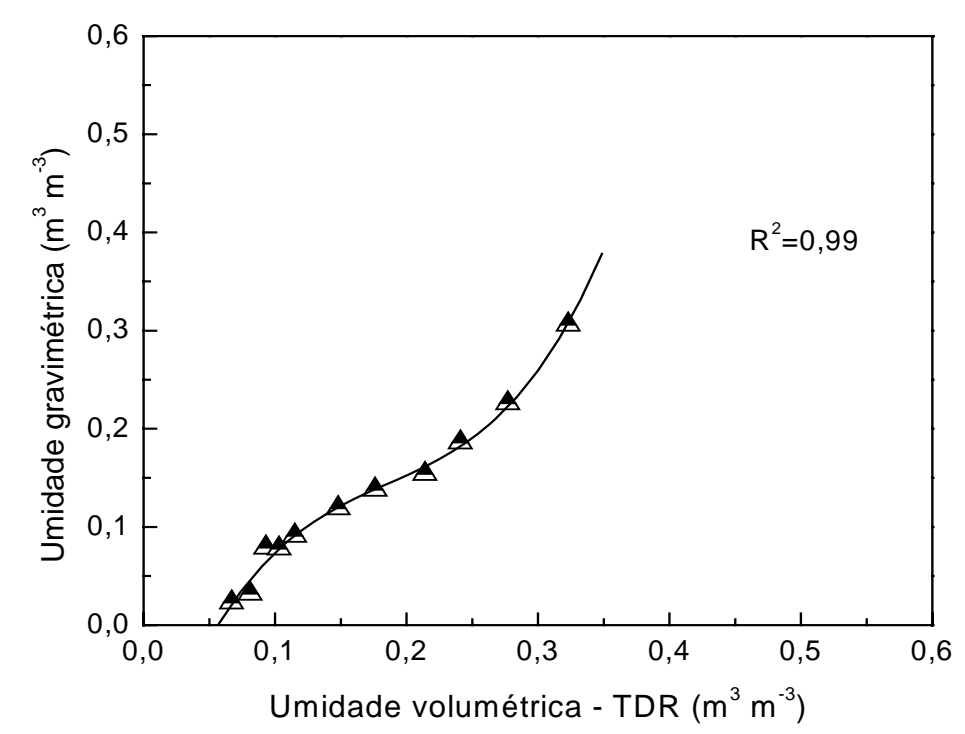

Figura 6. Correlação entre a técnica da TDR e a gravimétrica para o solo.

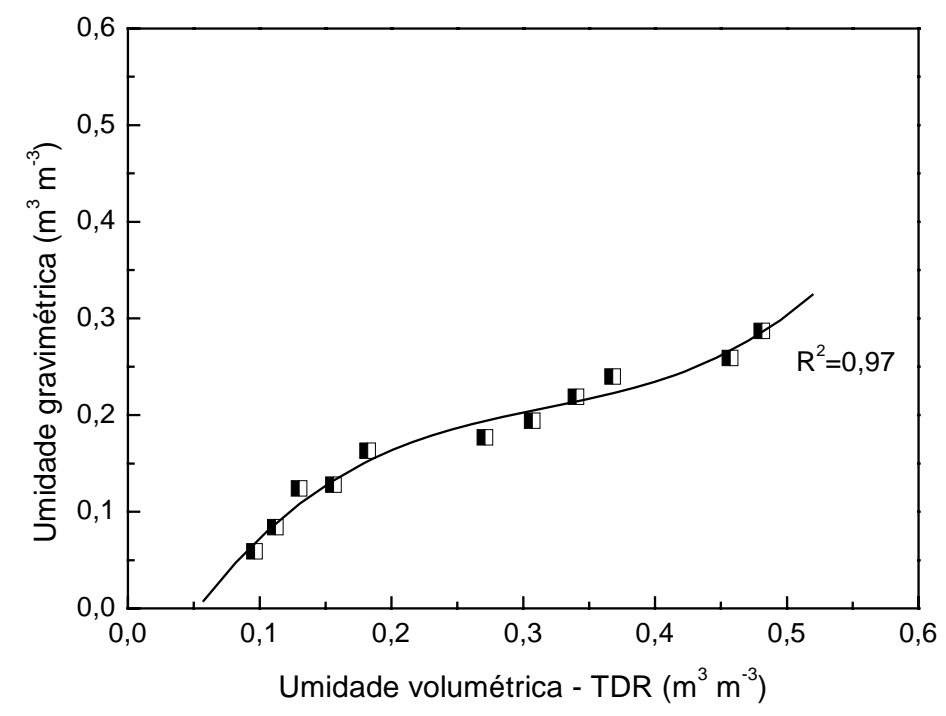

Figura 7. Correlação entre a técnica da TDR e a gravimétrica para o substrato plantmax ${ }^{\circledR}$.

Portanto, de acordo com os resultados os valores da constante dielétrica aparente (Ka) e da umidade gravimétrica do solo e dos substratos $\left(\mathrm{m}^{3} \cdot \mathrm{m}^{-3}\right)$ puderam ser ajustados por meio das equações polinomiais cúbicas obtidas na calibração da TDR, apresentadas na Tabela 8.

Tabela 8. Equações polinomiais cúbicas obtidas na calibração da TDR.

\begin{tabular}{llc}
\hline Material & \multicolumn{1}{c}{ Equações } & $\mathbf{R}^{2}$ \\
\hline Solo & $\theta=-1,83931 E-6 K a^{3}-3,5281 E-4 K a^{2}+0.0274 K a-0,4802$ & 0,99 \\
Plantmax ${ }^{\circledR}$ & $\theta=-3,37048 E-6 K a^{3}-4,93629 E-5 K a^{2}+0,2058 K a-0,01406$ & 0,99 \\
Fibra de Coco & $\theta=4,5707 E-K a^{3}-5,68676 E-4 K a^{2}+0,02947 K a-0,05237$ & 0,99 \\
\hline
\end{tabular}




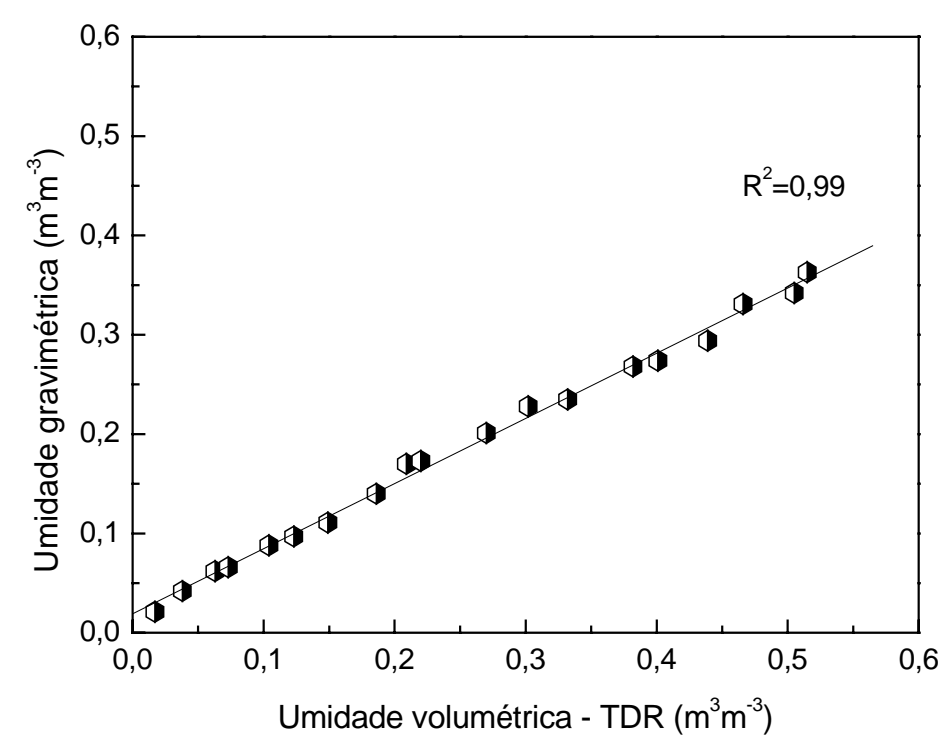

Figura 8. Correlação entre a técnica da TDR e a gravimétrica para o substrato de fibra de coco.

\subsection{Estimativa da regressão linear}

Verificou-se que os coeficientes de correlação entre os métodos de determinação da umidade no solo e nos substratos são satisfatórios e, que apenas o coeficiente angular da equação de regressão do solo ficou próximo a 1, conforme os dados apresentados nas Figuras de 9 a 11. Entretanto, os resultados comprovam existir uma associação linear entre as técnicas e indicam uma variação direta no valor da umidade volumétrica para um valor de umidade gravimétrica. Assim, com uma calibração, a técnica da TDR poderá ter um desempenho semelhante ao método gravimétrico para obtenção dos valores da umidade presente nos materiais analisados. Por outro lado, essa técnica promove agilidade na estimativa, uma vez que, o tempo envolvido na obtenção da umidade é extremamente inferior a essa determinação realizada pelo método padrão, proporcionando contribuições rápidas e precisas, de forma que as informações possam ser utilizadas para auxiliar nas melhores decisões possíveis dentro das condições de incerteza.

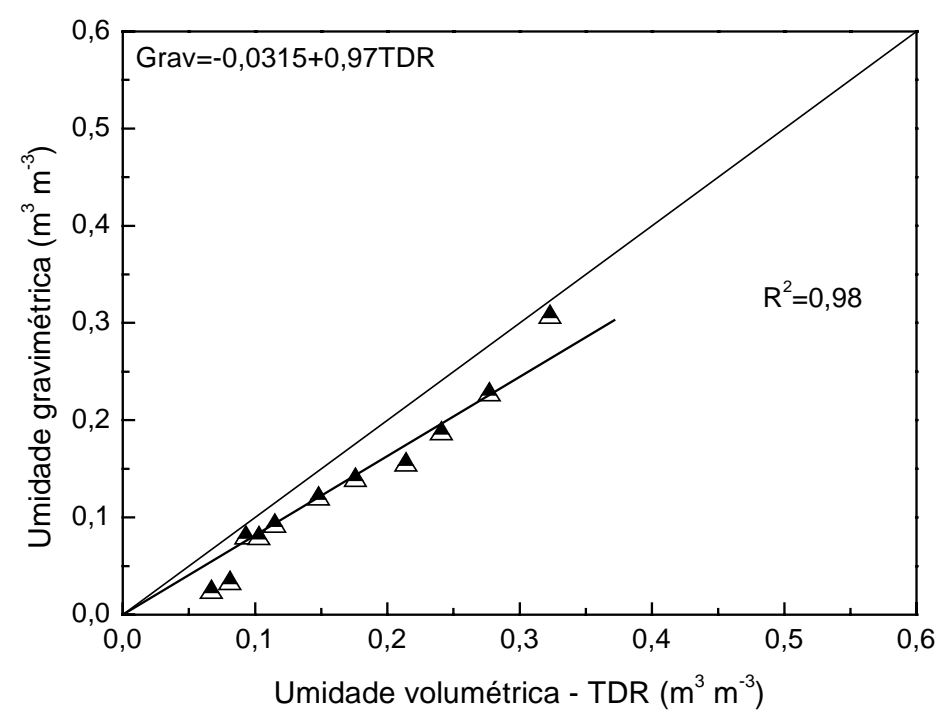

Figura 9. Regressão linear entre a umidade gravimétrica e volumétrica do solo. 


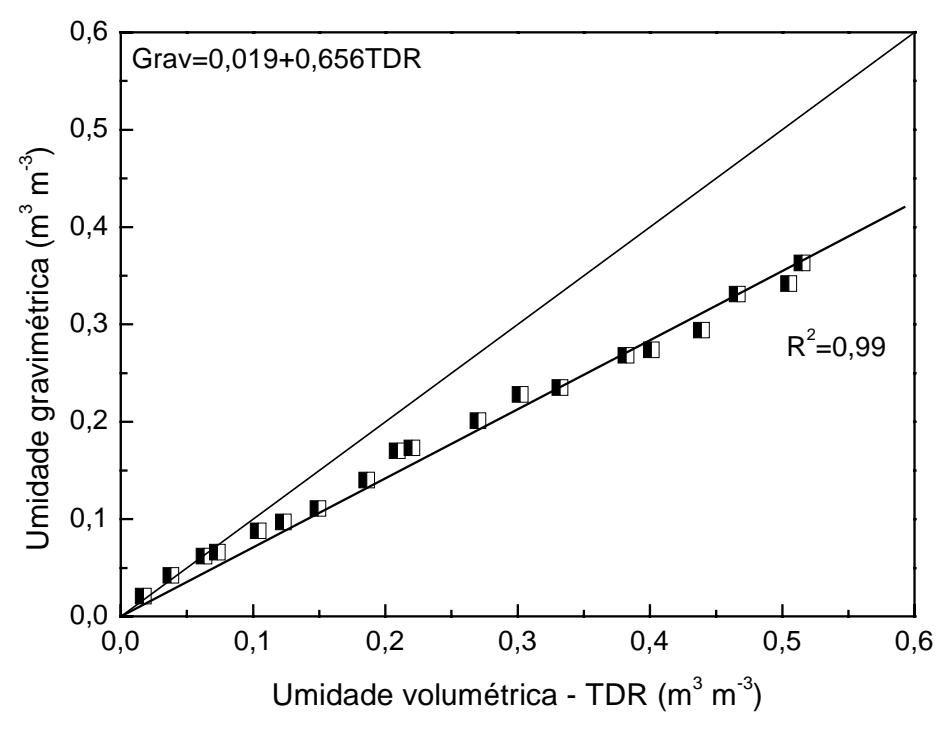

Figura 10. Regressão linear entre a umidade gravimétrica e volumétrica do substrato plantmax ${ }^{\circledR}$.

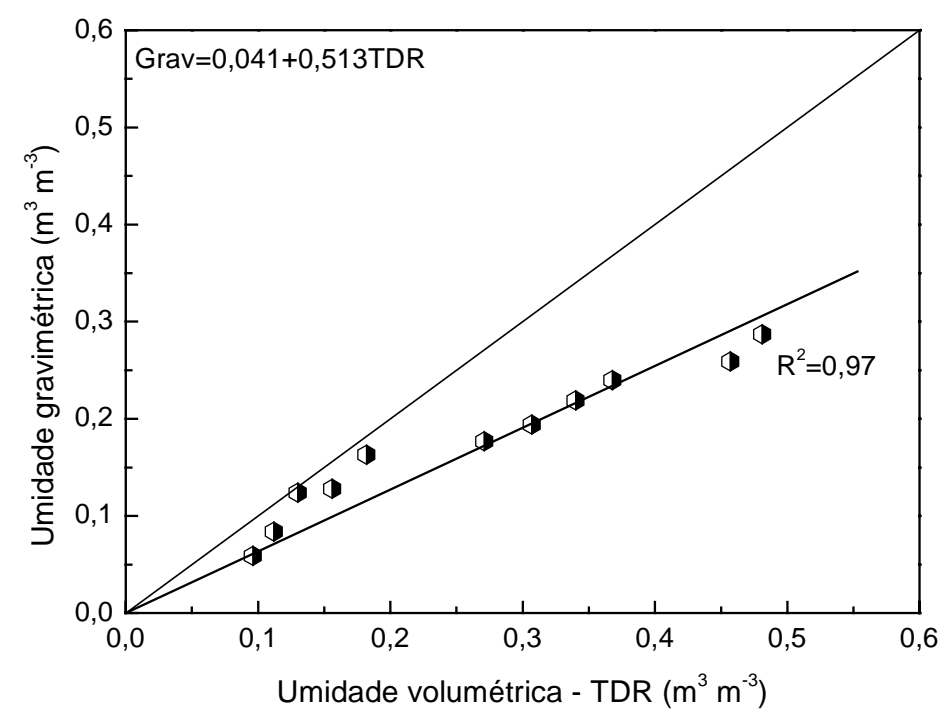

Figura 11. Regressão linear entre a umidade gravimétrica e volumétrica do substrato fibra de coco.

\section{CONCLUSÃO}

Diante dos resultados obtidos, pôde-se inferir que a sonda proposta apresenta o conjunto de critérios físicos que a qualificam como uma alternativa viável na obtenção da umidade do solo e dos substratos analisados, por meio da técnica indireta da reflectometria no domínio do tempo. As curvas de calibração da Ka e de umidade volumétrica obtidas em cada substrato mostraram-se adequadas e estatisticamente significativas no intervalo de aplicabilidade, ou seja, na faixa de água facilmente disponível nos substratos estudados.

A equação de calibração proposta por Topp et al. (1980) que acompanha equipamento (TDR 100) não é aplicável para estimativa de umidade volumétrica nos substratos estudados, necessitando de uma calibração individual para cada um deles. 


\section{AGRADECIMENTOS}

Os autores agradecem à Fundação de Amparo à Pesquisa do Estado de São Paulo pelos auxílios concedidos. (Proc. Número 05/00906-3 e 06/03241-5).

\section{REFERÊNCIAS}

COELHO, E. F.; OR, D. Flow and uptake patterns affecting soil water sensor placement for drip irrigation management. Transactions of the ASAE, St. Joseph, v. 39, p. 2007 2016, 1996.

CONCIANI, W.; HERRMANN, P. S. P.; MACHADO, S. L.; SOARES, M. M. O uso da técnica de reflectometria no domínio do tempo (TDR) para determinação da umidade do solo in situ. Revista Solos e Rochas, São Paulo, v. 19, p. 189-199, 1996.

HEIMOVAARA, T. J. Design of triple-wire Time Domain Reflectometry probes in practice and theory. Soil Science Society of America Journal, Madison, v. 57, p. 1410 - 1417, 1993.

HOFFMAN, G. Verbindliche Methoden zur Untersuchung von TKS und Gartnerischen Erden. Mitteilubngen der VDLFA, Heft, v. 6, p. 129-153, 1970.

HOOK, W. R; LIVINGSTON, N. J. Propagation velocity errors in time domain reflectometry measurements of soil water. Soil Science Society of America Journal, Madison, v. 28, p. 2345 - 2352, 1995.

KNIGHT, J. H. Sensitivity of time domain reflectometry measurements to lateral variations in soil water content. Water Resources Research, Washington, v. 28, p. 2345 - 2352, 1992.

MORA, A. L.; GARCIA, C. H. A cultura do eucalipto no Brasil. São Paulo: Verso e Reverso Comunicações, 2000. 112 p.

NOBORIO, K. Measurement of soil water content and electrical conductivity by time domain reflectometry: a review. Computers and Electronics in Agriculture, Amsterdam, v. 31, p. 213-237, 2001.

RÖBER, R.; SCHALLER, K. Pflazenermahrung im Gartenbau. Stuttgart: Ulmer, 1985. 350 p.

SELKER, J. R.; GRAFF, L.; STEENHUIS, T. Noninvasive time domainreflectometry moisture measurement probe. Soil Science Society of America Journal, Madison, v. 57, p. 934-936, 1993.

SOUZA, C. F.; MATSURA, E. E. Avaliação de sondas multi-haste segmentadas para o monitoramento da umidade do solo por meio da técnica de TDR. Revista Brasileira de Engenharia Agrícola e Ambiental, Campina Grande, v. 6, p. 63-68, 2002.

SOUZA, C. F.; MATSURA, E. E. Determination of the wetting front in drip irrigation using TDR Multi-wire probe. Agricultural Water Management, Amsterdam, v. 59, p. 205216, 2003.

SOUZA, C. F.; OR, D.; MATSURA, E. E. A variable-volume TDR probe for measuring water content in large soil volumes. Soil Science Society of America Journal, Madison, v. 68, p. 25-31, 2004. 
SOUZA, C. F.; FOLEGATTI, M. V.; MATSURA, E. E.; OR, D.; COELHO, E. F. Sondas de TDR para a estimativa da umidade e da condutividade elétrica do solo. Revista Irriga, Botucatu, v. 11, p. 12-25, 2006.

SPIEGEL, M. R. Estatística. 2. ed. Rio de Janeiro: Mc Graw-Hill, 1985. 454p.

TOMMASELLI, J. T. C.; BACCHI, O. O. S. Calibração de um equipamento de TDR para medida de umidade de solos. Pesquisa Agropecuária Brasileira, Brasília, v. 36, p. 1145-1154, 2001.

TOPP, G. C.; DAVIS, J. L.; ANNAN, A. P. Electromagnetic determination of soil water content: measurements in coaxial transmission lines. Water Resources Research, Washington, v. 16, p. 574-582, 1980.

VALERO, R. M. M. Uso da técnica da “TDR” na estimativa da umidade e condutividade elétrica em substratos orgânicos. 89f. 2006. Dissertação (Mestrado em Engenharia Agrícola) - Faculdade de Engenharia Agrícola, Universidade Estadual de Campinas, Campinas, 2006.

ZEGELIN, S. J.; WHITE, I.; JENKINS, D. R. Improved fields probes for soil water content and electrical conductivity measurements using TDR. Water Resources Research, Washington, v. 25, p. 2367-2376, 1989. 


ISSN = 1980-993X-doi:10.4136/1980-993X
www.agro.unitau.br/ambi-agua
E-mail: ambi-agua@agro.unitau.br
Tel.: (12) 3625-4116

\title{
Estado trófico da água na bacia hidrográfica da Lagoa Mirim, RS, Brasil \\ (doi:10.4136/ambi-agua.78)
}

\section{Ronaldo Fia ${ }^{1}$; Antonio Teixeira de Matos ${ }^{2}$; Paulo Carteri Coradi ${ }^{3}$; Orlando Pereira- Ramirez $^{4}$}

\author{
${ }^{1}$ Engenheiro Agrícola e Ambiental, Pós-doutorando em Engenharia Agrícola, UFV \\ E-mail: ronaldo.fia@ufv.br \\ ${ }^{2}$ Engenheiro Agrícola, D.Sc. Professor do Departamento de Engenharia Agrícola da UFV \\ E-mail: atmatos@ufv.br \\ ${ }^{3}$ Engenheiro Agrícola, UFPEL, Doutorando em Engenharia Agrícola, UFV \\ E-mail: paulocoradi@yahoo.com.br \\ ${ }^{4}$ Engenheiro Químico, D.Sc. Professor do Departamento de Engenharia Agrícola da UFPEL \\ E-mail: orlando@ufpel.edu.br
}

\section{RESUMO}

O objetivo deste trabalho foi analisar a variação espaço-temporal das características tróficas dos principais cursos de água afluentes à Lagoa Mirim, no estado do Rio Grande do Sul, por meio da determinação do Índice do Estado Trófico proposto por Toledo Jr. (IET $\mathrm{T}$ ) e Lamparelli (IET $\mathrm{L}_{\mathrm{L}}$ ), obtendo dados de qualidade das águas entre os anos de 1996 e 1998. Diante dos resultados foi verificado que os ambientes lóticos apresentaram condições de maior eutrofização quando avaliados pela metodologia de Toledo Jr, em que o $\mathrm{IET}_{\mathrm{T}}$ variou de Eutrófico a Hipereutrófico. No entanto, pela metodologia de Lamparelli, os ambientes avaliados apresentaram variações de Mesotrófico a Hipereutrófico, para o $\operatorname{IET}_{\mathrm{L}}$. Pela classificação proposta por Toledo Jr. os corpos de água lênticos foram considerados Mesotróficos ( $\left.\operatorname{IET}_{\mathrm{T}}>44\right)$ e Hipereutróficos $\left(\operatorname{IET}_{\mathrm{T}}>74\right)$, enquanto que, pela metodologia de Lamparelli estes foram classificados como Eutróficos $\left(\operatorname{IET}_{\mathrm{L}}>59\right)$ e Hipereutróficos $\left(\operatorname{IET}_{\mathrm{L}}>\right.$ 67). As concentrações de fósforo encontradas em todas as amostragens foram superiores ao limite estabelecido na Resolução CONAMA n 357 de 2005, para cursos de água em condição classe 2, provavelmente em função de despejos domésticos e industriais sem tratamento nas águas.

Palavras-chave: Eutrofização; nutrientes; fósforo; Índice de Estado Trófico.

\section{Trophic state of water in the watershed of Lake Mirim, RS, Brazil}

\section{ABSTRACT}

The objective of this work was to analyze the spacetime variations in the trophic characteristics of the principal water bodies feeding Lake Mirim, in the state of Rio Grande do Sul, by determination of the Trophic State Index proposed by Toledo Jr. (IET $\mathrm{T}_{\mathrm{T}}$ ) and Lamparelli $\left(\mathrm{IET}_{\mathrm{L}}\right)$, to assess water quality data between 1996 and 1998. It was verified that the lotic environments presented greater eutrophication conditions when evaluated by the Toledo Jr. methodology, in which the $\mathrm{IET}_{\mathrm{T}}$ varied from Eutrophic to Hypereutrophic. However, the evaluated environments showed variations from Mesotrophic to Hypereutrophic for the $\operatorname{IET}_{\mathrm{L}}$ when evaluated according to the Lamparelli methodology. From the classification proposed by Toledo Jr., lentic water bodies were considered Mesotrophic (IET 
$>44$ ) and Hypereutrophic ( $\left.\operatorname{IET}_{\mathrm{T}}>74\right)$, while the Lamparelli method classified them as Eutrophic ( $\operatorname{IET}_{\mathrm{L}}>59$ ) and Hypereutrophic $\left(\operatorname{IET}_{\mathrm{L}}>67\right)$. Concentrations of phosphorus encountered in all water samples were greater than the limits established by the CONAMA Resolution n. 357, 2005, for class 2 water bodies, probably due to the discharge of untreated domestic and industrial wastes into the waters.

Keywords: Eutrophication; nutrients; phosphorus; Trophic State Index.

\section{INTRODUÇÃO}

O crescimento demográfico e o aumento de atividades potencialmente impactantes tornaram crescente a preocupação em relação à qualidade das águas. O lançamento de matéria orgânica, substâncias tóxicas e nutrientes, via efluentes domésticos e industriais ou resultantes do manejo inadequado das lavouras e do solo, pode afetar a qualidade do ambiente para os organismos aquáticos ou mesmo a saúde humana, por meio da ingestão de águas contaminadas.

O crescimento excessivo de algas e plantas aquáticas, causado pelo lançamento de grandes quantidades de nutrientes nos corpos de água, em especial nitrogênio e fósforo, é denominado eutrofização. Esse excesso de nutrientes, associado às boas condições de luminosidade, favorece o crescimento das algas e outras plantas aquáticas. Segundo Mota (2006), a eutrofização pode levar à alteração no sabor, no odor, na turbidez e na cor da água; à redução do oxigênio dissolvido que provoca mortandade de peixes e outras espécies aquáticas, além de redução na balneabilidade da água.

O conceito de estado trófico é multidimensional, envolve aspectos de carga e transporte de nutrientes; concentração de nutrientes; produtividade, quantidade e qualidade da biota e a morfometria do lago (Duarte et al., 1998). Essa constatação leva a se estabelecer índices multiparamétricos, o que limita sua utilização devido ao número elevado de variáveis a serem medidas. Dessa forma, para identificação do estado trófico de um corpo hídrico, alguns índices têm sido utilizados, sendo o mais comum o de Carlson (1977), modificado por Toledo Jr. et al. (1983), utilizado na avaliação da qualidade das águas de rios e lagos de regiões de clima tropical.

Carlson (1977) definiu um índice do estado trófico usando uma transformação linear da transparência pelo disco de Secchi, que avalia a concentração de biomassa algal. Pela sua simplicidade e objetividade, esse índice é um dos mais utilizados para a classificação da qualidade da água de lagos. Além da transparência, o índice pode ser expresso em função das concentrações de fósforo Equação 1 e clorofila “a”, medidas em amostras coletadas próximo à superfície da água. Com estas três variáveis pode-se estimar, de forma independente, a biomassa algal.

$$
I E T_{C}=14,42 \times \ln (P)+4,15
$$

em que $P$ é a concentração de fósforo total em $\mathrm{mg} \mathrm{L}^{-1}$.

O Índice de Estado Trófico de Carlson (IET $\mathrm{C}$ ) foi desenvolvido para regiões temperadas, onde o metabolismo dos ecossistemas aquáticos difere dos encontrados em ambientes tropicais. A fim de adaptar uma nova metodologia para condições tropicais, Toledo Jr. et al. (1983) propuseram modificações na metodologia de Carlson (Equação 2) e os autores 
concluíram que as versões modificadas $\left(\mathrm{IET}_{\mathrm{T}}\right)$ eram mais adequadas para determinação do estado trófico, quando comparadas às formas originais.

$$
I E T_{T}=10 \times\left[6-\frac{\ln \left(\frac{80,32}{P}\right)}{\ln 2}\right]
$$

em que $P$ é a concentração de fósforo total em $\mu g \mathrm{~L}^{-1}$.

Lamparelli (2004) propôs índices (IETL) diferenciados para aplicação específica em ambientes lênticos Equação (3) e em ambientes lóticos Equação (4).

$$
\begin{aligned}
& \operatorname{IET}_{T}=10 \times\left[6-\frac{1,77-0,42 \times \ln (P)}{\ln 2}\right] \\
& \operatorname{IET}_{T}=10 \times\left[6-\frac{0,42-0,36 \times \ln (P)}{\ln 2}\right]-20
\end{aligned}
$$

em que $P$ é a concentração de fósforo total em $\mu g \mathrm{~L}^{-1}$.

Um índice de estado trófico funciona como um registro das atividades humanas nas várias bacias hidrográficas, além de oferecer subsídios para a formulação de planos de manejo e gestão de ecossistemas aquáticos, por meio de estratégias que visem à sustentabilidade dos recursos hídricos e que garantam os usos múltiplos da água, em médio e longo prazo.

Em síntese, neste trabalho teve-se como objetivo analisar a variação espaço-temporal das características tróficas dos principais cursos de água afluentes à Lagoa Mirim, no estado do Rio Grande do Sul, por meio da determinação do Índice do Estado Trófico (IET), verificando a qualidade das águas entre os anos de 1996 e 1998.

\section{MATERIAL E MÉTODOS}

A Bacia Hidrográfica da Lagoa Mirim compreende um espaço geográfico binacional, com parte desse espaço em território brasileiro e parte em território uruguaio. Situa-se no sudeste do estado do Rio Grande do Sul, entre as coordenadas geográficas de $31^{\circ} 30^{\prime}$ a $34^{\circ}$ $35^{\prime}$ de latitude Sul e $53^{\circ} 31^{\prime}$ a $55^{\circ} 15^{\prime}$ de longitude Oeste, correspondendo a uma superfície de $62.250 \mathrm{~km}^{2}$, dos quais, $47 \%$ estão em território brasileiro e $53 \%$ em território Uruguaio (Figura 1).

Foram selecionados 11 pontos amostrais na foz de diferentes corpos de água afluentes à Lagoa Mirim. Os corpos hídricos avaliados foram: Canal São Gonçalo, Arroio Pelotas, Rio Jaguarão, Rio Piratini, Rio Santa Isabel, Arroio Chuí, Barragem do Chasqueiro, Barragem da Eclusa, Porto, Dique e Reserva do Taim (Figura 2). Nesses pontos foram coletadas duas amostras mensais, entre os anos de 1996 a 1998, para determinação das concentrações de fósforo total, seguindo-se metodologia apresentada em APHA et al. (1998). A forma de amostragem foi do tipo manual, com utilização de recipientes plásticos com volume de dois litros. 
As análises laboratoriais foram realizadas no Laboratório de Controle de Poluição do DCTA, da Faculdade de Agronomia Eliseu Maciel, na Universidade Federal de Pelotas (UFPel), no estado do Rio Grande do Sul - Brasil.

A partir dos resultados obtidos, foram calculados os valores médios mensais de concentração de $\mathrm{P}_{\text {total }}$ na água e o IET modificado por Toledo Jr. et al. (1983) e o IET proposto por Lamparelli (2004). No caso do IET proposto por Lamparelli, fez-se a diferenciação entre os ambientes lênticos (Barragem do Chasqueiro, Barragem da Eclusa, Porto, Dique e Reserva do Taim) e lóticos (Canal São Gonçalo, Arroio Pelotas, Rio Jaguarão, Rio Piratini, Rio Santa Isabel, Arroio Chuí).

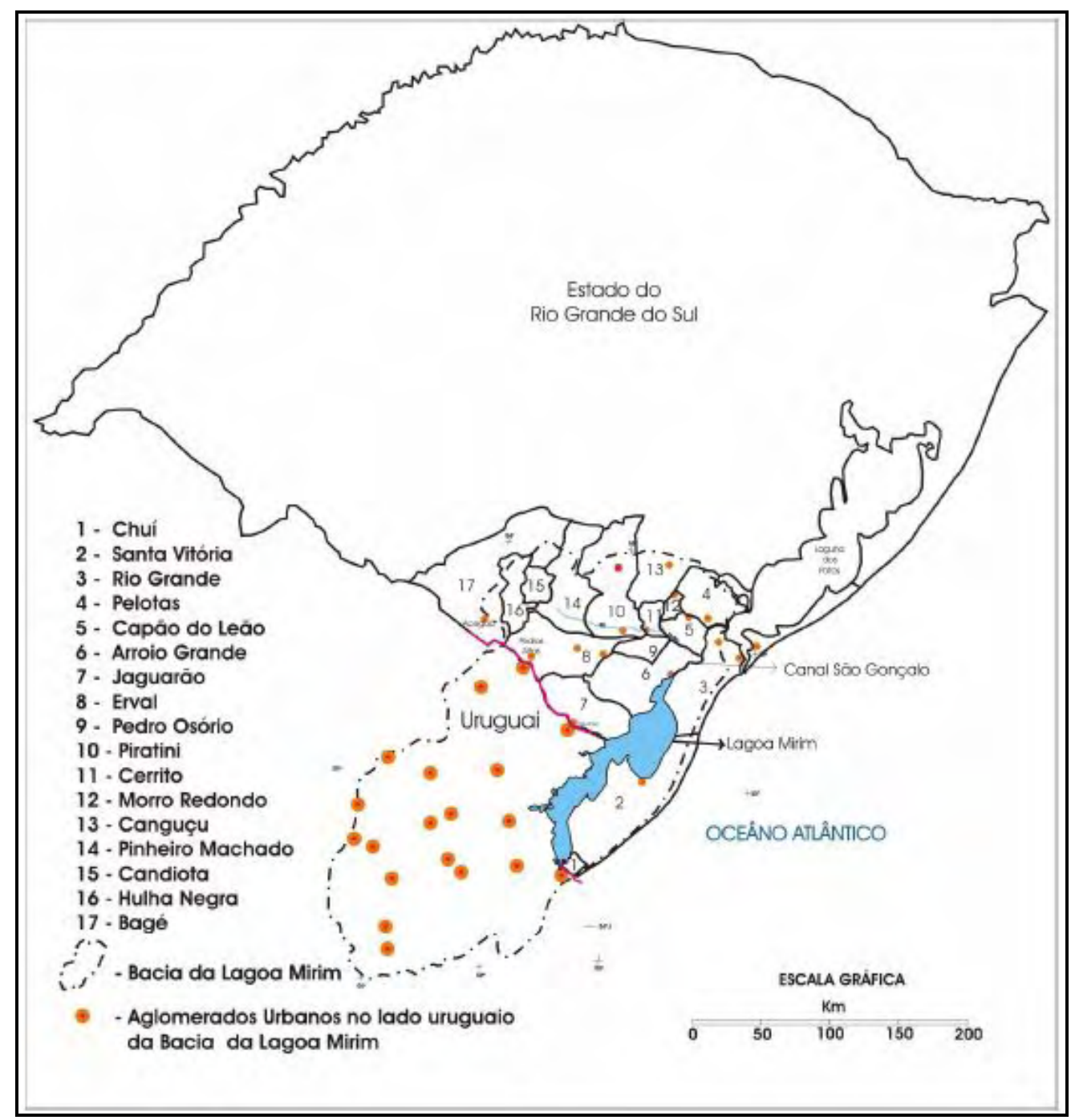

Figura 1. Localização da bacia hidrográfica da Lagoa Mirim - RS (adaptado de Machado, 2007). 
FIA, R.; MATOS, A. T.; CORADI, P. C.; PEREIRA-RAMIREZ, O. Estado trófico da água na bacia hidrográfica da Lagoa Mirim, RS, Brasil. Ambi-Agua, Taubaté, v. 4, n. 1, p. 132-141, 2009. (doi:10.4136/ambi-agua.78)

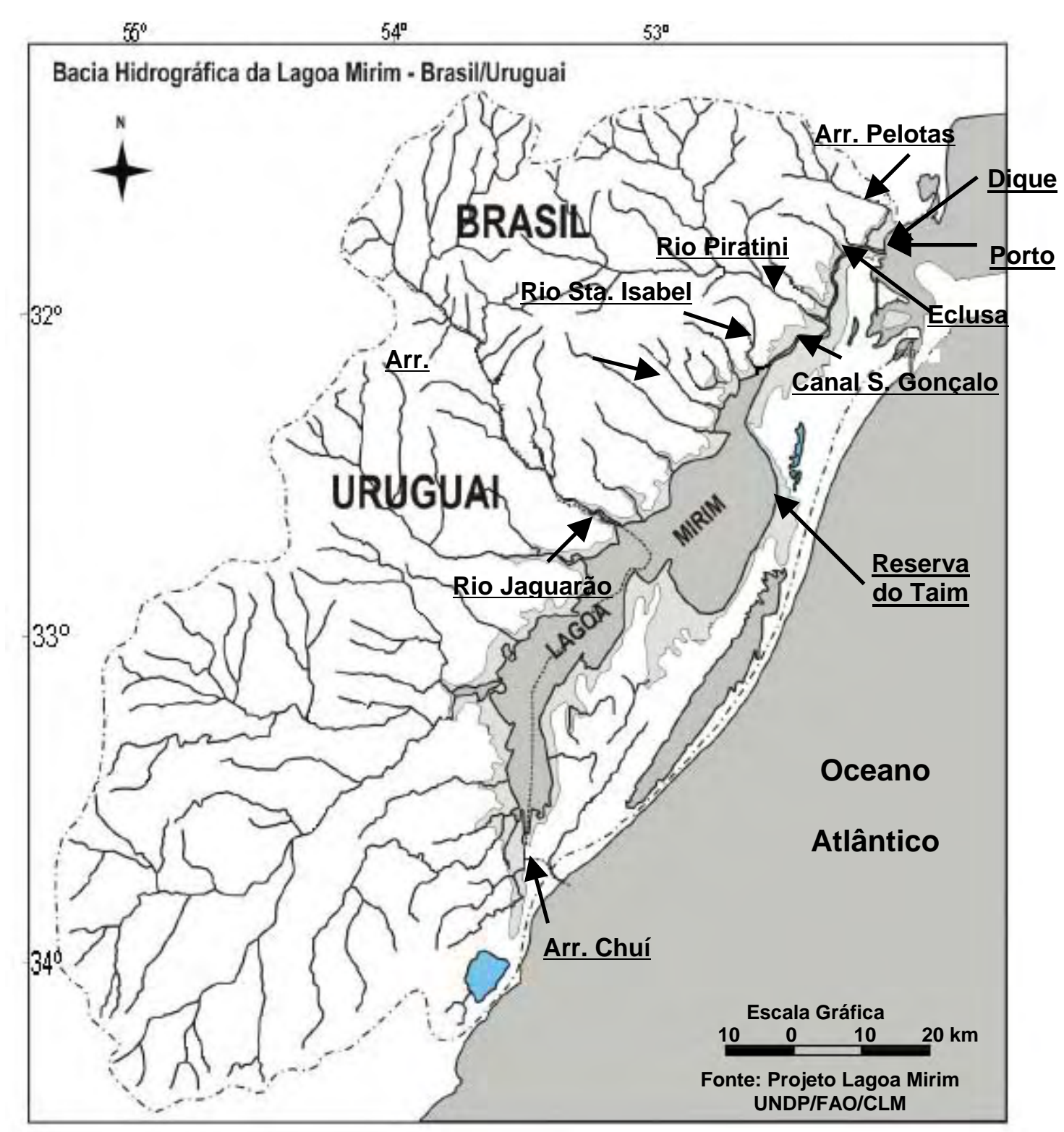

Figura 2. Localização dos principais corpos hídricos avaliados - RS (adaptado de Machado, 2007).

\section{RESULTADOS E DISCUSSÃO}

Na Tabela 1 estão apresentados os resultados máximos, mínimos, médios e o desvio padrão nas concentrações de fósforo, obtidos nas análises efetuadas nas amostras coletadas ao longo dos três anos de monitoramento, nos cursos de água que deságuam na Lagoa Mirim e que cortam a cidade de Pelotas. 
FIA, R.; MATOS, A. T.; CORADI, P. C.; PEREIRA-RAMIREZ, O. Estado trófico da água na bacia hidrográfica da Lagoa Mirim, RS, Brasil. Ambi-Agua, Taubaté, v. 4, n. 1, p. 132-141, 2009. (doi:10.4136/ambi-agua.78)

Tabela 1. Resultados máximos, mínimos, médios e desvio padrão das concentrações de fósforo nos corpos de água, durante os três anos de monitoramento.

\begin{tabular}{lrrrr}
\hline \multirow{2}{*}{ Corpo hídrico } & Máximo & Mínimo & Média & Desvio-padrão \\
\cline { 2 - 5 } & \multicolumn{4}{c}{$\mathbf{P}\left(\boldsymbol{\mu g} \mathbf{~ L}^{-\mathbf{1}}\right)$} \\
\hline Eclusa & 31.495 & 135 & 5.571 & 8.318 \\
Chasqueiro & 19.320 & 80 & 1.383 & 3.532 \\
Porto & 3.940 & 90 & 595 & 949 \\
Dique & 9.900 & 60 & 1.130 & 2.331 \\
Taim & 6.020 & 80 & 816 & 1.496 \\
Canal São Gonçalo & 67.917 & 41.429 & 57.463 & 6.235 \\
Arroio Pelotas & 28.078 & 153 & 3.711 & 8.126 \\
Rio Jaguarão & 12.320 & 80 & 1.232 & 2.496 \\
Rio Piratini & 28.500 & 65 & 1.650 & 5.128 \\
Rio Santa Isabel & 17.540 & 60 & 1.299 & 3.184 \\
Arroio Chuí & 12.530 & 110 & 1.666 & 3.185 \\
\hline
\end{tabular}

As concentrações de fósforo nas amostras estão elevadas, o que caracteriza esses cursos de água como hipereutróficos. Segundo a Resolução CONAMA nº 357 de 2005, para que um curso de água esteja na condição classe 2 são necessários, entre outras avaliações, que as concentrações de fósforo total sejam inferiores a $30 \mu \mathrm{g} \mathrm{L}{ }^{-1}$ em ambientes lênticos e inferiores a $50 \mu \mathrm{g} \mathrm{L} \mathrm{L}^{-1}$ em ambientes intermediários e tributários de ambientes lênticos (Brasil, 2005). Nota-se que em todas as amostragens as concentrações mínimas observadas foram superiores aos valores estabelecidos pela referida resolução. Devem-se destacar ainda as maiores concentrações de fósforo encontradas no Canal São Gonçalo, na Barragem da Eclusa, inserida no referido canal, e no Arroio Pelotas que recebe parte da poluição da cidade de Pelotas. Nas Figuras 3 e 4 estão apresentados, respectivamente, os Índices de Estado Trófico modificado por Toledo $\left(\mathrm{IET}_{\mathrm{T}}\right)$ e o sugerido por Lamparelli $\left(\mathrm{IET}_{\mathrm{L}}\right)$, para os corpos hídricos com características lênticas.

Pela classificação proposta por Toledo Jr. (1990) os corpos de água lênticos foram considerados Mesotróficos (IET $\mathrm{T}_{\mathrm{T}}>44$ ) e Hipereutróficos $\left(\operatorname{IET}_{\mathrm{T}}>74\right)$, enquanto que, pela metodologia de Lamparelli, eles foram classificados como Eutróficos ( $\operatorname{IET}_{\mathrm{L}}>59$ ) e Hipereutróficos ( $\operatorname{IET}_{\mathrm{L}}>67$ ).

Nas Figuras 5 e 6 estão apresentados, respectivamente, os Índices de Estado Trófico modificado por Toledo $\left(\mathrm{IET}_{\mathrm{T}}\right)$ e o sugerido por Lamparelli $\left(\mathrm{IET}_{\mathrm{L}}\right)$, para os corpos hídricos com características lóticas.

Os ambientes lóticos apresentaram condições de maior eutrofização quando avaliados pela metodologia de Toledo Jr, em que o $\mathrm{IET}_{\mathrm{T}}$ variou de Eutrófico a Hipereutrófico. No entanto, pela metodologia de Lamparelli, os ambientes avaliados apresentaram variações de Mesotrófico a Hipereutrófico, para o $\mathrm{IET}_{\mathrm{L}}$.

Assim, verifica-se que o $\mathrm{IET}_{\mathrm{L}}$ foi mais conservador que o $\mathrm{IET}_{\mathrm{T}}$ para ambientes lênticos, sendo observado o contrário para ambientes lóticos. Para os ambientes lóticos, o $\mathrm{IET}_{\mathrm{L}}$ apresentou maior sensibilidade às mudanças, aumentando, dessa forma, a amplitude das classificações tróficas. Já para os ambientes lênticos, essa maior sensibilidade e, consequentemente, maior amplitude de classes tróficas, foi verificado para o $\mathrm{IET}_{\mathrm{T}}$. Fato semelhante foi observado por Lima (2007) ao avaliar o estado de trofia do Açúde Acarape no Ceará. Garcia et al. (2007), ao contrário, constataram maior sensibilidade para o IET $_{\mathrm{L}}$ quando comparado ao $\mathrm{IET}_{\mathrm{T}}$ na avaliação do estado trófico do Reservatório de Ilha Solteira. 
FIA, R.; MATOS, A. T.; CORADI, P. C.; PEREIRA-RAMIREZ, O. Estado trófico da água na bacia hidrográfica da Lagoa Mirim, RS, Brasil. Ambi-Agua, Taubaté, v. 4, n. 1, p. 132-141, 2009. (doi:10.4136/ambi-agua.78)

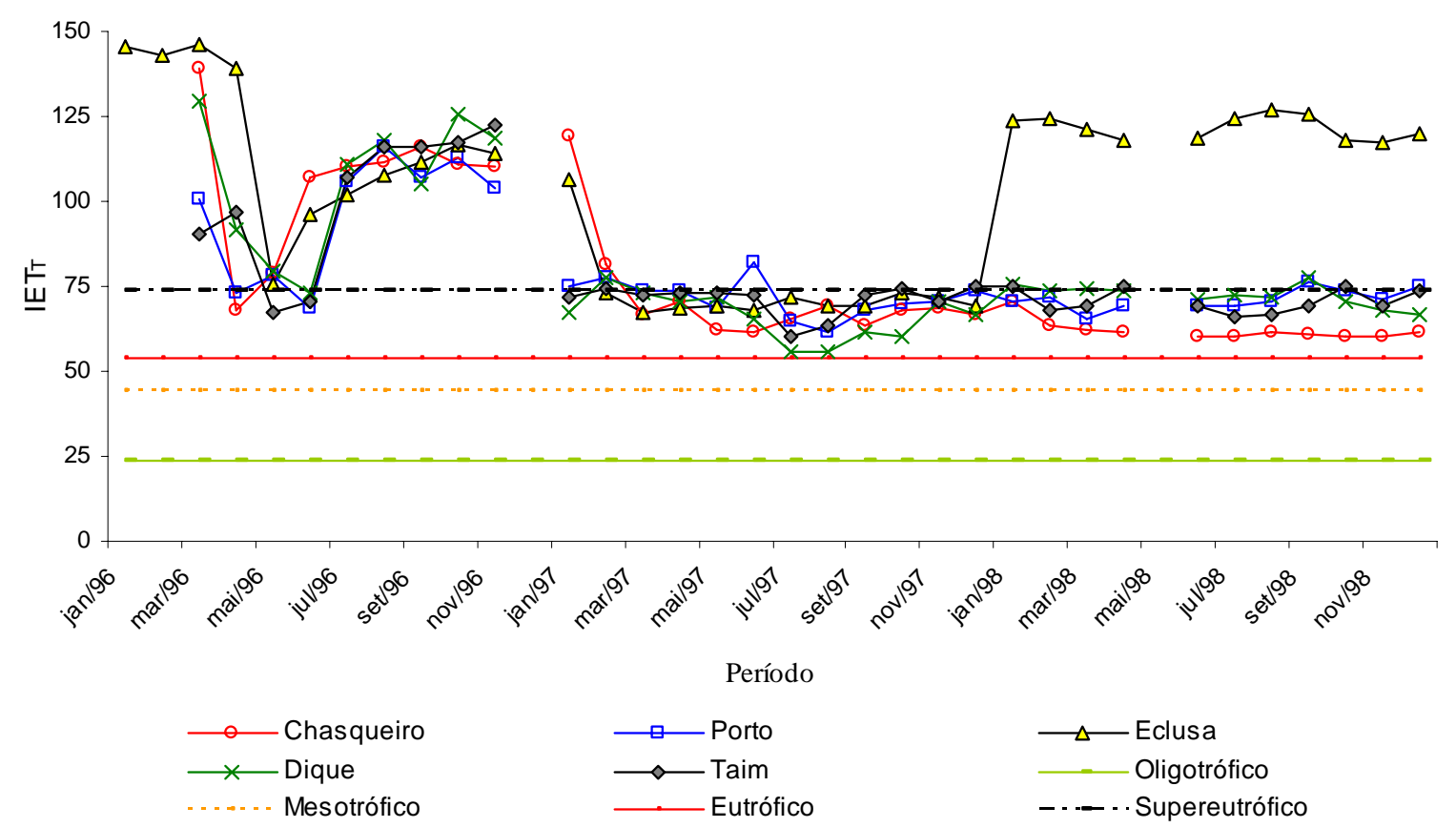

Figura 3. Valores de $\mathrm{IET}_{\mathrm{T}}$ obtidos na avaliação de alguns corpos de água lênticos da bacia da Lagoa Mirim.

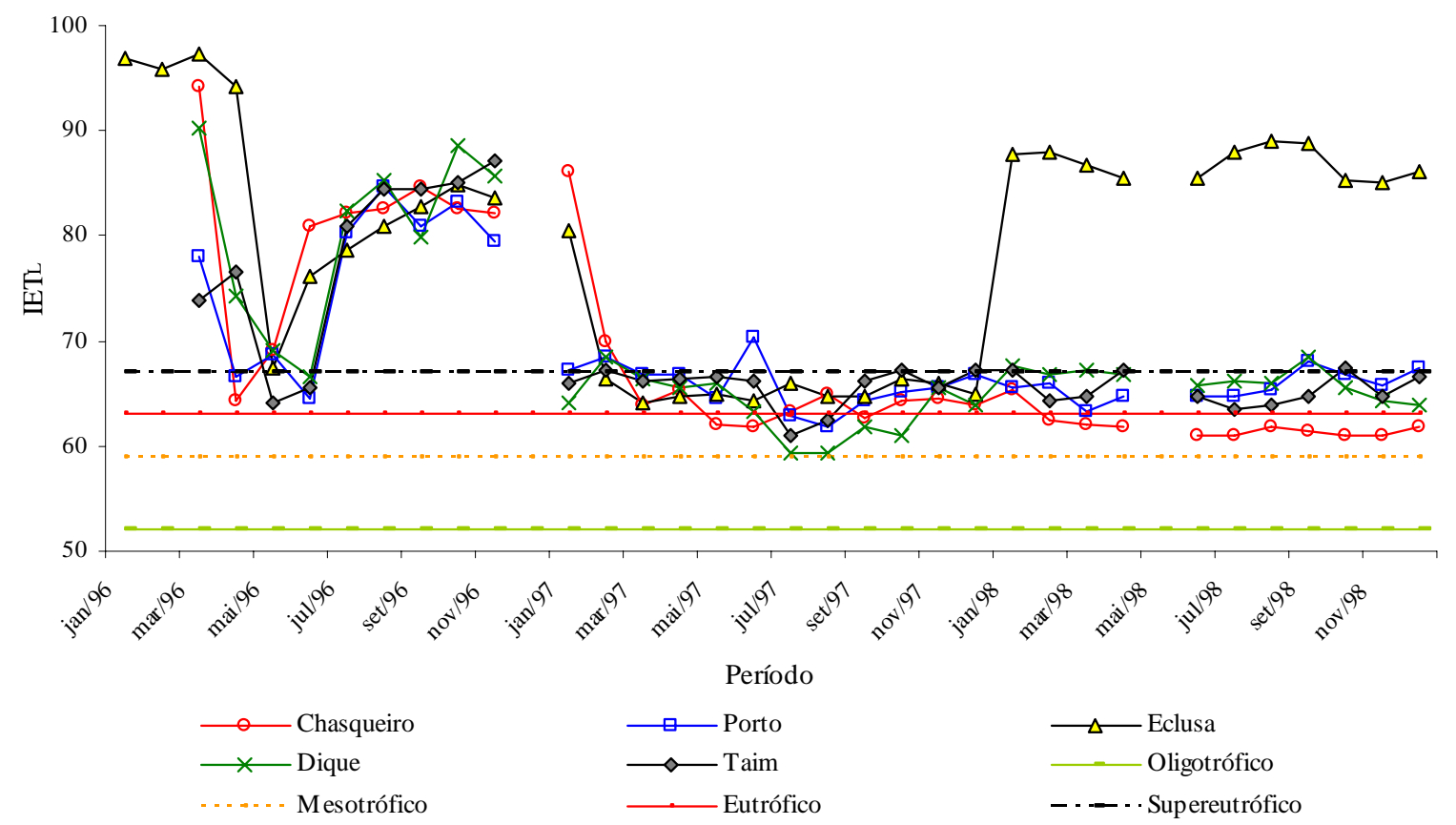

Figura 4. Valores de $\operatorname{IET}_{\mathrm{L}}$ obtidos na avaliação de alguns corpos de água lênticos da bacia da Lagoa Mirim. 
FIA, R.; MATOS, A. T.; CORADI, P. C.; PEREIRA-RAMIREZ, O. Estado trófico da água na bacia hidrográfica da Lagoa Mirim, RS, Brasil. Ambi-Agua, Taubaté, v. 4, n. 1, p. 132-141, 2009. (doi:10.4136/ambi-agua.78)

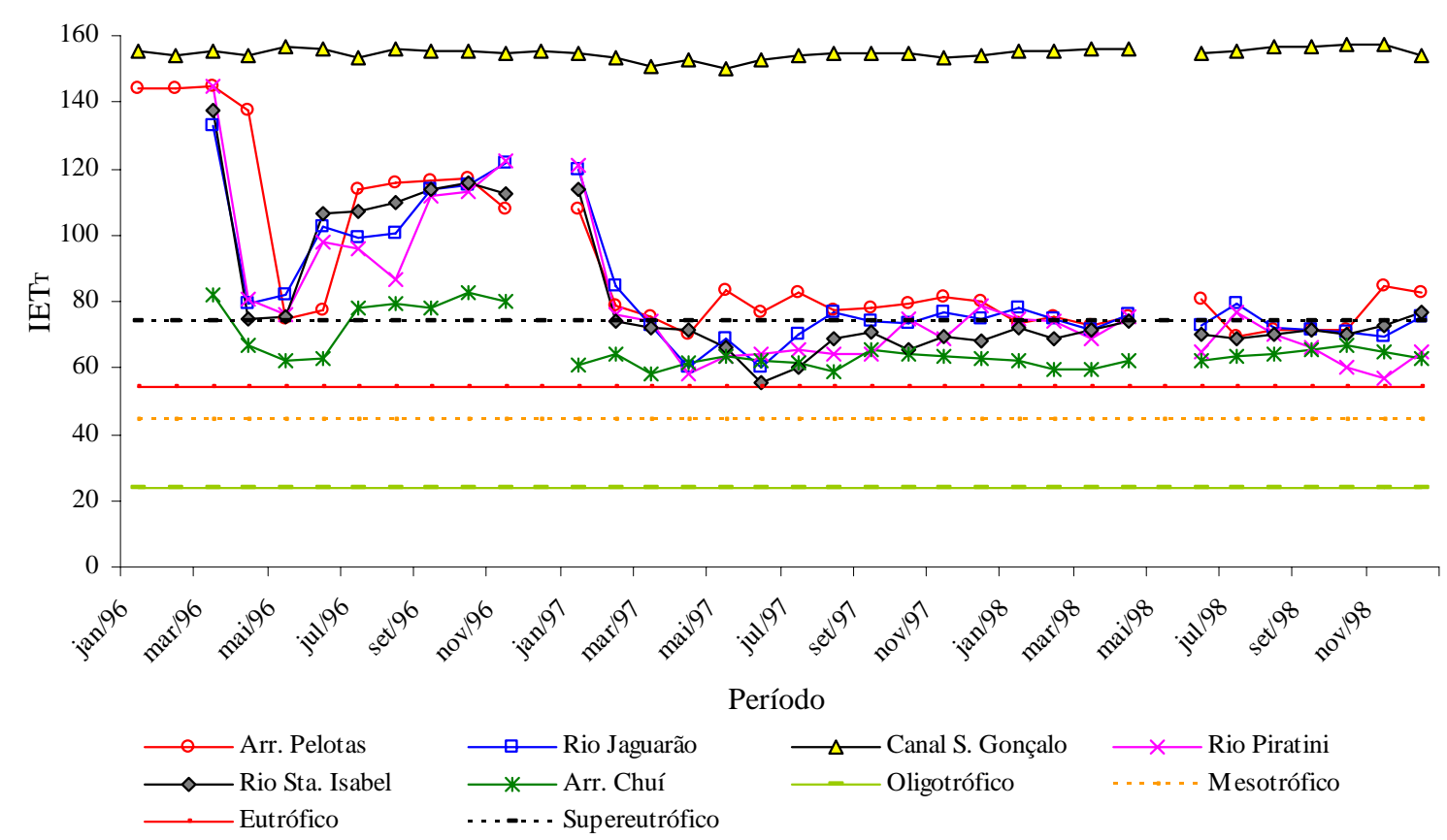

Figura 5. Valores de IET $_{\mathrm{T}}$ obtidos na avaliação de alguns corpos de água lóticos da bacia da Lagoa Mirim.

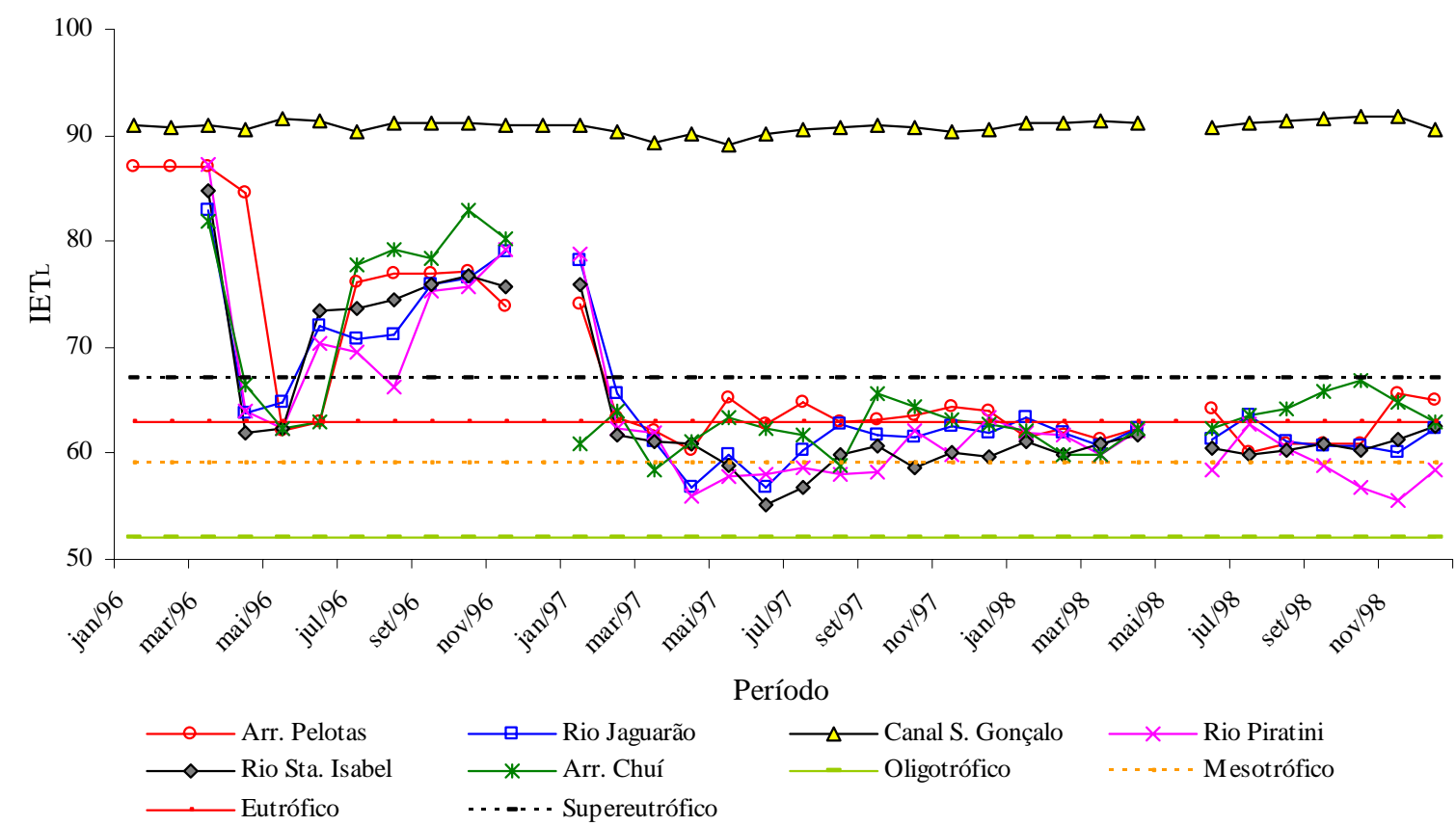

Figura 6. Valores de $\operatorname{IET}_{\mathrm{L}}$ obtidos na avaliação de alguns corpos de água lóticos da bacia da Lagoa Mirim.

Independente do IET utilizado é possível verificar que, após um período de elevada variabilidade do IET, durante praticamente todo o ano de 1996, houve tendência de estabilização nos valores nos anos de 1997 e 1998. Exceto para a Eclusa, em que se observa aumento nos valores de IET no ano de 1998. Verifica-se, também, a elevada concentração de fósforo e consequentemente elevação do IET no Canal São Gonçalo, comparado aos demais 
cursos de água. Não foi possível verificar influência das estações do ano em relação aos índices calculados.

Os resultados obtidos permitem dizer que o comportamento da variável avaliada é instável. Há períodos em que o estado trófico indica melhoria na qualidade da água e há períodos em que os valores alcançados tornam-se críticos, principalmente para o Canal São Gonçalo e para Eclusa, indicando deterioração na qualidade das águas.

Esse fato se deve às características do entorno dos cursos de águas. Alguns corpos hídricos cortam regiões de intensa atividade agrícola, como, por exemplo, o Canal São Gonçalo, que apresenta lavouras de arroz irrigado nas suas duas margens, sendo um significativo recurso hídrico utilizado pelos orizicultores da região de Pelotas, que o utilizam para captação de água com fins à irrigação de suas lavouras. Como em muitos cursos de água, neste também há devolução da água utilizada nas lavouras de arroz (Grützmacher et al., 2008), o qual poderá estar recebendo adubos químicos e orgânicos fosfatados. Esse tipo de atividade acaba por estabelecer uma contribuição difusa ao longo deles. Isso pode explicar a variabilidade encontrada no IET durante o período de observação. Além disso, o Canal São Gonçalo recebe parte dos efluentes da cidade de Pelotas, visto que a cidade possui rede coletora de esgoto que atende a, apenas, $67 \%$ da população, incluindo as indústrias, sendo tratado apenas $40 \%$ de todo o esgoto coletado (Silva, 2007).

Os corpos de água recebem, sem tratamento algum, os esgotos urbanos das cidades e efluentes industriais que carreiam material orgânico ricos em nutrientes e que superam em muito a capacidade depurativa destes. Essas fontes pontuais de poluição conduzem a uma queda na qualidade das águas e a um intenso processo de eutrofização, como observado em alguns ambientes aquáticos avaliados.

\section{CONCLUSÕES}

Pode-se concluir que:

- As concentrações de fósforo encontradas em todas as amostragens foram superiores ao limite estabelecido na Resolução CONAMA n 357 de 2005, para cursos de água em condição classe 2;

- A utilização do IET constitui metodologia de avaliação da qualidade de corpos de água bastante prática, facilitando a interpretação e divulgação dos resultados obtidos e, quando aplicado a corpos aquáticos de uma mesma região, permite a rápida avaliação comparativa do estado trófico dos mesmos;

- O Índice de Estado Trófico modificado por Toledo Jr. mostrou-se mais conservador para ambientes lóticos, quando comparado ao índice proposto por Lamparelli, e menos conservador para ambientes lênticos;

- Não foi possível diferenciar tendências de variação nos IET’s em função das estações do ano.

\section{REFERÊNCIAS}

AMERICAN PUBLIC HEALTH ASSOCIATION - APHA; AMERICAN WATER WORKS ASSOCIATION - AWWA; WATER ENVIRONMENT FEDERATION- WEF. Standard methods for the examination of water and wastewater. 20. ed. Washington: APHA/AWWA/WEF, 1998. 
BRASIL. Ministério do Meio Ambiente. Conselho Nacional de Meio Ambiente - CONAMA. Resolução $n^{0}$ 357, de 17 de março de 2005: dispõe sobre a classificação dos corpos de água e diretrizes ambientais para o seu enquadramento, bem como estabelece as condições e padrões de lançamento de efluentes. Disponível em: <http://www.mma. gov.br>. Acesso em: 15 de fevereiro de 2009.

CARLSON, R. E. A trophic state index for lakes. Limnology and Oceanography, v. 22, n. 2, p. 261-269, 1977.

DUARTE, M. A. C.; CEBALLOS, O.; SUSANA, B.; ANNEMARIE, K.; MELO, H. N. M.; ARAÚJO, J. A. H. Índice do estado trófico de Carlson (IET) aplicado em corpos aquáticos lênticos do nordeste do Brasil. In: CONGRESO INTERAMERICANO DE INGENIERÍA SANITARIA Y AMBIENTAL, 26., Lima, 1998. Resumes... Lima: Asociación Peruana de IngenierÝa Sanitaria y Ambiental - AIPS; AIDIS, 1998. p.1-5.

GARCIA, C. Z.; GARCIA, D. C. O.; LEITE, M. A. Comparação entre dois índices de estado trófico para o reservatório de Ilha Solteira. In: CONGRESSO DE ECOLOGIA DO BRASIL, 8., Caxambu, 2007. Anais... Caxambu, 2007. CD-ROM.

GRÜTZMACHER, D. D.; GRÜTZMACHER, A. D.; AGOSTINETTO, D.; LOECK, A. E.; ROMAN, R.; PEIXOTO, S. C.; ZANELLA, R. Monitoramento de agrotóxicos em dois mananciais hídricos no sul do Brasil. Revista Brasileira de Engenharia Agrícola e Ambiental, v. 12, n. 6, p. 632-637, 2008.

LAMPARELLI, M. C. Grau de trofia em corpos d’água do estado de São Paulo: avaliação dos métodos de monitoramento. 238f. 2004. Tese (Doutorado emEcologia Aplicada) - Universidade de São Paulo, São Paulo, 2004.

LIMA, F. F. Estado trófico do Açude Acarape do Meio com prognósticos usando modelagem matemática. 94f. 2007. Dissertação (Mestrado em Engenharia Sanitária) Universidade Federal do Ceará, Fortaleza, 2007.

MACHADO, G. Demanda e disponibilidade hídrica no sistema Lagoa Mirim - São Gonçalo Rio Grande do Sul. Revista Discente Expressões Geográficas, n. 3, p. 61-82, 2007.

MOTA, S. Introdução à engenharia ambiental. 4. ed. Rio de Janeiro: Abes, 2006. 388p.

SILVA, L. C. Plano de gestão ambiental e social. Programa de desenvolvimento municipal integrado, 2007. Disponível em: <www.bage.rs.gov.br/pdmi/plano_ambiental_e _social_do_pdmi.pdf $>$. Acesso em: 13 novembro de 2008.

TOLEDO Jr., A. P.; TALARICO, M.; CHINEZ, S. J.; AGUDO, E. G. A aplicação de modelos simplificados para a avaliação do processo da eutrofização em lagos e reservatórios tropicais. In: CONGRESSO BRASILEIRO DE ENGENHARIA SANITÁRIA E AMBIENTAL, 12., Camboriú, 1983. Anais... Camboriú, 1983. p. 1-34.

TOLEDO Jr., A. P. Informe preliminar sobre os estudos para obtenção de um índice para avaliação do estado trófico de reservatórios de regiões quentes tropicais. São Paulo: CETESB, 1990. 12p. (Relatório Interno CETESB). 


ISSN = 1980-993X - doi:10.4136/1980-993X
www.agro.unitau.br/ambi-agua
E-mail: ambi-agua@agro.unitau.br
Tel.: (12) 3625-4116

Efeito do antigo Lixão do Roger, João Pessoa, Brasil, na qualidade da água subterrânea local

(doi:10.4136/ambi-agua.79)

\author{
Gilson Barbosa Athayde Júnior'; Claudia Coutinho Nóbrega ${ }^{1}$; Carmem Lúcia Moreira \\ Gadelha $^{1}$; Irene Monteiro de Franca Souza ${ }^{2}$; Giulliano de Souza Fagundes ${ }^{3}$ \\ ${ }^{1}$ Departamento de Engenharia Civil e Ambiental, Centro de Tecnologia, Universidade Federal da Paraíba \\ E-mail: gilson@ct.ufpb.br; claudiacn@uol.com.br; carmemgadelha@yahoo.com.br \\ ${ }^{2}$ Bolsista de Iniciação científica CNPq/UFPB. E-mail: irenesouza1984@hotmail.com \\ ${ }^{3}$ Mestrando em Engenharia Urbana e Ambiental. UFPB. E-mail: giulliano_fagundes@yahoo.com.br
}

\title{
RESUMO
}

Ao longo de 45 anos (de 1958 a 2003), os resíduos oriundos dos municípios de João Pessoa, foram depositados no antigo lixão do Roger, que se assenta no manguezal adjacente ao rio Sanhauá, agravando os problemas ambientais e de saúde pública da população pessoense que mora nas proximidades. Entre 1999 e 2003, o antigo lixão também recebeu os resíduos dos municípios de Cabedelo e Bayeux. São vários os problemas ambientais resultantes dessa disposição inadequada de resíduos sólidos, incluindo-se a poluição de águas subterrâneas. A poluição das águas subterrâneas na região próxima ao lixão do Roger é o enfoque principal deste trabalho, no qual é discutido o monitoramento de seis poços situados na região de influência direta e indireta do antigo lixão. De acordo com os resultados, as águas subterrâneas coletadas não podem ser consumidas pela população sem tratamento prévio, pois têm apresentado parâmetros de qualidade acima do estabelecido pela Portaria 518/04 do Ministério da Saúde que define os padrões de potabilidade no Brasil. Os resultados obtidos evidenciaram poluição maior das águas subterrâneas nos poços situados mais próximos ao antigo lixão, onde há influência direta, que nos pontos adjacentes, destacando o impacto ambiental desencadeado por aquele antigo lixão.

Palavras-chave: Água subterrânea; lixão do Roger; qualidade da água.

\section{Effect of the decommissioned Roger open dump, João Pessoa, Brazil, on local groundwater quality}

\begin{abstract}
Throughout 45 years (1958-2003) the solid wastes from João Pessoa were disposed off in the former Roger's open dump, which is situated adjacent to the mangrove at the sides of Sanhauá river, intensifying environmental problems and threatening the health of people living nearby. Between 1999 and 2003 the decommissioned open dump received wastes from the cities of Cabedelo and Bayeux. Several environmental impacts result from this inadequate disposal of solid wastes, including the pollution of groundwater nearby the former Roger's open dump, which is the major point of investigation of this paper. The water quality of 6 wells situated in the region of influence of the open dump were monitored. Results have shown that the groundwater near the open dump cannot be drunk by the population without previous treatment, since it has some parameters of water quality in discordance with Brazilian legislation concerned with drinking water. Results have also shown that the level of pollution is higher in the wells closer to the open dump.
\end{abstract}

Keywords: groundwater; Roger’s open dump; water quality. 


\section{INTRODUÇÃO}

A maior parte da água do planeta (96,5\%) está nos oceanos. Do restante, 1,7\% está no gelo polar, 1,7\%, nas águas subterrâneas e apenas 0,1\%, nas águas do sistema superficial e atmosférico. Apenas 0,006\% da água doce está disponível em rios. A água biológica, fixada nos tecidos de plantas e animais, compreende a $0,003 \%$ de toda a água doce, equivalente a metade do volume contido nos rios.

As águas subterrâneas são fontes de água potável muito importante, capazes de suprir as necessidades humanas nas mais variadas formas de utilização. Fazendo um comparativo entre as águas superficiais e as subterrâneas, observa-se que estas apresentam inúmeras vantagens no tocante à qualidade da água, principalmente porque se encontram protegidas de agentes poluidores.

Por outro lado, o acelerado desenvolvimento tecnológico e industrial, associado ao crescimento populacional, faz com que a produção de resíduos sólidos aumente, exigindo medidas de controle e disposição final cada vez mais eficazes. Infelizmente, essas soluções ainda não atingem a maioria dos municípios brasileiros onde a disposição de resíduos é feita de forma inadequada, comprometendo a qualidade ambiental de modo geral e, muitas vezes, atingindo as águas subterrâneas. Os resíduos sólidos depositados a céu aberto diretamente sobre o solo chamados lixões, vazadouros ou monturos, constituem importante fonte de contaminação dos lençóis subterrâneos, devido à percolação do chorume até o nível do lençol. Chorume é o líquido oriundo da decomposição da matéria orgânica da massa de resíduos sólidos e é de grande potencial poluidor.

O objetivo deste trabalho é estudar os aspectos qualitativos das águas subterrâneas nas proximidades do antigo lixão do Roger, considerando que esse manancial, geralmente utilizado pela população, sem tratamento algum, deve atender aos padrões de potabilidade da água destinada ao consumo humano.

\subsection{Lixões e águas subterrâneas}

A disposição de resíduos sólidos nos lixões ainda é uma prática comum nos municípios brasileiros, apesar dos graves danos ao meio ambiente e à saúde pública que eles podem causar.

Devido à falta de impermeabilização, os lixões oferecem grandes riscos de contaminação dos solos e das águas subterrâneas pelo chorume, além de serem propícios à proliferação de macro e micro vetores responsáveis pela transmissão de inúmeras doenças. A Norma Brasileira NBR - 13.896 da Associação Brasileira de Normas Técnicas (ABNT, 1997) recomenda que os aterros sanitários devam ser construídos e operados de forma a manter a qualidade das águas subterrâneas. Tendo em vista o seu uso para o abastecimento público, essa norma considera que a qualidade das águas subterrâneas, na área da instalação, deve atender aos padrões de potabilidade estabelecidos na legislação vigente.

No Brasil, a portaria ${ }^{\circ}$ 518, de 25 de março de 2004, do Ministério de Saúde (Brasil, 2004) define o padrão de potabilidade que a água destinada ao consumo humano deve atender, determinando os Valores Máximos Permissíveis (VMP) para as características bacteriológicas, organolépticas, físicas e químicas da água potável.

Coelho e Santos (2004), em uma análise da qualidade da água subterrânea, em um local de disposição de resíduos no município de Uberlândia-MG, concluíram que a matéria orgânica e muitos outros compostos presentes ou produzidos na decomposição anaeróbia dos resíduos sólidos são solubilizados e transportados pela água de chuva através do solo e subsolo até as zonas de recarga das águas subterrâneas. 
Souza e Naval (2000), em pesquisa semelhante à dos autores supracitados, na região do aterro sanitário de Palmas-TO, verificaram que há variação na qualidade de água, podendo ser determinada pela percolação do chorume proveniente do aterro. Esses autores ressaltaram que mesmo os aterros que possuem todas as instalações de proteção ambientais não podem ser considerados como obras herméticas e existe sempre o risco de contaminação das áreas adjacentes ao aterro.

Santaella et al. (1999) explana que a poluição dos lençóis subterrâneos devido à disposição de resíduos ocorre de várias maneiras: pela infiltração direta da água, quando o nível do lençol freático atinge o da base do aterro, pela infiltração da água da chuva, pela transferência de gases solúveis e pela execução inadequada do aterro. Os referidos autores analisaram a região adjacente ao lixão de Fortaleza-CE e concluíram que o aquífero estudado possui naturalmente águas de boa qualidade para uso doméstico as quais têm sofrido modificações pela disposição inadequada de resíduos sólidos. Tais modificações são evidenciadas, principalmente pelas alterações nos valores de Demanda Química de Oxigênio (DQO) e cloretos, e intensificadas na época de estiagem.

Lopes e Schalch (2006) comparam os resultados de amostras do aquífero freático do aterro sanitário de Bauru com os limites estabelecidos pela Portaria N ${ }^{\circ}$ 518/2004 do Ministério da Saúde (Brasil, 2004). Para a análise desses resultados foi realizada Análise Multivariada dos dados, ou seja, as variáveis foram analisadas estatisticamente ao mesmo tempo com o objetivo de verificar se havia diferença significativa entre os poços. A probabilidade adotada foi $\mathrm{p}<0,05$, porcentagem de acerto equivalente a $95 \%$. Essa análise estatística dos ensaios físico-químicos demonstrou que a água do poço à montante do aterro apresentou melhor qualidade comparada à água dos poços à jusante, pois um número menor de parâmetros apresentou variação significativa. Com base na análise físico-química, esses autores inferiram que uma pluma de contaminação se move, conforme movimentação do lençol freático.

Mohammed et al. (2008) estudaram a vulnerabilidade ambiental do solo do lixão de Bommasandra na cidade de Bangalore (Índia). O estudo consistiu na coleta de amostras de solo nas proximidades do referido lixão para posterior caracterização. Os resultados apontaram para um ambiente moderadamente vulnerável a poluentes, e o transporte de cátions através do solo é mais retardado que o de ânions.

Rodrigues e Duarte (2002) estudaram maneiras de remediar a contaminação das águas subterrâneas oriundas de aterros sanitários e observaram que algumas plantas podem ser usadas para controlar o destino das águas de escoamento da precipitação que cai sobre um aterro sanitário, com objetivo de diminuir a infiltração e controlar a formação de lixiviados.

De acordo com os relatos citados anteriormente, constata-se que os lixões e até mesmo aterros sanitários podem contaminar as águas subterrâneas e o monitoramento destas nas proximidades dos lixões e aterros sanitários deve ser mantido para a segurança da população que consome essas águas.

\section{MATERIAIS E MÉTODOS}

\section{1. Área de estudo}

O antigo lixão do Roger abrange uma área de 17 ha e localiza-se na região metropolitana de João Pessoa (PB). O lixão está assentado no manguezal adjacente ao rio Sanhauá, o que contribui para o agravamento dos impactos ambientais negativos que qualquer depósito de resíduos sólidos a céu aberto e diretamente sobre o solo pode trazer. O antigo lixão foi fechado por ação do Ministério Público em outubro de 2003 e não mais recebeu resíduos. 
Nessa mesma data, João Pessoa passou a contar com um aterro sanitário em um outro local. Existe um projeto de recuperação/remediação da área do antigo lixão por parte da Prefeitura de João Pessoa, o qual foi executado parcialmente, dividindo toda a massa de resíduos em 5 células. Dessas 5 células, 2 já foram recuperadas pela instalação de drenos para coleta de chorume, drenos para coleta de gases, queimadores de gases e recobrimento das células com uma camada de solo, além da construção de uma estação de tratamento para o chorume coletado.

Para proceder ao estudo sobre a qualidade da água subterrânea na região próxima ao antigo lixão do Roger foram escolhidos, em um primeiro momento, para a coleta de amostras e posteriores análises de qualidade, quatro poços particulares (P1, P2, P3 e P4) já existentes na área de influência direta (dois poços) e indireta (dois poços) do referido lixão. Os poços P1 e P4 estão localizados dentro da área de influência direta do antigo lixão do Roger. O P1 é um poço profundo localizado em um antigo curtume (desativado) adjacente à área do antigo lixão e o P4, uma cacimba localizada em uma residência na Rua Anísio Salatiel, também nas proximidades do antigo lixão. Os pontos P2 e P3 encontram-se na área de influência indireta do lixão, ambos localizados numa empresa de cultivo de camarão, sendo o P2, um poço raso, e o P3, um poço profundo. Além desses quatro poços, foram perfurados na área interna de funcionamento do antigo lixão mais dois poços (P5 e P6) rasos, com $7 \mathrm{~m}$ de profundidade, sendo P5 à montante e P6 à jusante da massa de resíduos, segundo a direção predominante do fluxo subterrâneo. A Figura 1 mostra uma vista aérea da região na qual está situado o antigo lixão, bem como a indicação da localização dos poços.

Foram realizadas oito coletas de água nos poços citados, nas seguintes datas: 08/03/06, 09/08/06, 07/11/06, 28/02/07, 06/06/07, 12/09/07, 05/12/07, 20/02/08. No entanto, os poços P5 e P6 não foram amostrados nas duas primeiras datas em virtude de ainda não haverem sido construídos. O poço P4 não foi amostrado nas datas 28/02/07, 06/06/07, 12/09/07, 05/12/07 e 20/02/08, em virtude de não ser disponibilizado acesso por parte do proprietário da residência. No poço P5, não foi realizada coleta no dia 13/06/07, pelo fato de o poço ter sido obstruído por ato de vandalismo.

\subsection{Coleta e análise das amostras}

As coletas eram sempre efetuadas no período na manhã, entre $8 \mathrm{~h}$ e $11 \mathrm{~h}$. Nas amostras coletadas foram determinados os seguintes parâmetros: $\mathrm{pH}$, condutividade elétrica, dureza, turbidez, cor, sólidos totais dissolvidos (STD), DBO, cloretos, amônia, chumbo, alumínio e coliformes termotolerantes. Os parâmetros foram determinados por meio de análises em laboratório, seguindo a metodologia constante em Standard Methods for the Examination of Water and Wastewater (APHA et al, 1995). No momento da coleta, eram determinados os parâmetros $\mathrm{pH}$ e condutividade elétrica, e as amostras eram mantidas sob refrigeração para imediato transporte ao Laboratório de Saneamento da UFPB, onde eram processadas para a determinação dos demais parâmetros.

Para a comparação simultânea das médias dos parâmetros nos vários poços, utilizou-se análise de variância segundo o método GT-2 (com nível de significância de 5\%). Segundo esse método, os intervalos cujos limites se sobrepõem não têm médias significativamente diferentes entre si (Sokal e Rohlf, 1981).

\section{RESULTADOS E DISCUSSÃO}

Os resultados obtidos são descritos abaixo e apresentados nas Figuras de 2 a 13. 


\subsection{Potencial hidrogeniônico (pH)}

É a medida da concentração de íons $\mathrm{H}^{+}$na água. Na água quimicamente pura, os íons $\mathrm{H}^{+}$ estão em equilíbrio com os íons $\mathrm{OH}^{-}$e seu $\mathrm{pH}$ é neutro, igual a 7. Os principais fatores que determinam o pH da água são o gás carbônico dissolvido e a alcalinidade. Os valores obtidos ara o $\mathrm{pH}$ nas amostras se apresentaram variando entre 6,0 e 7,6, estando, portanto, dentro dos limites permitidos pela Portaria 518/2004 do Ministério da Saúde (Brasil, 2004). Na Figura 2, a análise estatística mostrou que houve diferença significativa (ao nível de 5\%) entre a média do poço P6 comparada com as médias dos poços P2 e P3, sendo o poço P6 localizado no lixão, onde há liberação de ácidos, devido à decomposição do lixo, diminuindo, portanto, o valor do pH, e os poços P2 e P3 são localizados na área de influência indireta do antigo lixão. Não houve outras diferenças significativas.

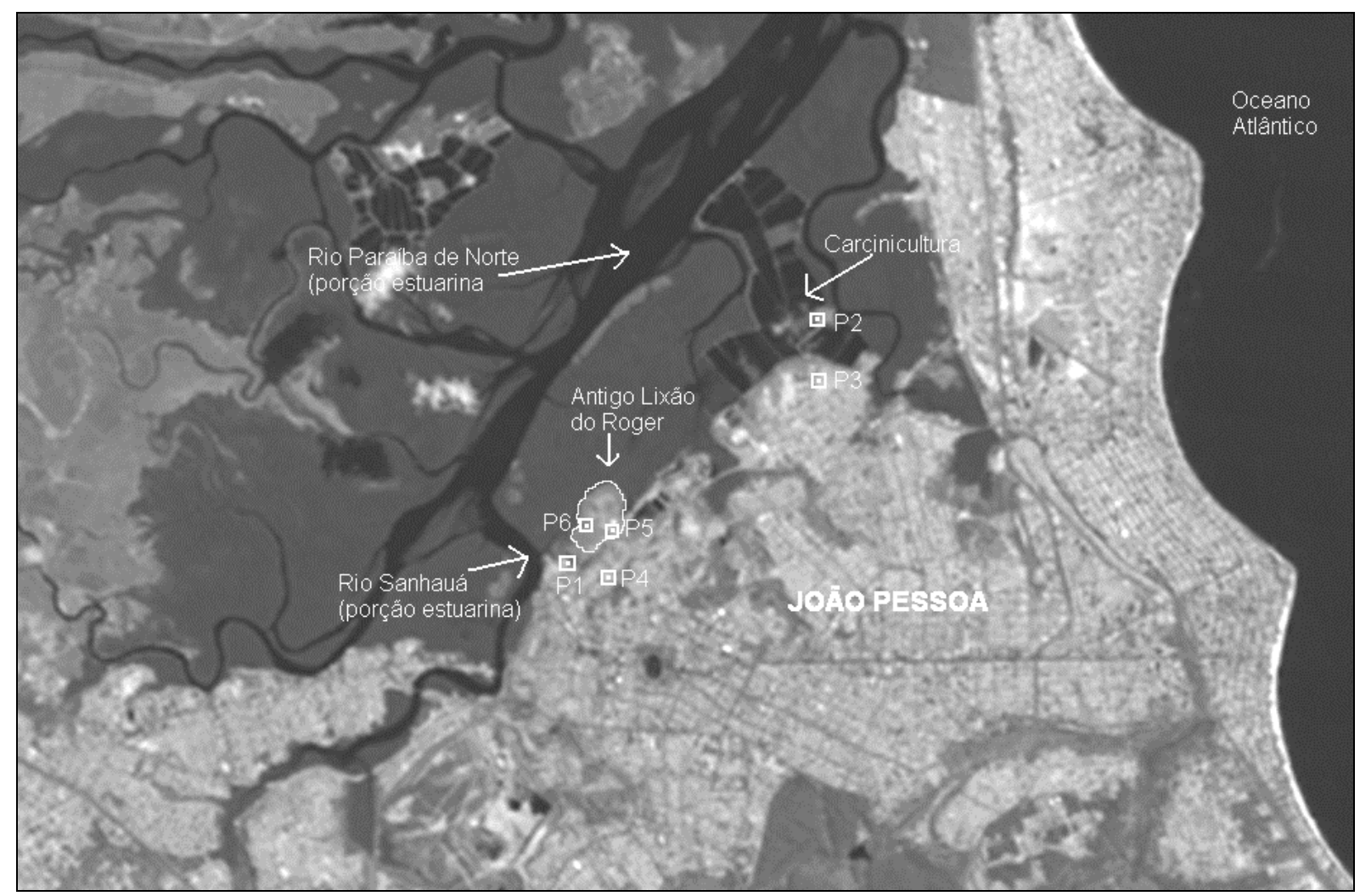

Figura 1. Vista aérea do antigo lixão do Roger.

Fonte: INTERSAT (2001).

\subsection{Condutividade elétrica}

Os sais dissolvidos e ionizados presentes na água transformam-na em um eletrólito capaz de conduzir a corrente elétrica. Como há uma relação de proporcionalidade entre o teor de sais dissolvidos e a condutividade elétrica, pode estimar, de modo rápido, a quantidade de STD presentes na água pela condutividade elétrica. Na maioria dos casos, os valores de condutividade ficaram dentro da faixa de $300-900 \mu \mathrm{S} / \mathrm{cm}$. O valor máximo $(1950 \mu \mathrm{S} / \mathrm{cm})$ ocorreu no ponto P6 na quinta coleta, enquanto que o ponto P1 apresentou o valor mínimo $(295 \mu \mathrm{S} / \mathrm{cm})$, na primeira coleta. Na Figura 3, a análise estatística mostra que houve diferença significativa (no nível de 5\%) entre a média do poço P6 e as médias dos poços P1, P2, P3 e P4, e entre a média do P5 e as médias dos poços P2 e P3. Não houve outras diferenças significativas entre as médias. 


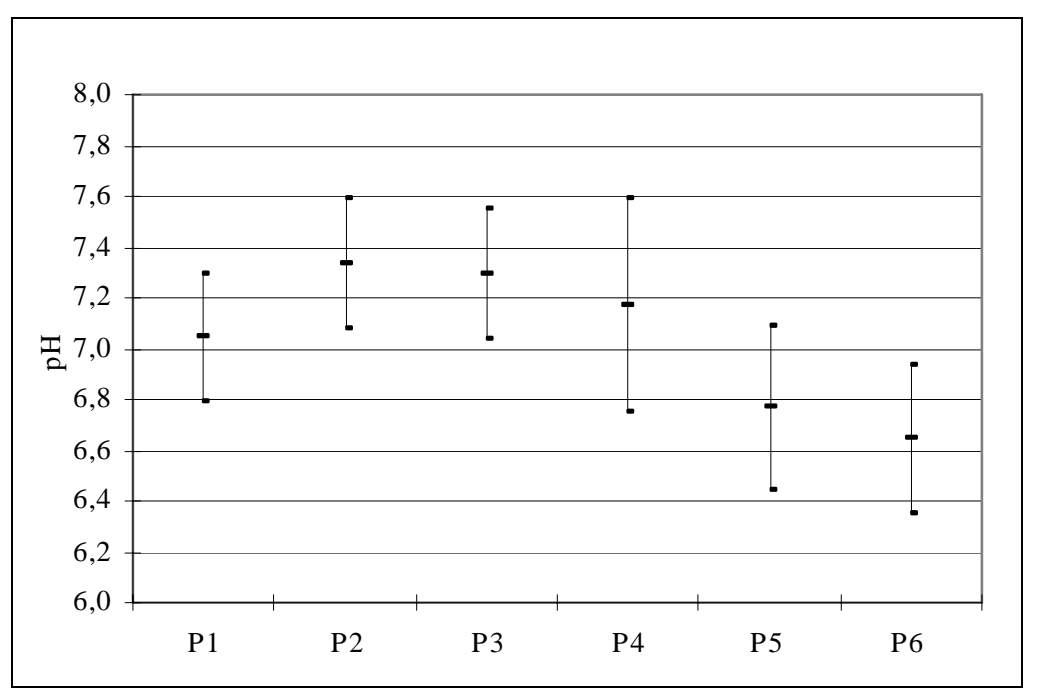

Figura 2. Comparativo entre as médias de $\mathrm{pH}$.

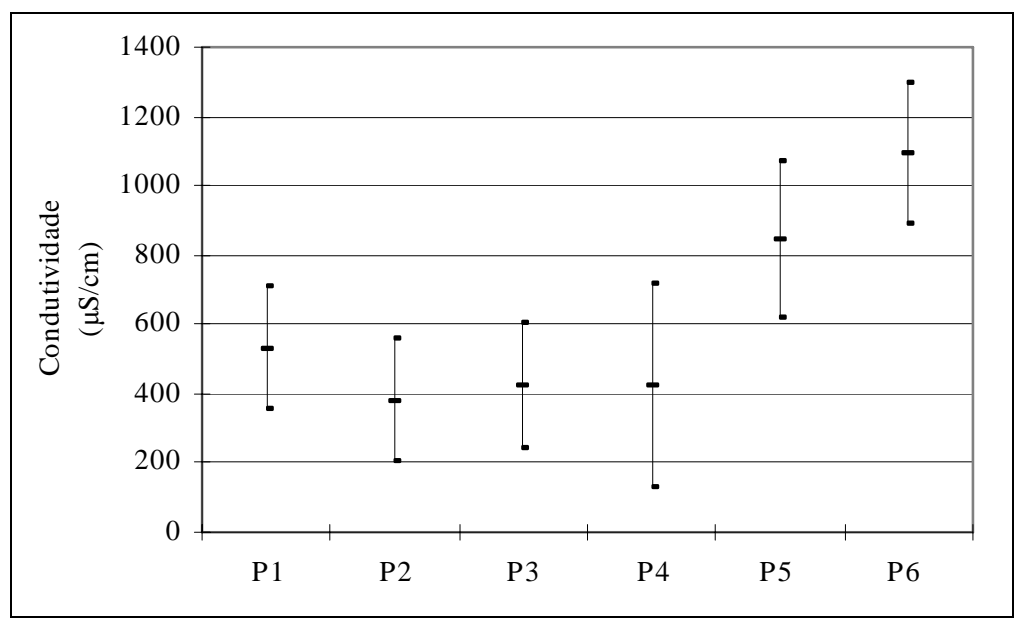

Figura 3. Comparativo entre as médias de condutividade elétrica.

\subsection{Sólidos Totais Dissolvidos (STD)}

Todas as impurezas presentes na água, com exceção dos gases dissolvidos, contribuem para a carga de sólidos. A Figura 6 apresenta os valores de STD encontrados nas amostras. A portaria 518/2004 (Brasil, 2004) determina que uma água que se destina ao consumo humano não pode ter valores de STD superiores a $1000 \mathrm{mg} / \mathrm{L}$. Nas amostras analisadas, o valor de STD não superou tal VMP, o que, segundo esse parâmetro, não compromete a segurança do uso dessa água para abastecimento humano. A Figura 4 mostra que houve diferença significativa entre as médias dos poços P5 e P6 comparadas com as dos poços P1, P2 e P3. Não houve outras diferenças significativas.

\subsection{Dureza}

Os principais íons metálicos que conferem dureza à água são os de cálcio e de magnésio, Águas duras são inconvenientes, porque o sabão não limpa eficientemente, aumentando seu consumo, e deixando uma película insolúvel sobre a pele, pias, banheiras e azulejos do banheiro. Para a água potável, o VMP para a dureza é de 500 mg/L (Brasil, 2004). Nos pontos P1, P2, P3 e P4, os valores encontrados foram menores que o VPM, com resultados máximos, no ponto P1, variando entre $298 \mathrm{mg} / \mathrm{L}$ e $389 \mathrm{mg} / \mathrm{L}$, e, mínimo de $144 \mathrm{mg} / \mathrm{L}$, no ponto P3, na segunda coleta, variando entre $144 \mathrm{mg} / \mathrm{L}$ e $355 \mathrm{mg} / \mathrm{L}$. Já nos pontos P5 e P6, os resultados 
obtidos ultrapassaram, em demasia, o VMP, com valores máximos no ponto P6, variando de 4217 a 11851 mg/L e mínimos no ponto P5, entre 987 mg/L e 3452 mg/L. Análise estatística revelou que a média do poço P6 foi significativamente diferente das dos demais poços (Figura 5). Analisando separadamente o conjunto dos poços P1, P2, P3 e P4, verifica-se que há diferença significativa entre a média do poço P2 e as médias dos poços P1 e P3. O poço P2 é o poço raso localizado na área de influência indireta do antigo lixão.

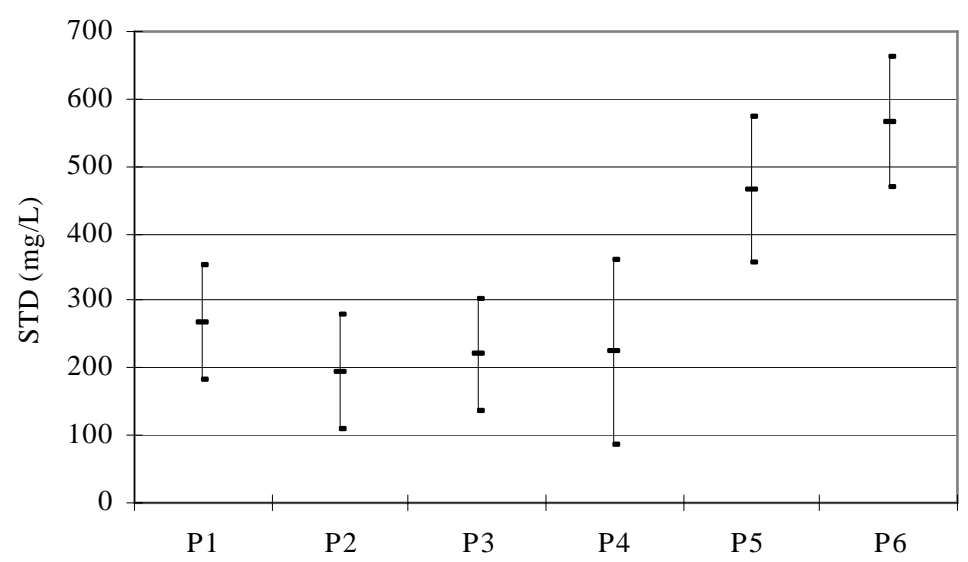

Figura 4. Comparativo entre as médias de STD.

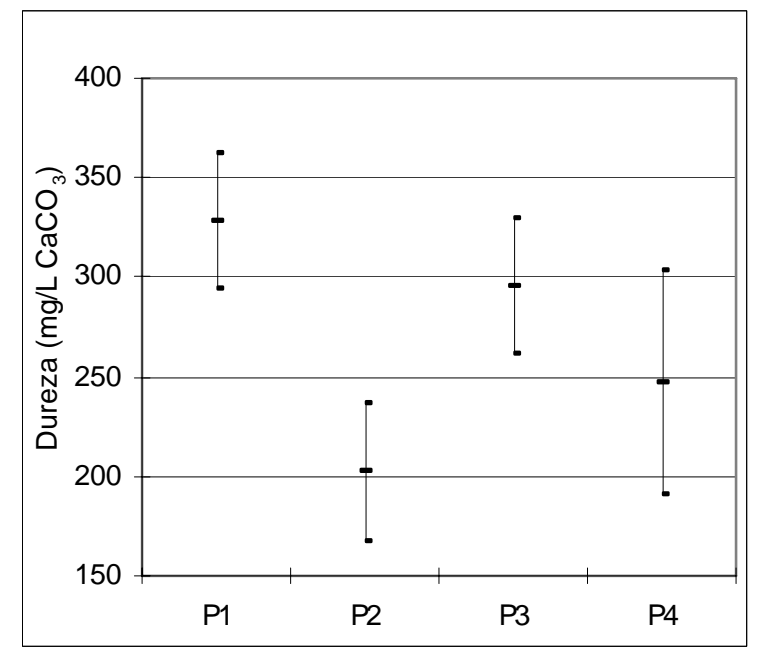

(a)

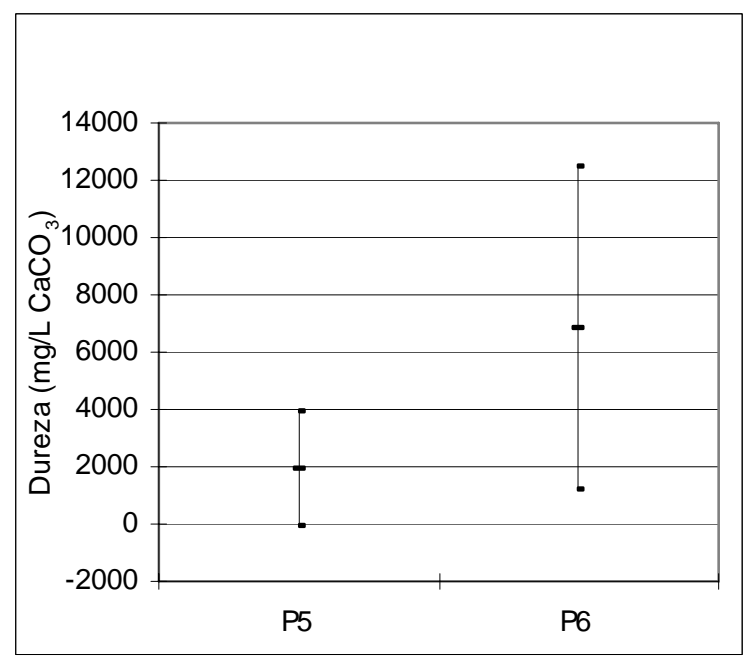

(b)

Figura 5. Comparativo entre as médias de dureza: (a) Pontos P1, P2, P3 e P4; (b) Pontos P5 e P6.

\subsection{Turbidez}

A Turbidez mede a dificuldade de um feixe de luz atravessar certa quantidade de água e é causada por matérias sólidas em suspensão (silte, argila, colóides, matéria orgânica, fitoplânctons e outros organismos microscópicos). As águas subterrâneas normalmente não apresentam problemas devido ao excesso de turbidez, porém, em alguns casos, águas que percolam solos ricos em íons de ferro, podem apresentar uma elevação de sua turbidez quando entram em contato com o oxigênio do ar. A turbidez máxima permissível para águas subterrâneas é de 1 UT (unidade de turbidez) em 95\% das amostras, após processo de desinfecção dessa água. Entre os 5\% dos valores de turbidez superiores ao VMP estabelecido, o limite máximo para qualquer amostra pontual deve ser 5 UT (Brasil , 2004). 
Nas amostras analisadas, os pontos P1, P2, P3 e P4 apresentam máximo de 3,87 UT, no ponto P3, na quinta coleta, e, mínimo de 0,10 UT, nos pontos P1, nas quarta e quinta coletas. Os resultados determinados para esse parâmetro não ultrapassaram o VMP de 1UT, não caracterizando qualquer impedimento dessa fonte para o caso de consumo humano, exceto, no ponto $\mathrm{P} 3$, nas quatro últimas coletas, correspondendo a $50 \%$ das amostras, a turbidez foi superior a 1 UT, caracterizando a água como imprópria para consumo, sem tratamento prévio. Nos pontos P5 e P6 os resultados ultrapassaram o VMP estabelecido, com máximo de 152 UT, no ponto P5, na oitava coleta, e, com mínimo de 5,5 UT, no ponto P5 na quarta coleta. Análise estatística mostrou que ocorreram diferenças significativas (ao nível de 5\%) entre as médias tanto do poço P5 quanto P6 e as dos poços P1, P2, P3 e P4. A análise estatística do conjunto de poços P1, P2, P3 e P4 revelou que houve diferença significativa entre as médias do poço P1 e P3 (Figura 6a).

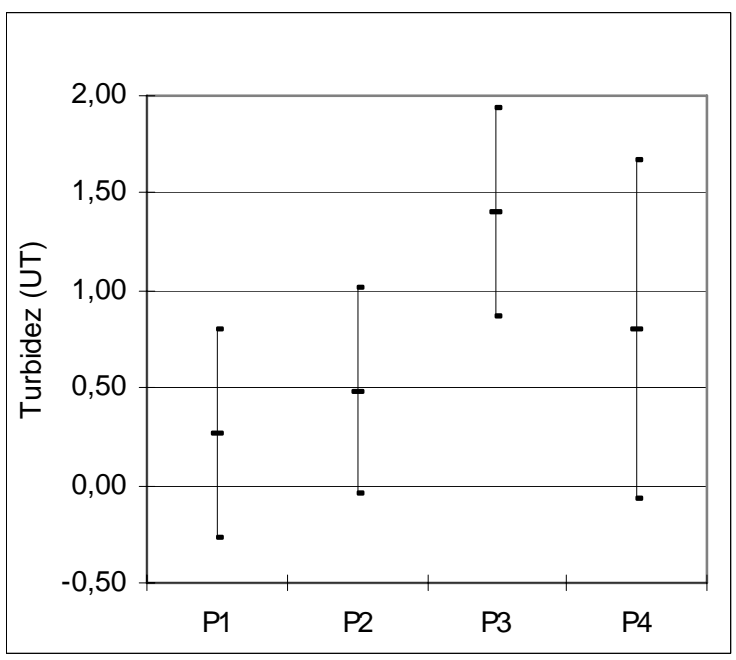

(a)

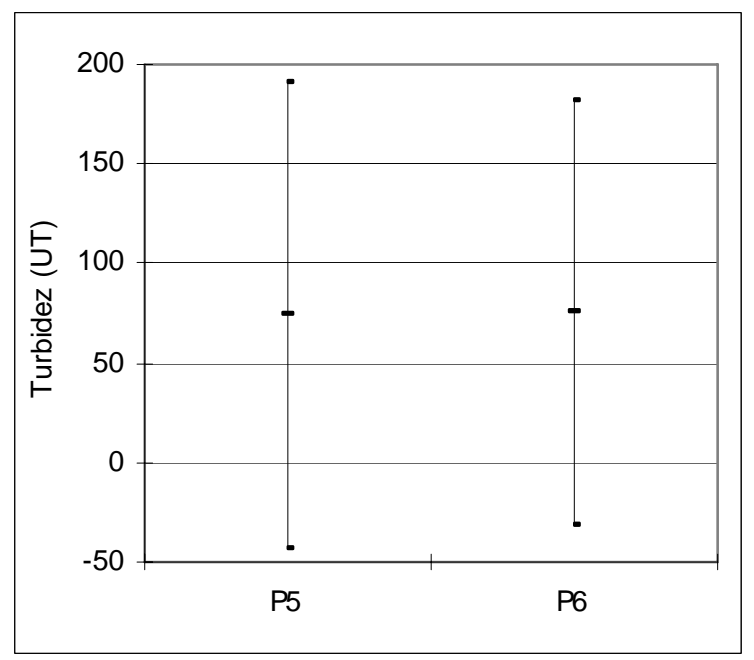

(b)

Figura 6. Comparativo entre as médias de Turbidez: (a) Pontos P1, P2, P3 e P4; (b) Pontos P5 e P6.

\subsection{Cor}

A cor de uma água é consequência de substâncias dissolvidas. Quando rica em ferro, a água é arroxeada, quando rica em manganês, é negra e, quando rica em ácidos húmicos, é amarelada (Pedrosa e Cateano, 2002). A cor também pode resultar da contaminação da água por efluentes industriais. Dentre os pontos P1, P2, P3 e P4, apenas, no ponto P4, na primeira coleta, o valor determinado para esse parâmetro atingiu o VMP, 15 uH (unidades Hazen), fato esse que não desqualifica o uso desse aquífero para consumo humano. Entretanto, nos pontos P5 e P6, os resultados obtidos ultrapassaram o VMP, com máximo de $600 \mathrm{uH}$, no ponto P5, na oitava coleta, e com mínimo de $80 \mathrm{uH}$, na terceira coleta, no ponto P6. A análise estatística revelou que houve diferença significativa (no nível de 5\%) entre as médias tanto do poço P5 quanto P6 e as dos poços P1, P2, P3 e P4. A Figura 7a mostra que, no conjunto dos poços P1, P2, P3 e P4, houve diferença significativa entre as médias do poço P4 e as dos poços P1, P2 e P3. 
ATHAYDE JÚNIOR, G. B.; NÓBREGA, C. C.; GADELHA, C. L. M.; SOUZA, I. M. F.; FAGUNDES, G. S. Efeito do antigo Lixão do Roger, João Pessoa, Brasil, na qualidade da água subterrânea local. Ambi-Agua, Taubaté, v. 4, n. 1, p. 142-155 2009. (doi:10.4136/ambi-agua.79)

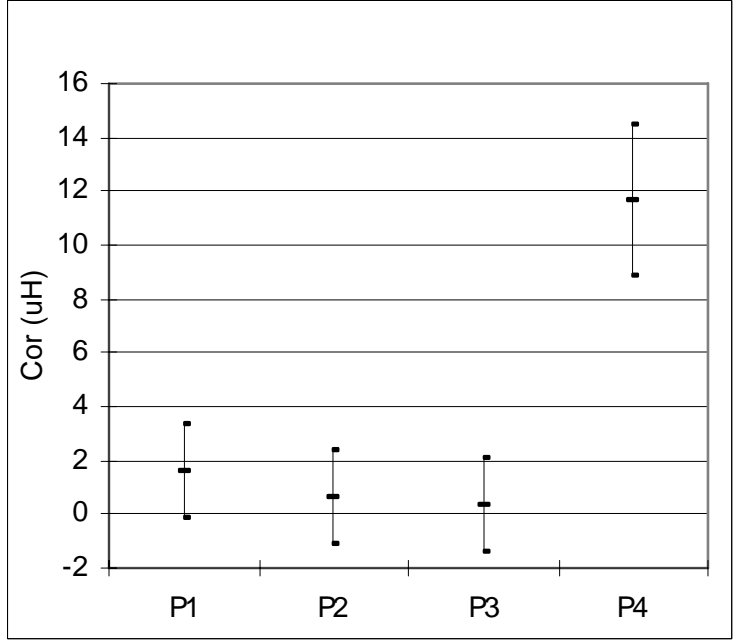

(a)

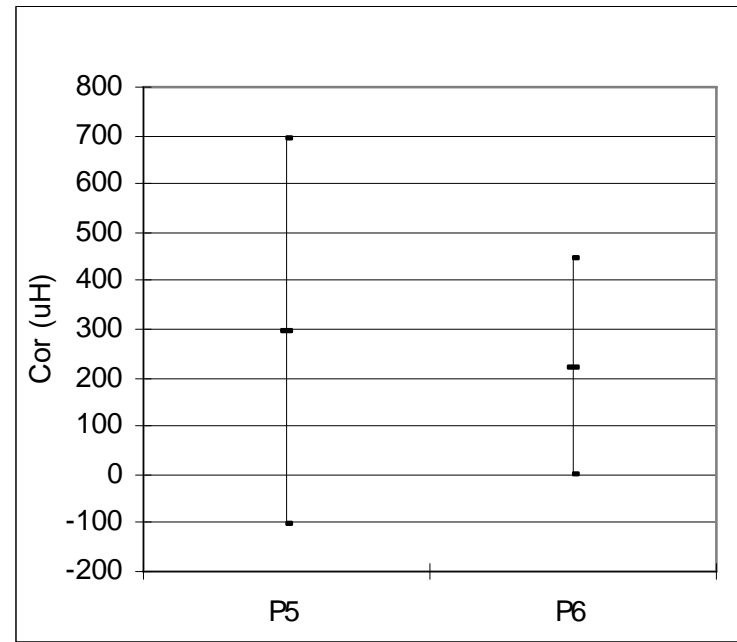

(b)

Figura 7. Comparativo entre as médias de cor: (a) Pontos P1, P2, P3 e P4; (b) Pontos P5 e P6.

\subsection{Demanda Bioquímica de Oxigênio $\left(\mathrm{DBO}_{5}\right)$}

O oxigênio é essencial a todas as formas de vida aquática e a $\mathrm{DBO}_{5}$ é um indicador do metabolismo dos micro-organismos vivos, pois esses utilizam matéria orgânica como alimento e consomem oxigênio nesse processo. Altos valores de $\mathrm{DBO}_{5}$ indicam a poluição da água por matéria orgânica biodegradável. Conforme a resolução 357/2005 do Conselho Nacional do Meio Ambiente (CONAMA), a água não poluída deve ter menos de $5 \mathrm{mg} / \mathrm{L}$ de $\mathrm{DBO}_{5}$. Nos poços P1, P2, P3 e P4, apenas o P3 apresentou valores de $\mathrm{DBO}_{5}$ abaixo desse limite, fato esse que pode ser atribuído à profundidade do poço, pois os aquíferos profundos são geralmente livres de contaminação. Na primeira coleta, apenas o ponto P4 (cacimba) apresentou $\mathrm{DBO}_{5}$ acima de $5 \mathrm{mg} / \mathrm{L}(10 \mathrm{mg} / \mathrm{L})$, na segunda coleta, os pontos P1 e P2 apresentaram $\mathrm{DBO}_{5}$ de 9,0 e 6,7 mg/L, respectivamente, e, na terceira coleta, ponto $\mathrm{P} 4$ exibiu $\mathrm{DBO}_{5}$ de $15 \mathrm{mg} / \mathrm{L}$, estando assim acima do limite sugerido para águas livres de contaminação. Porém, nos pontos P5 e P6, os resultados obtidos ultrapassaram acentuadamente o limite de 5 $\mathrm{mg} / \mathrm{L}$, com valor máximo de $420 \mathrm{mg} / \mathrm{L}$, no ponto P6, na terceira coleta, e, com mínimo de 50 $\mathrm{mg} / \mathrm{L}$, no ponto P6, na quinta coleta. Verificou-se que houve diferença significativa entre as médias dos poços P5 e P6 e as dos poços P1, P2, P3 e P4. Analisando-se o conjunto dos poços P1, P2, P3 e P4, verificou-se (Figura 8a) que existiu diferença significativa entre a média do $\mathrm{P} 4$ e as médias dos poços $\mathrm{P} 1, \mathrm{P} 2$ e $\mathrm{P} 3$.

\subsection{Cloretos}

O fato do esgoto doméstico conter elevadas concentrações de cloretos, a presença desse íon em concentrações muito elevadas indica a poluição desta por efluentes domésticos. Além de conferir gosto salino, concentrações elevadas de cloretos podem ser prejudiciais a pessoas portadoras de doenças cardíacas ou renais. Para cloretos, o VMP é de $250 \mathrm{mg} / \mathrm{L}$, segundo portaria 518/2004 (Brasil, 2004). Nos pontos P1, P2, P3 e P4, nenhuma das concentrações de cloretos obtidas nas diferentes amostras coletadas superaram $200 \mathrm{mg} / \mathrm{L}$. Mas, nos pontos P5 e P6, os resultados estabelecidos ultrapassaram consideravelmente o VMP, com valores máximos no ponto P6, variando de $9887 \mathrm{mg} / \mathrm{L}$ a $13452 \mathrm{mg} / \mathrm{L}$. A análise estatística revelou que as médias tanto dos pontos P5 quanto do P6 são significativamente diferentes dos poços P1, P2, P3 e P4. Esses quatro poços não apresentaram diferenças significativas entre si (Figura 9a). 
ATHAYDE JÚNIOR, G. B.; NÓBREGA, C. C.; GADELHA, C. L. M.; SOUZA, I. M. F.; FAGUNDES, G. S. Efeito do antigo Lixão do Roger, João Pessoa, Brasil, na qualidade da água subterrânea local. Ambi-Agua, Taubaté, v. 4, n. 1, p. 142-155 2009. (doi:10.4136/ambi-agua.79)

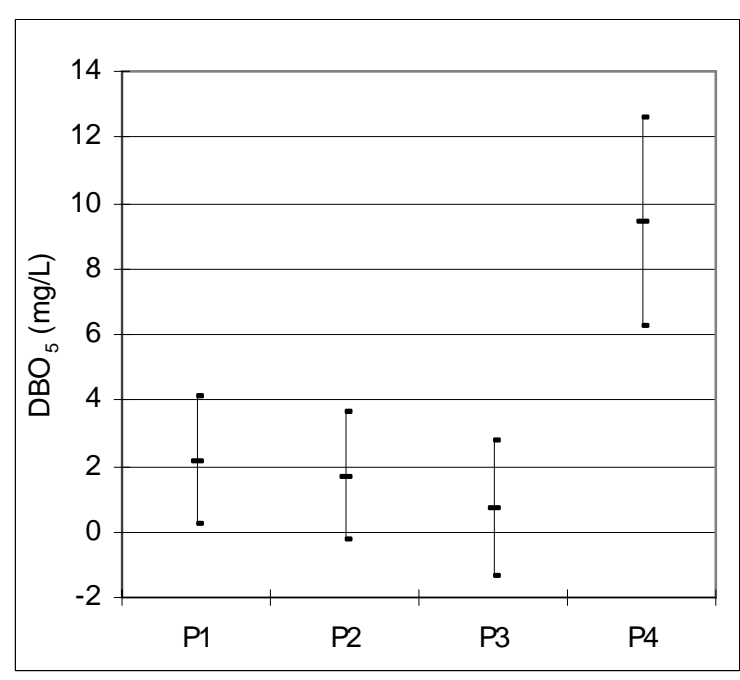

(a)

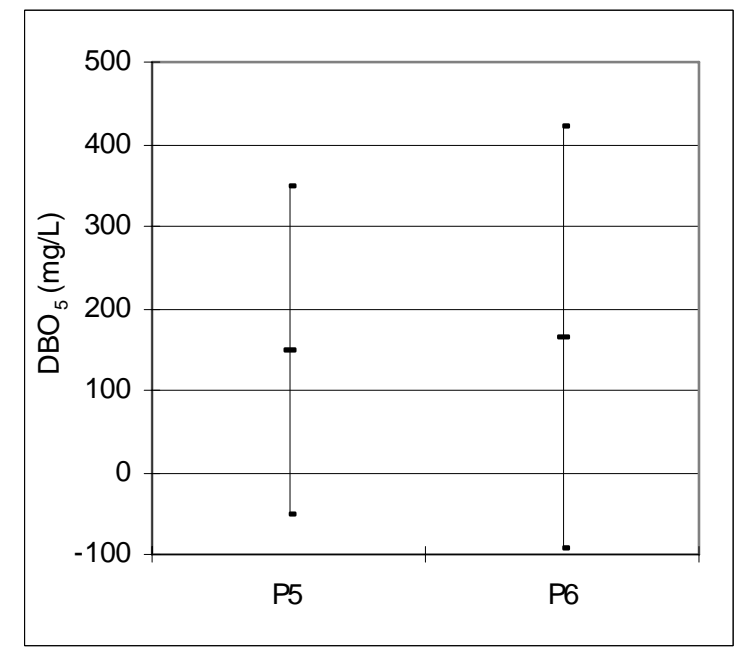

(b)

Figura 8. Comparativo entre as médias de $\mathrm{DBO}_{5}$ : (a) Pontos P1, P2, P3 e P4; (b) Pontos P5 e P6.

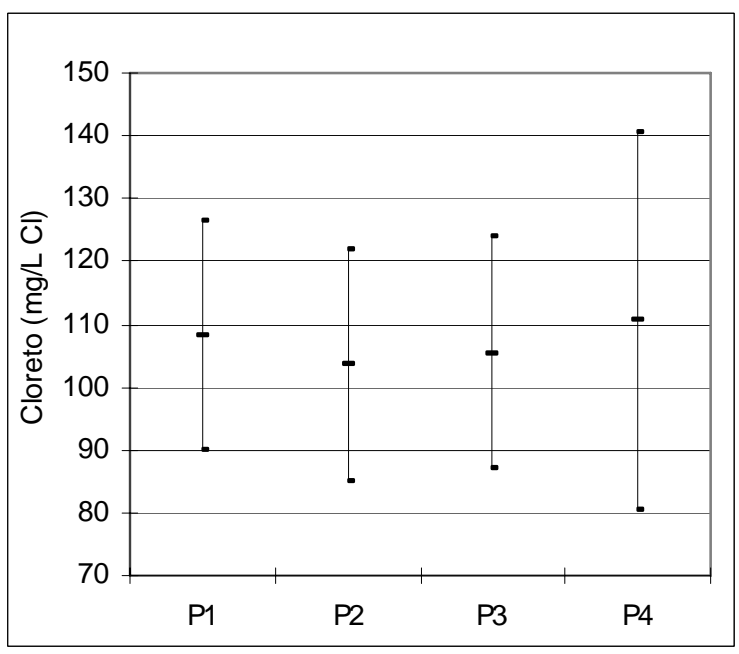

(a)

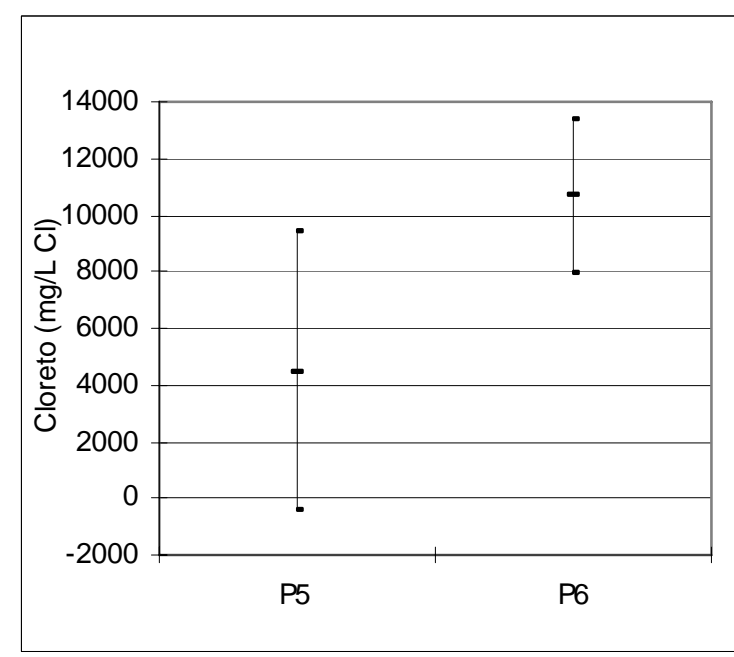

(b)

Figura 9. Comparativo entre as médias de Cloretos: (a) Pontos P1, P2, P3 e P4; (b) Pontos P5 e P6.

\subsection{Amônia}

O nitrogênio, na forma amoniacal, indica a ocorrência de contaminação direta por dejetos humanos ou de animais. De acordo com os padrões de potabilidade no Brasil, a concentração de amônia em uma água deve ser inferior a $1,5 \mathrm{mg} / \mathrm{L}$. Nos resultados obtidos, nos pontos P1, P2, P3 e P4, na primeira coleta, todas as amostras estiveram abaixo desse limite, porém, na segunda coleta, todas as amostras apresentaram valores de amônia acima do valor máximo permissível, e , no ponto P4 (cacimba), foi encontrado o valor máximo (2,5mg/L). Já na terceira coleta, apenas o P4 apresentou valor acima do permitido $(1,9 \mathrm{mg} / \mathrm{L})$, e, nas demais coletas, todas as amostras mostraram valores abaixo do limite. Contudo, nos pontos P5 e P6, os dados obtidos ultrapassaram de modo significativo o VMP, com valor máximo de 738,5 mg/L, no ponto P6, na terceira coleta, e, com mínimo de $201 \mathrm{mg} / \mathrm{L}$, no ponto P5, na oitava coleta. A análise estatística mostra que houve diferença significativa entre as médias tanto dos poços P5 quanto P6 e as médias dos poços P1, P2, P3 e P4. Não houve outras diferenças significativas (Figura 10a e b). 
ATHAYDE JÚNIOR, G. B.; NÓBREGA, C. C.; GADELHA, C. L. M.; SOUZA, I. M. F.; FAGUNDES, G. S. Efeito do antigo Lixão do Roger, João Pessoa, Brasil, na qualidade da água subterrânea local. Ambi-Agua, Taubaté, v. 4, n. 1, p. 142-155 2009. (doi:10.4136/ambi-agua.79)

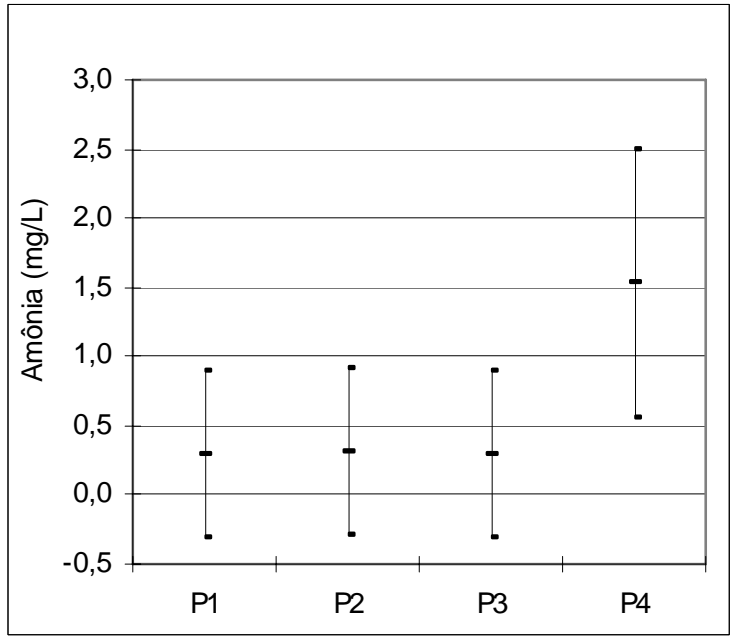

(a)

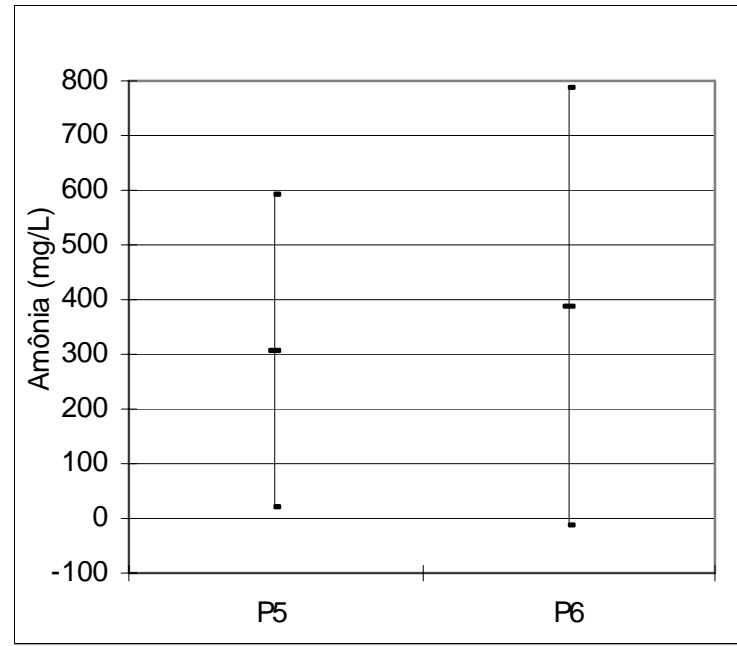

(b)

Figura 10. Comparativo entre as médias de Amônia: (a) Pontos P1, P2, P3 e P4; (b) Pontos P5 e P6.

\subsection{Alumínio}

Os efeitos do alumínio no organismo humano ainda não são bem esclarecidos, porém existem estudos que associam elevadas concentrações de alumínio com o mal de Alzheimer (Quintaes, 2000). A concentração de alumínio em uma água não deve ultrapassar 0,2 mg/L, segundo a portaria 518/2004 - Ministério da Saúde (BRASIL, 2004). Nos poços P1, P2, P3 e P4, a maior concentração de Alumínio foi de $0,04 \mathrm{mg} / \mathrm{L}$, inferior, portanto, ao VMP; entretanto, nos poços mais próximos ao antigo Lixão (P5 e P6), as maiores concentrações foram de 25,2 mg/L e 15,2 mg/L, tornando, assim, a água inadequada para o consumo humano. A Figura 11a e b revela que não há diferença significativa ( no nível de 5\%) entre as médias dos poços.

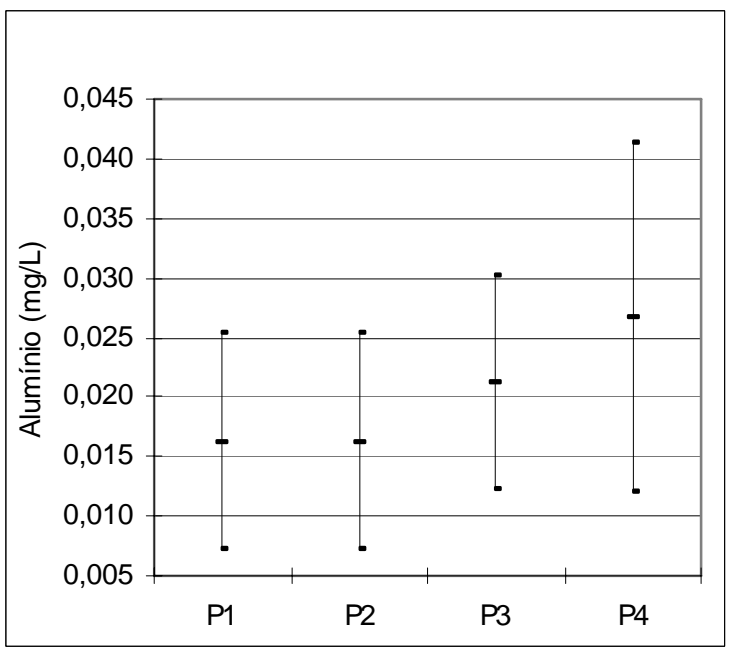

(a)

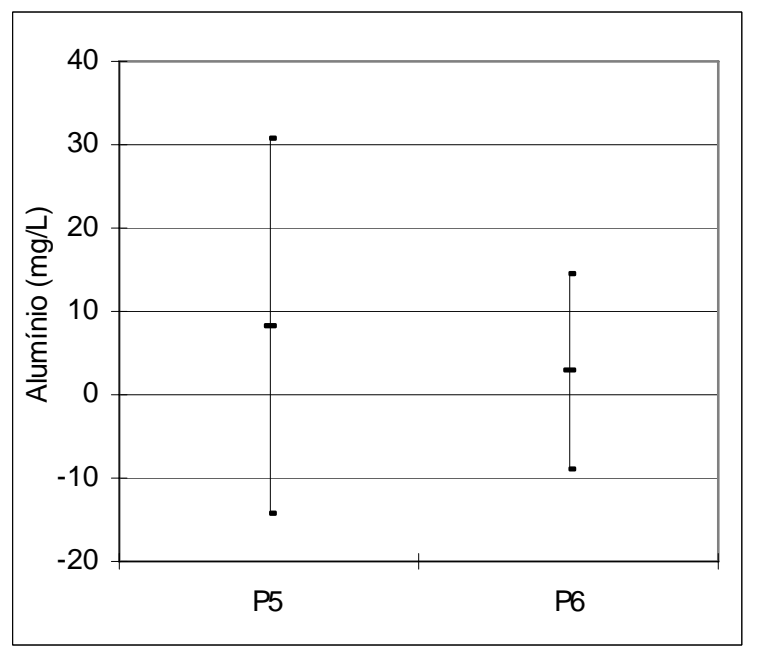

(b)

Figura 11. Comparativo entre as médias de Alumínio: (a) Pontos P1, P2, P3 e P4; (b) Pontos P5 e P6. 


\subsection{Chumbo}

O chumbo na água pode ser perigoso, pois se acumula no corpo humano causando saturnismo. As crianças estão mais susceptíveis a problemas causados pela presença de chumbo, incluindo retardo no desenvolvimento físico e mental, problemas nos rins, acúmulo no esqueleto, interferência no metabolismo do cálcio e da vitamina $\mathrm{D}$, toxidade para o sistema nervoso e elevação de pressão em adultos. A portaria $n^{\circ}$. 518/2004 - Ministério da Saúde (BRASIL, 2004) admite uma concentração máxima de $0,01 \mathrm{mg} / \mathrm{L}$ de chumbo na água. Nos poços P1, P2, P3 e P4, a concentração máxima foi de $0,1 \mathrm{mg} / \mathrm{L}$, na sexta coleta, determinando toxicidade(?) nessa água, segundo esse parâmetro, e, nos poços P5 e P6, mais próximos ao antigo Lixão, as concentrações obtidas $(0,5 \mathrm{mg} / \mathrm{L})$ revelaram que a água é imprópria para o consumo humano. A Figura 12a e b revela que não houve diferença significativa ( no nível de 5\%) nas médias entre os poços P1, P2, P3 e P4 nem entre os poços P5 e P6, contudo houve diferença significativa entre as médias dos pontos P5 e P6 quando comparadas com as médias dos pontos P1, P2, P3 e P4. Na Figura 12b, para o poço P5, não houve amplitude entre os limites inferior e superior do método GT-2 devido ao fato de não ter havido variação na concentração de chumbo nas coletas efetuadas, a qual foi sempre $0,5 \mathrm{mg} / \mathrm{L}$.

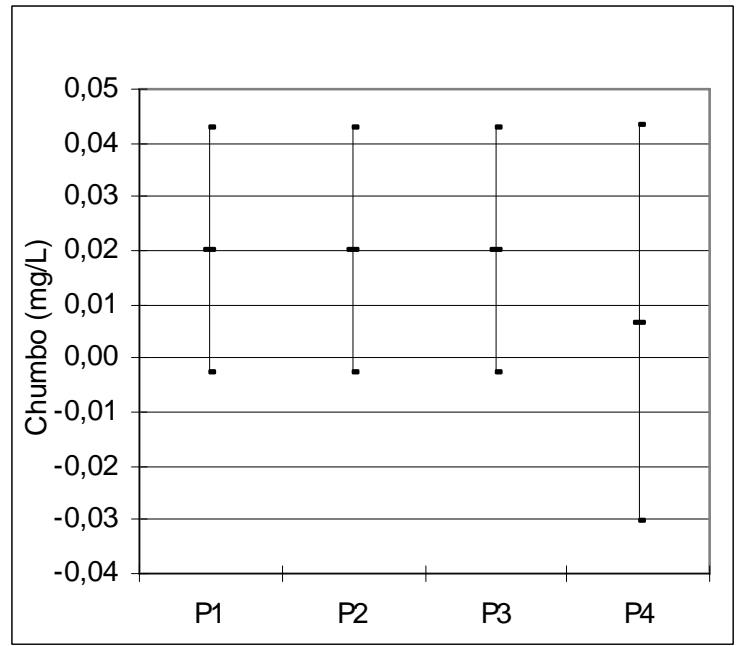

(a)

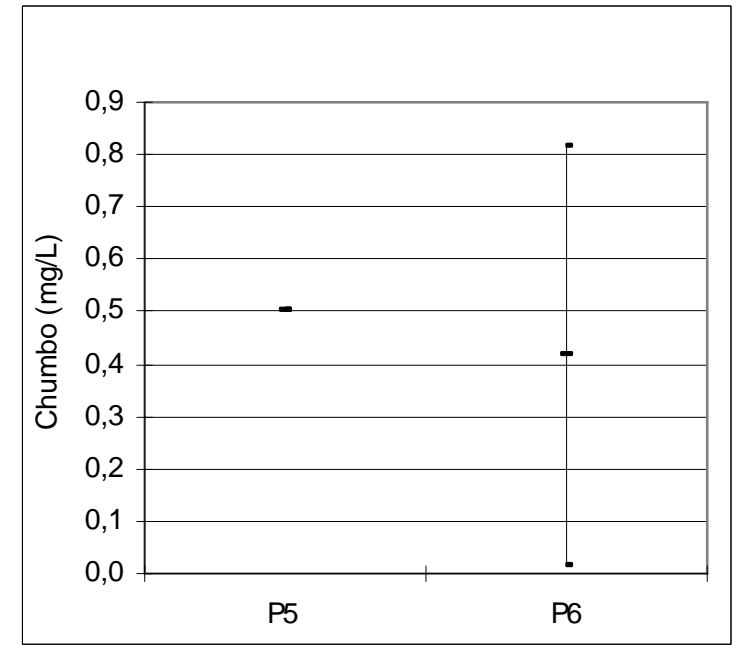

(b)

Figura 12. Comparativo entre as médias de Chumbo: (a) Pontos P1, P2, P3 e P4; (b) Pontos P5 e P6.

\subsection{Coliformes Termotolerantes}

A verificação da qualidade da água destinada ao consumo humano é feita indiretamente, por meio de organismos indicadores como a bactéria Escherichia coli ou bactérias coliformes termotolerantes. A portaria 518/2004 - MS (Brasil, 2004) determina que em uma água os coliformes termotolerantes devam estar ausentes. Para os casos estudados, na segunda coleta, nos poços P2 e P3, na terceira coleta apenas no poço P3, na sétima coleta, nos poços P1, P2 e $\mathrm{P} 3$ e, na oitava coleta, nos poços P1 e P6, os coliformes termotolerantes foram ausentes. $\mathrm{O}$ poço $\mathrm{P} 4$, que se situa no banheiro de uma residência, apresenta coliformes em todas as coletas realizadas. A água coletada caracteriza-se, portanto, como imprópria para consumo humano sem tratamento prévio. Na Figura 13, observa-se que não houve diferenças significativas ( no nível de 5\%) nas médias dos poços. Analisando o conjunto dos poços P1, P2, P3 e P4, verifica-se diferença significativa entre a média do poço P3 e P4 (Figura 13). 


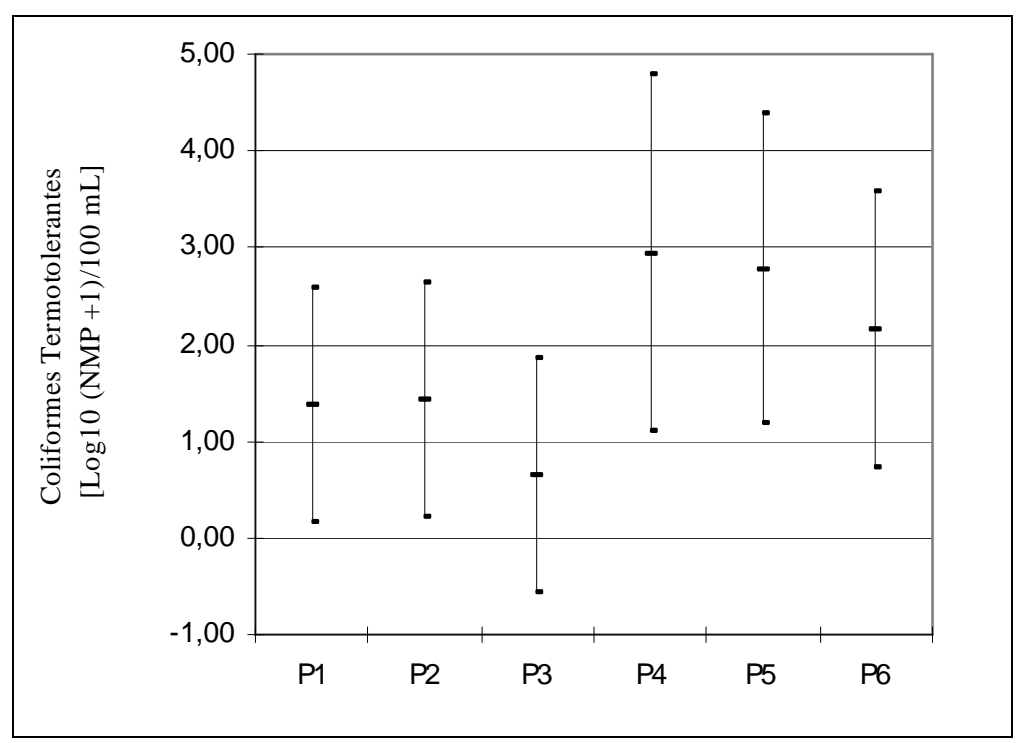

Figura 13. Comparativo entre as médias de Coliformes Termotolerantes.

\section{CONCLUSÕES}

As águas subterrâneas coletadas nos seis poços localizados na área de influência direta e indireta do antigo Lixão do Roger não podem ser consumidas pela população sem tratamento prévio, pois têm apresentado alguns parâmetros de qualidade acima dos VMP estabelecidos pela Portaria 518/04 do Ministério da Saúde, o que indica problemas de degradação da qualidade de águas subterrâneas.

As análises das águas coletadas nos poços P5 e P6, mais próximos à região onde os resíduos sólidos do lixão Roger eram depositados, têm revelado sempre indicativos de qualidade inferiores aos demais poços, sugerindo que o antigo Lixão do Roger ainda contribui para a deterioração da qualidade das águas subterrâneas nas suas proximidades. Esse resultado corrobora com outros estudos similares reportados na literatura.

Por outro lado, como a amônia é um parâmetro indicador de poluição orgânica recente, tudo leva a crer que há, na área estudada, outras fontes poluidoras das águas subterrâneas, além do antigo lixão, como esgotos domésticos, efluentes industriais e resíduos sólidos, já que o lixão fechou em agosto de 2003. Os coliformes termotolerantes também têm estado presentes em todos os pontos, o que reforça a suspeita de contaminação recente.

\section{REFERÊNCIAS}

AMERICAN PUBLIC HEALTH ASSOCIATION - APHA; AMERICAN WATER WORKS ASSOCIATION - AWWA; WORLD ECONOMIC FORUM - WEF. Standard methods of the examination of water and wastewater. 19.ed. . New York: Public Health Association, 1995.

ASSOCIAÇÃO BRASILEIRA DE NORMAS TÉCNICAS. NBR - 13.896: aterro de resíduos não perigosos - critérios para projeto, implantação e operação. Rio de Janeiro: ABNT, 1997. 
BRASIL. Ministério da Saúde. Portaria nº 518 de 25 de março de 2004. Estabelece normas e o padrão de potabilidade da água destinada ao consumo humano. Diário Oficial da União, Brasília, v. 59, p. 266-270, 26 mar. 2004, Seção 1.

COELHO, Márcia Gonçalves; SANTOS, Cristiane Lopes dos. Qualidade das águas subterrâneas em local de disposição dos resíduos sólidos urbanos do município de Uberlândia - MG. In: SIMPÓSIO INTERNACIONAL DE QUALIDADE AMBIENTAL, 4., 2004, Porto Alegre. Anais... Porto Alegre: ABES, 2004. CD-ROM. $7 \mathrm{p}$.

INTERSAT. Imagem Landsat/ETM+ em 04/08/2001. 2001. Disponível em: <www.intersat.com.br>. Acesso em: 15 jul. 2007.

LOPES, Adriana Antunes; SCHALCH, Valdir. Avaliação da qualidade da água do aqüífero freático do aterro sanitário de Bauru - SP, Brasil. In: SIMPÓSIO ÍTALO BRASILEIRO DE ENGENHARIA SANITÁRIA E AMBIENTAL, 8., 2006, Fortaleza. Anais... Fortaleza: ABES, 2006. CD-ROM. 13 p.

MOHAMMED, S. A. S.; NAIK, M.; FAKRUDDIN, S. P.; NAZEER, Z. A. M. Studies on contaminant transport at an industrial waste dumpsite of Bangalore, India. Revista Ambiente e Água - An Interdisciplinary Journal of Applied Science, v. 3, n. 3. P. 55 - 66, 2008.

PEDROSA, Célio Augusto; CAETANO, Francisco A. Águas subterrâneas. Brasília: Agência Nacional de Águas, 2002.

QUINTAES, Késia Diego. Utensílios para alimentos e implicações nutricionais. Revista de Nutrição, Campinas, v. 13, n. 3, p. 151-156, set./dez., 2000.

RODRIGUES, Sônia M.; DUARTE Armando C. Remediação de solos e águas subterrâneas contaminados: caso dos aterros sanitários. In: SIMPÓSIO LUSO-BRASILEIRO DE ENGENHARIA SANITÁRIA E AMBIENTAL, 10., 2002, Braga. Anais... Braga, 2002. CD-ROM. 11 p.

SANTAELLA, Sandra Tédde; PAIVA, Ipurinan de Oliveira; LEITÃO, Renato Carrhá. Qualidade das águas subterrâneas da região adjacente ao "lixão" de Fortaleza - CE. In: CONGRESSO BRASILEIRO DE ENGENHARIA SANITÁRIA E AMBIENTAL, 20., 1999, Olinda. Anais... Rio de Janeiro: ABES, 1999. CD-ROM. 2210 - 2219.

SOKAL, Robert R.; ROHLF, F. James. Biometry: the principles and practice of statistcs in biological research. 2. ed. - New York: W.H. Freeman, 1981. 858 p.

SOUZA, Alice Rocha de; NAVAL, Liliana Pena. Caracterização das águas sob influência do aterro sanitário de Palmas. In: SIMPÓSIO LUSO-BRASILEIRO DE ENGENHARIA SANITÁRIA E AMBIENTAL, 9., 2000, Porto Seguro. Anais... Porto Seguro, 2000. CD-ROM. p. $1371-1377$. 


\begin{tabular}{ccc|} 
ISSN = 1980-993X - doi:10.4136/1980-993X \\
www.agro.unitau.br/ambi-agua \\
E-mail: ambi-agua@agro.unitau.br \\
Tel.: (12) 3625-4116
\end{tabular}

\title{
Diagnóstico hidroambiental da bacia hidrográfica da Cachoeira das Pombas, município de Guanhães, MG, Brasil
}

(doi:10.4136/ambi-agua.80)

\author{
Kelly Cristina Tonello ${ }^{1}$; Herly Carlos Teixeira Dias ${ }^{2}$; Agostinho Lopes de Souza ${ }^{2}$; Carlos \\ Antonio Alvares Soares Ribeiro ${ }^{2}$ Deuseles João Firme ${ }^{3}$; Fernando Palha Leite ${ }^{3}$ \\ ${ }^{1}$ Dep. de Engenharia Florestal, UFSCar, SP 264, Km 110, CEP 18.052-780, Sorocaba-SP \\ E-mail: kellytonello@ufscar.br \\ 2Dep. Engenharia Florestal, UFV, 36571-000 Viçosa-MG \\ E-mail: herly@ufv.br \\ ${ }^{3}$ Celulose Nipo-Brasileira S.A - CENIBRA, Ipatinga-MG \\ E-mail: \{deuseles.firme, fernando.leite\}@cenibra.com.br
}

\section{RESUMO}

O objetivo deste trabalho foi avaliar o estado de conservação hídrica e ambiental da bacia hidrográfica da Cachoeira das Pombas, localizada no município de Guanhães-MG, visando a seu manejo integrado. A caracterização das nascentes foi realizada quanto ao seu tipo, persistência de fluxo, estado de conservação, valores de vazão e avaliação do estado de conservação hídrico e ambiental. Para uma análise mais detalhada, a bacia hidrográfica foi dividida em sub-bacias. De forma geral, quanto ao estado de conservação hídrico e ambiental da bacia hidrográfica, conclui-se pela necessidade de se realizar práticas de manejo integrado dos recursos naturais, uma vez que a vazão dos cursos d'água apresentou-se desregularizada, com grandes oscilações entre as estações chuvosa e seca, além da presença de vários focos de erosão e assoreamentos, no período estudado.

Palavras-chave: hidrologia florestal; manejo de bacias hidrográficas; nascentes; Eucalyptus sp.

\section{Hydrological and environmental diagnostic of the Cachoeira das Pombas's watershed, Guanhães, MG, Brazil}

\begin{abstract}
The objective of this work was to evaluate hydrological and environmental issues of Cachoeira das Pombas watershed, in Guanhães, eastern Minas Gerais State, Brazil, to support its management plan. The characterization of water springs included the definition of its types, assessment of flow persistence, conservation state, outflow values, and the hydrological and environmental conservation state of the watershed. For a detailed analysis, the watershed was studied considering each of its small watersheds. Analyzing the hydrological and environmental conservation state of the watershed, it was concluded that an integrated management of natural resources is necessary inasmuch as the flow rate showed to be irregular, with great variation between the rainy and dry seasons and several erosion and silting spots observed during the study period.
\end{abstract}

Keywords: forest hydrology; watershed management; springs; Eucalyptus sp. 


\section{INTRODUÇÃO}

A utilização da bacia hidrográfica como unidade de planejamento e gerenciamento ambiental não é recente. Há tempos os hidrólogos têm reconhecido as ligações entre características físicas de uma bacia hidrográfica e a quantidade de água que chega aos corpos hídricos. Por outro lado, os limnólogos têm considerado que as características do corpo d'água refletem as características de sua bacia de drenagem. Nesse sentido, as abordagens de planejamento e gerenciamento ambiental utilizando a bacia hidrográfica como unidade de estudo têm evoluído bastante, desde que estas apresentam características biogeofísicas que denominam sistemas ecológicos e hidrológicos relativamente coesos (Pires et al., 2002).

Para o trabalho de conservação do solo e da água, algumas regiões utilizavam como unidades de planejamento, a propriedade e a comunidade. No entanto, esses limites, via de regra, não coincidem com os limites naturais. O planejamento ambiental por bacia hidrográfica, por outro lado, apresenta a vantagem de concentrar as ações numa área geográfica definida previamente com o auxílio de cartas topográficas e delimitada pelos divisores de água, de onde fluem as águas da chuva para as partes mais baixas do terreno, formando os cursos d'água. Nas bacias estão localizadas as nascentes dos córregos, que compõem, junto com os rios dos quais são tributários, o sistema de drenagem de uma determinada região. Assim, as intervenções no nível da sub-bacia visam atenuar os impactos gerados pela ação humana nas cabeceiras dos rios, como forma de beneficiar tanto a população da área rural, quanto às populações das cidades, geralmente localizadas a jusante das bacias (Farah e Barboza, 2000).

O estudo e a compreensão da distribuição da água na vegetação, principalmente a florestal, podem gerar formas de manejo tecnicamente viáveis, facilitando a tomada de decisões importantes para o uso integrado das bacias hidrográficas (Valcarcel, 1984).

Durante a Conferência IUFRO sobre Silvicultura e Melhoramento de Eucaliptos, Lima (1997) discorreu sobre a polêmica das plantações florestais com espécies de rápido crescimento, principalmente com eucaliptos, criticadas por seus impactos ambientais. De acordo com o autor, as evidências disponíveis são claras para eliminar a maior parte das afirmações exageradas nesta polêmica, mas de qualquer forma, há bastante espaço para a melhoria das práticas de manejo das plantações florestais visando minimizar efeitos ecológicos, a fim de garantir a integridade do ecossistema. A noção da microbacia hidrográfica como unidade ecossistêmica de planejamento das atividades florestais, possibilita a identificação de indicadores hidrológicos para o manejo sustentável de recursos naturais.

É notório que a irregularidade da distribuição temporal das chuvas tem sido a responsável pela insatisfação dos consumos da população em épocas de estiagem. Contudo, a degradação ambiental dos recursos naturais de uma bacia hidrográfica pode comprometer as reservas subterrâneas, aumentando ainda mais essas dificuldades. Desse modo, torna-se necessário conhecer em profundidade o funcionamento dos ecossistemas e os fatores que atuam sobre eles, a fim de obter referenciais que permitam a avaliação da magnitude dos impactos ambientais decorrentes da intervenção antrópica sobre eles..

Diante do exposto, o objetivo deste estudo foi analisar o estado de conservação hídrica e ambiental da bacia hidrográfica da Cachoeira das Pombas, localizada no município de Guanhães-MG. 


\section{MATERIAL E MÉTODOS}

\subsection{Localização}

O presente estudo foi realizado em área de propriedade da empresa Celulose NipoBrasileira - CENIBRA S.A., nos limites do projeto Cachoeira das Pombas, município de Guanhães - MG, região do Alto e Médio rio Doce.

A bacia hidrográfica da Cachoeira das Pombas pertence à bacia do rio Corrente Grande, afluente à margem esquerda do rio Doce e drena parcialmente a região onde se inserem os municípios de Guanhães, Virginópolis, São João Evangelista, Gonzaga, Santa Efigênia de Minas, São Geraldo da Piedade, Açucena, Periquito, Governador Valadares e Divinolândia de Minas (Figura 1).

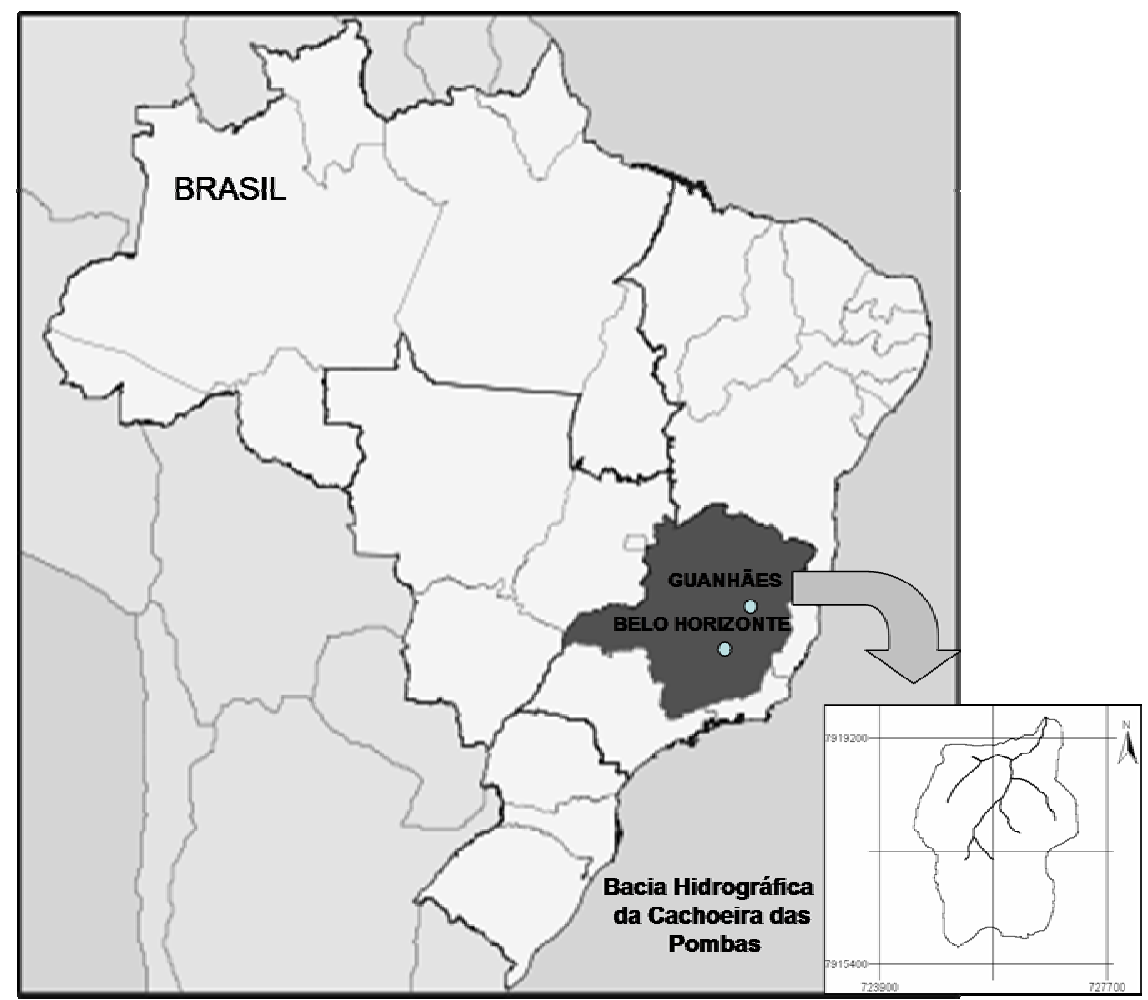

Figura 1. Localização da bacia hidrográfica da Cachoeira das Pombas, Guanhães-MG.

\subsection{Clima}

Segundo a classificação climática de Köppen, o clima predominante na região é Aw Clima Tropical chuvoso de savana, ou seja, inverno seco e chuvas máximas no verão. Conforme a classificação climática de Thornthwaite, o clima de Guanhães é $\mathrm{C}_{2} \mathrm{rB}^{`}{ }_{4} \mathrm{a}$ `, isto é, clima subúmido, com deficiência de água pequena ou nula, mesotérmico (Souza et al., 2006). De acordo com os dados registrados pela estação meteorológica da CENIBRA em Guanhães, para o período de 1985 a 2004, o município apresenta uma estação seca bem definida, de junho a agosto, correspondendo a 2,8\% do total anual precipitado. Esse período coincide ainda com o período de inverno, quando se observam as menores temperaturas. Os meses com maiores ocorrências de chuva correspondem ao período de outubro a março, sendo denominado de "estação chuvosa". Nesse período, observa-se o total precipitado de $87 \%$ do total anual. O balanço hídrico para o período de 1985 a 2004 (Figura 2) apresenta precipitação anual de $1179 \mathrm{~mm}$ e a temperatura média de $21,8^{\circ} \mathrm{C}$. 


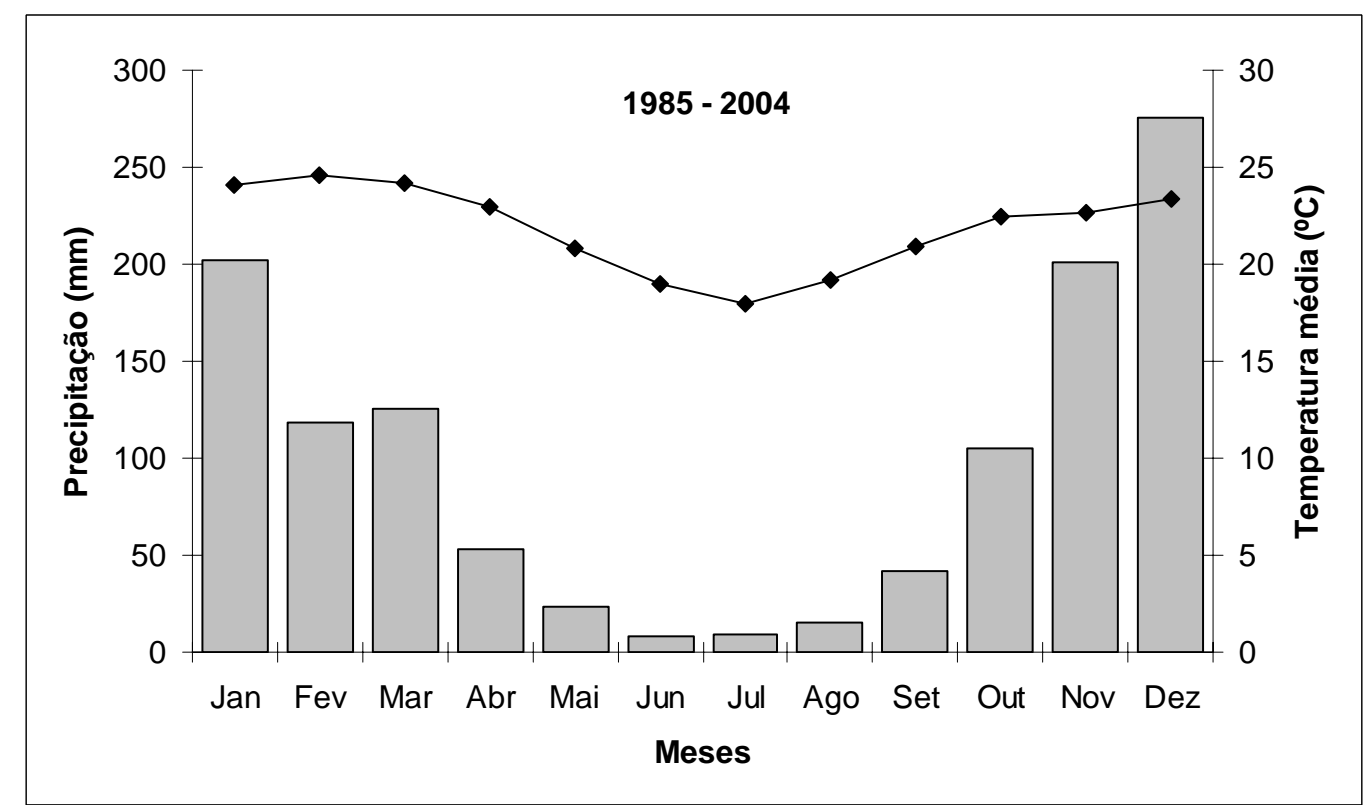

Figura 2. Precipitação total e temperatura média mensal para o município de Guanhães-MG, média para o período de 1985 e 2004.

\subsection{Morfometria da bacia hidrográfica}

De acordo com Tonello et al (2006), a bacia hidrográfica da Cachoeira das Pombas possui área de drenagem pequena (698,1 ha), altitude média igual a $921 \mathrm{~m}$, alta declividade (34\% - relevo forte ondulado) e forma alongada (fator de forma, coeficiente de compacidade e índice de circularidade iguais a 0,4, 1,6 e 0,4, respectivamente). A densidade de drenagem $\left(\mathrm{Dd}=1,0 \mathrm{~km} / \mathrm{km}^{2}\right)$ é baixa e grande porcentagem do terreno da bacia em estudo possui exposição do terreno para a face Norte - Oeste (aproximadamente $41 \%$ ), indicando deficiência na retenção de umidade.

As cinco sub-bacias são morfometricamente distintas. As sub-bacias 2, 3, 4 e 5 apresentam maior declividade do que a sub-bacia 1; as sub-bacias 1, 2 e 3 com áreas maiores e semelhantes e as sub-bacias 4 e 5 com áreas menores e também semelhantes, muito embora a forma das sub-bacias seja aproximadamente igual.

\subsection{Características geológicas e uso atual do solo}

A área de influência da CENIBRA S.A. está inserida em uma grande unidade geológica caracterizada por rochas proterozóicas, que ocupa grande extensão da bacia do Rio Doce. Localmente há ocorrência de granitos e itabiritos (Burla, 2001) e rochas magnesíferas, metabasaltos, anfibolitos, xistos e cataitabiritos (CENIBRA, 2003).

De acordo com Burla (2001), os solos da área de estudo possuem profundidade média à alta, fertilidade baixa, com alta acidez, textura argilosa à muito argilosa, e média vulnerabilidade quanto à erosão, compactação e presença de cascalho. A classificação dos solos nas áreas de plantio de eucalipto podem ser visualizadas na Figura 2. A classe de solo citada inicialmente é o predominante em cada talhão.

O histórico da área de estudo consta que, antes da aquisição da propriedade pela Florestas Rio Doce S.A. para plantio de eucalipto em 1972, toda a bacia era ocupada com vegetação nativa. Em 1984, a CENIBRA adquiriu a área, mantendo a mesma atividade econômica.

Desde o início do plantio de eucalipto na área (1972), a distribuição espacial do uso do solo (áreas de reserva legal, preservação permanente, plantios de eucalipto e represas) não 
sofreu mudanças significativas, sendo mínimos os impactos ambientais da atividade florestal sobre os remanescentes florestais nativos.

Cerca de 350 ha da bacia possui plantios efetivos de Eucalyptus grandis, em espaçamento $3 \times 2 \mathrm{~m}$, distribuídos em talhões reformados (auto-fuste) e regenerados (talhadia), com idade entre 8 e 11 anos. A limpeza anterior da área foi realizada com o uso de fogo e o preparo do solo, por coveamento manual $(20$ x 20 × $25 \mathrm{~cm})$.

\subsection{Características Biológicas}

A cobertura vegetal original onde se insere a área de estudo, a leste do Estado de Minas Gerais, está situada nos limites da Floresta Atlântica (Fundação S.O.S Mata Atlântica/ Instituto Nacional de Pesquisas Espaciais/ Instituto Sócio-Ambiental, 1998). Entretanto, devido à proximidade com o cerrado, a cobertura florestal dessa região sofre interferências desse ecossistema, evidenciado pela existência de diversas espécies típicas desse tipo de ambiente como Byrsonima sp., Cordia sellowiana, Machaerium villosum, Machaerium opacum, dentre outras (CENIBRA, 2003).

O Mapa de Vegetação do Brasil (Instituto Brasileiro de Geografia e Estatística, 1993), coloca as formações florestais de ocorrência natural da região como pertencentes à Região Ecológica da Floresta Estacional Semidecidual (Mata Semicaducifólia), assinalando que nessa região florestal são dominantes os gêneros neotropicais Tabebuia, Paratecoma, Cariniana, entre outros, em mistura com os gêneros paleotropicais Terminalia e Erithrina, e com gêneros austrálicos Cedrela e Sterculia (CENIBRA, 2003).

Na região de estudo, encontraram-se ainda, quatro espécies citadas na Lista de Espécies da Flora Ameaçada de Extinção publicada pelo IBAMA: Braúna (Melanoxylon brauna), Jacarandá-da-bahia (Dalbergia nigra), Gonçalo-alves (Astronium fraxinifolium) e Peroba-rosa (Aspidosperma polyneuron).

O uso do solo citado permitiu a regeneração de vegetação arbórea nativa, nas áreas preservadas, sendo que, segundo CENIBRA (2003), 38\% da área encontram-se nos estágios de sucessão secundária inicial e 51\%, em estágio médio de sucessão secundária. Os 11\% restantes compreendem áreas com afloramentos rochosos e vegetação rupestre, caracterizados pela ocorrência de solos rasos, ilhados pela vegetação arbórea, permitindo a ocorrência de ambientes rupestres, com árvores baixas e retorcidas e espécies das famílias Cyperaceae, Bromeliaceae, Gramineae e Orchidaceae.

\subsection{Caracterização das nascentes e diagnóstico hidroambiental}

Toda a bacia hidrográfica foi percorrida para um reconhecimento in loco de seus detalhes a respeito do uso do solo e conservação da bacia, assim como para a realização de medições de vazão das nascentes.

As nascentes foram caracterizadas quanto ao seu tipo e persistência, em que se avaliou também o seu estado de conservação, sendo classificadas como preservadas (quando da presença de vegetação nativa em um raio maior ou igual a $50 \mathrm{~m}$ ), perturbadas (quando não apresentam 50 metros de vegetação nativa no seu entorno, mas se encontram em bom estado de conservação) e degradada (presença de eucalipto no entorno, estradas, erosões e assoreamentos). Metodologia semelhante foi realizada por Pinto et al. (2004), Matteucci et al. (2007), Santana et al. (2007).

As aferições hidrológicas foram realizadas no mês de outubro de 2004, antecedendo o início das chuvas, representando, portanto, a vazão mínima das nascentes na bacia hidrográfica (fim da estação seca) e em janeiro de 2005, mês intermediário de estação chuvosa. As vazões foram obtidas por meio de método indireto, pelo uso de micromolinete 
modelo FP201 - Global Flow Probe. Quando da impossibilidade desse instrumento, trabalhou-se com o método direto, aplicável nos casos de pequenas vazões. Esse processo consistiu em três medições diretas do volume de água contido em um recipiente de 20 litros, armazenado em 10 segundos contabilizados com auxílio de um cronômetro digital. A vazão das nascentes foi obtida pela equação:

$$
\bar{Q}=\frac{\sum\left(\frac{V}{t}\right)}{3}
$$

em que,

$\bar{Q}=$ vazão média $(\mathrm{l} / \mathrm{s})$

$\mathrm{t}=$ tempo, em segundos

$\mathrm{V}=$ volume de água, em litros

\section{RESULTADOS E DISCUSSÃO}

Ao percorrer a área de estudo, foram identificadas três nascentes perenes, três nascentes intermitentes e cinco represas (Figura 3).

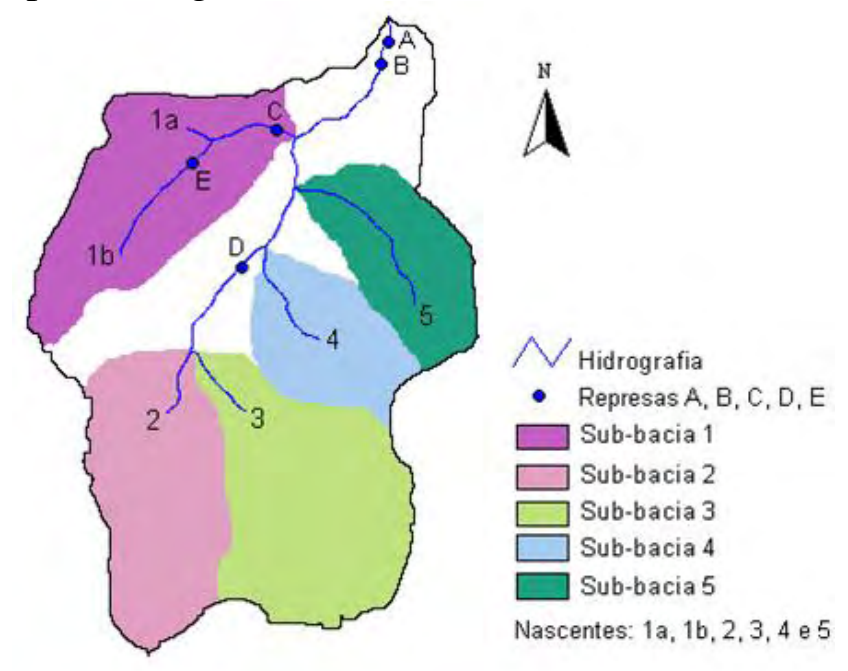

Figura 3. Delimitação das sub-bacias, nascentes e represas, Cachoeira das Pombas, Guanhães, MG, 2004.

Apesar das áreas de plantio possuírem seu sub-bosque protegido com a própria serapilheira, foram constatadas algumas falhas relacionadas à conservação de solo e água.

As nascentes 2 e 3 possuem vazão durante todo o ano e encontram-se preservadas, ao passo que a nascente 4, embora perene, apresentou-se perturbada (Tabela 1). As demais nascentes são caracterizadas como intermitentes e variam quanto ao tipo e estado de conservação. 
TONELLO, K. C.; DIAS, H. C. T.; SOUZA, A. L.; RIBEIRO, C. A. A. S.; FIRME, D. J.; LEITE, F. P. Diagnóstico hidroambiental da bacia hidrográfica da Cachoeira das Pombas, município de Guanhães, MG, Brasil. Ambi-Agua, Taubaté, v. 4, n. 1, p. 156-168, 2009. (doi:10.4136/ambi-agua.80)

Tabela 1. Caracterização das nascentes, Cachoeira das Pombas, Guanhães, MG, 2004.

\begin{tabular}{clllcc}
\hline Nascente & Persistência & Tipo & Vegetação & $\begin{array}{c}\text { Q estação seca } \\
\text { (l/s) }\end{array}$ & $\begin{array}{c}\text { Q estação } \\
\text { chuvosa (1/s) }\end{array}$ \\
\hline 1 a & Intermitente & Difusa & Degradada & - & - \\
1 b & Intermitente & Encosta & Preservada & 0,00 & 0,53 \\
2 & Perene & Encosta & Preservada & 0,19 & 1,01 \\
3 & Perene & Encosta & Preservada & 0,06 & 0,78 \\
4 & Perene & Encosta & Perturbada & 0,12 & 0,59 \\
5 & Intermitente & Encosta & Degradada & 0,00 & 0,08 \\
\hline
\end{tabular}

A represa D (Figura 4) recebe a água das nascentes 2 e 3. Por meio de um diagnóstico visual, observou-se um aspecto amarelado (barrento) da água, indicando a ocorrência de perda de solos, nutrientes e matéria orgânica nas áreas a montante da represa, ao contrário do que pôde ser observado durante a época de estiagem.

Para Mosca (2003), os indicadores visuais expressam o resultado das ações humanas ao longo do tempo, facilmente percebidas na paisagem. Ainda de acordo com o mesmo autor, como os parâmetros da qualidade da água, os atributos visualmente percebidos na paisagem permitem integrar respostas às práticas de manejo na escala de microbacia.

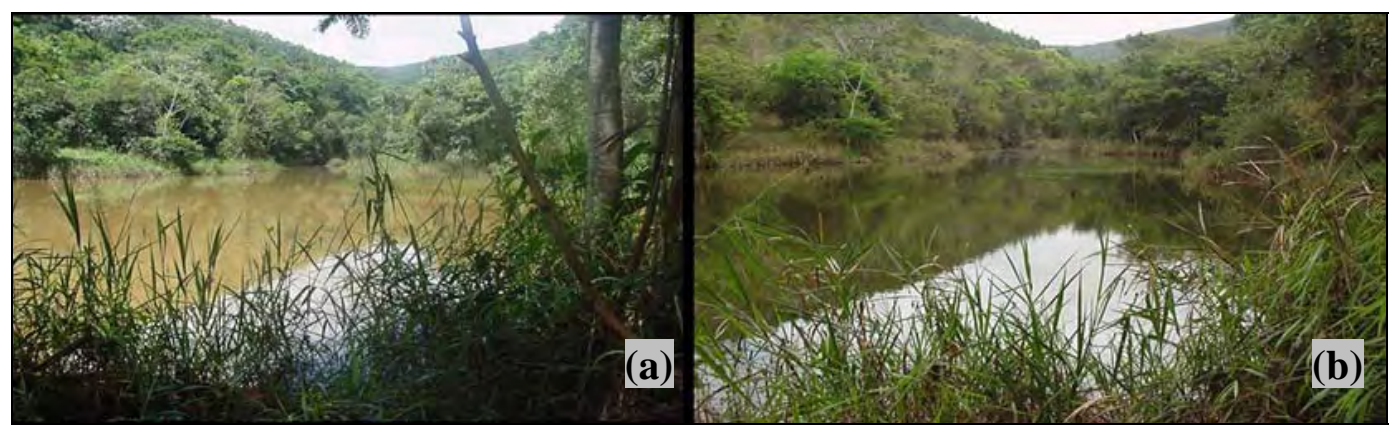

Figura 4. Visualização da represa D, bacia hidrográfica da Cachoeira das Pombas, Guanhães, MG, 2004. (a) estação chuvosa e (b) estação de estiagem.

A Figura 5 apresenta um panorama da área de contribuição da sub-bacia 1, onde estão inseridas as nascentes 1a e 1b. No divisor de águas dessa sub-bacia, foi possível identificar a presença de plantios de eucalipto e uma forte presença de rochas, muitas vezes expostas, formando um vale onde é notável a presença de floresta nativa. A variação de vazão da nascente $1 \mathrm{~b}$ entre outubro e janeiro pode estar relacionada ao afloramento de rochas como o granito, vindo a escoar superficialmente toda a água precipitada, contribuindo para as altas vazões no período chuvoso. Esse fato pode ser comprovado pela Figura 6, a qual ilustra a represa E que armazena a vazão da nascente $1 \mathrm{~b}$ nas estações de chuva e seca, respectivamente.

De acordo com Lima et al. (2002), o traçado inadequado de estradas e carreadores afeta o funcionamento hidrológico de toda a bacia. Os problemas mais graves causados pela má locação da rede viária estão associados à captação, à condução e ao deságüe concentrado de enxurrada em determinados pontos do terreno, ocasionando erosão laminar e, ou em sulcos na própria estrada e em talhões adjacentes. Além da queda de produtividade ocasionada pela erosão, o assoreamento de cursos d'água e a perda de valores estéticos e paisagísticos são danos possíveis da má locação e manutenção viária (Gonçalves, 2002), revestindo-se de 
TONELLO, K. C.; DIAS, H. C. T.; SOUZA, A. L.; RIBEIRO, C. A. A. S.; FIRME, D. J.; LEITE, F. P. Diagnóstico hidroambiental da bacia hidrográfica da Cachoeira das Pombas, município de Guanhães, MG, Brasil. Ambi-Agua, Taubaté, v. 4, n. 1, p. 156-168, 2009. (doi:10.4136/ambi-agua.80)

grande importância a captação e o disciplinamento dessas águas, de forma a eliminar seu efeito destruidor. Isso pode ser realizado acumulando-as em locais determinados e forçando sua penetração no solo, favorecendo o abastecimento do lençol freático e, consequentemente, alimentando as fontes e nascentes naturais. Ao percorrer as áreas de contribuição das subbacias, essa situação foi visualizada em vários pontos.

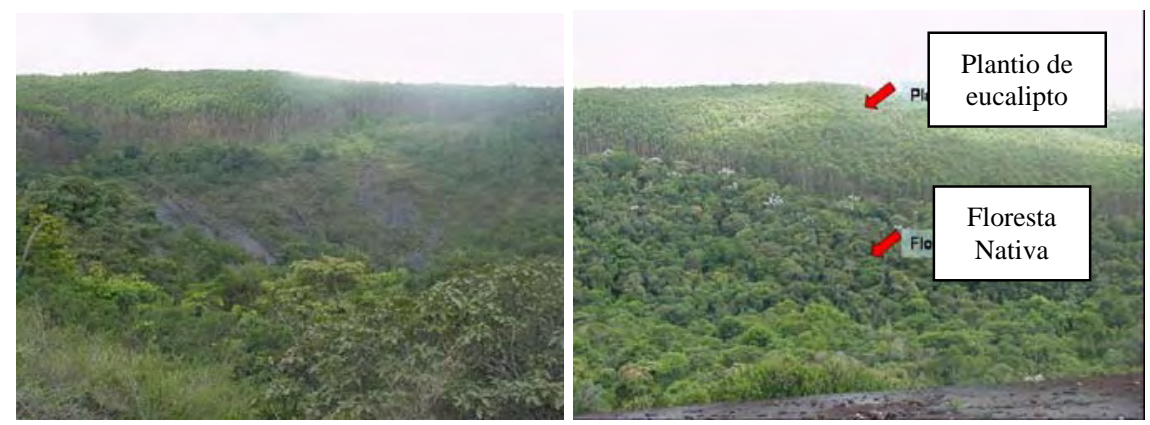

Figura 5. Área de contribuição da nascente 1b, Cachoeira das Pombas, Guanhães-MG, 2004.
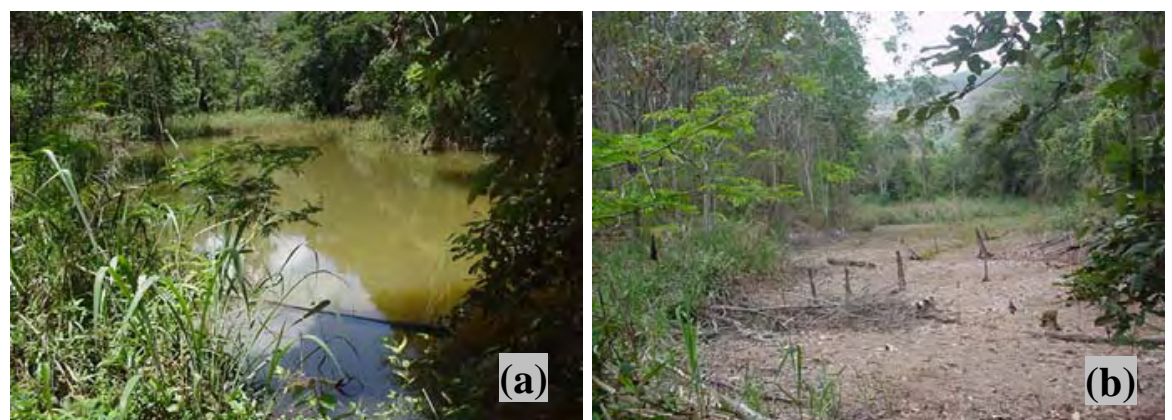

Figura 6. Represa E que armazena água da nascente 1b, Cachoeira das Pombas, Guanhães, MG, 2004: (a) estação chuvosa e (b) estação seca.

O diagnóstico realizado na nascente $1^{\mathrm{a}}$ constatou que ela possui vazão somente na estação de chuva, é do tipo difusa e caracterizada como degradada, uma vez que a estrada de contorno sobrepõe parte de sua zona ripária. Esse fato, aliado à presença de rochas impermeáveis nessa sub-bacia, acarreta a diminuição de infiltração de água no solo, impedindo o abastecimento do lençol subterrâneo.

A nascente 5, caracterizada como intermitente e degradada, está localizada a 20 metros da estrada, com remanescentes de eucalipto dentro do raio de 50 metros, apresentando em grande parte do curso d'água, a deposição de sedimentos e permanecendo, até mesmo na estiagem, assoreada (Figuras 7 e 8).
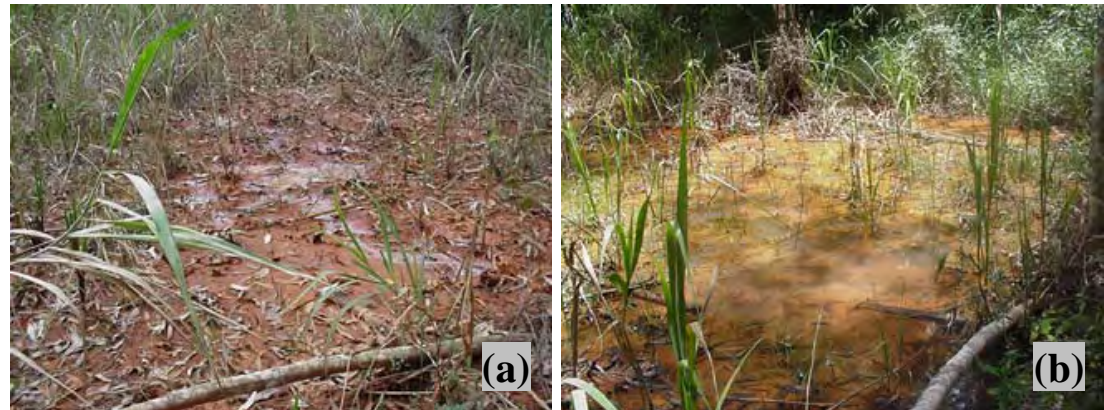

Figura 7. Nascente 5, Cachoeira das Pombas, Guanhães, MG, 2004: (a) estação chuvosa e (b) estação seca. 
TONELLO, K. C.; DIAS, H. C. T.; SOUZA, A. L.; RIBEIRO, C. A. A. S.; FIRME, D. J.; LEITE, F. P. Diagnóstico hidroambiental da bacia hidrográfica da Cachoeira das Pombas, município de Guanhães, MG, Brasil. Ambi-Agua, Taubaté, v. 4, n. 1, p. 156-168, 2009. (doi:10.4136/ambi-agua.80)
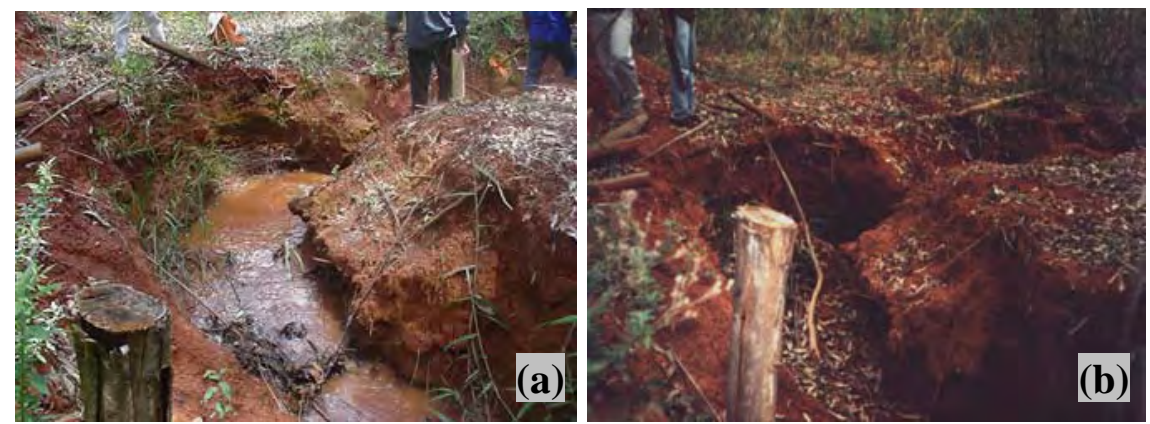

Figura 8. Curso d’água da nascente 5, Cachoeira das Pombas, Guanhães, MG, 2004. (a) estação chuvosa, (b) estação seca.

O curso d'água da sub-bacia 4 é interrompido pela estrada e embora ela possua um dispositivo de drenagem da água, este não foi suficiente para suportar a vazão da nascente durante a estação de chuva, inundando a estrada (Figura 9). Esse fluxo excessivo de água pode causar o empobrecimento do solo da bacia pela lixiviação de nutrientes, matéria orgânica e microfauna, resultando em perda de solo, água e nutrientes, além de originar processos de erosão e assoreamento de cursos d'água a jusante, que, por fim, repercutirão na vazão da Cachoeira das Pombas.

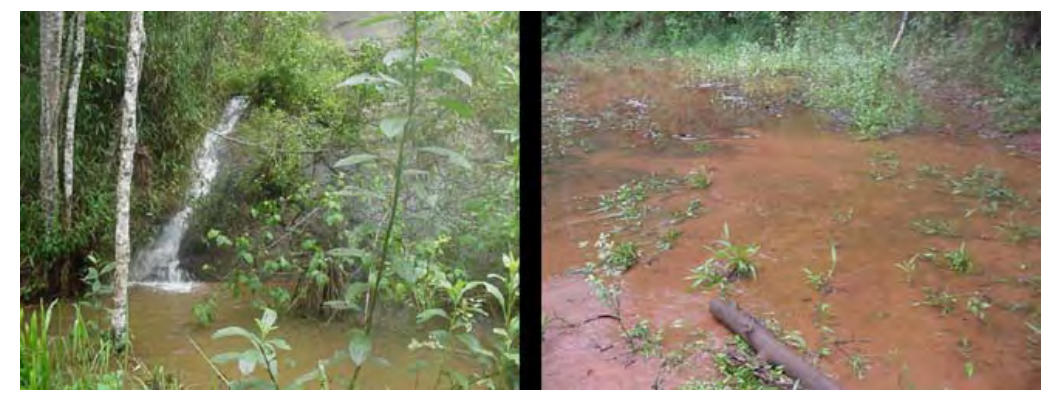

Figura 9. Inundação da estrada por água produzida pela nascente 4, bacia hidrográfica da Cachoeira das Pombas, Guanhães, MG, 2004.

Ao percorrer a bacia hidrográfica, também foram observados vários desmoronamentos de taludes, principalmente na estação chuvosa. Alguns deles chegavam a bloquear totalmente o acesso às estradas (Figura 10). Essas consequências, além de exigirem soluções de alto custo para corrigi-las, trazem danos aos mananciais hídricos pelo assoreamento das nascentes e cursos d’água e pela elevação do nível de turbidez das águas nas áreas adjacentes às estradas. De acordo com Arruda (1997), esses problemas são consequentes da ausência de padrões técnicos construtivos, deficiência do sistema de drenagem (ausência de dispositivos de drenagem superficial, profunda e de transposição de taludes), falta de suporte da camada de rolamento e do subleito (superfície da estrada muito defeituosa) e exposição do horizonte C.

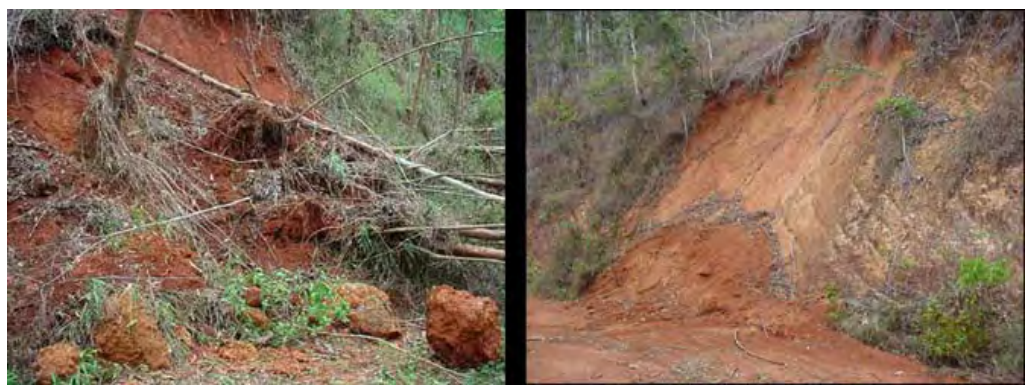

Figura 10. Desmoronamento de taludes na bacia hidrográfica da Cachoeira das Pombas, Guanhães, MG, 2004. 
As represas A e B (Figuras 11, 12) são as mais próximas da Cachoeira das Pombas. Estão diretamente conectadas e recebem toda a água produzida pela bacia hidrográfica direcionando-a para a Cachoeira das Pombas.

Como já esperado, a coloração da água nessas represas entre as estações de chuva e seca, reflete os impactos a montante. Nas chuvas, a água alcança a foz da bacia, ainda com o aspecto barrento como identificado nas áreas a montante. Nota-se um acúmulo de sedimentos em algumas partes da represa $\mathrm{B}$, provocando seu assoreamento.
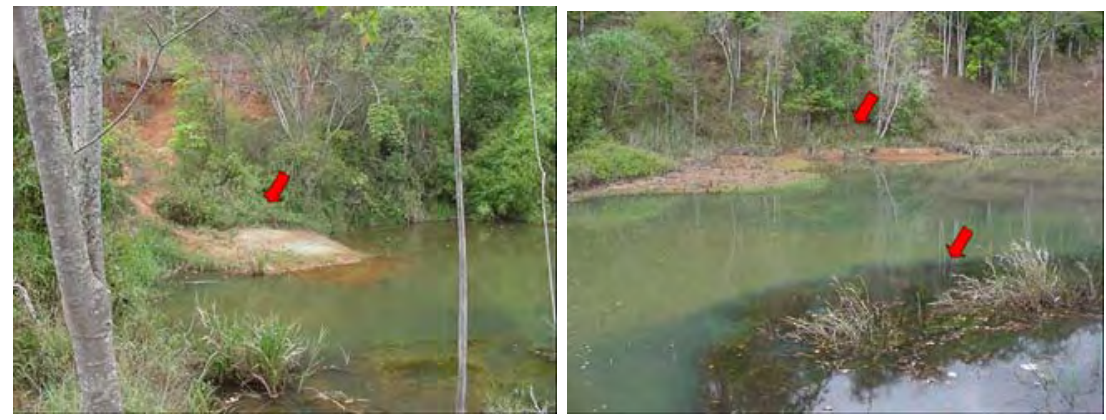

Figura 11. Focos de assoreamento na represa B durante a estação seca, Cachoeira das Pombas, Guanhães, MG, 2004.

Embora não tenha sido mensurado, observou-se uma nítida alteração, não somente da cor, mas também da turbidez da água da bacia em estudo (Figura 12). Essas alterações estão relacionadas à presença de partículas em suspensão nos corpos d'água, o que pode gerar uma considerável redução na quantidade de luz penetrada, com consequente diminuição da produtividade global do ecossistema aquático e com implicações sobre o seu conjunto de organismos.

Observa-se na Figura 13, grande variação na vazão entre as estações seca e chuvosa. Na estação seca (Figura 13b), a vazão foi de $0,34 \mathrm{~L} / \mathrm{s}$ enquanto que na estação chuvosa (Figura 13a) a vazão obtida foi de 6,10 L/s. Segundo depoimentos de moradores da região, a Cachoeira das Pombas possuía um volume de água maior que o atual, no entanto não existe um histórico da vazão da bacia registrado.

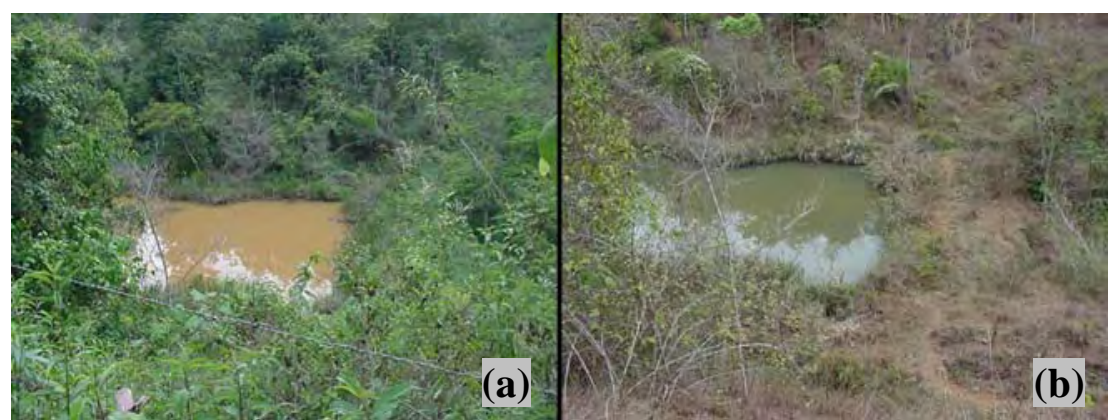

Figura 12. Aspecto da água da represa A, bacia hidrográfica da Cachoeira das Pombas, Guanhães, MG, 2004. (a) estação chuvosa, (b) estação de estiagem. 


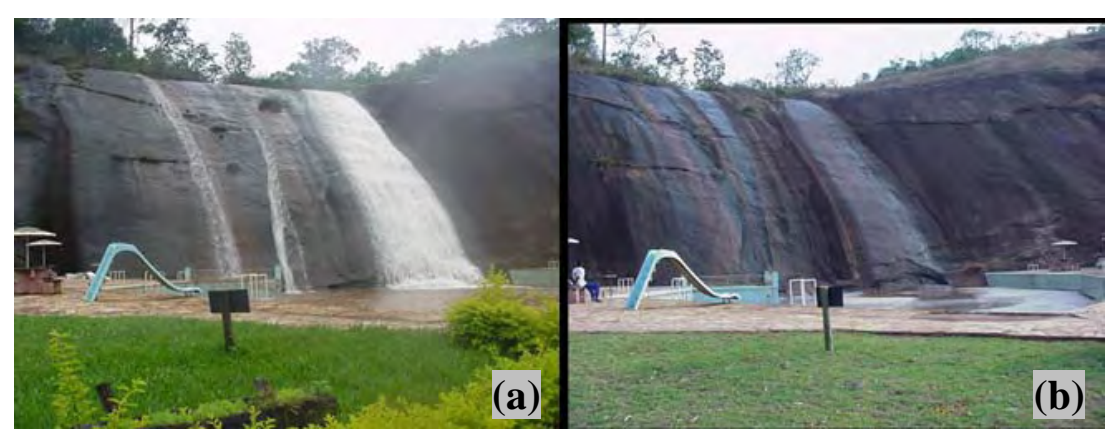

Figura 13. Cachoeira das Pombas, Guanhães, MG, 2004. (a) estação chuvosa e (b) estação seca.

\section{CONCLUSÕES}

Nas condições atuais analisadas na bacia hidrográfica, pode-se concluir que o estado de conservação hídrico e ambiental indica necessidade de integração dos recursos naturais por meio de um manejo integrado. Das seis nascentes caracterizadas, cinco são do tipo encosta e uma do tipo difusa. A verificação do estado de conservação permitiu concluir que das seis nascentes, três encontram-se preservadas, duas degradadas e uma perturbada. A vazão dos cursos d'água apresentou-se desregularizada, durante o período avaliado, com grandes valores na estação chuvosa e posterior redução na estiagem. Isso evidencia a necessidade urgente da realização de práticas conservacionistas de solo e água, assim como o monitoramento hidrológico. Dessa forma, torna-se imprescindível que se faça um planejamento em relação ao uso da terra e que seja embasado no conhecimento científico dos recursos existentes na bacia hidrográfica, de suas estruturas e interdependências.

\section{AGRADECIMENTOS}

À CENIBRA S.A., por todo apoio, fornecimento de dados e informações essenciais para este trabalho e ao CNPq pela concessão da bolsa durante parte do período de estudos.

\section{REFERÊNCIAS}

ARRUDA, P. R. R. Uma contribuição ao estudo ambiental da bacia hidrográfica do Ribeirão São Bartolomeu, Viçosa, MG. 1997, 108f. Dissertação (Mestrado em Ciências Florestais) - UFV, Viçosa-MG, 1997.

BURLA, E. R. Mecanização de atividades silviculturais em relevo ondulado. Belo Oriente: Cenibra, 2001. 144p.

CELULOSE NIPO-BRASILEIRA - CENIBRA. Estudo florístico, fitossociológico e paramétrico das áreas de reserva legal e de preservação permanente da Cenibra. Projeto Cachoeira das Pombas, Região de Guanhães. Belo Oriente: 2003. 143p. (Relatório).

FARAH, M. F. S.; BARBOZA, H. B. Novas experiências de gestão pública e cidadania. Rio de Janeiro: FGV, 2000. 296 p. (Coleção FGV Prática). 
FUNDAÇÃO S.O.S MATA ATLÂNTICA. INSTITUTO NACIONAL DE PESQUISAS ESPACIAIS/ INSTITUTO SÓCIO AMBIENTAL - SOS MATA ATLÂNTICA/ INPE/ ISA. Atlas da evolução dos remanescentes florestais e ecossistemas associados no domínio da Mata Atlântica. São Paulo: Fundação S.O.S. Mata Atlântica, 1998. 54p. (Relatório Nacional).

GONÇALVES, J. L. M. Conservação do solo. In: GONÇALVES, J. L. M.; STAPE, J. L. (ed.). Conservação e cultivo de solos para plantações florestais. Piracicaba: IPEF, 2002. p. 47-129.

INSTITUTO BRASILEIRO DE GEOGRAFIA E ESTATÍSTICA - IBGE. Recursos naturais e meio ambiente: uma visão do Brasil. Rio de Janeiro, 1993. 154p.

LIMA, W. P. Indicadores hidrológicos do manejo sustentável de plantações de eucalipto. In: IUFRO CONFERENCE ON SILVICULTURE AND IMPROVEMENT OF EUCALYPT. Proceedings... Colombo: Embrapa - CNPF, 1997. p. 13-29.

LIMA, W. P.; ZAKIA, M. J. B.; CÂMARA, C. D. Implicações da colheita florestal e do preparo do solo na erosão e assoreamento de bacias hidrográficas. In: GONÇALVES, J. L. M.; STAPE, J. L. (Ed.). Conservação e cultivo de solos para plantações florestais. Piracicaba: IPEF, 2002. p. 373-391.

MATTEUCCI, M. B. A.; COSTA, B. S.; GRASSI, G.; BRAGA, G. C.; MOTA, V.G.O.; FERNANDES, P. S. S. Avaliação ambiental da bacia do Meia Ponte: tributários da bacia dentro da cidade de Goiânia - GO. In: SIMPÓSIO BRASILEIRO DE RECURSOS HÍDRICOS E $8^{\circ}$ SIMPÓSIO DE HIDRÁULICA E RECURSOS HÍDRICOS DOS PAÍSES DE LÍGUA OFICIAL PORTUGUESA, 17., 25 - 29 nov. São Paulo. Proceedings... São Paulo: ABRH, 2007. 1 CD-ROOM.

MOSCA, A. A. O. Caracterização hidrológica de duas microbacias visando à identificação de indicadores hidrológicos para o monitoramento ambiental do manejo de florestas plantadas. 2003. 96f. Dissertação (Mestrado em Ciências Florestais) - ESALQ/USP, Piracicaba, 2003.

PINTO, L. V. A.; BOTELHO, S. A.; DAVIDE, A. C.; FERREIRA, E. Estudos das nascentes da bacia hidrográfica do Ribeirão Santa Cruz, Lavras, MG. Scientia Florestalis, n.65, p.1-10, 2004.

PIRES, J. S. R.; SANTOS, J. E.; DEL PRETTE, M. E. A utilização do conceito bacia hidrográfica para a conservação dos recursos naturais. In: SCHIAVETTI, A.; CAMARGO, A. F. M. (Ed.). Conceitos de bacias hidrográficas: Teorias e Aplicações. Ilhéus: Editus, 2002. p. 17-35.

SANTANA, J. R. O.; SOUSA, R. T. C.; MATTEUCCI, M. B. A. Diagnóstico ambiental das áreas de preservação permanente (app) do córrego Capim Puba, Goiânia, Goiás, Brasil. In: SIMPÓSIO BRASILEIRO DE RECURSOS HÍDRICOS E $8^{\circ}$ SIMPÓSIO DE HIDRÁULICA E RECURSOS HÍDRICOS DOS PAÍSES DE LÍGUA OFICIAL PORTUGUESA, 17., 25 - 29 nov. São Paulo. Proceedings... São Paulo: ABRH, 2007. 1 CD-ROOM. 
SOUZA, M. J. H.; RIBEIRO, A.; LEITE, H. G.; LEITE, F. P.; MINUZZI, R. B. Relação entre disponibilidade hídrica e produtividade do eucalipto em diferentes idades, em Guanhães, Minas Gerais. Revista Brasileira de Engenharia Agrícola e Ambiental, v. 10, n. 3, p. 629-638, 2006.

TONELLO, K. C.; DIAS, H. C. T.; SOUZA, A. L. de; RIBEIRO, C. A. A. S.; LEITE, F. P. Morfometria da bacia hidrográfica da Cachoeira das Pombas, Guanhães-MG. Revista Árvore, v. 30, n. 5, p. 849-857, 2006.

VALCARCEL, R. Balanço hídrico no ecossistema florestal e sua importância conservacionista na região ocidental dos Andes Venezuelanos. In: SEMINÁRIO SOBRE ATUALIDADES E PERSPECTIVAS FLORESTAIS, 11., 1984, Curitiba. Anais... Curitiba: Embrapa, 1984. 142p. 


ISSN = 1980-993X - doi:10.4136/1980-993X
www.agro.unitau.br/ambi-agua
E-mail: ambi-agua@agro.unitau.br
Tel.: (12) 3625-4116

\title{
Aplicação da probabilidade condicional e do processo de cadeia de Markov na análise da ocorrência de períodos secos e chuvosos para o município de Garanhuns, PE, Brasil \\ (doi:10.4136/ambi-agua.81)
}

\author{
Antonio Ricardo Santos de Andrade'; Joherlan Campos de Freitas²; José Ivaldo \\ Barbosa de Brito ${ }^{3}$; Hugo Orlando Carvallo Guerra ${ }^{4}$; Josilda de França Xavier ${ }^{5}$ \\ ${ }^{1}$ Unidade Acadêmica de Garanhuns - UAG, Universidade Federal Rural de Pernambuco - UFRPE \\ E-mail: arsauag@uag.urfrpe.br \\ ${ }^{2,3}$ Unidade Acadêmica de Ciências Atmosféricas - UACA, Universidade Federal de Campina Grande \\ E-mail: joherlancampos@yahoo.com.br, ivaldo@dca.ufcg.edu.br \\ ${ }^{4,5}$ Departamento Engenharia Agrícola - DEAg, Universidade Federal de Campina Grande - UFCG \\ E-mail: hugo_carvallo@hotmail.com,josildaf@yahoo.com.br
}

\section{RESUMO}

A agricultura apresenta grande dependência das condições climáticas, notadamente da precipitação pluviométrica da região. Por isso, faz-se necessário o estudo das probabilidades de ocorrência das chuvas no município de Garanhuns/PE devido a sua enorme irregularidade, de modo a apresentar subsídios, permitindo que o agricultor tome decisões mais confiáveis das atividades agrícolas. Dessa forma, os objetivos deste trabalho foram estimar a precipitação mensal provável com diferentes níveis de probabilidade e determinar as probabilidades de ocorrências de períodos secos e chuvosos para o município de Garanhuns, PE. Para o cálculo das probabilidades condicionais, utilizou-se o método da cadeia de Markov, admitindo-se a hipótese de que as ocorrências de dias secos e chuvosos são condicionalmente dependentes da sequência dos dias secos e chuvosos anteriores. Utilizaramse dados de precipitação pluviométrica mensal da série de dados compreendida entre 1913 e 1987. Os critérios discriminantes para identificar períodos secos e chuvosos, baseiam-se em quatro classes de chuvas acumuladas mensais: (S) mês seco, de 0 a $50 \mathrm{~mm}$; (PC) mês pouco chuvoso, de 50 a $100 \mathrm{~mm}$; (C) mês chuvoso, de 100 a $200 \mathrm{~mm}$ e (BC) mês bastante chuvoso, acima de $200 \mathrm{~mm}$. Dessa forma, foram analisadas as médias mensais de cada mês dentro das classes de chuvas com a finalidade de estimar as porcentagens de ocorrência provável pelo método proposto por Robertson (1976). Foi utilizada distribuição de probabilidade gama para estimativa da precipitação mensal provável, em níveis de 90, 80, 75, 70, 60, 50, 40 e 30\% de probabilidade. Para avaliar o ajuste dos dados estimados aos observados, utilizou o teste de aderência de Kolmogorov-Smirnov. Concluiu-se que a distribuição Gama apresentou bom ajuste ao nível de 1\% de significância com relação aos valores observados, possibilitando sua utilização para estimativas de precipitação pluvial provável mensal em diferentes níveis de probabilidade. Ficou caracterizada a estação chuvosa como sendo o período compreendido entre os meses de maio e agosto, e o período seco, aquele entre os meses de outubro e dezembro. As menores precipitações prováveis, abaixo de $50 \mathrm{~mm}^{\text {mês }}{ }^{-1}$ são registradas nos meses de outubro, novembro e dezembro, quando se deve empregar a irrigação na produção agrícola, recomendando-se ainda a utilização de espécies e cultivares de ciclo curto para semeaduras em outubro e de ciclo longo para abril, a fim de se reduzirem os riscos de prejuízos na colheita.

Palavras-chave: chuva; modelos probabilísticos; distribuição Gama; cadeia de Markov. 


\title{
Application of conditional probability and the Markov chain process in the analysis occurrence of dry and rainy periods in Garanhuns, Pernambuco, Brazil
}

\begin{abstract}
Agriculture presents dependence on the climatic conditions, especially on precipitation. This way, it is necessary to study the probabilities of occurrence of rain in Garanhuns municipality, Pernambuco State, especially due to its irregularity, to support farmer's decisions about agriculture activities. The objectives of this study were to forecast monthly rainfall at different significance levels and to determine the probabilities of occurrence of dry and rainy periods for Garanhuns region, state of Pernambuco, Brazil. Monthly rainfall data from 1913 to 1987 were analyzed. The criteria to identify dry and rainy periods were based on four classes of monthly rainfall: (S) dry month, from 0 to $50 \mathrm{~mm}$; (PC) low rain month, from 50 to $100 \mathrm{~mm}$; (C) rainy month, from 100 to $200 \mathrm{~mm}$ and (BC) very rainy month, above $200 \mathrm{~mm}$. Thus, the monthly averages were analyzed according to the four classes of rains to estimate the probable occurrence of rain following Robertson (1976). The Gamma probability distribution was also used to forecast monthly precipitation, at the following levels: 90, 80, $75,70,60,50,40$ and $30 \%$ of probability. The Gamma distribution adjusted well to the data of Garanhuns region, making possible the estimation of the probable rainfall amounts for each month of the year, at different levels of probability. Rainy season was the period between May and August, and the dry one between October and December. The lowest probable monthly rainfalls, below $50 \mathrm{~mm}$, were observed between October and December, when irrigation is required for food production, being recommended to plant annual crops and cultivars of short cycle to be sowing in October, and of long cycle to be sowing in April, in order to reduce the risks of damage.
\end{abstract}

Keywords: rainfall occurrence; probabilistic models; Gamma distribution; Markov chain.

\section{INTRODUÇÃO}

Situado no Agreste Meridional do Estado, o município de Garanhuns é um das mais importantes do estado de Pernambuco. Tem como principal atividade econômica a agropecuária que é fortemente influenciada pela ocorrência de períodos secos e chuvosos, fenômenos que muitas vezes causam sérios prejuízos à agricultura. Previsões precisas sobre a ocorrência de períodos secos e chuvosos, principalmente de longo prazo, são ainda inviáveis. Por esse motivo, estimativas probabilísticas desses fenômenos têm grande utilidade, pois possibilitam que muitas atividades agrícolas, tais como o plantio, aplicação de adubos e defensivos, a utilização de máquinas agrícolas, a semeadura e colheita, etc, possam ser realizadas em épocas mais favoráveis, reduzindo assim os riscos de perda na produção agrícola. Além disso, o conhecimento dos aspectos fundamentais dos cálculos da precipitação provável do período é uma necessidade essencial para o dimensionamento de barragens, de abastecimento de água, para o planejamento agrícola e para o dimensionamento de sistema de irrigação (Bernardo, 1995, Araújo et al., 2001).

No Brasil, principalmente para região Nordeste, a quase totalidade dos projetos de irrigação e drenagem visa a suprir todas as necessidades hídricas da cultura, sem observar a contribuição da precipitação do período. A precipitação provável do período é o elememto meteorológico determinante para a agricultura na região de Garanhuns, entretanto a 
ANDRADE, A. R. S.; FREITAS, J. C.; BRITO, J. I. B.; GUERRA, H. O. C.; XAVIER, J. F. Aplicação da probabilidade condicional e do processo de cadeia de Markov na análise da ocorrência de períodos secos e chuvosos para o município de Garanhuns, PE, Brasil. Ambi-Agua, Taubaté, v. 4, n. 1, p. 169-182, 2009. (doi:10.4136/ambi-agua.81)

quantidade de chuva e a sua distribuição, em certa localidade, podem determinar o tipo de atividade agrícola a ser desenvolvida e os níveis de produtividade a serem alcançados.

Admitindo-se que a ocorrência de dias secos ou chuvosos está associada com as condições pluviométricas anteriores, podem-se utilizar as distribuições ajustadas para estimar as probabilidades de chuva para cada mês, comparando-as aos valores observados (Keller Filho et al., 2006). Vários modelos de distribuição teóricas de probabilidade têm sido utilizados para a estimativa da precipitação provável para diferentes períodos de ocorrência. Dentre esses modelos, destacam-se a distribuição Normal (Frizzone, 1979; Assis et al., 1996; Andrade Júnior e Bastos, 1997), distribuição Gama (Castro Neto e Silveira, 1983; Rodrigues e Pruski, 1996, Ribeiro e Lunardi, 1997; Andrade Júnior e Bastos, 1997) e distribuição de Gumbel (Assis et al., 1996). Os autores recomendam o uso de funções probabilísticas, fazendo-se, posteriormente, a verificação do ajuste por meio de testes de aderência, por exemplo, o de Kolmogorov-Smirnov (2009).

Segundo Cunha et al. (1996), um modelo que vem sendo bastante citado para estimativa da precipitação pluvial provável mensal em diferentes níveis de probabilidade é o da distribuição Gama. Seu uso se atém ao fato de que as precipitações, sob o ponto de vista estatístico, não são distribuídas uniformemente em torno do valor médio, mas sim, de maneira irregular, com grande desvio em relação a esse valor médio (Krepper et al., 1989).

Utilizando dados de 30 anos (1949 -1978), Frizzone (1979) estimou a precipitação provável para a região de Viçosa/MG, em períodos de 5, 10, 15 e 30 dias, utilizando cinco modelos para cálculos de distribuição de frequência. Os resultados mostraram que a distribuição Gama incompleta pode ser usada para se estudar a distribuição das precipitações em períodos de 5 a 30 dias na referida região.

Segundo Castro et al. (1994), o uso da precipitação média no dimensionamento de projetos agrícolas têm-se constituído em risco para os produtores, porque valores médios de precipitação, em geral, apresentaram menos de $50 \%$ de probabilidade de ocorrência. De acordo com Bernardo (1995), para a minimização dos riscos, não se deve trabalhar com probabilidades de ocorrência de chuva inferiores a 75 ou $80 \%$. Entretanto, esses valores podem ser variáveis adotando-se um critério econômico, cujo nível de probabilidade esteja associando à redução na qualidade e quantidade de produção, decorrentes da deficiência hídrica pela falta de chuva, durante determinado período (Jensen, 1983).

Assis (1991) elaborou modelos teóricos para descrever a quantidade de chuvas diárias em Pelotas, RS, com base na distribuição binomial negativa truncada e na distribuição de probabilidade Gama. Ao analisar os totais semanais de chuva de Pelotas, correspondentes ao período de 1893 a 1991, concluiu que as chuvas podem ser adequadamente representadas pela função de distribuição de probabilidade gama.

Considerando a influência que as condições climáticas exercem em muitas atividades agrícolas, realizou-se este trabalho, cujo objetivo foi determinar a probabilidade de ocorrência de períodos secos (S) e chuvosos (C) para o município de Garanhuns/PE, considerando-se mês seco, de 0 a 50 mm; mês pouco chuvoso, de 50 a 100 mm; mês chuvoso, de 100 a 200 mm e mês bastante chuvoso, acima de $200 \mathrm{~mm}$.

\section{MATERIAL E MÉTODOS}

\subsection{Local do estudo e dados pluviométricos}

Os dados utilizados foram obtidos juntos aos registros pluviométricos diários da estação Agrometeorológica do Departamento de Agronomia (DEPA), UFRPE, Campus Dois Irmãos, no município de Garanhuns, PE, para um período de 75 anos (1913-1987). 

probabilidade condicional e do processo de cadeia de Markov na análise da ocorrência de períodos secos e chuvosos para o município de Garanhuns, PE, Brasil. Ambi-Agua, Taubaté, v. 4, n. 1, p. 169-182, 2009. (doi:10.4136/ambi-agua.81)

A área geográfica de Pernambuco oferece, do litoral ao sertão, uma sucessão de paisagens diferentes, marcadas por uma intensa diversificação de formas de uso do solo, grande variabilidade climática e estão divididas em 5 Mesorregiões e 19 Microrregiões geográficas (IBGE), conforme as Figuras 1 e 2. Cada Microrregião é constituída por municípios, perfazendo o Estado, que atualmente possui 185 unidades políticoadministrativas, juntamente com o Arquipélago de Fernando de Noronha (Andrade, 1999).O município de Garanhuns está localizado na porção sudoeste da região do Agreste Meridional de Pernambuco.

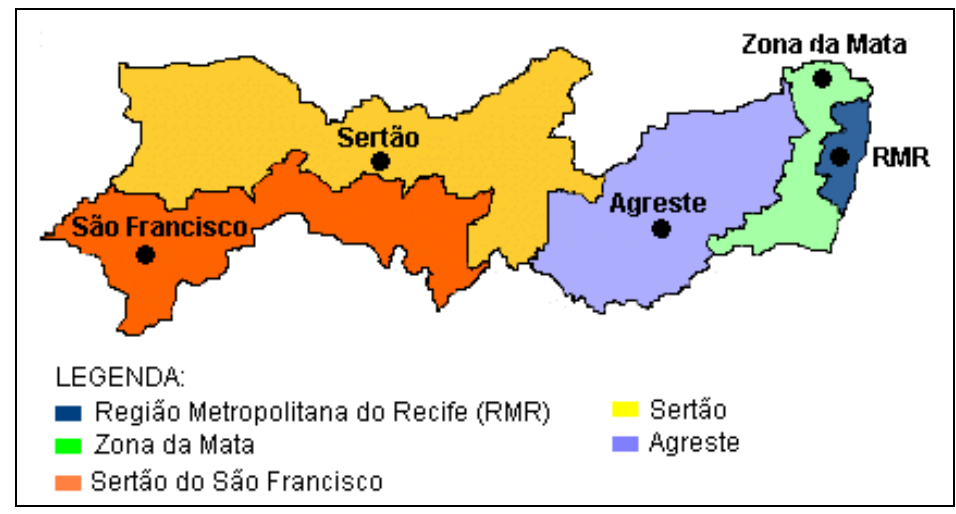

Figura 1. Mapa com a identificação das Mesorregiões geográficas em Pernambuco.

Fonte: Andrade (1999).

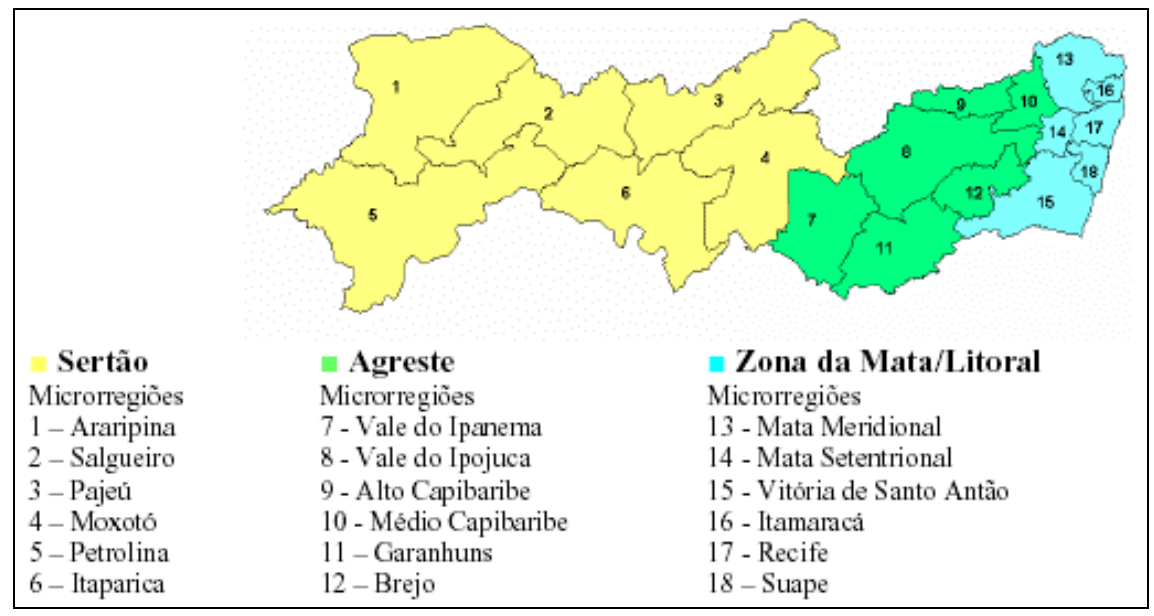

Figura 2. Mapa com a identificação das Microrregiões geográficas em Pernambuco.

Fonte: Andrade (1999).

O município de Garanhuns situa-se ao Sul da Chapada da Borborema, na mesorregião do Agreste pernambucano, a uma altitude média de $896 \mathrm{~m}$, chegando a $1.030 \mathrm{~m}$ de altitude no seu ponto mais elevado, usufruindo assim, de um clima menos árido do que o que predomina no interior do Estado e na região ocidental do município. Por estar localizado também em uma região de maior altitude, beneficia-se de temperaturas mais amenas e de uma ótima ventilação, o que proporciona um clima agradável em todos os meses do ano. A temperatura média anual oscila em torno dos $20^{\circ} \mathrm{C}$, podendo atingir $30^{\circ} \mathrm{C}$ nos dias mais quentes $15^{\circ} \mathrm{C}$ nas 
noites mais frias do ano. A umidade relativa média do ar, na área urbana, varia entre 75 e $83 \%$.

Segundo Almeira et al. (2004), o Agreste, região intermediária entre a Zona da Mata e o Sertão, apresenta semelhança climática tanto com o clima úmido (Mata), como com o clima seco (Sertão). As precipitações pluviométricas são menos concentradas do que no Sertão. Para a faixa mais ocidental do Agreste, nota-se que as contribuições dos sistemas de leste, são muito menos importantes do que as da Zona de Convergência Intertropical (ZCIT). Dessa forma, o Agreste apresenta, nas áreas mais próximas do Sertão, período que vai de maio a junho.

\subsection{Análise dos dados}

A estimativa de precipitação pluviométrica mensal provável foi obtida para os níveis de 90, 80, 75, 70, 60, 50,40 e 30\% de probabilidade, utilizando-se a função de distribuição Gama, conforme apresentado por Assis et al. (1996). A distribuição de probabilidade Gama é a mais utilizada para ajustar totais de chuva de períodos mensais ou menores. Sua função densidade de probabilidade apresenta a seguinte forma:

$f(x)=\left\{\begin{array}{l}\frac{1}{\beta^{\alpha} \Gamma(\alpha)} x^{\alpha-1} e^{-x / \beta}, 0<x<\infty \\ 0, \quad-\infty<x \leq 0\end{array}\right.$

$\Gamma(\alpha)$ é a função Gama, importante em muitas áreas da matemática, dada por:

$\Gamma(\alpha)=\int_{0}^{\infty} \mathrm{e}^{-\mathrm{x}} \mathrm{x}^{\alpha-1} \mathrm{dx}, \alpha>0$

Os parâmetros $\alpha$ e $\beta$ da distribuição Gama para uma dada variável aleatória foram estimados pelo método da máxima verossimilhança (Assis et al., 1996):

$\alpha=\frac{1}{4 \mathrm{~A}}\left(1+\sqrt{1+\frac{4 \mathrm{~A}}{3}}\right)$

$\beta=\frac{\bar{X}}{\alpha}$

$A=\ln \bar{X}-X_{g}$

sendo $\overline{\mathrm{X}}$ e $\overline{\mathrm{X}}_{\mathrm{g}}$ respectivamente, a média aritmética e a média geométrica das observações em escala de tempo mensal.

Cunha et al. (1996) sugerem que duas situações distintas podem ocorrer, quando se utiliza a distribuição Gama, a primeira é quando a série de dados não contém valores nulos; nesse caso, a estimativa da frequência de ocorrência é obtida por meio da distribuição cumulativa Gama, sendo possível a estimativa dos parâmetros da distribuição ( $\alpha$ e $\beta$ ) pelo método da máxima verossimilhança. A segunda, quando a série contém valores nulos, caso 
que pode ser contornado com a utilização da distribuição cumulativa Gama mista, a qual é determinada em duas partes, da seguinte forma (Assis et al., 1996):

$\mathrm{F}(\mathrm{X})=\mathrm{P}_{\mathrm{o}}+\left(1-\mathrm{P}_{\mathrm{o}}\right) \mathrm{G}(\mathrm{X})$

sendo:

$\mathrm{P}_{\mathrm{o}}=\frac{\mathrm{N}_{\mathrm{o}}}{(\mathrm{N}+1)}$

em que $\mathrm{P}_{\mathrm{o}}$ é a probabilidade de ocorrências de valores nulos (zero), $\mathrm{G}(\mathrm{X})$ corresponde a distribuição acumulada Gama e $\mathrm{N}_{0}$ é o número de valores nulos da série.

Para as estimativas dos valores de precipitação provável, utilizou-se o programa SISVAR 4.3, o qual retorna o inverso da distribuição acumulada Gama a partir dos valores da média $(\mu)$, desvio-padrão $(\sigma), \alpha, \beta$ e dos níveis de probabilidade de $90,80,75,70,60$, 50,40 e $30 \%$.

Foram criadas quatro classes de chuvas acumuladas mensais. O critério de escolha dessas quatro classes foi o de encontrar um intervalo o mais curto quanto possível, dentro do qual as probabilidades não apresentem grandes discrepâncias, a fim de se obter adequado grau de precisão nas estimativas das probabilidades de ocorrência de períodos secos (S) e chuvosos (C). Considerou-se como mês seco, de 0 a $50 \mathrm{~mm}$; mês pouco chuvoso, de 50 a 100 mm; mês chuvoso, de 100 a $200 \mathrm{~mm}$ e mês bastante chuvoso, acima de $200 \mathrm{~mm}$. Dessa forma, foram analisados os totais de cada mês dentro das duas classes de chuvas acumuladas, anteriormente apresentada, e verificou-se a porcentagem de ocorrência. As probabilidades (P) de ocorrerem períodos secos (S), pouco chuvosos (PC), chuvoso (C), bastante chuvoso (BC) e as probabilidades condicionais dias secos dado que o dia anterior também foi seco (S/S) e dias chuvosos dado que o dia anterior foi chuvoso $(\mathrm{C} / \mathrm{C})$, foram calculadas por meio da cadeia de Markov, utilizandoa frequência de dias secos (FS), dias pouco chuvoso (FPC), de chuvosos (FC), de dias bastante chuvosos (FBC), dias secos precedidos de dias secos (FSS) e chuvosos precedidos de dias chuvosos (FCC), conforme equações propostas por Robertson (1976) e Fietz et al. (1998):

$$
\begin{aligned}
& \mathrm{P}(\mathrm{S})=\frac{F S}{(F S+F C+F P C+F B C)} \\
& \mathrm{P}(\mathrm{PC})=\frac{\mathrm{FPC}}{(\mathrm{FPC}+\mathrm{FS}+\mathrm{FC}+\mathrm{FBC})} \\
& \mathrm{P}(\mathrm{C})=1-\mathrm{P}(\mathrm{S}) \\
& \mathrm{P}(\mathrm{BC})=\frac{\mathrm{FBC}}{(\mathrm{FBC}+\mathrm{FS}+\mathrm{FC}+\mathrm{FPC})} \\
& \mathrm{P}(\mathrm{S} / \mathrm{S})=\frac{F S S}{F S} \\
& \mathrm{P}(\mathrm{C} / \mathrm{C})=\frac{F C C}{F C}
\end{aligned}
$$


ANDRADE, A. R. S.; FREITAS, J. C.; BRITO, J. I. B.; GUERRA, H. O. C.; XAVIER, J. F. Aplicação da probabilidade condicional e do processo de cadeia de Markov na análise da ocorrência de períodos secos e chuvosos para o município de Garanhuns, PE, Brasil. Ambi-Agua, Taubaté, v. 4, n. 1, p. 169-182, 2009. (doi:10.4136/ambi-agua.81)

As probabilidades de ocorrência de períodos consecutivos secos (P(S,S,S...n)) e chuvosos (P(C,C,C...n) ) foram determinadas pelas seguintes expressões (Robertson, 1976):

$$
\begin{aligned}
& \mathrm{P}(\mathrm{S}, \mathrm{S}, \mathrm{S} . . . \mathrm{n})=\mathrm{P}(\mathrm{S}) \cdot \mathrm{P}(\mathrm{S} / \mathrm{S})^{\mathrm{n}-1} \cdot 100 \\
& \mathrm{P}(\mathrm{C}, \mathrm{C}, \mathrm{C} . . \mathrm{n})=\mathrm{P}(\mathrm{C}) \cdot \mathrm{P}(\mathrm{C} / \mathrm{C})^{\mathrm{n}-1} \cdot 100
\end{aligned}
$$

em que n é número de dias consecutivos de dias secos e/ou chuvosos do período.

Para avaliar o ajuste dos dados de precipitação observados com os estimados pela distribuição de probabilidade teórica Gama, aplicou-se o teste de aderência KolmogorovSmirnov (KS) no nível de significância de 1\%, de forma a verificar se os valores amostrais da precipitação mensal observadas podem ser considerados como provenientes de uma população com aquela distribuição teórica gama (Campos, 1979).

\section{RESULTADO E DISCUSSÃO}

De acordo com a série de dados de chuva, observou-se, para Garanhuns, PE, que a precipitação total foi de 769,2 m, sendo o mês de junho de 1951 o mais chuvoso, com 349,8 mm, e o mês de novembro de 1970 o menos chuvoso, com precipitação 0,1 mm. Os coeficientes de variação das médias mensais e o desvio-padrão foram elevados, evidenciandose a grande variabilidade da precipitação, e as variações menores ocorreram entre os meses de outubro e dezembro, e as maiores, entre os meses de maio e agosto que correspondem ao período mais seco e mais chuvoso, respectivamente (Tabela 1).

Tabela 1. Médias mensais, desvio-padrão, coeficiente de variação (CV) e valores extremos mensais de

\begin{tabular}{|c|c|c|c|c|c|c|c|}
\hline Mês & $\begin{array}{l}\text { Média } \\
(\mathrm{mm})\end{array}$ & $\begin{array}{c}\text { DP } \\
(\mathrm{mm})\end{array}$ & $\begin{array}{l}\text { CV } \\
(\%)\end{array}$ & $\begin{array}{c}\text { Máximo } \\
\text { (mm) }\end{array}$ & $\begin{array}{c}\text { Ano } \\
\text { Ocorrido }\end{array}$ & $\begin{array}{c}\text { Mínimo } \\
\text { (mm) }\end{array}$ & $\begin{array}{c}\text { Ano } \\
\text { Ocorrido } \\
\end{array}$ \\
\hline Jan. & 38,14 & 44,34 & 86,03 & 289,5 & 1914 & 1,3 & 1976 \\
\hline Fev. & 46,46 & 45,70 & 101,67 & 203,9 & 1924 & 1,3 & 1924 \\
\hline Mar. & 76,96 & 65,97 & 116,66 & 289,0 & 1941 & 1,2 & 1913 \\
\hline Abr. & 81,14 & 66,72 & 121,60 & 287,8 & 1920 & 2,7 & 1926 \\
\hline Mai. & 109,29 & 69,27 & 157,76 & 317,9 & 1945 & 16,9 & 1985 \\
\hline Jun. & 124,66 & 61,49 & 202,72 & 349,8 & 1951 & 32,6 & 1939 \\
\hline Jul. & 117,43 & 54,27 & 216,39 & 282,2 & 1919 & 34,3 & 1933 \\
\hline Ago. & 74,81 & 47,59 & 157,22 & 222,3 & 1914 & 11,1 & 1927 \\
\hline Set. & 36,69 & 27,44 & 133,70 & 97,4 & 1918 & 23,3 & 1937 \\
\hline Out. & 20,51 & 35,79 & 57,31 & 211,9 & 1965 & 0,5 & 1970 \\
\hline Nov. & 19,70 & 36,29 & 54,29 & 190,8 & 1947 & 0,1 & 1970 \\
\hline Dez. & 23,43 & 32,77 & 71,50 & 154,9 & 1915 & 0,2 & 1971 \\
\hline Período & & & 102,32 & 349,8 & 1951 & 0,1 & 1970 \\
\hline Total & 769.22 & & & & & & \\
\hline
\end{tabular}
precipitação pluviométrica e anos de ocorrência, em Garanhuns, PE para o período de 1913 a 1987.

DP = desvio-padrão; CV = coeficiente de variação.

Na Figura 3, são apresentados os valores médios mensais da precipitação pluviométrica no município de Garanhuns. Analisando-se a Figura 3, observa-se que o município tem um regime de chuvas unimodal, com o período menos chuvoso concentrado nos meses de outono, 
novembro e dezembro, confirmando a dinâmica regional. A distribuição das chuvas na região do Agreste pernambucano e de estados circunvizinhos está relacionada aos sistemas meteorológicos tipicamente nordestinos, que estão associados às oscilações da Zona de Convergência Intertropical (ZCIT), da Zona de Convergência do Atlântico sul (ZCAS), dos Vórtices Ciclônicos em Ar Superior (VCAS). Aos distúrbios de leste e às brisas (marítimas e terrestres), os quais são responsáveis pelas modificações do regime pluviométrico no Nordeste Brasileiro (NEB). Maiores informações a respeito da atuação dos sistemas no NEB podem ser encontradas em Molion e Bernardo (2002).

De acordo com Vasconcelos e Pinto (2004), para o Agreste Meridional mais próximo da Zona da Mata, o caso de Garanhuns, as contribuições dos sistemas de leste são muito mais importantes do que as da ZCIT, com o mês mais chuvoso se deslocando para junho.

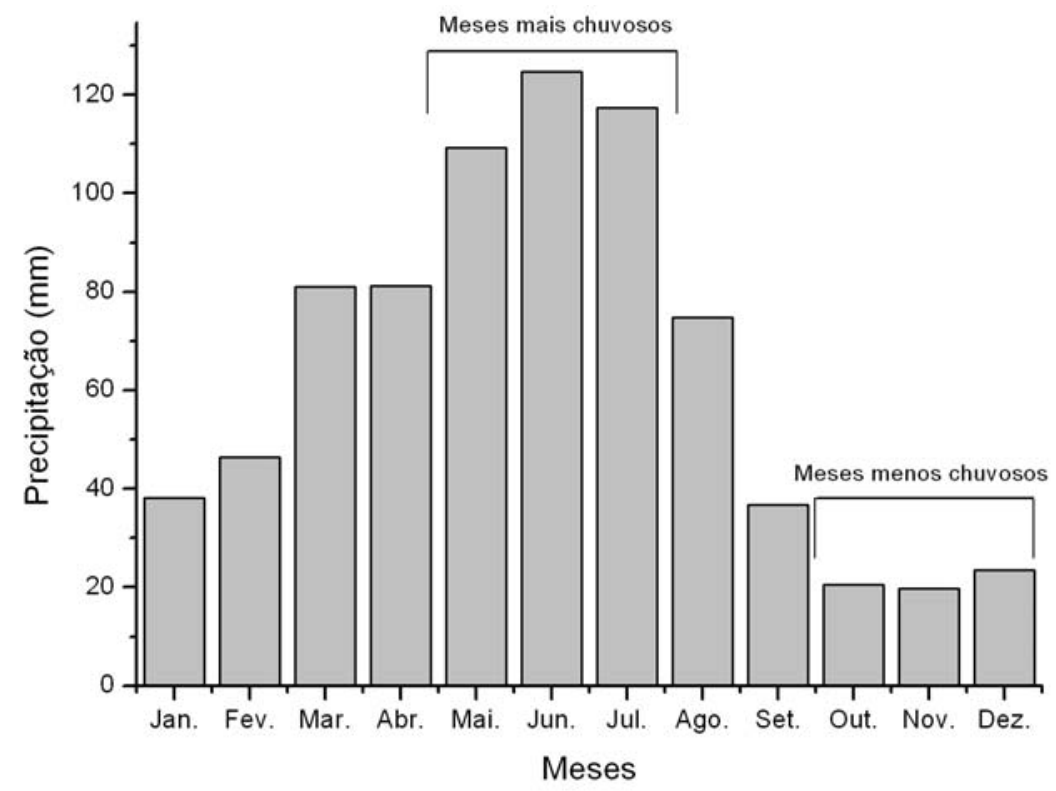

Figura 3. Histograma da distribuição mensal da precipitação pluviométrica média no município de Garanhuns, PE, para o período de 1913 a 1987.

Observa-se ainda pela Figura 3 que os maiores valores de precipitação ocorrem em maio, junho e julho, principalmente no mês de julho. Estudando a variação das chuvas no município de Arapiraca/AL, Xavier e Dornellas (2005) observaram característica semelhante em relação ao período chuvoso, concluindo que a maior parte de suas chuvas se precipita em apenas 3 meses (geralmente, maio, junho e julho). Em $51 \%$ dos anos da série, as chuvas dos três meses mais chuvosos representaram mais de $60 \%$ do total anual. E, em $85 \%$ dos anos, os três meses mais chuvosos concentraram mais de $50 \%$ do total precipitado no ano. Pode-se observar também que outubro, novembro e dezembro são os meses com os menores índices pluviométricos. Essa redução pluviométrica provavelmente está associada às oscilações dos distúrbios de leste - agrupamentos de nuvens que se movem no Atlântico, de leste para oeste, até atingirem a costa oriental da região Nordeste, durante o período de maio a agosto que são os maiores responsáveis pelas modificações do regime pluviométrico na região do Agreste Meridional de Pernambuco

A Tabela 2 apresenta os parâmetros ( $\alpha$ e $\beta$ ) da distribuição Gama e as estimativas das precipitações prováveis mensais em diferentes níveis de probabilidades, as quais são ferramentas úteis para uma possível programação de irrigação suplementar, se necessário. 
ANDRADE, A. R. S.; FREITAS, J. C.; BRITO, J. I. B.; GUERRA, H. O. C.; XAVIER, J. F. Aplicação da probabilidade condicional e do processo de cadeia de Markov na análise da ocorrência de períodos secos e chuvosos para o município de Garanhuns, PE, Brasil. Ambi-Agua, Taubaté, v. 4, n. 1, p. 169-182, 2009. (doi:10.4136/ambi-agua.81)

Para fins agrícolas, a precipitação pluvial média de uma determinada localidade não é um parâmetro adequado que deva ser utilizado, uma vez que a probabilidade de sua ocorrência com valor igual ou superior à média situa-se em torno de $30 \%$, o que é considerado baixo (Castro Neto e Silveira, 1981). Segundo Bernardo (1995), o nível de 50 a $70 \%$ de probabilidade de ocorrência de chuva é o mais confiável para dimensionamento de projetos agrícolas ou de irrigação. Medina e Leite (1984) recomendam que para minimizar os riscos no planejamento de uma agricultura racional não se devem usar probabilidades de ocorrência de chuva inferior a $50 \%$.

Tabela 2. Estimativas dos parâmetros da distribuição Gama ( $\alpha, \beta)$, da precipitação média mensal (mm) e precipitação mensal média provável (mm) para diversos níveis de probabilidade e nos diferentes meses do ano em Garanhuns, PE, com base na série histórica de 1913 a 1987.

\begin{tabular}{|c|c|c|c|c|c|c|c|c|c|c|c|}
\hline \multirow[b]{2}{*}{ Mês } & \multirow[b]{2}{*}{$\alpha$} & \multirow[b]{2}{*}{$\beta$} & \multirow{2}{*}{$\begin{array}{c}\text { Média } \\
\text { (mm) }\end{array}$} & \multicolumn{8}{|c|}{ Nível de probabilidade $\mathbf{P}(X \geq x i)$} \\
\hline & & & & 90 & 80 & 75 & 70 & 60 & 50 & 40 & 30 \\
\hline Jan. & 2,08 & 21,62 & 38,14 & 86,70 & 67,05 & 60,42 & 54,84 & 45,64 & 38,04 & 31,34 & 25,12 \\
\hline Fev. & 1,99 & 28,43 & 46,46 & 110,29 & 84,87 & 76,31 & 69,12 & 57,28 & 47,52 & 38,96 & 31,05 \\
\hline Mar. & 1,97 & 40,81 & 76,96 & 156,82 & 120,50 & 108,27 & 98,00 & 81,12 & 67,21 & 55,02 & 43,77 \\
\hline Abr. & 1,62 & 57,23 & 81,14 & 189,54 & 142,16 & 126,39 & 113,24 & 91,83 & 74,44 & 59,45 & 45,88 \\
\hline Mai. & 3,19 & 54,88 & 109,29 & 228,58 & 177,77 & 160,57 & 146,08 & 122,15 & 102,28 & 84,73 & 68,38 \\
\hline Jun. & 3,87 & 34,48 & 124,66 & 224,23 & 184,56 & 170,78 & 158,99 & 139,07 & 122,03 & 106,45 & 91,35 \\
\hline Jul. & 3,38 & 36,95 & 117,43 & 216,14 & 175,77 & 161,82 & 149,92 & 129,93 & 112,92 & 97,48 & 82,63 \\
\hline Ago. & 2,38 & 33,73 & 74,81 & 150,04 & 117,80 & 106,83 & 97,58 & 82,22 & 69,41 & 58,03 & 47,34 \\
\hline Set. & 2,62 & 11,52 & 36,69 & 71,04 & 58,13 & 53,65 & 49,83 & 43,39 & 37,90 & 32,89 & 28,05 \\
\hline Out. & 2,71 & 13,28 & 20,51 & 65,31 & 51,98 & 47,42 & 43,55 & 37,10 & 31,68 & 26,82 & 22,22 \\
\hline Nov. & 2,54 & 9,61 & 19,70 & 58,23 & 47,55 & 43,86 & 40,70 & 35,39 & 30,86 & 26,73 & 22,76 \\
\hline Dez. & 2,70 & 12,10 & 23,43 & 64,45 & 51,82 & 47,48 & 43,79 & 37,61 & 32,39 & 27,68 & 23,18 \\
\hline Per. & 1,63 & 44,93 & 64,10 & 149,88 & 112,55 & 100,12 & 89,75 & 72,86 & 59,13 & 47,28 & 36,55 \\
\hline
\end{tabular}

Confrontando os valores de precipitações médias mensais observadas, com o nível de probabilidade geralmente recomendado quando se estuda a precipitação provável na maioria dos municípios da região do Agreste pernambucano, e porção sudoeste da região Agreste dos estados de Alagoas e Paraíba, os valores encontrados para a probabilidade de ocorrência de valores médios de precipitação pluvial mensal, ocorreram próximos ao nível de $60 \%$ de probabilidade. Esse fato é atribuído à assimetria positiva apresentada pelas precipitações nos períodos estudados, realçando a boa aderência dos dados à distribuição Gama, isto é, ocorreram altas frequências esperadas no período seco (PC) com precipitação de 0 a $50 \mathrm{~mm}$ e pequenas frequências esperadas no período bastante chuvoso (BC), com valores de precipitações acima de $200 \mathrm{~mm}$, ao longo dos anos em cada mês (Figura 2). Esse fato, também, foi verificado por Saad (1990) e Fietz et al. (1998), os quais sugerem que a utilização desses valores no planejamento de sistema de irrigação, mesmo que complementar, acarretará em subdimensionamento de equipamentos e instalações.

Na Tabela 2, observa-se, ainda, que os valores estimados do parâmetro $\alpha$ foram menores no período de meses secos (fevereiro, março e abril), e maiores nos meses mais chuvosos (maio, junho e julho), o que sugere que os maiores valores de $\alpha$ estão associados com maiores precipitações. Logo esse parâmetro poderia ser usado como um indicador de precipitação mensal da região. Assim, estimativas menores e iguais que 3 , sugerem precipitações mensais menores e iguais que $100 \mathrm{~mm}$, valores maiores que 3, precipitações superiores a $100 \mathrm{~mm}$. Isso seria útil para uma possível programação de irrigação suplementar, 
se necessário. Esses resultados estão de acordo com Botelho e Morais (1999), que afirmam que isso pode ser explicado pela pronunciada assimetria positiva nos períodos dos meses mais secos, visto que a assimetria é proporcional a $\alpha$.

Os valores do parâmetro $\beta$ não excederam o valor 100 em nenhum dos meses, possibilitando assim a utilização na distribuição Gama para o cálculo da estimativa das precipitações mensais prováveis para Garanhuns, PE. De acordo com Thom (1958), para valores superiores a 100 se utiliza a distribuição Gama incompleta. Pode-se verificar que os maiores valores $\beta$ (30 a 60) ocorrem no período chuvoso. Esses resultados corroboram com aqueles encontrados por Murta et al. (2005), que encontraram valores menores do parâmetro $\beta$ nos meses mais secos para duas localidades do sudoeste da Bahia.

Os valores da distribuição de frequências de ocorrências observadas e prováveis para as quatro classes de chuvas acumuladas mensais são apresentados na Figura 4. Verificou-se que a função de distribuição Gama, segundo o teste de Kolmogorov-Smirnov, ajustou-se bem às quatro classes de chuvas acumuladas mensais estuda, (S) mês seco de 0 a 50 mm; (PC) mês pouco chuvoso de 50 a $100 \mathrm{~mm}$; (C) mês chuvoso de 100 a $200 \mathrm{~mm}$ e (BC) mês bastante chuvoso acima de $200 \mathrm{~mm}$ a todo o período, a 1\% de probabilidade (Figura 2). Também observou-se um decréscimo das frequências de ocorrências da precipitações mensais prováveis, estimadas pela distribuição Gama, no primeiro intervalo de 0 a $50 \mathrm{~mm}$, quando comparado com valores observados, seguido de um aumento na estimativa da frequência de ocorrência prováveis no intervalo de 50 a $100 \mathrm{~mm}$. Entretanto, para os dois últimos intervalos foram observadas diferenças pequenas entre os valores estimados e observados.

Nota-se, ainda, na Figura 4, que a quantidade do número de precipitações mensais superior a $200 \mathrm{~mm}$ (classe denominada bastante chuvosa - BC) em toda a série amostral de 75 anos, corresponde à menor frequência de ocorrência, totalizando 32 eventos em 900 observados (75 anos x 12 meses), o que representa $4 \%$ da série de dados.

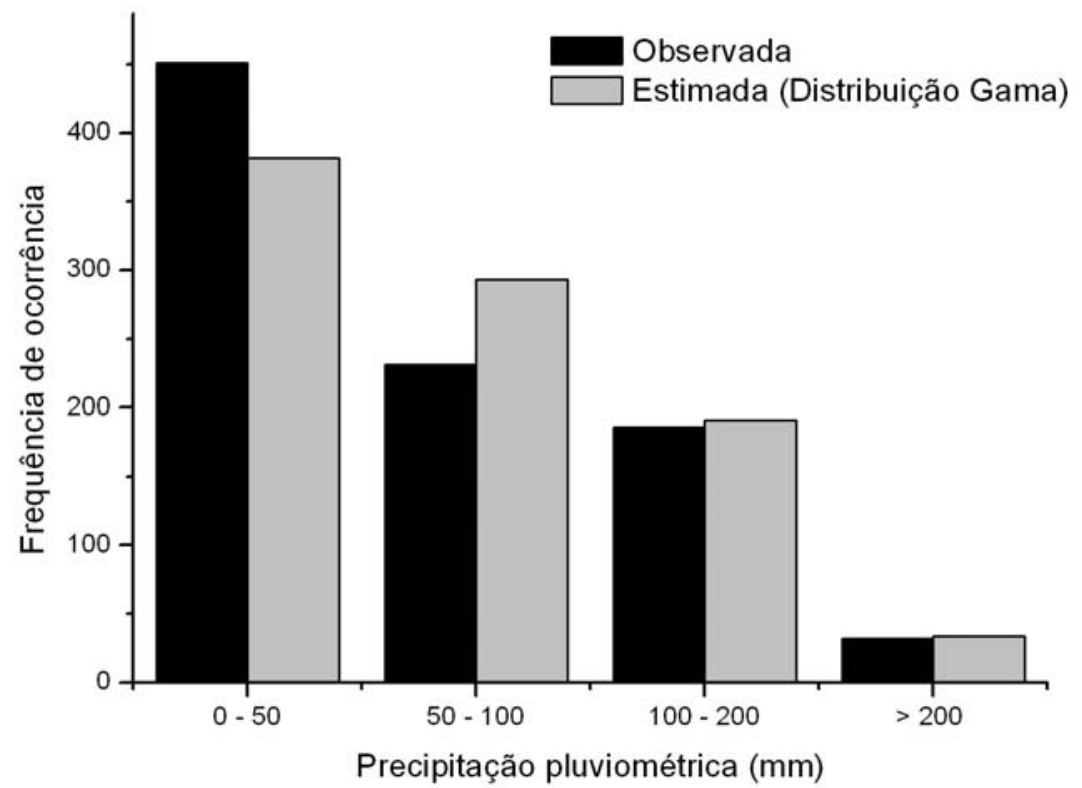

Figura 4. Frequência de ocorrência de eventos de chuva mensal observados e estimados pela distribuição Gama, no município de Garanhuns, PE, para o período de 1913 a 1987.

Analisando-se os valores de $\mathrm{P}(\mathrm{S})$ apresentados na Tabela 3, pode-se identificar os meses nos quais é esperado o maior número de dias secos. Em outubro, novembro e dezembro é esperado o maior número de dias secos. O mês de junho foi o que apresentou o menor número 

probabilidade condicional e do processo de cadeia de Markov na análise da ocorrência de períodos secos e chuvosos para o município de Garanhuns, PE, Brasil. Ambi-Agua, Taubaté, v. 4, n. 1, p. 169-182, 2009. (doi:10.4136/ambi-agua.81)

de dias secos, o que corresponde a uma probabilidade de 5,3\%. Da mesma maneira, com base em P(PC), verificou-se que julho e agosto apresentaram a maior probabilidade de ocorrência de meses chuvosos (cerca de 36 e 49,3\%, respectivamente). Nos meses de maio e junho, é esperado o maior número de dias bastante chuvosos (BC) no ano (cerca de 9,3\%). Com as expressões pospostas por Robertson (1976), podem-se determinar as probabilidades de ocorrência de períodos contínuos secos ou chuvosos, com duração de até quatro dias. Assim, por exemplo, pela Tabela 3 a probabilidade de ocorrerem 4 dias seguidos sem chuvas no mês de novembro é de $56,7 \%\left(0,880 \times 0,864^{4-1} \times 100\right)$ ou, aproximadamente, de um a cada quatro anos. Da mesma forma, a probabilidade de ocorrerem 4 dias consecutivos com chuvas no mês de junho é de $11,5 \%\left(0,533 \times 0,600^{4-1} \times 100\right)$.

Tabela 3. Probabilidades de ocorrência (P) de precipitações de dias secos (S), pouco chuvosos (PC), chuvosos (C), bastante chuvosos (BC), e dias secos dados que o dia anterior também foi seco (S/S) e dias chuvosos dado que o dia anterior foi chuvoso (C/C) em Garanhuns, PE para o período de 1913 a 1987.

\begin{tabular}{c|ccccccccc}
\hline \multirow{2}{*}{ Mês } & Média & \multicolumn{7}{c}{ Probabilidades de ocorrência (P) de precipitações } \\
\cline { 3 - 10 } & (mm) & $\mathbf{P ( S )}$ & $\mathbf{P ( C )}$ & $\mathbf{P ( P C )}$ & $\mathbf{P ( B C )}$ & $\mathbf{P ( S / S )}$ & $\mathbf{P ( C / C )}$ & $\mathbf{P ( S , 4 )}$ & $\mathbf{P ( C , 4 )}$ \\
\hline Jan. & 38,14 & 0,760 & 0,160 & 0,067 & 0,013 & 0,754 & 0,200 & 0,326 & 0,001 \\
Fev. & 46,46 & 0,587 & 0,293 & 0,107 & 0,013 & 0,545 & 0,000 & 0,095 & 0,000 \\
Mar. & 76,96 & 0,373 & 0,360 & 0,240 & 0,027 & 0,286 & 0,278 & 0,009 & 0,005 \\
Abr. & 81,14 & 0,387 & 0,253 & 0,293 & 0,067 & 0,379 & 0,364 & 0,021 & 0,014 \\
Mai. & 109,29 & 0,200 & 0,253 & 0,453 & 0,093 & 0,133 & 0,559 & 0,000 & 0,079 \\
Jun. & 124,66 & 0,053 & 0,320 & 0,533 & 0,093 & 0,000 & 0,575 & 0,001 & 0,115 \\
Jul. & 117,43 & 0,080 & 0,360 & 0,480 & 0,080 & 0,167 & 0,333 & 0,000 & 0,018 \\
Ago. & 74,81 & 0,293 & 0,493 & 0,187 & 0,027 & 0,409 & 0,214 & 0,020 & 0,002 \\
Set. & 36,69 & 0,667 & 0,333 & 0,000 & 0,000 & 0,680 & 0,000 & 0,026 & 0,000 \\
Out. & 20,51 & 0,880 & 0,080 & 0,027 & 0,013 & 0,864 & 0,000 & 0,182 & 0,000 \\
Nov. & 19,70 & 0,880 & 0,080 & 0,040 & 0,000 & 0,864 & 0,000 & 0,567 & 0,000 \\
Dez. & 23,43 & 0,853 & 0,093 & 0,053 & 0,000 & 0,828 & 0,000 & 0,513 & 0,000 \\
\hline Total & $\mathbf{6 4 , 1 0 2}$ & $\mathbf{6 , 0 1 3}$ & $\mathbf{3 , 0 7 8}$ & $\mathbf{2 , 4 8 0}$ & $\mathbf{0 , 4 2 6}$ & $\mathbf{5 , 9 0 9}$ & $\mathbf{2 , 5 2 3}$ & $\mathbf{1 , 7 6 0}$ & $\mathbf{0 , 2 3 4}$ \\
\hline
\end{tabular}

\section{CONCLUSÕES}

Sob as condições em que o estudo foi conduzido conclui-se:

a) Os dados de precipitação pluvial para todos os meses ajustaram-se à distribuição Gama, podendo essa ser usada para estimar a precipitação pluvial provável mensal em diferentes níveis de probabilidade, para fins de planejamento de projetos agrícolas na região de Garanhuns, PE.

b) Apesar do período chuvoso da região ser de maio a julho, são registradas chuvas significativas, acima de $50 \mathrm{~mm} / \mathrm{mês}$ com $60 \%$ de probabilidade de ocorrência, nos meses de fevereiro a agosto, período no qual se recomend a prática da agricultura de sequeiro.

c) As menores precipitações prováveis, abaixo de $50 \mathrm{~mm} / \mathrm{mês}$, são registradas nos meses de outubro, novembro e dezembro, onde deve se concentrar a agricultura irrigada, recomendando-se espécies e cultivares de ciclo curto para semeaduras em outubro, e de ciclo longo para agosto a fim de evitar prejuízos na colheita. 


\section{AGRADECIMENTOS}

Os autores são extremamente gratos ao professor Geber B. de A. Moura do Departamento de Agronomia Área de Meteorologia e Climatologia UFRPE, que viabilizou a parte técnica deste trabalho, e aos revisores anônimos da Ambi-Agua cujas sugestões contribuíram para melhoria do texto original.

\section{REFERÊNCIAS}

ANDRADE, M. C. O. Atlas de Pernambuco. João Pessoa: Grafset 1999. 112p.

ANDRADE JÚNIOR, A. S. de; BASTOS, E. A. Precipitação pluviométrica provável em municípios do cerrado piauiense. Teresina: EMPRABA-CPAMN, 1997. 22p. (Documentos, 25)

ARAÚJO, WELLINGTON F.; ANDRADE JÚNIOR, A. S.; MEDEIROS, R. D.; SAMPAIO, R. A. Precipitação pluviométrica mensal provável em Boa Vista, Estado de Roraima, Brasil. Revista Brasileira de Engenharia Agrícola e Ambiental, v. 5, n. 3, p. 563567, 2001.

ALMEIDA, T. A.; MONTENEGRO, S. M. G. L.; MONTENEGRO, A. A. A.; OLIVEIRA, O. F. Análise da variabilidade espacial da precipitação na Bacia do Rio Ipanema, Pernambuco. In: SIMPÓSIO DE RECURSOS HÍDRICOS DO NORDESTE, ABRH, 7., São Luis, 2004. Anais... São Luis: ABRH, 2004. 1 CD-Rom.

ASSIS, F. N. Modelagem de ocorrência e da quantidade de chuva e dias secos em Piracicaba - SP e Pelotas-RS. 1991. 134f. Tese (Doutorado em Agronomia) - Escola Superior de Agricultura de Luiz de Queiroz, Piracicaba, 1991.

ASSIS, F. N.; ARRUDA, H. V. de; PEREIRA, A. R. Aplicações de estatística à climatologia: teoria e prática. Pelotas: UFPel, 1996. 161 p.

BERNARDO, S. Manual de irrigação. 6.ed. Viçosa: Imprensa Universitária, 1995. 657p.

BOTELHO, V. A.; MORAIS, A. R. Estimativas dos parâmetros da distribuição gama de dados pluviométricos do Município de Lavras, Estado de Minas Gerais. Ciência e Agrotecnologia, Lavras, v. 23, p. 697-706, 1999.

CAMPOS. H. Estatística experimental não paramétrica. Piracicaba: ESALQ, 1979. 343p.

CASTRO NETO, P.; SILVEIRA, J. V. Precipitação provável para Lavras, região sul de Minas Gerais, baseada na função de distribuição de probabilidade Gama. l. Períodos mensais. Ciência Prática, Lavras, n. 5, v. 2, p. 144-151, 1981.

CASTRO NETO, P.; SILVEIRA, J. V. Precipitação provável para Lavras/MG, baseada na função de distribuição de probabilidade gama. III Períodos de 10 dias. Ciência e Prática, Lavras, n. 7, v. 1, p. 58-65, 1983.

CASTRO, L. H. R.; MOREIRA, A. N.; ASSAD, E. D. Definição e regionalização dos padrões pluviométricos dos cerrados brasileiros. In: ASSAD, E. D. (coord.) Chuvas no cerrados: análise e espacialização. Brasília: Embrapa, CPAC; Embrapa, SPI, 1994. p.13-23. 
ANDRADE, A. R. S.; FREITAS, J. C.; BRITO, J. I. B.; GUERRA, H. O. C.; XAVIER, J. F. Aplicação da probabilidade condicional e do processo de cadeia de Markov na análise da ocorrência de períodos secos e chuvosos para o município de Garanhuns, PE, Brasil. Ambi-Agua, Taubaté, v. 4, n. 1, p. 169-182, 2009. (doi:10.4136/ambi-agua.81)

CUNHA, A. R.; MARTINS, D.; PASSOS, J. R. S. O modelo Gama de probabilidade aplicado ao estudo da distribuição da chuva na região administrativa de Bauru, SP. In: CONGRESSO BRASILEIRO DE ENGENHARIA AGRÍCOLA, 25., Bauru, 1996. Anais... Bauru: Sociedade Brasileira de Engenharia Agrícola, 1996. 1 CD Rom.

FIETZ, C. R.; FRIZZONE, J. A.; FOLEGATTI, M. V. Precipitação esperada, em diferentes níveis de probabilidade, na região de Dourados, MS. Ciência Rural, Santa Maria, v. 28, n. 1, p. 29-34, 1998.

FRIZZONE, J. A. Análise de cinco modelos para o cálculo da distribuição e frequência de precipitação na região de Viçosa, MG. 1979. 100f. Dissertação (Mestrado em Engenharia Agrícola) - Universidade Federal de Viçosa, Viçosa, 1979.

JENSEN, M. E. Design and operation of farm irrigation system. New York: ASAE, 1983. 829p.

KELLER FILHO, T.; ZULLO JUNIOR, J.; LIMA, P. R. S. de R. Análise da transição entre dias secos e chuvosos por meio da cadeia de Markov de terceira ordem. Pesquisa Agropecuária Brasileira, v. 41, n. 9, p. 1341-1349, 2006.

KOLMOGOROV-SMIRNOV. Disponível em: <http:// www.physics.csbsju.edu/stats/KStest.html>. Acesso em: 24 dez. 2008.

KREPPER, C. M.; SCIAN, B. V.; PIERINI, J. O. Time and space variability of rainfall in central East Argentina. Journal of Climate, v. 2, p. 39-47, 1989.

MEDINA, B. F.; LEITE, J. A. Probabilidade de chuva em Boa Vista-RR. Pesquisa Agropecuária Brasileira, Brasília, v. 12, p. 1437-1441, 1984.

MOLION, L. C. B.; BERNARDO, S. O. Uma revisão da dinâmica das chuvas no nordeste brasileiro. Revista Brasileira de Meteorologia, v. 17, p. 1-10, 2002.

MURTA, R. M.; TEODORO, S. M.; BONOMO, P. Precipitação pluvial mensal em níveis de probabilidade pela distribuição gama para duas localidades do sudoeste da Bahia. Ciência e Agrotecnologia, Lavras, v. 29, n. 5, p. 988-994, set./out., 2005.

RIBEIRO, A. M. de A.; LUNARDI, C. A precipitação mensal provável para Londrina, PR, através da função gama. Energia na Agricultura, Botucatu, v. 12, p. 37-44. 1997.

ROBERTSON, G. W. Dry and wet spells: project field report agrometeorology A-6: UNDP/FAO Technical Assistence to the Federal Land Development Authotity. Jerantut: Tun Razak Agriculture Reserch Centre, 1976. 30 p.

RODRIGUES, L. N.; PRUSKI, F. F. Precipitação provável para João Pinheiro, Minas Gerais, utilizando funções de distribuição de probabilidade gama e log-normal. In: CONGRESSO BRASILEIRO DE ENGENHARIA AGRÍCOLA, 25., Bauru, 1996. Anais... Bauru: Sociedade Brasileira de Engenharia Agrícola, 1996. 1 CD-Rom.

SAAD, J. C. C. Estudo das distribuições de freqüência da evapotranspiração de referência e da precipitação pluvial para fins de dimensionamento de sistemas de irrigação. 1990. 124f. Dissertação (Mestrado em Irrigação e Drenagem) - Curso de Pós-Graduação em Agronomia, Escola Superior de Agricultura Luiz de Queiroz, Universidade de São Paulo, Piracicaba, 1990. 
ANDRADE, A. R. S.; FREITAS, J. C.; BRITO, J. I. B.; GUERRA, H. O. C.; XAVIER, J. F. Aplicação da probabilidade condicional e do processo de cadeia de Markov na análise da ocorrência de períodos secos e chuvosos para o município de Garanhuns, PE, Brasil. Ambi-Agua, Taubaté, v. 4, n. 1, p. 169-182, 2009. (doi:10.4136/ambi-agua.81)

THOM, H. C. S. A note on the gama distribuition. Monthly Weather Review, Washington, v. 86, p. 117-22, 1958.

VASCONCELOS, C. A.; PINTO, J. E. S. Caracterização têmporo - espacial da pluviosidade: o município de Sairé e sua microrregião - Brejo pernambucano. In: SIMPÓSIO BRASILEIRO DE CLIMATOLOGIA GEOGRÁFICA, 6., Aracaju, 2004. Programação e Resumos... Aracaju: FUFSE, 2004. 1 CD-Rom

XAVIER, R. A.; DORNELLAS, P. C. Análise do comportamento das chuvas no município de Arapiraca. Geografia, Londrina, v. 14, n. 2, p. 49-64, jul./dez., 2005. 